\title{
FUTURO PRETÉRITO: historiografia e preservação na obra de Gregori Warchavchik
}

Dissertação apresentada à Faculdade de Arquitetura e Urbanismo da Universidade de São Paulo para obtenção do título de mestre em Arquitetura e Urbanismo

Área de concentração:

História e Fundamentos da Arquitetura e do Urbanismo

Orientadora: Profa. Dra.

Mônica Junqueira de Camargo 
Autorizo a reprodução e divulgação total ou parcial deste trabalho, por qualquer meio convencional ou eletrônico, para fins de estudo e pesquisa, desde que citada a fonte.

e-mail autora: deniseinvamoto@gmail.com

e-mail orientadora: junqueira.monica@uol.com.br

Invamoto, Denise

I62f Futuro pretérito: historiografia e preservação na obra de Gregori Warchavchik / Denise Invamoto. --São Paulo, 2012. 366 p. : il.

Dissertação (Mestrado - Área de Concentração: História e Fundamentos da Arquitetura e Urbanismo) - FAUUSP.

Orientadora: Mônica Junqueira de Camargo

1.Arquitetura moderna (História ; Preservação) 2.Patrimônio cultural 3.Gregori Warchvchik (1896-1972) I.Título

CDU 72.036 
Para meus pais, por tudo. 



\section{AGRADECIMENTOS}

No percurso da pesquisa, muitas contribuições se somaram e estão contidas em sua fisionomia final. Daí a real necessidade de reverenciar e agradecer.

Agradeço, em primeiro lugar, à Mônica Junqueira pelo estímulo, confiança e presença nas horas decisivas.

À Silvana Rubino e José Lira, pelo debate na banca de qualificação. A José Lira, agradeço ainda pelas discussões colocadas na sua disciplina e por dedicar parte de seu tempo para falar de sua pesquisa; do mesmo modo, a Agnaldo Faria.

À Beatriz Kühl, por me receber no estágio PAE na disciplina de Técnicas Retrospectivas e pelas proveitosas conversas na hora do café, juntamente com Maria Lúcia Bressan Pinheiro, nos intervalos da disciplina de Técnicas Construtivas e nos eventos na área de patrimônio que organizam; assim como Fernanda Fernandes e José Pedro de Oliveira Costa pelo convívio durante a realização do estágio.

À Maria Arminda do Nascimento Arruda, Paulo César Garcez Marins e Ana Lanna pelos instigantes debates em suas disciplinas. À Ana Lanna também pelas já remotas mas frutíferas conversas.

Agradeço a Carlos Warchavchik pela generosa disposição em abrir o acervo da família, fornecer documentos e em me receber em obras da família, bem como a Mauris Ilia Warchavchik pela visita à Casa da Santa Cruz e a Paulo Mauro Mayer de Aquino e seu solícito atendimento às minhas demandas.

A José Antônio Domingues por seu entusiasmo em fornecer-me informações e documentos para a pesquisa sobre o conjunto da Rua Berta.

Aos funcionários do Centro Cultural Aúthos Pagano, Iphan, Condephaat, Biblioteca e Secretaria da Pós-graduação da FAUUSP, Arquivo Histórico de Santos, bibliotecas do Museu Lasar Segall e do Masp; aos funcionários do Conpresp, especialmente Wanda e Cida; aos funcionários do Arquivo Histórico Municipal, especialmente, Ricardo Mendes.

Aos companheiros de DPH de hoje e de ontem, especialmente Celso Ohno pelas conversas warchavchikianas e descobertas nos Arquivos; Ana Clara Giannecchini, Dalva Thomaz e Lícia Mara Alves de Oliveira, pela amizade e aprendizado; Lia Mayumi, Mauro Sanches, Tatiana Cipoli e demais colegas de Projeto, Restauro e Conservação, Cássia 
Magaldi, Leila Diêgoli, Henrique Serafim, Marco Winter, Valéria Valeri; e também a José Rollemberg, José Roberto Pinheiro, Mirthes Baffi, Ronaldo Parente, Sérgio Abrahão, Valdir Arruda, Walter Pires e aos funcionários administrativos, Aloísio, Helenita, Maria José, Sara e Sônia.

Aos amigos que contribuíram das mais diversas formas, do apoio logístico ao apoio moral: Gabriela Tamari pela encadernação; Lara Souza, Raquel Schenkman, Sarita Genovez, Priscila Miúra, Ana Paula Farah, Cláudia Nascimento, pelas conversas-preservação; Eric Buckup pela revisão do abstract; Gustavo Godoy pela tradução do russo; Leon Yajima, pelo auxílio nos desenhos; Camila Saraiva e Daniela Motisuke pela acolhida no Rio de janeiro e em Brasília; Paula Deddeca por compartilhar o percurso da pós-graduação, da sala de aula à biblioteca; Cristina Paiva, Maria Cristina Savaia Martini, e Diana Zatz, pelas profícuas discussões.

A meus pais, Juncko e Emílio; meu irmão Fábio. E Carlos, pela compreensão.

Esta pesquisa contou com auxílio financeiro do Cnpq.

Em três anos de trabalho, muita coisa aconteceu dentro e fora do âmbito acadêmico, portanto não é apenas protocolar o alerta de que possa estar esquecendo de pessoas que estiveram presentes neste processo. Agradeço verdadeiramente a todos. 


\section{RESUMO}

A História da Arquitetura e a Preservação de Bens Culturais entendidas como campos disciplinares autônomos, providos de referenciais teórico-metodológicos próprios, suscitaram a investigação sobre os seus possíveis entrelaçamentos, a partir de uma perspectiva que incorpora o instrumental e as noções operativas no campo da preservação.

As múltiplas temporalidades da obra arquitetônica, identificadas pelo estudo de suas transformações ao longo do tempo, a indagação ao objeto em sua consistência física à luz da cultura material e a utilização de suportes documentais diversos, resultam em um material historiográfico de interesse, possibilitando um novo olhar sobre a produção arquitetônica.

Através desses pressupostos, analisamos obras de Gregori Warchavchik tombadas ou preteridas em processos de tombamento, propondo uma reconstituição de suas trajetórias e utilizando-as como estratégia para pensar em que medida as interpretações oriundas da historiografia da arquitetura moderna vêm orientando as práticas de salvaguarda e conservação do patrimônio moderno, ou, falando de outro modo, como fundamentam critérios de seleção e de intervenção sobre o moderno.

Palavras-chave: 1. História da Arquitetura Moderna; 2. Preservação da Arquitetura Moderna; 3. Patrimônio Cultural; 4. Gregori Warchavchik (1896 - 1972);

\section{ABSTRACT}

The Architectural History and the Preservation of cultural heritage understood as autonomous fields, provided by its own theories and methodologies, raised the investigation study about its possible entanglements, from a perspective that incorporates the instrumental and the operational preservation concepts.

The multiple temporalities of the architectural work, identified by the study of its changes over time, the investigation of the object under the light of the material culture and the use of several document sets, result as a historiographical subject of interest, allowing a new point of view over the architectural production.

These are the starting points of a Gregori Warchavchik's architecture analysis. The research selected listed and excluded works from listing, doing a reconstitution of their trajectories and use them as a strategy to think about how the historiographical interpretations have been guiding the conservation and protective practices, or, the intervention's criteria on the modern.

Key-words: 1. Architectural history; Preservation of modern heritage; 3; Cultural heritage; 4. Gregory Warchavchik (1896 - 1972) 



\section{LISTA DAS FIGURAS}

\section{Capítulo 1}

ACRÓPOLE, 1941: 5, 8

BENEVOLO, 1998: 17

BRUAND, 1981: 12

COUTINHO, 2003: 15

DOMUS, 1952: 6

LIRA, 2008: 16

FARIAS, 1990: 14

FERRAZ, 1965: 10

GOODWIN, 1943: 3, 4, 7

HABITAT, 1965: 9

SARTORIS, 1932: 1, 2

SOUZA, 1982: 13

XAVIER, CORONA \& LEMOS, 1983: 11

\section{Capítulo 2}

ARCHITECT MAGAZINE. Disponível em: <http://www.architectmagazine.com/films/filmthe-pruitt-igoe-myth.aspx>: 18, 19

<http://arquitetablog.blogspot.com/2011_04_01_archive.html>: 22, 23, 25, 26, 28

BENIGNO, 2009. Disponível em: <http://www.flickr.com/photos/channelbeta/page252/>: 12

CASTRO e FINGUERUT, 2006: 35, 36

<http://frontpage.ccsf.edu/artarchive/images/Le\%20Corbusier\%20-\%20Villa\%20Savoye. jpg >: 20

GONÇALVES, 2007: 31, 33

HELBIG, 1999, Stadtarchiv Dessau. Disponível em: <http://www.meisterhaeuser.de/en/index.html>: 9

$<$ http://ilfotonauta.wodpress.com>: 11

INVAMOTO, 2002: 14, 15

INVAMOTO, 2003: 1, 29, 30 
INVAMOTO, 2011: 37

INVAMOTO, 2012: 38

MAYUMI, 2008: 33, 34

MARTÍNEZ, 2007: 17

MURPHY, 2002: 21, 24, 27

$<\mathrm{http} / /$ www.panoramio.com>: 4

SALVO, 2007a: 2, 7, 8

SHANKBONE, 2006. Disponível em: <http://en.wikipedia.org/wiki/ File:LeverHouseNewYork.JPG>: 6

STOLLER, 1952. Disponível em: <http://www.som.com/content.cfm/lever_house>: 5

THÖNER, 2002, Stadtarchiv Dessau. Disponível em: <http://www.meisterhaeuser.de/en/ index.html>: 10

$<$ http//www.xoomer.virgilio.it/wmaspes/pirellone>: 3

WAM, 2006. Disponível em: <http://www.worldarchitecturemap.org/buildings/firminychurch>: 16

WIKIPEDIA, 2006. Disponível em: <http://en.wikipedia.org/wiki/Saint-Pierre_church,_Fir$\min y>: 17$

\section{Capítulo 3}

Acervo da Biblioteca da FAUUSP: 33, 34, 135-142, 147, 150, 151, 156-160, 264, 385-391, $439,458,478-483,485-493,552-555$

Acervo CCAP: 328-330, 339, 254, 356, 357, 362

Acervo COPEDOC/IPHAN: 36, 39-45, 47, 91, 103, 277, 417-423

Acervo DPH: 26-30, 37, 48-55, 123, 124, 126, 127, 175-182, 218, 586-615

Acervo família Warchavchik: 4-17, 19-23, 82, 89, 90, 94, 95, 99, 102, 129, 146, 148, 149, $241,242,263,275,280,284,360,339-416,574-585$

Acervo José Antonio Domingues: 162, 183-217, 219-229, 257, 258

ACRÓPOLE, 1938: 459, 460

ACRÓPOLE, 1941: 484

APPM, 1989: 56

APPM, (199-): 57

Arquivo Geral de Processos PMSP: 1-3, 143-145, 163, 164, 335, 336, 340, 384, 440-448, 452,556 
Arquivo Histórico Municipal: 238-240, 436, 438

BENCLOWICS, 1989: 251-254

Bolsa do Café (Postal): 133

CIA. CITY, <http://www.ciacity.com.br/novo/index.php>: 327

CONGRESSO DE HABITAÇÃO (SÃO PAULO), 1931: 128

CONPRESP: 170-174, 461, 462, 568-571

FERRAZ, 1965: 18, 283, 291, 294, 296, 299, 337, 358

GALLO, 2001: 58, 64, 66, 68, 71, 73, 78, 87, 92, 96, 100, 104, 105, 108, 110, 122, 125

GALLO, 2006: 69, 75-77, 83, 85, 112-117

GOOGLE Street View: 237, 463

$<$ http://www.greatbuildings.com>: 161

HABITAT, 1952: 551

HABITAT, 1965: 287

INVAMOTO, 1998: 61, 63

INVAMOTO, 2006: 235, 236

INVAMOTO, 2008: 59, 60, 62, 64, 65, 67, 70, 72, 74, 79-81, 84, 86, 88, 93, 97,98, 101, $106,107,109,111,118-121,278,281,285,292,297,301-312$

INVAMOTO, 2009: 290, 424-435

INVAMOTO, 2010: 259-262, 279, 282, 286, 288, 289, 293, 295, 298, 313-326, 355, 359, $361,363-380,464-475,499-550$

INVAMOTO, 2010 (Alameda Barão de Limeira). Fonte: Acervo Carlos Warchavchik: 494498

INVAMOTO, 2010 (Rua Berta). Fonte: AGP, DPH e visitas de campo: 152-155

INVAMOTO, 2010 (Rua Itápolis). Fonte: Acervo Carlos Warchavchik: 269-274

INVAMOTO, 2010 (Avenida Morumbi). Fonte: Acervo DPH: 560-567

INVAMOTO, 2010 (Avenida Rebouças). Fonte: AGP: 453-457

INVAMOTO, 2010 (Rua Santa Cruz). Fonte: AGP, FERRAZ, 1965; GALVÃO, 1984; DPH, 2008: 24,25

INVAMOTO; YAJIMA, 2010 (Rua Bahia). Fonte: AGP: 392-398

INVAMOTO; YAJIMA, 2010 (Rua Barão de Jaguara). Fonte: AHMWL: 243-245

INVAMOTO; YAJIMA, 2010 (Rua Tomé de Souza). Fonte: AGP, FERRAZ, 1965 e visitas de campo: 341-348 
Mapa GEGRAN, 1972: 32b, 167, 247, 267, 333, 382, 450, 476, 558

Mapa GOOGLE MAPS, 2010: 134, 268, 334, 383, 451, 477, 559

Mapa GOOGLE MAPS, 2011: 168, 249, 437

Mapa SARA BRASIL, 1930: 31, 165, 246, 265, 331, 381

Mapa VASP, 1954: 32, 166, 248, 266, 332, 449, 557

MCB: 300

MIRANDA, 2004: 255, 256

Museu Lasar Segall, 1984: 38, 46

SARTORIS, 1932: 338

SANTOS, 2007: 130-132

SCHMIDT, 1946: 572, 573

SOUZA, 1982: 35, 169, 250, 276

YAJIMA, 2008: 62

\section{LISTA DE TABELAS}

Tabela 1. Comunicações nos seminários Docomomo Brasil com temas relativos à documentação e historiografia. Fonte: Anais eletrônicos disponíveis em < http://www.docomomo.org. $\mathrm{br} />$

Tabela 2. Comunicações nos seminários Docomomo Brasil com temas relativos à salvaguarda e conservação. Fonte: Anais eletrônicos disponíveis em < http://www.docomomo.org.br/> Tabela 3. Proteção legal das obras de Warchavchik. Fonte: Iphan: <http://www.iphan.gov.br/ ans/inicial.htm>; Condephaat: <http://www.cultura.sp.gov.br/portal/site/SEC>; Conpresp: < http://www.prefeitura.sp.gov.br/cidade/secretarias/cultura/cit/index.php?p=1160> 


\section{SIGLAS E ABREVIAÇÕES}

AGP - Arquivo Geral de Processos

AHM - Arquivo Histórico Municipal

AFW - Acervo família Warchavchik

APT - Abertura de Processo de Tombamento

CCAP - Centro Cultural Aúthos Pagano

CECRE - Curso de Especialização em Conservação e Restauro

CNBB - Conferência Nacional dos Bispos do Brasil

DARC - Departamento de Atividades Regionais de Cultura

DOCOMOMO - International working party for Documentation and Conservation of buildings, sites and neighbourhoods of the Modern Movement

DPH - Departamento do Patrimônio Histórico

EESC-USP - Escola de Engenharia de São Carlos

FAU-UFBA - Faculdade de Arquitetura e Urbanismo da Universidade Federal da Bahia

FAU-USP - Faculdade de Arquitetura e Urbanismo da USP

FSP - Folha de São Paulo

FUNCAP - Fundo de Proteção do Patrimônio Cultural e Ambiental Paulistano

$\mathrm{IAB}$ - Instituto dos Arquitetos do Brasil

IBRAM - Instituto Brasileiro de Museus

IEB-USP - Instituto de Estudos Brasileiros da USP

IHGGB - Instituto Histórico e Geográfico de Guarujá e Bertioga

IHGSP - Instituto Histórico e Geográfico de São Paulo

JB - Jornal do Brasil

MCB - Museu da Casa Brasileira

MP - Ministério Público

OESP - O Estado de São Paulo

PMSP - Prefeitura Municipal de São Paulo

PROPAR-UFRGS - Programa de Pesquisa e Pós-graduação em Arquitetura - Universidade Federal do Rio Grande do Sul

SEMPLA - Secretaria Municipal de Planejamento

SMH - Serviços de Museus Históricos

STCT - Seção Técnica de Crítica e Tombamento/DPH

STPRC - Seção Técnica de Projeto, Restauro e Conservação/DPH

TAC - Termo de Ajustamento de Conduta

USP - Universidade de São Paulo 



\section{SUMÁRIO}

17

25

26 Warchavchik, debatedor, autor

38 De produtor ativo a objeto histórico

57 Voz dissonante, mesmo referente

67 Consolidando o debate

81 Continuidades, revisões e novas perspectivas

115 Arquitetura e documento

\section{Capítulo 2 | Arquitetura moderna na pauta preservacionista}

121 Desenvolvimento do campo da preservação

127 A formação do patrimônio moderno

$149 \quad$ A realidade brasileira 



\section{INTRODUÇÃO}

A arquitetura moderna tem recebido tratamento metodologicamente diverso da arquitetura tradicional por uma parcela de restauradores, que interpretam sua especificidade como determinante de novas posturas de intervenção. Na realidade, o que se vê ocorrendo é o abandono das teorias de restauro desenvolvidas ao longo do século XX para a recuperação de uma orientação estilística que remete à concepção violletiana ${ }^{1}$. Nesta linhagem, a instância estética prepondera sobre a histórica, de modo que a reconstituição da figuração original seja legitimada como restauro da imagem, pondo em xeque a noção contemporânea de autenticidade material e descartando os diversos estratos da obra no tempo como contribuições válidas para a história dos bens ora preservados. Observadas as inúmeras intervenções que vêm fazendo de obras emblemáticas do movimento moderno maquetes 1:1 de si mesmas sem levar em conta o instrumental caro ao campo da restauração, percebeu-se que algo mais estava por trás da suposta autonomia disciplinar defendida pelos partidários do restauro $e x$ novo. Apesar de se constituírem em campos disciplinares diversos, dotados de referenciais teórico-metodológicos próprios, a restauração - ou de modo mais amplo, a preservação de bens culturais - se nutre da história. Ora, se o processo de reconhecimento e seleção para salvaguarda e conservação dos bens culturais parte das leituras oriundas da historiografia, o estudo sobre os efeitos dos discursos historiográficos sobre as políticas e práticas da preservação afigura-se como caminho de interesse para compreender o problema.

Por outro lado, é possível notar na prática profissional a distância entre as pesquisas históricas voltadas para a elaboração de projetos de restauro e aquelas encontradas na bibliografia sobre arquitetura moderna. As demandas resultantes da indagação à obra arquitetônica enquanto objeto material não vêm encontrando ecos na historiografia corrente relativa ao tema. Assumir a obra como artefato que contém traços materialmente inscritos capazes de trazer marcas específicas à memória, faz com que se coloque a possibilidade de olhá-la sob a perspectiva da cultura material, orientando leituras, como sugere Ulpiano Bezerra de Meneses, que permitem inferências sobre inúmeras esferas de fenômenos:

assim, a matéria prima, seu processamento e técnicas de fabricação, bem como 
a morfologia do artefato, os sinais de uso, os indícios de diversas durações, e assim por diante, selam, no objeto, informações materialmente observáveis sobre a natureza e a propriedade dos materiais, a especificidade do saber-fazer envolvido e da divisão técnica do trabalho e suas condições operacionais essenciais, os aspectos funcionais e semânticos - base empírica que justifica a inferência de dados essenciais sobre a organização econômica, social e simbólica da existência social e histórica do objeto. Mas, como se trata de inferência, há necessidade, não apenas de uma lógica teórica, mas ainda do suporte de informação externa ao artefato. Maior necessidade, ainda, haverá se reconhecermos que o artefato não é "an inert, passive object, but an interactive agent in sociocultural life and recognition (...) the signification of the artifact resides in both the object as a self-enclosed material fact and in its performance, 'gestural' patterns of behavior in relation to space, time and society”. Daí a importância da narrativa e dos discursos sobre o objeto para se inferir o discurso do objeto ${ }^{2}$

A leitura da obra arquitetônica enquanto documento na chave da cultura material, a relação elástica com suportes documentais diversos, o estudo da trajetória da obra e a explicitação da atuação do presente sobre ela, nos parece fazer de noções operativas no campo da preservação ferramentas de interesse para integrar-se, e mesmo para questionar determinados postulados advindos da historiografia da arquitetura. Não estamos com isso desmerecendo as importantes contribuições que esta bibliografia tem a dar. Apenas identificamos que existem repercussões desta historiografia nas práticas da preservação e que, entendendo que a história se escreve no plural, existem potencialidades no instrumental de outras especialidades da história e do campo da preservação.

Admitindo, portanto, o distanciamento e ao mesmo tempo a imbricação entre historiografia e preservação da arquitetura moderna, a pesquisa se propõe focar a investigação de seus entrelaçamentos, a dialética de suas relações ora reflexivas, ora conflitantes. Optamos então pela circunscrição do problema ao universo brasileiro, restringindo-nos à cidade de São Paulo, a partir da análise da obra de Warchavchik. A escolha do arquiteto nos pareceu adequada pois, "figura tão onipresente quanto mal conhecida" ${ }^{3}$, Warchavchik é personagem central na historiografia da arquitetura moderna no Brasil ao mesmo tempo em que um dos poucos arquitetos modernos a ter obras tombadas nas três esferas de preservação em São Paulo - IPHAN, Condephaat e Conpresp.

Nesta relação entre historiografia e preservação, o tombamento constitui-se como instância máxima de contato, na qual a história fundamenta o processo de reconhecimento

2 "um objeto passivo, inerte, mas um agente interativo na vida sociocultural, e o reconhecimento (...) da significação do artefato reside tanto no objeto como um fato material encerrado em si mesmo quanto em seu desempenho, padrões gestuais de comportamento em relação ao espaço, tempo e sociedade”. MENESES, 1998:91

3 LIRA, 2007:145 
e atribuição de valor na seleção de obras para proteção, e o tombamento consagra obras, como em um segundo nascimento, trazendo outras camadas de significação e demandas para a historiografia. De modo menos frequente, o tombamento impulsiona diretamente revisões historiográficas, especialmente quando fatores alheios à academia trazem à tona novos elementos para pensar as obras, como a ameaça de perda por demolição ou degradação. Inserido o estudo sobre os tombamentos das obras de Warchavchik em um panorama do tombamento de obras modernas, abre-se também a oportunidade de se avaliar e se comparar as formas como os órgãos de patrimônio vêm atuando no tocante ao tema no contexto de suas políticas.

Outro ponto que faz da análise da preservação da obra de Gregori Warchavchik meio adequado para os objetivos desta pesquisa se refere à existência de obras assinadas pelo arquiteto que passaram por restauração com projeto de restauro documentado e aprovado pelos órgãos preservacionistas. Assim como o tombamento, o restauro coloca-se como momento de verificação de quais leituras orientam as diretrizes, o partido, os caminhos técnicos e teóricos. Mais ainda, a elaboração de projeto e a obra de restauro colocam-se como instâncias de produção de conhecimento, revelando facetas de outro modo não percebidas, constituindo-se, portanto, em rico material historiográfico. Do levantamento das técnicas construtivas à caracterização de materiais, do levantamento arquitetônico ao levantamento de patologias, do levantamento fotográfico à visita in loco, da aprovação do projeto ao canteiro de obra, do equacionamento do programa ao desenho dos detalhes construtivos, da datação das intervenções realizadas ${ }^{4}$ ao estudo do contexto ambiental da obra, as pesquisas para a realização do projeto de restauro e a execução da obra revelam dimensões que se coadunam com as preocupações iniciais desta pesquisa.

Com isso, adotou-se como estratégia a análise de estudos de caso, elegendo-se as obras de Warchavchik tombadas ou preteridas nos processos de tombamento na cidade de São Paulo: Casas das ruas Bahia, Itápolis, Rebouças, Santa Cruz, Tomé de Souza, conjuntos residenciais das ruas Berta e Barão de Jaguara, edifício da Alameda Barão de Limeira e Capela do Morumbi. Com preteridas queremos dizer aquelas obras que tiveram processos de tombamento negados e arquivados - situação igualmente interessante para a verificação dos juízos em jogo. Das nove obras, deverão ser aprofundados os estudos da Casa Modernista da Rua Santa Cruz e da Vila à Rua Berta por terem sido objeto de restauração. Os demais casos justificam-se pela necessidade de compreensão do conjunto das obras tombadas frente ao restante da produção do arquiteto e às obras protegidas pelos órgãos de preservação.

Entretanto, deve-se colocar a ressalva de que não se tem como objetivo perscrutar exaustivamente cada obra, propor uma nova interpretação sobre o legado de Warchavchik no interior da historiografia ou examinar a trajetória do arquiteto. Tampouco temos a intenção de propor uma revisão sobre a história das instituições preservacionistas no Brasil ou

4 Que poderia ser auxiliada com a especialidade solidária ainda pouco disseminada no Brasil da arqueologia da arquitetura. 
das teorias de restauração, temas que vêm recebendo importantes contribuições nos últimos anos. Também não cabem as perigosas ideias de preenchimento de lacuna ou de justiça a um arquiteto há pouco escanteado. À parte a escassa bibliografia sobre o tema do patrimônio moderno ou sobre as implicações de um campo disciplinar sobre o outro, a pesquisa deve trazer elementos sobre historiografia, preservação e a obra de Warchavchik naquilo que interessa à sua condução.

A dissertação se desenvolverá, para tanto, em três capítulos.

O capítulo 1 pretende construir um panorama sobre a historiografia da obra de Warchavchik. Tem como objetivo identificar sob que enfoques o arquiteto é tratado, que aspectos são valorizados (ou depreciados), quais obras e como são analisadas, a partir de quais recortes temporais, pensando ao fim nas formas de uso das fontes.

O capítulo será organizado em quatro partes. Na primeira parte, o objetivo é mostrar um Warchavchik protagonista do debate arquitetônico coetâneo à sua primeira e consagrada fase de produção - pontuando considerações sobre seus escritos e o que se escreveu sobre ele. Na segunda, expor Warchavchik como produtor ativo retratado nos periódicos especializados, englobando o período que vai da difusão de projetos do arquiteto aos primeiros artigos e polêmicas sobre seu papel na história da arquitetura. Na terceira, investigar o momento em que Warchavchik transforma-se em objeto histórico nas histórias gerais da arquitetura moderna brasileira e trabalhos monográficos sobre o arquiteto - das primeiras obras que o veem em perspectiva histórica nos anos 1950 às variantes da historiográfica canônica levadas até os anos 1980. Na quarta, discutir as continuidades e aberturas de novas perspectivas analíticas a partir dos anos 1980 até os dias de hoje.

Apesar de os dois primeiros períodos não se constituírem em si como de produção historiográfica sobre o arquiteto, são fontes essenciais para o confronto com o que será a história produzida a partir de então e é a forma que encontramos de apresentar o arquiteto sem que tivéssemos que recorrer a excursos sobre sua trajetória. No capítulo, deverão ser aprofundadas as análises dos três trabalhos monográficos dedicados ao arquiteto, Warchavchik e a Introdução da Nova Arquitetura no Brasil - 1925 - 1940, de Geraldo Ferraz (1965), A Arquitetura Eclipsada: Notas sobre História e Arquitetura a Propósito da Obra de Gregori Warchavchik, Introdutor da Arquitetura Moderna no Brasil, de Agnaldo Farias (1990) e Fraturas da Vanguarda em Gregori Warchavchik, de José Lira (2008). Serão examinadas suas interpretações, estratégias argumentativas e formas de análise das obras. Como nos demais trabalhos abordados, serão repassados os marcos, debates, as principais obras e fases de Warchavchik sob o ponto de vista dos autores estudados. Mais elementos sobre a produção de Warchavchik propriamente aparecerão nos estudos de caso.

O capítulo 2 deverá fundamentar a discussão sobre a obra de Warchavchik como patrimônio histórico, fornecendo as bases conceituais para a análise desenvolvida no capítulo 3. Deverá ser apresentado em três partes - a constituição do campo da preservação, a formação do patrimônio moderno e a realidade brasileira. Ao longo do capítulo, problemas já levantados no primeiro referentes aos métodos, às formas de manipulação dos documentos, 
aos critérios e hierarquias de valores deverão ser apontados.

$\mathrm{Na}$ primeira parte, o capítulo trará elementos sobre a constituição do campo disciplinar, recuperando as teorias da restauração, de Viollet-le-Duc e John Ruskin a Cesare Brandi, de modo a fornecer subsídios para o debate em torno da construção da categoria de bem "patrimônio moderno", verificando as continuidades e aplicabilidade deste arcabouço conceitual, especialmente polarizado pelo pensamento violletiano e brandiano. Neste andamento, notas sobre a evolução do debate internacional consubstanciado nas Cartas de patrimônio deverão pontuar o capítulo. Entretanto, como alertado por Beatriz Kühl, as cartas patrimoniais não podem ser entendidas como um conjunto homogêneo que prescreve um receituário de simples aplicação, mas como resultado de postulados teóricos da época em que foram produzidas ${ }^{5}$.

Em seguida, deverá traçar um panorama internacional da preservação do patrimônio moderno, das origens aos casos recentes. O capítulo deverá problematizar o fenômeno do abandono das teorias do restauro na salvaguarda da arquitetura moderna, expondo as especificidades e desafios para a sua conservação e discutindo o conceito de autenticidade, reprodutibilidade e cópia à luz da verificação da aplicabilidade dos conceitos do restauro crítico à arquitetura moderna. Serão analisados casos de restauro, que terão pontos de contato com as primeiras experiências de restauro empreendidas pelo SPHAN nos anos 1930.

A terceira parte abre, portanto, com o exame do partido de restauro presente nas intervenções da primeira fase do SPHAN, passando à discussão de seus tombamentos internacionalmente pioneiros de obras modernas. Deverá então ser discutido o processo de alargamento do conceito de patrimônio cultural ao longo do tempo concomitante à criação e desenvolvimento dos três órgãos de preservação em São Paulo, localizando a forma como vêm tratando o tema do patrimônio moderno. Sobre a prática recente, a produção realizada para os encontros do Docomomo será também objeto de reflexão. As obras de Warchavchik entram neste caldo inaugurando a prática de tombamento do patrimônio moderno em São Paulo nos anos 1980, problema que será explorado no capítulo 3, referente aos estudos de caso.

O terceiro capítulo será aberto com um panorama sobre os tombamentos das obras de Warchavchik na cidade de São Paulo, seguido de subcapítulos correspondentes a cada uma das nove obras. Abrem as análises os casos aprofundados da Casa Modernista da Rua Santa Cruz e o conjunto da Rua Berta, pois ambos desencadearam o tombamento de outras obras, fazendo com que sua apresentação em primeiro lugar sirva de contextualização para as demais, organizadas em sequência cronológica.

Serão notadas assimetrias entre as obras, pois além de cada uma conter uma trajetória particular, mobilizando questões e temas diversos, a disponibilidade e o acesso a documentos não seguiu qualquer padrão. Enquanto o conjunto da Rua Berta conduz à discussão 
sobre habitação nos anos 1930, a casa da Avenida Rebouças ou a Capela do Morumbi trazem o problema das estratégias de visibilidade e valorização de empreendimentos imobiliários na cidade, mas a última também recupera o tema da intervenção em pré-existências. A casa da Santa Cruz é uma das obras mais comentadas pela historiografia, ao passo que a casa da Rua Tomé de Souza aparece apenas tangencialmente, porém traz à tona documentos sobre a construção que nenhuma outra terá, e assim por diante.

Daí se depreende que é a partir da análise das obras que traremos elementos sobre os contextos histórico cultural, social, econômico ou político, quando necessários à compreensão destas ou quando estas demonstrarem sua relevância para o entendimento ou mesmo alteração dos referidos contextos. Como subsídio, utilizaremos referenciais da história da arte, arquitetura, cultura e urbanização, da preservação, da nova história, da teoria da história, da teoria da restauração, da sociologia da arte e da cultura, da crítica literária e da filosofia.

Se o estudo da trajetória traz o tempo presente como ponto de partida de um olhar perspéctico, algumas ressalvas devem ser feitas, cabendo aqui paralelos com os gêneros das biografias e memórias humanas. Bosi lembra que

O testemunho quer-se idôneo, quer-se verídico, pois aspira a certo grau de objetividade. Como tal, casa memória individual com história. Mas o testemunho também se sabe obra de uma testemunha, que é sempre um foco singular de visão e elocução. Logo, o testemunho é subjetivo e, por esse lado, se aparenta com a narrativa literária em primeira pessoa ${ }^{6}$.

Bourdieu, por seu turno, alerta para o problema da Ilusão biográfica ${ }^{7}$, na qual a construção do relato de vida aparece como sequência coerente de acontecimentos com significado e direção. A diferença entre estas autoconstruções memoriais e biográficas e uma proposta de um estudo em terceira pessoa sobre a trajetória ou biografia de obras arquitetônicas evidentemente se encontra no local por onde se deposita a subjetividade, pois no primeiro caso sujeito e objeto fundem-se ao passo que no segundo caso, não. Mas o problema central permanece o mesmo, qual seja, o perigo de uma aparente objetividade totalizante, descolada de suas bases socioculturais. Em termos historiográficos o problema já foi enfrentado. No território específico da cultura material, Meneses pondera: o artefato não mente. "À integridade física do artefato corresponde sua realidade objetiva. Os discursos sobre os artefatos é que podem ser falsos”. De qualquer modo não é demais aqui recordar que não existe história isenta e imparcial, ainda que o norte de qualquer trabalho histórico seja seu compromisso com a verdade; é preciso saber ler os documentos, tanto nas informações que revelam quanto nas que ocultam ${ }^{9}$, praticando sempre o exercício da dúvida.

Texto sobre Memórias do cárcere, “A escrita do testemunho em Memórias do cárcere”. BOSI, 1995:309310.

7 BOURDIEU, 2000

8 MENESES, 1998:92

9 BURKE, 1992 
Neste sentido, discutir Warchavchik requer cautela e discernimento haja vista que se trata de um protagonista do embate que por muito tempo norteou a historiografia da arquitetura moderna brasileira e até hoje é capaz de causar alguma reserva. 


\section{DESENREDOS PELA HISTORIOGRAFIA: WARCHAVCHIK E SUAS IMAGENS}

Protagonista, coadjuvante, figurante ou mesmo ausente, Gregori Warchavchik tem sido quase exclusivamente tratado pela historiografia sob a perspectiva da genealogia da arquitetura moderna no Brasil. As abordagens, em geral - há exceções, evidentemente - orientam-se no sentido de situá-lo no processo de constituição da nova arquitetura, partindo de diferentes interpretações sobre o significado de seu primeiro conjunto de obras - escritas e arquitetônicas, deixando de lado outros enfoques e os demais períodos de produção do arquiteto.

A produção intelectual sobre o arquiteto foi sofrendo alterações no compasso das transformações experimentadas pelo próprio espaço do debate e da divulgação arquitetônica. De 1925 a meados da década de 1930, o debate, caracterizado pelo proselitismo e pelo combate, foi travado nos jornais diários; Os anos 1940 marcam a entrada das revistas especializadas, que divulgam projetos do arquiteto isoladamente ou inseridos em reportagens temáticas; a partir dos anos 1950, começam a surgir os primeiros livros de história da arquitetura moderna brasileira, nos quais o arquiteto já é visto sob perspectiva histórica. Os anos 1960 e 1970 enriquecem o número de publicações sobre história da arquitetura brasileira e já nos anos 1980 despontam os primeiros trabalhos acadêmicos sobre o tema. Os anos 1990 e 2000 consolidam e ampliam a tendência anterior, com aumento de produção acadêmica, de espaços especializados em revistas, revistas virtuais, seminários e revalorização do mercado editorial de arquitetura.

Construiremos a seguir um panorama historiográfico acerca de Warchavchik. Neste quadro, não temos como objetivo expor sua trajetória, analisar sua obra ou traçar uma contextualização histórica de sua produção. O estudo deverá se restringir ao universo das palavras: primeiramente, apresentaremos a produção intelectual do arquiteto e a recepção crítica na virada dos anos 20 para os anos 30 e a divulgação nos periódicos especializados entre os anos 1940 e 1950 para então discutirmos as interpretações da historiografia a partir dos anos 1950 em obras panorâmicas sobre arquitetura moderna no Brasil, das primeiras às mais recentes, e nos trabalhos monográficos dedicados ao arquiteto. Ficam de fora artigos, livros e mesmo trabalhos acadêmicos que tangenciam a obra de Warchavchik - em capítulos, recortes tipológicos, geográficos, etc., pois fogem ao escopo da pesquisa. O que nos interessa é compreender, nas obras gerais e específicas, os seus enfoques, recortes temporais e objetos, para podermos pensar a seguir de que modo as interpretações produzidas sobre o arquiteto 
vêm operando no processo de atribuição de valores para o tombamento e intervenção sobre suas obras.

WARCHAVCHIK, DEBATEDOR, AUTOR.

A atuação de Warchavchik em sua primeira fase da carreira é decerto a mais conhecida. Inicia-se com a publicação do fundante manifesto publicado em catorze de junho de 1925, sob o título "Intorno all'architettura moderna" no jornal ítalo-brasileiro Il Piccolo. O manifesto inseria-se na coluna Note d'arte, sob a chamada "Futurismo?" do diário ítalo-brasileiro, que introduzia o escrito assinalando a relevância da discussão por ele levantada, do problema da habitação, da construção das cidades e da arte propriamente, já antevendo os possíveis obstáculos à sua aceitação oriundos do preconceito.

O jornal, voltado à comunidade italiana de São Paulo, trazia notícias da cidade, da Itália, do Brasil e exterior, colunas de arte e entretenimento, esportes, crônica social, economia e comércio e classificados, com inserções comerciais em italiano de produtos e serviços correntes naquele período. Entre os artigos publicados no dia, destacava-se na capa "La fortuna di Lenin”, que descrevia os avanços do comunismo em regiões como Afeganistão, China, Chile, Marrocos, Bulgária. O jornal claramente apoiava as ideias do arquiteto, que por iniciativa de Osvaldo Costa, teve seu manifesto traduzido e publicado no jornal carioca Correio da Manhã em $1^{\text {a }}$ de novembro do mesmo ano como "Acerca da Arquitetura Moderna”. Com relativa aceitação na imprensa, pode-se, portanto, depreender que elementos contidos em Acerca da Arquitetura Moderna já encontravam respaldo na sociedade.

O manifesto abordava a noção histórica de beleza, a adequação da arquitetura ao espírito de sua época, a integração com o universo da industrialização, o rompimento com o passado:

Para que a nossa arquitetura tenha seu cunho original, como o têm as nossas máquinas, o arquiteto moderno deve não somente deixar de copiar os velhos estilos, como também deixar de pensar no estilo. O caráter da nossa arquitetura, como o das outras artes, não pode ser propriamente um estilo para nós, os contemporâneos, mas sim para as gerações que nos sucederão. A nossa arquitetura deve ser apenas racional, deve basear-se apenas na lógica, e esta lógica devemos opô-la aos que estão procurando por força imitar na construção de algum estilo ${ }^{1}$

Outro tema que se tornaria frequente na produção escrita do arquiteto, já se fazia presente no manifesto - o problema da casa econômica:

Construir uma casa a mais cômoda e barata possível, eis o que deve preocupar o arquiteto construtor da nossa época de capitalismo incipiente, onde a questão da 
economia predomina sobre as demais. A beleza da fachada tem que resultar da racionalidade do plano de disposição interior, como a forma da máquina é determinada pelo mecanismo que é sua alma ${ }^{2}$

Muito se debateu a respeito do universo de referências que presidiu a elaboração do manifesto ${ }^{3}$. Não entraremos nesta questão, mas observamos que a própria multiplicidade de interpretações sobre as filiações de Warchavchik revela a ausência de um caminho único, donde o arquiteto e suas referências compartilhavam de um mesmo universo cultural de renovação - desde a experiência no projeto de modernização conservadora da Companhia Construtora de Santos ${ }^{4}$ à sua formação em Odessa e Roma, ainda de ensinos academizantes, mas em ambientes culturais que proporcionaram a circulação de novas ideias e o nascimento de movimentos vanguardistas, bem como sua vivência em ambientes em plena transformação, tanto na Europa quanto no Brasil, poderiam ter contribuído processualmente para a construção de seu repertório crítico. E se as matrizes não estão claras neste momento, nos escritos seguintes, e posteriormente em sua produção arquitetônica, o arquiteto demonstrará pleno conhecimento dos grandes temas do front modernista.

O manifesto não encontrou impacto imediato, constituindo-se em "uma espécie de mensagem na garrafa, lançada às ondas na esperança de um leitor desconhecido ou um eventual cliente" ${ }^{5}$, em um ambiente arquitetônico então dominado pela polaridade Academia Francesa versus Neocolonial. Somente o ano de 1928 marcará a incursão de Warchavchik nos espaços dos diários.

Decadência e Renascimento da Arquitetura, texto de 5 de agosto de 1928, que prepara o leitor para a série de 10 artigos intitulada "Arquitetura do Século XX", publicada no Correio Paulistano entre 29 de agosto e 16 de dezembro do mesmo ano ${ }^{6}$, demarca o posicionamento de Warchavchik da arquitetura moderna como fato internacional, entretanto passível de adaptação local:

Haverá um só estilo moderno, com suas diferenças oriundas do clima e dos costumes. Teremos talvez uma arquitetura europeia, outra sul-americana, outra americana. Finalmente, todas juntas formarão um só estilo mundial, criado pelas mesmas exigências da vida, pelo material idêntico usado para a construção, o concreto,

2 WARCHAVCHIK, 2006:37

3 SANTOS, 1977:107; BRUAND, 1981:67; SOUZA, 1982:17; FARIAS, 1990:14; 176; LIRA, 2008:134; FALBEL, 2009:7;

4 Warchavchik imigra para trabalhar na empresa de Roberto Simonsen, que com suas teses de eugenia e industrialização planificada, aplicava o modelo de gerência científica, investia em pesquisas para industrialização da construção e projetos para habitação em escala, transformando o próprio processo de elaboração de projetos. Tais investimentos se revertiam paradoxalmente para uma arquitetura de estilos. Cf. MAZA, 2002; SANTOS, 2005; MEUCCI, 2009; e projetos consultados no Arquivo Histórico de Santos.

5 MARTINS, 2006:20

6 Todos republicados em WARCHAVCHIK, 2006 
o ferro, o vidro ${ }^{7}$.

E como fenômeno mundial, cita Warchavchik, já se desenvolve na França, com Le Corbusier, Garnier, Perret, Freyssinet; Na Alemanha, com Gropius e a Bauhaus, Poelzig, Taut, Mendelsohn; na Áustria, com Hoffmann, Behrens, Loos; na Itália, com Sartoris e C. E. Rava; na Holanda, com Van der Velde, Doesburg e outros; nos Estados Unidos, com Frank Lloyd Wright; cita ainda a Hungria, Rússia, Dinamarca e mesmo a Pérsia, com Guevrekian, que se notabilizaria pelo seu jardim cubista da Villa Noailles, projetada por Robert MalletStevens, comumente tido como referência para o jardim de Mina Klabin para a casa à Rua Bahia ${ }^{8}$.

O ponto inicial dos debates é a inauguração da sua primeira obra autoral, noticiada pelo Correio Paulistano em 8 de julho de 1928․ Ali, Warchavchik defende que o Brasil é terreno propício ao desenvolvimento da arquitetura nova, devido ao seu progresso vertiginoso e anuncia a Casa da Rua Santa Cruz como a primeira tentativa do gênero no país, concluindo com a célebre frase, "creio que consegui criar um tipo de casa racional, confortável, de pura utilidade, repleta de ar, de luz, de alegria; enfim, uma boa máquina para se morar nela" ${ }^{10}$. A entrevista é o ponto de partida para a polêmica travada com Dácio de Moraes via Correio Paulistano, através da referida série de artigos publicada ao longo do segundo semestre. O argumento da tradição como “veneno sutil” frente à "vida a viver" aparece aí pela primeira vez, argumento esse que será reiterado em escritos posteriores.

Estes escritos terão claro sentido didático, na defesa e justificativa da revolução arquitetônica de modo acessível ao público, versando sobre temas como os perigos da tradição e da história, a desmistificação do termo "futurismo" pejorativamente empregado para designar as manifestações modernas, a divulgação do conceito de casa-tipo, as ideias de Le Corbusier, a relação entre arte e cultura, o fenômeno do arranha-céu, a exposição em Stuttgart, o congresso dos CIAM em La Sarraz e outros eventos e realizações internacionais.

Ricardo Souza, em sua tese de doutorado sobre o debate arquitetônico entre os anos 1925 e $1936^{11}$, identifica a fortuna crítica de Warchavchik como de extrema coerência, consistência e constância, sofrendo poucas alterações ao longo de sua produção, de modo que tais ideias estarão presentes em maior ou menor grau nos escritos seguintes. Exceção feita ao primeiro sinal de reação nativa às manifestações do pioneiro, a entrevista concedida à revista modernista Terra Roxa e Outras Terras em 1926, na qual recomenda a adoção do classicismo para casas de grande porte e o colonial para as de pequeno porte ${ }^{12}$.

8 PERECIN, 2003

9 O artigo “A primeira Realização da Arquitetura Moderna em São Paulo” foi republicado em SOUZA, 1982

10 WARCHAVCHIK apud SOUZA, 1982:20

11 SOUZA, 2004

12 WARCHAVCHIK, 2006. 
Alguns artigos aqui e ali entre 1928 e 1929 versavam ainda sobre a Casa Modernista da Rua Santa Cruz, como o depoimento de Anísio Teixeira utilizado por Geraldo Ferraz na defesa pelo arquiteto russo ${ }^{13}$, mas também sobre a casa à Rua Mello Alves e demais casas construídas até então ${ }^{14}$. Entretanto são os anos de 1930 e 1931 que testemunham a completa consagração do arquiteto, refletida nos espaços dos diários. O ponto de virada é a exposição da casa modernista à Rua Itápolis (1930), que chega a ser noticiada em mais de quarenta artigos nos principais jornais diários da cidade em um espaço de menos de três meses ${ }^{15}$. A repercussão e o sucesso de público e de crítica levariam Warchavchik a outro patamar de visibilidade, no interior dos círculos modernistas e em termos de acesso a uma clientela mais endinheirada ${ }^{16}$. Entre as manifestações, destacamos os artigos de Mário de Andrade, por algum tempo ambíguo quanto ao moderno e o neocolonial, que louva a legitimidade da casa frente aos "falsos" dos estilos, mas ressalva que a proeminência de Warchavchik reside no seu isolamento: “(...) que mais três engenheiros principiem construindo casas assim aqui e o nome de Warchavchik desaparecerá das deles"17; De Oswald de Andrade, que em primeiro lugar acusará Mário de Andrade de ser o "pior crítico do mundo”, opondo-se com veemência à ideia de uma predestinação do arquiteto ao anonimato, pois se tratava de uma poética particular, apesar da generalização do estilo em processo. Também questiona as observações de Mário sobre a cadeira Luiz XV, que considerava perfeitamente compatível com a casa enquanto objeto artístico. Defendendo as qualidades da obra, estabelece-a como o fim do período de combate aberto pela Semana de 1922:

A casa de Warchavchik encerra o ciclo de combate à velharia, iniciado por um grupo audacioso, no Teatro Municipal, em fevereiro de 1922. É a despedida de uma época de fúria demonstrativa. (...) Da Semana de Arte Moderna à casa vitoriosa de Warchavchik vão oito anos de gritaria para convencer que Brecheret não era nenhuma blague, que Anita Malfatti era a coisa mais séria deste mundo, que a literatura da Academia Brasileira de Letras era uma vergonha nacional, etc., etc.!18

Muitos outros depoimentos positivos sobre a casa e a exposição serão publicados, entre eles de Flávio de Carvalho, Oswaldo Costa, Henrique Dória, Guilherme de Almeida e outros. A voz dissonante mais lembrada é de Christiano Stockler das Neves, opositor ferrenho ao modernismo - ou como Oswald de Andrade diria, um defensor dos "lulus";

Por esses anos, Warchavchik será chamado a opinar sobre os principais temas em pauta no campo disciplinar - O IV Congresso Panamericano dos arquitetos de 1930 no Rio

13 Entrevista concedida à "Tarde" da Bahia, reproduzida em 30 out. 1929 no Correio Paulistano de São Paulo.

14 Como referência utilizamos levantamento realizado por Ricardo Souza sobre o debate arquitetônico nos jornais, de 1925 a 1968, gentilmente disponibilizado por Mônica Junqueira de Camargo.

15 Idem.

16 LIRA, 2008

17 ANDRADE, 1930a

18 ANDRADE, 1930b 
de Janeiro - no qual apresentou sua tese "Como julgar a Tendência da Moderna Arquitetura - Decadência ou Ressurgimento?”, publicada no Correio Paulistano; A lei de censura de fachadas imposta pelo prefeito Anhaia Mello em 1931; O Congresso de Habitação de 1931 em São Paulo - que reservara espaço para exposição das obras do arquiteto e que tivera na programação um dia de visita ao novo loteamento da Companhia City no Pacaembu, incluindo a casa da Rua Bahia ${ }^{19}$; A reforma da Escola Nacional de Belas Artes, sendo consultado na condição de ex-professor. Neste período ainda, a inauguração da Casa Modernista da Rua Tonelero, em Copacabana, também merecerá destaque, com diversos artigos noticiando o acontecimento cultural; outras obras ainda serão objeto de reportagens, como a reforma da Associação Paulista de Medicina, ainda em 1931 ou a exposição do Apartamento Moderno do edifício Olinda, no Rio de Janeiro, em 1932.

Após a visita às obras de Warchavchik em 1929, quando de sua curta passagem pelo Brasil, como se sabe, Le Corbusier indicaria o arquiteto a representar a América do Sul nos CIAM. É nessa condição que Gregori faz sua primeira aparição nas publicações internacionais, quando em 1931 a revista Cahiers d'Art publica, por intermédio de Sigfried Giedion, o relatório L'architecture d'aujourd'hui dans l'Amerique du Sud ${ }^{20}$. Seus contatos internacionais fazem com que seja também o único brasileiro ${ }^{21}$ a ter suas obras divulgadas na publicação pioneira na sistematização da produção moderna pelo mundo, Gli Elementi dell'Architettura Funzionale, de Alberto Sartoris, editado em Milão em 1932.

Contraditoriamente, o que aparentava ser um movimento de ascensão e de reconhecimento cada vez maior do arquiteto como protagonista do processo de renovação arquitetônica no Brasil, a partir deste mesmo ano de 1932, vão se escasseando as aparições nos jornais. Algumas obras da sociedade com Lúcio Costa, um texto ou outro relembrando o pioneirismo do arquiteto entre 1933 e 1934, até a passagem de alguns anos sem ser lembrado.

Como já relatado pela historiografia, não à toa, o momento reflete certa reclusão do arquiteto $^{22}$, após um período de intensa atividade arquitetônica e intelectual, estampada nas celebradas exposições das casas modernistas; no envolvimento pessoal como docente na reforma curta e profícua da Escola Nacional de Belas Artes de 1931, a convite de Lúcio Costa; na sociedade com este, até o ano de 1933; nos encontros e atividades da Sociedade Pró-Arte Moderna (SPAM) - cujo episódio da dissolução traduz o clima que permeava o contexto cultural e social daquele período na cidade de São Paulo.

19 O Congresso de Habitação de São Paulo, entre outras abordagens, trouxe à pauta o barateamento e simplificação das construções para habitação, em teses como do Prof. Bruno Simões Magro, que, a despeito do conservadorismo estético, incorporava um dos grandes temas do século XX. Anais do Congresso de Habitação de São Paulo, 1931.

20 Traduzido e publicado em WARCHAVCHIK, 2006

21 Mesmo tendo se naturalizado brasileiro em 1927, estamos considerando aqui brasileiro, não como alguém natural do Brasil, mas que produz a partir dele.

22 FERRAZ, 1965; LIRA, 2008 
A Sociedade congregava mecenas da tradicional oligarquia paulista, imigrantes recém-enriquecidos, muitos dos quais de origem judaica, e artistas de vanguarda, tais como Anita Malfatti, Camargo Guarnieri, Francisco da Silva Telles, Gregori Warchavchik, Guilherme de Almeida, Jayme da Silva Telles, Jenny Klabin Segall, João de Souza Lima, José Wasth Rodrigues, John Graz, Lasar Segall, Mina Klabin Warchavchik, Mario de Andrade, Menotti Del Picchia, Olívia Guedes Penteado, Paulo Mendes de Almeida, Paulo Prado, Regina Gomide Graz, Sérgio Milliet, Tarsila do Amaral e Victor Brecheret ${ }^{23}$. Mina Klabin pertencia ao seleto grupo da comissão executiva e Warchavchik foi um dos doadores que viabilizaram a fundação da instituição. Segall, por seu turno, foi escolhido diretor artístico da SPAM, figura máxima dentro da entidade, que tinha como objetivo

Estreitar as relações entre os artistas e as pessoas que se interessam pela arte em todas as suas manifestações, (...) promover exposições de artes plásticas, concertos, conferências, reuniões literárias e dançantes, (...) organizar cada ano o mês da arte, (...) instalar uma sede social com salão de festas e exposições, sala de leitura, ateliê para $\operatorname{artistas}^{24}$.

O estranhamento étnico e as disputas internas não deixariam a entidade sobreviver por muito tempo ${ }^{25}$. As intensas transformações acarretadas pela Revolução de 30 e seus desdobramentos, bem como o levante constitucionalista de 1932, seriam sentidos no interior da Sociedade, seja pela repactuação das forças políticas em processo, seja pela aproximação político-ideológica com os regimes totalitários. A dissolução da SPAM poderia assim ser entendida como expressão do enfraquecimento da rede de interdependências montada ao longo dos anos 20 ou mesmo como sintoma da alteração na geografia das vanguardas ${ }^{26}$.

Antissemitismo, crise política, nascimento dos filhos e outros fatores, se não "explicam" o momento de silêncio de Warchavchik, ajuda a compreender a virada por que passava sua carreira. Ao que consta, o arquiteto ficaria longe das pranchetas - e dos jornais - pela segunda metade da década de 1930, chegando a não assinar nenhum projeto entre 1935 e 1937. Entretanto, sabe-se que as demandas familiares de gerenciamento e produção de empreendimentos imobiliários nos vastos estoques de terras dos Klabin o perseguiriam por toda a vida. Sua faceta urbanista e empreendedor imobiliário não foi suficientemente estudada até o momento, ficando difícil avaliarmos o quanto de tempo e se nesse período o arquiteto teria se dedicado a essas atividades menos visíveis aos olhos da sociedade ${ }^{27}$.

A retomada de interesse pelo arquiteto por parte da imprensa coincidiria com a volta à produção de projetos de maior destaque, mas o retorno agora se daria prioritariamente em outro veículo de comunicação em franco desenvolvimento: a revista especializada de arqui-

27 Aprofundaremos o problema no capítulo 3, ao tratar da casa da Avenida Rebouças. 
tetura. Até os anos 1930, as publicações especializadas ora priorizavam assuntos técnicos, como as Revistas Politécnica, Engenharia Mackenzie e A Construcção em São Paulo, ora eram contrárias à renovação arquitetônica em curso e privilegiavam a divulgação de obras com orientações academizantes à Beaux Arts, neocolonial ou conforme a moda hodierna - os Cottages, chalets, bungalows, etc., como as revistas Architectura no Brasil, A Casa e Architectura e Construcções, ligada ao Instituto Paulista de Arquitetos, que tinha entre seus frequentes colaboradores, Christiano Stockler das Neves ${ }^{28}$. Em realidade, o próprio campo disciplinar da arquitetura encontrava-se em construção, em um momento em que os profissionais reivindicavam a autonomização e a regulamentação da profissão - a ausência de espaços restritos à arquitetura apenas refletia essas condições. Os assuntos relativos à arquitetura e ao urbanismo eram tratados com grande frequência, até então, nos jornais diários - fato que demonstra, por um lado, a carência de espaços especializados, mas por outro, o interesse de um público mais amplo nas intensas transformações por que passavam a cidade e sua arquitetura.

Nos jornais, uma matéria ou outra neste intervalo relembrava o pioneirismo de Warchavchik, mas o arquiteto receberia destaque mesmo somente em 1939 quando vence o $2^{\circ}$ lugar no concurso para o Paço Municipal de São Paulo, com o recém-formado Vilanova Artigas, em reportagens sobre o concurso e as questões urbanas a ele relacionadas e em 1943, quando o Edifício à Alameda Barão de Limeira foi premiado por concurso promovido pela prefeitura de São Paulo para os mais belos edifícios de 1939 e 1940. Outro episódio que receberia algum espaço na mídia diária seria o projeto de um complexo urbano na Mooca desenvolvido pelo arquiteto apelidado "Cidadinha”, de 1945.

As revistas se diferiam dos jornais por se dirigir a um público especializado, em muitos casos em busca de informações técnicas e referências projetuais. Na trajetória de Warchavchik, podemos apontar como marco inicial de publicações destinadas à divulgação de seus projetos, o já mencionado livro de Alberto Sartoris, Gli Elementi dell'Architettura Funzionale. O catálogo reunia a produção de 58 países em imagens e plantas, sem informações sobre os arquitetos selecionados e mesmo sobre as obras publicadas. Do Brasil, apenas obras de Warchavchik - a casa da Rua Itápolis, a residência Dr. Cândido Silva, casa da Rua Santa Cruz e da Rua Bahia ${ }^{29}$ (figs. 1 e 2).

Mas o momento em que se tornam correntes suas aparições nas revistas coincide com o lançamento da Acrópole, em maio de 1938 e com os impactos da publicação de duas de suas obras - Casa da Rua Bahia e Edifício à Alameda Barão de Limeira - na Exposição Brazil Builds e respectivo catálogo de 1943 (figs. 3 a 5). Até então, tentativas pioneiras de criação de revistas ligadas aos ideais modernistas, como a revista Base - que publicou o

28 SOUZA, 1997:23; SILVA, 2008. Devemos lembrar que somente os anos 1940 assistiriam ao surgimento de escolas de arquitetura constituídas independentemente das Escolas de Engenharia em São Paulo.

29 Somente na edição de 1940 aparecerá o pavilhão brasileiro da feira internacional de Nova York em 1939, de Oscar Niemeyer e Lúcio Costa. 
conjunto habitacional da Gamboa, da sociedade Warchavchik \& Lúcio Costa (1933) ${ }^{30}$ ou a revista Forma, que contou com a colaboração do próprio arquiteto, não passaram de experiências isoladas de curta duração. A revista Acrópole não se identificava com uma ou outra orientação arquitetônica, mas sim, se constituía como mostruário da produção contemporânea, no qual conviviam todos os estilos, sendo o moderno considerado apenas mais um dentro do vasto repertório disponível. Mesmo os posteriormente "convertidos" ao modernismo, como Eduardo Kneese de Mello e Oswaldo Bratke, então sob o comando da firma Bratke e Botti, por exemplo, tinham espaço garantido para suas obras neocoloniais e ecletizantes. Ainda no ano de 1938, apesar do pouco espaço que a revista Acrópole dedicava a temas mais teóricos, Warchavchik teve seu manifesto republicado na edição de setembro, e em dezembro, seria publicada a residência à Avenida Rebouças. Até os anos 1960, seus projetos foram frequentes nas páginas da revista, entre residências, residências de veraneio ou campo, equipamentos esportivos, edifícios residenciais ou comerciais ${ }^{31}$.

Já a exposição Brazil Builds, realizada pelo Museu de Arte Moderna de Nova York em 1943, proporcionaria interesse mundial pela produção brasileira, e o próprio Warchavchik seria beneficiado por isso. O premiado Edifício à Barão de Limeira ${ }^{32}$, após a publicação no catálogo, lhe renderia sua volta aos espaços internacionais de divulgação. Assim, o edifício seria publicado em duas ocasiões pela americana Architectural Record, primeiramente em janeiro de $1943^{33}$, dentro de reportagem sobre a arquitetura brasileira, nos moldes de Brazil Builds - obras do período colonial lado a lado com modernas, e novamente em outubro de 1944, sob o título "Apartment House in Sao Paulo, Brazil" ${ }^{4}$.

Em 1946, Warchavchik será lembrado por Richard Neutra como pioneiro da arquitetura moderna no Brasil em matéria sobre sua viagem à América Latina ${ }^{35}$, e o arquiteto, prefaciado por Warchavchik na edição brasileira de seu livro "Arquitetura Social em países de clima quente” (1948), publicará, no mesmo ano, a residência de veraneio dos Crespi, no Guarujá, em reportagem sobre os sistemas de controle solar na arquitetura latino-america-

30 Mais informações sobre a revista Base e seu criador, Alexandre Altberg, em MOREIRA, 2006.

31 Em 1938, a revista republica o manifesto de 1925 e a Residência à Avenida Rebouças, de 1937. Em fevereiro de 1940, aparece a residência Perez Moral à Rua Chile; Em 1941, o Edifício à Barão de Limeira e uma residência à rua Venezuela em março, a residência Clinton Edward Croke na Vila Mascote, Jabaquara, em novembro; e em 1942, são publicadas a residência Salomão Klabin, residência à rua Honduras e "residências modernas na Av. Europa". O edifício à Barão de Limeira seria publicado novamente na revista em fevereiro de 1943 por conta do prêmio recebido no concurso instituído pela Prefeitura Municipal de São Paulo para edifícios construídos até 1942, em matéria assinada pelo seu ex-detrator, Dácio de Moraes.

32 A construção foi premiada em concurso municipal promovido por Prestes Maia na categoria Edifícios de apartamentos, sendo noticiado, por exemplo, no Estado de São Paulo de 9 jan. 1943 e na Acrópole n.58, p.370-371, fev.1943

33 Architectural Record, Architecture of Brazil, jan. 1943, p.34-56

34 Idem, n.4 v.96, oct. 1944

35 Richard Neutra, Observations on Latin America, may 1946, p.67-72 
na $^{36}$. A residência Crespi ainda é publicada nas revistas Architectural Forum ${ }^{37}$ em 1947 em um especial sobre o Brasil, com a exposição de diversos projetos organizados por tipos, na L'Architecture d'Aujourd'Hui, em 1948, em uma matéria sobre habitações individuais no Brasil ${ }^{38}$ e na Domus em fevereiro de $1949^{39}$. Já em dezembro de 1952, a revista italiana publicaria a casa de veraneio do arquiteto e o pavilhão Marjorie Prado (fig. 6), no Guarujá, com textos bastante positivos quanto à simplicidade e integração com o ambiente praiano, sem que as casas de fim de semana fossem reproduções miniatura das casas de semana ${ }^{40}$.

Curioso é constatar que a residência de veraneio Crespi, mesmo tendo sido publicada em diversas revistas internacionais, no Brasil aparece somente na revista Arquitetura e Engenharia, do IAB-MG, em 1951 e em uma Acrópole de 1954, mas já dentro de uma matéria retrospectiva, o que reflete certo descompasso ou ausência de trocas, que em princípio poderíamos supor haver especialmente dos editores brasileiros em busca de referências nas revistas estrangeiras. Em plano nacional, a Acrópole seguia solitária ao longo dos anos 1940, tendo em vista que somente na década seguinte surgiriam publicações como a Habitat, Bem Estar, AD Arquitetura e Decoração, Módulo, Brasil Arte Contemporânea.

Neste período, a Acrópole privilegiou as residências unifamiliares assinadas por Warchavchik, mas também publicou edifícios residenciais ${ }^{41}$, comerciais $^{42}$ e equipamentos esportivos $^{43}$. No ano de 1958, Warchavchik publicaria na revista seu último artigo, "Importâncias e diretivas da arquitetura brasileira", quase três décadas após o turbilhão polemista dos anos 1930, no qual propõe uma reflexão sobre a produção arquitetônica contemporânea.

Em primeiro lugar, reiterava seu posicionamento fiel a Gropius de que a arquitetura é um fato internacional, refletido nas necessidades locais. Ao mesmo tempo, a considera um fenômeno coletivo, no qual o relevo do país no cenário mundial é incontestável, mas "não pode e não deve ser considerado um 'êxito pessoal' de ninguém, mas de toda uma equipe de trabalho" ${ }^{44}$. Mais do que isso, a crítica ao excesso formalista por que vinha passando a arquitetura brasileira tornava evidente o recado à produção personificada por Oscar Nie-

\footnotetext{
36 Richard Neutra, Sun Control Devices, oct. 1946, p.45-46

37 Architectural Forum, Brazil, nov. 1947, p.65-112

38 L'Architecture d'Aujourd'Hui, Habitations Individuelles au Brésil, jul. 1948, p.72-82

39 N²33, de acordo com CAPPELLO, 2005. O número não está disponível em nenhuma das bibliotecas da USP. Segundo a autora, o arquiteto apareceria também em abril de 1933, no nº 64 com o artigo "Architettura Moderna al Brasile: Gregori Warchavchik"

40 Domus, La casa col Giardino di Sabbia; Il 'Padiglione di Marjorie' alla spiaggia di Pernambuco, dez. 1952, p. $2-5$

41 Como o Edifício “Terejeba”, no Guarujá e o próprio edifício à Alameda Barão de Limeira.

42 Como o Edifício "Leôncio Perez".

43 Como o Estádio Municipal de Santos, o projeto da sede do Clube Atlético Paulistano, capa da Acrópole de janeiro de 1958, o salão de festas do clube Pinheiros e o ginásio do clube A Hebraica, também tema de capa da Acrópole de dezembro de 1958.

44 WARCHAVCHIK, 2006:176
} 
meyer, que já vinha sendo questionado no Brasil e mesmo no exterior ${ }^{45}$ :

No sentido profundo de nossa arquitetura, na intimidade de seu papel criador, pode-se dizer que há duas grandes tendências dominantes: uma, em que se verificam saudáveis manifestações que se inscrevem, com toda a propriedade, na arquitetura orgânica; e outra, que é aquela em que preocupações demasiado plásticas interferem (...). Verificamos, porém, que em muitos casos a se classificarem neste quadro a fórmula plástica subverte o construtivo, e cai tudo em formalismos de fachada, perdendo-se toda a organicidade que a arquitetura viva implica. É a influência, que chamei uma vez de inflacionária, no terreno da arquitetura e da construção, em que se cristalizou o pseudomoderno ${ }^{46}$.

Outra importante crítica se referia à elitização dessa arquitetura, que a despeito de ter surgido como "árvore frondosa", não teria tantas "raízes", nem ainda "chão em que se desdobre" - e a consequência mais grave disso seria a não resolução do problema da habitação. Do mesmo modo, apontava o problema da dissociação da arquitetura ao urbanismo, do pensamento isolado no edifício em si mesmo: "Esta é a palavra de ordem: Urbanismo como orientação para os arquitetos" ${ }^{47}$. Warchavchik apontava como saída, a incorporação desses temas no ensino de arquitetura, quando aproveitava para relembrar o papel que a reforma da Escola Nacional de Belas Artes nas mudanças de rumos da arquitetura a partir de 1931.

$\mathrm{Na}$ década seguinte, a quase inexistência de projetos publicados revelaria a própria diminuição do ritmo do arquiteto em atividade autoral, inicialmente por conta dos trabalhos à frente da construtora Warchavchik - Neumann, até sua aposentadoria. Entretanto, o que gostaríamos de assinalar é que o arquiteto se manteve relativamente presente nas páginas dos periódicos especializados por todo seu período produtivo, chegando a ter obras destacadas internacionalmente, o que explicita que as escolhas que os historiadores fazem para tornar visíveis determinadas obras pode significar também o apagamento de outras, como será verificado com a eleição das obras iniciais e descarte das demais.

Como se vê, a revista Acrópole desempenharia um papel crucial na difusão da obra de Warchavchik. Não sendo uma revista orientada pelo e para o modernismo na sua fase editorial inicial, que vai do lançamento em maio de 1938 até a substituição do seu diretor, Roberto Correia Brito, por Max Gruenwald em setembro de $1952^{48}$, projetos não enquadrados no cânone modernista do arquiteto tiveram seu espaço, o que talvez não coubesse na segunda fase da revista, claramente vinculada ao movimento. Seu caráter informativo foi fundamental para a documentação do legado do arquiteto nesse período.

45 Como a crítica de Max Bill, quando da sua visita ao Brasil em 1953.

46 WARCHAVCHIK, 2006:176-177

47 WARCHAVCHIK, 2006:181

48 MIRANDA, 1998; FONSECA, 2008; 
Nem na revista Habitat, que, mesmo tendo a colaboração de Geraldo Ferraz, principal defensor do protagonismo de Warchavchik na introdução da arquitetura moderna no Brasil e cuja direção de arquitetura lhe coube de novembro de 1955 até o encerramento da revista, em dezembro de $1965^{49}$, o arquiteto tivera tanto espaço destinado aos seus projetos. Como apontado por Lira, o próprio Ferraz, na sua ânsia por demonstrar o pioneirismo do arquiteto, descartando as demais fases de sua produção, alimentou a ideia de que o que realmente interessava eram os anos iniciais, contribuindo a contragosto para o apagamento por que este se sujeitaria por décadas.

De qualquer modo, a revista Habitat exercerá papel fundamental, menos pela divulgação de projetos de Warchavchik, e mais para consagrá-lo simbolicamente como pioneiro da arquitetura moderna no Brasil, através da ação militante de Ferraz. Em um período de quinze anos de existência, a revista apenas publicou três projetos de Warchavchik: a casa de praia do arquiteto, no Guarujá, o projeto para a Sede Social e sinagoga da Congregação Israelita Paulista e a sede do Clube Atlético Paulistano. Por outro lado, sua produção era frequentemente lembrada em reportagens temáticas, editoriais, notas, etc. No artigo intitulado "Duas datas da arquitetura brasileira", Ferraz rememorava o significado da Sede da Associação Brasileira de Imprensa (1936), dos irmãos Roberto e da Casa Modernista da Rua Tonelero (1931), como etapas fundamentais para o desenvolvimento da arquitetura moderna no Rio de Janeiro. No editorial da revista de março de 1956, “Arquitetura e Economia”, o conjunto da Mooca (1929) de Warchavchik e da Gamboa (1933), da sociedade Warchavchik \& Lúcio Costa, são mencionados ao mesmo tempo em que é feita crítica ao conjunto do Pedregulho que, a despeito de suas inúmeras qualidades, seria inviável como solução habitacional em escala no Brasil.

Em diversos artigos, Ferraz fazia lembrar que o início árduo da renovação arquitetônica brasileira se fez por homens como Warchavchik e Flávio de Carvalho, mesmo que o assunto principal não fosse este. Em seu segundo número, de janeiro a março de 1951, a revista republicava o manifesto de Warchavchik, ilustrado por fotogramas da reportagem realizada pela Rossi Filmes sobre a exposição da casa modernista da Rua Itápolis, sob a rubrica "Documento da Arte Brasileira". O texto era antecedido por uma apresentação:

"HABITAT" recolhe aqui alguns manifestos iniciais da arquitetura nova no Brasil. Trata-se, em primeiro lugar, da palavra com que se lançou a nova concepção arquitetônica, devida ao arquiteto G. Warchavchik, que chegado da Europa em 1923, aqui publicava, em novembro de 1925, no "Correio da Manhã", do Rio uma artigo: "Acerca da arquitetura moderna". Este é o primeiro documento escrito no Brasil, defendendo as idéias constantes, nesse mesmo ano, do Bauhaus, de Dessau, do primeiro "Bauhausbücher", de Walter Gropius, "Internationale Architektur", e do pavilhão de "L'Esprit Nouveau", da exposição de Paris, quando Le Corbusier dava a primeira demonstração de suas idéias em arquitetura, num certame inter- 
nacional ${ }^{50}$.

Ao final, ainda a revista relembra que três anos depois o arquiteto construiria na Vila Mariana a primeira Casa Modernista. Suas aparições já denotavam certo sentido histórico das iniciativas de Warchavchik mais que a divulgação de sua produção ativa e contemporânea. Mas gostaríamos de destacar um dos momentos mais contundentes na atuação da revista para a valorização do papel de Warchavchik. Em março de 1956, a Habitat, já sob direção de arquitetura de Geraldo Ferraz, inaugurava a seção "Individualidades na história da atual arquitetura no Brasil”, trazendo um balanço da trajetória de arquitetos considerados fundamentais para a constituição da arquitetura moderna no Brasil. Iniciava por Warchavchik, por ser considerado pioneiro, autor do primeiro manifesto e da primeira casa. A série contaria ainda com artigos dedicados a Affonso E. Reidy (abril de 1956), Rino Levi (maio de 1956), Irmãos Roberto (junho de 1956), Lúcio Costa (outubro de 1956) e Burle Marx (novembro de 1956). A partir de fevereiro de 1957, Ferraz iniciava uma nova seção, "Novos Valores na Arquitetura Brasileira", dedicada à produção de arquitetos da nova geração, abrindo-a com Abelardo de Souza. No texto de abertura, justifica o fim de "Individualidades" pela necessidade de muita pesquisa e tempo empregado para sua realização, tornando-se inviável no cotidiano corrido da redação. Mas considerava "os seis retratados não obstante dos mais significativos valores que iniciaram a nova arquitetura entre nós" ${ }^{51}$, ficando de fora apenas Oscar Niemeyer, Jorge Machado Moreira e Álvaro Vital Brazil e poucos mais, "sendo a maior contribuição a dos que lhes seguem" 52 .

Nas páginas dedicadas a Warchavchik, Ferraz divide o texto em quatro partes, sendo as três primeiras correspondentes a três períodos identificados na sua trajetória. "Warchavchik, pioneiro da arquitetura viva no Brasil” frisa seu papel pioneiro na publicação do manifesto de 1925 e nas primeiras casas modernistas de São Paulo e do Rio de Janeiro, traçando também uma sumária biografia sugerindo paralelos entre o arquiteto e Richard Neutra, imigrado para os Estados Unidos no mesmo ano e contextualizando a publicação do manifesto com as ações de Le Corbusier e Walter Gropius na Europa.

O segundo período, "Da primeira casa modernista de 1927-28, à 'Exposição de uma casa modernista', em 1930”, traz o debate suscitado pela casa da Santa Cruz nos jornais diários, entre defensores e opositores da primeira experiência moderna, entre os quais Mário de Andrade, Anísio Teixeira, Dácio de Morais e o próprio Warchavchik. Deste período, ainda fala das casas da Rua Melo Alves, Thomé de Souza e da Itápolis, da qual descreve a exposição lá realizada em 1930.

O terceiro período, “Aspectos consequentes da revolução no domínio das artes plás-

50 DOCUMENTO da arte brasileira, Habitat, 1951, p.51.

51 FERRAZ, 1957:2

52 A ausência de Oscar Niemeyer parece revelar sua antipatia para com o arquiteto, expressada em artigos em que criticava a atitude antiética do arquiteto em burlar concursos de arquitetura. Um episódio de briga física, em que Niemeyer revidava as críticas, foi relatado pelo jornalista em seu livro de memórias. 
ticas e da arquitetura", foca os desdobramentos da Revolução de 1930, com a reforma da ENBA empreendida por Lúcio, cujo "grande mérito é o de ter vindo a São Paulo para escolher aqui G. Warchavchik para participar da renovação da escola" ${ }^{53}$ e a realização do $38^{\circ}$ Salão de Belas Artes até a produção mais recente do arquiteto. Warchavchik é retratado como protagonista da reforma e pioneiro da arquitetura moderna no Rio, seja por sua construção à Rua Tonelero, seja por sua sociedade com Costa, onde o jovem Oscar Niemeyer se iniciava na nova arquitetura. O reconhecimento internacional refletido na indicação de Warchavchik por Le Corbusier ao CIAM, na publicação no Cahiers d'Art de 1931 e na antologia de Sartoris, Gli Elementi dell'architettura funzionale é também lembrado. Aspecto que merece destaque em sua exposição, é que o jornalista via a efetiva contribuição de Warchavchik limitar-se somente até a construção do Ministério da Educação e Saúde (1936-1945), ainda que identificasse projetos de extrema qualidade como do edifício à Alameda Barão de Limeira, da residência Antônio Prado Júnior, das novas instalações do Clube Atlético Paulistano, ainda em construção àquela altura e do projeto vencedor do concurso para a sede do Esporte Clube Pinheiros: "A importância consequente da atuação de Warchavchik no meio técnico e artístico vai até a formação do grupo do Ministério da Educação (...)" ${ }^{54}$.

O artigo é uma primeira avaliação retrospectiva da produção do arquiteto, na qual se esboça a pista da tônica a ser dada pelo crítico em Warchavchik e a Introdução da Nova Arquitetura no Brasil - 1925 - 1940, publicado em 1965. A série de artigos "Individualidades" tinha como objetivo avaliar como se deu o processo de chegada das novas ideias e sua repercussão no Brasil, de como o movimento moderno internacional era assimilado pela produção brasileira. Revelava-se a intenção do crítico em escrever uma história de via alternativa, contrapondo-se ao discurso que já circulava por aqueles tempos, advindo de uma historiografia que se tornava hegemônica, seguindo as trilhas de Brazil Builds e Arquitetura Brasileira $^{55}$, além de Modern Architecture in Brazil ${ }^{56}$, que viria a ser lançado naquele mesmo ano. Esta tensão tornou-se explícita na discussão travada entre Geraldo Ferraz e Lúcio Costa em 1948 a respeito das origens da arquitetura moderna no Brasil.

\section{DE PRODUTOR ATIVO A OBJETO HISTÓRICO}

A polêmica de 1948 é episódio bem conhecido da historiografia da arquitetura brasileira. No ano anterior, os alunos da Faculdade Nacional de Arquitetura organizavam na revista editada por eles, Anteprojeto, um álbum especial intitulado Arquitetura Contemporânea no Brasil, dedicado "ao arquiteto Lúcio Costa, mestre da arquitetura tradicional e pioneiro da

Idem.

COSTA, 1952

56 MINDLIN, 1956 
arquitetura moderna", levando Geraldo Ferraz a publicar o artigo "Falta o depoimento de Lúcio Costa", no jornal O Diário de São Paulo em fevereiro de 1948. Neste, reivindicava a primazia de Warchavchik e Flávio de Carvalho sobre os cariocas e reclamava de Lúcio Costa o restabelecimento da "verdade histórica, escamoteada no primeiro documentário que se publica no país acerca da nova arquitetura", "desfazendo o falseamento informativo em que começa a ser baseada a história da arquitetura moderna no Brasil”. Como sabemos, Lúcio Costa responderia ao chamamento ironicamente, reconhecendo o pioneirismo paulista, que para ele, não teria maiores consequências, pois o que importava era que a nova arquitetura que ganharia destaque internacional, encarnada na figura de Niemeyer, tinha vínculos diretos com as "fontes originais" do movimento moderno, passando ao largo da contribuição dos pioneiros ${ }^{57}$.

O episódio revela o segundo plano ao qual Warchavchik era deixado. Esquecido pelos alunos e preterido por Lúcio na genealogia da arquitetura moderna brasileira, o arquiteto estrangeiro de discurso internacionalista não tinha lugar na narrativa nacionalista de caráter identitário dentro de um contexto de reconfiguração do Estado Nacional. A essas alturas, o caso já se transformava em sintoma do processo identificado por Martins e Farias $^{58}$ como de consolidação da trama historiográfica hegemônica da arquitetura brasileira. O obscurecimento do arquiteto ligava-se à disputa pela definição das regras do campo arquitetônico ${ }^{59}$ que se reconfigurava naqueles anos de intensas transformações em todos os espectros da vida social brasileira - o que pressupunha o controle simbólico da sua gênese, a alimentar a escrita da história oficial, vista "de cima". O processo de apagamento será por muitos anos irreversível. Trabalhos mais recentes vêm colocando em xeque a história ortodoxa, mas como veremos, seus meandros continuam presentes em publicações contemporâneas, refletindo o fôlego de sua interpretação.

A exposição Brazil Builds, realizada em 1943 pelo MoMA de Nova York é considerada a etapa inicial deste processo. O primeiro levantamento sistemático da produção brasileira, como se sabe, era motivado pelo desejo de estreitamento de laços culturais com o Brasil, um país que viria a ser um "futuro aliado". Inserida na Política de Boa Vizinhança, a exposição revelava o esforço de aproximação cultural com o Brasil, proporcionando ao mesmo tempo a visibilidade internacional e a legitimação interna da arquitetura moderna produzida no país. Goodwin reconhecia as qualidades peculiares de uma produção que assimilava o modernismo internacional em uma leitura própria a partir da adaptação ao clima, aos costumes e tradições locais. A dita matriz historiográfica que se inaugurava se traduzia na naturalização de um processo de continuidade entre arquitetura colonial e moderna, omitindo-se o período eclético e evocando a originalidade do moderno em sua articulação com o tradicional. Produzido com a colaboração Governo Brasileiro, através do Ministério da Educação e Saúde, do Serviço do Patrimônio Nacional e do Departamento de Imprensa 
e Propaganda, não se pode obliterar o caráter oficial que o evento impingia na seleção do que seria representativo da produção brasileira. $\mathrm{O}$ aproveitamento das ideias contidas em "Razões da Nova Arquitetura” (1936) de Lúcio Costa é inquestionável.

O catálogo dividia a exposição em arquitetura colonial e arquitetura moderna, tendo cada uma das partes a sua respectiva introdução. $\mathrm{Na}$ "Introdução II", dedicada à segunda, Philip Goodwin relata que "Muito antes do advento do governo Vargas, em 1930, apareciam no Brasil os primeiros ensaios de arquitetura moderna. De início modesto, coincidindo com uma verdadeira febre de construções, generalizou-se rapidamente" ${ }^{60}$, sem citar arquitetos ou obras. Para ele, "embora os primeiros ímpetos modernos tenham chegado por importação, bem logo o Brasil achou um caminho próprio". Com grande influência francesa sobre a cultura brasileira na educação, nas artes, na literatura, asseverava Goodwin, Le Corbusier teve suas ideias bem recebidas e postas em prática "com brilho particular no Ministério da Educação e outras obras em Belo Horizonte" ${ }^{61}$. Para o arquiteto, a grande contribuição brasileira se dava nas soluções de controle da luz e do calor, nos desenvolvimentos do brise soleil corbusiano, sendo o edifício do MES o exemplo máximo, bem como o edifício da Associação Brasileira de Imprensa (ABI), dos irmãos Roberto, o Iate Clube da Pampulha e a Obra do Berço de Oscar Niemeyer, e a Estação para hidroaviões de Atílio Correia Lima.

$\mathrm{Na}$ apresentação das obras, a seleção privilegiava exemplares da produção carioca, apesar de incluir obras de um Rino Levi ou de um Bernard Rudofsky. Na resenha de Modern Architecture in Brazil, o crítico Geraldo Ferraz fazia referências ao catálogo, apontando não só a omissão completa sobre o papel pioneiro de Warchavchik, mas também sobre Reidy, lembrado apenas por fazer parte da equipe do projeto do Ministério, sem ao menos seu Albergue da Boa Vontade, para Ferraz, a primeira obra pública moderna, ser mencionado. Carlos Lemos, em Arquitetura Contemporânea, compartilhava da crítica à ausência de Reidy no livro. Martins aponta também a omissão com relação a Flávio de Carvalho e Luiz Nunes, que teve sua obra referida apenas de passagem ${ }^{62}$.

Warchavchik não é sequer citado no texto de introdução, o que torna curiosa a inserção de imagem de uma residência de sua autoria sem nenhuma relação com o que está escrito, sob a legenda "Uma casa simples em São Paulo, de Gregori Warchavchik" 63. A obra em questão é a residência Clinton Edward Croke, publicada em novembro de 1941 pela Acrópole (figs. 6 e 7), mas sem qualquer repercussão ${ }^{64}$. No espaço reservado à apresentação

60 GOODWIN, 1943:81

61 Todas as citações em GOODWIN, 1943:81-84

62 FERRAZ, 1957. LEMOS, 1983; MARTINS, 2010

63 GOODWIN, 1943:99

64 A casa, projetada e construída entre 1940 e 1941, já não tinha a radicalidade dos projetos de 1930, apesar de despojada. Como outros projetos residenciais dos anos 1940, Warchavchik jogava com a decomposição de volumes, trabalhando também texturas (pedras, tijolos, cerâmicas, argamassa pintada) e cores para distingui-los. Nestes projetos, o arquiteto abandonava a cobertura em laje e passava a utilizar o entelhamento na composição. Quanto à aleatória inserção no texto introdutório de Goodwin, apenas pode se especular sobre a origem americana do proprietário. Croke residia no Brasil, trabalhando como diretor da Goodyear brasileira 
propriamente dos projetos no catálogo, há duas obras: o Edifício à Alameda Barão de Limeira e a casa da Rua Bahia. Esta foi erroneamente creditada com a legenda "esta construção de Gregori Warchavchik é, geralmente, considerada a primeira casa moderna construída em São Paulo" ${ }^{65}$, e trazia uma fotografia de enquadramento estranho. Ao invés de optar-se por fotos de plano geral da fachada frontal, voltada à Rua Bahia ou mesmo da fachada posterior, orientada para a Rua Itápolis, em imagens divulgadas, por exemplo, na publicação de Sartoris de 1932, selecionou-se uma fotografia de enquadramento fechado em apenas parte de um dos dois blocos que se voltam para o jardim, recoberto pela vegetação, de modo a tornar a construção ininteligível. Já do edifício à Alameda Barão de Limeira, há uma foto em tamanho pequeno em uma vista semilateral do edifício em um ângulo que atenua a curva do balcão frontal, diminuindo o seu impacto, tão valorizado nas fotografias de Zanella publicadas na Acrópole em 1941.

O que causa perplexidade é que a publicação primava por suas fotos de extrema qualidade, de Kidder-Smith e demais colaboradores, mas no caso das obras de Warchavchik, as escolhas parecem ter sido infelizes. Na produção do livro, como assinalado em seu prefácio, as obras que não puderam ser fotografadas pelos americanos, tiveram fotos aproveitadas de outros fotógrafos, recebendo a colaboração dos diversos arquitetos compilados para a reunião do material. Mesmo as duas obras tendo sido amplamente documentadas por notabilizados fotógrafos brasileiros, como Leon Liberman e Hugo Zanella, optou-se por não aproveitá-las. Quem teria auxiliado na seleção destas imagens e com qual critério? Não se trata de apontar “injustiças” nos desenvolvimentos fomentados e alimentados pela historiografia. Seria improdutivo pensar em teorias conspiratórias, mas não se pode ignorar o papel central da imagem fotográfica na divulgação das obras, entendendo-a como representação a partir do real, resultante de uma seleção orientada cultural, técnica e esteticamente pelo fotógrafo ${ }^{66}$. Na mesma linha, há que se pensar nos critérios de seleção e aproveitamento das imagens dentro da linha editorial intencionada. Não há como explorarmos em mais profundidade o papel da fotografia em Brazil Builds ${ }^{67}$, mas o caso ao menos revela o pouco investimento em obras que eram consideradas secundárias na produção do catálogo.

Maria Beatriz Cappello demonstrou o poder de disseminação da exposição nas inúmeras publicações internacionais especializadas ao longo dos anos 1940, que, no geral, acompanhavam a matriz interpretativa proposta por Goodwin e faziam das fotos de KidderSmith a principal fonte de "recepção à distância" das obras abordadas ${ }^{68}$. Única exceção apontada pela autora foi a crítica publicada na coluna "Astragal's Notes and Topics" do The Architect's Journal de 16 de dezembro de 1943, onde se assinalava o pouco apreço pelo detalhe arquitetônico na arquitetura brasileira, ao contrário, por exemplo, da arquitetura

e era sócio do Automóvel Clube do Brasil, possivelmente o meio de contato com o arquiteto.

65 GOODWIN, 1943:178

66 KOSSOY, 2009

67 Sobre o tema, cf. COSTA, 2009

68 CAPPELLO, 2005 

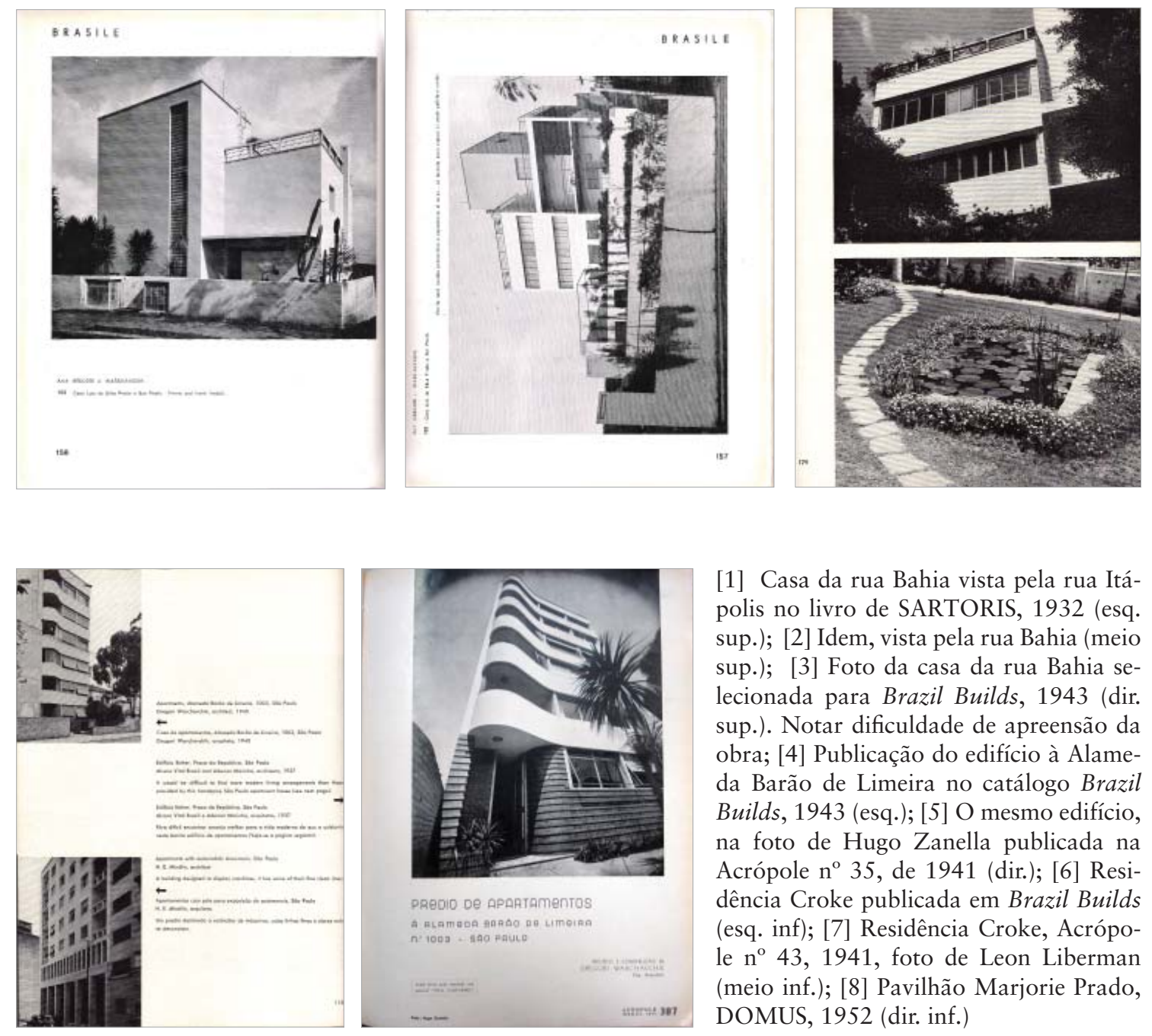

[1] Casa da rua Bahia vista pela rua Itápolis no livro de SARTORIS, 1932 (esq. sup.); [2] Idem, vista pela rua Bahia (meio sup.); [3] Foto da casa da rua Bahia selecionada para Brazil Builds, 1943 (dir. sup.). Notar dificuldade de apreensão da obra; [4] Publicação do edifício à Alameda Barão de Limeira no catálogo Brazil Builds, 1943 (esq.); [5] O mesmo edifício, na foto de Hugo Zanella publicada na Acrópole $n^{\circ}$ 35, de 1941 (dir.); [6] Residência Croke publicada em Brazil Builds (esq. inf); [7] Residência Croke, Acrópole $n^{\circ} 43,1941$, foto de Leon Liberman (meio inf.); [8] Pavilhão Marjorie Prado, DOMUS, 1952 (dir. inf.)
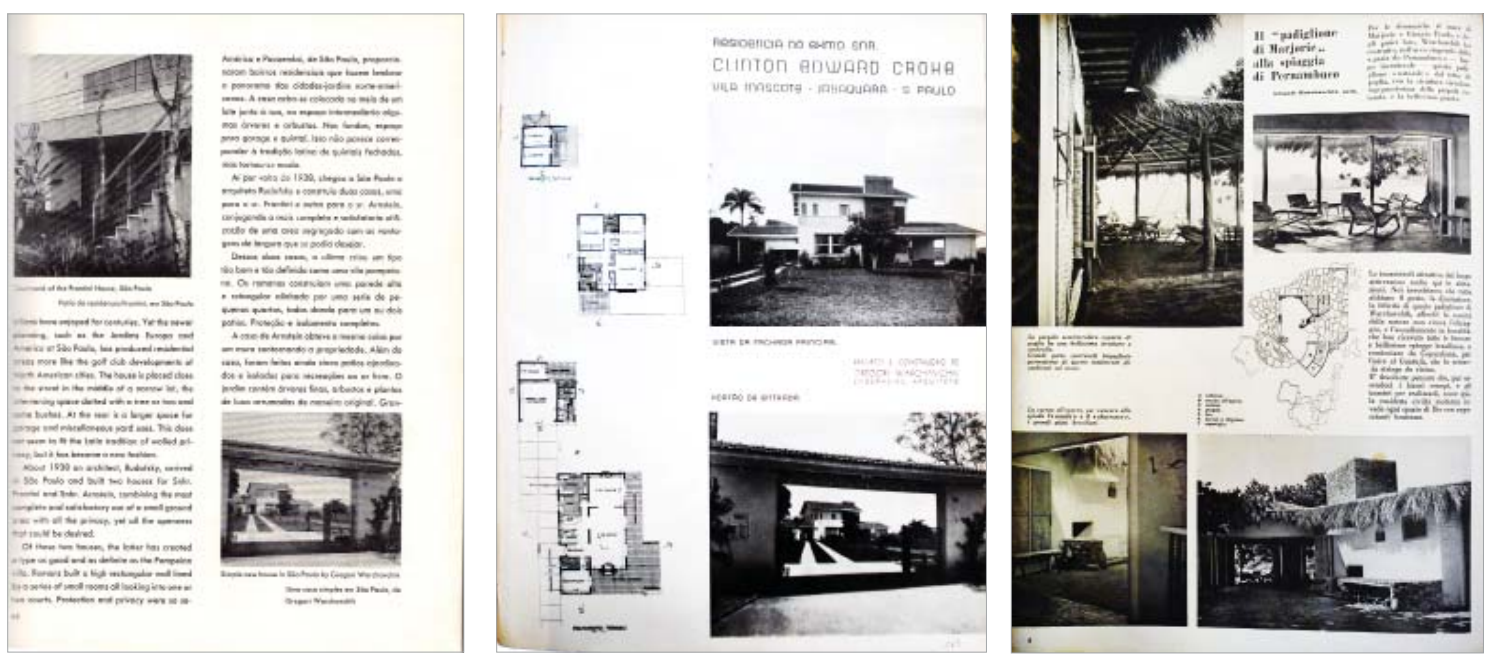
escandinava, e em relação ao catálogo, a ausência de plantas e cortes e a inserção de comentários vagos, apesar de isso não comprometer, para o autor, o interesse que o livro trazia.

Se Brazil Builds se constituiu em primeiro levantamento sistemático desta produção, em 1952, Lúcio Costa publicaria a primeira história geral da arquitetura moderna brasileira, Arquitetura Brasileira, pelo Ministério da Educação e Saúde. O pequeno livro tinha como objetivo rememorar a atividade arquitetônica da primeira metade do século XX no Rio de Janeiro "a fim de precisar melhor os antecedentes do movimento restrito e autônomo, mas persistente, que, por suas realizações, teve o dom de despertar o interesse dos arquitetos estrangeiros a ponto de lhes merecer a visita e o empenho espontâneo da divulgação" ${ }^{69}$. Notase o uso do reconhecimento internacional refletido na exposição do MoMA e artigos nos periódicos especializados estrangeiros como fator legitimador da produção que gravitava em torno do Ministério. Nota-se também o significado do uso do termo "dom" - um talento, uma aptidão nata, para não dizer, uma graça divina, visão coerente com o que proporá em seu livro.

$\mathrm{Na}$ sua investigação sobre os antecedentes desta produção, mostra a inadequação da arquitetura de estilos e infere ser a arquitetura brasileira produto de um desenvolvimento não evolutivo, mas composto de episódios desconexos, sem que um se constituísse em estágio preparatório para outro. Esta parece ser a chave para desvincular a produção do grupo carioca do processo de transformações por que vinha passando a arquitetura no Brasil, crença já bem argumentada em sua carta-depoimento de 1948, bem como para associar o modernismo à arquitetura colonial.

Para ele, embora já se avistasse obras pioneiras, como do edifício "A noite" do engenheiro Emílio Baumgart e da casa da Vila Mariana de Warchavchik, no Rio de Janeiro somente após a reforma da Escola Nacional de Belas Artes ocorreu o processo de renovação:

Conquanto o movimento modernista de São Paulo já contasse desde cedo com a arquitetura de Warchavchik (o romantismo simpático da sua casa de Vila Mariana data de 1928), aqui no Rio, somente mais tarde, depois da tentativa frustrada de reforma do ensino das belas-artes, de que participou o arquiteto paulista e que culminaria com a organização do Salão de 1931, foi que o processo de renovação, já esboçado aqui e ali individualmente, começou a tomar pé e organizar-se ${ }^{70}$.

Costa lista uma série de experiências no Rio de Janeiro, entre as quais as residências Nordschild (Warchavchik, 1931), Schwartz (Warchavchik \& Lúcio Costa, 1932), Albergue da Boa Vontade (Reidy e Pinheiro, 1930-1931) e obras dos irmãos Roberto, Oscar Niemeyer e Carlos Leão. Lembra ainda das primeiras manifestações de descontentamento com o ensino da ENBA, a primeira assinatura de revista L'Esprit Nouveau, por Jayme da Silva Telles, o uso do primeiro brise-soleil por Alexandre Baldassini e dos pilotis por Stelio Alvez de Souza 
em 1931.

Para ele, com esse conhecimento prévio ${ }^{71}$ e com a análise minuciosa das teses de Le Corbusier, foi possível colocar o conhecimento em prática nas obras da ABI (1936-38), dos irmãos Roberto, na Obra do Berço (1937) de Oscar Niemeyer e no Aeroporto de Atílio Correa Lima (1938). Mas o marco definitivo seria o edifício do MES (1936-1945), por seu padrão internacional, com a aplicação da doutrina de Le Corbusier em escala monumental. Belo e simbólico, "porquanto a sua construção só foi possível na medida em que desrespeitou tanto a legislação municipal vigente, quanto a ética profissional e até mesmo as regras mais comezinhas do saber viver e da normal conduta interesseira" 72 .

No livro, ainda, era ressaltado o protagonismo de Oscar Niemeyer neste processo, “arquiteto de formação e mentalidade genuinamente cariocas - conquanto, já agora, internacionalmente consagrado - soube estar presente na ocasião oportuna e desempenhar integralmente o papel que as circunstâncias propícias lhe reservaram e que avultou, a seguir, com as obras longínquas da Pampulha"73. Comparando-o a Aleijadinho, Costa o considerava "chave de enigma" da produção "numerosa e esplêndida" de arquitetos como Reidy, (“impecável veterano"), Mindlin, Irmãos Roberto e outros, em obras muitas vezes enriquecidas também com os jardins de Burle Marx.

Considerava que a arquitetura brasileira, com feição internacional própria, como a arte medieval e renascentista, a essas alturas já se distinguia do conjunto da produção contemporânea - conscientemente desenvolvida com esse propósito - e refutava as orientações de caráter racionalista refratárias aos "rasgos da pura intuição", pois para ele, eram cheias de riscos de se cair em "precoce academicismo".

De um lado, é clara a reiteração da matriz proposta por Goodwin, exacerbando-se o papel de seus agentes; de outro, nota-se o próprio desenvolvimento do programa contido em “Razões da Nova Arquitetura”, publicado em 1936 pela Revista da Diretoria de Engenharia da Prefeitura do Distrito Federal - $P D F^{74}$, orientação muito possivelmente pautadora da própria pesquisa empreendida por Goodwin, a considerar quais foram seus interlocutores no Brasil. No artigo, elegia Le Corbusier como o grande mestre da arquitetura moderna, gênio equiparável a Brunelleschi em suas produções "desconcertantemente originais"; defendia a necessidade de a arquitetura ajustar-se às transformações que se processavam no período, especialmente com relação à revolução construtiva trazida pela indústria e pela estrutura independente - que liberava a fachada e possibilitava a planta livre - deduzindo-se a inadequação dos estilos históricos aos novos recursos; do mesmo modo, mostrava como a comunhão entre arte e arquitetura, expressa na ornamentação realizada por grandes arte-

71 Nota-se que apesar de o arquiteto afirmar o desenvolvimento desconexo da arquitetura brasileira, assume implicitamente o papel das experiências antecedentes ao que considerava seu marco referencial.

72 COSTA, 1952:33-34

73 COSTA, 1952:36

74 Diz-se que foi escrito em 1930, mas consideraremos apenas o ano de publicação. 
sãos, substituída por peças industrializadas, perdia sentido e se re-equacionava na integração entre arquitetura, pintura e escultura; contra as críticas ao internacionalismo da arquitetura moderna, acusada por arquitetos contemporâneos de "judaísmo" - como o grande defensor do Neocolonial José Mariano, argumentava que o internacionalismo era fato tradicional na arquitetura, presente já nas arquiteturas românica, gótica, no classicismo do século XVIII e no academismo que se seguiu. E também negava raízes germânicas, a despeito de a Alemanha contar com inúmeros exemplares. Para Costa, neste país prevalecia a quantidade sobre a qualidade - com exceção da produção de arquitetos como Walter Gropius e Mies van der Rohe - em uma arquitetura que conservava no modernismo "traços inconfundíveis" do "barroquismo", do "assanhamento ornamental" para ele próprios do "barbarismo atávico".

Em Arquitetura Brasileira, a experiência de Warchavchik não é omitida, mas sim assimilada novamente como fato antecedente sem consequências para o desenvolvimento central da arquitetura moderna brasileira reconhecida internacionalmente produzida pelo grupo do Rio de Janeiro; ao chamar de "romantismo simpático" o modernismo de Warchavchik e pontuar como experiências isoladas as residências Nordschild, Schwartz e dos demais arquitetos já mencionados, procura varrer a produção contemporânea a partir de uma interpretação fechada da gênese da produção moderna, procurando não omitir, mas minimizar a relevância destes, em oposição à consagração de determinada orientação como sendo a própria definição do que seria a arquitetura moderna brasileira. Na disputa entre diversos grupos no estabelecimento do campo arquitetônico, dos modernos com relação aos arquitetos de outras orientações - acadêmicas ou tradicionalistas, e mesmo entre modernos, os cariocas imporiam sua vertente como orientação hegemônica, e como ideologia acobertada pelo próprio sistema simbólico construído, tornar-se-ia aceita por todos, sendo gradativamente pensada como única possível ${ }^{75}$. Apesar de o livro ter sido preterido de trabalhos de revisão historiográfica como de Martins, Farias ou de Nelci Tinem ${ }^{76}$, que elegeram Goodwin, Mindlin e Bruand como os passos da construção desta coordenada interpretativa, é óbvio seu poder discursivo, levando-se em consideração a própria ascensão que o arquiteto Lúcio Costa exercia sobre o meio arquitetônico brasileiro por aqueles anos.

No mesmo ano de 1952 era produzida uma pesquisa que seria publicada no ano seguinte, intitulada Architettura Italiana a San Paolo, de Anita Salmoni e Emma Debenedetti, a qual dedicaria parte de suas páginas a Warchavchik, constituindo-se assim no primeiro estudo publicado sobre sua produção. O livro foi resultado de premiação promovida pelo Instituto Cultural Ítalo-Brasileiro para incentivar trabalhos sobre a relação Brasil - Itália.

75 Como desenvolvido STEVENS, 2003, que propõe uma interpretação bourdiana do campo arquitetônico.

76 Apesar de Martins elaborar sua interpretação da trama historiográfica a partir de Lúcio Costa em sua dissertação de mestrado, o artigo "Há algo de irracional”, escrito a partir de um capítulo da dissertação e que possivelmente tornou-se mais conhecido no meio acadêmico, não faz referência ao livro de Lúcio. FARIAS, 1990; MARTINS, 1987; TINEM, 2006 
À exceção de artigos de 1929 e 1951, de Yan de Almeida Prado, tratava-se também de $1^{\circ}$ trabalho a abordar de forma sistemática a participação italiana "no labor arquitetônico de São Paulo" a partir do ultimo quartel do século XIX ${ }^{77}$. No capítulo reservado à arquitetura moderna, além dos arquitetos italianos imigrados para o país a partir da $2^{\text {a }}$ Guerra Mundial, Lina Bo Bardi, Daniele Calabi e Giancarlo Palanti, as autoras justificavam a inclusão de Warchavchik e Rino Levi não por serem italianos ${ }^{78}$, mas porque "ambos afirmam dever a seus estudos naqueles anos, não somente o preparo técnico, mas também sua profunda formação cultural"79.

Abrindo o capítulo com epígrafe de Bruno Zevi, que versa sobre a influência italiana sobre a produção mundial consistir menos na presença de suas obras que pelo pensamento que as originou, as autoras fazem considerações sobre o ambiente conservador da cultura arquitetônica em São Paulo e sobre o desenvolvimento tardio do modernismo na Itália, contextualizando assim a atuação de ambos os arquitetos, "aos quais se deve a introdução em São Paulo dos primeiros sinais de uma renovação na arte de construir" ${ }^{80}$. Para elas, Warchavchik foi um "homem que sozinho, por esforço pessoal, iniciou o movimento em prol da arquitetura moderna em São Paulo (...)" ${ }^{81}$. Especulavam sobre viagens de estudo que ele teria realizado em seu período de formação em Roma, "assistindo às batalhas que os pioneiros da arte moderna aí conduziam para o triunfo de próprias ideias" ${ }^{82}$. Seu pioneirismo se atestava na publicação do manifesto em 1925 - inserido integralmente no livro - e a construção da casa da Rua Santa Cruz em 1928, desencadeando a grande polêmica nos jornais, na qual apenas Mário e Oswald de Andrade penderiam para seu lado. Além disso, é relatada a dificuldade que o arquiteto teve para aprovar o projeto na prefeitura, tendo que colocar cornijas para atenuar a nudez das paredes. A casa, para as autoras, continha referências de Loos, Behrens e Gropius, traduzindo assim, suas viagens de estudos.

Sem ter como objetivo uma análise total da obra do arquiteto, as autoras, entretanto, propõem uma periodização de sua produção, identificando duas fases: a primeira, que vai do início até a Casa da Rua Itápolis e sua exposição em 1930, como exemplar que encerrava o ciclo de difusão da arquitetura moderna no Brasil ${ }^{83}$; a segunda, que se iniciava com os acontecimentos no Rio de Janeiro, com a chegada de novos protagonistas, como Lúcio Costa, que chamou Warchavchik para a cátedra de arquitetura na reforma da ENBA, Frank

77 Luiz Alberto do Prado Passaglia, prefácio de SALMONI; DEBENEDETTI, 1981:11.

78 Warchavchik era russo e Levi brasileiro, descendente de italianos.

79 SALMONI; DEBENEDETTI, 1981:130.

80 Idem.

81 ibidem.

82 SALMONI; DEBENEDETTI, 1981:132.

83 Na versão traduzida de 1981 é dada a informação de que Geraldo Ferraz noticiara a aprovação de Le Corbusier à casa da Itápolis no Diário da Noite, repetido em um volume sobre Warchavchik que saiu poucos meses depois da edição italiana. Na versão original, as autoras anunciam que volume deveria sair em poucos meses. Ao invés de manter a informação original os tradutores optaram por atualizá-la. Entretanto, nos parece que o dito volume deva ser aquele publicado em 1965 pelo jornalista. 
Lloyd Wright em sua passagem pela capital em 1931, Oscar Niemeyer e um grupo de jovens arquitetos que expuseram no " $1^{\circ}$ Salão de Arquitetura tropical". As autoras explicitam os objetivos do trabalho:

Não é nossa tarefa de narrar os acontecimentos através dos quais a arquitetura moderna conseguiu triunfar no Brasil, tanto mais que eles são brilhantemente narrados pela pena do jornalista Geraldo Ferraz que, por dever do seu ofício, seguiu de perto todas as fases da luta. Nós desejamos somente levar a nossa pesquisa até podermos individuar nas obras de Warchavchik aqueles elementos que seriam dificilmente explicáveis, sem recorrer a uma influência direta da arte italiana, e àquela profunda cultura geral, que se costuma chamar de humanística e que somente é adquirida por quem tenha familiaridade com a história, o pensamento, os monumentos do classicismo ${ }^{84}$.

Geraldo Ferraz é tratado como uma fonte bibliográfica reconhecida, não só para o estudo de Warchavchik, mas da própria história da arquitetura moderna no Brasil, orientando a periodização e a leitura empreendida pelas autoras. Posteriormente, o jornalista se tornará referência para o estudo de Warchavchik, mas perderá espaço para a interpretação canônica da qual ele não compartilhava, justamente com relação às origens da nova arquitetura no Brasil.

Segundo as autoras, Warchavchik teria assimilado as lições dos mestres Gustavo Giovannoni e Marcello Piacentini. Seus projetos italianos de 1921 para habitação aludiam em linguagem simplificada, os palácios do século XVIII e da Renascença. As diferenças entre os projetos de 1921 e as atividades de Warchavchik após 1927, já no Brasil, refletiriam o processo de absorção de obras que arquiteto teria visto no período, como de Loos, Behrens, ou Gropius. Inspiração gropiusiana e cubista seriam visíveis nas casas da Rua Santa Cruz (1927-1928), Mello Alves (1928-1929) e Itápolis (1928-1930). Mas as autoras identificam também traços de um gosto clássico em algumas obras, como na Santa Cruz, na casa da Rua Avanhandava (1928-1929), nos grupos de casas econômicas à Rua Barão de Jaguara (19271929) e Rua Berta (1929-1930).

No projeto originário para casa Klabin à Av. Europa (1940) previa-se pátio retangular com dupla fileira de pilares, o que para as autoras, remetia aos claustros da Renascença. Já o projeto do Paço Municipal (1939) teria lembranças precisas das praças italianas, inclusive com a presença de alta torre isolada. O embasamento do edifício e sua monumentalidade evocavam a obra de Piacentini. Por último, a residência Warchavchik no Guarujá (1949) teria inspiração lombarda, com revestimento em pedras brutas, que lembram moradas rurais do Ticino.

Ao final do livro, foram dispostos anexos com lista de obras, escritos dos arquitetos e dados bibliográficos e, acrescidos na tradução de 1981, dos congressos e exposições que 
Warchavchik participou, além de informações atualizadas, posteriores a 1953. Ao longo do texto e na lista anexa de obras, são inseridas informações sobre o estado atual de alguns imóveis, algo atípico nos trabalhos de história da arquitetura aqui estudados e na bibliografia subsequente sobre Warchavchik. Da casa da Rua Santa Cruz, por exemplo, diz-se "parcialmente modificada" em 1935; as casas da Mello Alves e da Avanhandava, posteriormente modificadas; os blocos da Rua Berta com Afonso Celso, conservadas parcialmente; casa da Rua Itápolis, levemente alterada; casa da Rua Estados Unidos, modificado o telhado.

A despeito do questionável etnocentrismo da leitura, gostaríamos de destacar que ao se desobrigar do debate sobre o "triunfo" do modernismo no Brasil, focando a produção de Warchavchik pela perspectiva de sua formação italiana, o livro não se restringiu à sua fase inicial, considerada a mais relevante posteriormente pela historiografia, abarcando a análise, ainda que sumária, de obras até 1949, data da última construção comentada.

Pouco sabemos a respeito da recepção ou o alcance que o livro teve, considerando-se que sua versão para o português só se deu em 1981. Na edição de março de 1954 da revista Acrópole, $\mathrm{n}^{\circ} 186$, foi publicada uma resenha sobre o livro, escrita por José J. Vicari extremamente elogiosa dos resultados da pesquisa, por se constituir em um estudo panorâmico, mas detalhado sobre as influências italianas em São Paulo.

Em 1956, foram publicados dois trabalhos de grande importância para o estudo da historiografia de Warchavchik, o especial da Habitat, "Individualidades na história da atual arquitetura no Brasil”, já comentado, e Modern Architecture in Brazil, de Henrique Mindlin, um dos marcos da historiografia da arquitetura moderna brasileira.

A obra de Mindlin surgia como uma atualização de Brazil Builds, treze anos após seu lançamento, mas, conforme sua própria observação, por ter este livro sido esgotado há anos, foram incorporados também os projetos julgados mais relevantes lá publicados, como o edifício do MES (Lúcio Costa e equipe), ABI (irmãos Roberto), Barão de Limeira (Warchavchik), Esther (Álvaro Vital Brazil), Grande Hotel de Ouro Preto (Oscar Niemeyer), Obra do Berço (Oscar Niemeyer), Estação de Hidros (Atílio Corrêa Lima), Instituto Vital Brazil (Álvaro Vital Brazil), Cassino, Casa de Baile e Iate Clube de Pampulha (Oscar Niemeyer) e Pavilhão brasileiro de Nova York (Lúcio Costa e Oscar Niemeyer). Seu objetivo:

O objetivo deste livro é antes apresentar, da forma mais condensada e ordenada possível, por meio de um certo número de exemplos selecionados, a imagem daquilo que o Brasil alcançou no campo da arquitetura moderna, de modo a permitir um julgamento fundamentado, tanto por parte dos próprios arquitetos quanto dos críticos daqui e do exterior $^{85}$.

Os mais de 100 projetos, de cerca de 70 arquitetos, foram divididos em quatro categorias - 1. Residências unifamiliares, edifícios de apartamentos, hotéis e projetos de ha- 
bitação; 2. Escolas, hospitais, edifícios religiosos, museus e edifícios de exibição; 3. Administração, comércio e indústria; 4. Transportes, planejamento e paisagismo. Cada projeto era apresentado em uma ou duas páginas, através de texto descritivo sumário, plantas e por vezes cortes e elevações em escala e fotos. Alguns projetos tiveram maior espaço, como o conjunto de Pedregulho, o Centro Tecnológico da Aeronáutica ou o edifício do MES. Entre os arquitetos que mais tiveram projetos publicados, tanto ao longo do texto introdutório quanto no inventário propriamente, podemos destacar Oscar Niemeyer, com 29 projetos, Rino Levi, com 15, Affonso Eduardo Reidy, com 13 e irmãos Roberto, com 12. A qualidade técnica da apresentação dos projetos trazia outro patamar de representação com relação a Brazil Builds, que de fato pecava pela quase completa ausência de desenhos e informações.

Mas sabe-se que a importância do livro extrapola seu caráter documental da produção arquitetônica até 1956. O livro, como continuidade de Brazil Builds, do ponto de vista interpretativo, teria força ainda maior. Com adesão explícita ao pensamento costiano, mas não sem trazer elementos próprios que o diferenciava, o livro logo se tornava obra de referência, aclamada pelos arquitetos daqueles tempos.

O texto era antecedido pelo prefácio de Sigfried Giedion, que com sua autoridade crítica, chancelava o trabalho de Mindlin, fato que, para uma publicação que se pretendia instrumento de divulgação da arquitetura brasileira no exterior, em suas versões em inglês, francês e alemão, não pode ser esquecido. Na conclusão, dizia: "Espero que este livro ajude o mundo a ter uma melhor percepção sobre o que ocorreu no Brasil durante as duas décadas mais importantes de seu desenvolvimento arquitetônico" ${ }^{86}$. Giedion ressaltava a descentralização do movimento moderno, com o surgimento de arquiteturas de alto nível em países periféricos como Brasil e Finlândia. Procurando historiar o rápido desenvolvimento do país, da colonização à modernização do século XX, mostrava-se perplexo diante de um país de industrialização incipiente, mas em franco processo de verticalização: "Há qualquer coisa de irracional no desenvolvimento da arquitetura brasileira" ${ }^{87}$. Também criticava os contrastes entre a especulação imobiliária, "câncer do desenvolvimento brasileiro” e a ocupação precária das periferias.

Referendando Lúcio Costa como principal mentor dos desenvolvimentos próprios da arquitetura moderna no país, opinava que além das obras de individualidades excepcionais, havia qualidade na produção média da arquitetura, característica ausente em outros países - tal visão será negada por outros críticos do livro, como veremos adiante. Para ele, as características que destacavam a produção nativa eram os tratamentos dados às fachadas, quebrando a rigidez encontrada em outros países sul-americanos, os elementos de controle da luz e tratamento de painéis e azulejos, as interessantes soluções de espaços internos, como em Pedregulho, de Reidy, no Centro Técnico da Aeronáutica e no Pavilhão de Exposições do Parque do Ibirapuera, ambos de Oscar Niemeyer, além da relação com a natureza, destacan- 
do a contribuição de Burle Marx.

A seguir, Mindlin abria seu texto já informando o tom a ser dado:

A história da arquitetura moderna no Brasil é a história de um punhado de jovens e de um conjunto de obras realizado com uma rapidez inacreditável. Em poucos anos, uma idéia que teve apenas o tempo de lançar suas raízes, em São Paulo e no Rio de Janeiro, floresceu e alcançou uma maturidade paradoxal. Não demandou sequer, como se poderia supor, o tempo de uma geração, mas apenas os poucos anos da passagem de uma turma pela escola de arquitetura ${ }^{88}$.

Para o arquiteto, "talvez a explicação deva ser procurada antes nos fatores subjetivos de preparação espiritual e de ambiente intelectual do que na evolução da arte da construção ou no desenvolvimento do país" ${ }^{89}$. Da mesma forma, foi por mérito pessoal do Ministro da Educação, Gustavo Capanema, que o curso da história foi mudado: "Foi então que se produziu um desses fatos inesperados que muitas vezes mudam o curso da história. O ministro da Educação, Gustavo Capanema, inspirado por uma mistura de visão, audácia e bom senso que o caracterizava, tomou a decisão pessoal que mais contribuiu para o desenvolvimento da arquitetura moderna no Brasil" ${ }^{90}$.

A personificação do processo de desenvolvimento da arquitetura brasileira retrocede em sua construção teleológica até o período colonial, no qual Aleijadinho retratava o gênio do povo, a mistura das raças, dando sua contribuição própria à história da arte e demarcando pela primeira vez traços de uma interpretação brasileira ao cânone da arquitetura religiosa herdada da metrópole.

O passo seguinte, com a chegada da Corte e a missão francesa de 1816, era marcado por uma importação acadêmica que não correspondia à realidade brasileira, tão bem assimilada na arquitetura nativa de tradição portuguesa, gerando o que Mindlin chamou de "fator de desagregação", e revelava a decadência que a própria natureza desse movimento propiciava. O processo de distanciamento da nossa realidade se estendia pelo período da independência, com uma profusão de estilos, levando à formulação de uma arquitetura de protesto consubstanciada no Neocolonial, como forma de recuperar a que se considerava única tradição legítima: "Se essa reação levou arquitetos menos abertos a uma série de novos pastiches, para outros, como Lúcio Costa, ela clareou rapidamente o problema, levando-os a retomar a tradição de uma construção mais próxima da realidade brasileira" ${ }^{91}$. Se as notas sobre a arquitetura colonial davam pistas, agora a referência explícita a Lúcio Costa torna bastante fácil a identificação de elementos de sua orientação intelectual na interpretação de Mindlin.

\footnotetext{
88 MINDLIN, 2004:23

89 Idem.

90 Ibidem

91 MINDLIN, 2004:25
} 
Para o arquiteto, a união desse sentido de adaptação resgatado da tradição colonial com o "impacto estimulante" das ideias de Le Corbusier, proporcionaria a eclosão do movimento moderno no Brasil. A novidade com relação a Brazil Builds é a consideração sobre alguns fatores antecessores, como a Semana de Arte Moderna de 1922, que, ainda que produzida por um sentido de importação, já expressava a ânsia por uma expressão nacional liberta das influências europeias, como assinalada no radical Movimento antropofágico. Também são lembradas as publicações do Manifesto de Warchavchik e a Carta de Rino Levi de 1925, o projeto de Flávio de Carvalho para o concurso do Palácio do Governo em São Paulo, em 1927 e a inauguração da primeira casa modernista de Warchavchik em 1928. Com isso, quando Le Corbusier realizou sua visita em 1929, "encontrou o terreno mais ou menos preparado".

Então passa a discorrer detalhadamente sobre o concurso e a elaboração do projeto para o MES, aproveitando para lembrar o destaque internacional que a obra de Oscar Niemeyer vinha recebendo, com a elaboração de projetos como do Museu de Caracas, conjunto habitacional em Berlim e participando do projeto para a Sede das Nações Unidas que serviria de ponto de partida para a solução final.

Consciente do papel de Brazil Builds para o reconhecimento internacional e mesmo nacional da arquitetura moderna brasileira, Mindlin alertava, no entanto, para os muitos problemas que ainda se colocavam no caminho - a ausência de planejamento das cidades, o ensino antiquado que forçava os alunos a se formarem de modo autodidata, a mão de obra desqualificada - mas que Mindlin era esperançoso quanto ao processo de qualificação, através da criação dos centros de formação do SENAI - e o fornecimento de materiais de construção, ainda que em crescente produção nacional e padronização. Para ele, os principais problemas, entretanto, eram relacionados às infraestruturas de transporte ferroviário, rodoviário e aéreo, além da falta de capitais e juros altos, que dificultavam os investimentos em longo prazo.

Entre os fatores que destacavam a arquitetura brasileira no plano internacional, sua opinião não difere muito da dos demais críticos, especialmente de Lúcio Costa de Arquitetura Brasileira: os estudos de insolação e as soluções de controle da luz; o desenvolvimento do concreto armado, permitindo economia, estruturas leves, pilotis e os panos livres das fachadas; a integração com as artes, no uso inovador do azulejo, nos painéis e na relação com as demais artes aplicadas; a relação com a natureza, através do trabalho fundante de Burle Marx, o qual auxilia o autor a chegar à sua síntese sobre o que considerava ser a arquitetura moderna:

O paralelismo entre as conquistas de Burle Marx e as da moderna arquitetura brasileira é tal que, colocando à parte as diferenças de escopo e de escala, elas quase poderiam ser descritas nos mesmos termos: espontaneidade emocional, esforço de 
integração às condições do terreno e do clima e reavaliação da linguagem plástica e dos meios de expressão, tudo isso submetido a uma crescente disciplina intelectual ${ }^{92}$.

Como visto, Gregori Warchavchik aparecia no texto inicial como fato antecessor, tendo a casa da Santa Cruz apenas mencionada. Entretanto, outros três projetos do arquiteto compareciam na introdução, ainda que sem relação direta com o texto: as casas das ruas Itápolis, Thomé de Souza e Estados Unidos.

Entre os projetos apresentados, de Warchavchik foram selecionados três: a residência de veraneio do Conde Raul Crespi, de 1943, o pavilhão de praia para sra. Jorge Prado, de 1946 e o edifício à Alameda Barão de Limeira, de 1939. Nas indicações bibliográficas sobre tais projetos, Mindlin listava a Architecture d'Aujourd'Hui e a Architectural Forum que publicaram a residência Crespi e a Domus que publicou o pavilhão. $\mathrm{O}$ arquiteto alertava para a limitação da listagem final de arquitetos, obras e referências bibliográficas, que de fato se confirma na ausência de citação às aparições do edifício à Barão de Limeira em periódicos, como já comentado, mas o que queremos ressaltar aqui é que ele conhecia parte do material publicado no exterior, o que de alguma forma pode ter orientado ou contribuído para a sua seleção.

Da casa dos Crespi no Guarujá, Mindlin destacava que o arquiteto, "um dos pioneiros do movimento moderno no Brasil", conseguiu encontrar boa solução diante de lote exíguo. Para Mindlin, o pavilhão da sra. Jorge Prado, "que já é parte da vida social de São Paulo, mostra uma sofisticação de outro tipo, parcialmente disfarçada pela extrema simplicidade da sua construção", seguindo a opinião da revista Domus que anteriormente elogiara o projeto. Por ultimo, com relação ao edifício à Barão de Limeira, aponta para a "planta bem concebida, aberta e imaginativa", enfrentando o problema para ele comum aos arquitetos no Brasil, que era da exiguidade dos lotes, de modo engenhoso, gerando uma planta compacta, dispensando os acessos de serviços e aposentos de empregados, ainda muito comuns no Brasil.

Modern Architecture in Brazil teve ampla repercussão no meio arquitetônico da década de 1950, o que torna interessante reservarmos algumas palavras sobre sua recepção e sobre os debates que a publicação suscitou por aqueles anos.

Ainda em 1956, foram publicadas resenhas sobre o livro na revista BAC-Brasil Arte Contemporânea, ${ }^{\circ} 8$ e na revista Arquitetura e Engenharia, ligada ao IAB, $\mathrm{n}^{\circ} 42$. Nesta, o texto, não assinado, celebra a ocupação de um vazio que o livro vinha a preencher, como livro de referência para o estudo da produção contemporânea brasileira - ideia que aparece em maior ou menor grau nos artigos que o sucederam. A reivindicação de uma versão em português $s^{93}$, "pois indiscutivelmente se trata da mais perfeita obra de introdução à moderna 
arquitetura brasileira que dispomos", também aparece em algumas das resenhas seguintes. Trata-se de um texto mais descritivo do que crítico, de apresentação e divulgação do trabalho de Mindlin.

Por outro lado, o espaço reservado a ele na $B A C$, já traria novas reflexões críticas. Foram publicados dois textos, sendo o primeiro, "O livro de Henrique E. Mindlin", assinado por "C.M.B", possivelmente, pela relação de colaboradores da revista, C. Magalhães Bastos, de caráter mais descritivo, valorizando o caráter de inventário do livro e noticiando que a versão brasileira dependia de acordo com o Ministério das Relações Exteriores. Já o texto seguinte, "Modern Architecture in Brazil", assinado por "L.C.”, que, pela lista de colaboradores e mesmo pelo estilo do texto, aparenta ser de Lúcio Costa, não se resume a descrever a obra resenhada. Aponta o valor do inventário organizado segundo critério de Mindlin, bem como sua qualidade técnica, mas lembra de que se trata de

Tarefa trabalhosa e ingrata essa de inventariar pois sempre deixa nos interessados a impressão de que faltou alguma coisa, de que as fotografias reproduzidas nem sempre foram as melhores e de que houve, por vezes, desacerto na escolha das que foram ampliadas ${ }^{94}$.

Quanto às omissões, entretanto, traz uma justificativa com a polidez que é a cara de alguém como Lúcio Costa, que dispunha de amplos conhecimentos da arquitetura colonial brasileira:

E de fato houve omissões, como, entre tantas outras, a falta de referência à obra persistente e valiosa de Arcuri, em Juiz de Fora, e à atuação fecunda de Borsói em Pernambuco e na Paraíba. Sirva de atenuante o precedente do vereador segundo da Câmara de Mariana que ao inventariar, em 1790, a arquitetura mineira esqueceu de mencionar a igreja de S. Francisco de Assis, de Ouro Preto - obra prima de Antônio Francisco Lisboa.

Também a famosa modéstia do arquiteto apareceria a seguir, como nenhum outro arquiteto ousaria questionar a sua contribuição:

Em compensação houve também "surenchère", como a desculpável tendência a dar ênfase à contribuição de Lúcio Costa, ainda mesmo naqueles casos onde foi, apenas, caudatária. Resulta deste balanço juízo favorável e a convicção de que nossa arquitetura ainda tem seiva e já não corre o risco de uma degenerescência precoce, pois apesar da onda de pernosticismo e mau gosto que ainda se observa na obra bastarda de tantos construtores, incorporadores, arquitetos e engenheiros irresponsáveis, ela tem sabido preservar as suas qualidades fundamentais de simplicidade, graça e invenção. 
E por fim, avalia que, passado o primeiro surto renovador, as soluções vinham caminhando sempre no mesmo sentido, o que poderia levar à conclusão de que "a arquitetura brasileira já se desincumbiu do seu recado" ${ }^{95}$. No entanto, apontava que mal o livro era lançado, já se encontrava desatualizado: o resenhista concluía que as construções de Niemeyer para a nova capital mostravam que o ciclo ainda não estava fechado.

Elementos desta crítica apareceriam dois anos depois na resenha de Henry-Russel Hitchcock, publicada no Jornal of Architectural Historians em 1958. Para o crítico, a expectativa em torno de Brasília ${ }^{96}$, fora dos planos do livro em menos de dois anos atrás, demonstrava a velocidade com que a arquitetura brasileira se desenvolvia. Outra questão que Hitchcock tocava era o problema dos caminhos da arquitetura nos anos 1950, não só no Brasil, mas também no plano internacional, quando algumas das ideias geniais expressas nas primeiras obras modernas começavam a se vulgarizar em clichês usados "ad nauseum".

Para o autor, o livro de Mindlin não era apenas complemento de Brazil Builds, mas antes, um amplo panorama da produção arquitetônica brasileira, precedida de uma interessante contextualização histórica que remontava à colonização do Brasil e que o fazia concordar com a consideração de que a valorização desta arquitetura ao longo dos anos 1920 não se constituía em uma barreira, mas sim, em uma preparação de terreno para a recepção das ideias de Le Corbusier. Hitchcock valorizava ainda a pesquisa que Mindlin fazia a respeito dos primórdios da arquitetura moderna no Brasil:

A despeito da forte impressão que o edifício do Ministério da Educação causou pelo mundo afora, concluído nos anos de guerra quando a produção de edifícios tinha praticamente cessado por todo o mundo ocidental, esta obra-prima (...) da arquitetura moderna é em geral creditada erroneamente. Não é pouca a virtude da consciência histórica de Mindlin, que dá um quadro mais acurado dos primeiros dias da arquitetura moderna no Brasil do que o que havia disponível anteriormente.

Gregori Warchavchik, arquiteto russo diplomado em Roma, construiu a primeira casa moderna no Brasil em São Paulo em 1928, um ano antes das primeiras palestras de Le Corbusier a caminho de casa, partindo de Argentina e Uruguai. Nem esta nem outras casas construídas por Warchavchik nos próximos anos são dignas de nota, exceto pela data, e hoje elas passam quase despercebidas ${ }^{97}$.

95 Idem.

96 A qual Hitchcock atribui autoria a Lucio Costa, ao mesmo tempo "pai da arquitetura moderna no Brasil” e responsável por seu patrimônio histórico, através da direção do SPHAN.

97 HITCHCOCK, 1958:30-31. Tradução livre de "Despite the striking impression the Ministry of Education Building made on the outside world, rising to completion in the war years when building production had all but ceased throughout the Western World, this masterpiece (...) of modern architecture is often misattributed. It is not the least virtue of Mindlin's historical conscientiousness that he gives a more accurate picture of the early days of modern architecture in Brazil that has previously been generally available.

Gregori Warchavchik, a Russian-born architect trained in Rome, built the first modern house in Brazil at São Paulo in 1928, the year before Le Corbusier first lectures there on his way home from Argentina and Uruguay. 
De qualquer modo, o artigo não deixa de ressaltar o vigor da "Cariocan School" nos seus ícones máximos, reservando alguns parágrafos para o projeto do MES, e seus congêneres. Por fim, concluía:

Certamente todos os que estão interessados nas realizações do século XX vão encontrar aqui um material excepcionalmente animador para um julgamento otimista sobre os resultados do transplante de arquitetura moderna europeia para 0 Novo Mundo (grifo nosso) ${ }^{98}$

O livro, noticiado brevemente na Módulo nº7, de fevereiro de 1957, que na edição anterior publicara um anúncio comercial do mesmo na seção "noticiário", teria boa recepção também na Acrópole e na Habitat. Na Acrópole n 219, de janeiro de 1957, o livro aparece em dois momentos. Primeiramente, no boletim do IAB, em nota sobre artigo positivo publicado no New York Times e na seção "Biblioteca", com a resenha de Eduardo Corona, que elogiava a qualidade da publicação, constituindo-se em documentário o mais representativo possível da produção brasileira dos últimos vinte anos.

Um dos aspectos que Corona destacava era que o livro, não fosse o prefácio de Giedion, poderia dar uma falsa impressão da realidade brasileira. Lembra ele que Giedion denunciava a especulação imobiliária, o "câncer do desenvolvimento brasileiro" e a generalização da moradia precária na periferia. Também elogiava a personalidade de Mindlin, arquiteto militante, que trazia à tona um livro que tinha por mérito abrir os olhos da sociedade "levando pouco a pouco nossa atividade em defesa sempre de uma cultura" 99 .

Geraldo Ferraz abria sua resenha publicada na Habitat $\mathrm{n}^{\circ} 43$, de julho-agosto de 1957, com o mesmo tipo de crítica de Corona. Alertando para pequena quantidade de exemplares de qualidade, desde o passado colonial até a produção contemporânea, criticava o surto imobiliário desmedido, vendo o caso de São Paulo, "a cidade que mais cresce no mundo", com grande preocupação. "Ao participar da arrancada imobiliária, até arquitetos de ilustre nomeada, como Oscar Niemeyer, chegam ao que de pior têm em sua carreira (vejam-se os edifícios construídos em S. Paulo: o Califórnia, o Montreal, o arranha-céu do largo da Misericórdia)" ${ }^{100}$.

Ao contrário do que opinava Giedion, Ferraz entendia que "pouco se avançou no quadro da generalização de novos bons resultados, sendo lastimável que não se encontrem, fora da grande maioria edifícios antológicos, remanescentes do inventário tentado pelos

Neither this nor the other houses Warchavchik built in the next few years are remarkable except for their date and they pass almost unnoticed today".

98 HITCHCOCK, 1958:31. Nota-se o conflito desta ideia de transplante com a matriz historiográfica encampada no Brasil. Tradução livre de "Certainly all who are interested in the achievements of the twentieth century will find here unusually heartening material for an optimistic judgment on the results of the transplantation of European modern architecture to the New World".

99 CORONA, 1957:115

100 FERRAZ, 1957:30. 
autores do 'Brazil Builds' multiplicado número de algo mais tangível”. Considerava que afora a equipe revelada no projeto do Ministério, mais os MMM Roberto, Rino Levi, Warchavchik e poucos mais, não se viu surgir mais novos nomes a fornecer exemplos de mesma qualidade.

Aproveitava o texto para falar sobre o livro de Goodwin, reconhecendo-o como sendo de fato o primeiro levantamento geral da arquitetura brasileira, até então inédito. Ferraz reconhecia os méritos de Brazil Builds, que, a despeito de suas necessidades táticas e estratégicas, se colocava apenas como reportagem de circunstância, a cujo esforço deveríamos ser gratos, mas "Philip Goodwin e Kidder Smith vieram de fora, realizaram um contato, brilhante e proveitoso, viram, fotografaram, tomaram notas, apanharam o avião e foram embora" e conclui: "Essa reportagem adquiriu o valor de um documentário circunstancional" 101.

Já Mindlin, por sua autoridade no movimento moderno, sua cultura, seus conhecimentos técnicos, sensibilidade e interesses, seria um autor dos mais habilitados para esta tarefa. Elogiando as vinte páginas em que o arquiteto sintetizava a história da arquitetura moderna no Brasil, traçando relações com o modernismo nos demais campos artísticos, compondo o quadro para o aparecimento das ações pioneiras de Warchavchik e Rino Levi, Geraldo Ferraz lamentava, entretanto, que o livro não trazia ilustrações da primeira casa modernista nem fizesse referências à primeira casa modernista do Rio de Janeiro, construída por Warchavchik quando de suas idas à capital para lecionar na ENBA, embora outras de suas construções figurassem com destaque no corpo do texto. O fato de o livro abordar os períodos anteriores e posteriores ao levantado por Brazil Builds, fazia deste, segundo Ferraz, um balanço mais completo da arquitetura brasileira.

Como destacado pelos demais comentaristas, para o crítico, o livro era uma catalogação altamente informativa e ilustrativa da arquitetura moderna brasileira, tornando-se um instrumento para o estudo dos projetos, com a apresentação de desenhos em escala, um padrão eficiente de leitura, etc., um "precioso auxiliar para a escola”. De fato, o jornalista alertava que não se podia esperar desta obra uma produção crítica: "no caso de Mindlin, a impossibilidade ética de um julgamento é compreensível”, o que não diminui a envergadura do trabalho do arquiteto.

Apesar de elogiar o trabalho de Mindlin, criticando apenas a ênfase ou não no tratamento dado a algumas obras de Warchavchik, Ferraz irá produzir a seguir uma obra que propõe uma interpretação da gênese da arquitetura moderna totalmente diversa deste. 


\section{VOZ DISSONANTE, MESMO REFERENTE}

Do livro de Mindlin à próxima publicação a tratar de Gregori Warchavchik passarão dez anos. Editado em 1965 e lançado em 1966, Warchavchik e a Introdução da Nova Arquitetura no Brasil - 1925 - 1940, de Geraldo Ferraz, surgiria como voz dissonante com relação ao esquema interpretativo hegemônico. Mas neste intervalo ainda ocorreriam mais três aparições significativas de Warchavchik. Em 1958, o arquiteto assinaria seu último artigo, "Importância e diretivas da arquitetura brasileira”, já comentado; em 1962, seria entrevistado para o "Inquérito Nacional da Arquitetura", realizado pela revista Arquitetura, editada pelo IAB/RJ e em 1963 seria homenageado em sala espacial sobre os pioneiros da arquitetura moderna no Brasil na VII Bienal Internacional de São Paulo.

O livro teve como motivação inicial a polêmica travada em 1948 entre Ferraz e Costa. Para Ferraz em seu livro de memórias "Depois de Tudo" ${ }^{102}$, Lúcio Costa teria cedido, em sua "Carta-depoimento" ao seu ponto de vista, "embora ironizando nosso zelo pela 'verdade histórica'”. E segue: "O que reclamávamos de Warchavchik era a publicação de sua biografia dos anos pioneiros" ${ }^{103}$. Entretanto, levaria anos para convencer Warchavchik sobre a validade do livro e mesmo para a sua fatura: desenvolvido ao longo dos anos $1950 \mathrm{e}$ 1960, com a colaboração de Mina Klabin Warchavchik, esposa do arquiteto, foi concluído por volta de $1963^{104}$. De acordo com relato dos filhos do casal Warchavchik, Sonia e Mauris Ilia Warchavchik, Ferraz passava os domingos na Santa Cruz para trabalhar no livro "que se arrastou por muito tempo" ${ }^{105}$. Mina também teria sido responsável pela consulta a outros interlocutores para avaliar a argumentação desenvolvida por Ferraz, entre os quais Lourival Gomes Machado, Tarsila do Amaral e Lina Bo Bardi, que teriam aprovado o texto sem alterações ${ }^{106}$.

Ao longo desses anos, Ferraz tentara publicar o trabalho sem sucesso, chegando a anunciar o seu lançamento na capa da revista Habitat n ${ }^{\circ}$ 82, de março/ abril de 1965, que continha uma imagem da casa da Rua Itápolis e uma legenda no rodapé: "São Paulo, 1930. A primeira casa modernista, projetada e construída em 1930 pelo arq. Gregori Warchavchik, à Rua Itápolis ${ }^{107}$. Esta casa será mostrada detalhadamente no livro 'Warchavchik', a sair brevemente, em impressão de Habitat Editora Ltda.” Entretanto, o livro só sairia em 1966, portanto depois do encerramento da revista, impresso na gráfica da Habitat editora, editado pelo Museu de Arte de São Paulo e distribuído pela Kosmos livraria. O apoio do

\footnotetext{
102 FERRAZ, 1983

103 FERRAZ, 1983:176-177

104 Idem.

105 Entrevista concedida à Tatiana Perecin e José Lira, em 8 de outubro de 2001, constante do Anexo 1 da dissertação de mestrado de Perecin (2003). Segundo os entrevistados, o longo período de confecção do livro também se devia ao perfeccionismo de sua mãe.

106 FERRAZ, 1983:177

107 É curioso notar que Ferraz ora atribui à casa da Santa Cruz ora da Itápolis o título de $1^{\text {a }}$ casa modernista. A discussão de 1948 parece ter lhe criado um grande trauma.
} 
diretor do MASP, P. M. Bardi, que também foi o autor do prefácio teria sido fundamental para a viabilização do trabalho ${ }^{108}$.

Como informa nota publicada na Revista Acrópole em novembro de 1966, "Já tendo sido posto à venda em São Paulo, o livro não teve aqui a repercussão que encontrou na ex-capital, onde o lançamento foi considerado o principal acontecimento artístico da semana" ${ }^{109}$. No Rio de Janeiro, o lançamento se realizou no Museu de Arte Moderna e contou com a presença de nomes como Lúcio Costa, Jorge Machado Moreira, Olavo Reidig de Campos, Quirino Campofiorito, entre outros ${ }^{110}$.

O livro não nascia com a finalidade de levantar e interpretar a história da arquitetura moderna brasileira sob um ponto de vista panorâmico - mas se tratava, sobretudo, de um dos primeiros trabalhos monográficos dedicados ao estudo de um arquiteto. Contudo, acabava por propor uma via alternativa para a versão canônica da gênese da arquitetura moderna brasileira como um todo, ainda que partindo do exame de um personagem. Por mais óbvia que a observação de que se trata não de um livro panorâmico, mas sim monográfico, o seu próprio formato deve ser posto em discussão, pois, para além do pioneirismo da sua forma monográfica dedicada a um arquiteto no Brasil ${ }^{111}$, este demonstrou o alcance e o poder que a análise de uma produção particular tem de reconfigurar ou ao menos problematizar todo o campo historiográfico. As quase 30 páginas de texto que precedem a apresentação dos projetos e obras de Warchavchik passam a ser item obrigatório para qualquer estudioso que venha a se debruçar sobre o tema.

Outro aspecto que se depreende da opção formal do trabalho é que este, por não ser um balanço da arquitetura no Brasil, se libera do debate com a história hegemônica, constituindo o livro como uma proposta de outra chave de entendimento das origens da nova arquitetura brasileira. Busca para isso outros eixos referenciais, em um discurso que conecta Warchavchik ao plano internacional do movimento moderno, por um lado, e à vanguarda artística tributária da Semana de 22, por outro, assentando-se em uma noção linear de história, que tem como propósito a busca pela "verdade histórica".

Para Ferraz, há uma história objetiva, baseada em documentos entendidos como provas, cuja finalidade é reconstituir os fatos, no dizer de Ranke, "como eles realmente aconteceram"112. Poderíamos, portanto, identificar no autor traços de uma abordagem tra-

108 Ferraz e Bardi estabeleceram contato desde a chegada deste no Brasil, em 1946, quando o então jornalista dos Diários Associados tomara parte com o empreendimento do crítico de arte italiano e Assis Chateaubriand de criação de um museu de arte para São Paulo.

109 ACRÓPOLE, 1966:20.

110 CORREIO DA MANHÃ, 1966.

111 Até aquele momento, as quatro publicações dedicadas a trajetórias individuais então publicadas eram estrangeiras. Rino Levi, arquiteto / obras 1928 -1940, é praticamente um catálogo bilíngue; The work of Oscar Niemeyer de 1950 e Works in progress de 1956 de Stamo Papadaki; e Affonso Eduardo Reidy. Bauten und Projekte, de Klaus Frank e Sigfried Giedion de 1960. CAMARGO, 2009

112 RANKE apud BURKE, 1992:15 
dicional da história, cientificista, positivista ${ }^{113}$, que se manifestará ao longo de seu discurso - no trato cronológico linear do tempo através de sucessão de fatos, no centramento dos eventos na ação de indivíduos, na forma de utilização dos documentos, na própria busca por uma verdade unívoca.

O livro é composto pelo prefácio de Bardi, o texto de Ferraz, "Warchavchik e a Nova Arquitetura", e "A obra de Warchavchik", uma seleção de obras e projetos do arquiteto. Ao longo do livro, excertos de artigos de intelectuais, artistas e arquitetos influentes à época de sua primeira produção foram sendo inseridos de modo a dar legitimidade à argumentação então desenvolvida e ao fim, foram reunidas correspondências internacionais diversas, novamente como o objetivo de comprovar o protagonismo de Warchavchik no período retratado.

A escolha de Bardi como prefaciador nos parece estratégica no sentido de associar ao livro a autoridade de um crítico de arte influente, articulado no plano internacional, tendo no currículo, entre outros, o envolvimento com o movimento de renovação arquitetônica na Itália, a participação nos Congressos Internacionais de Arquitetura Moderna (CIAM) e a elaboração do prefácio de Gli Elementi dell'Architettura Funzionale ${ }^{114}$ de Alberto Sartoris. Neste, Bardi elogia a imparcialidade de Sartoris, que, de um ponto de vista italiano, investiga as manifestações arquitetônicas associadas à civilização moderna - ponto de vista valorizado pelo jornalista no tocante à reabilitação de Antonio Sant'Elia na sua posição de precursor. De certo modo, a mensagem se assemelha ao prefácio de Warchavchik, pois para ele,

O mérito deste livro, todavia, é ter fixado fatos históricos, e a sua finalidade será de servir de documentário e de ponto de partida para o historiador que, algum dia, escreverá a história da arquitetura nova no Brasil, no período de 1925 a 1940. Porque este período, realmente, abriu a trilha que depois se alargou em estrada para a arquitetura contemporânea brasileira, hoje tão falada no mundo inteiro; e, certamente, lembrará quem foi que plantou a primeira estaca no marco zero: Warchavchik ${ }^{115}$.

Em outras palavras, o que Bardi destaca é a suposta isenção na reconstituição de fatos históricos por meio de documentos - que para ele, nesse momento, não estariam sendo interpretados, tarefa posterior para os historiadores; e os documentos, inquestionáveis, atestariam o pioneirismo de Warchavchik. Uma perigosa visão que seduziria autores até hoje ${ }^{116}$.

113 Cf. BURKE, 1992; LE GOFF, 2003

114 SARTORIS, 1932. Além do prefácio de Bardi, introduzido na segunda edição, o livro mantém o prefácio da primeira edição, escrito por Le Corbusier.

115 BARDI, 1965:10

116 O livro não é uma compilação de dados, mas antes, uma proposta de interpretação da obra de Warchavchik e da gênese da arquitetura moderna no Brasil, ainda que travestida da objetividade positiva. Tal é a força do discurso deste livro, que mesmo pesquisas recentes se deixam seduzir por ele: “(...) apesar do caráter monográfico de seu título, (o livro) tem como objetivo contribuir para a constituição da história da arquitetura moderna brasileira. Propõe-se a oferecer dados para uma nova versão dessa história, reivindicando para o arquiteto título do livro a condição de pioneiro do movimento local”. TINEM. 2006:33. 
Seu texto investe na imagem da individualidade que vence por conta própria, formada em contexto negativo de Odessa e Roma e ambientada em meio conservador de São Paulo. Chama a atenção o paralelo que estabelece entre a resistência que Warchavchik teve de enfrentar e a missão francesa de 1816. Vítima da "gritaria" dos artesãos portugueses, tornava-se "impossível à Missão Francesa a tarefa de civilizar as artes com os progressos da atualidade de então"117. Uma visão com resquícios imperialistas que bateria de frente com a versão canônica da história da arquitetura brasileira.

Já o texto de Ferraz, "Warchavchik e a nova arquitetura", é dividido em duas partes, "A nova arquitetura" e "A atuação de Warchavchik", a primeira fornecendo o panorama da constituição do movimento moderno no plano internacional e a segunda discorrendo sobre a trajetória de Warchavchik, permeada pelos acontecimentos históricos julgados decisivos.

Sua argumentação fundamenta-se nas genealogias propostas pelos primeiros intérpretes da arquitetura moderna, em especial Pevsner e Giedion: Individualidades de exceção (como Frank Lloyd Wright, Auguste Perret, Peter Behrens, Adolf Loos, Berlage e Mackintosh), em ambientes negativos traduzem um estado de espírito que leva ao desenvolvimento de novas formas arquitetônicas, propiciadas pelo desenvolvimento técnico do ferro, aço, concreto e ascensor; pela eclosão da Escola de Chicago, do Jugendstil e do Art Nouveau e sua nova noção de moralidade; e pelo surgimento das vanguardas artísticas - em especial o cubismo e o futurismo, que trouxeram novas percepções sobre o espaço-tempo moderno, equiparando-se à revolução causada pelo advento da perspectiva no século XV.

A seguir, despontam Gropius e Le Corbusier como os representantes das duas grandes correntes do movimento moderno, sendo o primeiro considerado o "grande coordenador das ideias do século XX": "Pessoalmente, coloco na hierarquia dessas concepções, em primeiro lugar, a obra de Walter Gropius. Sua concepção didática é mais concretamente planejada, mais objetiva do que a dinâmica propaganda de Le Corbusier" ${ }^{118}$.

Para Farias, tal hierarquização revela a necessidade de contrapor-se à historiografia hegemônica que privilegiou Le Corbusier como o semeador da nova arquitetura brasileira, propondo mais adiante a sintonia da poética de Warchavchik com o internacionalismo do arquiteto alemão ${ }^{119}$. De Le Corbusier, Ferraz destaca o Pavilhão da L’ Esprit Nouveau, pelo interesse especial que trazia consigo, pois entre outras coisas, "guardadas as devidas proporções, (foi) reproduzido no Brasil em 1930, por Warchavchik, na Exposição da 'Casa Modernista' do Pacaembu" ${ }^{120}$. Relembra de seu projeto para o concurso para a sede da Sociedade das Nações que com sua negativa, torna-se ponto de partida para a convergência entre os diferentes grupos no interior do movimento moderno, culminando na criação dos CIAM, em 1928. Esta é, por fim, a chave da passagem do texto para Warchavchik, que já 
estaria nesse ano polemizando com suas primeiras casas modernistas em São Paulo e seria nomeado no ano seguinte delegado dos CIAM para a América do Sul. Ou seja, Warchavchik é introduzido no texto a partir de sua inserção internacional no movimento moderno.

A mesma tônica das genealogias é dada na abordagem de Warchavchik. A ideia geral é que Warchavchik, sintonizado com o espírito do tempo, por esforço pessoal impõe sua arquitetura em ambiente cultural conservador e sem condições materiais propícias. Mesmo com o modernismo literário e artístico já iniciado, não se tinha correspondência na arquitetura, pois quase não havia arquitetos, em um meio dominado por engenheiros e mestres de obras. Tampouco ocorriam discussões sobre urbanismo: "Foi nesse relativo deserto, onde não medravam ainda as novas concepções, que Warchavchik se viu na contingência de rasar caminho, sem muita esperança, entretanto, de poder dar expansão às suas ideias sobre os novos rumos da arte de construir" ${ }^{121}$.

Para Ferraz, com a publicação do manifesto, Warchavchik logo se diferenciaria de seu antigo empregador, Marcello Piacentini. O jornalista aproxima o arquiteto a Gropius e seu manifesto Internationale Architektur e mesmo a Giedion, no compartilhamento da visão de que o "estilo do tempo" é passível de identificação somente no futuro e da ideia de florescimento de uma "nova tradição". Acerca da arquitetura moderna atestaria o pioneirismo de Warchavchik por se tratar da única manifestação relativa à nova arquitetura no Brasil.

O que ele considera o marco seguinte do pioneirismo do arquiteto é tratado nas páginas subsequentes. A casa da Rua Santa Cruz é apresentada primeiramente através das reportagens de época; depois com depoimentos do próprio Warchavchik, de Anísio Teixeira e relato da visita de Le Corbusier, cujo destaque dado por Ferraz é a brasilidade da casa e a adaptação às condições da América do sul. Nesta sequência, Ferraz conclui que a repercussão nos jornais e o depoimento de figuras como Teixeira e Le Corbusier "sejam quais forem as restrições que se queiram levantar quanto a este ou aquele aspecto da construção" ${ }^{122}$, já seriam suficientes para atestar ao arquiteto o título de pioneiro. Não apontando que tipo de restrições se levantava sobre a casa, a seguir descreve as dificuldades enfrentadas no seu processo de construção - a partir do relatório enviado a Giedion contendo detalhes sobre os problemas relacionados aos materiais e mão de obra locais, da descrição da dificuldade que o arquiteto teve de aprovar o projeto na Prefeitura, e mesmo da polêmica que travou com Dácio de Moraes - que revelava o conservadorismo da sociedade - apesar de que tal episódio tenha rendido a Warchavchik um espaço importante de divulgação e discussão nas páginas do Correio Paulistano.

A casa da Vila Mariana, os textos da série "Arquitetura do Século XX” publicados no Correio Paulistano e uma série de construções em que pôde experimentar os lentos avanços técnicos são, para Ferraz, ensaios preparatórios para a realização da "Exposição de uma Casa Modernista”, de março de 1930. A casa da Itápolis receberá grande atenção do crítico, 
em primeiro lugar como alvo das boas impressões de Le Corbusier registradas em entrevista ao crítico quando de sua passagem pelo Brasil em 1929, e que culmina de certo modo, na indicação de Warchavchik para representante sul-americano nos CIAM; Também é destacada a ampla repercussão que a Exposição teve junto aos artistas e intelectuais nos jornais.

É curioso notar que ao longo do texto, Ferraz discute as obras de Warchavchik do ponto de vista das polêmicas, da repercussão, do debate, mas não se propõe analisá-las do ponto de vista estritamente linguístico e arquitetônico. Nem mesmo as casas da Rua Santa Cruz e da Rua Itápolis, que são as que recebem maior destaque, ganham comentários dessa natureza. Enquanto busca aproximar Warchavchik da Bauhaus e Gropius no plano teórico, não pontua como tal matriz se manifesta nas obras.

O crítico segue sua narrativa em "A Revolução de 1930 e o seu Reflexo nas Artes” na qual enfatiza o papel de Warchavchik na reforma da ENBA. A Revolução de 1930 é tratada como uma oportunidade de mudança para o país “logo desfeita”, pois para Ferraz, "os homens de uma certa mentalidade pensavam que iriam ruir os velhos métodos de uma política de clientela”, que se renovariam os processos de educação de massas, que a produção recebesse "um influxo decisivo, para o que havia tantas energias moças e livres num País inteiro a organizar" ${ }^{123}$. Tal visão pode ser considerada fator de diferenciação da historiografia hegemônica, que oculta o episódio e o período do Estado Novo, destacando apenas o esclarecimento do grupo ao redor do Ministério da Educação.

Em “A Casa Modernista no Rio de Janeiro”, Ferraz faz um retrospecto do período carioca após a tentativa frustrada de reformar a Escola de Belas Artes. Passa pela Casa Modernista da Rua Tonelero, com ampla descrição da exposição e seus visitantes, pela divulgação internacional da obra do arquiteto naquele ano de 1931 - na Cabiers D'Art no 2 e no livro de Sartoris, pelo Apartamento moderno, pela sociedade com Lúcio Costa. Sobre esta, assinala que é através das construções realizadas com Warchavchik que Costa terá sua adesão concreta ao movimento moderno, pois até então se limitava a uma questão de princípios. Também relembra que é lá que Oscar Niemeyer tem seu primeiro contato com a arquitetura moderna. Por fim, destaca o $1^{\circ}$ Salão de Arquitetura Tropical, de 1933, como o fim do período de divulgação dos princípios da arquitetura moderna carioca e início de uma fase de pesquisas que terá maior relevância após 1935.

Em seguida, “O período de 1933-1934" é retratado como uma fase pobre de realizações em todas as áreas da economia e da cultura, em função da crise de 1929 e do movimento constitucionalista de 1932. Neste trecho, são destacadas a criação da Sociedade Pró Arte Moderna (SPAM), as atividades do Comité Internacional pour la Réalisation des Problemes d'Architecture Contemporaine (CIRPAC), bem como a indicação de nomes para o CIAM enviados por Warchavchik a Giedion para representar o Brasil - entre eles Lúcio Costa "arquiteto de talento, desinteressado e sério, e que fez muito pela arquitetura moder- 
na no Brasil" 124 . Os abalos mundiais que culminariam na $2^{a}$ guerra mundial explicariam por fim a perda de contato de Warchavchik com os CIAM e "fatos novos, trazidos também, pela situação interna" confinaria os "agrupamentos de São Paulo e do Rio, em suas áreas de influência" 125 .

O trecho seguinte, "O Convite de Le Corbusier", retrata o período da realização do concurso do Ministério da Educação e Saúde. Entretanto, apesar da chamada, Ferraz dedica poucos parágrafos para o projeto, enfatizando o processo de realização do concurso, o convite a Le Corbusier e a projeção internacional que este conferira à equipe do projeto, já tendo em vista uma crítica aos seus influenciados:

Tal influência, entretanto, nem sempre foi benéfica, pela eventual ausência de senso crítico de seus discípulos, pela contrafação do caráter da arquitetura, deixando de ser "a expressão do propósito de uma construção retratada no desenho", como dizem A. E. Richardson and Corfiato em "The Art of Architecture" (Londres, 1948). Salienta-se, dessa forma, um excesso de valorização romântica na transcrição de certas indicações características de Le Corbusier, transcrição essa que perde sua força construtiva para se desdobrar numa espécie de modismo equívoco ${ }^{126}$.

Nada mais será dito sobre o Ministério. Na realidade, os comentários sobre o projeto mais parecem uma estratégia para criticar o formalismo que tomara conta dos arquitetos que tiveram "contato direto com as fontes originais do movimento moderno", possivelmente em conformidade com o balanço crítico desta produção, que se começava a fazer nos anos 1950-60.

O capítulo segue destacando os projetos e obras de Warchavchik do período - os concursos do Paço Municipal, da Praça da República e o edifício da Alameda Barão de Limeira: "Enquanto se passava no Rio a história do edifício do Ministério, Warchavchik, alheio aos acontecimentos realizava seus trabalhos e participava de concursos" ${ }^{127}$.

Em "Marcos de uma História” são refeitos os passos da análise empreendida por Ferraz, esboçando-se algumas conclusões. Primeiramente busca-se "sob uma reprodução direta dos fatos" enfatizar a contribuição essencial e singular de Warchavchik, mesmo que seja "ilógico comparar, é evidente - as primeiras casas de Warchavchik, esforço de um particular lutando sozinho, com um monumento arquitetônico da ordem do programa que teve o Ministério da Educação, obra do governo, com todos os seus imensos recursos" ${ }^{128}$. Entretanto, o autor defende que mesmo uma residência modesta pode ser uma contribuição inovadora, pois, citando Pio Montesi, entende que a casa também é fato arquitetural, e "é da ordenação 
dada ao espaço que temos que deduzir se esses momentos da arquitetura correspondem ou não a etapas definitivas" ${ }^{129}$.

Outro aspecto abordado se refere à influência que Warchavchik exerceu sobre o meio arquitetônico. Em primeiro lugar, é assinalada sua contribuição para as inovações na indústria de móveis, quase se tornando "escola", e o aproveitamento de plantas inovadoras nos conjuntos de habitação econômicas implantados pela cidade; em seguida, seu trabalho pioneiro em São Paulo, no Rio, na ENBA e à frente da firma Warchavchik \& Lúcio Costa, são colocados como fatos que não podem ser ignorados, pois seria "deixar em aberto e sem explicação o período de 1927 a 1937 (...)”.

Por fim, Ferraz coloca em evidência o seu entendimento sobre as etapas da introdução da arquitetura moderna no país, divididas em três momentos: o primeiro, que se inicia em 1928 com as casas iniciais, os artigos e a Exposição da Casa Modernista, a exposição no Congresso de Habitação e o projeto do Tênis Clube Paulista, de Warchavchik; os projetos para o Palácio do Governo e a embaixada da Argentina, de Flávio de Carvalho; o projeto da Santa Casa de Santos, de Jayme da Silva Telles; o edifício Columbus, de Rino Levi. A segunda etapa corresponde ao desenvolvimento da iniciativa no Rio de Janeiro, com a exposição da Casa da Rua Tonelero - e os debates com Frank Lloyd Wright, Warchavchik e Lúcio Costa presenciados por estudantes e jovens arquitetos e a exposição do apartamento moderno. Já a exposição de Arquitetura Tropical de 1933 constituiria o terceiro marco. Ferraz não se estende e não justifica os critérios utilizados nessas escolhas.

A parte final do texto "Um coordenador de progresso" nos parece servir de evocação a uma possível atualidade do pensamento warchavchikiano - pois os problemas que apontava trinta anos atrás relativos à habitação e ao urbanismo não teriam sido superados. Warchavchik é descrito como alguém que rechaça o padrão norte-americano de consumo e exalta o legado da Bauhaus, imaginando o quanto mais a escola poderia contribuir ao progresso, não fosse a sua violenta supressão pela Alemanha hitlerista.

Em resumo, temos que no plano internacional, da confluência da revolução técnica oriunda da revolução industrial, das novas expressões como o Art Nouveau, Escola de Chicago e precursores como Frank Lloyd Wright, Berlage, Oud e outros, desponta a arquitetura moderna no século XX, como expressão atenta às necessidades de seu tempo, personificada em duas individualidades - Walter Gropius e Le Corbusier, sendo Gropius eleito o principal mestre do movimento moderno. Nos idos de 1928 estariam articulando-se em torno dos CIAM, e é nesse contexto de movimentação internacional que surge Warchavchik no Brasil, em meio às grandes transformações de ordem econômica, política, social e cultural que se processavam no país. Como figura solitária, criava suas primeiras polêmicas arquitetônicas por esses anos, do manifesto de 1925 até a Casa da Santa Cruz; da polêmica da Casa da Santa Cruz até a Exposição da casa da Rua Itápolis. Ferraz segue sua periodização com a revolução de 1930 e a reforma da Escola Nacional de Belas Artes; o período de 1933 a 1934 
- fase sem muitos projetos, decorrente de crise mundial e conflitos nacionais; O fim dos anos 1930 - Le Corbusier e o Ministério de um lado, criações independentes de Warchavchik de outro;

Um aspecto interessante do livro é que, com a sua intenção de reconstruir objetivamente os fatos históricos, os acontecimentos são narrados a partir da visão coetânea que se tinha deles. Ou seja, são apresentados textos jornalísticos de época, críticas e outros tipos de documentos, produzidos contemporaneamente aos períodos retratados, sem que a produção de Gregori tivesse ainda se historicizado.

A terceira parte do livro é dedicada à apresentação dos projetos e obras de Warchavchik no período de 1925 a 1940. Os projetos foram organizados de acordo, em primeiro lugar, com a periodização apresentada no texto introdutório, e em segundo, por critérios tipológicos - como as moradias econômicas ("Casas populares"), projetos residenciais de pequeno porte ("Pequenas residências") ou o mobiliário. Ganham destaque as obras que são assinaladas na cronologia de Ferraz - Casa da Santa Cruz, Casa da Itápolis, Casa da Tonelero, Apartamento moderno, concursos, Edifício da Alameda Barão de Limeira, além das residências de maior porte - das Ruas Bahia e Estados Unidos. Outros agrupamentos também comparecem, como as obras da sociedade com Lúcio Costa e projetos de 1929-31.

Como já dito, ao longo do livro são inseridos excertos de entrevistas e artigos de artistas, jornalistas, escritores, arquitetos, intelectuais de modo geral, com dizeres sobre Warchavchik e suas obras: Lúcio Costa, Anísio Teixeira, Osvaldo Costa (duas citações), Mário de Andrade (três citações), Hermes Lima, Osório César, Oswald de Andrade, Christiano das Neves, Menotti del Picchia, Richard Neutra, Le Corbusier (nota sobre visita às obras), Guilherme de Almeida, Paulo Mendes de Almeida, Hélio Silva, Carlos Pinto Alves, Flávio de Carvalho, Mário Longo, Thadeu Sampaio, Alberto Sartoris, Revista Forma, Paulo Torres. À exceção de Christiano das Neves, todos os excertos são colocados no sentido de exaltar as qualidades da arquitetura de Warchavchik. Mesmo as passagens selecionadas de Lúcio Costa são editadas para tornarem-se positivas: Do depoimento em resposta a Ferraz sobre a homenagem recebida de seus alunos, aparece apenas o trecho em que diz não contestar a Warchavchik "a prioridade de haver construído as primeiras casas modernas do Brasil, nem que tais casas foram edificadas, primeiro em São Paulo e depois aqui no Rio de Janeiro". Textos do próprio Warchavchik complementam a documentação escrita posta ao longo da monografia, como a carta a Giedion, o relatório para o CIAM e o artigo "Arquitetura Viva".

Imagens de revistas, jornais, livros, convites, fotogramas, catálogos, e mesmo uma versão fac-símile do catálogo da "Exposição de uma casa modernista" complementam a apresentação das obras e projetos, mostrados através de fotos e plantas, além de cortes, elevações, perspectivas isométricas e à mão livre em alguns casos. Não há textos de apresentação das obras, nem descritivos nem analíticos - os comentários aparecem nas legendas das fotos. Se Ferraz elogiava a qualidade dos desenhos na publicação de Mindlin, dizendo que 
"pela primeira vez se colocou, efetivamente, a planta em escala, os desenhos foram refeitos um por um, os clichês espelham um padrão de ordem e de eficiente leitura, tornando-se por isso absoluta a sua inclusão ilustrativa"130, o mesmo não se repete em seu livro. Os desenhos são apresentados sem escala, norte, cotas - salvo exceções, com diferentes padrões de representação. Quase não são apresentadas implantações dos edifícios, nem mesmo cortes são frequentes, dificultando a compreensão dos projetos. As fotos parecem ser o meio eleito para informar as obras, complementadas pelos desenhos.

Infelizmente, não há créditos nas fotos. Entretanto, sabe-se que foram realizadas por estúdios profissionais, como o Foto Studio Hugo Zanella, Zanella \& Moscardi, Leon Liberman, P. C. Scheier, M. Stein, de São Paulo, e Foto Studio Rembrandt e Sacha Arte fotográfica do Rio, entre outros ${ }^{131}$. Dispostas no livro em tamanhos grandes, as imagens são formas poderosas e silenciosas de valorização do ideário estético de Warchavchik, ainda que com a aparência de elemento isento, fonte pura de informação. As tomadas externas no geral se apresentam em perspectivas que destacam os volumes claros das edificações, enfatizados pelo alto contraste, por vezes com relação ao fundo formado pelos jardins de Mina, mas especialmente pela iluminação escolhida - forte insolação, com sombras riscadas, definidas, como em uma elevação desenhada. Os enquadramentos e ângulos das fotos também são pensados no sentido de valorizar os aspectos que mais se queria comunicar.

A própria seleção do que mostrar deve ser levada em conta. Podemos tomar como exemplo as fotos da residência Antônio da Silva Prado, na Rua Estados Unidos. Das dezessete fotos publicadas, onze retratam diretamente a laje em balanço e varanda frontal do edifício e quatro procuram destacar a transparência e integração visual obtida com os panos envidraçados e a continuidade das salas de estar e jantar. Apenas uma foto mostra a vista dos fundos da casa, em perspectiva que privilegia a fachada voltada para a piscina. Tal fachada posterior não é retratada em vista perpendicular, assim como a lateral oposta ao lado da piscina (correspondente às áreas de serviços). Não sabemos como eram essas fachadas e ao observarmos a planta, veremos que a transparência e a leveza da laje em balanço são dois elementos entre outros possíveis de apreender, selecionados nas fotos por serem considerados os mais relevantes sobre a obra. Poderia ser destacado, por exemplo, o fato de esse espaço contínuo estar na realidade confinado entre dois blocos maciços, pontuados por pequenas aberturas. Enfim, nota-se que a sequência de fotos é uma interpretação da obra retratada.

Outro caso que notamos uma opção talvez deliberada é da casa da Rua Avanhandava. Apesar de não receber nenhum destaque no livro, verifica-se que foi selecionada a fachada lateral oeste para ser retratada e não a fachada frontal, que em teoria, depreendendo das outras obras de Warchavchik, teria um peso significativo. Analisando a planta apresentada, verifica-se a sua simetria, com as três aberturas alinhadas no centro do pano de alvenaria e a repetição das mesmas no térreo e no piso superior. A fachada não fica totalmente simétrica, 
pois há um terraço assimétrico destacado do volume principal. Ainda assim, não pareceria ser um aspecto a ser valorizado em uma obra tida no livro como menor do arquiteto.

Na sequência das obras estão dispostas cópias de correspondências de Warchavchik com interlocutores nacionais e internacionais, como Costa, Giedion, Sartoris e outros e no final do livro, é apresentada uma listagem de artigos e estudos publicados por Warchavchik, sobre Warchavchik, a bibliografia utilizada para o texto de Ferraz e a cronologia das exposições. Tais informações, como o conjunto de elementos apresentados ao longo do livro, resultam em uma sistematização importante da documentação sobre a obra de Warchavchik até então. A despeito da intenção de produzir um trabalho isento, baseado em fatos, com toda a credibilidade das fontes reunidas, ainda hoje o livro é uma das principais referências bibliográficas na história da arquitetura moderna brasileira, não como fonte à espera de um historiador, mas como discurso que organiza uma interpretação sobre a obra de Warchavchik.

\section{CONSOLIDANDO O DEBATE}

No mesmo ano do lançamento do livro de Geraldo Ferraz, 1965, saía Quatro Séculos de Cultura na Cidade do Rio de Janeiro, volume publicado por ocasião do quarto centenário da cidade. O livro era resultado de uma série de conferências, entre as quais de Paulo Santos, criador da cadeira de Arquitetura do Brasil em 1946 na Faculdade Nacional de Arquitetura, no Rio de Janeiro. Em 1977, o capítulo do professor seria editado independentemente como Quatro Séculos de Arquitetura, pela Fundação Educacional Rosemar Pimentel ${ }^{132}$, sendo reeditado em dezembro de 1981 pelo IAB-RJ. No livro, Paulo Santos reitera o caminho já consolidado por seus antecessores, apesar de incorporar novos elementos, traçando um panorama da história da arquitetura brasileira adotando a divisão contida na história política - Brasil Colônia, Império e República. Em que pese sua inserção original em publicação voltada à história do Rio de Janeiro, é explícita certa visão "riocentrista" da história da arquitetura do século XX:

A arquitetura do Rio de Janeiro - porque no Brasil foi aqui, com arquitetos daqui, que a reviravolta se deu - rapidamente vai situar-se: não mais subserviente a Portugal, como no período colonial; não mais subserviente à França, como no período imperial; mas dona de seus próprios destinos, no primeiro plano da Arquitetura Universal ${ }^{133}$.

O texto não se desenvolve linearmente, apesar de seguir mais ou menos cronologi- 
camente a exposição dos diversos tópicos abordados. Sobre o século XX, Santos começa discorrendo sobre as reformas de Pereira Passos, as implicações da industrialização para a produção de ornamentos, o processo de verticalização, as experiências pioneiras em estruturas de concreto armado, como no Copacabana Palace ou no edifício "A Noite"; Passa então a expor o Rio de Janeiro como palco de conflitos entre tendências tradicionais e modernas, entre os estilos classicizantes e o neocolonial. Ainda antes de entrar no tema da arquitetura moderna, Paulo Santos insere algumas entradas antecipando o assunto, como nas menções a Le Corbusier quando fala da década de 1920-1930 e quando critica as estruturas encobertas pela arquitetura de estilos, ou então, quando tratando do neocolonial apresenta a seção "constantes de sensibilidade", aludindo a permanência de certos valores da tradição na obra, por exemplo, de um Lúcio Costa, que promovia a "reconstituição de ambientes a testar a força das constantes de sensibilidade da raça, que nas situações mais imprevistas irrompem com inesperado vigor" (Grifo nosso) ${ }^{134}$. Para ele, o neocolonial trazia de saldo positivo, para influir no movimento moderno, o estudo "de questões de raça, costumes, economia e vida social e artística de nosso povo" ${ }^{135}$.

Então, passa a discorrer sobre o surgimento do movimento moderno no país, com as primeiras manifestações no campo das artes plásticas e literárias - a exposição de Anita Malfatti de 1917, a Semana de Arte Moderna de 1922, realizada em São Paulo, a atuação de Graça Aranha na Academia Brasileira de Letras, em 1924, no Rio, o movimento Pau-Brasil (1924), Verde-Amarelo (1924), Anta (1927), Antropofágico (1928), constituindo-se como um movimento destruidor; Lembra ainda, do Manifesto regionalista de Gilberto Freyre, de 1926, que pretendia reabilitar a tradição nordestina, e da vinda de Marinetti para Rio e São Paulo em 1926.

Lembrando que a arquitetura ignorou a Semana, assevera: "A grande figura do Movimento Moderno na Arquitetura da década 20-30 foi Gregori Warchavchik (...) e o marco zero dessa Arquitetura, o seu Manifesto, publicado em 1925 no Correio da Manhã. (...)" ${ }^{136}$. Santos sugere que o contato de Warchavchik com os ideais de renovação se deu já durante seu período de formação. Conheceu as vanguardas russas em Odessa e as lições italianas "lhe fizeram compreender que os clássicos também foram modernos em sua época" ${ }^{137}$. Afirma então Warchavchik não ter sido influenciado nem por Piacentini, seu principal empregador na Itália, nem por Le Corbusier; "Se influências houve sobre a arquitetura de Warchavchik no Brasil é dele a informação - foram as de seus mestres de Odessa, embora o Manifesto inequivocadamente se ajuste também às idéias especificas de Le Corbusier, com a repetição inclusive da boutade famosa: casa, máquina de morar" ${ }^{138}$.

134 SANTOS, 1977:103. Notar a semelhança com os termos utilizados por Costa nos textos do período.

135 SANTOS, 1977:104.

136 SANTOS, 1977:106

137 SANTOS, 1977:107. A formulação é próxima ao prefácio de Bardi para o livro de Ferraz, sugerindo que Santos o tenha consultado.

138 SANTOS, 1977:107 
Sem encontrar muita repercussão, entretanto, relata Santos, somente em 1928 a palavra passava à ação, com a construção da primeira casa moderna, que adjetiva citando Costa, "a romântica casa da Vila Mariana”, logo seguida por outras, "apelidadas pelo povo de futuristas". Então escreve sobre a forte impressão causada a Le Corbusier que indicava Warchavchik, então, como delegado da América do Sul para os CIAM. Em 1971, após palestra proferida por Paulo Santos no IAB carioca, na qual assinalava o pioneirismo de Warchavchik, este lhe enviara uma carta de agradecimento:

Logo depois recebi uma carta de Warchavchik agradecendo que o tenha apresentado como pioneiro da Arquitetura Moderna do Brasil, posição comprovada pelo seu Manifesto de 1925, publicado no Correio da Manhã do Rio de Janeiro, suas casas de 1928 de Vila Mariana em São Paulo, e o ter sido escolhido (sic), em 1929, pelos CIMAs (sic), representante da América do Sul junto a essa organização - os Congressos Internacionais de Arquitetura Moderna. Senti-me feliz de ter podido dizer-lhe, antes que falecesse, o que aconteceu logo depois, que nós, arquitetos do Rio de Janeiro e o Instituto, o tínhamos nessa elevada conta ${ }^{139}$.

Além de Warchavchik, Santos destaca outras figuras dos primórdios, como Flávio de Carvalho e seus projetos para os concursos para o Palácio do Governo de São Paulo e embaixada da Argentina no Rio, Alessandro Baldassini, o primeiro "pseudomodernista" em terras cariocas e Alexander Buddeus, que já havia realizado obras importantes no seu país de origem; discorre sobre as influências francesas sobre a arquitetura e o urbanismo no Brasil, com a realização da Exposição de Artes Decorativas de Paris, o plano de Agache e a vinda de Le Corbusier em 1929. Encerrando o período da década de 20-30, Santos expõe o IV congresso Pan-Americano de Arquitetos, realizado em 1930, no qual o conflito entre os movimentos moderno, neocolonial e neoclássico tornava-se patente. Jayme da Silva Telles, Warchavchik e Flávio de Carvalho, "os três arquitetos que os jornais da Paulicéia apresentavam como líderes da Corrente Moderna”, defenderiam suas teses - mas o primeiro não compareceu, o segundo delegou a sua a Flávio de Carvalho, que também defendeu a sua "Cidade do Homem Nu", a tese mais discutida do Congresso.

Apesar de dividido em fragmentos, o desenvolvimento do livro de Paulo Santos seguia relativamente em uma direção na qual essas experiências se mostravam relevantes. Entretanto, quando entra os anos 1930, imediatamente é descartada a argumentação que vinha sendo construída até então, aparentando tratar-se de outro texto, sem nenhuma relação com os conteúdos antecedentes. Propõe Santos uma periodização da arquitetura moderna que começa com a reforma da ENBA, como o que segue:

$\left.1^{a}\right)$ Fase de implantação (ou "heroica" na interpretação de Warchavchik): da posse de Lúcio em 1930 na direção da ENBA à vinda de Le Corbusier; 
$\left.2^{a}\right)$ Da vinda de Le Corbusier em 1936 e início da construção do Ministério da Educação e Saúde à Pampulha (1941);

$\left.3^{a}\right)$ Da Pampulha (1939-1941) a Brasília (1957-1961);

4ª) Iniciada com Brasília (1957...)

As duas primeiras fases tiveram como palco a Cidade do Rio de Janeiro; as duas seguintes se processaram fora do Rio, mas por obra predominante de arquitetos cariocas; diplomados aqui militando aqui, que daqui irradiaram suas idéias para todo o Brasil e para fora do Brasil, situado o Rio como um dos focos da arquitetura universal ${ }^{140}$

Descrevendo a reforma articulada por Costa, diz: "Buddeus e Warchavchik fizeram na Escola verdadeira revolução (...). Warchavchik como pioneiro do Movimento Moderno, trazia para o Ensino o prestígio das casas 'modernas' que desde 1927-1928 construíra em S. Paulo e o de ter sido escolhido por Le Corbusier representante dos CIAMS para toda a América do Sul" ${ }^{141}$. E então fala dos impactos na formação dos alunos, comparando o curto ciclo da reforma à transferência da Bauhaus de Weimar para Dessau. Nesta história da arquitetura moderna que se centra no Rio, chama ainda atenção a afirmação de que a reforma do Salão de Belas Artes tivera maior importância e repercussão do que a Semana de 1922, evocando a opinião de Rodrigo Melo Franco de Andrade.

Outro episódio apresentado como definidor da primeira fase, é a vida de Frank Lloyd Wright e suas prelações quase diárias na "primeira casa modernista da Cidade, na Rua Toneleros”, de Warchavchik. Santos atribui ao balcão prismático da casa a fonte de inspiração para o projeto da Falling Water, acompanhando a opinião de Lúcio Costa. Conclui:

Com a construção dessa casa, os pronunciamentos de Wright, o ambiente de tensão na ENBA, a projeção de vários dos participantes nos episódios, a cooperação da Imprensa, a perplexidade simpatizante dos arquitetos e acima de tudo o prestígio pessoal de Lúcio Costa e a força que emanava de suas convicções, estava definitivamente lançada a arquitetura moderna.

Desta primeira fase, cita o Albergue da Boa Vontade de Reidy e Gerson Pompeu Pinheiro e as escolas da PDF, de Wladimir Alves de Souza, Enéias Silva e Paulo Camargo - em uma arquitetura que interpretava ainda literalmente o slogan "casa, máquina de morar”, cheia de falhas construtivas. Também menciona as obras da sociedade Warchavchik \& Lúcio Costa, o Salão de Arquitetura Tropical de 1933, projetos urbanos que vinham sendo desenvolvidos, e a regulamentação da profissão. 
O texto da segunda fase se abre, evidentemente, com a descrição do concurso para o Ministério da Educação e Saúde, seguido da contratação da equipe liderada por Lúcio sob consultoria de Le Corbusier. Como outros de sua geração, atribui o feito à iniciativa pessoal esclarecida de personalidades políticas, como Capanema neste caso, Rockroy, quando da construção da Torre Eiffel e Juscelino Kubitschek, em Pampulha e Brasília. Para se ter ideia da dimensão dada ao edifício do MES, anteriormente, em discurso proferido pelo professor na condição de paraninfo da turma de arquitetos da Faculdade Nacional de Arquitetura do ano de $1953^{142}$, Santos fez considerações sobre o desenvolvimento da arquitetura moderna em nível internacional, das origens na revolução industrial à formulação dos cinco pontos de Le Corbusier. Para ele, olhando para os 150 anos de atividade industrial, três monumentos se sobressaíam, como os mais significativos da nova mentalidade: o Crystal Palace, a Torre Eiffel e o MES, "síntese estrutural e plástica, a mais expressiva e a mais pura da Civilização Industrial” ${ }^{143}$.

Assim, o professor dedica algumas páginas a Le Corbusier propriamente no livro suas conferências, seus métodos de projeto e sua intimidade, suas contribuições no projeto do MES e da Cidade Universitária. E então, do mestre internacional, passa ao mestre nacional e seu texto doutrinário, "Razões da Nova Arquitetura”, para então abordar as obras orientadas pelo cânone: MES, ABI e Obra do Berço, além do aeroporto Santos Dumont, estação de Hidros, Instituto dos Industriários e outras.

A terceira fase, que cobria o período do Pavilhão do Brasil na Feira de Nova York a Pampulha, se definia pela "superação da ortodoxia funcional e regularidade geométrica de traçados, rumo à procura da liberdade formal” ${ }^{144}$. Em realidade, exclusivamente estas obras definiam a própria fase, o que demonstra não se tratar de emblemas de um período, mas de exemplares excepcionais, mas cuja evolução das formas e concepções era parte de um desenvolvimento que Santos identificava ser como da própria arquitetura brasileira. Do mesmo modo como o Rio de Janeiro expressava toda a revolução que ocorria no campo arquitetônico, um punhado de obras de exceção definia o paradigma, tornando-se inquestionável que a evolução da arquitetura passasse univocamente pela libertação da forma e demais questões colocadas pelo trabalho de Niemeyer. Tais passos, resumia, ocorreram em vinte anos (19201940), da Câmara dos deputados com sua estrutura independente ainda que recoberta por motivos clássicos ao Albergue da Boa Vontade com sua simplificação geométrica, mas ainda subordinada a eixos de simetria; do MES e ABI e a afirmação da independência da estrutura desnuda, da aplicação dos panos de vidro, dos brises, da solução espacial orientada por questões funcionais e plásticas, mas com contenção regular dos traçados ao Pavilhão de Nova York e a Pampulha, guiados pelas mesmas ideias, mas com a liberdade das formas, as curvas, nas quais "a qualidade plástica é a nota dominante do conjunto". 
Por mais que o arquiteto traga as contribuições anteriores e simultâneas ao conjunto da produção carioca, sua narrativa fragmentária permite reforçar a ideia da construção da história da arquitetura por episódios desconexos, assim como Costa em Arquitetura Brasileira, e, ainda que traga com maior ênfase o papel atribuído a Warchavchik e outros personagens nos períodos iniciais do movimento, estes são facilmente deixados de lado na história que realmente lhe interessa - aquela protagonizada pelo grupo carioca em seu epicentro fluminense a partir da década de 1930.

Se Santos trazia uma perspectiva carioca, em novembro de 1978 se iniciaria a publicação de fichas na revista Construção São Paulo, que se estenderia até o ano de 1983, sob o título "Roteiro da Arquitetura Contemporânea em São Paulo", assinado por Carlos A. C. Lemos, Alberto Xavier e Eduardo Corona. Este inventário da produção paulista seria posteriormente reunido em volume único, sob nome de Arquitetura Moderna Paulistana, editado pela PINI em 1983. Neste, afirmavam ser objetivo da publicação "arrolar obras significativas da arquitetura moderna paulistana, estabelecendo itinerários onde curiosos, turistas, estudantes e pesquisadores de arte pudessem localizar exemplares significativos de nossa produção" ${ }^{145}$. Atendo-se à dificuldade de definição da modernidade em arquitetura, os autores adotam a modernidade da arquitetura racionalista definida pelo domínio do concreto armado. Com isso, fixam como marco inicial em São Paulo, a estação da estrada de ferro de Mairinque, de Victor Dubugras, em 1907, seguido de manifestações art deco, “cujo introdutor oficial sem dúvida foi Warchavchik, principalmente em suas definições de interiores, onde sempre buscava uma verdadeira integração das artes”. O guia é aberto, entretanto, com o edifício da Avenida Angélica, de 1927, de Júlio de Abreu Júnior, considerado pelos autores o primeiro edifício moderno na cidade de São Paulo. As fichas eram compostas pela identificação do bem, ano, endereço, autor, geralmente duas fotos, uma planta e textos sintéticos, de um a dois parágrafos, sobre as obras e seus arquitetos.

Duas obras de Warchavchik sucedem o edifício da Avenida Angélica: a casa modernista da Rua Itápolis (fig. 10) e da Rua Bahia. A primeira, erroneamente datada como de 1927 na versão da revista e 1928 na versão do livro, chega a ter os jardins de Mina Klabin Warchavchik referidos como pioneiros no uso de elementos próprios da flora brasileira - datas e informações sabidamente atribuídas à casa da Rua Santa Cruz. Quanto à ficha da casa da Rua Bahia, entre a publicada em 1978 e a de 1983, há na revisão uma diminuição do alcance da obra de Warchavchik, na interpretação dos três arquitetos. Na primeira versão:

Num curto período, compreendido entre 1927 e 1933, realiza Warchavchik uma obra precursora, que em muito contribuiu para encarar a arquitetura como uma manifestação liberta dos moldes estilísticos e históricos.

E então prosseguem: 
No entanto não interferiu ela no desenvolvimento imediato da arquitetura brasilei$\mathrm{ra}$, cujos fundamentos se apoiaram nos princípios de Le Corbusier, via arquitetos cariocas $^{146}$.

Na segunda versão:

(...) No entanto não interferiu ela no desenvolvimento imediato da arquitetura paulista e muito menos brasileira, cujos reais fundamentos apoiaram-se nos princípios de Le Corbusier, via arquitetos cariocas, a partir de 1936 e, nesta ocasião, expressivamente representados em São Paulo pelo edifício Esther (grifos nossos) ${ }^{147}$.

As reticências quanto à obra de Warchavchik ficariam ainda mais evidentes com a publicação ainda em 1979, de Arquitetura Brasileira de Carlos A. C. Lemos. A exemplo do trabalho de Paulo Santos, pretendia-se um livro panorâmico, mas enquanto aquele era pensado a partir do contexto carioca, este incorporava elementos da história paulista. Nesta obra exporia sua concepção de arquitetura moderna, que se notabilizaria pelo juízo depreciativo do legado de Warchavchik, tendo em vista o seu não enquadramento no cânone. Assim como a mudança ocorrida entre Roteiro da Arquitetura Contemporânea em São Paulo e Arquitetura Moderna Paulistana, este livro seria o passo inicial para uma crítica avassaladora da obra de Warchavchik, contida no capítulo "Arquitetura Contemporânea", escrito por Lemos para a História Geral da Arte no Brasil, organizada por Walter Zanini em 1983 - nota-se inclusive a coincidência de datas das primeiras às segundas versões. O texto de 1983 já contava com o subsídio do influente Arquitetura Contemporânea no Brasil, de Yves Bruand, editado em 1981 em português, comentado a seguir, e condenava as iniciativas de Warchavchik, não restando pedra sobre pedra sobre as possíveis contribuições do arquiteto para a formação da arquitetura moderna brasileira.

Em Arquitetura Brasileira, Lemos abre o livro com capítulo dedicado aos "tempos recentes", fazendo considerações sobre as alterações no programa residencial em decorrência do fim da escravidão e das novas noções de higiene. Passa a discorrer sobre o eclético e a introdução de materiais importados, para pensar a seguir "quando surgiu a idéia, dentro do ecletismo, de se reviver o velho estilo português barroco, ou a velha moda brasileira, nas novas construções” ${ }^{148}$, traçando um quadro do neocolonial em São Paulo e no Rio de Janeiro.

Tal é o cenário no qual o autor situa a Semana de Arte Moderna de 1922, e então, a aparição da carta de Rino Levi de 1925 e do manifesto de Warchavchik, “’Acerca da Arquitetura Moderna', para o qual a apologia dos novos conceitos sobre a 'máquina de morar', demonstrava estar bem enfronhado nos postulados de Le Corbusier" ${ }^{149}$. Passa então a falar das conferências proferidas pelo suíço no Rio e em São Paulo, que, segundo Lemos, desper- 
tariam o interesse de alguns jovens arquitetos, como Lúcio Costa ${ }^{150}$. Este é o gancho para falar da Reforma da Belas Artes, da greve dos estudantes, etc.

Mas o arquiteto considera que em "termos práticos” a década de 1930 teve poucos exemplares modernos racionalistas na arquitetura, predominando o art deco, apelidado "futurista", assim como fora alcunhada a "casa modernista" de Warchavchik de 1928. A década marca a propagação do concerto armado e a aceitação do prédio de apartamentos pela classe média, ainda que com resquícios da organização escravagista da sociedade, com a separação das circulações nobres e de serviços, bem como a presença dos cômodos para os criados. Uma ideia que permanecerá em Arquitetura contemporânea é a de que a produção desse período se deu por "manifestações isoladas e personalistas dos primeiros a desejarem a implantação do modernismo", mas que, no entanto, não criaram prosélitos: Warchavchik, mesmo com seu manifesto, casas modernistas e experiência pedagógica, não teve seguidores; Flávio de Carvalho não foi levado a sério; Álvaro Vital Brazil foi praticamente arquiteto de uma obra só, assim como Júlio de Abreu.

Em compensação, no Rio de Janeiro, apesar de a clientela particular se assemelhar à paulista, o Estado tomava outro partido - Lemos engrossa o coro da valorização do esclarecimento de Gustavo Capanema e Rodrigo Melo Franco de Andrade. Para recuperar a história do concurso e construção do MES, recorre a Mindlin em Modern Architecture in Brazil, afirmando tratar-se de "marco da arquitetura moderna, o divisor de águas que separa duas eras e propicia o renome internacional de nossos profissionais do Rio de Janeiro" ${ }^{151}$. Sobre esses, conclui:

Realmente, em menos de dez anos, a partir da decisão histórica de Gustavo Capanema, a nossa arquitetura, graças a esses pioneiros cariocas mais voltados às teorias de Le Corbusier, mas com alguns deles também atentos às lições de Mies Van der Rohe e Gropius, definiu-se como uma expressão cultural nacional independente da conceituação e de seus modelos originais europeus e, pela terceira vez entre nós, como ocorrera em São Paulo bandeirista e em Minas de Aleijadinho, é caracterizada por recreações e invenções locais ${ }^{152}$.

Lemos prossegue discorrendo sobre o contexto de guerra em duas questões: a escassez de materiais importados e a necessidade de desenvolvimento da tecnologia do concreto e suas aplicações nos edifícios modernos e os impactos da exposição Brazil Builds, que caracterizou a capital do país como polo irradiador "de toda uma tecnologia e de novo modo brasileiro de encarar a arquitetura moderna". O arquiteto lamenta que o livro não tenha dedicado páginas a Reidy, citando o famoso aposto de Lúcio Costa, "impecável veterano". Se Ferraz criticava a ausência do Albergue da Boa Vontade, Lemos, que o considerava da

150 Apesar deste ter dito que à época não sabia quem era o mestre e não assistira à sua palestra, como relatado em Registro de uma vivência, 1995

151 LEMOS, 1979:141

152 LEMOS, 1979:141-142 
maior importância no panorama arquitetônico carioca, lembrava da qualidade do conjunto do Pedregulho e do MAM carioca, produzidos, entretanto, posteriormente à exposição, o que torna difícil precisar se o autor se refere a estas apontando a omissão ou apenas para destacar o que considera ser suas obras mais importantes. De qualquer jeito, a ambiguidade renderia mais pontos a discutir, pois, mesmo que se considerasse a segunda opção, Reidy deveria ser lembrando, então, por volta de 1943, por obras como o Albergue, que a uma rápida análise guardaria similaridades de características encontradas na casa da Santa Cruz, como a geometria organizada por eixos de simetria, resquícios de plantas tradicionais, feições do racionalismo internacional, etc., que farão parte dos argumentos contra a modernidade da obra de Warchavchik.

Seguindo a historiografia hegemônica, concluirá com os mesmos passos que seus congêneres. Com Brazil Builds consagrando arquitetos em plano internacional, as encomendas ao grupo carioca aumentavam. Juntamente com o pavilhão de Nova York, a exposição consagraria definitivamente Lucio Costa e Oscar Niemeyer. Com isso, os anos 1940 testemunhariam o nascimento da Pampulha, obra máxima do arquiteto que mais uma vez era comparado a Aleijadinho. Traçando uma carreira ascendente até Brasília, Lemos não critica nem mesmo as obras comerciais renegadas por Niemeyer em São Paulo dos anos 1950 condenadas por Ferraz como exemplos do poder do mercado imobiliário na cidade sobre a produção arquitetônica - considerando-as reflexo de problemas nos sistemas de contrato nos quais sua responsabilidade se diluía com a de terceiros. Lemos participou da equipe de Niemeyer em seus projetos paulistas, portanto, suas posições a esse respeito e mesmo, o seu tipo de envolvimento na discussão da historiografia devem ser pensadas, não se exigindo imparcialidade, mas explicitando-se a de que lugar os diversos agentes falam ${ }^{153}$.

Parece-nos que os passos de consolidação da produção carioca aqui se repetem; o que aparenta ser uma nova contribuição com relação aos trabalhos predecessores se refere ao olhar sobre a produção paulista, pouco comentada até então. $O$ autor traz à baila as contribuições de Rino Levi, Oswaldo Bratke, Jayme Fonseca Rodrigues, Oswaldo Correia Gonçalves, dos imigrantes do pós- $2^{\text {a }}$ Guerra - Calabi, Korngold, Palanti, Lina, Heep; encerra o livro apresentando Vilanova Artigas como o protagonista que definiu a arquitetura paulista.

Apesar do capítulo “Arquitetura Contemporânea” fazer referências a Arquitetura Brasileira em grande parte do texto, o salto dado de um ao outro no tratamento dado a Warchavchik é impressionante. Em primeiro lugar, o manifesto. Enquanto no primeiro escrito, este figura entre as primeiras manifestações, ainda que isoladas, da modernidade arquitetônica, no qual a alusão à "máquina de morar" demonstra a boa informação sobre os preceitos de Le Corbusier, no segundo, é tido como texto amadorístico e conflitante com seus projetos de quatro anos antes sob os olhos de Piacentini, o "arquiteto de Mussolini” e na Companhia Construtora de Santos. Ainda que não pudesse ser compreensível a mudan- 
ça de orientação em quatro anos de percurso profissional ${ }^{154}$, em um contexto de intensas transformações, seja no campo cultural, seja no campo geopolítico, seja na história pessoal do arquiteto, fica-se com a impressão da existência de dois pesos e duas medidas ao longo de sua narrativa. Enquanto Warchavchik é "condenado" por tais mudanças, como se sua biografia estivesse maculada por tais antecedentes, ou tivesse que se desenvolver dentro de determinada linha de modo coerente e sem mudanças de rumos, o critério é alterado ao falar de Lucio Costa e mesmo de outros arquitetos posteriormente convertidos ao moderno no cenário paulista, como Oswaldo Bratke, Rino Levi e mesmo Vilanova Artigas.

Mas voltando ao manifesto, apesar de Lemos considerar o seu pioneirismo, demonstra um entendimento de que o campo das ideias, do discurso - e será que também dos projetos? - deva ser apartado do campo das obras construídas, subentendendo o descarte ou a diminuta relevância dessa categoria para a apreensão das práticas arquitetônicas:

Essa primazia ninguém lhe tirará. Porém, julgamos que seu comportamento e seu texto deveriam ser melhor estudados porque se Warchavchik muito recomendou, pouco executou. Não estamos querendo ser injustos, mas é necessário separar as suas palavras das obras feitas, isolar a intenção da realização ${ }^{155}$.

A mesma opinião Carlos Lemos dava no catálogo da exposição Warchavchik, Pilon Rino Levi, organizada pelo Museu Lasar Segall no mesmo ano, em seu texto "Os três pretensos abridores de uma porta difícil":

O verdadeiro modernismo arquitetônico chegou-nos só depois da $2^{\mathrm{a}}$ grande guerra e isso desejamos explicar melhor em poucas palavras, querendo situar Warchavchik como um introdutor da idéia, sem praticá-la, contudo, nos $1^{\circ}$ s dias; nisso contrariando suas próprias palavras escritas ${ }^{156}$.

Agnaldo Farias, em sua dissertação de mestrado questiona o entendimento de Lemos sobre o que é arquitetura, "por condicionar sua existência exclusivamente à existência física. Como ficariam as obras de Piranesi e Sant'Elia, por exemplo, que não chegaram a construir e foram pouco conhecidos do público?” ${ }^{157}$.

A negação do manifesto é sucedida pela afirmação de Razões da Nova Arquitetura como o primeiro manifesto erudito, com conceituação teórica "pertinente". Mas ao passar das palavras à ação de Warchavchik, Lemos será ainda mais radical. O casamento com a “jovem milionária Mina Klabin” possibilitaria a realização da casa da Santa Cruz: "Foi sua primeira tentativa de arquitetura moderna, infelizmente, a nosso ver, sem validade, porque

154 Também deveria ser mais bem esmiuçado de que projetos Lemos está falando, pois mesmo José Lira (LIRA, 2008) conclui pela ausência de informações sobre a produção de Warchavchik em Santos e na Europa.

155 LEMOS, 1983a:831

156 LEMOS, 1983b:4

157 FARIAS, 1990:125 
se ateve somente aos aspectos formais" ${ }^{158}$. Ancorado na análise de Yves Bruand sobre as contradições entre forma e seus aspectos construtivos e a não incorporação dos pontos de Le Corbusier, ainda que justificadas na correspondência com Giedion, conclui: "podemos dizer que a casa da Vila Mariana era também uma casa tradicional, porém 'despida' e, por isso, moderna" ${ }^{159}$. A mesma afirmação estará em Alvenaria Burguesa, quando o arquiteto considera a Santa Cruz não a primeira casa moderna, mas a "última de tijolos". Note que no escrito de 1979 nada disso é pontuado, o que nos leva a crer que algo se alterou no percurso intelectual de Lemos entre 1979 e 1983, e que, sem podermos examinar mais a fundo sua fortuna crítica, parece se relacionar diretamente com o impacto da tese de Bruand. Seu entendimento de arquitetura é lastreado pelo texto doutrinário de Lúcio Costa; sua interpretação da emergência da arquitetura moderna brasileira, por Mindlin; e agora, o papel secundário de Warchavchik, por Bruand, apesar de mais severo que este ${ }^{160}$.

Arquitetura Contemporânea no Brasil, originalmente L'Architecture contemporaine au Brésil, Tese defendida por Yves Bruand em 23 de dezembro de 1971, na Universidade de Paris IV, foi publicada em 1981, sob tradução de Ana M. Golberger, para a editora Perspectiva. A publicação, considerada uma das mais exaustivas sobre o tema, reforça a ideia do desenvolvimento da arquitetura nacional de destaque por meio do talento individual de algumas personalidades. Segundo Martins ${ }^{161}$, a obra de Bruand consolida a narrativa iniciada com Goodwin e ampliada por Mindlin. Mas ao contrário dessas obras, que se caracterizavam por sua natureza de difusão, este trabalho propõe investigar sob perspectiva histórica, em seu perfil acadêmico, a produção arquitetônica moderna brasileira. Bruand abre seu trabalho trazendo elementos do meio físico-geográfico, econômico, político, social e histórico, com pinceladas de uma história das mentalidades e da psicologia do povo brasileiro, ancorado em Fernando de Azevedo. A visão por vezes determinista faz com que Martins julgue seu resultado ambíguo.

Um aspecto que interessa destacar, é que Bruand propõe uma "explicação" para a adesão brasileira à matriz corbusiana em detrimento dos demais mestres da arquitetura moderna internacional:

Portanto, não foi por mero acaso que, dos três grandes mestres da arquitetura internacional no período entre as duas guerras, Gropius, Mies Van der Rohe e Le Corbusier, aquele que teria influência determinante na arquitetura brasileira tenha sido Le Corbusier. Independentemente das razões culturais (...), o contexto econômico e social justifica a pequena repercussão alcançada pelo pensamento e obra de

158 LEMOS, 1983a:832

159 Idem.

160 Convém assinalar que tais considerações não têm por objetivo tirar os méritos e a importância do trabalho, que além de ser um dos poucos a enfrentar uma perspectiva panorâmica da história brasileira, traz contribuições específicas quanto aos aspectos antropológicos do morar (TINEM, 2006), a moradia rural e a arquitetura moderna paulista, entre outros.

161 MARTINS, 2010 
Gropius e Mies Van der Rohe, quando comparada pelo sucesso alcançado pelo de Le Corbusier. As preocupações democráticas de Gropius, relacionando a arte ao conjunto das atividades sociais do indivíduo e ao nível de vida das classes produtoras, não poderiam exercer qualquer influência numa sociedade de oligarquia rural, indiferente a este assunto (...). Da mesma forma, a obra de Mies Van der Rohe, seu sucessor na direção da Bauhaus - fundamentada numa concepção nitidamente mais aristocrática da arquitetura, cujo valor decorreria de um acabamento perfeito, obtido pelo emprego de mão de obra altamente qualificada e pela utilização de produtos industriais impecáveis -, não podia encontrar repercussão num país onde nenhum desses princípios poderia ser resolvido satisfatoriamente ${ }^{162}$.

O livro é composto por uma introdução, que contém as determinantes acima mencionadas, e três partes: "De um ecletismo sem Originalidade à Afirmação Internacional da Nova Arquitetura Brasileira (1900-1945)”, “A maturidade da Nova Arquitetura Brasileira: Unidade e Diversidade", "Arquitetura e Urbanismo", além da conclusão e as listas de fontes e referências bibliográficas. A parte que mais nos interessa, referente ao período de surgimento e afirmação da "nova arquitetura brasileira", como se depreende do título, faz um movimento do eclético ao moderno, que reitera o esquema de Lúcio Costa, pois traça um caminho natural entre o eclético, negativo, passando pelo neocolonial, para chegar ao racionalismo moderno. Por outro lado, Bruand reservará à Semana de 1922 e especialmente a Warchavchik, papel central como "Premissas da renovação". Assinala Bruand, que o movimento moderno não surgiu repentinamente, mas como "resultado da evolução do pensamento de alguns grupos intelectuais brasileiros, especialmente paulistas, evolução essa que criou um mínimo de condições favoráveis, sem as quais as primeiras realizações do gênero não teriam frutificado" ${ }^{163}$. O panorama artístico e literário e a Semana de 22 são retratados para mostrar sua importância não como influência direta sobre a arquitetura, mas como forma de criar condições psicológicas para o seu desenvolvimento:

Era um primeiro passo, ao qual poderia se seguir o surgimento de uma clientela interessada numa arquitetura nova, por pouco que esta tivesse a oferecer em termos de propostas concretas e realizáveis. O mérito de compreender esse fato coube a um jovem arquiteto vindo da Europa e chegado a São Paulo um ano depois da Semana de Arte Moderna: Gregori Warchavchik ${ }^{164}$

Bruand destacava ação pioneira do arquiteto, que teve de lançar mão de diplomacia para convencer e vencer obstáculos, como a legislação municipal, hostilidade e as técnicas construtivas artesanais. Sua formação europeia também é considerada fator positivo ao seu favor, pois lhe abrira as portas no Brasil, para a contratação pela companhia de Simonsen, 
além de ser mais aberta, apesar de acadêmica, que o ensino na América Latina. Bruand lembra que valores como simplicidade e verdade não eram preocupações exclusivas das vanguardas, estando presentes, por exemplo, no neoclassicismo monumentalizante de Piacentini. $\mathrm{O}$ ensino acadêmico italiano, segundo Bruand, não era voltado à cópia de formas do passado, "nem impedia a pesquisa de uma arquitetura prática e econômica, de volumes e linhas puras, onde os elementos decorativos fossem reduzidos ao mínimo e correspondessem a uma função, sem jamais esconder a estrutura do edifício" ${ }^{165}$. Aliado ao ensino oficial clássico mas relativamente aberto, o burburinho em torno das vanguardas se colocava em toda a Europa, tendo proporcionado a Warchavchik o contato com os escritos doutrinários de Le Corbusier, àquela altura ainda não colocados em prática, que tomaria emprestado para a formulação de seu manifesto de 1925.

No Brasil, de acordo com o autor, Warchavchik teria sua ação marcada pela prudência, adaptando-se ao país, utilizando-se do prestígio de sua formação europeia. A publicação do Manifesto em 1925 é comparada com a carta de Rino Levi, tendo em comum a noção de arquitetura ditada pela prática e economia, a redução ao mínimo de elementos decorativos, correspondentes à função e a união entre artista e técnico na figura do arquiteto. Entretanto, as diferenças se sobressaíam, pois Warchavchik trazia um programa bem mais radical, rejeitando a ideia de estilo e aderindo às formulações de Le Corbusier. Mas Bruand não critica a falta de originalidade do manifesto, pois o que estaria em jogo seria a divulgação daquelas ideias em nível local:

A sinceridade das idéias expostas, a simplicidade um tanto vaga das fórmulas propostas e, sobretudo o espírito sistemático que presidira a elaboração da doutrina proposta, estavam aptos para responder à ânsia de reformas que, há alguns anos e em todos os setores, vinha-se apoderando de algumas classes do país ${ }^{166}$.

Como os demais trabalhos que trataram de Warchavchik, este seguia analisando a casa da Rua Santa Cruz, a obra que colocaria em prática seus princípios. Bruand evoca novamente as dificuldades na construção da casa quanto a sua aprovação e construção. Warchavchik deveria optar entre adequar-se às técnicas disponíveis ou investir em protótipos, ainda que em um primeiro momento tivessem um custo maior. Optando pela segunda solução, o arquiteto apresentava sua obra como um manifesto - que proporcionou amplo debate na opinião pública -, marcado pelas preocupações formais - que Bruand associa à Casa Steiner de Adolf Loos. Possivelmente seja este livro o primeiro a esmiuçar as contradições entre a doutrina contida no manifesto e os resultados da obra construída, apontando as ilusões de ordem construtiva e planimétrica - aparência de concreto, janelas de canto, telhado escondido por platibanda, janela que escondia a varanda. Bruand sugeria ainda que, apesar de Warchavchik aparentar proximidade com as formulações de Gropius, inspiravase de fato em Le Corbusier. Mas aí o próprio paleógrafo criava uma armadilha, pois, se se 
afirmava a doutrina corbusiana, não se cumpririam os "5 pontos", sendo apenas aquele referente às janelas horizontais cumprido parcialmente. A questão é: deveria cumprir? Seria suficiente atribuir tal filiação pelo fato de Warchavchik trabalhar com formas elementares, ângulo reto, regularidade do conjunto e detalhes correspondentes ao "espírito formal" do francês (argumento último, aliás, não desenvolvido)? Poderia se tirar tais conclusões a partir de apenas uma obra só, repleta de contradições, sem se considerar o estudo da série?

Vemos aqui que o autor expõe tais questões sem, no entanto, julgar o arquiteto pela vagueza do manifesto ou pelas contradições da casa, destacando suas contribuições para a formação de um pensamento arquitetônico moderno em um contexto provinciano, como um primeiro passo, ainda que mais restrito ao campo estético, apesar de assim fornecer munição para a condenação de Lemos em Arquitetura Contemporânea.

O capítulo segue com a análise das obras seguintes de Warchavchik até as casas do Rio de Janeiro. Nestas, Bruand afirma ter sido possível aplicar integralmente suas formulações, não restando resquícios da arquitetura do passado - residência Max Graf, João de Souza Lima, Dr. Cândido da Silva, Luis da Silva Prado e finalmente, casa da Itápolis; Unidade de estilo total, jogos de planos e volumes, contrastes cromáticos. Desta fase, Bruand passa ainda pela visita de Le Corbusier em 1929 ao Brasil e a indicação de Warchavchik ao CIAM e pela exposição da Casa Modernista da Itápolis ${ }^{167}$. Aqui caberia observar certa falta de cuidado no tratamento das imagens, tendo em vista que a casa teve sua foto publicada invertidamente (fig. 11). Teria Bruand visitado a obra e/ou participado da seleção das imagens e revisão do livro ${ }^{168}$ ?

$\mathrm{Na}$ sequência, trata da atuação do arquiteto russo na cidade do Rio de Janeiro, com a atividade didática na curta reforma da ENBA, a casa da Rua Tonelero como palco das discussões sobre os rumos dessa reforma, contando com o envolvimento de Frank Lloyd Wright, a sociedade com Costa - que mesmo estando em pé de igualdade com Warchavchik, em sua opinião, marcava-se por obras na mesma linha de pesquisa das construções anteriores deste, caracterizadas pela inspiração em Le Corbusier, funcionalismo e cubismo arquitetônico, sem concessões à imaginação formal.

Para Bruand, esta é exatamente a explicação para o declínio do papel decisivo de Warchavchik por volta de 1935/1936: a austeridade de seus princípios, compreensível em um primeiro momento de combate, caía no desagrado, por seu excessivo rigor. Aplicando os princípios do mestre sem flexibilidade, percorreu o caminho inverso a ele, que com o tempo libertou-se progressivamente do que sua teoria poderia ter de restritivo. Mesmo considerando um panorama de crise, o arrefecimento de sua ação é dado como um problema de responsabilidade do próprio arquiteto em sua rigidez doutrinária, uma questão interna à sua

167 Que teve sua foto publicada invertidamente

168 Observamos que em Arquitetura Brasileira, de Carlos Lemos, além da impressão de imagens invertidas, um erro ainda mais grosseiro: o edifício CBI-Esplanada é identificado na legenda como sendo o edifício Esther, à p.137 
própria atuação: "Além de sua capacidade criadora ter-se esgotado muito rapidamente, era muito estrangeiro para o país e muito radical para conseguir realmente naturalizar-se" ${ }^{169}$. Vemos aqui os limites da estrutura de desenvolvimento da tese, em que as condicionantes sociais, políticas, culturais, econômicas, etc. são colocadas como capítulo à parte, antes da análise propriamente dos períodos da produção arquitetônica, nos quais o autor pouco recorre aos demais campos disciplinares. A obra de Warchavchik teria representado, então, uma "etapa necessária", uma forma de preparar o caminho para forjar uma nova mentalidade nos jovens arquitetos do Rio de Janeiro, tratados no capítulo 3, "A transformação decisiva (1936-1944)".

Os cariocas são presença absoluta ao longo do livro, que reserva proporcionalmente muito poucas páginas à produção paulista e menos ainda a produtores de outras regiões do Brasil. Martins aponta algumas omissões como a questão da habitação, na qual conjuntos como o de Pedregulho seriam apenas a ponta de um Iceberg e da produção do convênio escolar paulista. Não seria o caso de listar outros arquitetos ou manifestações que tenham ficado de fora, mas apenas admitir que se trata de um recorte, de uma tese desenvolvida na década de 1960 e defendida em 1971, que assimila e reforça a linha interpretativa que perpassa Goodwin, Costa, Mindlin, Santos e Lemos, que evidentemente têm suas diferenças, entre mais e menos apologéticos e mais e menos envolvidos diretamente com o movimento, como procuramos assinalar ao longo do texto, mas tendo como denominador comum a periodização e a seleção dos fatos, marcos e protagonistas históricos, na qual a eleição do grupo carioca como vetor dominante e definidor da arquitetura brasileira no mais reflete a própria ascendência destes sobre os espaços de atuação e discussão no campo arquitetônico até o advento de Brasília.

\section{CONTINUIDADES, REVISÕES E NOVAS PERSPECTIVAS}

\section{Os anos 1980}

Se até a publicação de Arquitetura Contemporânea no Brasil poderíamos localizar Geraldo Ferraz como a única voz dissonante, os anos 1980 sinalizam para o surgimento de novas perspectivas que passam a conviver com a interpretação consolidada na historiografia do papel de Warchavchik. Em 1982, o Departamento de Informação e Documentação Artísticas da Secretaria Municipal de Cultura de São Paulo realizava, sob coordenação de Ricardo Christiano Forjaz de Souza, o volume para a coleção "Cadernos de Cultura", Trajetórias da Arquitetura Modernista, que procurava resgatar os debates no processo de constituição da 

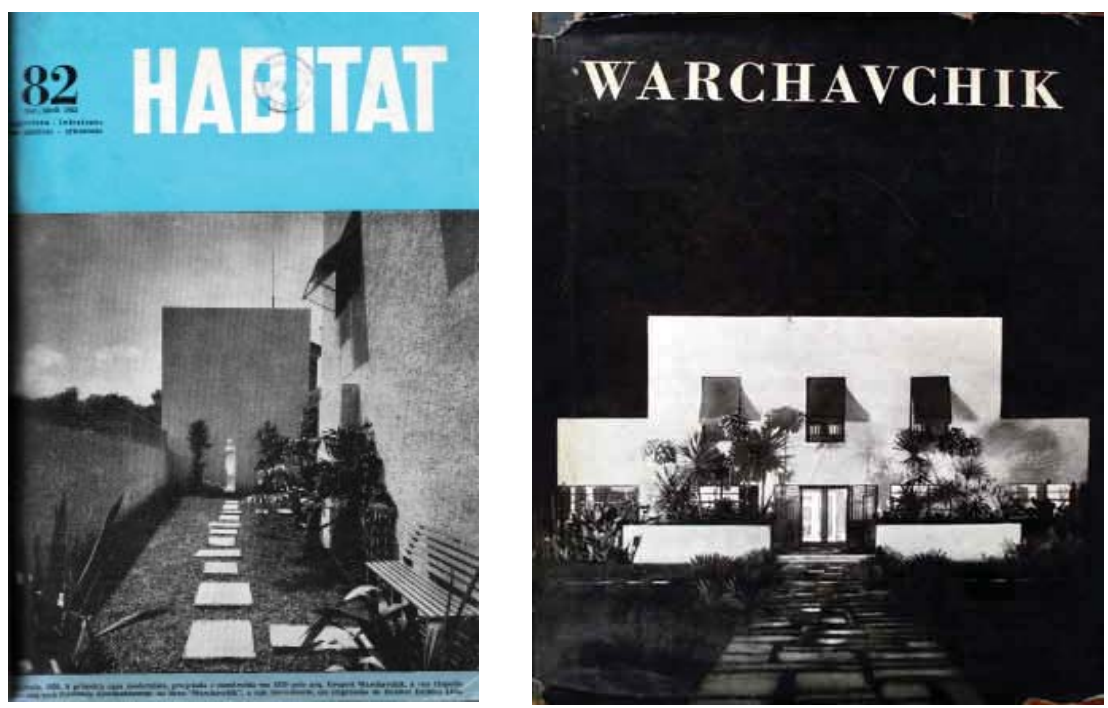

[9] Capa de Habitat anunciando o lançamento do livro de Ferraz, em 1965. [10] Capa do livro de Ferraz sobre Warchavchik (1965), com a imagem que ficará marcada da Casa Modernista da Rua Santa Cruz; [11] Ficha da Casa Modernista da Rua Itápolis contida em XAVIER, CORONA e LEMOS (1983); [12] Página do livro de Bruand com a foto da casa da Rua Itápolis está invertida; [13] Página de Trajetórias da arquitetura modernista (1982), com fotos da Casa da Itápolis em dois momentos.
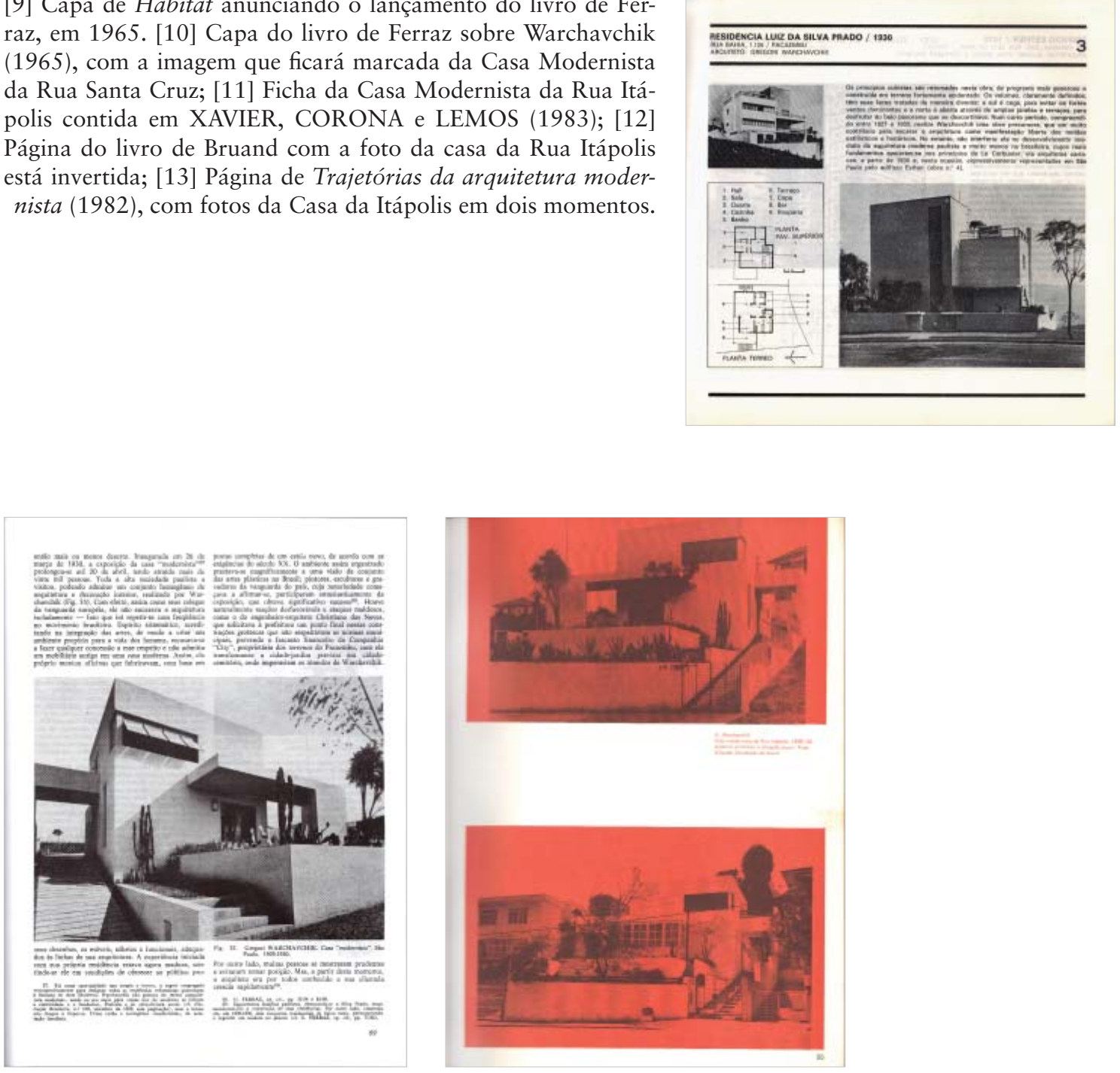
arquitetura moderna em São Paulo. Como obra focada nas obras escritas de Warchavchik, Rino Levi, Flávio de Carvalho e Jayme da Silva Telles, inseridas no debate arquitetônico dos anos 1920-1930, não se deixava pautar pelo tratamento dado pelas obras panorâmicas, que no geral tendiam a ver a obra de Warchavchik pelo que vinha depois. Também não se propunha a analisar suas obras construídas, mas sim a produção intelectual desses protagonistas por Souza recuperados. Ainda assim, considerava essa primeira produção resultado de ações isoladas que pouco puderam ser colocadas em prática, sendo Warchavchik mesmo o grande precursor, com obras que representavam a inserção de uma arquitetura internacional intrusa antes do que uma resposta brasileira ao novo conceito no país.

A arrancada inicial dos paulistas é, enfim, menos uma primeira resposta do País ao novo conceito da arquitetura, do que a intromissão, nos vazios conquistados ao Brasil tradicional, de uma estética importada sem retoques da Europa e com anseios de validez internacional ${ }^{170}$.

Por outro lado, este aspecto não é desmerecido e o pesquisador tem o mérito de investigar as contribuições de personagens pouco estudados ou não estudados sob esta perspectiva. De Warchavchik, traz, em primeiro lugar, o Manifesto de 1925, para Souza, inspirado em passagens de Internationale Architektur de Walter Gropius. O texto segue publicando e comentando outros textos-chave do arquiteto, como o depoimento sobre a Casa da Santa Cruz, de 1928; alguns dos capítulos de "Arquitetura do Século XX"; sobre o IV Congresso Pan-americano, a censura estética das fachadas, o Congresso de Habitação e a reforma da ENBA $^{171}$.

Depois de expor e debater os escritos dos demais arquitetos, Souza conclui que Warchavchik foi de fato o introdutor da arquitetura moderna, nenhum dos demais se equipara a ele. Entretanto, colheu menos do que semeou e Rino Levi, que polemizou menos, seguiu carreira mais segura, protegida dos erros "pueris" dos revolucionários apressados. Souza aponta o esquecimento da obra de Warchavchik, como se nada tivesse ocorrido antes de 1936, citando a polêmica entre Ferraz e Costa de 1948. Para o autor, a debilidade do ciclo paulista deve ser atribuída a não correspondência daquela nova corrente de pensamento às condições concretas de produção e da realidade nacional - e daí o seu sucesso provisório.

Primeiramente, deve ser assinalada a contribuição incomum aos demais trabalhos de história da arquitetura brasileira, qual seja, o foco na produção intelectual escrita dos seus protagonistas, no discurso verbal, nas concepções dos pioneiros - postura diametralmente oposta a Carlos Lemos. Sobre esse tipo de abordagem, Segawa na resenha do livro, publicada na revista Projeto em 1984, lembra do alcance de Ornamento é Crime de Loos, muito maior que de suas obras, os desenhos de Mendelsohn e Sant'Elia, o poder de Vers une Architecture. Por fim, pondera: 
O apego à obra construída, via de regra, escamoteia o alcance das concepções não realizadas (...). Estamos desacostumados a essa vertente analítica e a prática profissional é avaliada e avalizada apenas pela expressão construída. Talvez o único dos nossos arquitetos poupados do limbo por sua expressão escrita é Lúcio Costa ${ }^{172}$.

Outra característica que foge do padrão das publicações sobre o tema, é que o livro publica fotos não somente dos edifícios recém inaugurados, mas também fotos atualizadas de algumas das obras, constituindo-se em registro comparativo valioso, revelando suas condições nos anos 1980 (fig. 12).

No mesmo ano, era publicada a Arquitetura Moderna Brasileira, de Sylvia Fischer e Marlene Acayaba, pela Projeto editores. O livro sistematizava a produção moderna brasileira das origens aos anos 1970, a partir de uma periodização que marca quatro etapas - origem, difusão, Brasília, regionalização. O trabalho é aberto com uma passagem rápida sobre Warchavchik, como pioneiro da arquitetura moderna, tanto por seu manifesto quanto pela casa da Santa Cruz, para adotar a reforma da ENBA como ponto crucial para o primeiro desenvolvimento da arquitetura moderna no Brasil. Então, percorre as obras canônicas - o edifício do MES, o hotel de Ouro Preto, o conjunto da Pampulha, entre outras obras do grupo carioca. O passo seguinte, "A Difusão da arquitetura moderna brasileira", trata da assimilação desta escola pelo grupo de Recife liderado por Luis Nunes, de Salvador, com Paulo Antunes Ribeiro e Diógenes Rebouças e de São Paulo, apresentado como em uma situação peculiar, decorrente da formação originária de seus arquitetos na Politécnica, e não nas Belas Artes, e da contribuição dos arquitetos imigrantes.

Brasília recebe grande destaque no manual, seja com seu plano urbanístico seja com a análise de alguns edifícios. Para as autoras, a cidade coroava a influência das teorias europeias, especialmente de Le Corbusier, que, a exemplo do MES, contribuía para a formação de uma linguagem arquitetônica única, extrapolando o interesse nacional: "Com Brasília, afirmação plena do Movimento Moderno, as teorias assimiladas e desenvolvidas foram concretizadas em edifícios e no urbanismo, ultrapassando o interesse regional e convertendo-se em uma contribuição internacional" ${ }^{173}$. Mas o processo de modernização nas diversas regiões do Brasil, a partir dos anos 1960, faz emergir tendências de cores locais, identificadas em quatro eixos: região sul - São Paulo, Curitiba e Porto Alegre; Rio de Janeiro e Brasília; Região Nordeste - Salvador, Recife e Fortaleza; Região Norte - Manaus. Nota-se que este trabalho é o primeiro a tratar da produção arquitetônica para além do Sudeste - São Paulo e especialmente Rio de Janeiro - algo somente esboçado - e não cumprido - pela obra de Bruand, e que procura demonstrar a pluralidade de expressões decorrente das diferenças regionais. 


\section{A arquitetura eclipsada e o universo acadêmico}

Mais explícito no questionamento à trama historiográfica posta, a Dissertação de Mestrado de Agnaldo Farias, A Arquitetura Eclipsada: Notas sobre História e Arquitetura a Propósito da Obra de Gregori Warchavchik, Introdutor da Arquitetura Moderna no Brasil, elaborada na década de 1980 e defendida em 1990 pelo IFCH-UNICAMP, parece reivindicar caminhos metodológicos e categorias de análise que, se não expressam as indagações geracionais daquele período - o que não caberia aqui avaliar, ao menos sinaliza para um processo de mudança no trato historiográfico conferido a Gregori Warchavchik. De partida, dois aspectos acerca do contexto de elaboração da dissertação dizem algo sobre a tônica que lhe será conferida. Em primeiro lugar, destaca-se que seu autor, Agnaldo Farias, crítico de arte, arquiteto e então professor da Escola de Engenharia de São Carlos da Universidade de São Paulo (EESC- USP), optou por desenvolvê-la no âmbito do programa de pós-graduação em História Social do Trabalho do Instituto de Filosofia e Ciências Humanas da Universidade Estadual de Campinas (IFCH-UNICAMP), criado em 1976 - em detrimento do programa de pós-graduação da Faculdade de Arquitetura e Urbanismo da Universidade de São Paulo (FAU-USP), criado em $1972^{174}$. Em segundo lugar, que sua produção intelectual priorizava e prioriza - a crítica de arte: artigos, catálogos, capítulos de livros publicados nos anos 1980 versavam predominantemente sobre artistas e artes plásticas.

Um olhar atento às problemáticas da história - como campo disciplinar das ciências humanas, apontava para um duplo problema: de um lado, a historiografia pouco se ocupava da arquitetura; de outro, historiadores da arquitetura, salvo exceções, no geral desconheciam que a história da arquitetura fosse um campo particular da história. Farias reclamava da história da arquitetura um tratamento guiado pelas questões internas à disciplina ao mesmo tempo em que assumisse a dimensão estética das obras arquitetônicas como elemento fundamental à sua interpretação, como elemento estruturador, citando Le Bot, de uma "ordem de visibilidade"175. Com isso, intencionava propor uma revisão historiográfica a partir da reflexão sobre os métodos no campo da história e das relações entre história e arquitetura.

É nessa chave que Farias pensa a obra de Warchavchik, apontando-a como preterida na historiografia por ter passado ao largo de questões como tradição e identidade nacional. Concorre, assim, para o "desvendamento de uma trama, de um ardil historiográfico que, por ter sido identificado como a primeira leitura consequente dentro dos moldes modernos,

174 Segundo Farias, a constatação da ausência de rigor nos trabalhos de história da arquitetura então produzidos o levou a procurar o programa de pós-graduação na História da Unicamp, que tinha nos seus quadros destacados historiadores, como Edgar Dedecca ou Maria Stella Bresciani. Entrevista cedida à autora em 07/01/2011.

175 LE BOT, Apud FARIAS, 1990:10. Além de Le Bot, Farias alude como suas principais referências Panofsky e Calabrese, que tem raízes no "Puro visibilismo" de Fiedler e a "ciência da arte" de Wölfflin, mas incorporando criticamente as contribuições de outros campos teóricos. 
assumiu a proporção de um discurso totêmico e, como tal, indiscutível" ${ }^{176}$. Recupera para isso, a abordagem de Carlos Martins, que empresta de Paul Veyne a ideia de trama historiográfica ${ }^{177}$. Se outros autores também identificavam o privilégio de tais questões por parte da história canônica ${ }^{178}$, Farias explicitaria as consequências disso para o esquecimento, ou eclipse, da obra de Warchavchik. Acaba, portanto, por chamar à discussão a polarização entre o marco originário do Ministério da Educação e Saúde (MES) fixado pela historiografia hegemônica e a habilitação da imagem de pioneiro de Warchavchik - que ele procurará demonstrar por meio das qualidades plásticas de suas obras e sua inserção histórica no contexto das vanguardas, proposta que guarda alguma similitude com a interpretação de Geraldo Ferraz, ainda que com muitas ressalvas. Assim como Ferraz, Farias tem como referente a pauta hegemônica, mas para contrapô-la.

Ainda seguindo o caminho interpretativo de Ferraz, o autor desenvolve e aprofunda a ideia de um diálogo de Warchavchik com matrizes internacionais do movimento moderno e de uma postura eminentemente de vanguarda ao mesmo tempo em que propõe novos caminhos de análise: "espera-se provar que eram reais e conscientes os elos que o arquiteto mantinha com os grupos de arquitetura ligados às vanguardas modernas e, em segundo lugar, que a qualidade da sua obra não justifica o tratamento secundário que lhe deu a historiografia" ${ }^{179}$. Sabemos que Ferraz não empreende em seu livro uma análise de obra, mas sim, apresenta uma interpretação do significado de Warchavchik na cultura arquitetônica brasileira fixando-o como marco inicial da arquitetura moderna. As obras são publicadas sob a forma de catálogo, sem que sejam discutidas em termos arquitetônicos - aspecto que será abordado por Agnaldo Farias. O crítico ainda recorrerá aos documentos escritos de Warchavchik - manifesto e artigos para refletir sobre seu conjunto de referências.

Isso quer dizer que o esforço da pesquisa é enfrentar os postulados da história hegemônica provando o pioneirismo de Warchavchik, na linha proposta por Ferraz, mas por meio de estratégias diversas. Ou seja, o tema da origem permanece; também não lhe escapa o risco de personificação do gênio que introduz um novo pensamento arquitetônico: "Contemplar as obras de Warchavchik, passear por seus contornos exatos, é reviver o desembarque e a surpresa da razão ocidental diante da canícula e da claridade desmedida. É como assistir à chegada de Apolo aos trópicos” ${ }^{180}$. Com esta afirmação, reitera a imagem mítica proposta por Ferraz, de uma individualidade solitária que por esforço pessoal iniciou o movimento de renovação da arquitetura brasileira. Ressalvamos que não estamos aqui afirmando a dissertação de Farias como pura continuidade do livro de Ferraz, tendo em vista 
seus formatos, métodos e estratégias distintos. Ademais, enquanto este apresenta um tom apologético, aquele é desinteressado; contudo, a intenção de ambos os aproxima, à medida que reivindicam a Warchavchik a posição de introdutor da nova arquitetura no Brasil explorando a sua conexão com o movimento moderno internacional.

Por outro lado, a estratégia de Farias de inserir o arquiteto em uma discussão ancorada na constituição do modernismo, entendido como "movimento realizado no Brasil que (...) pautava-se entre outras preocupações, pelo desejo ambíguo de, simultaneamente, fazer com que o país se modernizasse e construísse uma identidade para si” ${ }^{181}$, traz à cena o campo da cultura como categoria privilegiada de análise - talvez aí um aspecto contrastante com que uma história de cunho mais clássico poderia enfatizar. Fatores econômicos, sociais ou políticos do período estudado subsumem-se à história cultural, e em alguns momentos chegam a desaparecer dos horizontes de reflexão.

Com isso, o trabalho foca a investigação das relações entre modernismo e tradição na cultura e na história. Warchavchik propriamente terá algumas aparições ao longo da dissertação, mas somente no quinto capítulo será o assunto principal, após as ponderações sobre o contexto cultural que habilita e legitima sua obra como pioneira ao mesmo tempo em que explica o seu obscurecimento.

A dissertação constrói o universo com que a obra de Warchavchik irá se relacionar partindo da definição do modernismo artístico, passando ao modernismo em arquitetura, entrando na historiografia dessa arquitetura, iniciando um exame sobre as vanguardas históricas e seus manifestos para fazer a ponte com os escritos de Warchavchik e chegar à análise de suas obras.

O capítulo introdutório apresenta os referenciais teóricos e metodológicos, questões, objetivo e estrutura da dissertação, como de praxe. Entretanto, nos parece um dos elementos mais interessantes da pesquisa à medida que problematiza o ofício do historiador da arquitetura, trazendo à baila elementos da literatura, da história da arte, da micro-história, da filosofia da história, etc., de modo a recolocar a história da arquitetura como ramo da história, o que para aquele contexto de início de programas de pós-graduação no qual arquitetos propunham-se a fazer história, não nos parece pouco.

Como o fio condutor da pesquisa é o obscurecimento ou deslocamento de Warchavchik a segundo plano como consequência de uma suposta ausência de brasilidade de suas obras, o autor irá apresentar o modernismo artístico e arquitetônico dentro da chave da ambiguidade, da tensão entre ruptura e tradição. No campo da arquitetura, versa sobre o ecletismo, o neocolonial e sobre o papel de Lúcio Costa na construção do modernismo no Brasil, seja em sua atuação na reforma da ENBA, seja na sua leitura sobre a modernidade. Tal leitura pautará as interpretações presentes na historiografia da arquitetura, examinada a partir de Martins. Farias compartilha com este a ideia proposta por Bonta, de que a crítica 
e a historiografia da arquitetura têm participação ativa na propagação e geração da cultura arquitetônica $^{182}$, complementada por Argan, de que "a obra de arte sofre com o passar do tempo a agregação das várias leituras que se lhe fizeram" ${ }^{183}$. Sob esta perspectiva, passa a investigar como os livros de história da arquitetura tratam a obra de Warchavchik. Entre as obras estudadas por Martins - Brazil Builds (Philip Goodwin, 1943), Modern Architecture in Brazil (Henrique Mindlin, 1956), Warchavchik e a Introdução da Nova Arquitetura no Brasil (Geraldo Ferraz, 1965), Arquitetura Contemporânea no Brasil (Yves Bruand, 1977) e Arquitetura Contemporânea (Carlos Lemos, 1983), Farias apenas não abordará a última.

Sua análise, explicitamente tributária da reflexão de Martins, passa por Goodwin, Mindlin e Bruand como os três passos da consolidação da interpretação canônica da história da arquitetura moderna no Brasil: o primeiro, influenciado por Lúcio Costa, definindo a matriz interpretativa; o segundo, ampliando o leque de obras estudadas e preenchendo lacunas; o terceiro, consolidando tal matriz em trabalho de sistematização. Com relação ao tratamento dado a Warchavchik, Farias aponta a obra de Goodwin como "a primeira a tratar da produção de Warchavchik de um modo totalmente incompatível com a sua importância" ${ }^{184}$, dada a quase completa omissão, malgrado as inserções de fotografias do edifício à Alameda Barão de Limeira e da casa da Rua Bahia, com sua legenda equivocada; em Mindlin, tido como elaborador de levantamento mais amplo e rigoroso, destaca a retirada de viés determinista presente em Goodwin e a leitura de Warchavchik como contribuição à preparação de terreno para a entrada e fixação da arquitetura moderna; já sobre Bruand, dedica um número maior de páginas, enfatizando suas associações entre leituras psicologizantes com fatos históricos e especialmente o inventariamento de movimentos e grupos paralelos ao carioca, e que, a despeito de assumir os marcos da historiografia hegemônica, recuperou a figura de Warchavchik como introdutor da arquitetura moderna no Brasil. Entretanto, Bruand o coloca apenas como etapa necessária, mas esgotada, cuja estrangeiridade fora seu maior limite.

Farias prossegue com sua análise partindo da afirmação de Bruand de que Warchavchik não teria conseguido impor sua arquitetura: "Impor a quem? Ao público? Não teria conseguido impô-la porque em parte não foi construída, ou porque não foi construída em obediência exata às normas relativas aos procedimentos construtivos e materiais modernos?" 185 . Sobre esse ultimo aspecto, sustenta ser esse um argumento comum na historiografia para diminuir a importância da obra do arquiteto, como em Lemos, que em "Alvenaria Burguesa" chega ao extremo de colocar a casa da Rua Santa Cruz como fim de uma era, e não início de outra e trata apenas da existência física das obras. O limite técnico, para Bruand, fez com que o arquiteto renunciasse aos cinco pontos da arquitetura de Le Corbusier, como se fosse a única forma de validar uma obra como moderna: "o fato dele não haver cumprido os cinco pontos além de ser insuficiente para julgar a validade de suas 
proposições, denuncia a opção estética do autor [Bruand]" ${ }^{186}$.

Já Geraldo Ferraz ${ }^{187}$ é apresentado como personagem que pretende resgatar o papel pioneiro do grupo paulista, especialmente de Warchavchik e Flávio de Carvalho em proposição de nova matriz interpretativa, que "ainda que possua méritos inquestionáveis, uma e outra vez soará mais como revanchismo bairrista do que como uma desejável exigência de rigor" ${ }^{188}$. Ocorre que tanto em Farias quanto em Martins, tal afirmação não é seguida de qualquer explicação. Sabe-se dos laços de amizade entre Ferraz e os arquitetos paulistas, assim como de sua militância nos diversos artigos publicados em Habitat e na imprensa diária em favor dos precursores; também é conhecida a sua rivalidade com os cariocas, especialmente Oscar Niemeyer - a própria expressão "revanchismo bairrista" é alcunhada por Lúcio Costa no episódio de 1948. Mas nos perguntamos como estariam essas questões expressas no livro.

Sobre esse aspecto, gostaríamos de comentar as assimetrias no tratamento dado aos personagens abordados pela historiografia. Nos trabalhos que vimos comentando, é comum a apresentação de Warchavchik acompanhada do preâmbulo - da sua saída de Odessa, formação em Roma e trabalho com Piacentini, imigração e contrato com a Companhia Construtora de Santos... E o casamento com Mina Klabin como forma de viabilizar suas obras. Quando tratam do grupo dominante, não se explicita as relações e de que lugar surgem, pelo contrário, acabam por endossar a visão proposta por Lúcio do talento e mesmo do gênio, como é o caso de Oscar, o que tira qualquer necessidade de saber de onde veio ou quais redes de relações o colocaram em situação privilegiada para despontar para a arquitetura brasileira - como se eles não mobilizassem também seus capitais sociais na disputa pelos espaços de atuação e consagração. Poderíamos pensar o mesmo com relação aos críticos. Não se reflete sobre o tipo de relação que Paulo Santos, Mindlin ou Carlos Lemos, pra não dizer o próprio Lúcio Costa, estabeleciam com o grupo dominante. Entretanto, as falas sobre Geraldo Ferraz apontam os laços de amizade e aproximação com os pioneiros paulistas como algo a retirar a credibilidade. A aceitação parcial do trabalho do crítico, acompanhada de certa desconfiança ou descrédito de seus atributos foge do escopo do presente trabalho, entretanto, chama-nos a atenção observações como as de Martins, que lembra que ele "apesar de não ser historiador”, propõe e desenvolve outra matriz interpretativa ${ }^{189}$; ou de Tinem, de que por ser jornalista, o trabalho é pouco disciplinado ${ }^{190}$. Sua amizade com Warchavchik é comumente desqualificada, chegando ao absurdo de ser proposta como a motivação da feitura do livro - em retribuição à doação de papel para a impressão do romance de sua au-

187 Erroneamente identificado como Geraldo Galvão Ferraz - cartunista filho de Geraldo Ferraz e Patrícia Galvão (Pagu).

188 FARIAS, 1990:127

189 MARTINS, 1987:30

190 TINEM. 2006:200 
toria "Doramundo"191. Tais assimetrias no tratamento dado aos protagonistas desta história nos diversos trabalhos da área - não na valoração, mas nos modos como os personagens são apresentados, parecem revelar as idiossincrasias do campo disciplinar.

Voltando ao trabalho de Farias, o autor aponta na obra de Ferraz o abandono da noção da arquitetura moderna brasileira como fruto de desenvolvimento da herança lusobrasileira e afirmação desta como fato internacional, ancorando-se em Giedion. "Portanto nada de raízes verdadeiras da arquitetura moderna, nada de relações com o passado, a entrada da arquitetura moderna no Brasil estaria balizada pelo quadro das profundas alterações ocorridas na vida econômica, política e cultural de São Paulo, após a primeira guerra mundial" ${ }^{192}$. No seu discurso, Warchavchik teve que enfrentar sozinho ambiente eclético dominado por construtores sem distinção de formação, em cidade de industrialização incipiente.

A hierarquização e eleição de Walter Gropius como principal personagem do movimento moderno é vista como estratégia para identificá-lo com Warchavchik ao passo que Le Corbusier já estaria identificado com o grupo carioca e portanto assimilado como principal referência para o modernismo brasileiro na historiografia hegemônica.

Por fim, Agnaldo Farias pondera que Ferraz, ao tentar combater a acusação de estrangeirismo de Warchavchik, acaba por cair na armadilha ideológica, recorrendo ao depoimento de Anísio Teixeira, que expressava sentir a brasilidade de suas obras.

Antes de partir para a análise das obras, ainda há um capítulo em que o autor discorre sobre o repúdio do movimento moderno à história, em um momento em que esta era vista como prejudicial à formação do arquiteto. Percorrendo os manifestos e documentos das vanguardas europeias, a seguir Farias analisará o Manifesto de 1925 de Warchavchik, buscando o seu parentesco. Também por esse viés irá tratar da série dos dez artigos "Arquitetura do Século XX”, publicados no Correio Paulistano ao longo de 1928, procurando demonstrar o elo consciente do arquiteto com o movimento internacional.

Farias seleciona cinco obras para análise - casas das ruas Santa Cruz, Melo Alves, Itápolis, Bahia e Estados Unidos. Como critério, busca obras anteriores ao projeto e construção do marco do Ministério da Educação e Saúde, que "pela excelência de todas elas, são suficientes para comprovar a existência dessa convergência e a consistência das ideias aqui colocadas em defesa do pioneirismo do arquiteto" ${ }^{193}$. Dentro da sua perspectiva de tratar de Warchavchik como pioneiro por sua proposição de uma nova "ordem de visibilidade", a análise das obras ficará centrada nos seus aspectos visuais e compositivos - jogos de volumes e fachadas, relação com aberturas e plantas, ritmos e movimentos estabelecidos. Apenas a casa da Rua Santa Cruz será objeto de outras considerações, por sua situação peculiar na historiografia. Defendendo-a das acusações comumente feitas, Farias remete o classicismo de sua fachada e a hierarquização da composição ao referencial clássico do arquiteto, recor- 
rendo para isso aos seus escritos; com relação ao falseamento construtivo da cobertura, assevera: "esse procedimento pode ser entendido como um expediente engenhosos que o arquiteto encontrou para, simultaneamente, driblar a inexistência de técnicas que lhe permitissem a impermeabilização de lajes e, mais importante, afirmar a supremacia do credo estético - da supracitada construção de uma 'ordem de visibilidade', sobre as barreiras tecnológicas" 194 .

A casa da Rua Melo Alves é vista como ensaio para a casa da Rua Itápolis em que ambas partem do cubo; a casa da Rua Bahia representa a decomposição dos volumes; a casa da Rua Estados Unidos tem como elemento compositivo o paralelepípedo, "variação perfeitamente previsível dentro do horizonte de especulações de Warchavchik" ${ }^{195}$. Com esta constatação, sugere uma linha evolutiva, na qual Warchavchik estaria construindo um repertório formal próprio, ideia recuperada posteriormente por José Lira. Os textos são acompanhados por fotografias e plantas sem escala, orientação solar, implantação, etc., e ambas não são creditadas, mas ao que parece extraídas do livro de Ferraz. Sobre esse aspecto fica patente uma fragilidade do trabalho, pois mesmo que reivindique o rigor metodológico da história da arquitetura, acaba por não empreender a crítica das fontes. Fotos e plantas são informações puras, que chegam a iludir o observador. Sobre a fachada posterior da casa da Rua Itápolis: "Natureza e arquitetura aqui se entrelaçam num diálogo tenso como uma poesia de João Cabral. A luz ilumina tão fortemente o volume elementar branco e chapiscado, que chega a desmontá-lo momentaneamente, fazendo-o oscilar em direção ao plano, ao mesmo tempo em que rompe sua unicidade pela irrupção de lâminas angulares de sombras" 196 (fig. 13)- em que medida tais atributos são da obra ou da imagem fotográfica ${ }^{197}$ ?

Como dissertação pertencente às primeiras fornadas dos programas de pós-graduação então em formação, entendemos que entre seus valores está a preocupação com a constituição e desenvolvimento de um campo da crítica e história da arquitetura, especialidade cujo amadurecimento só se viabilizou com a tomada de consciência desta enquanto tal a partir mesmo do agregar de significados possibilitado pelas revisões historiográficas dos anos 1980. O trabalho de Farias, em sua natureza acadêmica, trouxe uma importante contribuição para o estudo sobre Warchavchik, levantando pontos que se hoje nos parecem óbvios e naturais, é porque rapidamente foram assimilados.

\section{As obras recentes}

Em 1998 surgiria mais uma obra de referência, a seguinte após a publicação de Bruand a se propor a construção de um panorama da arquitetura contemporânea brasileira. Hugo Segawa, em Arquiteturas no Brasil - 1900 - 1990, expressava a frustração de uma geração

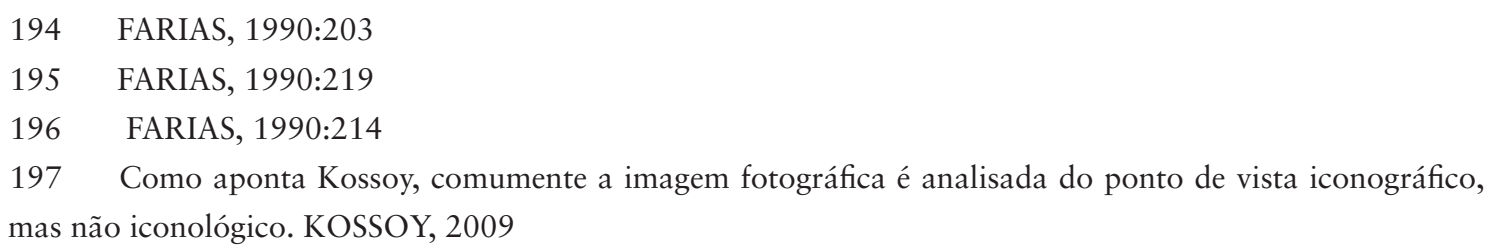


formada por professores que viam o arquiteto como messias na transformação da sociedade, que traziam à sala de aula as histórias da arquitetura totalizantes, de cunho teleológico, como as genealogias de Pevsner, Giedion, Hitchcock, Zevi e outros, e seu abismo com relação à prática profissional. $\mathrm{Na}$ esteira das revisões historiográficas, Segawa colocava em pauta as contribuições de outros campos da história e da filosofia da história, da história dos "vencidos", das micro-histórias, do olhar sobre o fragmento, da assunção da pluralidade daí o título Arquiteturas. O próprio autor também deixa explícito em sua introdução suas referências bibliográficas. Como obra que visava ser um manual de arquitetura, Segawa consultou Quatro séculos de Arquitetura de Paulo Santos, Atlas dos Monumentos Históricos e Artísticos do Brasil, de Augusto Carlos da Silva Telles, Arquitetura Brasileira, de Carlos Lemos; também esteve entre suas referências Arquitectura y Urbanismo en Iberoamerica, de Ramón Gutiérrez e mesmo os catálogos Brazil Builds e Modern Architecture in Brasil foram levados em consideração, dada a quase ausência de trabalhos desta natureza. Mas as obras que mais se aproximavam das intenções da pesquisa do arquiteto eram Arquitetura Contemporânea no Brasil, de Yves Bruand, Arquitetura Moderna Brasileira, de Sylvia Fischer e Marlene Acayaba e o capítulo “Arquitetura Contemporânea”, escrito por Carlos Lemos para a História Geral da Arte no Brasil, coordenada por Walter Zanini.

Contudo, o arquiteto matizava a importância de tais obras frente às suas especificidades, ressalvando as obras de Paulo Santos, Carlos Lemos e Augusto da Silva Telles como partícipes do movimento; os catálogos de Goodwin e Mindlin como trabalhos apologéticos formadores das "mitografias" do moderno; da tese de Bruand como um dossiê calcado na visão hegemônica do movimento.

Questionando as abordagens consolidadas na historiografia da arquitetura, procurava romper com a pesquisa focada na figura de personalidades e suas obras, mas sim, adotar a ideia de "processos da constituição da nossa arquitetura moderna em matizes diversos, caracterizando modernidades distintas" ${ }^{198}$, na qual, arquitetos e obras se inserem nos debates arquitetônico e cultural, tratados através de certo recorte da história - "exceções honrosas" a Warchavchik, Niemeyer, Lúcio Costa e Vilanova Artigas.

Deste modo, Segawa organizava sua obra propondo a identificação de diversas "modernidades", que dão nome a alguns dos capítulos - estratégia que evita a definição unívoca do "moderno": “Modernismo Programático 1917 - 1932”, “Modernidade Pragmática 1922 - 1943”, “Modernidade Corrente - 1929 - 1945”. O livro se desenvolve em linha cronológica, mas com sobreposições decorrentes do recorte proposto: $\mathrm{O}$ processo de urbanização do Brasil, de 1862 a 1945, a emergência do movimento neocolonial e a "Busca de alguma modernidade", as três vertentes acima citadas nas origens do movimento, a afirmação da escola carioca (1943 - 1960), a hegemonia e consolidação da arquitetura moderna (1945 - 1970) e os espaços da arquitetura paulista, os grandes projetos urbanísticos, infraestruturais ou de equipamentos públicos em escala (1950 - 1980), encerrando-se com um capítulo 
que trata da produção mais recente, “Desarticulação e rearticulação? 1980 - 1990”.

Mas o esforço de uma abordagem plural é parcialmente atingido, pois, se o arquiteto abre o trabalho com a ideia de perspectivas paralelas de modernização arquitetônica e cultural brasileira, das pioneiras manifestações neocoloniais às três modernidades propostas - de linhas proselitistas associadas às vanguardas europeias, encabeçada por Warchavchik; da assimilação e atualização construtiva guiada pelo "estilo moderno"; da arquitetura moderna brasileira canônica - logo é guiado pela terceira, que se desdobrará pelos capítulos seguintes, ainda que de modo crítico.

Warchavchik é, evidentemente, abordado no capítulo dedicado ao "Modernismo programático". Neste, Segawa segue uma construção interpretativa já proposta por alguns de seus antecessores: São Paulo abriga manifestações do modernismo literário e artístico, que culminam na Semana de Arte Moderna de 1922, a qual não tem desdobramentos significativos sobre a arquitetura; em 1925, Warchavchik e Rino Levi publicam seus escritos clássicos; Warchavchik cai então nas graças dos modernistas, como atesta o depoimento para Terra Roxa e outras terras; novamente, o casamento com Mina Klabin é destacado como forma de lhe garantir acesso aos círculos da elite local e realizar suas primeiras experiências arquitetônicas.

A casa da Santa Cruz, construída em 1928, é tida por Segawa como "a primeira expressão de arquitetura moderna nos termos do proselitismo do arquiteto", alvo de polêmicas e debates por aqueles anos. O autor destaca então, a realização da casa da Rua Itápolis, bem como da "Exposição de uma casa modernista" como feitos que mais se aproximavam do ideal da Bauhaus de integração das artes, a indicação de Warchavchik para os CIAM por Le Corbusier e a publicação de suas obras no livro de Sartoris.

Acompanhando a argumentação de Bruand a respeito da Casa da Rua Santa Cruz, Segawa não a considerava fiel ao ideário moderno ou ao discurso revolucionário de seu autor. Pelo contrário, a apresenta como contraditória, nos mesmos termos que o francês já apontara - simetria da fachada x planta; aparência de concreto x alvenaria tradicional. Quanto ao problema da cobertura em telha, avança ainda mais: mostra que para os brasileiros, Warchavchik sinalizava o seu uso como evocação às tradições locais, ao passo que no relatório enviado a Giedion, era resultado da ausência de material isolante adequado. A produção artesanal em sua oficina também era questionada, tendo em vista o encarecimento da construção frente ao discurso de barateamento pela adoção de peças estandardizadas.

Por outro lado, Segawa reconhece Warchavchik como construtor habilidoso, recorrendo a uma entrevista que tomara de Álvaro Vital Brazil em 1987, para a revista Projeto, na qual o autor do edifício Esther relembra a visita que realizara à residência e atelier de Lasar Segall em construção em 1934. Considera também que o caráter panfletário de suas obras demandava cuidado extra para não cair na boca da imprensa conservadora e dos arquitetos passadistas e utiliza o relatório redigido por Warchavchik endereçado a Sigfried Giedion, para falar sobre suas obras. 
A avaliação do papel de Warchavchik para a construção da modernidade arquitetônica brasileira aparece em "Limites da modernidade de Warchavchik". Segawa entende que o arquiteto teve sua importância mais como agitador cultural, do que em sua contribuição no campo construtivo, tendo em vista que suas obras não correspondiam plenamente às suas intenções. Caberia aqui o questionamento de Farias quanto ao entendimento de Lemos sobre o que é arquitetura, bem como sua defesa da importância do problema visual nas obrasmanifesto de Warchavchik. A repercussão mais significativa de sua ação, na interpretação de Segawa, foi o convite para participar na reformulação do curso de arquitetura da ENBA. Antes disso, o último acontecimento de grande repercussão havia sido a Semana de 1922. $\mathrm{O}$ arquiteto lembra ainda que o apoio inicial dos modernistas da Semana foi se perdendo à medida que Warchavchik se distanciava do ideário moderno nacionalizante e assim, seu papel seria muito mais de pioneiro na ruptura com a arquitetura passadista.

Além de não acompanhar o ideário nacionalizante, Warchavchik não conseguiu absorver o conteúdo social do modernismo europeu, do qual era tributário.

Gregori Warchavchik não vai acompanhar a politização do modernismo brasileiro, tampouco participará da cooptação da linguagem moderna pelo Estado na década de 1930. Pode-se afirmar que o papel de protagonista da arquitetura moderna de Warchavchik encerrou-se no alvorecer da década de $1930^{199}$.

Devemos observar que a estruturação em desenvolvimentos paralelos de "modernismos" não dá a Segawa a chance de articular suas relações levando-o a responsabilizar o próprio Warchavchik pela perda de protagonismo na década de 1930.

Em 2001, Lauro Cavalcanti lançava o Guia de Arquitetura 1928 - 1960, período selecionado sob a justificativa de que "parece consensual que a casa paulistana de Gregori Warchavchik, ainda que tímida na aplicação dos elementos e possibilidades estruturais, assinala, em 1928, o início do estilo entre nós; Brasília, por seu turno, inaugurada em 1960, marca o ápice e final da linguagem modernista 'clássica'” ${ }^{200}$. Cavalcanti adota a noção de estilo e procura uma compreensão mais abrangente de moderno, não se restringindo às filiações corbusiana ou bauhausiana, podendo assim apresentar arquitetos por vezes preteridos, como Flávio de Carvalho.

Trabalhando na ideia de preenchimento de lacuna - haja vista que Brazil Builds permanece esgotado, a obra de Mindlin varre a produção brasileira somente até 1955 , deixando de fora obras importantes até a construção de Brasília e o trabalho de Bruand apresenta lacunas e problemas conceituais - o guia, justifica Cavalcanti, compilou não só obras construídas, mas também projetos não executados e obras já demolidas, os primeiros para ilustrar as concepções dos arquitetos e os segundos, para não decretar uma segunda morte, aquela do esquecimento. O livro não pretende ser uma catalogação completa do movimen- 
to, mas sim, uma compilação das obras mais significativas, entretanto sem se explicitar os critérios operantes em tal processo de seleção.

O florescimento do estilo é decorrente, segundo Cavalcanti, das trocas culturais proporcionadas pelas imigrações, pelos jovens que se formaram no norte e pelo entusiasmo pelo novo pelas gerações mais novas, como em outros países pelo mundo. Em um sentido mais amplo, as relações com o campo internacional foram essenciais em vários momentos da história cultural brasileira, das missões francesas ao plano de Agache, da política de boa vizinhança à vinda de Piacentini e Le Corbusier ao Brasil. O diferencial brasileiro residia na conjunção desses fatores com o processo de modernização em um momento econômico favorável, com amplo investimento do Estado e penetração da "brilhante geração" nos aparelhos do Estado. Como desenvolvido em As preocupações do belo, Cavalcanti identifica os fatores para a consagração do grupo envolvido com a modernização arquitetônica em torno do projeto varguista: a vitória dos modernistas frente aos neocoloniais e acadêmicos consubstanciada no edifício do MES, o controle do capital simbólico através da criação do SPHAN pelos modernistas, a inserção da pauta da habitação social, deslocando o debate estético com seus oponentes, para o debate ético, no qual o estilo moderno seria o que melhor atenderia às demandas de construção massiva.

O guia é organizado por ordem alfabética de arquiteto - o que reforça o culto da personalidade, não permitindo a exposição de uma produção mais anônima, como de departamentos públicos em projetos de equipamentos e infraestruturas diversas - reservandose para cada arquiteto, uma pequena apresentação com biografia sumária e alguns poucos exemplares organizados por ordem cronológica de construção. Sobre Warchavchik, o guia traz os mesmos pontos de sua trajetória que vem sendo repetidos pela bibliografia, entre os quais a construção "d'aquela que foi considerada a primeira residência moderna do Brasil" (grifo nosso) ${ }^{201}$; mas ao contrário da maioria dos trabalhos panorâmicos, sua biografia sumária ultrapassa a reforma da ENBA: é citada sua obra da Tonelero, de 1931, "considerada a primeira residência em estilo modernista da cidade”202., a sociedade com Lúcio Costa, a participação no Salão de Arquitetura Tropical, a vitória no concurso para o estádio municipal de Santos e, erroneamente, para o edifício à Barão de Limeira, de 1939203. Cita ainda, o conjunto da Barão de Jaguara, as casas no Guarujá, como o Pavilhão Marjorie Prado, de 1946. Conclui: "Em seus trabalhos revelou sempre a preocupação com a funcionalidade, aliada a uma marcante sensibilidade estética” ${ }^{204}$.

As obras apresentadas: Casa da Rua Santa Cruz, Itápolis, Tonelero, Edifício à Barão de Limeira, Pavilhão Marjorie Prado. Em cada ficha, há um texto explicativo, fotos, plantas, leituras sugeridas - informação interessante para identificar as próprias referências utiliza-

\footnotetext{
201 Mais uma vez a reticência subentendida sobre o arquiteto e a casa.

202 CAVALCANTI, 2001:109

203 Foi inscrita e vencedora de um concurso de fachada promovido pela prefeitura, mas o projeto nasceu de demandas da própria família.

204 CAVALCANTI, 2001
} 
das pelo guia - e informações sobre visitação e a situação do imóvel.

Para falar da casa da Rua Santa Cruz, o guia recupera a história inicial de Warchavchik no Brasil, o manifesto, o trabalho com Simonsen, o casamento com Mina Klabin. O serviço de censura de fachadas da prefeitura é entendido por Cavalcanti como forma de controle dos arquitetos acadêmicos na produção da cidade, assegurando que o cânone acadêmico estava sendo seguido. E a casa da Santa Cruz era o contrário do desenho apresentado, "uma casa convencional despida de seus ornamentos. Teve, contudo, a grande virtude do pioneirismo e de demonstrar a factibilidade do estilo, fornecendo aos modernistas um manifesto, desta vez construído em tijolos” ${ }^{205}$. Com isso, observamos o entendimento de Cavalcanti de que a questão construtiva não descarta o papel precursor da obra, habilitada, como em Farias, por sua característica formal. Uma questão que chama atenção é que o guia afirma que a casa encontra-se preservada em sua forma original, o que demonstra, por um lado, a falta de cuidado na verificação do estado atual das obras (também não foi inserido o endereço completo desta casa), e por outro, a ausência total de informações sobre a intervenção realizada por Warchavchik em 1935 na bibliografia, talvez, até esse momento citada somente no trabalho de Salmoni e Debenedetti e de Ricardo Souza, que desconhecemos até que ponto circulou no meio arquitetônico. Interessante pensar que o guia, preocupado em apresentar projetos não construídos e obras demolidas, não tenha lidado com a transformação desta obra.

A “casa modernista” da Rua Itápolis é aqui chamada de pavilhão modernista por seu caráter expositivo e promocional do movimento modernista. O texto é focado na exposição e na análise formal e compositiva da construção. A "Casa Nordchild” (sic), já demolida, é apresentada dentro de uma linha evolutiva na obra do arquiteto, que desta vez inova na interpenetração de volumes. A visita de Frank Lloyd Wright é destacada, e Cavalcanti cita a sugestão de Lúcio Costa de que a casa poderia ter influenciado na criação do balcão em balanço da casa Kaufmann. O edifício da Barão de Limeira marca, de acordo com o guia, o abandono do partido dos prismas cubistas para a pesquisa da forma curva e o contraste de materiais. Por último, é exposto o "Pavilhão da casa da Sra. Marjore Prado", cujo texto remete a sua publicação na revista Domus, pois defende que a sofisticação deste provém "do arranjo de elementos simples e comuns nas praias brasileiras” ${ }^{206}$.

Em 2002, a Universidade Federal de Pernambuco editava um livro organizado por Roberto Montezuma, intitulado Arquitetura Brasil 500 Anos - uma Invenção Recíproca. Tratava-se de mais uma obra panorâmica, dividida por períodos e temas da arquitetura brasileira. $\mathrm{O} 1^{\circ}$ volume era destinado à arquitetura indígena, a de linguagem clássica, moderna, e Brasília - novamente, a cidade era tratada como capítulo em si da arquitetura brasileira, além de um capítulo chamado "continuando o debate". O $2^{\circ}$ volume se iniciava com a arquitetura popular e trazia um apanhado da produção separada por décadas - anos 
1960-1970, anos 1980 e anos 1990, além de um capítulo, chamado "desenhando o futuro", dedicado à projeção das perspectivas para os anos 2000.

O capítulo que trata da arquitetura moderna, "Moderna (1930-1960)", de autoria de Carlos Eduardo Comas, começa com a reforma da ENBA. Na periodização do arquiteto, a arquitetura moderna passou por uma fase de incubação, de 1930 a 1936, de emergência, de 1936 a 1945, de consolidação, de 1945 a 1950, de hegemonia, de 1951 a 1955 e de mutação, de 1955 a 1960, cujo encerramento se dá com o advento de Brasília. A eleição da escola carioca como a própria definição do que é arquitetura moderna se mostra na supressão, não só de Warchavchik mas de todas as demais manifestações que compareceram ao debate entre os anos 1920 e 1930, bem como nos demais períodos, com a omissão aos trabalhos de arquitetos fora do círculo carioca - apenas alguns arquitetos paulistas vão aparecer marginalmente no período de "consolidação", de 1945 - 1950 e de "hegemonia" 1951 a 1955 e somente no período de "mutação", de 1955 a 1960, Comas insere a arquitetura "brutalista" paulista. Outras produções ficam deliberadamente de fora:

A arquitetura moderna se confunde com a arquitetura do grupo carioca. Niemeyer é o líder inconteste da invenção plástica; Lucio, o intelectual de proa demonstrando o traço refinado no Parque Hotel, concluído em 1945, e em dois blocos do Parque Guinle já terminados; os Roberto, uma força inventiva talvez subestimada; Burle Marx, o parceiro genial de todos; Reidy e Moreira, a promessa esperando oportunidade; Vital Brazil, um coadjuvante; Bolonha e Ferreira ensarilhavam armas e Correia Lima havia morrido. Rino Levi e Artigas eram a exceção que confirma a regra; Lina, uma incógnita ${ }^{207}$.

Warchavchik é citado de passagem por sua contratação para a Escola Nacional de Belas Artes, apresentado por Comas como o arquiteto formado na Itália sob Piacentini, que desde 1927 fazia casas "futuristas" (grifo nosso) e era delegado dos CIAM desde visita de Le Corbusier em 1929. Ao se referir à sociedade com Lúcio Costa, torna-se evidente que Comas não distingue os termos com que se adjetivavam as obras de Warchavchik ao que o próprio arquiteto procurava combater. Como vimos anteriormente, ele mesmo escreve um artigo para esclarecer o significado de "futurismo", relativo ao movimento italiano, diferenciando o termo daquilo que era empregado pelo senso comum, e desmistificar a tensão passadistas x futuristas que se colocava no debate no fim dos anos 1920: "Sócio de Warchavchik no Rio, de 1931 a 1933, Lucio firma junto algumas casas, mas o adjetivo 'futurista' não devia agradar quem não deixara de ver na arquitetura colonial e imperial um exemplo a emular" ${ }^{208}$. Dentre os trabalhos contemporâneos, talvez este seja o mais seco e deliberadamente fiel ao cânone.

Por outro lado, no ano seguinte, saía pela PUC do Rio de Janeiro, o primeiro tra- 
balho acadêmico a versar sobre a obra de Warchavchik sob uma perspectiva que punha em questão a historiografia da arquitetura moderna a partir da mobilização de conceitos oriundos da problemática da memória: Memória e Esquecimento - Casa Nordschild e a Formação da Arquitetura Moderna no Brasil, de Sylvia Coutinho. Neste trabalho, a autora partia da análise da casa da Rua Tonelero na historiografia, verificando que, quando abordada, era considerada apenas do ponto de vista do pioneirismo e da presença de Frank Lloyd Wright. Sua estratégia contemplava a reconstituição de cinco memórias: aquela que ela chama de coletiva, da documentação da casa pela imprensa; Frank Lloyd Wright; Lúcio Costa; Gregori Warchavchik; clientes e usuários. Adotando a orientação teórica de David Lowenthal, Coutinho assumia o sentido policrônico das memórias, que ao trazerem à luz diferentes perspectivas, levariam ao abandono da narrativa unidimensional, assumindo-se o caráter multiforme do passado.

O espaço dedicado aos registros da imprensa talvez se constitua como o mais frágil metodologicamente, pois assume esta como depositária da memória coletiva sem conceituála, procurando constituir certo paralelismo com as demais memórias quando de fato se trata de outra categoria narrativa. A pesquisadora apenas relata o noticiário coetâneo à exposição da casa e a sua repercussão nas revistas.

Para analisar a memória de Frank Lloyd Wright, Coutinho utiliza os escritos contidos em Frank Lloyd Wright - Collected Writings sobre sua passagem pelo Rio de Janeiro em 1931 - um artigo para a revista T-Square em fevereiro de 1932, "For all may raise the flowers now for all have got the seed", durante a exposição The International Style do MoMA e uma crônica de viagem, "The invited Guest: Rio de Janeiro, Brazil”, presente no volume referente ao período de 1931-39. Neste artigo, Wright registra sua perplexidade diante do amplo reconhecimento de sua obra no Brasil - como bem detecta Coutinho - em um momento de declínio do seu prestígio diante da presença dos arquitetos estrangeiros nos Estados Unidos.

No primeiro artigo, o alvo da crítica era a definição a priori do International Style europeu, que invadia países como Estados Unidos, Japão e Brasil. Wright relata a ânsia dos estudantes brasileiros para saber se a casa da Rua Tonelero era arquitetura moderna, e que ele respondera que pelo termo incorreto, provavelmente era, mas era uma arquitetura que negava a natureza, o clima e as características do meio-ambiente.

Neste ponto, a dissertação revela o potencial de sua estratégia de análise, não só da manipulação de diferentes memórias, mas do confronto de diferentes momentos no interior de cada uma delas. Ao comparar o escrito, coerente com posições tomadas pelo arquiteto no contexto do debate arquitetônico norte-americano naquele período, com um depoimento de 1993 de Alcides da Rocha Miranda, que desempenhou o papel de intérprete entre Warchavchik e Wright, demonstra a não linearidade da memória e suas reformulações como 
constituição do passado para um determinado presente. Segundo Miranda, Wright teria dito a Gregori: "se eu fosse você fazia aqui um ressalto ainda maior, acho que a superfície está muito lisa - aí olhou para as casas vizinhas e mudou de ideia - olha professor, você faz muito bem de fazer coisas assim bem simples. Continue assim” ${ }^{209}$.

Lúcio Costa é analisado a partir de seu Registro de uma vivência, para Coutinho, um livro que revela a natureza fragmentária e não linear da memória. A obra escrita em fim de vida é tida como um ready-made, que a autora interpreta a partir da combinação de suas peças. Em certo ponto, Costa dispõe o texto "ENBA 1930-31 - Situação do ensino na Escola de Belas Artes" ao lado da famosa foto dele ao lado de Warchavchik e Wright na casa, junto de logomarca da Bauhaus e da inscrição "Bauhaus + Taliesin" ${ }^{210}$. Coutinho considera que inscrição revela uma percepção da soma das diferentes contribuições e coesão entre aqueles engajados numa causa internacional. Um Frank Lloyd Wright orgânico e Bauhaus racionalista não são excludentes, há um ideal comum. Já o texto, uma crítica ao ensino da escola e ao Salão, denota uma postura aberta às vanguardas europeias, prevalecendo uma visão internacionalista do movimento moderno, em amplo processo civilizatório. Como a reforma fracassa, Coutinho propõe que associação entre texto e foto pode ser uma forma de compensação, pois foi uma espécie de território livre para reunião em torno dos novos ideais.

Em outro ponto do livro, Costa publica artigo escrito por ocasião da morte de Warchavchik junto de fotos de três das obras construídas pela sociedade. No texto, o arquiteto expõe suas críticas à obra do russo, explicitando predileção pela arquitetura corbusiana. Mas compensa a crítica com elogios de ordem pessoal e admitindo papel precursor, que marcou época - não dito em que termos, denotando episódio de página virada, esgotamento da influência purista germânica.

A última citação está no artigo "Muita construção, alguma arquitetura e um milagre”, publicado em 1951 no Correio da Manhã, que constitui em um balanço da produção arquitetônica desde fins do XIX. Os marcos são os mesmos que irão aparecer em Arquitetura brasileira: o Edifício "A Noite”, "o romantismo simpático da casa da Vila Mariana”, a reforma frustrada da ENBA e o Salão; Casa Nordschild de Warchavchik, casa Schwartz de Costa $^{211}$, Albergue de Reidy, apartamentos de Nunes, casas de Roberto, etc.; como marco definitivo assinala o Ministério.

Coutinho passa então a investigar as memórias de Gregori Warchavchik, recorrendo ao seu discurso proferido por ocasião do Encontro Nacional em comemoração aos 50 anos do Instituto dos Arquitetos do Brasil. Do programa de abertura constavam três exposições - "Retrospectiva da obra de Gregori Warchavchik", "Croquis inéditos de Le Corbusier" e "Projetos de Flávio de Carvalho"; Entre os palestrantes, figuravam Paulo Santos, com seu tema "Influências da Arquitetura Colonial na Arquitetura Contemporânea"; Costa e "In- 
fluências Externas na Arquitetura/ Le Corbusier", Flávio de Carvalho e Alcides da Rocha Miranda e "Arquitetura Brasileira: Uma Nova Linguagem" e Warchavchik e "Arquitetura Brasileira no Início do Século XX". Na interpretação de Coutinho, o tema delimita o lugar de Warchavchik como precursor, como se sua obra não tivesse tido continuidade e desdobramentos significativos.

$\mathrm{Na}$ sua palestra, o arquiteto abre agradecendo a lembrança, o "reconhecimento a um arquiteto que há tempos se afastou da vida profissional":

Que haja um esquecimento coletivo, que a autoridade não se lembre, tanta história se passou, compreende-se. Que o meio profissional, então dê uma prova como esta, é o prêmio maior, aquele prêmio que não pensei jamais um dia receberia (...), tenho que agradecer: as coisas boas não acontecem todos os $\operatorname{dias}^{212}$.

O capítulo é utilizado para apontar o apagamento da obra de Warchavchik, evocando os trabalhos de Agnaldo Farias e Abílio Guerra ${ }^{213}$; avaliar as intenções de Warchavchik perante a reforma da ENBA, quando considerou seu "dever cumprido" ao passar o bastão para a geração seguinte - que Coutinho ilustra com o depoimento de Alcides da Rocha Miranda em que assume ter sido graças ao arquiteto que os alunos abandonaram imediatamente o ecletismo e com a imagem de duas obras de Reidy e Vital Brazil que evocam o racionalismo germânico.

No depoimento, Warchavchik reforça a ideia do pioneiro solitário, em país com tudo por fazer, no qual inovou com o manifesto de 1925, lembra ele, mesmo ano do pavilhão de Le Corbusier e manifesto de Gropius - argumento comumente utilizado por Geraldo Ferraz em seus escritos sobre o arquiteto - e em seguida com as casas da Santa Cruz e da Tonelero. Sobre este aspecto, poderia ter rendimento alguma referência ao potencial narrativo da memória como autoconstrução.

$\mathrm{Na}$ análise da obra, Coutinho relaciona a evolução técnica com a plástica ao se referir ao volume dinâmico, não monolítico, acomodado à inclinação do terreno e às grandes aberturas, que promoviam a integração interior x exterior e a circulação de ar e boa luminosidade - aspectos dos mais comentados pela imprensa à época da exposição, em um momento em que as preocupações de higiene e salubridade pautavam as discussões. Tal preocupação, segundo a autora, se revelava também na escolha dos materiais de revestimento, conforme descrito no memorial, como as paredes em afresco nas áreas sociais, que podiam ser lavadas com água e sabão e em azulejo nas áreas de serviços, que também contavam com piso em "granito artificial". A obra é descrita ainda em seus materiais, na relação entre planta e fachada livre, na disposição dos ambientes e nas suas filiações.

Um dos pontos mais interessantes da dissertação é a recuperação da memória dos clientes e usuários da casa, na qual Coutinho recorre aos depoimentos das filhas do comi- 
tente, William Nordschild. A pesquisa intencionava elucidar os caminhos que levaram à sua construção, esclarecer o sentido que a casa alcançou para seus usuários, a ligação entre o usuário anônimo e a trajetória de uma geração de arquitetos na busca de uma nova "imagem simbólica da paisagem arquitetônica do país". "Propõe-se, dessa forma, levar em conta a figura do cliente e usuário, geralmente desprezada pela crítica modernista, como significativa no contexto dos acontecimentos analisados” ${ }^{214}$.

Tecendo considerações sobre o uso de fontes orais e os processos de rememoração e narração com base em David Lowenthal e Pierre Nora, Coutinho situa a história de William Nordschild para compreendermos o momento da contratação de Warchavchik para a realização de sua casa à Rua Tonelero. Não há evidências de como Nordschild teria conhecido Warchavchik, e com isso, Coutinho atribui à proximidade entre os círculos da burguesia progressista, não considerando também a origem judia de ambos. $\mathrm{Na}$ lembrança das filhas, Renate e Gabriele, a casa remetia à amplidão e liberdade, dada a fluidez dos espaços e circulação, e também à diversão, pois tinha cantinhos, vários andares, jardins. A autora descreve a rotina da família, dos momentos de trabalho e estudos, como as aulas de desenho que as filhas recebiam com o pintor Guignard, inspiradas pela paisagem avistada do terraço. Gabriele se lembra do estranhamento que tinha reciprocamente com a casa de uma amiga decorada com motivos tradicionais de inspiração francesa, que para ela mais parecia um museu. Se no subcapítulo que tratava da memória de Warchavchik, a autora priorizou a análise arquitetônica, se apoiando em fotografias de época e plantas extraídas do livro de Ferraz, ilustra a memória dos usuários, fotos da família, cenas domésticas, com a casa como pano de fundo (fig. 14).

$\mathrm{Na}$ concepção de Coutinho, as trajetórias individuais são elementos não apenas constitutivos, mas constituidores da sociedade moderna, e a casa Nordschild é um episódio concreto do investimento no projeto de modernidade:

O sentimento de claridade que também permeia a vivência na Casa Nordschild remete tanto ao sentido da luminosidade solar que tomava conta do ambiente, como ao de uma racionalidade esclarecida. Os dois sentidos somam-se na promoção de uma satisfação para aqueles que, de posse de uma formação e visão humanista, acreditaram e investiram no projeto da modernidade. É nesse ponto que se dá a intersecção entre a memória da arquitetura moderna e a de um indivíduo que, num ambiente conservador e hostil ao novo, demanda uma construção radicalmente moderna para si. Quanto às utopias sociais mais amplas ou a utopia pessoal mais íntima, o tempo encarregou-se, por diversas razões, de liquidá-las. De qualquer forma, sabe-se, são os projetos, utópicos ou não, que dão sentido à vida e impulsionam as transformações ${ }^{215}$. 
A autora considera que, em termos metodológicos, o entrelaçamento das memórias dos agentes envolvidos possibilita a reconstituição da rede de relações e encontros culturais que favoreceram a formação das diversas concepções de arquitetura moderna no Brasil. Refuta teses de que contexto do fracasso da reforma da ENBA e da casa da Tonelero não fornecia as condições necessárias para a implantação da arquitetura moderna, pois não há hierarquia que pré-determine a ordem para o desencadeamento dos processos. Também descartam autonomia do pensamento e criação artística, que se inserem em quadro de transformações mais amplas, constituindo-se simultaneamente em sintoma e resposta a demandas.

Em 2004 um novo trabalho historiográfico era lançado. Arquitetura Moderna Brasileira, organizado por Adrian Forty e Elisabetta Andreoli, intencionava repassar de forma alternativa à história por eles identificada como ortodoxa, propagandística, o chamado "período heroico" do modernismo - uma formulação que antevê a contradição que irá nortear em parte os ensaios reunidos - nega-se a historiografia oficial, mas assume-se seus termos, sua periodização, seus marcos e em alguns casos, privilegia-se os mesmos agentes.

Constituído pelo texto introdutório dos organizadores, cinco ensaios e um capítulo dedicado a projetos recentes, o livro não se propõe a construir um panorama da arquitetura moderna brasileira, mas de revisá-la em perspectiva crítica nos ensaios ora apresentados, independentes, sem que tenham algum encadeamento em busca de síntese. Percebe-se, nos diversos olhares, que a discussão da origem, que tanto permeou a historiografia clássica, perde sua razão de ser, apesar de que em alguns momentos a discussão desaparece por estar subentendida uma origem conforme a versão hegemônica da história ${ }^{216}$. Deste modo, Warchavchik pouco é tratado nos trabalhos, porque não se desvinculou do debate da origem. Outra questão que chama atenção é a ideia de continuidade da arquitetura moderna aos dias de hoje com a publicação de projetos contemporâneos.

Talvez o mais próximo ao cânone seja o ensaio que abre a publicação, "Modernidade Congênita", de Guilherme Wisnik, que embora se proponha avaliar a produção arquitetônica moderna brasileira de um ponto de vista da história cultural, traçando paralelos com a música ou a literatura, sua reflexão permanece centrada nos mesmos atores - Niemeyer, Artigas e Paulo Mendes da Rocha.

De certo ponto de vista, os ensaios de Roberto Conduru, "Tectônica tropical” e Luiz Recamán, "Forma sem utopia" seguem com o paradoxo, no qual fazem a crítica mas a partir dos mesmos objetos. Entretanto é visível em todos a procura por novos enfoques, apesar de que a proposta de novas pautas esteja ainda colocada timidamente.

Conduru procura repensar o descompasso entre os princípios do movimento moderno e a realidade brasileira, comumente vista de forma negativa. Pensando o potencial do fenômeno para avaliar as relações centro-periferia, questões como a falsa correspondência entre estética e sistemas de materiais industrializados, como nas obras de Warchavchik e da 
primeira leva da escola carioca, passam a ser de interesse historiográfico.

Recamán aborda a arquitetura moderna como componente cultural ideológico fundamental no processo de modernização conservadora do Brasil. Aponta o autor que os dilemas iniciais dos modernos consistiam na polaridade entre o potencial social e utópico da forma e sua dimensão comunicativa e linguística, colocando-se assim em pé de igualdade as primeiras obras de Warchavchik e o Ministério, pois ambos em suas construções artesanais simulavam aparência moderna. Entretanto, decreta: "O Ministério de Educação e Saúde é a origem da arquitetura moderna brasileira" ${ }^{217}$. O texto prossegue com uma crítica contumaz ao caráter ideológico e dissimulado da produção modernista brasileira, contudo chocandose com a própria forma sedutora do livro, com suas imagens ilustrativas de grandes formatos, lindas, das obras ora analisadas acabadas, perfeitas.

O livro segue com “A Casa moderna brasileira”, de João Massao Kamita, sobre o morar moderno. O ensaio se abre com a casa modernista de Gregori Warchavchik, datada equivocadamente como de 1929-1930, como protótipo da habitação moderna de referencial racionalista associado às teses do CIAM. Relembrando a incipiência da indústria da construção civil naqueles anos, considera a casa uma experimentação mais de cunho estético que tornou permeável a relação entre moderno e tradicional. Da casa, Kamita seleciona três fotos dos interiores, o que faz com que talvez esta seja o único trabalho que a ilustra a não publicar a foto clássica da fachada em 1928. Entretanto, um equívoco salta aos olhares mais atentos: a foto de maior destaque revela um acesso de escada de um ambiente de pé direito duplo e uma viga que percorre o teto denunciando não tratar-se da casa da Santa Cruz. $\mathrm{Na}$ realidade, a imagem se refere à casa da Rua Tonelero ${ }^{218} \mathrm{e}$ faz-nos pensar na necessidade do crítico e historiador da arquitetura experimentar a obra construída, percebê-la in loco.

O ensaio de Pedro Arantes, "Reinventando o canteiro de obras", constitui-se no texto mais instigante da coletânea, por adotar uma abordagem completamente fora dos padrões da historiografia brasileira. Brasília, que será seu ponto de partida para análise da arquitetura através dos meios de produção, é entendida como consagração máxima e explicitação do estado de subdesenvolvimento nacional, revelando as contradições entre um projeto de intenções progressistas e as violências sofridas pelos trabalhadores no canteiro de obras, identificadas em ao menos quatro: Desqualificação, Superexploração, Apagamento ${ }^{219}$, Segregação. Ilustra o texto um conjunto de imagens da construção de Brasília, da montagem das formas e armações em aço densamente dimensionadas sendo amarradas por

\section{RECAMÁN, 2004:112.}

218 Devemos salientar que a imagem foi equivocadamente catalogada no acervo fotográfico de Warchavchik contido na biblioteca da FAUUSP e no escritório de seu neto.

219 O apagamento consiste no ocultamento, por meio dos revestimentos brancos de Niemeyer, dos vestígios do esforço humano por trás da construção - "Há uma autonomização completa da obra em relação aos produtores, exacerbada por um desenho ultra-autoral. Essa autonomização se apresenta, por sua vez, não como fetiche da mercadoria, mas como manifestação da abstração e domínio do Estado sobre a realidade social”. ARANTES, 2004:175. 
operários que dariam forma às curvas consagradas do mestre. Tal discussão o leva a recuperar os debates entre o Canteiro e o desenho polarizados por Artigas e o grupo Arquitetura Nova (Ferro, Lefèvre e Império) e coloca as experiências dos mutirões autogestionários dos anos 1990 como material historiográfico.

No ano de 2005, Ricardo Souza enriqueceria a discussão sobre o plano das ideias no campo arquitetônico, iniciada com Trajetórias da Arquitetura Modernista, de 1982, com a elaboração de sua tese de doutorado, O Debate Arquitetônico Brasileiro - 1925 - $36^{220}$. Nesta, estuda a obra escrita dos autores que considera mais atuantes por aqueles anos - José Mariano Filho ("Tradição Nacional”), Christiano Stockler das Neves (“Academia Francesa"), Gregori Warchavchik ("Bauhaus germânica”) e Flávio de Carvalho, Carlos Prado e Mário de Andrade ("Futurismos"), apontando as inter-relações com um segundo grupo de intelectuais, como Alexander Buddeus, Jayme da Silva Telles e Henrique Dória.

No capítulo dedicado a Warchavchik, Souza perscruta a obra escrita do arquiteto, em seus discursos, filiações, debates e embates. O pesquisador demonstra que Warchavchik desenvolve um trabalho extremamente coerente, consistente e homogêneo em suas convicções, sem grandes variações ao longo de sua história. Para ele, o arquiteto é o grande renovador do cenário estudado, e traz consigo a negação da tradição francesa de pensamento, explicada pelo repúdio das regiões menos ditosas do velho mundo aos impérios centrais na guerra de $1914-1918$.

Desse modo, Warchavchik traz para o Brasil não apenas as inquietações de uma região do continente europeu que se rebelou contra a influência cultural em todo o Hemisfério Ocidental, como também os modos próprio de arrostar a arquitetura dos países que primeiro testaram e efetivamente conviveram com a alternativa modernista. Seu discurso no combate permanente da hegemonia artística e arquitetônica francesa e no elogio incansável das experiências de caráter modernista exercidas na Alemanha, na Áustria, na Itália, na Holanda, na Rússia ${ }^{221}$.

Como vimos, o apogeu de Warchavchik pensador coincide com seu período de maior produção. Sua obra será mais concentrada até 1929 e passará então a aparecer em ocasiões especiais. Souza identifica que com o tempo o caráter didático e instruído dos primeiros escritos é substituído por colagens, ideias repetidas, tendo como denominador comum o desejo de libertação do passado - o progresso que se realiza na construção do novo que mata a perspectiva preexistente, sem meio termo. Em síntese:

220 Destacamos que em 1992, Ricardo Souza assinava uma reportagem retrospectiva sobre a obra de Warchavchik, na revista Arquitetura e Urbanismo n.44, avaliando o legado do arquiteto, transcorridos 20 anos de sua morte. Tratava-se do primeiro artigo a percorrer a produção de toda a trajetória do arquiteto: os trabalhos publicados até aquele momento focavam o período inicial de atuação - mesmo as obras monográficas a seu respeito, como a de Geraldo Ferraz e de Agnaldo Farias.

221 SOUZA, 2005:108. 
O autor estabelece uma oposição radical entre passado e futuro, que complementa entretanto com o método de abordagem da realidade sugerido pela filosofia de Spengler. Warchavchik crê na constituição paulatina de uma etapa nova da história humana, sem qualquer parentesco com as etapas anteriores, que põe em convivência, no momento atual, forças reativas e forças renovadoras. Para a época é necessário então deduzir uma nova arquitetura que deve atender a formações sociais de nova qualidade, nas quais os problemas de economia preponderam sobre os demais. Chega-se à orientação modernista 'oficial' ensaiada pela Bauhaus, que Warchavchik apresenta como adequada às exigências contemporâneas. O movimento moderno passa a constituir referência para compreensão de ideias do autor, voltadas à democratização arquitetônica e utilizando como expoente a produção mecânica do edifício. Warchavchik assume as consequências estéticas dos novos métodos produtivos que, como no caso das máquinas modernas, comprometem a beleza arquitetônica com a adaptação correta da obra para seus fins; e prognostica um futuro de grande criatividade para o arquiteto, no qual sua atividade livre não impede a afirmação de um novo estilo mundial ${ }^{222}$.

Para Souza, como Warchavchik parte do pressuposto de que a arquitetura moderna encerra um valor em si mesma devido à consciência do momento atual, mesmo nos casos mal resolvidos, leva em consideração o desejo de colaboração com o novo ciclo histórico e assim, o arquiteto jamais criticará as expressões mal sucedidas. Souza também identifica em Warchavchik uma clara filiação à Bauhaus, apontando sua reticência à linha corbusiana.

Souza conclui que Warchavchik, quanto mais se integra ao país, mais distante fica da realidade nacional. No relatório ao CIAM, fala da industrialização retardatária e de entraves ao projeto no Brasil. É como se não se identificasse com a Nação e descrevesse o país como um europeu falando a europeus sobre os hábitos de uma civilização remota. Aí estaria o limite da fortuna crítica do arquiteto:

Em verdade, um de seus grandes equívocos, pelo qual pagará preço alto, é justamente o alheamento da Nação, o cosmopolitismo que excede a mera admiração modernista pelas benesses do progresso e adentra o fascínio pela vida dinâmica, barulhenta e nervosa dos grandes centros mundiais, isto quando toda uma geração que viveu a descoberta do passado nacional procura o denominador comum entre modernidade e tradição ${ }^{223}$.

Pelo contrário, considera o país jovem, sem tradição, no qual é mais fácil vencer os "fantasmas do passado", como se Brasil não tivesse história.

Em 2006, saía publicado o livro Arquitetura na Formação do Brasil, organizado por Paulo e Briane Bicca, para a UNESCO, que buscava traçar um panorama da arquitetura e 
urbanismo brasileiros na organização do território, associando-os aos ciclos econômicos e regionais: A arquitetura do açúcar, texto assinado por Geraldo Gomes; Arquitetura da mineração nos Estados de Minas Gerais e Goiás, por Myriam Andrade Ribeiro de Oliveira; Arquitetura e economia do gado na Região sul, por J. N. B. de Curtis; A arquitetura do café, por Gustavo Rocha Peixoto; A arquitetura maranhense e a economia do algodão, por Luiz Phelipe de Carvalho Castro Andrès; Arquitetura da borracha na Amazônia (1850-1920), por Jussara da Silveira Derenji; e Arquitetura da Industrialização, no capitulo "Rumo à industrialização: arquitetura da primeira metade do século XX”, de autoria de Hugo Segawa.

A proposta geral do livro era de associar os desenvolvimentos arquitetônicos à história econômica do país. A Segawa coube a tarefa de escrever sobre a arquitetura e o urbanismo da era industrial, que o arquiteto recorta em um período do fim do século XIX à Brasília. Mas ele destacará os anos 1930, com a ascensão de Getúlio Vargas, como momento de estabelecimento das condições para a modernização do país. Entre antecedentes, assinala a atuação dos engenheiros, a reforma de Pereira Passos, a construção de Belo Horizonte, a fundação das escolas superiores para formação de corpo técnico, as inovações técnicas oriundas da arquitetura de ferro importada, o estabelecimento da Companhia de Cimento Portland, e as novas possibilidades técnicas do concreto armado, verificadas na estação de Mairinque de Victor Dubugras e nos novos arranha-céus, como o Martinelli, A Noite, Sulacap e outros.

A visão sobre Warchavchik se assemelhará àquela já presente em Arquiteturas no Brasil:

Nesses anos, em que obras como o Elevador Lacerda ou a Usina do Gasômetro eram inauguradas, Gregori Warchavchik agitava o provinciano meio paulistano com suas casas modernistas. Tratava-se de uma modernidade retórica: suas obras apresentavam aparência moderna, mas eram pouco revolucionárias quanto ao aspecto construtivo e da organização de plantas. Todavia, o proselitismo de Warchavchik foi importante para despertar a discussão sobre a arquitetura moderna com o reconhecimento dos modernistas da Semana de $1922^{224}$.

E então passará a discorrer sobre o período Vargas, na reorganização das relações industriais, na construção dos Ministérios, nas políticas de habitação com os IAPs, na construção de edifícios para educação e saúde em escala, nos investimentos para a integração do território nacional - entre os quais os marcos da arquitetura moderna no conjunto do Santos Dumont no Rio de Janeiro - e demais equipamentos públicos. O período sinaliza para uma convivência entre diferentes estilos, ideia que Segawa retoma de seu livro de 1998, entre uma modernidade pragmática ou também das orientações diversas entre segmentos dentro do governo, como a linha adotada nos edifícios do Ministério da Guerra, do Trabalho, da Agricultura e o da Educação. Dos dois últimos, destaca também a coerência estética adota- 
da na construção de seus equipamentos, o primeiro com a adesão ao gosto neocolonial e o segundo, ao moderno.

A seguir, expõe o cenário cultural dos "anos dourados", incluindo a consagração da arquitetura do grupo carioca, cujo corolário foi Brasília. A cidade também será tratada dentro da política de Juscelino, em uma exposição antecedida por considerações sobre os diversos planos urbanísticos desenvolvidos no período.

\section{Fraturas da vanguarda}

A última obra que abordaremos neste trabalho, Fraturas da Vanguarda em Gregori Warchavchik, de José Tavares Correia de Lira, data de 2008 e foi desenvolvida como Tese de Livre Docência pela FAUUSP. José Lira elabora um trabalho de fôlego, que varre um amplo arco temporal, investigando a fundo a trajetória de Warchavchik e tornando-a tema transversal para pensar a própria constituição da modernidade no Brasil.

Como o próprio autor assinala no capítulo introdutório da tese, abandona-se o tema das origens, da dualidade precursor x esboço individual sem grandes consequências; sua tese não se pretende obra de revisão e de debate a respeito das matrizes historiográficas vivas na produção brasileira, mas evidentemente, como todo trabalho de história, contém uma proposta historiográfica. Lira se serve de elementos não só da história, mas também de outros campos disciplinares, como a crítica literária, a sociologia e a filosofia, entrelaçando o exame da produção arquitetônica às estruturas e aspectos culturais, econômicos, sociais, políticos, urbanísticos, estéticos, materiais, técnicos, sem no entanto incorrer em interpretações totalizantes, que prescindam das obras. Ao contrário, as suas particularidades serão fundamentais no tratamento dado às obras, também trabalhadas em função de suas questões internas. Sua abordagem, à medida que rompe com o tema da origem e se desvincula do embate com o cânone, lança novas perguntas sobre o arquiteto, parecendo com isso refletir as próprias transformações no campo da história.

Ao estender o período de reflexão para além da fase pioneira e de destaque de Warchavchik, colocando-a em perspectiva sob uma trajetória pelo próprio pesquisador reconstituída - que inclui os anos antecedentes e ulteriores à fase áurea da carreira do arquiteto, Lira faz emergir continuidades e descontinuidades, contradições, permanências e transformações só possíveis de serem observadas em uma abordagem do conjunto. A estratégia de análise de trajetória é profícua no sentido de articular fragmentos, preencher lacunas e mesmo desconstruir mitologias, sem que o autor caia na ideia de gênio.

Para enfrentar a questão que irá nortear a tese, "que relações, afinal, manifestações estéticas de vanguarda como aquelas guardavam com as conjunturas materiais e culturais contemporâneas, a economia das construções e os esquemas mentais e significados associa- 
dos à sua técnica, à sua forma, a seu programa?"225, propõe a ideia de "fratura", ancorada em Tafuri, como forma de verificação do projeto moderno como projeto de crise. Para ele, não há como enfrentar a problemática do modernismo como manifestação cultural dissociada do processo de modernização capitalista brasileiro. Desse modo, a obra arquitetônica é entendida como mediação entre os diversos agentes sociais e a sociedade.

A tese abrange o período que vai do fim do século XIX aos anos 1950, propondo uma nova periodização da trajetória de Warchavchik - nova por se tratar de primeiro trabalho a enfrentar em profundidade os períodos para além da "fase heroica" do arquiteto, mas também por criar sobreposições que extrapolam a lógica essencialmente cronológica de Ferraz. Grosso modo, a tese propõe quatro grandes momentos da trajetória de Warchavchik - os períodos de formação, combate, silêncio e rotinização. Para isso, estrutura-se em quatorze capítulos, agrupados por quatro partes, "Deslocamentos”, "Ruptura”, "Atualizações” e "Rotinas". As sobreposições ocorrem especialmente nos capítulos da $2^{\mathrm{a}}$ e $3^{\mathrm{a}}$ parte.

Sobre os anos de formação de Warchavchik, o historiador traz à luz elementos que deixam de naturalizar a sua imigração como fato dado. Em Odessa, recupera temas como a sua origem social, o ambiente cultural e artístico da cidade, a organização do ensino de arquitetura, assim como expõe o problema dos fluxos imigratórios judaicos e conflitos étnicos, inserindo as saídas de Warchavchik de Odessa e da Itália, associadas a outros fatores, dentro de um panorama de êxodo judaico em escala mundial. Com isso, a questão do desterro será tratada em outro patamar. Nos anos italianos, Lira investiga o ensino romano e suas reformulações no período em que Warchavchik passa pela Universidade - estrutura curricular, professores, habilitações, os debates sobre o papel do arquiteto - e recupera documentos da passagem de Warchavchik pela escola. A seguir, apresenta os anos de atuação como arquiteto, suas colaborações, e especialmente o papel e a influência exercida por Marcello Piacentini, cujo perfil oscilava entre o conservador e o renovador. Ao fim do capítulo, faz uma instigante análise dos projetos italianos de Warchavchik, que no livro de Ferraz e mesmo no catálogo da exposição realizada em 1971 pelo MASP226, foram inseridos com caráter meramente ilustrativo. Lira demonstra que o léxico formal de Warchavchik não se assentava exclusivamente sobre a produção italiana coeva de referencial clássico, mas também sobre elementos antiacadêmicos russos, o vernáculo protoindustrial, entre outros, revelando a proximidade de seus estudos com a obra de Ivan Fomin - situada e contextualizada pelo autor na produção russa - em uma fase que oscilava entre o Secessão e as variações neorrussas do moderno. Tal aspecto traz novos horizontes sobre as matrizes que permeavam a produção de Warchavchik, pois se se sabia que não viera ao Brasil já aderido ao movimento moderno, não se imaginava que já flertava com pesquisas de natureza antiacadêmica.

$\mathrm{Na}$ sequência, Lira especula sobre as motivações para a transferência de Warchavchik para o Brasil, aliando às oportunidades profissionais, o exame do momento geopolíti- 
co vivido na Europa do pós-primeira guerra mundial, a ascensão do antissemitismo, as redes judaicas de colaboração internacional, as recentes restrições à imigração nos demais polos receptores no continente americano. Com relação ao contrato com a Companhia Construtora de Santos, o autor investiga o funcionamento da empresa, as concepções de Simonsen, os tipos de trabalho desenvolvidos e a forma anônima de seu desenvolvimento, formulando então a hipótese de que "apenas no Brasil - e não desde a Europa - o arquiteto tenha pessoalmente se deparado com esse polo da vanguarda mais adiante recrutado em massa para as tarefas de reorganização produtiva do grande capital"227.

Com isso, descarta as buscas por filiações a esta ou aquela corrente vanguardista europeia, corrente na bibliografia, como se Warchavchik já tivesse aportado no Brasil com um ideário pronto, e mais, como se suas formulações tivessem origem exclusivamente na importação do discurso de vanguarda europeu. Como o tratamento que dá ao manifesto de 1925, no qual refuta as propostas de Bruand, Ferraz, Farias, Santos e Souza ${ }^{228}$ e sugere matrizes teóricas fora do campo da arquitetura, de autores como Wölfflin e Spengler, muito influentes no período. Para Lira, a ideia em Warchavchik de que "na base das transformações dos estilos (...) havia uma necessidade interna, derivada da atualização histórica de um Zeitgeist, ecoa diretamente essa matriz" 229 . Entretanto, é difícil crer, e a tese não consegue demonstrar o contrário, mesmo que sugira não haver evidências, que Warchavchik não tenha tido qualquer contato com o ideário moderno nas cidades e círculos estudantis e profissionais por que passara. Por outro lado, sai do ponto de vista de que a arquitetura moderna inaugura um conjunto de discussões, como a industrialização ou pré-fabricação da construção e a economia de materiais, temas que já permeavam a cultura dos arquitetos nas Escolas de Belas Artes, Liceus, Politécnicas e mesmo na prática profissional: tratava-se de questões colocadas pela modernização urbana e atualização tecnológica em andamento.

Lira segue com a análise dos demais escritos produzidos por Warchavchik até 1928, que, contrariando o ponto de vista de Ricardo Souza, apontava para uma falta de unidade programática - para ele, reflexo da diversidade, incertezas e conflitos entre as correntes que permeavam o seu ideário, o que não permite associá-lo categoricamente a uma matriz de renovação específica. Por meio da repercussão dos textos, são apontados caminhos para falar do processo de inserção de Gregori nos círculos intelectuais, artísticos e das elites paulistas, situando-o nos seus meios de sociabilidade e troca, na qual sua atuação seria inscrita no processo de virada de fase negativa para construtiva da vanguarda. Constrói-se, enfim, o clima em que se forjará a casa da Rua Santa Cruz.

O capítulo 5, "Antinomias da Vanguarda Arquitetônica", é inteiramente dedicado à análise da casa da Rua Santa Cruz de modo a explorar as suas contradições, não como falhas ou limitações de que a bibliografia tratou de julgar ou acusar o arquiteto, mas como 
expressões das próprias contradições da sociedade brasileira; e não enquanto desenho de síntese, mas como ponto de partida para compreender as fissuras do processo de modernização brasileiro.

O problema é que raras vezes se aprofundou o significado dessas contradições e adaptações para além da censura, do anedotário ou das generalizações interpretativas. Pois em vários sentidos, a casa da Rua Santa Cruz, porque contraditória, é a obra mais emblemática da virada arquitetônica brasileira. Urbana e suburbana, moderna e clássica, inovadora e convencional, provinciana e cosmopolita, a casa representa eloquentes matrizes compositivas e, simultaneamente, a negação de todos os estilos ${ }^{230}$.

Com tal percepção, essa obra icônica, tão reproduzida nos diversos trabalhos sobre arquitetura moderna brasileira, tão denunciada em seus falseamentos construtivos, tão referenciada circularmente no episódio da censura de fachadas, quase banalizada em torno de argumentos reificadores do momento de constituição do movimento moderno no Brasil, passa a receber novo tratamento. "Gostemos ou não de seu resultado formal”, as diversas tensões corporificadas na casa revelam, segundo Lira, as ambiguidades e idiossincrasias nas mais diversas frentes - do campo disciplinar em busca de autonomização, na relação com a questão fundiária ou com a expansão urbana, na esfera aristocrática e de elite de atuação, nos limites técnicos e produtivos, nas bases de sustentação técnica e social. A casa, de exceção, passa a ser emblema.

Outro aspecto que merece atenção é que o autor trata da associação entre moderno e regional preconizada por Warchavchik, nos seus depoimentos sobre a casa da Rua Santa Cruz, não tentando verificar se sua intenção foi bem sucedida ou não ou acusando de ter sido este um compromisso provisório, logo abandonado, mas assinalando que a casa foi assim interpretada por seus contemporâneos e por isso "produziu efeitos na maneira como se pensava e se faria arquitetura no país" ${ }^{231}$.

Além da casa da Rua Santa Cruz, a casa da Rua Itápolis tem um capítulo inteiramente dedicado a ela, no qual o autor faz uma análise detalhada da obra e repassa a "Exposição de uma casa modernista", sua repercussão e seu significado, colocando-a como ponto de viragem na trajetória de Warchavchik, que a partir dela, assume nova posição no interior do mercado local de arquitetura - tema que será desenvolvido no capítulo seguinte. Entre os elementos analisados, figuram a composição volumétrica, planta, jardim, técnica construtiva, exploração dos materiais, interiores, método de projeto, filiações. As descrições são recursos utilizados com precisão, linguisticamente enxutas, constituindo-se em uma seleção de aspectos para a construção de uma interpretação, que no capítulo seguinte será recuperada para o desenvolvimento da análise da série. 
Nesta perspectiva de conjunto, são tratados os projetos residenciais - coletivos e unifamiliares, tanto de São Paulo quanto do Rio de Janeiro. A ênfase da análise recai sobre a casa da Rua Melo Alves - para Lira, de mesmo protótipo da casa da Itápolis, casa da Rua Avanhandava, Rua Bahia e Rua Estados Unidos, por constituírem uma sequência que expressa todo "o fio experimental e ao mesmo tempo disciplinado de toda essa fase de sua carreira" ${ }^{232}$. Nas análises, busca-se também demonstrar um Warchavchik informado das obras dos mestres do modernismo internacional, seja por meio do texto, seja por meio de imagens.

Ao longo de toda a tese, a pesquisa iconográfica é extremamente rica, complementando e acrescentando significados aos objetos analisados. Quando Lira traça paralelos entre as obras analisadas e as referências com que dialogam, empreende um estudo visual comparativo que comunica mais do que muitas descrições textuais, por vezes enfadonhas, inócuas ou de difícil compreensão. Quando apresenta os documentos que recupera da fase europeia, estes contribuem para construir o clima daqueles ambientes em que Warchavchik transitou e que a própria tese abre para o nosso conhecimento hoje. Com relação às obras dos períodos menos consagrados, as imagens têm o papel essencial de informá-las, posto que, salvo exceções, eram até então desconhecidas quase por completo do público, abarcando o estudo das obras de Warchavchik em seu período mais comercial, no contexto de crescimento e profissionalização do mercado imobiliário em um momento de verticalização e intensificação do processo de urbanização da cidade. Ainda na questão da análise de obras, observamos que o uso das fotografias prepondera sobre as peças gráficas.

A discussão do "aperfeiçoamento" de obra a obra, do ponto de vista técnico e construtivo torna-se passagem para o desenvolvimento de "Projeto, Canteiro e Capital". Neste capítulo, são sugeridas assimetrias entre arquitetura de vanguarda e barateamento através de técnicas tradicionais; entre canteiro racionalizado das arquiteturas de estilo de Ramos de Azevedo ou Simonsen e canteiro tradicional das obras de vanguarda de Warchavchik. Tal questão é ponto de partida para cercar o problema pela perspectiva do atraso da indústria de materiais e componentes, das relações entre artesãos, "gamelas", engenheiros e arquitetos em vias de regulamentação profissional, trazendo à pauta a discussão de Sérgio Ferro, a partir da qual Lira reitera que o atraso da construção civil levou à intensificação da renda da terra e à exploração da mão de obra tradicional. A partir daí, o autor passa a investigar a consolidação do capital imobiliário dos Klabin, o papel de Warchavchik na gestão dos negócios do ramo familiar que lhe dizia respeito, analisando correspondências, entrevistas e projetos. Tal abordagem abrirá caminho para a discussão que será desenvolvida a respeito da fase "pós-reclusão" de Warchavchik, mas já nesse momento prenunciando um tratamento completamente novo à interpretação de seu legado.

Em seguida, o período de atuação no Rio de Janeiro é tratado, passando-se pelo IV Congresso Panamericano de Arquitetos, a reforma da Escola Nacional de Belas Artes, a $38^{\circ}$ 
Exposição Geral de Belas Artes, os projetos da Rua Tonelero e a cobertura da Av. Atlântica e suas respectivas exposições, a sociedade com Lúcio Costa e o Salão de Arquitetura Tropical. Neste capítulo, Lira descarta a oposição na chave das discussões das origens da arquitetura moderna brasileira, compreendendo Warchavchik e cariocas como episódios de um mesmo processo de formação de um sistema arquitetônico brasileiro $^{233}$ :

Seria errôneo imaginar que a emergência da arquitetura moderna no Rio de Janeiro não tenha encontrado na presença de Warchavchik um momento crucial. Se apenas com a sede do Ministério da Educação e Saúde, o Pavilhão Brasileiro na Feira de Nova York, o conjunto da Pampulha, etc., a formação de um sistema arquitetônico moderno no país viria a se completar, essa origem supostamente milagrosa não é mais do que o episódio mais visível de um estado de tensão já latente, no qual a experiência carioca, docente e profissional de Warchavchik havia protagonizado a entrada em cena do moderno no teatro dos procedimentos de projeto ${ }^{234}$.

Ainda sob a perspectiva desse processo de formação, outros aspectos da estruturação do campo são tratados, como a criação de instituições profissionais, revistas especializadas, concursos, exposições, publicações, fixação de profissionais estrangeiros fornecendo novos parâmetros de organização dos escritórios, elementos, enfim, que ensaiavam a passagem de manifestações arquitetônicas de exceção ao sistema arquitetônico propriamente dito.

Neste momento, a tese passa a tratar do período identificado como de reclusão ou silêncio. O momento de consolidação do campo coincide com as transformações de ordem política e todas suas implicações na área da cultura. Perda de importância do mecenato oligárquico e arrefecimento geral das vanguardas em São Paulo, impactos da Revolução de 1930 e migração das questões do campo da estética para o social, impactos da Revolução de 1932 e reconfiguração política do país, passagem dos salões paulistas para o aparato institucional de Estado no Rio de Janeiro, desenhavam uma nova geografia das vanguardas no Brasil. É dentro desse panorama que Lira irá delinear o momento de recolhimento de Warchavchik, do fim de sua sociedade com Lúcio Costa, da experiência da SPAM minada pelo antissemitismo, do afastamento progressivo dos CIAM, da estagnação de sua carreira. Uma leitura que, apesar de se assentar em elementos já consagrados da história do Brasil, em sua articulação, projeta um entendimento que rompe com a responsabilização pessoal de Warchavchik pelo arrefecimento de sua carreira ${ }^{235}$. A isso se contrapõe a equipe do Ministério e toda uma nova geração de arquitetos cariocas "saída da reforma do ensino, absorvida pelo

233 Aqui nos parece evidente a aproximação com a ideia de "manifestações literárias" x "sistema literário" desenvolvida por CÂNDIDO, 1962.

234 LIRA, 2008:296-297

235 Como na interpretação de Bruand, para quem Warchavchik teria esgotado sua capacidade criativa e era demasiadamente estrangeiro para prosseguir com sua arquitetura ou de Segawa, na qual a falta de envolvimento político ou de sensibilidade para os programas sociais da arquitetura moderna determinaram sua perda de protagonismo 
Estado, produzindo para o Estado, reunida em organismos profissionais" em circuito mais regular de encomendas e intercâmbios capitaneados pela doutrina de matriz corbusiana de Lúcio Costa.

O período é retratado como de quase paralisação, com poucas obras e projetos, e ainda por cima, em geral irrelevantes. Destes, são analisadas as reformas do ateliê e residência de Lasar e Jenny Segall, na Rua Afonso Celso com Rua Berta e a reforma de sua própria residência entre 1934 e 1935. A reforma da casa da Rua Santa Cruz, para José Lira, manifesta certas dificuldades e hesitações por parte do arquiteto. Justificadas as necessidades de adequação da casa às novas solicitações - demandas familiares e sociais - são descritas as alterações no programa, na planta, fachadas e esquadrias, que para ele, revelam incongruências que assinalam um momento de crise nos procedimentos projetuais de Warchavchik em relação às próprias referências de vanguarda. A experiência é colocada como oportunidade de revisar a fachada clássica, mas que o novo elemento, ao invés de corrigir, acentuava aquilo que deveria ser incômodo àquela altura da carreira de Warchavchik. Entretanto, não nos é apresentada nenhuma evidência de que o arquiteto tenha desejado "corrigir" a referida fachada, ou mesmo que ela realmente fosse incômoda.

Após o período retratado como de recolhimento, Lira contextualiza a retomada de Warchavchik em um ambiente de retrocesso nas artes, literatura e também na arquitetura. O predomínio das grandes construtoras lideradas por engenheiros e capitalistas e firmas de porte médio de arquitetos e engenheiros no mercado da construção acabava por impingir à cidade a arquitetura de estilos e a eleição do Art Déco como estratégia monumentalizante em programas públicos. Apesar da participação destacada do arquiteto nos concursos para a Praça da República e o Paço Municipal - oportunidades para o exame das formulações urbanísticas de Warchavchik - o fim dos anos 1930 marca o abandono das plataformas de vanguarda e a aproximação do arquiteto com o mercado que se estruturava, colocando lado a lado realizações mais consistentes e arquiteturas de estilo, sem qualquer traço de resignação. Se na trajetória reconstruída ao longo da tese o arquiteto aparece como o assalariado anônimo, passando ao arquiteto liberal atuante em episódios de exceção e ao gestor do capital imobiliário da família, a partir da sua retomada será apresentada sua relação com o processo de expansão e verticalização da cidade, o consumo da arquitetura por uma nova elite em ascensão, o aparecimento de novas práticas e agentes induzindo ao reposicionamento do arquiteto na divisão social do trabalho. Tais as senhas para discutir a metáfora da fratura:

A inflexão que seu trabalho tomara daí em diante, à medida que se engajava na realidade urbana do capital imobiliário, revela sem qualquer resíduo utópico das poéticas de vanguarda as fraturas constitutivas do próprio projeto moderno: a introdução local, talvez, de uma 'ideologia do plano' em um design cada vez mais profundamente ligado à cidade como estrutura produtiva ${ }^{236}$. 
Ruptura e impossibilidade de realização do projeto moderno. E como fraturas constitutivas do próprio projeto moderno, por extensão, toda a produção arquitetônica coeva é posta em cheque, inclusive daqueles que se colocavam como porta-vozes da vanguarda nacional. Poderíamos pensar à primeira vista, que o historiador estivesse propondo uma distinção entre uma fase de arquitetura pura ${ }^{237}$ de vanguarda contraposta a uma fase de concessões ao gosto do freguês. Entretanto a ideia de forma como dependente do campo, da obra como mediação material, social e econômica, da construção como agenciador dos diversos aspectos constituintes da ação arquitetônica e especialmente, o movimento de alargamento e expansão do objeto arquitetônico isolado à cidade, são elementos claros e decisivos para que se confirme que a tese não caiu em armadilhas que ela mesma poderia ter criado.

Tal é a consciência do autor, que ao discutir a afirmação da hegemonia carioca nos anos 1940, assinala a estratégia de Warchavchik para romper com o esquecimento propiciado por seu fardo de pioneiro superado - imagem que, como Lira nos lembra, o próprio Geraldo Ferraz, a despeito de suas intenções, acabou por ajudar a criar - para uma intencional incorporação dos elementos canônicos em sua arquitetura, aceitando, portanto, os novos códigos estabelecidos pelo grupo dominante:

Sua atitude de pesquisa, aberta ao recrutamento da geração mais jovem de cariocas recém-chegados a São Paulo, é também um atestado de perícia técnica. Tudo se passa como se o arquiteto que - bem notou Christiano de Souza - há muito tempo vinha recuando do front revolucionário, precisasse confirmar destreza e elegância na manipulação dos códigos canônicos para que pudesse continuar a praticar uma arquitetura mais terra a terra, às vezes mais fecunda, ainda que constantemente ameaçada pelo lugar comum, o conformismo, o capricho, o pastiche e a irresolução ${ }^{238}$.

Nesta fase, o autor nos apresenta Warchavchik como um arquiteto que incorpora referenciais cariocas e corbusianos, americanos, clássicos e mesmo oriundos das manifestações paulistas que começavam a emergir e se destacar, com mesma desenvoltura e desprendimento; mais uma vez evidencia-se que não há arquitetura verdadeira, com "causa”, e arquitetura de mercado: todas as formas são equivalentes, indiferentes como a postura de Warchavchik - que importa um projeto, como o da sede do Automóvel clube (fig. 15), possuir uma fachada neoclássica ou moderna? Talvez aí resida uma denúncia latente da falsidade do projeto emancipatório do movimento moderno.

Quanto aos programas, Lira destaca a atuação do arquiteto enquanto expoente dos fetiches de sua clientela abastada: o clube e a casa de veraneio, dedicando páginas à análise especialmente das casas do Guarujá. Mas é na abordagem dos programas de arranha-céus que ele novamente tecerá considerações sobre o cruzamento entre renda fundiária e capital 
financeiro, especulação imobiliária e produção da cidade.

Como vimos, a tese traz contribuições de várias naturezas, seja no âmbito dos métodos de análise e de procedimento, no tratamento das fontes, no uso articulado de diversos campos disciplinares, na interpretação da obra de Warchavchik e inserção de novos referenciais teóricos para o seu enfrentamento, seja na reflexão sobre a modernidade cultural e modernização econômica do Brasil, seja nas considerações sobre o papel das vanguardas nesse processo.

\section{ARQUITETURA E DOCUMENTO}

Verificamos a relevância da produção intelectual de Warchavchik e sua participação do debate arquitetônico na fase inicial de sua carreira até a primeira metade da década de 1930. O arquiteto constituía-se em principal referência na divulgação da nova arquitetura, escrevendo ora artigos combativos ora de sentido didático para um público mais amplo. Vimos que o arquiteto, como protagonista do debate, era chamado a opinar sobre os principais temas da disciplina, não somente aqueles relacionados ao modernismo, mas também relativos aos principais eventos arquitetônicos e urbanísticos da cidade.

Ocorre então um período de silêncio, na segunda metade da mesma década, quebrado na virada dos anos 1930 para os anos 1940. Entretanto, sua retomada ao espaço público de debate e difusão acompanha o amadurecimento pelo qual passava o campo da arquitetura, em busca de autonomização e diferenciação, coincidindo com o fortalecimento dos periódicos especializados como espaço privilegiado de comunicação. Neste momento, a produção textual é substituída pela divulgação de projetos, em um primeiro momento exclusivamente através das páginas da revista Acrópole, mas a partir da publicação de Brazil Builds, se fazendo presente em veículos internacionais. A partir dos anos 1950, novos periódicos nacionais são criados, mas o arquiteto é pouco publicado, exceção feita à Acrópole, que pelo perfil editorial de sua primeira fase, possibilitou a documentação de obras pouco conhecidas e prestigiadas de Warchavchik. No período, a revista Habitat exercerá papel fundamental, menos pela divulgação de projetos e mais como questionadora da versão que começava a se consolidar sobre a constituição da arquitetura moderna no Brasil, defendendo o protagonismo de Warchavchik, Flávio de Carvalho e outros, em momento anterior aos marcos cariocas a partir da segunda metade da década de 1930.

Por esses anos de 1950, Warchavchik, portanto, passa a ser alvo de discussões sobre as origens da arquitetura moderna no Brasil, passando a ser tratado como objeto historiográfico, em um momento em que começam a surgir as primeiras histórias produzidas no Brasil a abordar a arquitetura moderna.

Constatamos a continuidade, circularidade e agregação de camadas de reificação de uma interpretação que encontrava variantes em versões que ignoravam, minimizavam ou 
depreciavam a contribuição do arquiteto para a cultura arquitetônica moderna no Brasil em detrimento do cânone estabelecido pelo grupo carioca que gravitou em torno do projeto do Ministério da Educação. Tais obras tratavam Gregori Warchavchik exclusivamente através do tema da origem, muitas vezes o utilizado apenas como argumento teleológico para afirmação da arquitetura hegemônica que viria a seguir. Mesmo Geraldo Ferraz, personagem de exceção, elaborou uma obra que insistia no tema, mas para provar a relevância do arquiteto e reforçar a sua imagem de pioneiro.

Grosso modo, somente a partir dos anos 1980 começam a surgir, paralelamente à historiografia dominante, ainda viva, revisões e novas perspectivas, no que diz respeito aos temas, recortes, métodos, perguntas. Com o amadurecimento dos programas de pósgraduação, emergem trabalhos acadêmicos significativos até a atualidade, simultaneamente à publicação de novas obras de âmbito panorâmico, que, por seu turno, não representaram grandes alterações do quadro já estabelecido.

De modo geral, vem prevalecendo o exame do período de produção inicial de Warchavchik, sob o ponto de vista simbólico da origem, da construção da imagem de pioneiro - com ou sem consequências para os desenvolvimentos da arquitetura moderna brasileira -, e dos aspectos visuais das primeiras residências modernistas. Por hora é difícil avaliar o impacto das obras recentes que propõem outras abordagens sobre a historiografia da obra de Warchavchik em relação à periodização e significação, bem como mensurar sua recepção.

Os trabalhos, nas mais diversas orientações, não vêm utilizando as próprias obras construídas como material documental de interesse para a reflexão historiográfica, privilegiando a fotografia, o projeto e fontes textuais secundárias. Apenas Souza, Coutinho e Lira ${ }^{239}$ utilizaram fontes documentais diversas, em substituição ou complementação: Souza e os textos de época como material para discutir o debate arquitetônico; Coutinho e as fontes orais e escritos memoriais; Lira e os documentos primários sobre a formação de Warchavchik.

Nos documentos fotográficos, a prioridade dada ao período pioneiro do arquiteto é revertida em seleção de fotografias as-built das obras, realizadas nos momentos inaugurais das construções, repetidas nas mais diversas publicações.

Dos trabalhos estudados, verificamos que apenas Trajetórias da Arquitetura Modernista ${ }^{240}$ e Memória e Esquecimento - Casa Nordschild e a Formação da Arquitetura Moderna no Brasil não se restringem às fotografias do estado inicial. O primeiro trouxe também imagens que registravam o estado das obras à época da publicação - entretanto, é um trabalho que não tem como objetivo analisar obras arquitetônicas -, e o segundo inseriu ao lado das fotos originais, registros fotográficos de família nos ambientes da casa.

Até os anos 1950, a fotografia de arquitetura moderna privilegiava a comunicação 
de "relações espaciais e o desenho original do arquiteto em imagens precisas e limpas, sem a presença de elementos móveis, como pessoas e veículos" ${ }^{241}$, a exemplo dos trabalhos de fotógrafos que registraram obras de Warchavchik, como Leon Liberman, Peter Scheier, José Moscardi e Hugo Zanella. São fotos que retratam as obras recém-construídas, etéreas, perfeitas, monumentais, atemporais, sem apropriações humanas, em ângulos, enquadramentos e iluminação que ajudaram a forjar a imagem de modernidade a que pretendia Warchavchik e que, implicitamente, tal o seu caráter acabado e atemporal, não supunham o envelhecimento delas ${ }^{242}$.

O privilégio dado à fotografia as built não se restringe ao tratamento dado a Warchavchik, nem à produção brasileira. Tournikiotis, em The Historiography of Modern Architecture $^{243}$, examina trabalhos escritos entre os anos 1920 e 1960 que tratam da gênese, triunfo e declínio do movimento moderno, selecionando autores que considera representativos das principais direções investigativas da história da arquitetura moderna: Nikolaus Pevsner, Emil Kaufmann, Sigfried Giedion, Henry-Russel Hitchcock, Bruno Zevi, Leonardo Benevolo, Reyner Banham, Peter Collins e Manfredo Tafuri. Dos trabalhos analisados, sem entrar no mérito da concepção historiográfica e rendimento do trabalho, apenas a Storia dell' architettura moderna (1960) de Benevolo se utiliza de fotos que registram as obras no estado em que se encontravam à época da produção do livro (fig. 16), de modo a explicitar a relação das obras com o presente e mostrar que aqueles edifícios realmente existem e são sujeitos à passagem do tempo ${ }^{244}$. Tournikiotis observa que obras como a Villa Savoye e a Bauhaus não envelheceram bem ${ }^{245}$, e os registros dos edifícios deteriorados tiram o encantamento do projeto, de modo que a própria emoção causada pelas imagens merece reflexão histórica. Uma emoção despida de qualquer dimensão estética. Conclui Tournikiotis:

Benevolo enfatiza esse caráter existencial do edifício que descreve selecionando fotos contemporâneas dele. Afastando-se completamente da prática de outros autores em nosso corpus, que escolhem imprimir vistas dos edifícios fora do tempo (o edifício em condição perfeita, a estudada ausência da figura humana, tempo imaginário, etc.) - e, portanto, no fim das contas, publicam repetidamente as mesmas fotografias originais - Benevolo nos mostra o edifício no seu atual e negligenciado estado, acentuado por vezes por meio da perfeitamente normal presença humana e às vezes mostrando-as na chuva. Há mais valor no estado físico e social da arqui-

241 Em GOUVEIA, 2009:17

242 A discussão da fotografia como discurso, documento/ representação pode ser verificada em KOSSOY, 2009

243 TOURNIKIOTIS, 1999

244 Observamos o mesmo fenômeno em Gillo Dorfles, L’Architettura Moderna, 1954; Renato de Fusco, Storia dell'architettura contemporanea, 1985, Kenneth Frampton, Modern Architecture: A Critical History, 1981. Exceção a Alan Colquhoun, Modern Architecture, 2002, que também optou por publicar fotos atuais de algumas das obras retratadas.

245 As retomaremos no próximo capítulo 
tetura do que o caráter ideal de um protótipo imutável ${ }^{246}$.

A opção pelas fotos das obras nos momentos iniciais, auxiliadas por vezes, por plantas, demonstra o privilégio da concepção e da autoria sobre sua dimensão real e concreta no tempo. Quer dizer, no limite projeto e obra se confundem, sem que esta última seja considerada documento histórico do presente.

Devemos deixar claro aqui que as considerações sobre a eleição das fotos as built das construções não têm como intenção apontar falhas, limites ou diminuir os méritos das obras analisadas. Ao contrário, tentamos expor ao longo do capítulo os múltiplos avanços e contribuições dos trabalhos, nos diferentes contextos e momentos históricos. Quando questionamos posicionamentos dos autores, procuramos fazê-lo por meio de argumentos específicos para cada trabalho e não pelo fato em si de não darem à obra construída status de documento; não queremos reduzir o legado historiográfico a mera análise de imagem. É inquestionável a produtividade e potência de trabalhos que investigam dimensões as mais imateriais e metafísicas possíveis da arquitetura. Já por algum tempo descartada a possibilidade de uma História total, cada documento traz e suscita questões conforme as perguntas e articulações propostas por cada historiador.

As fotografias são apenas uma entre outras categorias de documentos que falam de uma obra arquitetônica e suas mediações e como tal, não são fragmentos de algo que sobreviveu do passado, mas sim, consistem em "uma escolha efetuada quer pelas forças que operaram no desenvolvimento temporal do mundo e da humanidade, quer pelos que se dedicam à ciência do passado e do tempo que passa, os historiadores" 247. Diz Veyne, "Por essência, a história é conhecimento mediante documentos. Desse modo, a narração histórica situa-se para além de todos os documentos, já que nenhum deles pode ser o próprio evento; ela não é um documentário em fotomontagem e não mostra o passado ao vivo 'como se você estivesse lá’" 248 : o historiador deve sempre questionar seus documentos ${ }^{249}$.

Ao trazermos a discussão para o campo da história da arte e da arquitetura, nos deparamos com algumas especificidades, como apontado por Giulio Carlo Argan, para quem a história da arte "é a única, entre todas as histórias especiais, que é feita na presença dos

\footnotetext{
246 "Benevolo emphasizes this existential character of the building he describes by selecting contemporary photographs of them. Departing completely from the pratice of the other authors in our corpus, who chose to print views of the buildings outside time (the buildings in perfect condition, the studied absence of human figures, imaginary weather, etc. - and thus ultimately published the same original photographs again and again - Benevolo show us the buildings in their modern, neglected state, accentuated sometimes by means of the perfectly normal presence of human figures and sometimes by showing them in the rain. (...) There is more value in the physical and social state of architecture than in the notional character of an unchanging prototype". TOURNIKIOTIS, 1999:105-106.

247 LE GOFF, 2003:525.

248 VEYNE, 1982:12

249 Cf. BURKE, 1992; FOUCAULT, 2000; LE GOFF, 2003
} 
eventos e que, portanto, não deve evocá-los, reconstruí-los ou narrá-los" ${ }^{250}$. Estes devem ser descritos, entendendo-se a descrição, seguindo Baxandall, como "ato de representação - através do qual indicamos um aspecto que atrai nosso interesse" 251 . Para o historiador da arte inglês, "na crítica de arte ou na história da arte, o que determina o sentido das palavras é se o objeto está presente ou é acessível, seja na realidade, seja na forma de uma reprodução ou de uma lembrança (...)" ${ }^{252}$. Entretanto, há que se matizar tais afirmações antes de estendê-las à arquitetura. Como abordar a obra arquitetônica como evento? Até onde o projeto ou a fotografia podem servir de base para a interpretação da obra construída? E as formas de representação bidimensionais ao objeto tridimensional? Qual a especificidade da experiência na obra construída, da sua percepção no tempo e no espaço? Na sua dimensão material? Enfim, quais são os limites do evento arquitetônico e sua duração?

Argan prossegue com sua inferência:

Mas a obra de arte que o historiador da arte tem diante de seus olhos não muda: ela é como sempre foi. E, se os acontecimentos e o tempo a desgastaram, o historiador evita aceitar esta alteração, esforçando-se, ao contrário, de todas as formas, para revertê-la à condição original, ao momento do seu advento flagrante" 253 .

Contudo, a relação das artes e da arquitetura com o tempo é diversa. Nas artes plásticas, os desdobramentos contemporâneos talvez ponham em xeque a noção subentendida de obra acabada contida na asserção, mas de qualquer modo o autor tem controle sobre sua produção, podendo definir o momento em que a obra está pronta, mesmo quando sua intenção seja de torná-la aberta às dinâmicas com o público, ambiente, etc. Já o arquiteto é apenas uma peça da cadeia de agentes e determinantes para a realização da obra, não tendo o controle sobre sua produção; e após sua conclusão, o edifício ganha vida própria, sofrendo uma série de apropriações na cidade, na sociedade, no tempo. Qual seria, em arquitetura, o advento flagrante? Como as transformações ao longo do tempo - apropriações, adaptações, intervenções, transformações intencionais ou fortuitas - deveriam ser tratadas?

O entendimento da obra construída como documento, portanto, traz à tona sua presentificação, fazendo com que o historiador deva reconhecer sua transmissão até o tempo presente, o que significa admitir que a obra, entendida como objeto histórico, possui, ela mesma, uma trajetória. Deste modo, a duração do evento se estende e deixa de residir apenas no âmbito da concepção do autor, do contexto histórico do momento inaugural consubstanciado na obra, que passa a assumir-se como artefato, como materialidade que adquiriu significação ao longo do tempo, e assim, entra em uma zona de fronteira e justaposição entre os domínios da historiografia e da preservação de bens culturais. 

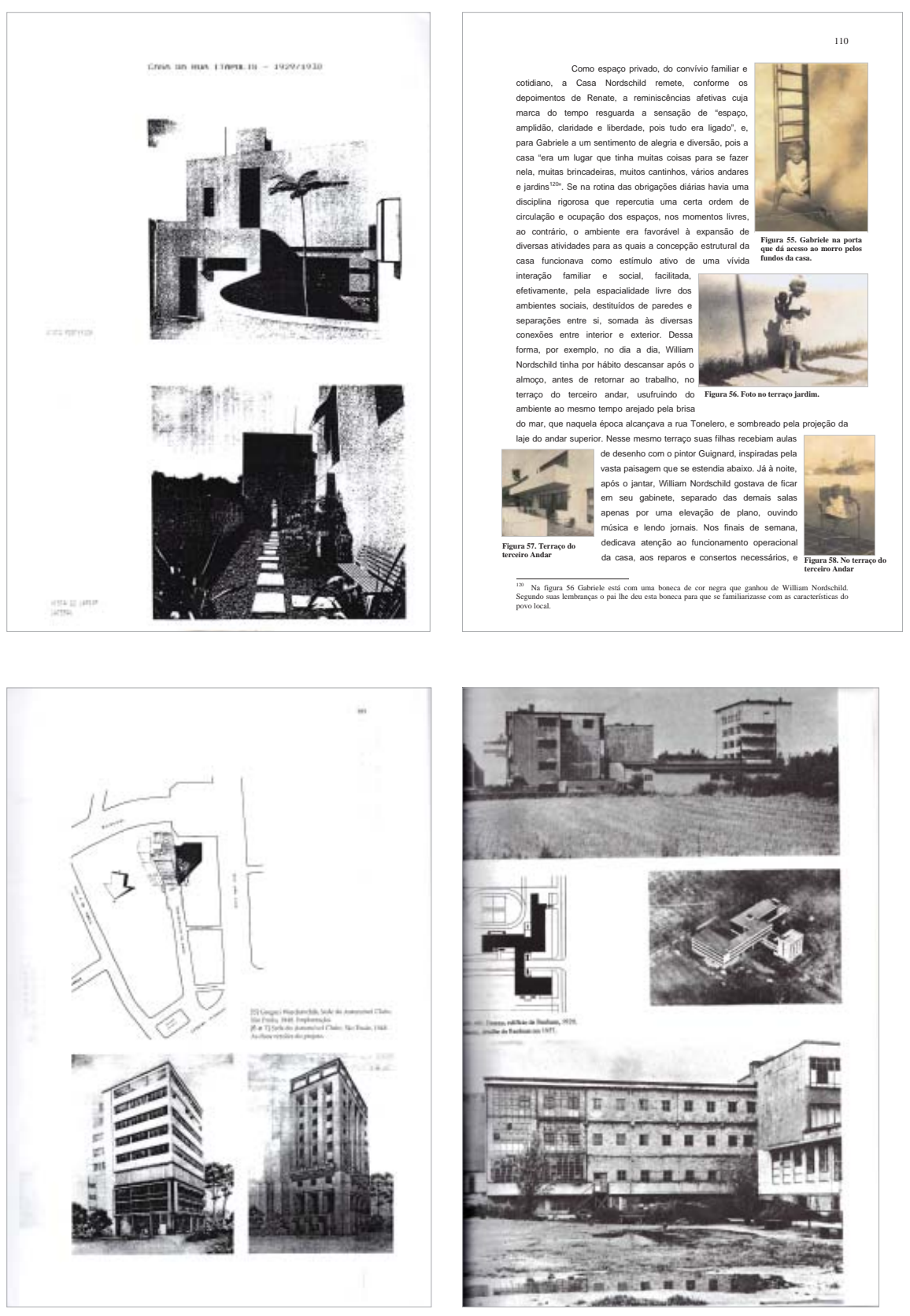

Em sentido horário: [14] Ilustrações da Casa da Rua Itápolis em FARIAS, 1990; [15] Imagens de família na Casa Modernista à Rua Tonelero (Rio de Janeiro), em COUTINHO, 2003; [16] Dois estudos de Warchavchik para o Automóvel Clube, em LIRA, 2008; [17] Imagem do edifício da Bauhaus no estado em que se encontrava à época da feitura de Storia dell'architetura moderna (1960), de Benevolo. 


\section{ARQUITETURA MODERNA NA PAUTA PRESERVACIONISTA}

\section{DESENVOLVIMENTO DO CAMPO DA PRESERVAÇÃO}

O processo de constituição do campo da preservação remete à revolução cultural engendrada pelo Iluminismo e pelo entendimento moderno de história no qual alterou-se a percepção sobre a relação presente/ passado, acentuada pelas intensas transformações acarretadas pela Revolução Industrial, pelas destruições massivas vivenciadas a partir da Revolução Francesa e pela constituição dos Estados nacionais ${ }^{1}$. O modo de lidar com o legado do passado deixava de se guiar por ações pragmáticas e passava a assumir conotação cultural e científica, focalizando os "aspectos estéticos, históricos, memoriais e simbólicos dos bens, também com fins educativos" ${ }^{2}$.

Neste processo, foram inúmeras as iniciativas nos âmbitos normativo, teórico, prático e de registro até a sua consagração. As diferentes posturas identificadas no século XIX costumam ser sintetizadas nas figuras de John Ruskin (1819-1900) e Eugène Emmanuel Viollet-le-Duc (1814-1879), cujas formulações encontram desdobramentos até a atualidade, permanecendo o legado do arquiteto francês no centro das práticas relativas ao patrimônio moderno.

Para Viollet-le-Duc, "restaurar um edifício não é mantê-lo, repará-lo ou refazêlo, é restabelecê-lo em um estado completo que pode não ter existido nunca em um dado momento" ${ }^{3}$. Como concepção idealista que supre qualquer individualidade do edifício e qualquer marca da passagem do tempo sobre ele, o restauro é convertido em intervenção idealizada, baseada em conhecimentos apriorísticos disponíveis das formas pretéritas. Escrito como verbete para o Dictionnaire Raisonné de l"architecture Française du XVe au XVIe siècle ${ }^{4}$, Restauração encarna a crença na infalibilidade positiva da ciência. 
Em suma, o chamado restauro estilístico, disseminado por toda Europa ${ }^{5}$, tinha como pressuposto o princípio de que "cada edifício ou cada parte de um edifício devam ser restaurados no estilo que lhes pertence, não somente como aparência, mas como estrutura" ${ }^{6}$. Admitindo ter de enfrentar as inúmeras transformações sofridas pelos exemplares a serem restaurados, Viollet-le-Duc entendia ser necessário ao arquiteto o conhecimento profundo dos estilos, escolas, formas, tipos arquitetônicos, estruturas, construção e associá-los a pesquisas de documentos, levantamentos arquitetônicos e mesmo ao procedimento de colocarse no lugar do arquiteto primitivo, imaginando o que ele faria. Embora exigisse, portanto, o rigor de uma pesquisa histórico-arquitetônica, sua abordagem priorizava o aspecto estético do edifício em detrimento de qualquer traço de historicidade.

John Ruskin situava-se no extremo oposto, apontando o problema ético no qual os contemporâneos não teriam direito de intervir nos monumentos, por estes pertencerem tanto ao passado quanto às futuras gerações. Sua Lâmpada da Memória ${ }^{7}$ é escrita em forma de aforismos, indicando a conotação moral de suas preleções. Para ele, a arquitetura seria o único meio de que dispomos para conservar vivos os laços com o passado ao qual devemos nossa identidade e por isso as marcas do tempo tinham um caráter sagrado e faziam parte da própria essência dos edifícios, objetos únicos fruto da criação de um artista ou artesão em um contexto histórico específico. Com seu epígono e fundador da Society for the Protection of Ancient Buildings (SPAB), William Morris, repudiaram as restaurações fantasiosas que vinham ocorrendo na Inglaterra e no continente europeu, recusando o conceito de "restauração", para eles, de conotação negativa, para então propor o conceito de "conservação", que remeteria à mínima intervenção possível, à estabilização, proteção e consolidação das estruturas.

Além de fundadores de escolas de pensamento no campo da preservação, ambos são situados nas pontas iniciais das genealogias da arquitetura moderna por diversos historiadores, juntamente com William Morris e o Arts and $\mathrm{Crafts}^{8}$, mais pela ruptura com a arquitetura de orientação clássica - como no redescobrimento da arquitetura medieval ou no culto ao pitoresco -, do que por uma postura análoga diante da história, já que o movimento moderno, de natureza anti-historicista, refutava a restauração, vista como apologia do historicismo, como culto da erudição eclética?.

No contexto italiano, paralelamente aos adeptos das duas vertentes, via-se surgir na geração seguinte uma espécie de $3^{\mathrm{a}}$ via, chamada restauro filológico, formulada a partir dos estudos filológicos da linguística nos círculos acadêmicos de Milão. Entendendo o mo-

5 Mesmo na Inglaterra, berço do movimento antirrestauração, da SPAB, de John Ruskin e William Morris, houve grande penetração, tendo sido Viollet-le-Duc indicado como membro honorário do RIBA (Royal Institute of British Architects). JOKILEHTO, 2006:155

6 VIOLLET-LE-DUC, 2000:47

7 Capítulo de As Sete Lâmpadas da Arquitetura (1849). RUSKIN, 2008

8 Cf. TOURNIKIOTIS, 1999

9 Cf. CERÁVOLO, 2010 
numento como construção portadora de uma mensagem e em si um documento, seu texto representaria uma fonte para verificação da história, e portanto, não poderia ser falsificado. Camillo Boito (1836-1914), romano de nascença, formado em Veneza, mas professor da Academia de Belas Artes de Milão, retoma conceitos desenvolvidos pelos círculos milaneses enfatizando o valor documental da obra e realiza um trabalho de síntese, tomando emprestado de Ruskin e Morris a concepção de conservação baseada na autenticidade, a preservar não só a pátina, mas os sucessivos acréscimos devidos ao tempo e de Viollet-le-Duc, a prioridade do presente sobre o passado. Mas para ele, a restauração só deveria ser aplicada caso outras tentativas de salvaguarda tivessem fracassado, como a manutenção, a consolidação e os consertos imperceptíveis. Quando necessários acréscimos e renovações, os novos elementos deveriam se diferenciar, mas sem destoar, do conjunto, através de materiais diversos, formas simplificadas, inscrições, etc. ${ }^{10}$

Para Choay, "Os conceitos de autenticidade, hierarquia de intervenções, estilo de restauração permitiram a Boito estabelecer os fundamentos críticos da restauração como disciplina" ${ }^{11}$, sendo o conjunto de regras aprimorado devido às guerras, mas em essência válido até hoje. Ao lado de Boito, Alois Riegl (1858-1905) foi outra figura central para o processo de consolidação da preservação como campo disciplinar ${ }^{12}$, não do ponto de vista dos paradigmas para a restauração, mas do desenvolvimento da noção de monumento histórico e de aspectos normativos a ele relacionadas. Sua obra, O culto moderno dos monumentos (1903), escrita para fundamentar a nova legislação para conservação dos monumentos na Áustria, quando era então o presidente da Comissão Austríaca dos Monumentos Históricos, é considerada fundadora, por abordar, sem ambiguidades, um sistema de valores para proteção dos bens.

Riegl trazia novas categorias de valores, extrapolando as questões histórico-artísticas, organizadas em duas chaves: os valores de rememoração e os de contemporaneidade, "passando a considerar também as formas de recepção e de fruição dos monumentos (...)" ${ }^{13}$. O valor de "antiguidade", pertencente ao primeiro grupo, seria a base para a formulação do projeto de lei, por ser o mais inclusivo e perene - quando houvesse conflito entre valor de uso e valor de antiguidade, deveria prevalecer o segundo. Kühl destaca o interesse sobre este valor, que fundamenta a preservação dos traços da passagem do tempo sobre as obras, "apreciando-se inclusive o efeito subjetivo e afetivo das próprias formas de dissolução do monumento, independentemente de sua destinação e significação inicial” ${ }^{14}$. A autora ainda assinala a novidade que a proposta trazia para a práxis austríaca, pautada até então exclu-

10 KÜHL, 2002:26.”, introdutório à versão brasileira da conferência realizada por Boito em 1884, intitulada Os restauradores

11 CHOAY, 2001:167

12 Cabe esclarecer que estamos considerando o restauro como disciplina no interior de um campo de conhecimento mais amplo aqui denominado preservação, que envolve, entre outros, aspectos do sistema de proteção, inventariamento, e da própria restauração, que é etapa desse processo de salvaguarda de bens culturais.

13 KÜHL, 2009:63

14 Idem. 
sivamente pela unidade de estilo e pela preservação voltada exclusivamente aos objetos de excepcional relevância histórica e artística.

Nessa linha, Gustavo Giovannoni (1873-1947) deu atenção à “arquitetura menor”, ao contexto urbano e à cidade histórica, ampliando a noção de patrimônio. Giovannoni consolidou os princípios modernos de restauração na Itália através do chamado restauro científico, difundido através de suas aulas de restauração na Universidade de Roma. Neste período, as discussões sobre preservação passaram a ocorrer em âmbito internacional, culminando na Carta de Restauro de Atenas de 1931, resultante de conferência organizada pelo Escritório Internacional dos Museus da Sociedade das Nações, cujos princípios convêm assinalar:

Qualquer que seja a diversidade dos casos específicos - e cada caso pode comportar uma solução própria -, a conferência constatou que nos diversos Estados representados predomina uma tendência geral a abandonar as reconstituições integrais, evitando assim seus riscos, pela adoção de uma manutenção regular e permanente, apropriada para assegurar a conservação dos edifícios. Nos casos em que uma restauração pareça indispensável devido a deterioração ou destruição, a conferência recomenda que se respeite a obra histórica e artística do passado, sem prejudicar o estilo de nenhuma época.

A conferência recomenda que se mantenha uma utilização dos monumentos, que assegure a continuidade de sua vida, destinando-os sempre a finalidades que o seu caráter histórico ou artístico.

O texto registrava, portanto, a substituição gradativa da orientação estilística por uma abordagem mais conservativa, focada nos aspectos documentais dos edifícios. Entretanto, as destruições massivas provocadas pela $2^{\text {a }}$ Guerra Mundial punham em evidência os limites das teorias desenvolvidas até então para lidar com o problema em uma escala mais ampla.

Ainda em 1938, o historiador da arte Giulio Carlo Argan (1909-1994) formula o projeto para fundação do Instituto Central de Restauro (ICR) em Roma, que deveria colaborar com as instituições de preservação governamentais e fomentar pesquisas técnicas e teóricas para o desenvolvimento do campo. Com a abertura do ICR em 1939, Cesare Brandi (1906-1988) torna-se seu primeiro diretor, que em conjunto com Argan buscava formular uma base científica unificada para a restauração de monumentos e obras de $\operatorname{arte}^{15}$. A preocupação em restabelecer um lugar ao problema estético antecipava as questões colocadas pelas reconstruções do pós-guerra.

Um novo grupo de teóricos reabilitava a questão estética, entretanto de modo diverso do restauro estilístico, mas levando em conta que cada monumento representava uma 
obra de arte única, podendo, portanto, libertar-se de adições insignificantes. Com diferentes ênfases, autores como Roberto Pane (1897-1987), Renato Bonelli (1911) e Cesare Brandi contribuíram para a formulação dos princípios do restauro crítico, sendo o último o principal expoente. As intervenções deixam de ser enquadradas em categorias pré-estabelecidas, como nas linhas do restauro filológico e científico, e, sem o ranço positivista, passam então a ser analisadas caso a caso, conforme as especificidades de cada obra ${ }^{16}$. O restauro é então encarado como

Ato histórico-crítico que considera concomitantemente os aspectos materiais, formais e documentais da obra, que deve respeitar as várias fases por que ela passou e que preserva a pátina, ou seja, conserva as marcas de sua própria translação no tempo. Ademais, assume-se que qualquer ação no bem intervém inexoravelmente em sua realidade figurativa (...) e a restauração assume para si a tarefa de prefigurar, controlar e justificar alterações ${ }^{17}$.

Cesare Brandi em Teoria da restauração, de 1963, traz importantes contribuições que ressoam até hoje, sendo o último teórico a conceituar o termo "restauro". Para Brandi, o restauro parte do reconhecimento da obra de arte enquanto tal, que, como produto da atividade humana, coloca uma dúplice instância: estética, cuja artisticidade faz com que a obra de arte seja obra de arte, e histórica, como produto humano realizado em um certo tempo e lugar e que em certo tempo e lugar se encontra ${ }^{18}$. Daí vem sua definição:

A restauração constitui o momento metodológico do reconhecimento da obra de arte, na sua consistência física e na sua dúplice polaridade estética e histórica, com vistas à sua transmissão para o futuro ${ }^{19}$.

Para Brandi, a consistência física "representa o próprio local da manifestação da imagem, assegura a transmissão da imagem ao futuro e garante, pois, a recepção na consciência humana" ${ }^{20}$. Propõe assim seu $1^{\circ}$ axioma: Restaura-se somente a matéria da obra de arte. Diferenciando na matéria "estrutura" e "aspecto" (como por exemplo a tábua da madeira de uma pintura e o pigmento colorido sobre a tela, respectivamente), afirma, entretanto, não existir matéria de um lado e imagem do outro. Mas também trabalha com a noção de unidade potencial da obra de arte, assumindo que a imagem é somente aquilo que aparece, mas também, que uma obra fracionada, destituída de partes, continua a subsistir potencialmente como um todo, em cada um de seus fragmentos ${ }^{21}$. Com isso, Brandi chega ao $2^{\circ}$ princípio:

$\begin{array}{ll}16 & \text { Cf. CARBONARA, } 1997 \\ 17 & \text { KÜHL, 2009 } \\ 18 & \text { BRANDI, 2004 } \\ 19 & \text { BRANDI, 2004:30 } \\ 20 & \text { Idem } \\ 21 & \text { BRANDI, 2004:46 }\end{array}$


A restauração deve visar ao restabelecimento da unidade potencial da obra de arte, desde que isso seja possível sem cometer um falso artístico ou um falso histórico, e sem cancelar nenhum traço da passagem da obra de arte no tempo ${ }^{22}$

Brandi aponta a relação em princípio conflitiva entre as duas instâncias, sendo que a primeira tende a remover qualquer acréscimo sobre a obra, e a segunda, a conservar - entretanto a contemporização entre as instâncias estética e histórica representaria a própria dialética da restauração. Como dito, o método não pressupõe respostas únicas extraídas de classificações pré-estabelecidas, mas pelo contrário, exige profundo conhecimento histórico, artístico e filosófico orientado por princípios gerais para a leitura caso a caso, através de ato crítico e criativo.

Em 1964 novamente as discussões internacionais caminham para um consenso instaurado pela Carta de Veneza, resultante do $2^{\circ}$ Congresso Internacional de Arquitetos e Técnicos dos Monumentos Históricos promovido pelo ICOMOS. Até hoje, a carta tem seus princípios válidos, sendo complementada ou aprofundada por documentos posteriores ${ }^{23}$.

Kühl sintetiza os princípios fundamentais da restauração: "Distinguibilidade", entendendo o tempo como irreversível e não se podendo induzir o observador ao engano, documentando-se a intervenção a si própria; "Reversibilidade" ou "retrabalhabilidade" - a intervenção deve facilitar intervenções futuras, inserindo-se de modo respeitoso no preexistente; "Mínima intervenção" - a restauração deve respeitar estratificações da obra e sua imagem figurada; "Compatibilidade de técnicas e materiais" - uso de técnicas compatíveis, de eficácia comprovada através de anos de experimentação ${ }^{24}$.

Apesar do denso e estruturado desenvolvimento conceitual dos princípios operantes no campo da preservação, seja em âmbito teórico e metodológico, seja em âmbito operativo, das intervenções de restauro à consagração dos monumentos, o enfrentamento da problemática da preservação de edifícios produzidos pelo movimento moderno - tema relativamente recente na pauta preservacionista - vem predominantemente ocorrendo dissociado da discussão que até então se acumulara.

22 BRANDI, 2004:33

23 Deve-se entretanto ressalvar que isso não significa que as Cartas patrimoniais, resultantes de encontros institucionais das mais diversas naturezas, constituam um conjunto homogêneo, a lembrar da antítese à Carta de Veneza representada pela Carta de Burra de 1980, documento produzido pelo ICOMOS australiano para seu contexto local, em que se entende o restauro como restabelecimento do bem a um estado anterior e que se admite a reconstrução como categoria de preservação. Para um aprofundamento do tema, cf. "Notas sobre a Carta de Veneza", KÜHL, 2010.

24 KÜHL, 2009:78. A autora indica ainda as três tendências contemporâneas do restauro explicitadas no contexto italiano: Restauro crítico, Hipermanutenção e Manutenção-repristinação. 


\section{A INSTITUIÇÃO DO PATRIMÔNIO MODERNO}

Como de praxe, a preservação do patrimônio moderno tornou-se questão quando a sociedade se deparou com a efetiva possibilidade de perda de obras associadas ao movimento moderno em decorrência de ameaças de demolição e do estado de abandono e degradação de exemplares icônicos. Porém, ao contrário do patrimônio antigo, normalmente deixado aos especialistas, o patrimônio moderno viu ampliada a gama de interlocutores envolvidos na sua preservação - arquitetos militantes, historiadores, conservadores, políticos, economistas e comunidade usuária passaram a se envolver na sua tutela, ainda que de modo desarticulado $^{25}$. Casos isolados mas significativos envolvendo obras modernistas vinham ocorrendo desde os anos 1940, entretanto o problema passa a ganhar corpo somente entre meados dos anos 1980 e início dos anos 1990.

O Brasil é um dos países pioneiros na proteção do legado moderno, atuando desde a década de 1940 no tombamento de obras paradigmáticas. A equipe da Divisão de Estudos e Tombamento (DET) chefiada por Lúcio Costa no SPHAN tomba a Igreja de São Francisco de Assis, no conjunto da Pampulha, em 1947; o Ministério da Educação e Saúde, em 1948; a Estação de Hidroaviões em 1957; o Catetinho, em 1959; o Aterro do Flamengo em 1965; e a Catedral Metropolitana de Brasília em $1967^{26}$.

No plano internacional, destacamos a campanha internacional de salvamento, articulada por Le Corbusier, da Villa Savoye, a partir de 1958, cuja proteção se efetiva em 1968; A doação da Falling Water em 1953 após a morte do sr. Kaufmann, por parte do filho, para a instituição de preservação local convertê-la em museu; a proteção do Weissenhof em Stuttgart entre 1956 e 1958, considerado por Theodore Prudon o marco inicial para a preservação da arquitetura moderna ${ }^{27}$; o edifício da Bauhaus em Dessau, reconhecido localmente em 1964 e nacionalmente em 1974, pela Alemanha Oriental; e em 1962, o reconhecimento do sanatório Zonnestraal, na Holanda.

Como se vê, trata-se de exemplares icônicos da primeira fase do modernismo, em alguns casos protegidos a partir de iniciativas dos próprios partícipes do movimento moderno, o que revela a consciência sobre as obras em perspectiva histórica, bem como aponta para uma relação coincidente entre a primazia do cânone modernista na historiografia e a preservação destes exemplares.

Por outro lado, a produção do pós-guerra tem tido tratamento diverso, especialmente os conjuntos habitacionais em escala, torres comerciais e edifícios projetados segundo a

25 SALVO, 2007a. O momento de integração das obras modernas ao rol de bens culturais coincide com a maior permeabilidade do patrimônio a agentes externos aos órgãos de preservação bem como sua integração a outras esferas da atuação governamental, como o planejamento urbano e as políticas de turismo.

26 Informações disponíveis em: < http://portal.iphan.gov.br/portal/baixaFcdAnexo.do?id=1356>. Nos anos 1970 não ocorre nenhum tombamento de obras modernas e dos anos 1980 em diante, haverá outros exemplares protegidos, entre os quais as casas da Rua Bahia, Itápolis e Santa Cruz de Warchavchik. Voltaremos a falar do SPHAN e do contexto brasileiro mais adiante.

27 PRUDON, 2008 
estética brutalista, em virtude das consequências sociais e econômicas, a obsolescência funcional ou o desprestígio de alguns de seus exemplares. A falta de distanciamento histórico, o envolvimento de profissionais que se viam em linha contínua com a genealogia moderna, prontos a aperfeiçoar a obra dos mestres, o contexto de revisão crítica do modernismo, a ausência de uma historiografia consolidada a respeito das obras recentes relegaram-nas outra abordagem, de cunho mais pragmático, sem o efetivo reconhecimento de valor cultural ${ }^{28}$.

Em ambos os casos - o sentimento de emergência no salvamento de relíquias ou o pragmatismo na intervenção em obras sem valor - resultaram em um desenvolvimento próprio do problema, derivado da observação empírica e do material historiográfico existente, sem qualquer respaldo nas teorias da restauração consolidadas. Em linhas gerais, as intervenções sobre as obras icônicas do primeiro período visavam a sua recondução ao estado figurativo primitivo, enquanto nas obras do pós-guerra eram guiadas pelo contingenciamento de demandas práticas e funcionais, com o objetivo de recuperação econômica, funcional e simbólica ${ }^{29}$. Tais práticas fizeram com que em certo ponto se reivindicasse autonomia ao chamado "restauro do moderno" ou "restauro do novo" em contraposição ao "restauro do tradicional" ou "restauro do antigo".

Muito contribuiu para o quadro o surgimento do Docomomo (International Committee for DOcumentation and COnservation of buildings, sites and neighbourhoods of the MOdern MOvement) em 1988 na Holanda, fundado por profissionais da Universidade de Delft. Com imediato sucesso internacional, a organização não governamental disseminouse através de seminários, publicações e da promoção de atividades a partir da criação de seções locais em diversos países. Atualmente, o Docomomo conta com mais de 50 seções, organizadas de forma independente por cada país, predominando o vínculo a instituições universitárias, seguido por museus, arquivos e fundações, como a Fundação Mies van der Rohe, Bauhaus ou Alvar Aalto ${ }^{30}$. Nota-se pouca relação com órgãos de preservação governamentais nas regiões, constituindo-se o Docomomo em um misto de espaço de discussão acadêmica, inventariamento não oficial e grupo de pressão. O marco simbólico de fundação foi a $1^{a}$ conferência internacional ocorrida em 1990 em Eindhoven, Holanda, de onde saiu a Declaração de Eindhoven, contendo os objetivos do Docomomo - conscientização e luta para preservação do patrimônio moderno; registro de obras e lugares significativos; desenvolvimento de técnicas de conservação e restauração adequadas; criação de fundos para documentação e conservação ${ }^{31}$.

Apesar de identificadas algumas diferenças no interior do grupo - de integrantes de perfil técnico a apaixonados pelo modernismo, de visão mais ou menos restritiva ao que foi o movimento moderno (em termos cronológicos e formais) - e a despeito do trabalho de

30 Informações pesquisadas no site da instituição: <http://www.docomomo.com/chapters_worldwide.php>

31 Docomomo, Eindhoven Statement, 1990 
alargamento e reabilitação de elementos deixados de fora pela historiografia hegemônica ${ }^{32}$, Simona Salvo identifica na Instituição traços comuns de uma abordagem retrospectiva e tecnicista, que passa ao largo de qualquer formação em matéria de restauro, caminhando da prática para a teoria ${ }^{33}$. Não poderia ser mais explícita a proposta do arquiteto Hubert-Jan Henket $^{34}$, fundador do Docomomo Internacional, na qual defende uma abordagem diversa entre as obras "icônicas" e "ordinárias" - nas quais as primeiras devem ser restauradas o mais próximo do original e as segundas, quando desprestigiadas (como os conjuntos habitacionais do pós-guerra), podem ser apenas registradas; e entre obras de relevância internacional e nacional, devendo as primeiras ser restauradas e as segundas podendo receber ações mais pragmáticas, desde que as adições sejam respeitosas com o original.

Outro índice da consolidação do patrimônio moderno como questão nos anos 1990 é a realização do Conselho da Europa, em 1991, que resultou na elaboração da Recomendação $R(91) 13$, que versava sobre princípios a serem perseguidos pelos países signatários, de estratégias para a identificação (estudos e inventários), proteção (critérios de seleção, medidas legais) e gestão (uso, conservação física e formação de especialistas) do patrimônio do século XX. O documento visava ainda enfrentar o problema da falta de distanciamento histórico e abundância de exemplares, que faziam com que poder público e população não se conscientizassem da sua importância como testemunhos culturais, recomendando formas de sensibilização de ambos, e também trazendo diretrizes para a promoção de cooperação entre os países europeus.

O documento propunha que a seleção deveria favorecer o reconhecimento de obras relevantes no conjunto dos estilos, tipos e métodos de construção do século XX; as obras dos criadores mais reconhecidos, mas também de exemplares menos conhecidos, mas representativos da história e da arquitetura de um determinado período; a valoração não apenas do ponto de vista estético, mas também histórico com relação às técnicas construtivas, os desenvolvimentos sociais, políticos, econômicos e culturais; a seleção não apenas de obras isoladas, mas de conjuntos, cidades e espaços livres; a extensão da proteção aos equipamentos e mobiliário concebidos simultaneamente com a arquitetura.

Entretanto, a leitura da Recomendação sobre o patrimônio moderno se mostrou mais abrangente que a prática, que veio privilegiando o legado dos arquitetos de maior renome e o período inicial do movimento ${ }^{35}$. Em termos de conservação, as diretrizes também se revelaram diversas da realidade, pois apontava-se a necessidade de desenvolvimento de pesquisas teóricas e práticas sobre os métodos e materiais de construção, bem como técnicas para sua manutenção e restauro; de elaboração de rigorosa documentação sobre as intervenções efetuadas; de criação de um sistema de informação e registro arquitetônico; e de ado-

\footnotetext{
32 MUSCHAMP, 2001

33 SALVO, 2007a

34 HENKET, 1998

35 No site do Docomomo alemão, por exemplo, o corte é explícito: o foco do trabalho é o modernismo

“clássico”, dos anos 1920/30 e continuação até 1945. <http://www.docomomo.de/>
} 
ção, nas intervenções, dos mesmos princípios fundamentais utilizados para outras categorias de patrimônio arquitetônico. Ocorre na prática exatamente o oposto: uma tendência à autonomização do tratamento dado à arquitetura moderna, fundada a partir de um conjunto de argumentos e noções que se desdobram em diferentes níveis de problemas.

Em primeiro lugar, aponta-se o paradoxo em preservar uma manifestação que não tinha como objetivo se perenizar. Pergunta-se Cunningham: "Como a conservação de edifícios dedicados ao futuro e à mudança pode ser intelectualmente justificada?" ${ }^{36}$. Entretanto, argumenta Heynen, o aspecto fugidio e transitório da modernidade não se convertia, na arquitetura, em edifícios que se intencionavam de vida curta, mas sim na afirmação de que as mudanças eram inevitáveis e a arquitetura deveria se adaptar a elas. Portanto, seria um erro defender que modernos eram favoráveis a edifícios de ciclo curto para legitimar demolição e desfigurações ${ }^{37}$. De qualquer modo, é necessário ter em mente que nenhum monumento histórico - ao contrário do monumento, na acepção proposta por Françoise Choay - quis na origem se perenizar. Falando de outro modo, a vontade de conservar é ato do presente, fundado em reconhecimento de valores interpretados a partir deste presente, validando-se, portanto, para manifestações de qualquer época, a partir de suas especificidades.

A questão reside em uma espécie de síndrome de Dorian Gray, donde a arquitetura do eterno presente fez com que os arquitetos supusessem que ela não poderia envelhecer. Uma arquitetura de cunho autoral, e em alguns casos, de experimentação prototípica, converteuse em intervenções de restauro que descartam a pátina em detrimento do caráter modelar dessas obras e que recorrem à repristinação em nome da intenção do arquiteto. Perguntamonos se seria essa autoproclamada autonomização fruto de uma simbiose entre sujeito do presente e objeto histórico, na qual o agente contemporâneo assimila a ideologia moderna compreendendo o modernismo como externo ao conjunto das manifestações arquitetônicas. Aparentemente, consiste esta espécie de permanência do discurso anti-historicista moderno em uma contradição discursiva, tendo em vista a prática de restauro de orientação estilística (na qual a forma primitiva prepondera) aplicada a uma arquitetura que supunha a sujeição da forma à função e aos condicionantes técnicos, climáticos e ambientais; a adaptação às necessidades contemporâneas; a negação dos estilos; a subordinação ao espírito do tempo. Ao contrário do intencionado, talvez a abordagem se mostre pouco sensível aos princípios que nortearam aquela arquitetura.

O fundamento para a cisão da unidade metodológica conquistada pelos teóricos do campo da preservação é a proposta de um novo entendimento sobre a autenticidade da obra arquitetônica no qual a autenticidade material deixa de ter tanta relevância. No contexto de ampliação e relativização do conceito de autenticidade na Conferência de Nara, em $1994^{38}$,

36 "How can the conservation of buildings dedicated to the future and to change, be intellectually justified?”, CUNNINGHAM, 1998:4

37 HEYNEN, 1998

38 O documento, declaradamente elaborado no espírito da Carta de Veneza de 1964, busca ampliar a noção de autenticidade levando-se em conta a pluralidade cultural e os modos de valoração específicos de cada 
o Docomomo apresentou uma proposta de revisão do conceito na reunião do ICOMOS em Paris, no mesmo ano, aliando à noção de autenticidade material, a autenticidade da ideia, autenticidade da forma e autenticidade da construção e dos detalhes ${ }^{39}$.

A abordagem idealista, de valoração da visualidade original, da intenção do arquiteto e do estilo, remete à concepção formulada por Viollet-le-Duc no século XIX, mesmo quanto ao método de se colocar no lugar do arquiteto que concebeu a obra. Prudon vê um interesse renovado sobre a obra do arquiteto francês, enquanto fundamento para a preservação de edifícios modernos ${ }^{40}$. Com a recuperação do pensamento violletiano, a segunda metade do século XX assistiu a uma guinada conservadora na abordagem do problema, substituindo a noção de processo por fato e da assunção de múltiplos agentes em diversas instâncias da produção e da vida da obra pelo culto à personalidade e à intenção originária. A filiação à escola estilística do arquiteto francês se evidencia quando o assunto é a dimensão histórica da obra arquitetônica: "reconstituindo um tipo, ele (Viollet-le-Duc) se mune de uma ferramenta didática que restitui ao objeto restaurado um valor histórico, mas não sua historicidade" ${ }^{41}$ - o mesmo se aplica à abordagem retrospectiva contemporânea.

Mas a ideia de que um edifício possa "voltar" a um estado original parece confrontar-se com a própria natureza dinâmica da arquitetura:

“(...) Consagrados ao uso, seus edifícios são destinados, essencialmente, à impermanência: reparados, adaptados, transformados de acordo com as vontades das demandas e dos estilos. A ilustração mais banal é fornecida pelas inumeráveis igrejas góticas que justapõem todos os períodos deste estilo sem temer as adições barrocas ou clássicas. Privilegiar um momento de seu devir como autêntico seria absurdo" ${ }^{42}$;

O problema desse tipo de abordagem reside na relação com as temporalidades da obra. O restauro de repristinação, como aponta Brandi, quer eliminar o lapso de tempo que há entre o fim do processo criativo do artista e o tempo histórico do observador, entre a criação da obra e sua recepção no presente. Para o restaurador italiano

O único momento legítimo que se oferece para o ato da restauração é o do próprio presente da consciência observadora, em que a obra de arte está no átimo e é presente histórico, mas é também passado e, a custo, de outro modo, de não pertencer à consciência humana, está na história. A restauração, para representar uma operação legítima, não deverá presumir nem o tempo como reversível, nem a abolição da história ${ }^{43}$.

cultura.

39 CARVALHO, 2005

40 PRUDON, 2008:46

41 CHOAY, 2001:158

42 CHOAY, 1995

43 BRANDI, 2004:61 
Com isso, Brandi conclui que o restauro é ato do presente, evento histórico, que deve respeitar a pátina, considerada como o próprio sedimentar do tempo sobre a obra, como ofuscamento que a novidade da matéria recebe através do tempo. Os conflitos já apontados entre as instâncias estética e histórica recaem sobre a pátina de um modo independente, pois se esta é considerada uma adição, ainda que não controlada pelo homem, deveria ser removida, segundo a instância estética. Mas a pátina faz com que matéria desapareça enquanto matéria e se valha apenas como imagem:

Se então a matéria se impuser com tal frescor e irrupção a ponto de primar, por assim dizer, sobre a imagem, a realidade pura da imagem ficará perturbada. Por isso, a pátina, do ponto de vista estético, é aquela imperceptível surdina colocada na matéria que é constrangida a manter uma posição mais modesta no cerne da imagem ${ }^{44}$

Como vimos, além da pátina, há uma série de apropriações e transformações sofridas pela obra ao longo da história, que fazem com que ela seja única, portadora de uma trajetória para além do momento de sua criação, alterações essas que devem ser equacionadas com os problemas de ordem figurativa. Entretanto, nessa contemporização entre as instâncias histórica e estética, Brandi aponta a diferença fundamental entre as adições e as remoções: ambas são produtos do fazer humano, portanto igualmente inserem-se na história, mas ao passo que a adição decanta novas estratificações na obra, a remoção "destrói um documento e não documenta a si própria, donde levaria à negação e destruição de uma passagem histórica e à falsificação do dado" ${ }^{45}$.

O problema fica claro quando observamos os resultados de restaurações como da Villa Savoye ou da Casa Schröder, que se valendo da orientação repristinatória, fizeram suas empenas brancas brilharem de tal modo que mais parecem maquetes 1:1 que objetos reais no tempo e no espaço ${ }^{46}$. O congelamento de ambas em certo estado de perfeição, em uma cuidadosa reprodução do building-as-new eliminou toda vida que contiveram, todos os traços de uso e ocupação, o que, na avaliação de Heynen, desmente a ideia de dinamismo e funcionalidade que eram a essência de sua concepção original ${ }^{47}$.

Por uma transposição de $A$ obra de arte na era de sua reprodutibilidade técnica ${ }^{48}$ à arquitetura, os teóricos do novo acreditam haver uma suposta perda de aura e fácil reprodutibilidade técnica dos elementos construtivos da arquitetura moderna. Entretanto, partindo do próprio Benjamin verificamos a inadequação desta interpretação:

Mesmo na reprodução mais perfeita, um elemento está ausente: o aqui e agora da

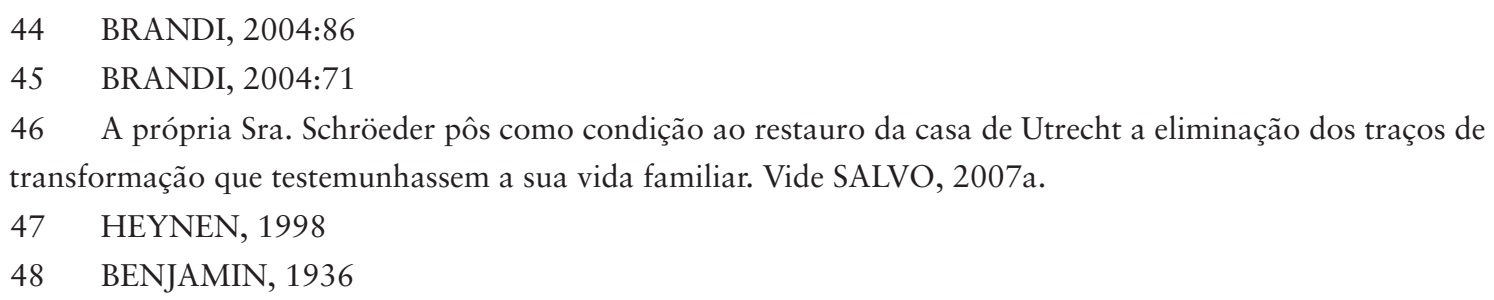


obra de arte, sua existência única, no lugar em que ela se encontra. É nessa existência única, e somente nela, que se desdobra a história da obra. Essa história não compreende apenas as transformações que ela sofreu, com a passagem do tempo, em sua estrutura física, como as relações de propriedade em que ela ingressou (...). A esfera da autenticidade, como um todo, escapa à reprodutibilidade técnica, e naturalmente não apenas à técnica.

(...) A autenticidade de uma coisa é a quintessência de tudo o que foi transmitido pela tradição, a partir de sua origem, desde sua duração material até o seu testemunho histórico. Como este depende da materialidade da obra, quando ela se esquiva do homem através da reprodução, também o testemunho se perde ${ }^{49}$.

Benjamin se refere às categorias de manifestações artísticas que, por meio da reprodução, substituem a existência única por uma existência serial. Lançando mão de um retrospecto sobre as técnicas de reprodução, como a xilogravura, a imprensa, água-forte, litografia, chegando à fotografia e ao cinema, Benjamin via neste processo um potencial emancipatório, no qual se liquidaria o valor tradicional do patrimônio da cultura e se descartaria a ideia de gênio. Mas é necessário questionarmo-nos se a discussão proposta pelo filósofo caberia à arquitetura e se de fato os elementos descritos estão ausentes das obras arquitetônicas modernas. Deve-se pesar, em primeiro lugar, a diferença quanto à especificidade da matéria. No cinema, como na música, a matéria é o trâmite para a expressão artística, ao passo que na arquitetura, como nas artes plásticas, a matéria é o próprio meio de expressão $0^{50}$. Ou como proposto por Henri Focillon, há uma diferença entre as artes que se desenvolvem no "tempo" (como a música ou a literatura) e no "espaço" (artes plásticas, arquitetura), sendo que as últimas exprimem suas mensagens através da forma ${ }^{51}$. Deste modo, não cabe a dissociação entre autenticidade da imagem ou da forma e autenticidade material, tendo em vista que na arquitetura e nas artes visuais, a matéria é o próprio local de manifestação da imagem, é, nos termos brandianos, a epifania da imagem. Além disso, Brandi amplia os limites da matéria com relação à consistência material de que resulta a obra, devendo-se levar em conta elementos ambientais intermediários entre objeto e observador ${ }^{52}$, não passíveis de reprodução. A diferença de categorias se evidencia pelo fato de que entre as artes que tem a matéria como trâmite, a perda de aura é uma característica constitutiva, não uma escolha, ao passo que a arquitetura, realizada mediante um aqui e agora que não pode ser reproduzido, apenas oferece aos incautos a opção pela supressão de suas camadas de historicidade, eliminando todos seus traços de autenticidade através da crença na sua materialidade similar às primeiras.

Do ponto de vista operativo, a arquitetura moderna criou a ilusão quanto à sua

$\begin{array}{ll}49 & \text { BENJAMIN, 1994:167-168 } \\ 50 & \text { KÜHL, 2009:96, a partir de Cesare Brandi. } \\ 51 & \text { Cf. LEMAIRE, 1994 } \\ 52 & \text { BRANDI, 2004:96 }\end{array}$


reprodutibilidade técnica alimentada por uma ilusão criada pela farta documentação traduzida em amplos acervos fotográficos, projetos executivos ultradetalhados e testemunhos de partícipes das construções. Entretanto, sabe-se que entre o projeto executivo e o que de fato é construído há uma grande distância. Desde alterações oriundas de mudanças no programa à necessidade de substituição de algum material faltante no mercado, de problemas na compatibilização dos projetos complementares ao atendimento de alguma norma não prevista, de corte orçamentário à dinâmica do canteiro, etc., etc., são muitas as mediações para a realização final de uma obra.

As fotografias, por sua vez, seduzem por sua presumida objetividade, apesar das distorções de cor (do preto e branco aos diferentes coloridos resultantes das químicas nos diversos tipos de filme e das calibragens dos registros digitais), dos enquadramentos valorizadores de determinados aspectos, da ausência de registros de áreas não notáveis (como as áreas de serviço ou fachadas menos favorecidas plasticamente), da atmosfera que altera a própria textura dos elementos registrados, enfim, dos aspectos que fazem da fotografia uma interpretação, uma leitura, um discurso. As distorções ocorridas em razão da inversão estabelecida entre obra construída e imagem consagrada na historiografia criaram, no extremo, o fenômeno da repristinação não ao estado original as built, mas ao estado as published ${ }^{53}$.

O envolvimento de personagens ligados às obras pode se mostrar mais perigoso ainda, primeiramente porque a memória é um processo de recuperação de experiência em constante transformação, um ato que se dá no presente para responder a questões do presente ${ }^{54}$, não podendo de forma alguma ser tratada como dado objetivo. Em segundo lugar, porque tanto as ligações afetivas quanto as profissionais mobilizam memórias e demandas conforme suas necessidades. Os primeiros querem que as obras voltem ao ponto que afetivamente consideram importante, suprimindo qualquer outra transformação por que tenham passa$\mathrm{do}^{55}$; os segundos, veem o momento como oportunidade de continuidade da obra do mestre, correção ou aperfeiçoamento ${ }^{56}$.

São documentos extremamente valiosos, tanto de um ponto de vista historiográfico como para a própria preservação, mas como qualquer documento, devem ser objeto de crítica, e sua abundância não pode fazer com que por isso o restauro do moderno seja diferente. Aliados a pesquisas histórico-documentais e bibliográficas de outras naturezas e ao exame das próprias obras em levantamentos métricos, fotográficos e laboratoriais, com atenção às características construtivas, tipológicas e formais, fornecem material que possibilita a aproximação ao original, mas jamais conseguirão, como qualquer outro campo da história, fazer com que o evento seja plenamente reconstituído e o tempo seja reversível. Tais materiais

\footnotetext{
53 KÜHL, 2008-2009:95

54 MENESES, 1992

55 Como o "restauro afetivo" de Antoni Moragas Filho sobre o Hotel Park de Barcelona, de seu pai, homônimo, que tinha como objetivo conservar o edifício nos seus mínimos detalhes. Simona Salvo, op. cit.

56 Como no restauro da Lever House, realizada pelo próprio escritório Skidmore, Owings and Merrill, nos anos 1990, em que puderam modernizar o curtain wall. Para outros exemplos, SALVO, 2007b
} 
devem ser articulados de modo a dar ao restaurador ferramentas para alimentar o conhecimento da obra e sua história, dialogando com a indagação dela mesma como documento. Para Salvo,

A experiência sobre o antigo ensina que somente interrogando diretamente o artefato se pode aspirar a uma plena compreensão de seu significado histórico e estético, a uma correta avaliação de seu envelhecimento e degradação; somente conhecendo a fundo a origem, história e estado atual do objeto se pode enfrentar as dificuldades técnicas ${ }^{57}$

A outra face do problema se refere à efetiva possibilidade técnica de reprodução dos materiais. De um lado, temos obras que utilizam técnicas e procedimentos tradicionais ou artesanais, como a alvenaria de tijolos recoberta por argamassa pintada, os revestimentos pétreos ou outros materiais já bem conhecidos, como o concreto armado aparente, cuja expressão ou testemunho das marcas do trabalho humano não é reproduzível. De outro lado, temos materiais industrializados, que apesar de em teoria serem mais fácil de serem reproduzidos que os artesanais, são exatamente o oposto. Tanto materiais experimentais de fabricação restrita quanto de uso corrente e massivo têm a vida marcada pelo mercado, e se tornam um problema quando deixam de ser fabricados. Mesmo perfis metálicos, telhas, azulejos e outras peças padronizadas têm as bitolas, especificações técnicas e características alteradas conforme os desenvolvimentos tecnológicos, a moda ou a norma ${ }^{58}$. Em outras palavras, os materiais industriais também são objetos da história, e mesmo o Urinol de Duschamp ou as peças de Lucio Fontana a despeito de suas intenções, não se traduzem em objetos efêmeros, antiauráticos, reprodutíveis (a não ser como cópia, o que se aplica a qualquer objeto artístico, mesmo tradicional). $\mathrm{Na}$ realidade, como alerta Boriani, o fatto a mano é mais fácil de reproduzir que o fatto a machina, do ponto de vista técnico e econômico ${ }^{59}$.

O próprio paradigma do restauro ao com'era, dov'era contribui para o diminuto conhecimento que temos de alguns materiais ou técnicas recentes, pois valendo-se do pressuposto de que a forma prescinde da matéria, as restaurações não são utilizadas como oportunidade de ampliação do conhecimento das técnicas construtivas, características e comportamento dos materiais, formas de degradação e acomodação e compatibilidade com as inserções, retiradas e limpezas promovidas pela intervenção de restauro. Assim, não se vê ocorrer o círculo vitorioso derivado da boa conservação, identificado por Bonelli para o tradicional, perfeitamente aplicável ao moderno, no qual o conhecimento histórico nutre e

57 "L'esperienza sull'antico insegna che solo interrogando direttamente i manufatti si può aspirare a una piena comprensione del loro significato storico ed estetico, a una corretta valutazione del loro invecchiamento e del loro degrado; solo conoscendo a fondo origine, storia e stato attuale dell'oggetto se ne possono affrontare le difficoltà tecniche”. SALVO, 2007a:324.

58 Apenas para ilustrar, no ano passado, a fábrica Jatobá deixou de produzir as pastilhas de porcelana tão difundidas pela arquitetura dos anos 1970, criando um futuro problema para a conservação das inúmeras fachadas revestidas por esse material nos próximos anos.

59 BORIANI, 1990 
sustenta a boa intervenção de restauro, que, por sua vez, alimenta a pesquisa ${ }^{60}$.

Empregadas tanto as técnicas e materiais os mais tradicionais e reprodutíveis (sob os quais, por dedução lógica então também recairiam os paradigmas do restauro do tradicional) quanto os mais experimentais (irreprodutíveis ou de custos inviáveis para reprodução), o problema não pode ser reduzido à mera questão técnica. Mesmo se fosse possível a aquisição de pleno conhecimento e de possibilidade de reprodução, ainda assim o problema da autenticidade estaria colocado. É evidente que a arquitetura moderna tem sua especificidade e cria novos desafios ao campo da preservação, mas não justifica a fundação de uma nova orientação, como seria absurdo imaginarmos que todo o restante da produção arquitetônica ocidental ("tradicional" por contraste) se reduzisse a somente um corpus homogêneo, ou que se devesse pensar uma orientação para cada nova questão mobilizada pelas especificidades de cada estilo ou período histórico.

Se do ponto de vista operativo observamos os limites da reprodutibilidade da arquitetura moderna, deveríamos pensar do ponto de vista ético e filosófico não a possibilidade, mas a propriedade do conceito de autenticidade que fundamenta essa orientação. Como enunciado por Choay em conferência sobre o tema, "o conceito de autenticidade encontrase no fundamento da cultura ocidental que relaciona, na sua origem, à autoridade de textos normativos e instauradores, no duplo campo do direito e da religião". Suas origens remontam à Idade Média, com desenvolvimento no Renascimento, quando o conceito é então utilizado em sua antítese, a inautenticidade, traduzindo-se em perseguição aos falsos ou às cópias deliberadas ${ }^{61}$. O conceito estende-se sob os mais diversos campos da cultura, e, no campo artístico, passa a relacionar-se diretamente com o conceito próximo de "originalidade", já que uma cópia ou reprodução são autênticos, à medida que são objetos reais, sem ser, entretanto, originais ${ }^{62}$. Com o processo de consagração do monumento histórico e combate às restaurações fantasiosas, o advento do restauro filológico ou científico faz com que as reconstituições passem a ser rechaçadas, associadas à ideia de falso histórico. O critério permanece em documentos posteriores, como a Carta de Veneza de 1964, as cartas italianas de restauro de 1972 e 1987, e mesmo a Carta de Nara de 1994, que apesar de relativizá-la, a reitera como fundamento para a valoração do patrimônio, situando-se o conceito de autenticidade na própria base de toda a doutrina moderna de conservação e restauração dos monumentos históricos ${ }^{63}$.

Percebeu-se que o conceito de autenticidade varia de cultura para cultura e no seio de uma própria cultura, não se constituindo em noção única e absoluta, mas pelo contrário,

60 BONELLI apud SALVO, 2007a:307. A potência do restauro como processo de produção de conhecimento a partir de elementos não acessíveis de outro modo a não ser no contato com a própria obra foi apontada, por exemplo, nos casos do restauro do convento de La Tourette, de Le Corbusier e do Pavilhão de verificação de óbitos de Luiz Nunes e equipe. O’CONNOR, 2007; ANDRADE et al, 2003.

61 Inicialmente no campo jurídico e religioso. CHOAY, 1995; LE GOFF, 2003

62 Que também diferem da falsificação, que é a cópia que quer se passar por original. MARTÍNEZ, 2007

63 LEMAIRE, 1994 
como concepção culturalmente determinada, sofre com elas todas as transformações a que historicamente estão suscetíveis. Lemaire evoca como exemplos limites os templos imperiais de Ise, no Japão e o Parthenon, em Atenas. No primeiro caso, os cento e vinte templos dispostos em pares lado a lado são reconstruídos a cada vinte anos, servindo um como modelo do outro. No segundo caso, apela-se para todos os procedimentos científicos para consolidar as peças da ruína, investindo-se esforços para catalogação e exato posicionamento das peças identificadas. O primeiro foca na manutenção de um saber ${ }^{64}$, desinteressando-se pela matéria em detrimento da forma exata ao passo que o segundo esquece a forma e "'santifica" o material, convertido em relíquia, mesmo desprovido da lembrança de sua forma original" ${ }^{65}$.

Se o entendimento do conceito de autenticidade varia com o tempo - assim como juízos sobre as obras sujeitam-se aos desenvolvimentos históricos e historiográficos - e se o tempo é entendido como irreversível, volta-se ao problema ético levantado desde Ruskin, quanto ao direito que temos de desnaturar e negar às gerações futuras o contato com o material autêntico. Diz Carbonara: "O escopo do restauro não é reproduzir ou imitar, mas conservar e deixar o texto em condições ótimas de fruição estética e legibilidade histórica" ${ }^{66}$. Texto que, como o antigo, devemos estudar e interrogar, sem achar que o compreendemos ou decodificamos completamente ${ }^{67}$.

Para além da abordagem retrospectiva, é possível verificar a validade e aplicabilidade dos princípios essenciais do restauro, "distinguibilidade", "mínima intervenção", "reversibilidade" e "compatibilidade técnica dos materiais" 68 , fundados no respeito à matéria autêntica, às intervenções em obras modernas a partir de casos concretos.

É sabido que a melhor forma de conservar um edifício é manter-lhe um uso compatível e adotar uma prática de manutenção programada ${ }^{69}$. Do mesmo modo as intervenções de restauro em uma perspectiva mais conservativa podem trazer resultados interessantes ${ }^{70}$, como o restauro da Casa del Fascio (1932-1936) em Como, Itália, de Giuseppe Terragni, que se constitui em caso pioneiro, estabelecendo termo positivo de comparação frente aos casos de repristino, demonstrando que o restauro tradicional, com seu método científico e histórico-crítico, é adequado à arquitetura moderna; o complexo esportivo Bellerive Plage (1936-1937), em Lausanne, de Marc Picard, escrupulosamente restaurado na forma e função por equipe suíça formada na academia local, “um dos raros nichos de reflexão crítica

64 Lia Mayumi discute a noção de autenticidade a partir dos casos brasileiro e japonês em Monumento $e$ autenticidade, 1999

65 LEMAIRE, 1994

66 "Scopo del restauro nono è di riprodurre o imitare ma di conservare e lasciare il testo in condizioni ottimali di godibilità estetica e di legitimità storica” CARBONARA, 2007:11

67 Idem

68 Ver p. 126

69 Portanto não se pode afirmar a fragilidade dos materiais modernos - evidente em algumas aplicações -diante da ausência de manutenção e abandono constatados em muitos casos.

70 Os casos a seguir foram citados por SALVO, 2007a 
no panorama mundial"71; na região de Zurique, o Siedlung Neubühl (1930-1932), outra interessante intervenção, realizada nos anos 80 por Arthur Ruegg e o considerado insólito restauro da sede suíça da Eternit, realizado com painéis do material homônimo, "quintessência” do não conservável; a Villa La Ricarda (1949-1963), em Barcelona, de Antonio Bonet, para Salvo, objeto do sensível intervento "científico" por parte de Fernando Alvarez e Jordi Roig, que atentaram-se aos detalhes tecnológicos, mas sem privar a residência de melhoramentos funcionais ${ }^{72}$; a Villa Mairea (1938-1939) em Noormakku, Finlândia, de Alvar Aalto; o Instituto Italiano de Cultura em Estocolmo e o arranha-céu Pirelli de Gio Ponti e Nervi em Milão. Este último, alvo de um acidente aéreo que condenou parte da fachada e interiores dos andares atingidos, pôde comprovar ser possível a adoção dos procedimentos afeitos à teoria "clássica" da restauração a um edifício contemporâneo, mesmo no tratamento ao curtain wall. Comprovou-se ainda, o barateamento com relação a uma reconstrução, contrariando o senso comum de que o restauro é a priori mais custoso que a obra nova ${ }^{73}$.

Mas os restauros fundados nos princípios da disciplina ainda se constituem em exceção. A abordagem retrospectiva vem prevalecendo, especialmente no tratamento dado às obras icônicas, entendidas mais como símbolo do que como objetos realmente existentes, como por exemplo, as intervenções de restauro da Villa Savoye realizadas dos anos 1960 aos 1990, comentadas adiante; a repristinação gradual da Bauhaus de Dessau, a partir de 1965, suprimindo a experiência dramática da $2^{a}$ GM e as marcas da ocupação nazista ${ }^{74}$; as residências do Weissenhof, cujo restauro privilegiou a valorização do caráter prototípico da experiência, ainda que "corrigindo" alguns detalhes construtivos ${ }^{75}$; a Casa da Cultura (1955-1958), de Aalto em Helsinki, objeto de repristinação com modernização funcional ${ }^{76}$; a escola infantil Saint'Elia, em Como, de Terragni, cujo restauro foi realizado pelos sobrinhos do arquiteto visando superar deficiências da execução original, corrigir incongruências do restauro anterior e dar solução para a incompletude de partes do projeto original, reconstruindo o edifício como inaugurado em 193777; a Penguin Pool londrina (1934), de Berthold Lubetkin, obra importante no cenário inglês, refeita e modernizada com consultoria do próprio Lubetkin, ainda vivo na ocasião ${ }^{78}$; a Villa Noailles, de Robert Mallet-Stevens, restaurada em $1985^{79}$; a Casa Wittgenstein em Viena, valioso exemplo de escola loosiana e

\footnotetext{
71 SALVO, 2008

72 Para mais informações cf. PROZOROVICH; ROIG, 2004

73 Para mais informações sobre o restauro do Pirelli, ver Salvo, 2007b; __, 2006

74 CARVALHO, 2005. Martínez aponta o problema político e simbólico envolvido em certas operações de demolições e reconstruções, como a demolição do Palácio da República, erigido pela Alemanha comunista sobre o antigo Palácio Real, então reconstruído nos anos 2000 e as inúmeras demolições das marcas do regime soviético e reconstruções de edifícios czaristas. MARTÍNEZ, 2007

75 CARBONARA, 1997

76 MUSTONEN, 1998

77 CASCIATO; DELL'ERBA, 1998

78 CARVALHO, 2005. Para Moore, a intervenção se constituiu em uma reinterpretação sobre a obra, ou seja, a Penguin Pool de 1987 não é a mesma da de 1934. MOORE, 1990

79 LEROY; BIOLLE; REPIQUET, 1998
} 

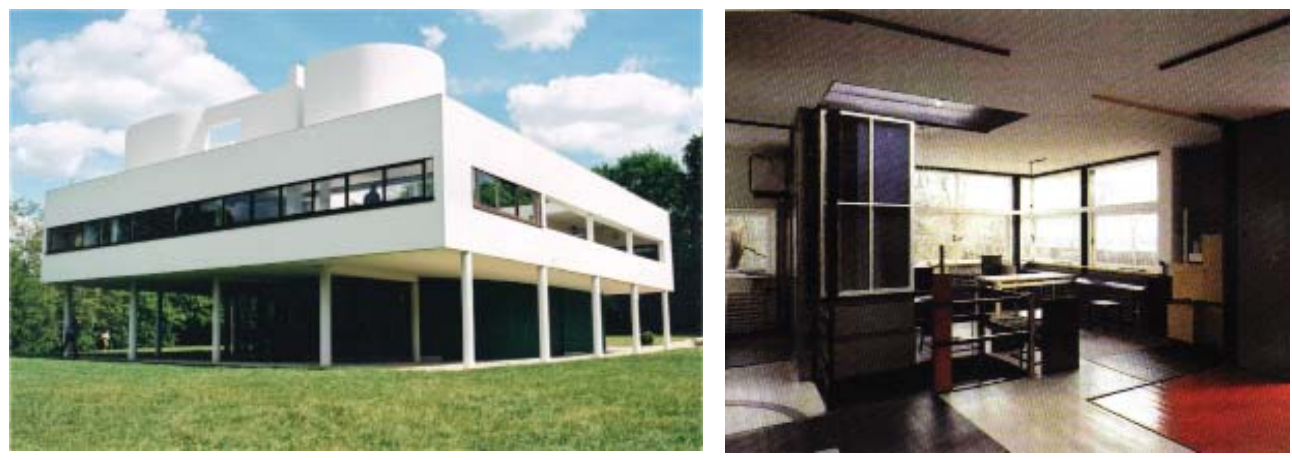

[1] Villa Savoye em 2003. [2] A casa Schroeder por dentro, após a restauração, sem indícios da vida dos antigos moradores.
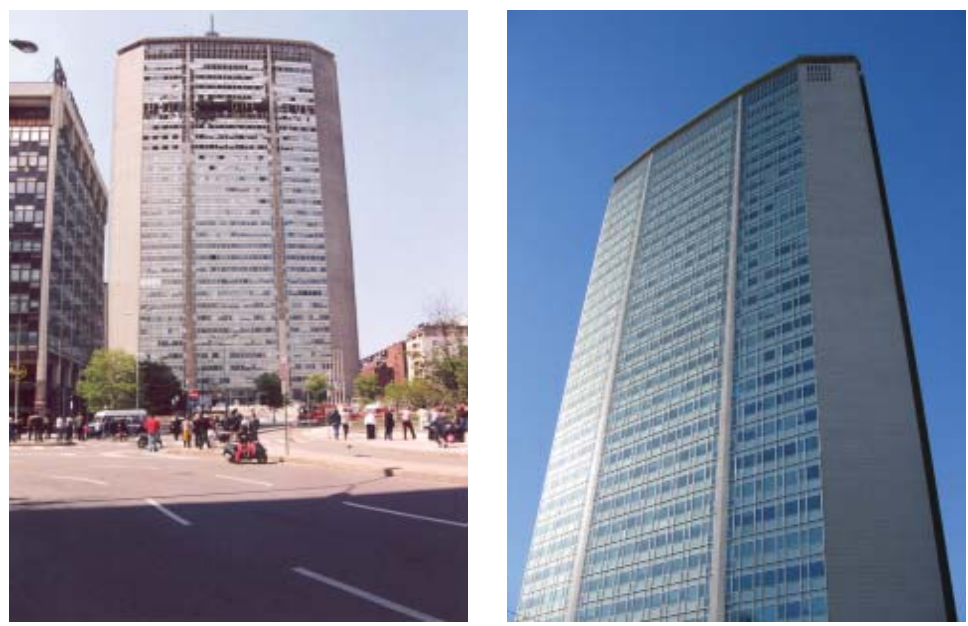

[3] Edifício Pirelli, Milão, (Gio Ponti), após o acidente aéreo em 2002 que levou ao restauro. [4] O edifício após o restauro, que se apoiou nos preceitos do campo, em uma operação que além de conservar o sistema curtain wall existente, trouxe economia à intervenção.
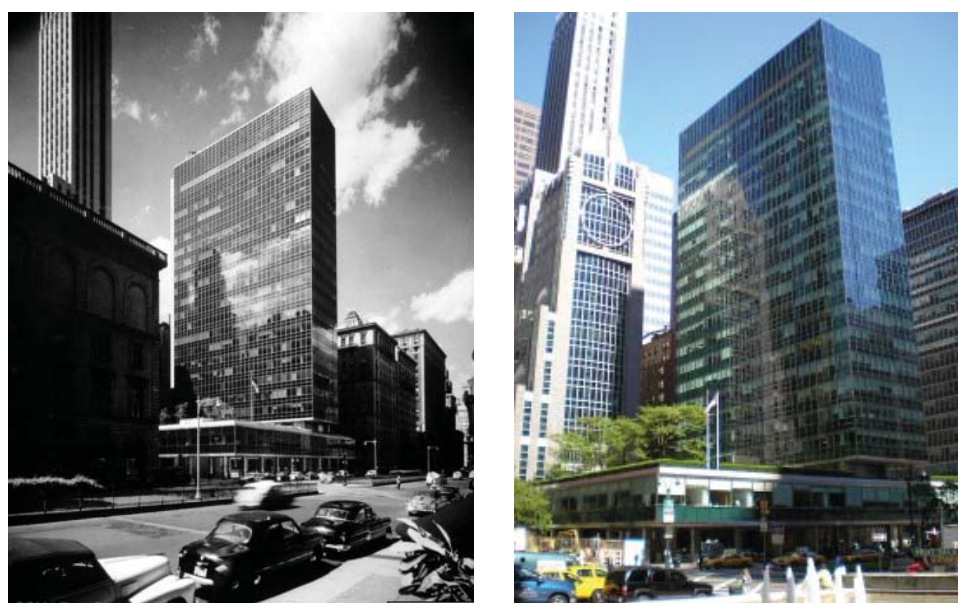

[5] e [6] Edifício Lever House (SOM) em 1952 e após a obra de 2001, que substituiu e aperfeiçoou o sistema do curtain wall.
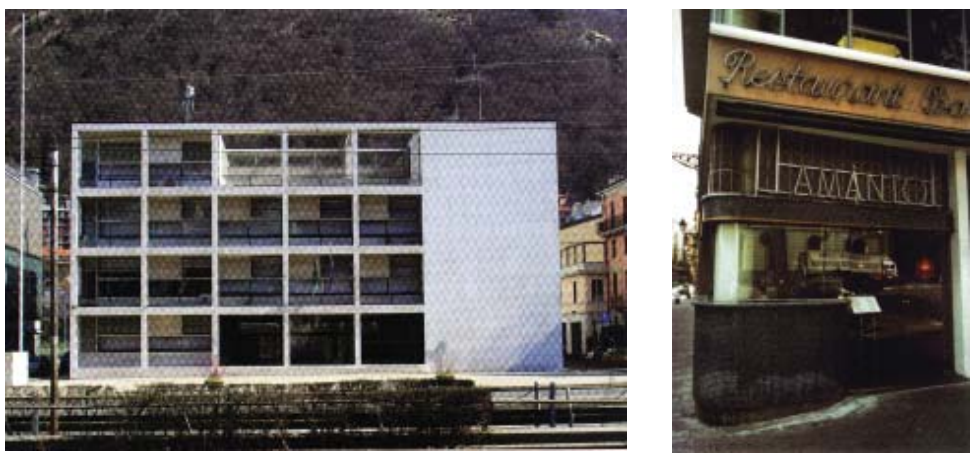

[7] Antiga Casa el Fascio (Terragni), Como/ Itália, restaurada entre 1988 e 1992 por meio de operações tradicionais de conservação (limpeza, consolidação, estucamento e proteção). [8] Hotel Park, Barcelona (Moragas e Galissa). Recebeu inervenção do filho de Moragas entre 1988 e 1990. 

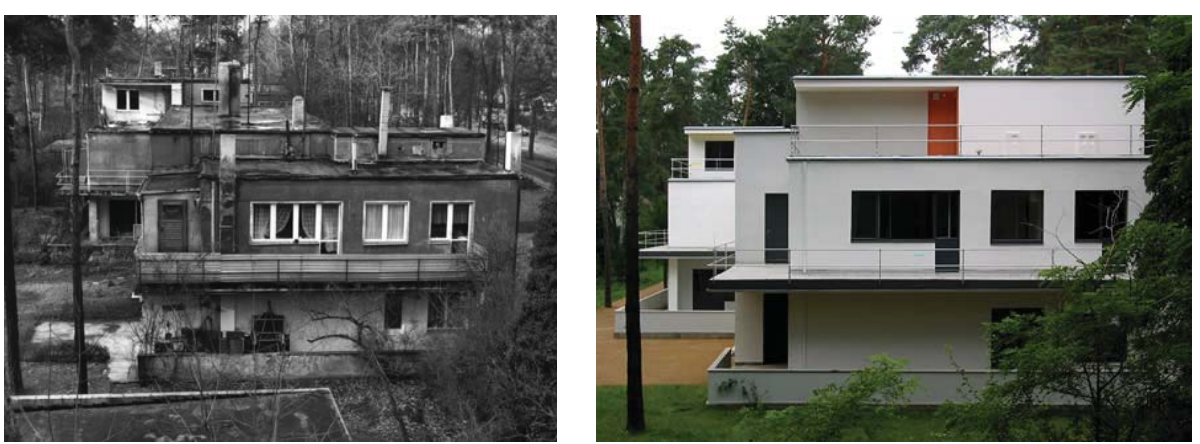

[9] e [10] Moradia dos mestres na Bauhaus Dessau. Casa de Muche em 1999 e em 2002, após restauro e reconstrução.
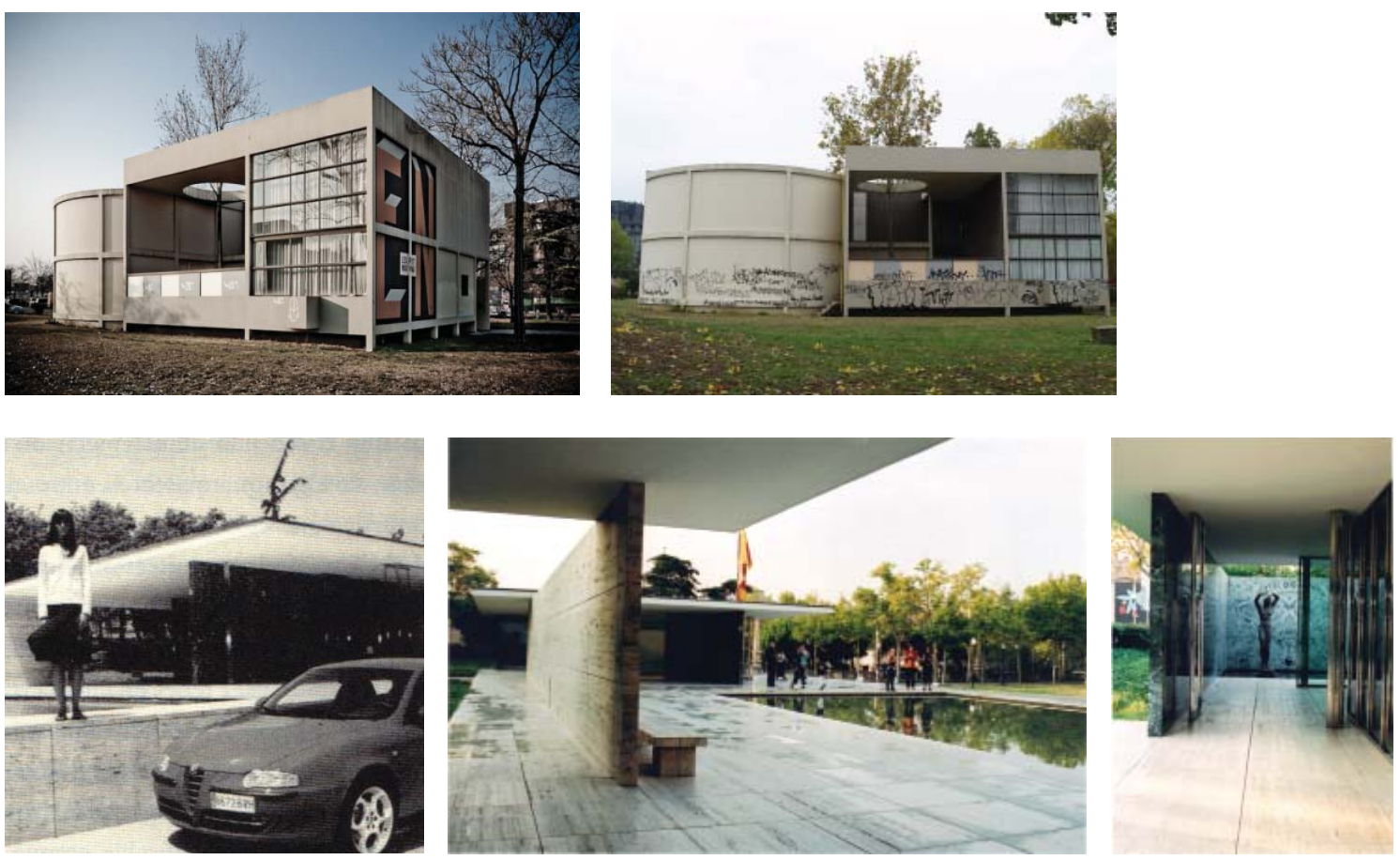

[11] e [12] O pavilhão da L'Esprit Nouveau, reconstruído em Bolonha. À direita, as pichações atestam o abandono e alheamento ao contexto em que está inserido. [13] Imagem publicitária com o Pavilhão Barcelona como locação. [14] e [15] O pavilhão em 2002.
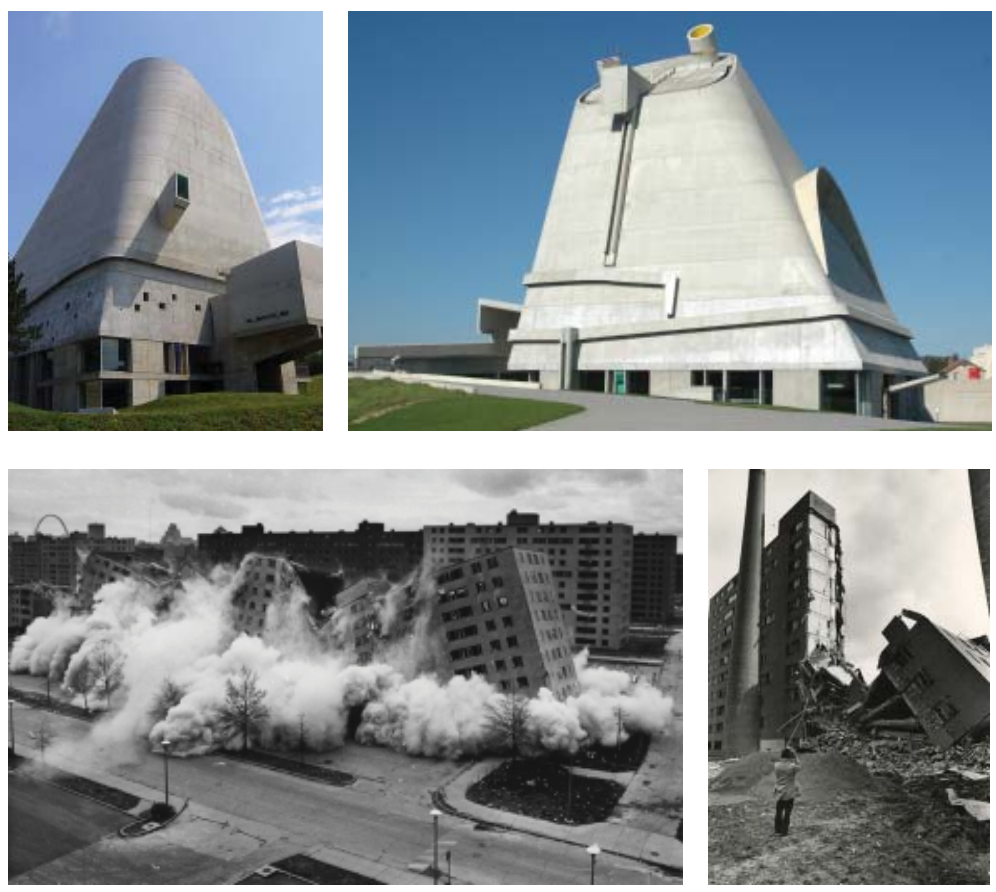

[16] e [17] Imagens da obra póstuma de Le Corbusier, a Igreja de Saint-Pierre em Firminy (França), inaugurada em 2006. [18] e [19] Demolição do conjunto Pruitt-Igoe em Saint-Louis (EUA) em 1972 registrada e transmitida por televisão. O espetáculo aumentou o evento. 
outros exemplos irreais realizados por um estudioso de Loos, Bernhardt Rukschio, a partir de experimentação "histórica-arqueológica” na Casa Steiner, edifício Goldmann \& Salatsch e American Bar em Viena; a Maison de Verre parisiense,o Pavilhão Dresselhuys, o sanatório Zonnestraal,em Hilversum, entre outros ${ }^{80}$.

A exacerbação desta abordagem levou ao extremo a valorização dos aspectos figurativos em detrimento dos aspectos históricos aliado ao descarte da autenticidade material, culminando no surgimento de casos de reconstrução total de obras já desaparecidas, como o pavilhão da L'Esprit Nouveau em Bolonha em 1977, construído a partir de iniciativa de arquitetos italianos reunidos em torno da revista Parametro; o pavilhão espanhol da Exposição Universal de Paris de 1937, de Josep Lluís Sert e Luis Lacasa, reconstruído em Barcelona em 1992 pelo Instituto Municipal de promoção urbanística de Barcelona, sob direção dos arquitetos Miguel Espinet, Antoni Ubach e Juan Miguel Hernández León; e o pavilhão alemão em Barcelona, de Mies van der Rohe, demolido em 1930 e reconstruído entre 19831986 sob direção de Cristian Cirici, Fernando Romas e Ignasi de Solà-Morales ${ }^{81}$. Conquanto estivesse presente o caráter experimental e temporário do pavilhão, os três casos logo se converteram em obras-chave da história da arquitetura moderna em escala mundial e espanhola no caso do pavilhão catalão. As reconstruções realizadas em Bolonha e Barcelona (Pavilhão de Paris) criam uma nova situação em que a cópia se realiza com'era, mas não dov'era. Destituídas de seu contexto ambiental e social original, das relações com seu entorno, seus significados nas cidades de origem, tornam-se obras estranhas à sociedade local.

Como símbolo da modernidade arquitetônica, os arquitetos ligados à revista $\mathrm{Pa}$ rametro propõem reconstruir o primeiro em 1977, quando a França participa do Salão Internacional da Construção de Bolonha, justamente no aniversário de cinquenta anos do pavilhão. Reconstruído através de uma extensa pesquisa em diversos arquivos, houve, entretanto, inúmeras alterações na reconstrução com relação ao projeto original. Em primeiro lugar, os desenhos de Le Corbusier eram vagos, sendo que muitas questões foram definidas na obra. Além disso, foi necessário trocar alguns materiais, já que a obra agora seria erigida em local definitivo, não devendo ser desmontável. Implantado em uma área distante e isolada da cidade, hoje o pavilhão está fechado, desconhecido da população e repleto de pichações que atestam seu abandono. Mas sua inauguração foi, na percepção de Martínez, "o ponto de partida de um novo impulso no aprofundamento do legado arquitetônico de Le Corbusier através da organização a de numerosas exposições e da publicação de estudos e ensaios, um interesse que trouxe consigo também a restauração de alguns de seus edifícios mais emblemáticos" ${ }^{82}$.

No caso do pavilhão espanhol da exposição de Paris, somou-se à descontextualização da obra em sua inserção em Barcelona, a perda de parte de sua significação quando dei- 
xou de expor as grandes obras artísticas integradas originalmente à construção no espírito da "arte total”, como a Guernica de Picasso, El payés catalán y la revolución de Joan Miró, peças de Alexander Calder e de diversos outros importantes artistas espanhóis. Assim como o pavilhão bolonhês, a réplica espanhola partiu de grande respeito aos materiais e métodos construtivos originais, ao lado da preocupação em simular a mesma situação do terreno e mesma orientação solar.

Já o Pavilhão Barcelona, após inúmeras tentativas desde 1955, teve sua reconstrução levada a cabo entre 1983 e 1986 no mesmo local da exposição originária de 1929, a partir de encomenda da municipalidade. Em realidade, a obra foi viabilizada quando em 1981 assume o cargo de diretor do Departamento de Habitação e Urbanismo de Barcelona, Oriol Bohigas, o primeiro arquiteto a levantar a bandeira da sua reconstrução em 1955. Como os desenhos originais estavam perdidos, Mies, em duas das tentativas frustradas, ofereceu os serviços de seu escritório para refazer o projeto, aproveitando a oportunidade para rever elementos que gostaria de aperfeiçoar. Foram escritos artigos e realizados seminários defendendo a realização da obra e até mesmo exposições comemorativas do aniversário do pavilhão ${ }^{83}$.

Solà-Morales, um dos autores da reconstrução, considerava que a obra, ícone da arquitetura moderna, talvez uma das mais importantes do movimento, deveria passar por uma reinterpretação, já que não seria mais provisória. Com isso, elementos estruturais, de captação das águas pluviais e outras instalações foram reprojetadas para dar conta de sua nova natureza perene. Também foram alterados aspectos da obra original em decorrência da pesquisa fundamentada nas imagens consagradas na historiografia, como o brilho dos pilares e a descarga da cobertura, originalmente também apoiada nas paredes. Por outro lado, houve grande fidelidade aos materiais da primeira versão como a utilização de mármores extraídos das mesmas regiões dos originais ${ }^{84}$. Kühl sintetiza a experiência:

Segundo o arquiteto G. Klaus König (...), Mies não se teria ocupado da construção, que era provisória e destinada a desaparecer; seu cuidado voltou-se para o controle das fotografias que seriam divulgadas e a fortuna crítica da obra se deu através dessas imagens. Esses fatos colocam uma questão da maior importância: a reconstrução de 1986 deveria se ater à obra como de fato construída, ou à imagem da obra como perpetuada pela crítica? A opção foi pela segunda alternativa, reconstruir segundo os desenhos de Mies feitos a posteriori, sendo uma versão revista de como ele gostaria que a obra tivesse sido construída ${ }^{85}$.

Como ocorrido com o pavilhão da L'Esprit Nouveau, o impacto da reconstrução dessa obra canônica foi imediato, repercutindo nas principais revistas arquitetônicas pelo 
mundo ${ }^{86}$, constituindo-se em locação para diversas peças publicitárias ${ }^{87}$, tornando-se rota obrigatória para os apreciadores da arquitetura moderna. O pavilhão merecia ser reconstruído, segundo Bohigas, por ser ele uma das obras fundamentais do século XX, ou dito de outra forma, por sua excepcionalidade e portanto, por sua unicidade - paradoxalmente imitada pela réplica. Os casos de reprodução extrapolam a esfera da preservação, pois, apesar de requererem alto grau de pesquisa para tornarem-se verossímeis, não guardam nenhuma relação com as teorias de restauro ${ }^{88}$. No limite, que diferença epistemológica a reconstrução dos pavilhões modernos guarda com relação a uma Stoa de Attalos em Atenas, fielmente reconstruída entre 1952 e 1954 ou um Parthenon construído em Tennessee em 1985 também para uma exposição internacional? Destituído de historicidade, mas realizado mediante ato histórico culturalmente reconhecido, o mito do objeto antiaurático fez com que um pavilhão como o Barcelona, fetiche do movimento moderno, se convertesse, na acepção choaysiana, não em monumento histórico mas em monumento simplesmente. Monumento intencional de si mesmo, feito para a sua celebração, para o seu culto e, como ícone, para o culto a todo o movimento moderno, ao seu valor de novidade ${ }^{89}$; também para a diferenciação e construção de singularidades com a propagação de Barcelona no circuito cultural mundial através da afirmação da cidade como capital do Design ${ }^{90}$.

Tanto a reconstrução do pavilhão alemão quanto o da exposição universal de Paris se situam no bojo de políticas de revitalização e especulação imobiliária, estando a última associada aos investimentos para a realização das Olimpíadas em Barcelona em 1992 ${ }^{91}$. Inserem-se na tendência mundial de instrumentalização da cultura iniciada nos anos 1980 para finalidades econômicas ${ }^{92}$, donde a cultura passa a ter papel preponderante para a afirmação de identidades no contexto de mundialização, através da qual a promoção do consumo dos lugares passa a ser chave para captação da mais-valia urbana e das rendas obtidas com o turismo. Choay e Arantes apontam como tendência dominante em relação às práticas patrimoniais contemporâneas o que denominam "Animação Cultural" ${ }^{33}$. Esta consiste na mediação que tem como objetivo facilitar o acesso às obras ora valorizadas a fim de tornálas consumíveis. Arantes afirma ainda que "a cultura se transformou em uma peça central na máquina reprodutiva do capitalismo", tornando-se a sua mola propulsora, um dos carroschefes das chamadas políticas de "revitalização". O momento reflete a mudança de para-

86 Em busca rápida, localizamos 20 artigos escritos entre 1985 e 1986, a partir de buscas no Art Index e na página < http://eng.archinform.net/projekte/2095.htm>

87 No site da Fundação Mies van der Rohe, a locação publicitária e para eventos é encorajada. Cf. http:// www.miesbcn.com/es/alquiler.html

88 Tais procedimentos não pertencem à esfera da preservação, mas podem ser historicamente legítimas, como a reconstrução das cidades devastadas pelas Grande Guerras, de Varsóvia, Ypres, Dresden e outras.

89 Na acepção riegliana.

90 MARTÍNEZ, 2007

91 Idem

92 JOSÉ, 2007

93 ARANTES, 2001; CHOAY, 2006. 
digmas nas políticas de preservação, antes voltadas à constituição de memórias nacionais no momento de fortalecimento dos Estados nacionais, agora orientadas pela competição na escala das cidades:

Objetivando modernizar recursos potenciais para uma melhor inserção das cidades históricas no contexto da "concorrência intercidades", através dos usos do patrimônio na captação de recursos, as políticas de "revitalização" têm desenvolvido, no curso crescente da desregulamentação "neoliberal" da economia mundial, uma complexa política cultural de gentrification ${ }^{94}$

Da Paris do Beaubourg, La Defense e Biblioteca Nacional à Pirâmide do Louvre, das Docklands de Londres ao Museu Guggenheim de Bilbao, da Vila Olímpica catalã à Expo 98 em Lisboa, da Potsdamer Platz ao Reichtag em Berlim, a cultura como imagem e como mercadoria vem se colocando como motor de uma série de investimentos públicos voltados à valorização, gentrificação e acumulação, alavancando as economias das cidades proponentes deste tipo de políticas ${ }^{95}$. Martínez identifica no problema certo risco de disneylização, em decorrência da construção cenográfica e espetacularizada do patrimônio, histórico ou não.

O fenômeno poderia se enquadrar naquilo que Monnier chama de "edifício-evento", entendido como "aquele que o emprego maciço das técnicas de informação insere de forma importante e súbita no espaço público (no sentido proposto por Habermas), para neste exercer uma representação forte e impositiva" ${ }^{96}$. Os edifícios-evento são divididos entre programados (intencionais) ou fortuitos (ocorridos por acasos ou desastres não controlados, como o ataque às torres gêmeas). Como edifícios-eventos programados, os pilares dos planos de revitalização carecem de ampla disseminação midiática para que ganhem mais força em termos de reconhecimento e valoração. O Centro Georges Pompidou, por exemplo, teve impacto tão forte nos meios de comunicação, que pôde consagrar todos os atores envolvidos, dos arquitetos aos políticos. Mesmo os Pavilhões de que tratamos tiveram tal repercussão, com maior destaque para o Pavilhão Barcelona, que alimentou-se de sua dupla característica de edifício-evento, enquanto pavilhão e enquanto reconstrução, fazendo com que a obra e seu criador passassem por mais uma reavaliação na historiografia. Monnier afirma ainda que "essas informações, por seu número e significados, envolvem o edifício com representações tão maciças e tão fortes que o mascaram para a observação direta" ${ }^{97}$. Inevitável pensar no quanto o conjunto habitacional Pruitt-Igoe se notabilizou internacionalmente através da sua aclamada demolição, resignificando o próprio movimento moderno, não apenas para Charles Jencks ${ }^{98}$, mas como marco para a historiografia. Não fosse a espetacularização de

$\begin{array}{ll}94 & \text { LEITE, 2004:61 } \\ 95 & \text { ARANTES, 2001; CHOAY, } 2006 . \\ 96 & \text { MONNIER, 2006:12 } \\ 97 & \text { MONNIER, 2006:13 } \\ 98 & \text { Que estabeleceu as 15:00 de } 16 \text { de março de 1972, horário da demolição, como o momento da morte }\end{array}$ do movimento moderno. 
sua demolição, o Priutt-Igoe possivelmente seria apenas mais um desprestigiado e anônimo empreendimento dentre tantos outros conjuntos do pós-guerra, culpabilizados pela degeneração social assistida em seus territórios ${ }^{99}$.

Mas a questão não fica restrita às grandes "cidades globais". Na França, desde os anos 1990 o país que mais recebe turistas no mundo, o turismo é peça central da economia. Nos anos 1980, o patrimônio cultural chegou a representar mais de 30\% das despesas com atividades culturais e cerca de $5 \%$ do orçamento nacional, respaldado por uma população habituada a frequentar museus, tornando-se a área cultural peça estratégica na política externa francesa ${ }^{100}$. Observamos o fenômeno mesmo em cidades de menor porte, como Firminy. Construindo diversos edifícios no distrito de Firminy-Vert desde 1955, Le Corbusier foi contratado em 1960 para desenvolver o projeto para a Igreja de Saint-Pierre, com a colaboração de José Oubrerie e José Luis Miquel. O projeto foi concluído em 1965, mesmo ano em que veio a falecer. Três anos depois é criada a associação Le Corbusier para a Igreja de Saint-Pierre, para arrecadar fundos para a sua construção, levantando a discussão sobre autenticidade de construção de obras póstumas. A pedra fundamental é lançada em 1970, mas a construção inicia efetivamente em 1973 e é paralisada em 1978. Em 1996, a "ruína moderna" é decretada monumento nacional, mas as verbas públicas para a conclusão da obra só são liberadas em 2003, quando a obra é retomada sob direção de Oubrerie e finalizada em $2006^{101}$. A pequena cidade, povoada por menos de 20 mil habitantes, tem na exploração turística do conjunto de Firminy-vert uma grande fonte de renda.

Já a pequena Poissy, distante cerca de $30 \mathrm{~km}$ de Paris, apesar de ter o grosso de suas receitas arrecadadas com as inúmeras indústrias ali instaladas, guarda como capital simbólico a Villa Savoye, quase unanimemente considerada ao lado do pavilhão de Mies e o edifício da Bauhaus em Dessau uma das obras mais influentes do movimento moderno. Lugar de peregrinação de apreciadores de todo o mundo, a obra máxima dos cinco pontos de Le Corbusier contém uma trajetória que abarca diversos aspectos do andamento da historiografia e da preservação da arquitetura moderna, valendo a pena um exame mais atento.

Projetada em 1928 e construída de 1929 a 1930, tornando-se habitável somente a partir de 1931, a casa recebe a visita de Giedion diversas vezes antes mesmo de concluída, que confessa em carta ao editor Christian Zervos, a dificuldade de fotografá-la ainda em construção de modo que aparentasse acabada para a sua publicação na $4^{a}$ edição da Cahiers d'art, de 1930. Como colaborador de arquitetura da revista, no artigo atribuía a Le Corbusier papel de liderança do movimento e à Villa Savoye a síntese da nova maneira de construir ${ }^{102}$. Para Tournikiotis, os registros de Giedion deram à obra dimensão simbólica mesmo antes de acabada, mas seu papel na consagração da Villa e de Le Corbusier se completa com

99 O desprestígio da arquitetura social massiva do pós-guerra tornou a preservação de importantes conjuntos um desafio para as instituições preservacionistas. Sobre o tema, cf. NASCIMENTO, 2007

100 MICELI, 1987

101 Informações disponíveis no site de Firminy-Vert, http://www.sitelecorbusier.com/en/eglise.php.

102 TOURNIKIOTIS, 2007 
a introdução da Oevre complete 1929-1934 e com Espaço, Tempo e Arquitetura.

Entretanto, a Villa pouco tempo foi utilizada como residência pelos Savoye. Correspondências de 1930 a 1937 entre Le Corbusier e Émile Savoye atestam as inúmeras queixas da cliente com relação aos defeitos da casa, como infiltrações e vazamentos em diversos ambientes, prontamente atendidas pelo arquiteto, ciente da importância de sua obra. Em 1938 o casal Savoye deixa a casa e em 1940 desativam-na definitivamente como residência temporária ${ }^{103}$. Durante a $2^{a}$ Guerra Mundial, a casa é ocupada sucessivamente pelas forças germânicas e americanas, que produzem as primeiras alterações. Finda a guerra, Émile Savoye estava viúva e empobrecida, mudando-se para uma fazenda nas proximidades e utilizando a casa como celeiro para suas atividades rurais, sem ter recursos para recuperá-la.

Com o processo de urbanização e a implantação de indústrias na região, a área externa da casa então abandonada torna-se local de feira livre em 1951, até que em 1958 o governo local a desapropria, a despeito da resistência da família, para transformá-la em escola secundária, sendo realizadas diversas alterações para torná-la segura para crianças.

Mme. Savoye era bastante apegada à casa, mesmo com seus problemas técnicos, tendo tomado a iniciativa de defender a sua preservação assim que soube da desapropriação, informando Le Corbusier que no mesmo dia disparou telegramas para Giedion, Sert e outros, e contatou instituições como a UNESCO e o Ministério da Cultura francês, então chefiado por André Malraux. Naquele momento, o arquiteto suíço não tinha em mente transformá-la em monumento nacional, mas mesmo que quisesse, encontraria impedimentos legais, já que a legislação francesa não permitia a proteção de obras de arquitetos vivos ${ }^{104}$. Entretanto, já se discutia seu uso, se museu, centro de pesquisa ou a sede da Fundação Le Corbusier, projeto que vinha sendo amadurecido. A ocasião gerou manifestações de defesa em jornais e revistas e grande mobilização de intelectuais e arquitetos pelo mundo, como André Chastel, Pevsner e Giedion, um dos principais articuladores da defesa do edifício. Já pelos anos 1960, conclui Murphy, a Villa Savoye, que serviu breve e imperfeitamente como residência, reafirmava sua única função de manifesto estético do arquiteto, a despeito da defesa de seu funcionalismo. O foco das discussões indicava a percepção da casa como fenômeno histórico e a liderança de Le Corbusier para a sua preservação revelava certo ponto de vista nostálgico, como quem já via as obras dos anos 1920 como fase superada, de um racionalismo já substituído pelo vocabulário à Ronchamp ${ }^{105}$.

Em 1962 Malraux chama Le Corbusier para coordenar uma obra de conservação financeiramente limitada, mas que pudesse garantir a reversão das patologias mais ameaça-

103 Todo o histórico da ocupação da casa em MURPHY, 2002

104 Macinnes aponta as consequências danosas ao patrimônio moderno de critérios de preservação baseados no desaparecimento dos autores das obras ou de distância temporal mínima, como nos casos da Inglaterra (30 anos), Estados Unidos (50 anos) e Austrália (a Carta de Burra define um corte em 1960). Em muitos casos, o restauro se torna mais drástico do que se houvessem intervenções com menor distância temporal. MACINNES, 1994.

105 MURPHY, 2002. 

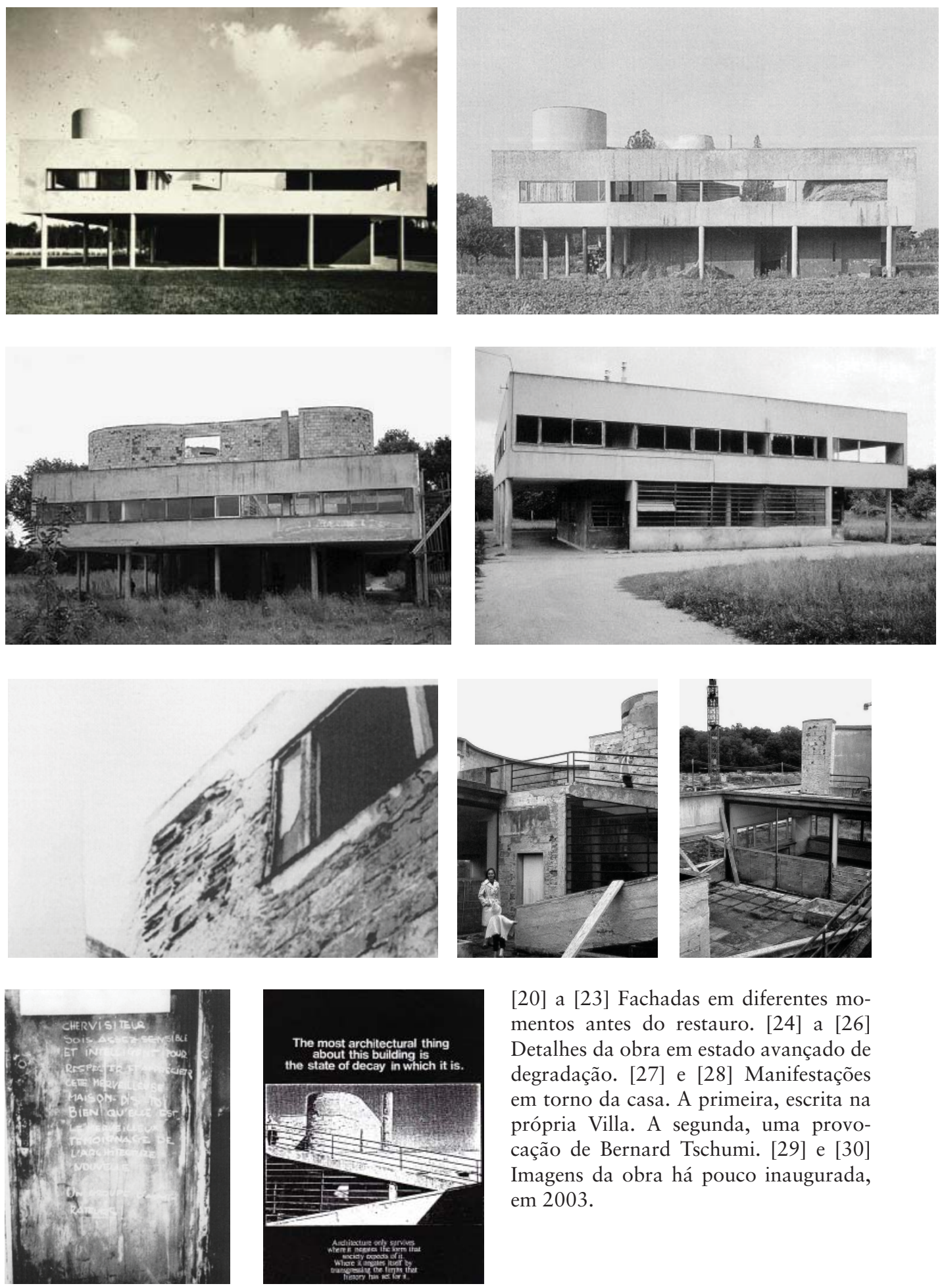

[20] a [23] Fachadas em diferentes momentos antes do restauro. [24] a [26] Detalhes da obra em estado avançado de degradação. [27] e [28] Manifestações em torno da casa. A primeira, escrita na própria Villa. A segunda, uma provocação de Bernard Tschumi. [29] e [30] Imagens da obra há pouco inaugurada, em 2003.
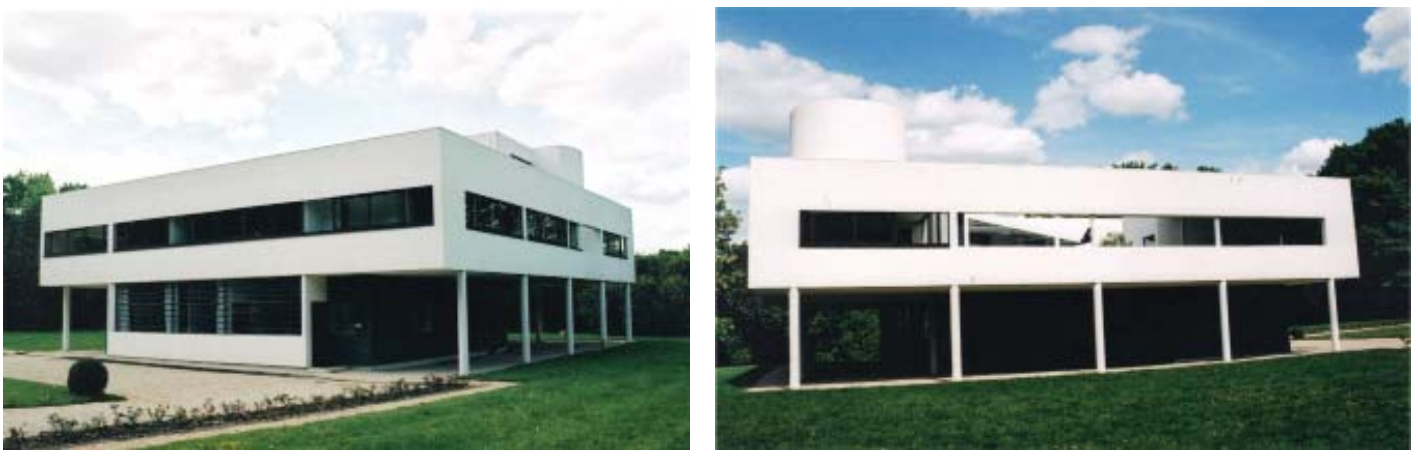
doras e a retirada das intervenções posteriores. Porém, a obra foi abandonada por trabalhadores que não receberam o pagamento, deixando-a com os andaimes montados e serviços incompletos, entre os quais as estruturas deixadas expostas, agravando ainda mais a deterioração das alvenarias. Apesar de o Ministério da Cultura vir gradativamente assumindo mais responsabilidade pela preservação da casa, a lentidão do governo foi extremamente danosa. Tendo em vista a impossibilidade de transformá-la em Monumento Nacional, o Ministério declara a Villa Bâtiment civil como subterfúgio e inicia o desenvolvimento do projeto de restauro, chamando Le Corbusier como consultor informal, em primeiro lugar por impedimento legal na sua contratação formal, pois só poderiam trabalhar no projeto funcionários do ministério, e em segundo lugar, porque o responsável pelo projeto tinha receio do envolvimento do arquiteto, que apesar de dizer que queria a reconstituição exata do estado original do edifício ${ }^{106}$, de fato intencionava promover profunda modificação no projeto original, conforme atestam as correspondências trocadas com um dos arquitetos da equipe do governo $^{107}$. Le Corbusier ficaria então responsável apenas pela proposta cromática e a supervisão da reconstrução do teto-jardim e solarium. Contudo, o arquiteto morrera alguns meses depois do fechamento do escopo do trabalho, em agosto de 1965, não participando de nada.

Paradoxalmente, sua morte renovou a mobilização internacional pela restauração da Villa Savoye e possibilitou a sua inscrição como Monumento Nacional em dezembro do mesmo ano. Entretanto, a posição ambígua de Malraux em defender mas efetivamente não agir incisivamente para a preservação da Villa fez com que a degradação do edifício se agravasse com o tempo, chegando a ser denunciada em exposição montada no MoMA de Nova York em 1966, Destruction by neglect. Então em 1967, foi realizada uma obra parcial de restauro visando a recuperação da caixilharia e a recolocação de revestimento externo. Para o chefe da restauração realizada em 1985, a má execução e “mão pesada” da intervenção dos anos 1960 fez com que as estruturas novamente já se encontrassem expostas, implicando na substituição das argamassas de revestimento internas e externas. A obra dos anos 1980 também previu a repintura das alvenarias, realizada com base somente em conjecturas, já que com a morte de Le Corbusier e a irreversível substituição das argamassas nas primeiras obras de restauro, qualquer informação havia se perdido. Começaram a ser realizados estudos mais profundos por estes anos sobre os esquemas de cor utilizados pelo suíço, baseados em outros exemplares do período, o que torna evidente o problema dessa postura de visar o restabelecimento da figuração original, que por dedução supõe o que o mestre teria feito, seguindo os ensinamentos de Viollet-le-Duc de tentar se colocar no lugar do arquiteto primitivo. Finalmente em 1998 a Villa passa por uma restauração conclusiva, abrindo-se então para visitação.

Já nas primeiras intervenções o imóvel recebeu o plantio de densa vegetação nos limites do terreno, para que a Villa permanecesse monumentalmente isolada não só no lote, mas também sem interferências visuais da Poissy industrial. A brancura dos volumes, alternados 
com cores escolhidas sob critérios talvez questionáveis, em um imóvel vazio, percorrível para seu próprio culto, pouco documenta a rica história por ela vivida, testemunhando no máximo a passagem do momento de consagração originado na profícua relação entre Giedion e Le Corbusier e o momento de sacralização imposto pela conversão em monumento e pelos restauros, viabilizados fundamentalmente através da participação de ambos no reconhecimento de seu valor histórico em contraposição à sua historicidade ${ }^{108}$.

A trajetória da Villa, desde seus momentos originários da relação dos Savoye com Le Corbusier a todo o processo de transformação em museu de si mesma, mostra a riqueza de uma história que extrapola o período de criação sob perspectiva da autoria. O episódio também demonstra o valor heurístico da análise da preservação como forma de compreensão da recepção da obra, das interpretações sobre seus valores, do protagonismo deste campo na reiteração do cânone, da permeabilidade à historiografia hegemônica.

\section{A REALIDADE BRASILEIRA}

A abordagem retrospectiva, ancorada nas formulações violletianas, repercute até os dias de hoje, marcando presença no tratamento predominantemente dado ao patrimônio moderno. No Brasil, o paradigma é assimilado desde as primeiras experiências de restauro promovidas pelo SPHAN ${ }^{109}$ que se davam em consonância com o projeto simbólico-cultural construído pelo órgão no interior do processo de modernização e consolidação do Estado brasileiro, desde sua criação em 1937 no seio da ditadura varguista. Para Miceli, "a modalidade técnica escolhida para o trabalho de restauração enquadra-se nessa lógica de embelezamento do estilo e consequente diluição das marcas sociais" ${ }^{110}$ sem superação da doutrina da reintegração estilística, que "não é outra coisa senão o delírio de 'purificar' o prédio em vias de restauração de quaisquer acréscimos posteriores à sua construção original" ${ }^{111}$.

Mais que retirar os acréscimos posteriores às construções originais, os restauros chegavam a promover verdadeiras transformações figurativas visando o restabelecimento de suas supostas feições primitivas. Os edifícios restaurados encontravam-se entre aqueles

108 Nota-se que a visão critica sobre o histórico de intervenções não leva à argumentação de que todas as transformações pelas quais a obra sofreu deveriam ser preservadas. Como tentamos expor ao longo do capítulo, trata-se de assunto complexo, em que o equilíbrio entre as instâncias estética e histórica deve ser encontrado mediante ato crítico e criativo a partir da singularidade de cada caso, mas conforme princípios gerais norteadores.

109 O órgão teve diversos nomes ao longo do tempo: Serviço do Patrimônio Histórico e Artístico Nacional (Sphan, 1937-1946), Diretoria do Patrimônio Histórico e Artístico Nacional (Dphan, 1946-1970), Instituto do Patrimônio Histórico e Artístico Nacional (Iphan, 1970-1979), Secretaria do Patrimônio Histórico e Artístico Nacional (SPHAN, 1979-1990), Instituto Brasileiro do Patrimônio Cultural (IBPC, 1990-1994) e novamente Instituto do Patrimônio Histórico (IPHAN, de 1994 até hoje). Para simplificar, denominá-lo-emos SPHAN até o fim da "fase heroica" em 1967, e IPHAN a partir de então.

110 MICELI, 1987:44

111 MICELI, 1987:45 
bens exemplares tipificados, de conotação identitária inseridos no processo de construção da memória nacional. Nas palavras de Miceli, "o Sphan é um capítulo da história intelectual e institucional da geração modernista, um passo decisivo da intervenção governamental no campo da cultura e o lance acertado de um regime autoritário empenhado em construir uma 'identidade nacional' iluminista no trópico dependente" ${ }^{112}$.

Como é sabido, o barroco mineiro foi eleito como ponto de partida para o processo de seleção dos bens a configurarem a identidade brasileira. Sem a exuberância dos seus pares mineiros ou baianos, a arquitetura colonial a evocar a "identidade paulista" não deveria ser tombada por seu valor artístico, no entender do responsável pela regional paulista, Mário de Andrade, mas sim pelo seu valor histórico, conforme explicitado em carta a Rodrigo Mello Franco de Andrade:

E há o problema geral de São Paulo. Você concordará comigo que não é possível entre nós descobrir maravilhas espantosas, do valor das mineiras, baianas, pernambucanas e paraibanas em principal. A orientação paulista tem de se adaptar ao meio: primando a preocupação histórica à estética. Recensear e futuramente tombar o pouco que nos resta de seiscentista e setecentista, os monumentos onde se passaram grandes fatos históricos. Sob o ponto de vista estético, mais que a beleza propriamente (esta questão quase não existe), tombar os problemas, as soluções arquitetônicas mais características ou originais ${ }^{113}$

Dizia Mário, “em vez de se preocupar muito com a beleza, há de se reverenciar e defender especialmente as capelinhas toscas, as velhices dum tempo de luta e os restos de luxo esburacado que o acaso se esqueceu de destruir" ${ }^{114}$. Mas como aponta Rubino, mais que constatação resignada, a visão de Mário norteou o trabalho de inventário em São Paulo ${ }^{115}$, selecionando os exemplares a serem preservados e constituindo-se como ponto de partida de uma atuação característica do órgão em São Paulo.

Trabalhos recentes evidenciaram um traço comum às intervenções realizadas pelo Sphan, norteadas por uma metodologia de restauro desenvolvida a partir da experiência prática. Frente à generalizada ausência de documentação, o método percorria o caminho não da investigação do monumento ao projeto, mas da aplicação a ele das teorias que se tinha a respeito da arquitetura a que pertencia. Nos casos examinados por Andrade, Gonçalves e Mayumi ${ }^{116}$, não se cogitou outro critério a não ser o restauro de repristinação.

Fora do Estado de São Paulo, há exemplos como a restauração da Igreja Nossa Senhora do Carmo ${ }^{117}$ (1939), em Recife, para a qual os carmelitas desejavam construir a

MICELI, 1987:44

113 ANDRADE apud RUBINO, 1992:124

114 ANDRADE apud GONÇALVES, 2005:105

115 RUBINO, 1992:128.

116 ANDRADE, 1993; GONÇALVES, 2005; MAYUMI, 2008

117 Abordada por ANDRADE, 1993 
segunda torre, nunca existente, nos moldes da simetricamente oposta. A orientação de Lúcio Costa era de que se reproduzisse fielmente a torre existente e que se removesse todos acréscimos posteriores à fase inicial da construção. Rodrigo M. F. de Andrade apoiou o parecer de Lúcio, ressalvando apenas que em muitos casos esse tipo de solicitação sai da esfera da preservação e pode ser danosa aos monumentos, mas que nesse caso em apreço a igreja visivelmente estava inacabada e necessitava de melhor aspecto. O serviço, entretanto, não foi executado e não houve interesse posterior em retomar tal projeto. Em 1961, foi iniciada obra para recuperação do frontispício, cujo parecer de Lúcio Costa contrariava aquele de 1939, pois desta vez, considerava necessário respeitar as intervenções oitocentistas. Rodrigo então determinou que a decisão ficasse a cargo do chefe do distrito, Ayrton Camargo, que optou pela repristinação.

Outro caso que merece atenção é o do convento de Santo Antônio ${ }^{118}$ (restaurado nos anos 1950), também em Recife, pois as decisões de restauro normalmente restritas às decisões internas do órgão entraram em choque com as defendidas pela província dos padres franciscanos, que chegaram a levar o caso à justiça pelo embargo da obra. O Sphan estava seguindo o partido recorrente ao órgão, o que implicaria, além de significativa alteração visual/ ornamental, a supressão de uma área de cerca de $40 \mathrm{~m}^{2}$ para restituir a feição primitiva da Galilé. Os padres argumentavam que a intervenção sacrificava a função religiosa da igreja, questionando a orientação adotada:

(A) conservação e restauração dos edifícios tradicionais não importa necessariamente em repô-los no seu estado originário. Fosse assim, e por exemplo, a catedral de São Paulo, o maior, mais suntuoso templo de que se ufana o Brasil, teria de ser reduzida à humilde palhoça que os jesuítas edificaram (...). Também as atuais pontes do Recife voltariam a ser os tôscos engenhos com que as administrações coloniais, portuguesas e holandesas, conseguiram vencer (...) o obstáculo oposto pelo rio à travessia de pedestres e veículos.

Não chega a tanto a tradição. Tudo quanto o homem constroe, posto que traga a marca indelével do seu tempo, é eminentemente funcional. E a função adapta-se aos tempos.

(...) Nenhuma orientação radical se deve adotar nesse assunto: nem o fetichismo da manutenção pura e simples do aspecto primitivo das edificações, nem tão pouco o sacrifício completo da tradição arquitetural às necessidades funcionais. Um meio termo de equilíbrio, enfim ${ }^{119}$

Entretanto, os questionamentos não encontraram ressonância no órgão, tendo Lúcio Costa e Rodrigo M. F. de Andrade negado qualquer reconsideração sobre o partido adotado. A ação judicial não prosperou, mas houve acordo entre as partes.

118 Idem.

119 Frei Heriberto Dulkowski apud ANDRADE, 1993:137 
O caso mais radical de repristinação ocorreria na Casa de Câmara e Cadeia de Atibaia $^{120}$ (1958-1961). Preterida da lista inicial de bens de interesse para tombamento, produzida por Mário de Andrade em 1937, o edifício foi tombado em 1955 a partir da mobilização da comunidade local diante do estado crítico e da ameaça de demolição por esses anos.

O edifício, datado do século XIX, com inspirações neoclássicas, teve sua obra de restauro coordenada pelo arquiteto Luis Saia, diretor da regional de São Paulo desde 1938, ano que marca a saída de Mário em decorrência dos caminhos tomados pelo Estado Novo ${ }^{121}$. Previa-se a consolidação estrutural em concreto armado, a retirada da platibanda e suposto restabelecimento do beiral, a reconstituição da escada nobre, forros e assoalhos, a substituição das instalações elétricas e hidráulicas. Como de praxe nos restauros da regional paulista, as obras iniciavam-se com a retirada de todo o revestimento interno e externo para avaliação das alvenarias. Com isso, eliminou-se a platibanda e todos os elementos decorativos da fachada, o que "indica a desconsideração por estes elementos, desde o início afirmando-se o desejo de suprimi-los" ${ }^{122}$. A proposta de Saia fundamentava-se na sua "leitura da arquitetura tradicional paulista e do modelo representativo - e idealizado - correspondente a esta produção" ${ }^{123}$.

Mesmo documentada a grande alteração ocorrida na segunda metade dos oitocentos, com a substituição da taipa pela alvenaria de tijolos - prospectada na obra em curso - e com o aumento do número de vãos e toda a reconfiguração da fachada, Saia insistiu na retomada de uma suposta feição original, ignorando as características construtivas existentes ${ }^{124}$, vinculando a obra à tipologia representada pelo exemplo da Casa de Câmara e Cadeia de Santos. Chegou com isso a receber questionamento de seus colegas, como Edgar Jacintho: o "Dr. Saia recuou demais no tempo, ao emprestar fisionomia arcaizante a um lídimo monumento novecentista, cuja modenatura em geral, e em particular nos vãos, encarecia-o como, na espécie, exemplar excepcional do período em causa" ${ }^{125}$; ou Renato Soeiro, então diretor da Divisão de Conservação e Restauração, que questionava a base do argumento de que a obra seria em taipa, não permitindo certas liberdades. Eliminando também a sineira adicionada em fase posterior, a população, que se mobilizou pela preservação do edifício, pouco se reconheceu na feição adquirida pós-intervenção.

Antonio Luis Dias de Andrade demonstra no caso da Igreja Nossa Senhora do Rosário em Embu (1939) o mesmo problema criado pela reconstituição sem bases “irrefutáveis",

120 Estudada por Andrade e Gonçalves

121 Mário de Andrade é forçado a mudar-se para o Rio de Janeiro em decorrência de perseguições políticas aos fundadores do Departamento de Cultura de São Paulo, entre eles, Paulo Duarte. As informações em GONÇALVES, 2005.

122 ANDRADE, 1993:143

123 GONÇALVES, 2005:144

124 E a incompatibilidade do grande número de vãos imposto pela modenatura da fase eclética à arquitetura em taipa.

125 Edgar Jacintho apud ANDRADE, 1993:145. 
quando um longo debate entre Luis Saia e Lúcio Costa foi travado em torno da reconstituição do telhado da torre sineira, se em duas ou em quatro águas. O último defendia a recomposição do conjunto arquitetônico de acordo com o espírito de época, conferindo algumas liberdades de projeto dentro dos princípios da época. No processo de pesquisa, foi encontrada uma fotografia desfocada, que parecia registrar a cobertura em duas águas, tornando-se assim a solução adotada. Entretanto, cita Andrade a localização posterior de fotografia no arquivo Washington Luiz por Carlos Lemos que demonstra ter sido o telhado da torre sineira em três águas, atestando, enfim, que a solução adotada nunca existiu.

Estes casos ilustram os métodos de trabalho da regional paulista que, desenvolvidos a partir da prática, prescindiam de um projeto elaborado previamente a partir de orientação de Luis Saia com sua concepção modelar da arquitetura - "modelo, este, 'colonial' por excelência" que negava os "partidos remanescentes, excepcionais ou não, do período eclético" ${ }^{126}$. Os casos iniciais da Igreja de Nossa Senhora do Rosário do Embu (1939), da Igreja de São Miguel Paulista (1939) e da Casa-sede e Capela do sítio Santo Antônio (19401947) são considerados por Gonçalves e Mayumi como exemplares paradigmáticos dos métodos paulistas. Neste último, demoliu-se acréscimo do século XIX à casa-sede ("casa do Barão"), destacando-se o volume primitivo, reconstruiu-se em concreto autoclavado parcela arruinada original, reforçou-se em concreto armado as alvenarias de taipa, inseriu-se placa de concreto na base externa das alvenarias de modo a impermeabilizar as paredes e combater a erosão provocada pelos respingos de água da chuva, reconstituiu-se o alpendre da capela a partir de elementos deduzidos na obra e dos conhecimentos pré-existentes sobre a tipologia da arquitetura rural paulista. Tais elementos estarão em maior ou menor grau presentes nos restauros subsequentes, como na Casa do Padre Inácio (1947), na Igreja de Nossa Senhora da Escada (1954), nos trabalhos conjuntos com o Departamento de Cultura da cidade de São Paulo, da Casa do Butantã (1954), Casa do Caxingui ${ }^{127}$ (1967) e Sítio Mirim (1967) ${ }^{128}$.

O método pressupunha uma primeira etapa de prospecções, com a retirada de toda a argamassa de revestimento para visualização dos elementos originais e posicionamento primitivo das envasaduras. Simultaneamente às prospecções, já se demoliam todas as paredes e elementos não pertencentes à configuração original. Procedia-se então à consolidação estrutural em concreto e em alguns casos, à proteção do sopé da taipa com placas de concreto. Por fim, a recomposição seguia o partido pré-estabelecido.

O uso do concreto na consolidação estrutural tinha suas primeiras aplicações na restauração da Igreja de São Miguel Paulista e do convento do Embu (ambas de 1939) e estava em consonância com as diretrizes estabelecidas pela Carta de restauro de Atenas, de 1931, que preconizava o emprego de técnicas modernas, especialmente do concreto armado, de-

\footnotetext{
126 GONÇALVES, 2005:156

127 Como no caso da Igreja Nossa Senhora do Rosário em Embu a intervenção alterou o número de águas da cobertura, das três encontradas para quatro, sem que houvesse qualquer comprovação da existência do desenho proposto. Cf. MAYUMI, 2008:109-141

128 MAYUMI, 2008:67
} 
vendo, no entanto, "ser dissimulados, salvo impossibilidade, a fim de não alterar o aspecto e o caráter do edifício a ser restaurado" ${ }^{129}$.

Em uma atuação impermeável, pautada pela autoridade intelectual de um grupo autônomo isolado institucionalmente, composto predominantemente por arquitetos, elegeu-se os monumentos "de pedra e cal" como bens a preservar, descartando-se o projeto andradino para o Sphan e sua visão mais abrangente documental e etnograficamente do patrimônio. A arquitetura colonial era representada nos mais diversos aspectos da vida da colônia - público e privado, leigo e eclesiástico, rural e urbano, afluente e decadente. A já conhecida predileção pelo colonial, carro-chefe dos tombamentos, se revelava também pelo seu inverso, a quase ausência de outras manifestações na pauta preservacionista. Diz Miceli: "O reverso desse tesouro tão apreciado é a amnésia da experiência dos grupos populares, das populações negras e dos povos indígenas" ${ }^{130}$. Já o ecletismo explicitamente deveria ser combatido, ou ao menos relegado ao esquecimento ${ }^{131}$, pois se tratava, para Lúcio e companhia, da síntese da falsidade construtiva, da importação e da inadequação dos estilos históricos a serem expurgados pela verdadeira arquitetura nacional. Como consequência, é notável o desequilíbrio no número de tombamentos pelo Brasil ${ }^{132}$, sendo a eclética São Paulo um verdadeiro "patinho feio" sem muitos exemplares dignos de tombamento.

Antônio Arantes, em “Documentos Históricos, Documentos de Cultura” (1987), aponta que "uma das peculiaridades talvez mais marcantes do patrimônio cultural de toda a região sul do Brasil é a sua tão mal preservada diversidade", citando o exemplo de que o Casarão do Chá seria naquele momento o único bem reconhecido em nível federal associado à presença dos imigrantes ${ }^{133}$ (em Mogi das Cruzes) a despeito dos visíveis traços de presença italiana, alemã, judaica, japonesa, etc., na região. Em levantamento por nós realizado em $2006^{134}$, verificamos que ante as 56 edificações e 3 conjuntos urbanos tombados em São Paulo, haviam respectivamente 151 e 10 na Bahia e 162 e 13 em Minas Gerais.

Andrade, Gonçalves e Mayumi são unânimes em localizar nos restauros empreendidos pelo Sphan e pelo Departamento de Cultura a própria visão modernista de monumento, tema também explorado por Cerávolo ${ }^{135}$, visível nas aproximações às Cartas de Atenas (de Restauro e do CIAM). Mayumi traz uma esclarecedora passagem do artigo publicado por

131 Assim como o neocolonial, como a emblemática demolição do Solar Monjope de José Mariano, ocorrida após parecer ambíguo de Lúcio Costa de 1973, publicado nos Documentos de Trabalho, p. 283-284, resultando no arquivamento do processo de tombamento.

132 Rubino examina os tombamentos por século, tipologia, região, tornando clara a predileção pelo colonial em seu ponto máximo, qual seja, a arquitetura religiosa. RUBINO, 1992

133 ARANTES, 1987:48

134 A partir de dados disponíveis no site do Arquivo Noronha Santos,

< http://www.iphan.gov.br/ans/inicial.htm>

135 CERÁVOLO, 2010 

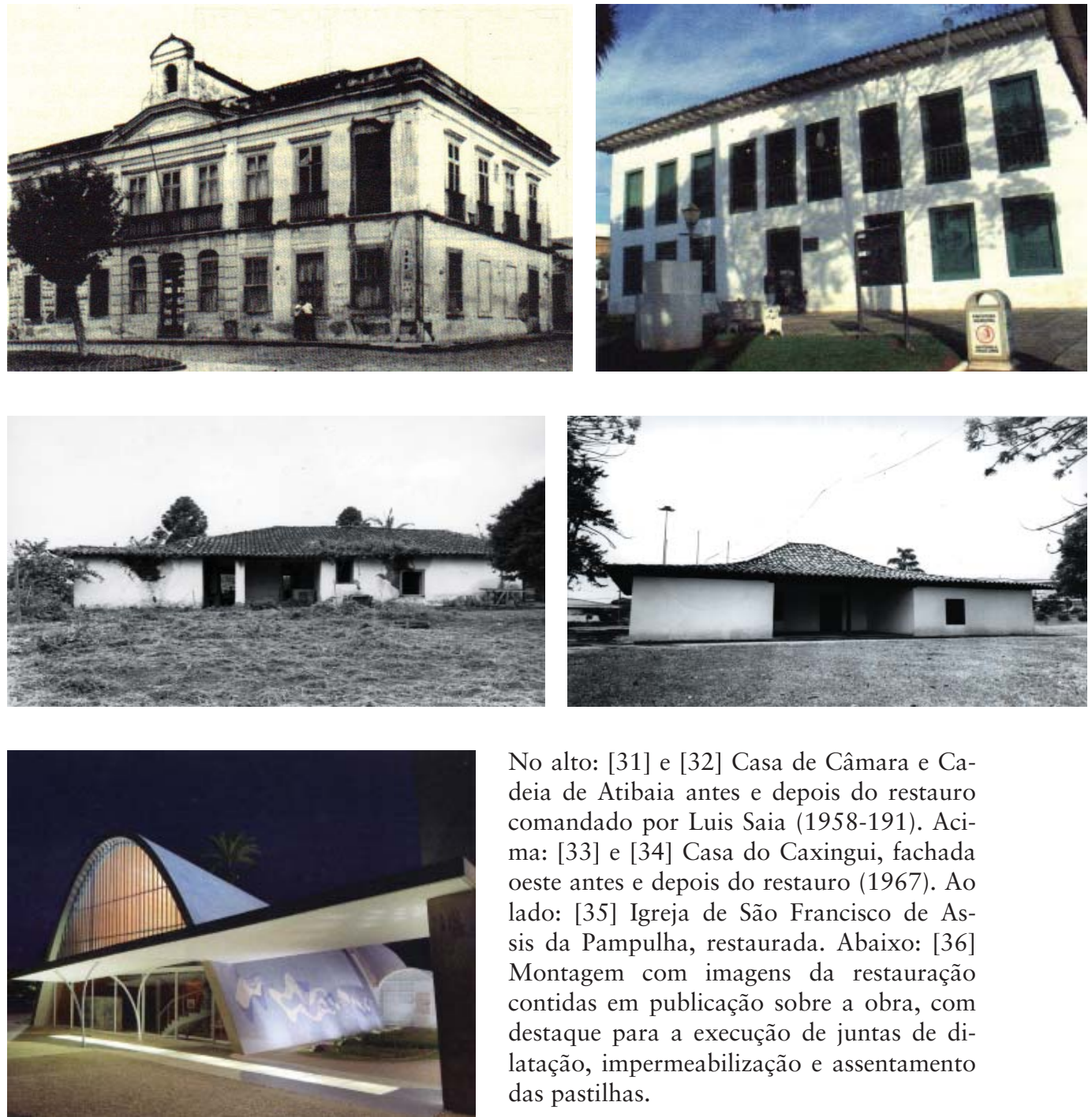

No alto: [31] e [32] Casa de Câmara e Cadeia de Atibaia antes e depois do restauro comandado por Luis Saia (1958-191). Acima: [33] e [34] Casa do Caxingui, fachada oeste antes e depois do restauro (1967). Ao lado: [35] Igreja de São Francisco de Assis da Pampulha, restaurada. Abaixo: [36] Montagem com imagens da restauração contidas em publicação sobre a obra, com destaque para a execução de juntas de dilatação, impermeabilização e assentamento das pastilhas.
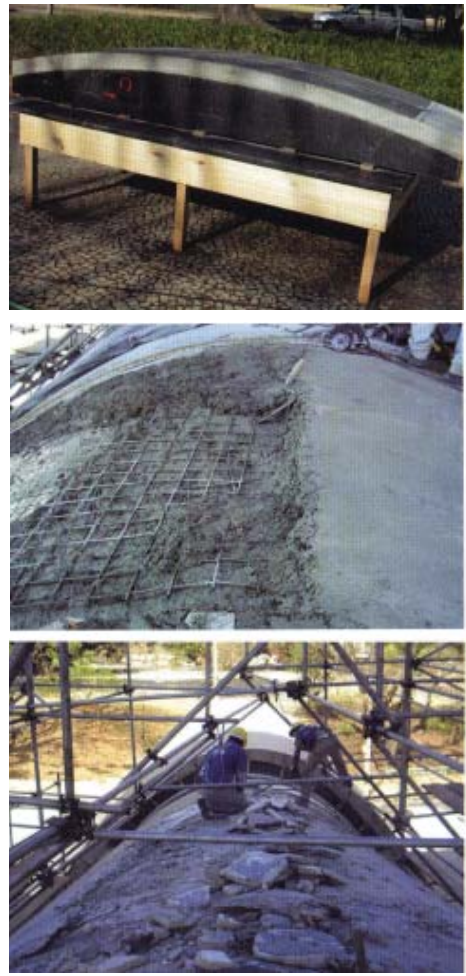
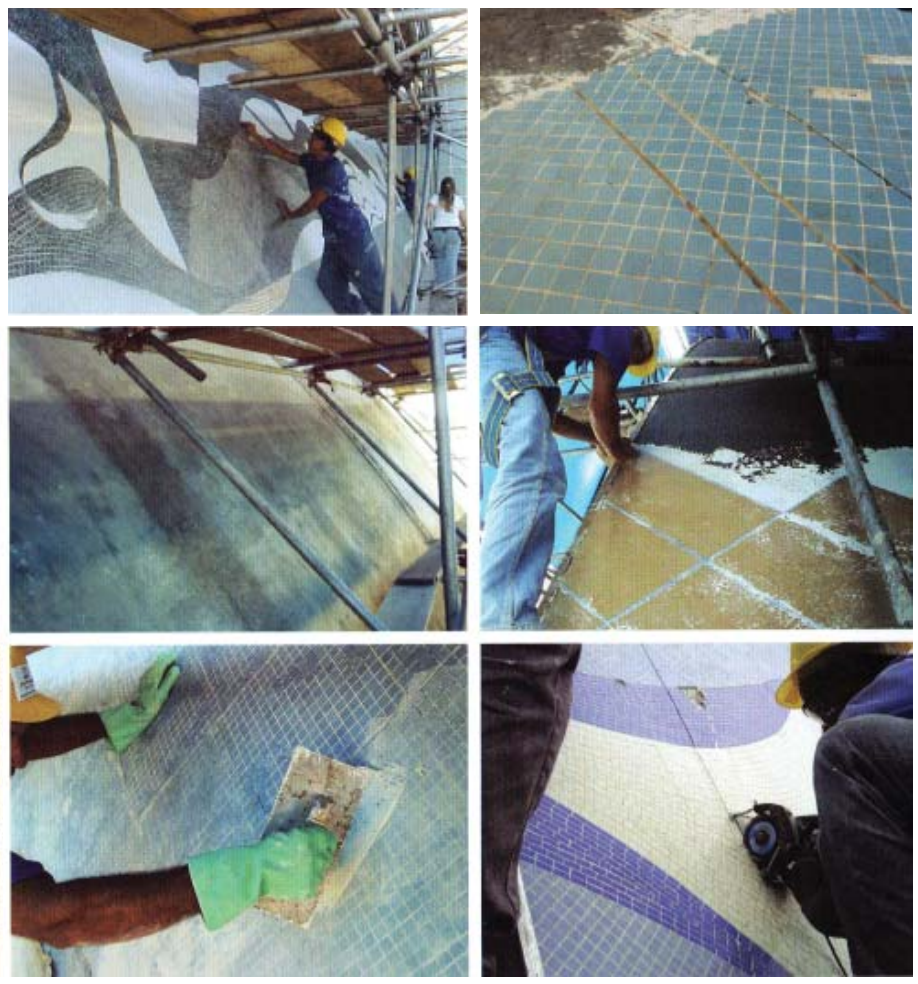
Saia em 1944 em que enunciava seus fundamentos:

Do ponto de vista apenas documentário, foi obedecido um preceito da arquitetura moderna: honestidade no uso do material, respeito às legítimas verdades arquitetônicas, que mandam conservar aquelas peças que realmente sejam documentos de uma época e de um povo. Da maneira com que se agiu ninguém, conhecedor de engenharia, pode ser enganado a respeito do processo de restauração, nem a respeito da obra tradicional ${ }^{136}$.

A limpeza dos volumes brancos sob a luz, a libertação de seus espaços envoltórios em um isolamento monumentalizante, a valorização da austeridade e racionalidade da arquitetura rural paulista, a experimentação do concreto armado revelam o duplo papel daqueles profissionais que se encarregaram de selecionar os bens simbólicos nacionais e simultaneamente atuaram nas vagas modernistas pela implantação e domínio do campo arquitetônico ${ }^{137}$. Nesta dupla atuação, o controle sobre o capital simbólico nacional possibilitou a legitimação da arquitetura moderna como continuidade histórica que recupera o colonial, trazendo ao mesmo tempo para o colonial, o moderno, afirmando-os como manifestações autênticas, verdadeiramente correspondentes a seus tempos e representativas da identidade nacional.

Se o barroco era o estilo eleito e se tinha correspondência direta com o modernismo - manifestações encarnadas, na narrativa costiana, em Aleijadinho e seu sucessor, Oscar Niemeyer - o duplo estabelecido trazia como consequência natural o reconhecimento de valor da própria produção coetânea, culminando nos tombamentos internacionalmente pioneiros de duas obras canônicas: a Igreja de São Francisco de Assis (Pampulha) em 1947 e o Ministério da Educação e Saúde em 1948.

A Igreja por esses anos já se encontrava ameaçada, pois o arrojado projeto estrutural de Joaquim Cardoso, que previa a inserção de três juntas de dilatação, não foi respeitado pelos construtores, ocorrendo rapidamente trincas, perdas de pastilhas, infiltrações ${ }^{138}$. Aliado ao problema construtivo encontrava-se o problema do abandono da construção dada a rejeição do inovador desenho de Niemeyer por parte dos representantes católicos, permanecendo a igreja fechada desde sua inauguração em 1943 - esta só seria consagrada em 1959. Diante de tal situação, sua inscrição no livro de tombo de Belas Artes ocorreria em $1^{\circ}$ de dezembro de 1947, a partir de parecer de Lúcio Costa, que solicitava tombamento preventivo da edificação.

A argumentação do arquiteto versava sobre o problema do abandono e arruinamento da construção, sobre o extravio e o uso indevido de peças integrantes da capela em 
outras edificações e sobre o "louvor unânime despertado por essa obra nos centros de maior responsabilidade artística e cultural do mundo inteiro, particularmente da Europa e dos Estados Unidos" ${ }^{139}$. Nota-se aí o mesmo expediente de afirmação de valor assentado no reconhecimento internacional da arquitetura moderna brasileira para sua legitimação, estratégia inaugurada com a publicação de Brazil Builds (1943). O caráter preventivo do tombamento balizaria a promoção de ações para a conservação do edifício. A igreja passaria por obras de conservação e restauração em 1954, 1957, 1980, 1989-1992, 2004-2005, algumas das quais visando corrigir intervenções inadequadas antecedentes ${ }^{140}$.

Mais rápido que os três meses levados para o tombamento da igreja da Pampulha, em apenas quinze dias ${ }^{141}$ o edifício do Ministério da Educação e Saúde teve seu tombamento efetivado, a partir de parecer de Alcides da Rocha Miranda, com inscrição no livro de Belas Artes em 18 de março de 1948 - a pouco menos de três anos de sua inauguração em 3 de outubro de 1945. O tombamento preventivo e precoce do edifício juntamente com seu uso como ministério garantiu excelentes condições de manutenção, condição apenas alterada quando da transferência do ministério para a nova capital federal em $1960^{142}$.

Não é necessário rediscutir aqui o significado atribuído a ambas as obras pela historiografia, que consensualmente assinala o Ministério como grande marco da vitória modernista no campo arquitetônico - da derrotada reforma da Escola Nacional de Belas Artes ao concurso anulado do Ministério e o triunfo do grupo carioca assessorado por Le Corbusier naquela obra que seria aclamada pela crítica internacional; e a Igreja de São Francisco de Assis, bem como todo o conjunto da Pampulha como início de uma "fase de superação da ortodoxia funcional e regularidade geométrica de traçados, rumo à procura da liberdade formal" ${ }^{143}$.

Curioso é notar que tais tombamentos ocorrem concomitantemente ao processo de amadurecimento da crítica de arquitetura no Brasil, tanto em termos de trabalhos historiográficos quanto em revistas de arquitetura, que se desenvolvem com maior vigor ao longo dos anos 1950. Tratando-se de duas das mais emblemáticas obras do cânone, poderíamos nos indagar em que medida os processos de seleção e tombamento, ajuizados pelo mesmo grupo a atuar na frente modernista, contribuíram para a afirmação mesma desse cânone. Estas aproximações parecem se dar em mais de um nível. O tombamento poderia ser considerado como reflexo de uma mesma visão de mundo daqueles que estiveram à frente dos

139 Lúcio Costa, em seu parecer sobre o tombamento da Igreja de São Francisco de Assis da Pampulha. COSTA apud PESSÔA, 2004:68

140 CASTRO; FINGUERUT, 2006

141 CARVALHO, 2005

142 Com a saída do ministério, os recursos para a manutenção do edifício começaram a se escassear, acumulando problemas até que nos anos 1980 já necessitava de ações urgentes. Paulo Eduardo Ribeiro relata as diversas ações para preservação do bem em Palácio Gustavo Capanema - Processo de restauração e revitalização, 1999

143 SANTOS, 1977:135. 
projetos, mas também como ação integrante da disputa de espaço ou reprodução das tensões colocadas no estabelecimento das regras do campo ${ }^{144}$, constituindo-se como nova etapa de consagração - ou sacralização - das obras icônicas do movimento. Basta ver o tombamento precoce não só da igreja da Pampulha e do MES, mas das sucessivas: a Estação de Hidroaviões (Atílio Corrêa Lima), em 1957; o Catetinho (Oscar Niemeyer ${ }^{145}$ ), em 1959; o Aterro do Flamengo (Affonso Eduardo Reidy e Roberto Burle Marx), em 1965; e a Catedral Metropolitana de Brasília (Oscar Niemeyer), em 1967, as duas últimas obras tombadas antes mesmo de serem concluídas. A Catedral Metropolitana teve um primeiro pedido de tombamento em 1962 recusado por Lúcio Costa, por estar ainda em construção. Entretanto, considerando o precedente do tombamento do parque ainda inacabado e o apoio do prefeito e do arcebispo, aprova o tombamento preventivo da Catedral ${ }^{146}$. O expediente do tombamento preventivo não é apenas a garantia da consagração pública destes exemplares convertidos em monumento, mas da própria viabilização desta arquitetura em terras brasileiras.

Nos anos 1970 não ocorrerá nenhum tombamento de obras modernas pelo Sphan, refletindo a própria transformação sofrida pelo órgão, pela sociedade e pela noção de valor, que vinha de um movimento de ampliação do que era considerado bem cultural. $\mathrm{O}$ ano de 1967 marca a aposentadoria de Rodrigo Melo Franco de Andrade, encerrando o que se costuma intitular a "fase heroica" do Sphan, sucedida pela "fase moderna" 147.

Neste período também se inicia o processo de criação de órgãos de preservação em nível estadual e municipal, deslocando-se as práticas da preservação no Brasil do eixo da Nação para as Cidades - em termos temáticos e institucionais:

A partir dos anos 70, (...) em decorrência da impossibilidade de o IPHAN manter, com recursos do Governo Federal, uma agenda atualizada de conservação e manutenção desse patrimônio, inicia-se o processo de descentralização das políticas de preservação no Brasil, cujo resultado contribuiu também para flexibilizar a difícil tarefa de atribuição de valores a certos bens que podiam ter relevância para estados e municípios, mas não para a genérica concepção do IPHAN a respeito de memória e identidades nacionais ${ }^{148}$

Em abril de 1970 ocorre o Encontro de Governadores, resultando no Compromisso de Brasília no qual se reconhece "a inadiável necessidade de ação supletiva dos Estados e dos Municípios à atuação federal” ${ }^{149}$ e em outubro de 1971, é assinado o compromisso de Salvador, ratificando-o e acrescentando recomendações referentes à associação do patrimônio ao turismo.

145 Se bem que tombada no livro histórico, como $1^{\text {a }}$ residência do Presidente Juscelino Kubistchek

146 PESSÔA, 2004:183, 212

147 Cf. FONSECA, 2005

148 LEITE, 2004:53

149 Compromisso de Brasília, em CURY, 2004:137 
Neste período, marcado pelo autoritarismo, centralização política e desenvolvimentismo econômico, a preservação passa por um processo de abandono das antigas práticas fundadas em critérios técnicos/ estilísticos para uma visão associada a critérios econômicos e sociais. Assim, surge na Secretaria do Planejamento (Serplan) em 1973, o Programa de Reconstrução de Cidades Históricas (PCH), cujo objetivo era desenvolver o turismo, especialmente no Nordeste, tendo em vista a diminuição das desigualdades regionais em uma nova orientação que refletia uma mudança de critérios nas políticas de preservação: "as demandas empresariais da indústria do turismo não subvertem apenas a lógica da seleção dos bens a ser preservados, evidenciando apenas aqueles potencialmente bons para o retorno financeiro. Pelo consumo massificado, reforçam exatamente os aspectos mais monumentais desses bens, alienando-se os seus significados históricos locais, construídos pelas práticas cotidianas daqueles que com eles convivem" ${ }^{150}$.

São Paulo tem seu órgão estadual criando antes mesmo do Encontro de Governadores, a exemplo do Rio de Janeiro (Instituto Estadual do Patrimônio Cultural - INEPAC) e Paraná (Coordenadoria do Patrimônio Cultural - CPC). O Conselho de Defesa do Patrimônio Histórico, Artístico, Arqueológico e Turístico do Estado de São Paulo - CONDEPHAAT - é fundado em 1967, responsabilizando-se pela preservação do patrimônio cultural local, em consonância com a visão desenvolvimentista que atrelava a cultura a finalidades econômicas associadas ao desenvolvimento das cidades. Embora criado sob nova perspectiva, o órgão herdaria a ortodoxia do Iphan e teria traços de uma perspectiva mais conservadora de história, com a presença de conselheiros como Luis Saia e de representantes do Instituto Histórico e Geográfico, imperando nos primeiros anos de vida do órgão o tombamento de remanescentes do bandeirismo, das arquiteturas ligadas aos ciclos econômicos e a exaltação dos grandes heróis do passado ${ }^{151}$. A eleição dos bens "de pedra e cal” se contrapunha ao antiecletismo, fazendo com que o Condephaat deixasse de tombar edifícios em decorrência de sua má arquitetura, da importação de estilos, etc., testemunhando assim a demolição de exemplares significativos sob outros pontos de vista.

A partir da segunda metade dos anos 1970, o órgão assistiria à convivência da ortodoxia com novas abordagens, sob impacto do curso de especialização realizado na FAUUSP em convênio com o Iphan, Condephaat e UNESCO, que relativizaria os conceitos de patrimônio e os trataria pela primeira vez em termos conceituais. O patrimônio natural ganharia seus primeiros tombamentos e o conceito de patrimônio ambiental urbano aproximaria a preservação ao planejamento urbano em um momento que a Emplasa e o Cogep (órgão antecessor da Secretaria de Planejamento do município de São Paulo) assimilariam o listing às políticas de zoneamento. Antes mesmo da criação do Conselho Municipal de Preservação do Patrimônio Histórico, Cultural e Ambiental da Cidade de São Paulo (Conpresp) em 1985, que teria o poder de deliberar sobre tombamentos em nível municipal152, era aprovada a lei 
nº.328 de 1975 que estabelecia a zona Z8-200 (Zona de preservação de imóveis de caráter histórico, artístico, cultural e paisagístico), tornando-se o primeiro instrumento municipal de preservação de bens culturais. O Condephaat elaboraria planos de revitalização do patrimônio ambiental urbano e pleitearia recursos do $\mathrm{PCH}^{153}$, em consonância com a tônica tecnicista e desenvolvimentista da década. Em plano internacional, a Norma de Quito (1967) introduzia o componente econômico e turístico à preservação e a Declaração de Amsterdã (1975) versava sobre a Conservação Integrada, alertando para a necessidade de união entre preservação, planejamento e espírito de justiça social.

Esta época marca também a mobilização da sociedade civil em torno da defesa do patrimônio, tendência que será acentuada na década seguinte com a formação de movimentos organizados, acompanhando o processo de abertura política brasileiro. Casos como do Colégio Caetano de Campos, condenado inicialmente à demolição pelo Metrô, mas tombado a partir da mobilização de ex-alunos e professores, da antiga Escola Alemã (Colégio Porto Seguro), do tombamento do Morro Grande em Caucaia do Alto a partir de pressão da sociedade civil, entidades ambientalistas e imprensa e da Estação da Luz, protegida após denúncias de descaracterização publicadas nos jornais, revelam uma maior permeabilidade do órgão à participação popular, que trazia à tona o componente afetivo e referencial do patrimônio, bem como a consciência sobre a sua relação com a qualidade de vida no presente para a sociedade.

Desta mistura de defesa do patrimônio ambiental, mobilização popular e especulação imobiliária, ocorreria o tombamento da Casa da Rua Santa Cruz e sua área verde em 1984, no qual um movimento articulado por moradores do entorno do imóvel, a imprensa e os órgãos de preservação conseguiriam reverter a construção de três torres residenciais no terreno de doze mil metros quadrados. O caso será tratado no próximo capítulo.

No Condephaat o tombamento da Casa da Rua Santa Cruz vinha também na esteira do reconhecimento do patrimônio moderno em São Paulo, emblematicamente iniciado com os tombamentos do edifício da FAUUSP em 1981, do MASP e da Fazenda Capuava (de Flávio de Carvalho) em 1982, além do Teatro Oficina em 1983. A década de 1980 assistirá ainda ao tombamento da Casa de Vidro em 1987 e à abertura de processos de tombamento que se concluirão nos anos 1990 e 2000, como dos edifícios Esther (1985, tombado em 1990) e Louveira (1985, tombado em 1992), Parque do Ibirapuera (1987, tombado em 1992), Sociedade Harmonia de Tênis (1981, tombado em 1992), e Sedes Sapientiae (1986, tombado em 2010).

Em nível federal, a Casa Modernista da Rua Santa Cruz será tombada em conjunto com as casas da Rua Itápolis e Rua Bahia em 1986, considerados os primeiros exemplares modernos no Brasil e etapas decisivas da elaboração vanguardista de Warchavchik. Nesta década ocorrem ainda diversos tombamentos e abertura de processos de tombamento 
de obras modernas após o interlúdio dos anos 1970, representado pela criação do Centro Nacional de Referência Cultural (CNRC) em 1975 e da direção de Aloísio Magalhães, que adotou uma postura sobre o patrimônio menos calcada nos bens arquitetônicos e mais no mapeamento das práticas e saberes populares ${ }^{154}$, refletindo-se na expressiva redução do número de tombamentos. Além das casas modernistas de Warchavchik, foram tombados o edifício da Associação Brasileira de Imprensa (1984), o Hotel do Parque São Clemente em Nova Friburgo (1985), o Conjunto Residencial Parque Guinle (1986) e abriu-se o processo de tombamento do pavilhão de verificação de óbitos de Luis Nunes em Recife (1986), tombado em 1998. Ao mesmo tempo em que se reiterava o cânone, as transformações por que passava o Iphan caminhavam junto com a revisão historiográfica em andamento, oferecendo um novo lugar a Warchavchik, por décadas eclipsado ${ }^{155}$.

Os anos 1990 testemunham uma nova orientação na política preservacionista, que, embora se mantenha atenta às relações entre patrimônio, interesses econômicos e turismo colocadas desde os anos 1970, assinalam uma nova correlação de forças e interesses. O Ideário neoliberal passa a habilitar representantes do capital na discussão, em um contexto de enxugamento de atribuições e investimentos decorrentes da forte crise financeira do Estado e da crescente participação de empresas privadas nas chamadas "parcerias público-privadas". Quer dizer, a orientação voltada ao consumo dos lugares não muda, mas sim a lógica de participação dos setores público e privado, alterando-se assim os critérios de preservação. O denominado Planejamento Estratégico faz com que o patrimônio cultural ressurja como carro-chefe dos processos de Gentrification que irão ocorrer em diversas cidades do mundo.

Inserem-se nessa lógica instrumentalizadora da cultura, por exemplo, a série de investimentos realizados na região da Luz, a partir do programa BID - Monumenta, que tinha como condição para implementação, pelo menos um imóvel tombado em nível federal - o que até aquele momento não havia, dado a herança eclética predominante no local. Para viabilizar a captação do recurso, ocorre em 1996 o tombamento da Estação da Luz ${ }^{156}$. A ideia de alavancamento da economia urbana por meio de intervenções pontuais é totalmente compartilhada com o governo estadual, que investe no restauro da Estação Julio Prestes e instalação da Sala São Paulo (inaugurada em 1999). A inversão causada pela busca por financiamentos internacionais é assistida também em Pernambuco, com o tombamento federal do centro histórico do Recife, justificado a partir de uma nova visão no órgão, qual seja, compreender um conjunto urbano não naquilo que o torna homogêneo, mas exatamente na sua diversidade, nas múltiplas temporalidades presentes em um mesmo tecido urbano ${ }^{157}$.

É evidente que não se pode reduzir a riqueza de uma visão menos monolítica do pa-

154 Retomado nos anos 2000 com a política de salvaguarda do patrimônio imaterial. Em plano internacional, a Recomendação R9, sobre Paisagem Cultural (1995) e a Convenção para a Salvaguarda do Patrimônio Cultural Imaterial (2003) contribuíam para a diminuição da ênfase sobre o patrimônio arquitetônico edificado. 155 Termo utilizado por FARIAS, 1990

156 Esta história é contada em detalhes em JOSÉ, 2007

157 LEITE, 2004 

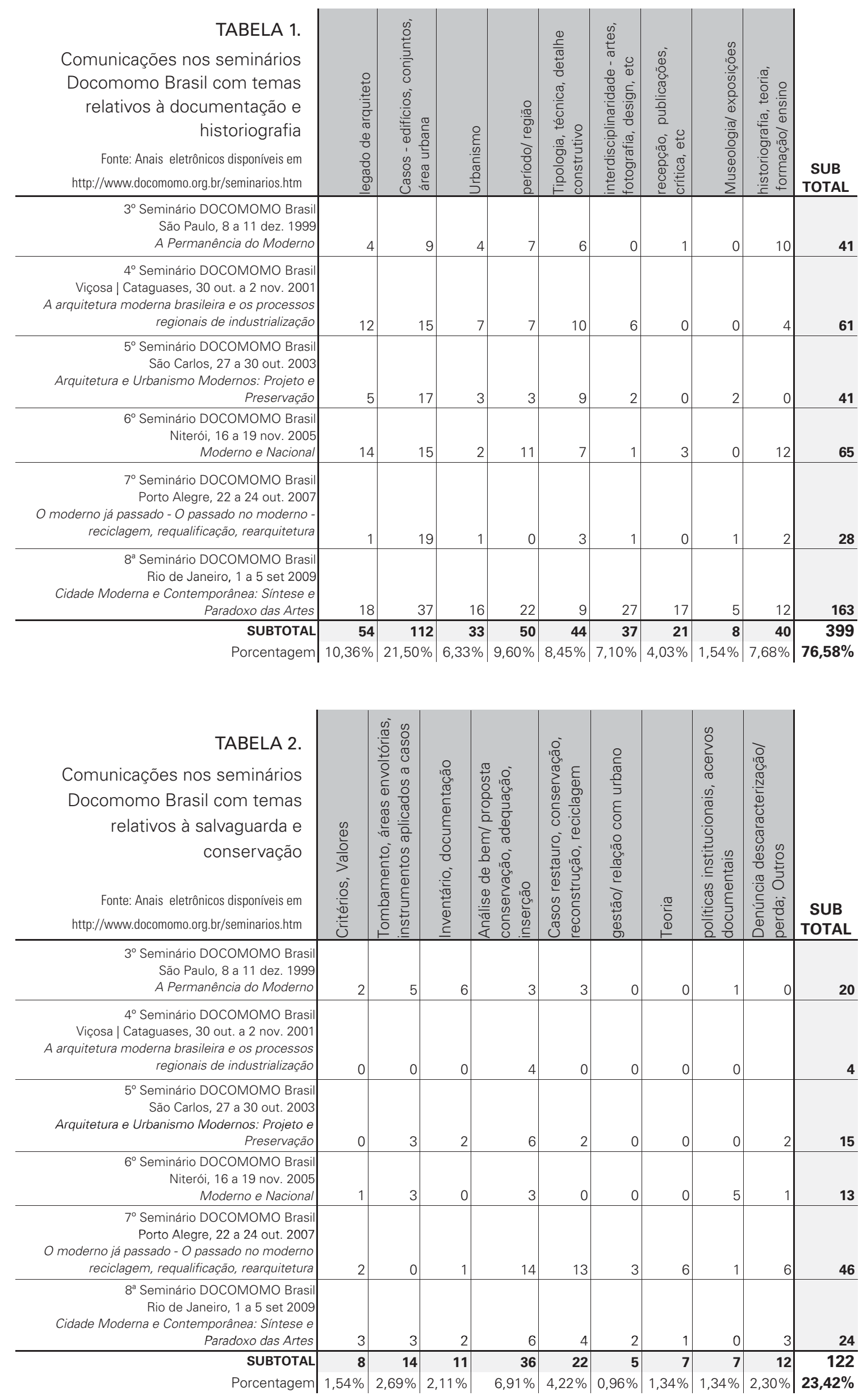
trimônio urbano à simples necessidade de angariar recursos sob a chancela do BID, pois se o Iphan pôde justificar o tombamento por este viés é porque de fato esta mudança de orientação estava semeada entre os técnicos, como visto também na abertura de tombamento do conjunto urbanístico de Cataguases, em Minas Gerais (cujo tombamento se efetivaria em 2003).

A década de 1990 representa um momento delicado para o órgão, cujos efeitos do desmonte promovido durante o governo Collor se fez sentir por anos e se refletiu diretamente no número reduzido de tombamentos, 34 ante a 282 entre 1938-1939, 189 na década de 1940, 159 nos anos 1950, 154 nos anos 1960, 86 nos anos 1970 e 97 nos anos 1980, devendo-se lembrar entretanto que nas últimas décadas o tombamento passa a ser questionado como único instrumento de proteção de bens culturais - apesar de que a elaboração de alternativas ainda seja uma discussão por fazer ${ }^{158}$. Dos 34 bens tombados nesta década, apenas três são ligados ao movimento moderno: O Conjunto urbanístico de Brasília (1990), após a capital já ter sido considerada Patrimônio da Humanidade pela Unesco em 1987; o conjunto arquitetônico da Pampulha (1997), cuja igreja havia sido tombada em 1947 e o Pavilhão Luís Nunes, concluindo o processo de tombamento aberto em 1986.

No Condephaat, dos seis tombamentos de obras modernas que ocorrem na década de 1990, cinco são de tombamentos iniciados nos anos 1980, ficando apenas o Memorial da América Latina (1997) como estudo iniciado na própria década. Os demais: edifício Esther (1990), Edifício Louveira (1992), Parque do Ibirapuera (1992), Sociedade Harmonia de Tênis (1992) e homologação do tombamento ex-officio (1994) das casas Modernistas da Rua Itápolis e Rua Bahia de Warchavchik, inscritas no livro do tombo em 1987. Nos anos 2000, são tombados o edifício sede do IAB-SP (2002), a Capela do Cristo Operário (2004, com obras de importantes artistas modernistas, como Volpi e Geraldo de Barros), o Conjunto Nacional (2005), a Escola Nossa Senhora da Penha (2009), o Teatro Cultura Artística (2009, já incendiado), o Antigo Instituto de Filosofia, Ciências e Letras Sedes Sapientae (2010) e os Edifícios Paulicéia e São Carlos do Pinhal (2010) ${ }^{159}$.

Ainda na década de 1990, ocorrem dois novos eventos significativos para a arquitetura moderna no Brasil e em São Paulo: a fundação do Docomomo Brasil em 1992, e o início das atividades do CONPRESP ${ }^{160}$, com tombamentos importantes para a arquitetura moderna na cidade.

O Docomomo abrigou-se em seus primeiros anos no mestrado da FAU-UFBA, passando a funcionar na FAU-USP (2000-2001), na EESC-USP (2002-2005), na FAU-USP novamente (2006-2007), sendo sediado desde 2008 no PROPAR-UFRGS. No espírito do 
Docomomo internacional, desde 1995 são organizados seminários nacionais bianualmente nos quais se vê refletida a produção brasileira sobre o tema do patrimônio moderno. Assim como na organização internacional, o Docomomo - Brasil é prioritariamente dirigido por pesquisadores ligados a universidades, transformando-se num reconhecido espaço de reflexão acadêmica. Inicialmente, o fórum contava com maior participação das instituições de patrimônio, chegando a estabelecer convênios como do inventário da arquitetura do Convênio Escolar em São Paulo, firmado com o DPH ${ }^{161}$, mas com o tempo, passou a ter perfil mais acadêmico. Outra semelhança guardada com seu par internacional se refere ao número pouco expressivo de comunicações relativas à teorização do restauro do moderno. Por outro lado, fica bem atrás quando se trata de casos concretos de restauro. Evidentemente a própria escolha dos temas dos seminários direciona os tipos de trabalhos apresentados, privilegiando-se o universo da DOcumentação mais que da COnservaçãa ${ }^{162}$.

É digno de nota que os encontros têm se constituído como importante espaço de intercâmbio e divulgação de trabalhos, entre os quais de recuperação da memória de arquitetos pouco conhecidos, da produção arquitetônica de cidades fora do eixo Rio - São Paulo que tanto polariza a historiografia, e de outros temas que escapam ao mercado editorial corrente, demonstrando também o interesse que a arquitetura moderna ainda desperta como objeto de pesquisa por todo o território brasileiro.

Através de levantamento realizado nos seminários nacionais que têm os anais disponíveis na internet ${ }^{163}$, é possível verificar, a partir da leitura dos resumos das comunicações, a significativa superioridade numérica de trabalhos que giram em torno da documentação da produção arquitetônica, com recortes regionais, geográficos, institucionais, autorais, tipológicos ou temporais, representando cerca de $77 \%$ de um universo de 521 trabalhos. Do restante dos trabalhos, distribuídos entre temas atinentes à preservação - denúncias de descaracterização, inventários, instrumentos legais, gestão, políticas institucionais, entre outros - os casos de restauração, conservação, requalificação, reuso e reciclagem representam apenas $4,22 \%$, as discussões sobre critérios e valores $1,54 \%$ e teorias e métodos de restauração e documentação apenas $1,34 \%$ do total ${ }^{164}$.

O balanço demonstra não apenas a baixa participação de trabalhos de âmbito teórico, mas também a fraca representatividade do número de casos efetivos de restauro. Entre os trabalhos apresentados, figuram relatos e denúncias sobre o estado de conservação de

\section{BAFFI, 1999}

162 Basta notar que o seminário que contou com maior número de trabalhos na área de patrimônio foi o $7^{\circ}$, cujo tema foi “O moderno já passado/ O passado no moderno - reciclagem, requalificação, rearquitetura" (Porto Alegre, 2007), enquanto o $4^{\circ}$ seminário, “A arquitetura moderna brasileira e os processos regionais de industrialização" (Cataguases, 2001) teve o menor número.

$1633^{\circ}$ ao $8^{\circ}$ seminário, disponíveis em: < http://www.docomomo.org.br/seminarios.htm>

164 Ver tabela anexa. Evidentemente a leitura dos resumos pode dar impressão diversa do que realmente tratam os textos, causando eventual imprecisão na contagem, mas a divisão em temáticas gerais dá ao menos a ordem de grandeza. 
edifícios, especulações sobre possíveis restaurações, casos de reuso e reciclagem (de conotação mais econômica) e apenas uma parcela de comunicações sobre experiências concretas de restauro e conservação, o que possivelmente reflita uma realidade atenta ao moderno como questão historiográfica, mas pouco aguda quanto à necessidade de conservação de exemplares em moldes menos pragmáticos e mais fundamentados nas orientações do campo.

Tal constatação é verificável no tratamento que vem sendo dado a ícones da arquitetura paulista, como os edifícios do MASP e da FAUUSP. O MASP desde sua inauguração em 1968 começou a sofrer com problemas de infiltrações decorrentes da má execução da impermeabilização nas lajes e vigas transversais e da ausência de impermeabilização nas vigas principais. Como à época havia uma crença de que o concreto protendido era impermeável, Lina Bo Bardi não teria autorizado o serviço para que o aspecto estético do concreto não fosse alterado ${ }^{165}$.

Porém, com o avanço da deterioração ligada às infiltrações, entre 1988 e 1991 foi substituída toda a impermeabilização existente e aplicada a controversa pintura vermelha nas vigas e pilares. Para Lina, a ideia já era aventada desde a concepção do projeto e tornouse um problema de conservação resolvido esteticamente. Nesta época, ainda se cogitava o polimento do concreto para melhorar sua aparência, mas Lina argumentava que isto implicaria na perda da pátina, tema caro à escola italiana de restauro, e que além do mais, não prejudicava a estética da construção.

Outras pequenas reformas foram realizadas ao longo dos anos, mas os problemas administrativos e financeiros foram responsáveis pelos maiores danos potenciais felizmente não levados a cabo. Nascido endividado, o museu desde o início buscou formas de obter rendimentos, tendo sido considerada a exploração comercial de outdoors na frente do edifício ou construção de megatorres, como em 1991 e nas propostas de 2004 a 2007 do arquiteto Júlio Neves, em um momento que o edifício chegou a ter o fornecimento de energia cortado após sete anos sem pagamento, em um rombo de $\mathrm{R} \$ 3$ milhões.

Em sua gestão, além de serviços de manutenção do concreto, como sua protensão e descupinização dos caixões perdidos, muitas intervenções trouxeram prejuízos à obra, como a substituição do sistema de iluminação e ar condicionado, superdimensionado, que além da interferência visual, gera ruídos em nível inadequado. Sua finalidade seria resolver o problema que o pano de vidro criaria para o controle da temperatura, mas como Giannecchini lembra, este tipo de demanda requer soluções criativas que respeitem o edifício, sugerindo, por exemplo, o estudo de uma caixilharia com característica isolante, constituída por paredes duplas que formem câmaras de $\operatorname{ar}^{166}$.

A sensação de amplidão também se acabou, com o fechamento da Pinacoteca com painéis de gesso até o teto formando pequenos nichos, em uma proposta que nega a concepção museográfica de Lina, que é um dos pilares da formulação de todo o edifício. A 
injustificável substituição do piso em pedra mineira por granito no subsolo bem como a instalação de bilheterias e painéis divisórios sobre um novo piso cimentício no vão livre são outras intervenções que vão contra a natureza do edifício, sem qualquer respeito ao seu valor referencial para a cultura arquitetônica e para a cidade. Intervenções estas de caráter meramente pragmático, que ignoram tratar-se de um bem cultural que carece de um olhar atento à sua preservação.

O mesmo pragmatismo vem regendo as intervenções no edifício da FAUUSP, com o agravante de se tratar da casa de muitos arquitetos em São Paulo. A concepção de continuidade espacial e flexibilidade deu fôlego para o edifício comportar inúmeras alterações ao longo dos anos, mas com o crescimento natural das demandas de ensino, pesquisa e extensão e mesmo com a mudança nas didáticas do curso, as áreas saturaram-se. Laboratórios de pesquisa, sala de informática, expansão do acervo da biblioteca, entre outras demandas não previstas inicialmente, levaram à construção do anexo, retirando os laboratórios do edifício (o LAME, do subsolo, o LPG, vídeo e fotografia, da biblioteca).

Para Pinheiro, esta mudança seria talvez a primeira grande descaracterização da FAU, pois concebida no espírito da Bauhaus, pautava-se na união entre teoria e prática e na vivência integral do edifício por parte de professores e alunos: "o sentido de coletividade implícito no projeto original foi irremediavelmente quebrado com o desmembramento do prédio" ${ }^{167}$. Sobre a expansão do programa, Giannecchini também pondera que a ocupação dos vazios traduz-se em incompreensão da proposta de Artigas e Cascaldi - como nas salas administrativas que bloqueiam a comunicação do Salão Caramelo com o "corredor das humanas", as saletas no Ateliê Interdisciplinar ou os puxadinhos à frente da seção de alunos. Neste caso, como na recente reforma dos departamentos e nas salas administrativas, os painéis divisórios, caixilhos e demais componentes não obedecem a qualquer padrão, provocando ruídos visuais e tornando clara a falta de consciência do edifício como monumento histórico. Pinheiro considera que isto pode derivar tanto de desconhecimento sobre os princípios conceituais básicos de restauração, quanto de uma postura pragmática por se tratar de obra moderna, ou ainda de uma indiferença resultante de uma excessiva proximidade com o edifício.

Entretanto, a questão mais desafiadora relativa à conservação do edifício Vilanova Artigas é a cobertura e suas demandas de restauração do concreto, restabelecimento dos sistemas de impermeabilização e drenagem e conforto ambiental. Ao que parece, na concretagem da cobertura não se previu a contraflexa, fato que aliado ao descimbramento precoce, ocasionou a flexão acima do previsto, dificultado o escoamento das águas pluviais. Soma-se a isso o fato de que foi executada a metade dos condutores de águas pluviais de $\varnothing 100 \mathrm{~mm}$ prevista $^{168}$. Com a ausência de manutenção, o avançado sistema de impermeabilização não 
resistiu aos níveis de deformação e para piorar, como solução foram sendo superpostas camadas sobre camadas alternando impermeabilizante e proteção mecânica ao longo dos anos que, sem estarem amarradas, criaram caminhos por onde a água infiltrou-se causando enormes danos ao concreto, como a aparição de eflorescências e a oxidação das ferragens.

Há relatos de inúmeros testes e estudos realizados desde os anos 1990, mas até hoje não há consenso sobre a solução mais adequada. A última proposta, objeto de caloroso debate, previa a retirada de toda impermeabilização e instalação de uma sobrecobertura dita provisória - solução que conflita com o que é a síntese do edifício, a cobertura como abrigo das atividades, do encontro, etc. Afora esta proposta, o conjunto de projetos de 2009 tornou-se polêmica menos por seus conteúdos e mais pela ausência de discussão. $O$ fato positivo foi o desdobramento - a formação de um conselho curador paritário e de equipes interdisciplinares de trabalho para a elaboração de um Plano Diretor Participativo, traduzindo-se o próprio processo como de interesse didático.
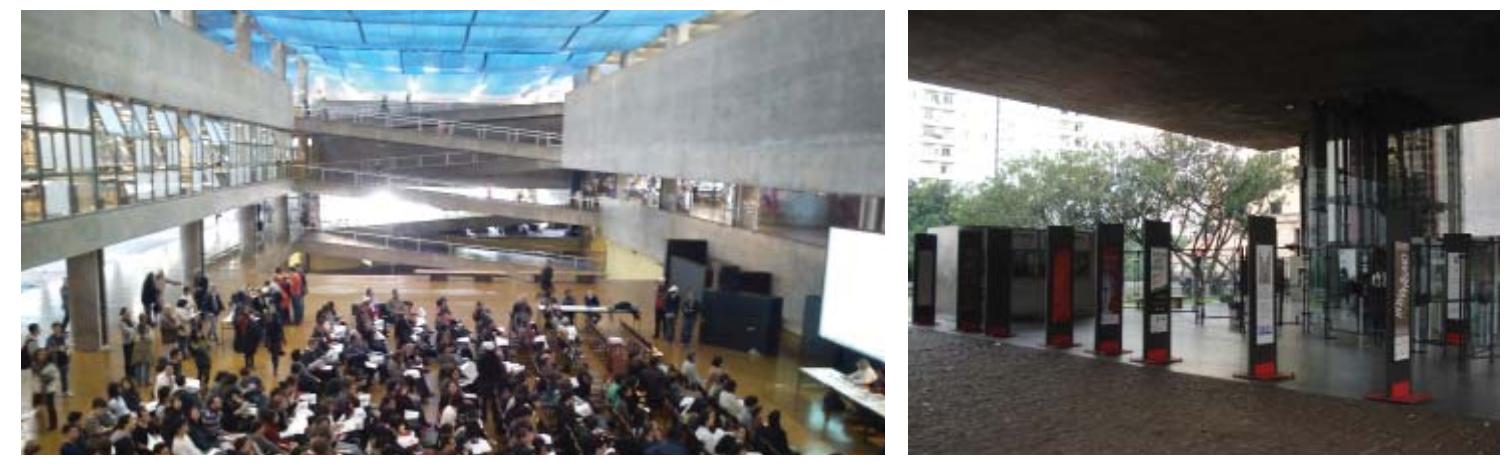

[37] Assembleia do Plano Diretor Participativo no Salão Caramelo/ FAUUSP, realizada em 31/05/2011. Sob a cobertura foi instalada tela de proteção devido ao risco de desprendimento de fragmentos da cobertura. [38] Nova bilheteria do MASP, com diferenciação de piso e divisão em tapumes.

Voltando ao panorama da preservação da arquitetura moderna em São Paulo, a atuação do DPH e o advento do Conpresp trarão importantes contribuições a partir dos anos 1980, com maior ênfase nos anos 1990. O DPH mostra-se atento à questão antes mesmo de o Conpresp efetivamente adotar a prática do tombamento, que se inicia em 1988. O órgão participou ativamente da mobilização pela preservação da Casa Modernista da Rua Santa Cruz em 1984, coordenando vistorias para fiscalizar a eminente destruição do imóvel, manifestando-se através da diretoria nos jornais e tendo uma das arquitetas de seu corpo técnico, a atual diretora da Superintendência Regional do IPHAN em São Paulo, arquiteta Ana Beatriz Galvão, inscrita no Curso de Especialização em Conservação e Restauro (CECRE) em 1984, ligado à UFBA, realizando precursor estudo sobre a conservação da Casa Modernista, tratada pela primeira vez dentro do âmbito da preservação. A arquiteta tão logo seria incorporada ao corpo docente da UFBA, tornando-se uma das responsáveis pela fundação do Docomomo brasileiro. Outros membros do DPH estiveram presentes na coordenação do Docomomo, como a ex-diretora da Divisão de Preservação do DPH, arquiteta Mirthes Baffi, membro do comitê executivo nacional de 2000 a 2007 e vice-coordenadora do núcleo 
São Paulo ou o atual diretor do DPH, Walter Pires, pertencente à comissão organizadora do seminário Docomomo - Brasil realizado em São Paulo em $1999^{169}$.

Quando o Conpresp inicia suas atividades, tão logo o patrimônio moderno se fará presente, com a APT em 1989 dos teatros Paulo Eiró, João Caetano e Athur de Azevedo, de Hélio Duarte e equipe, e do conjunto residencial da Rua Berta, de Warchavchik, a ser comentado no próximo capítulo (os teatros tiveram o tombamento definitivo em 1992 e o conjunto em 1990). Dentre as regulamentações de áreas envoltórias, tombamentos de edifícios, conjuntos ou monumentos de diferentes épocas, a arquitetura moderna sempre esteve presente, seja por solicitações internas quanto externas, seja a partir de instruções próprias, seja por tombamentos ex-officio, em alguns momentos sobrepondo-se tais situações.

Nos anos 1990, além do tombamento do conjunto da Rua Berta, ocorre a APT do conjunto da Rua Barão de Jaguara e do edifício da Alameda Barão de Limeira, ambos de Warchavchik, como desdobramento do primeiro; a APT do edifício Lauzanne e dos imóveis enquadrados como Z8-200, dentre os quais a Sede do IAB (Rino Levi, Abelardo de Souza, Hélio Duarte, Zenon Lotufo e outros), os Edifícios Esther e Arthur Nogueira (Álvaro Vital Brazil), o Copan e o edifício do Bradesco (Oscar Niemeyer), Edifício Jaçatuba (Oswaldo Bratke), o edifício da FAUUSP, a Escola Estadual de Primeiro Grau Prudente de Moraes (Hélio Duarte), o Cine Art-Palácio (Rino Levi) e o MASP (Lina Bo Bardi); o tombamento ex-officio dos imóveis protegidos pelo Condephaat até 1992 (como as casas modernistas de Warchavchik, a Casa de Vidro, o MASP, o Teatro Oficina, os edifícios Esther e Sociedade Harmonia de Tênis, já comentados); o tombamento conjunto da área de entorno do Vale do Anhangabaú (1992), incluindo a Galeria Metrópole (Aflalo, Gasperini e Salvador Candia), edifícios Califórnia, Montreal e Eiffel (Niemeyer), CBI Esplanada (Lucjan Korngold), Cine Ipiranga, Cine Art Palácio e Edifício Sarti (Rino Levi), Antigo edifício do Estado de São Paulo e Edifício Itália (Franz Heep); o tombamento de uma série de edifícios em Higienópolis em 1994, incluindo o Edifício Prudência e Capitalização (Rino Levi) e o Louveira (Vilanova Artigas), já em 2002; e o tombamento do Parque do Ibirapuera (1998).

Nos anos 2000, além dos já citados, ocorrem as APTs da casa Rio Branco e Paranhos e do Santapaula Iate Clube (Artigas) em 2001 e 2007, respectivamente, do edifício então usado pelo Detran e do edifício Triângulo (Niemeyer) em 2003 e 2004, respectivamente, da residência do arquiteto Hans Broos, em 2008, da Capela do Cristo Operário em 2004 e dos espaços internos do Cine Ipiranga em 2009, já protegido externamente pela Resolução 37/92, que tomba o Anhangabaú e arredores.

Em 2004 ocorre a APT da lista de imóveis indicados como ZEPEC (Zona Especial de Proteção Cultural) no Plano Diretor Estratégico (lei 13.430/02). A zona, criada através da lei n ${ }^{\circ} 13.885 / 04$, que estabelece normas complementares ao Plano Diretor, institui os Planos Regionais Estratégicos das Subprefeituras e dispõe sobre o parcelamento, uso e ocupação 
do solo de São Paulo, prevê a possibilidade de transferência do potencial construtivo ${ }^{170}$. De acordo com o texto, os imóveis podem ser enquadrados como ZEPEC quando são tombados pelos órgãos de preservação municipal, estadual e federal, quando integrantes às antigas leis de zoneamento como Z8-200 e quando indicados pela própria lei ${ }^{171}$. Dentre os indicados pela própria lei, constam aqueles selecionados pela população através das audiências públicas previstas na elaboração dos Planos Regionais, marcando seguramente um dos momentos mais participativos no processo de valoração dos bens culturais em São Paulo.

Entre os bens indicados pela própria lei, consta uma lista especifica de arquitetura moderna, publicada como quadro anexo. Nesta, são indicados 79 bens, dos quais 15 já estavam protegidas, em um universo delimitado pelo recorte temporal do período entre 1920 e 1970, focalizando a arquitetura autoral em um vasto leque de arquitetos, como Vilanova Artigas, Paulo Mendes da Rocha, Sérgio Ferro, Rodrigo Lefevre, Bernard Rodofsky, Ícaro de Castro Melo, Oswaldo e Carlos Bratke, Ruy Ohtake, Eduardo Corona, Joaquim Guedes, Sylvio Sawaya, Pedro Paulo de Melo Saraiva, Plínio Croce, Roberto Aflalo, Giancarlo Gasperini, Siegbert Zanettini, Hélio Duarte, Abelardo de Souza, Eduardo Kneese de Mello, Flávio de Carvalho, Carlos Millan, Fábio Penteado, Marcello Frageli, MM Roberto, Rino Levi, Júlio de Abreu, Warchavchik, Franz Heep, Jacques Pilon e muitos outros.

A difícil e talvez descabida hierarquização de valores nacional, estadual e municipal de que se fala, tendo em consideração a conceituação abstrata e ideológica de Nação, identidade paulista e paulistana, reproduz alguns padrões da historiografia da arquitetura moderna. Os tombamentos do Iphan na fase heroica refletem o cânone da escola carioca, sendo exceção, em decorrência das circunstâncias de revisão dos anos 1980 e de ameaça de perda, o tombamento conjunto de três casas modernistas de Gregori Warchavchik. Nos anos 1990, a instituição federal quase não tomba, mas seu olhar está atento ao tombamento em escala urbana. Somente nos anos 2000 outra representante paulista, Lina Bo Bardi, figura nos tombamentos, que ainda assim, estão centrados em obras icônicas. A década de 2000-2010 é muito próxima para que uma avaliação possa ser feita, mas a política de patrimônio imaterial e a atenção dada ao PACH - Cidades históricas (Plano de Ação Cidades Históricas), posteriormente convertido em PAC - Cidades históricas (Plano de Aceleração do Crescimento, carro chefe do governo Lula e da gestão Dilma Rousseff) demonstram a perda do protagonismo do instrumento do tombamento na atual política do órgão federal.

Em plano estadual, por sua vez, são rememorados ícones da arquitetura paulista, como Artigas, Lina Bo Bardi, Rino Levi, Flávio de Carvalho e Warchavchik, ficando de fora inexplicavelmente um dos grandes expoentes da Escola Paulista, Paulo Mendes da Rocha. O tombamento da casa da Rua Santa Cruz parece ser um episódio chave não apenas do ponto de vista do significado da obra, mas como fruto do contexto de redemocratização política no 
Brasil, quando novos personagens entram em cena ${ }^{172}$ e os órgãos de preservação se mostram mais permeáveis à sociedade civil organizada.

No município, grandes nomes da arquitetura moderna brasileira que construíram na cidade têm obras tombadas isoladamente e dentro de tombamentos de conjuntos em conotações urbanísticas, da criação da zona Z8-200 ao tombamento do Anhangabaú, do tombamento de edifícios em Higienópolis à APT da ZEPEC.

Mas se a prática do tombamento do patrimônio moderno foi incorporada à rotina dos órgãos de preservação, a conservação e a restauração de edifícios modernos sob a orientação de preceitos básicos do campo ainda não estão incorporadas à cultura arquitetônica brasileira - nem mesmo obras icônicas escapam a uma abordagem pragmática. Tal escassez ombreia com a parca reflexão teórica sobre o tema, visível no baixo número de trabalhos de caráter teórico publicados, mesmo em fóruns como o Docomomo.

Neste cenário, as obras de Warchavchik, tombadas nas três esferas de preservação, se apresentam em momentos cruciais ou não, mas que falam das vicissitudes do campo da preservação no Brasil.

172 Trata-se do nome de livro de Éder Sader sobre os movimentos sociais populares e sua importância na abertura política brasileira. Aliás os temas da participação e da sociedade civil como novo sujeito social aparecem em diversos trabalhos nos anos 1980. 
CAPÍTULO 3

\section{ESTRATIGRAFIAS DO PRESENTE}

O presente capítulo abordará as obras de Gregori Warchavchik tombadas e preteridas nos processos de tombamento arquivados na cidade de São Paulo, procurando refletir sobre suas trajetórias até o tempo presente. Deste modo, buscará olhar para as obras focando, além do momento de formulação, ao menos dois outros aspectos - o contexto de tombamento e o estado atual. De acordo com a documentação encontrada, será possível trazer outros momentos de suas histórias, de modo certamente proporcional à diversidade, disponibilidade, relevância e acessibilidade das fontes. Serão aprofundados os casos da Vila Bertha e da Casa Modernista da Santa Cruz, por terem passado por obras de restauro documentadas e terem seus tombamentos se desdobrado em outros cinco, iniciando assim o capítulo. Os demais casos ao mesmo tempo trazem uma visão de conjunto e apontam outras questões de interesse para pesquisa, por isso a opção por uma seleção ampla, admitindo os diferentes graus de aprofundamento.

Deste modo, valeria à pena preceder à análise dos casos um panorama sintético dos tombamentos e negativas. A casa da Avenida Rebouças está destituída de qualquer forma de proteção, tendo sido excluída da resolução 14/CONPRESP/90, que abria processo de tombamento em conjunto com o edifício da Alameda Barão de Limeira e com a vila da Rua Barão de Jaguara. Esta APT se deu como desdobramento da APT da Vila Bertha (1989), então ameaçada de demolição. O Condephaat, que também abriu processo de tombamento desta, arquivou-o em 2007, assim como o fez com a Capela do Morumbi em 1983.

O caso da Capela do Morumbi merece atenção porque se trata de uma obra peculiar no universo projetual de Warchavchik, na qual propõe uma intervenção sobre uma ruína preexistente revelando um aspecto ausente em suas obras vanguardistas. Pouco reconhecida como obra de Warchavchik, é justamente sua intervenção que servirá de argumento para o arquivamento estadual, permanecendo protegida apenas pelo município.

Curiosamente, são exatamente estes dois casos - Conjunto da Rua Berta e Capela do Morumbi - os únicos a terem processos instruídos com estudos específicos para o tombamento definitivo em nível municipal (1991 e 2005 respectivamente). Os demais imóveis ou são tombados ex-officio ou estão em APT.

Ao lado do edifício à Alameda Barão de Limeira e conjunto à Rua Barão de Jaguara, a casa da Rua Tomé de Souza é protegida somente por uma APT (1992), mas ao contrário dessas, preservadas em função da autoria de Warchavchik, apenas se encontra na lista de 
862 imóveis enquadrados como Z8-200․ . Vale lembrar que em nível municipal a APT tem força de tombamento, prevista pela lei de criação do Conpresp, $n^{\circ} 8.252 / 85$, no Art. $14^{\circ}$ $\$ 2^{\circ}$ : “Com a abertura do processo de tombamento o bem em exame terá o mesmo regime de preservação do bem tombado até a decisão final do Conselho”.

Já as Casas da Rua Santa Cruz, Bahia e Itápolis são protegidas nas três esferas, tendo sido a primeira objeto de estudos tanto no Iphan (1986) quanto no Condephaat (1984). As demais foram instruídas no Iphan (1986) e tombadas ex-officio pelos órgãos estadual e municipal (1994 e 1991 respectivamente). Esta sobreposição de tombamentos significa que as obras são tuteladas simultaneamente pelas três esferas, devendo respeitar a cada uma das normativas de tombamento. Por exemplo, qualquer tipo de intervenção nestes imóveis deve ser objeto de autorização prévia pelos três órgãos, que analisam separadamente os projetos, sem que haja hierarquia no poder conferido a cada um, prevalecendo no caso de divergências, as regras mais restritivas. No universo estudado, as resoluções de tombamento não trazem diretrizes textualmente claras, como quais elementos devem ser preservados (volumetria, fachadas, caixilhos, pinturas murais, áreas internas, etc.), e quais tipos de restrições e intervenções admitidas. Deste modo, nas solicitações de aprovação de projetos, fica a cargo do técnico ou equipe responsável pelo parecer, estabelecer as diretrizes para as intervenções, o que torna o processo sensível aos juízos e a subjetividades das análises, sendo assim determinante a formação destes e a historiografia que fundamenta suas interpretações.

Na tabela 3 é possível observar sobreposições entre as três esferas de preservação e no interior da esfera municipal, resultante das diferentes origens das iniciativas de preservação. Além dos três órgãos, foram considerados os bens indicados como Z8-200 no zoneamento em vigor de 1975 a 2004 (lei no 8.328/75), quando então passa a ser denominado Zepec ${ }^{2}$ (lei $\mathrm{n}^{\circ}$ 13.885/04) no novo Plano Diretor Estratégico (lei $\mathrm{n}^{\circ}$ 13.430/02). Nestas colunas, estão sendo considerados aqueles imóveis indicados pelas respectivas leis de zoneamento. Os três imóveis listados como Z8-200 foram acrescidos por leis complementares, sendo a casa da Tomé de Souza enquadrada através da lei no 8.759 de 1978 e a casa da Rua Santa Cruz e Capela do Morumbi através da lei $n^{\circ} 9.725$ de 1984. Destas, apenas as duas primeiras foram incluídas na Resolução 44/CONPRESP/92 de APT dos imóveis listados como Z8-200, possivelmente porque a listagem se baseou na publicação Bens culturais arquitetônicos no município e na Região Metropolitana de São Paulo, de $1984^{3}$, que deixou de fora a Capela.

Em 2004 o Conpresp abriu a APT da relação de imóveis indicados como ZEPECs nos Planos Regionais Estratégicos das Subprefeituras e daqueles já enquadrados como ZEPECs pela SEMPLA no Quadro n 06 da mesma lei, entre os quais o Edifício da Alameda Barão de Limeira, já protegido pela Resolução 14/CONPRESP/90 e o Museu Lasar Segall, que apesar de ser parte integrante do conjunto da Rua Berta, é apenas área envoltória do

1 Cf. Capítulo 2.

2 Idem

3 SNM, EMPLASA, SEMPLA, 1984. A casa da Santa Cruz foi incluída em listagem anexa intitulada "Complemento". 
TABELA 3. Proteção legal das obras de Warchavchik

\begin{tabular}{|c|c|c|c|c|c|c|c|c|}
\hline IMÓVEL & \multicolumn{2}{|c|}{ IPHAN } & \multicolumn{2}{|c|}{ CONDEPHAAT } & \multicolumn{2}{|c|}{ CONPRESP } & Z8-200 & ZEPEC \\
\hline Rua Bahia & $\mathrm{T}$ & 1986 & TEO & 1994 & TEO & 1991 & - & - \\
\hline Rua Berta & - & & NEG & 2007 & $\begin{array}{c}\mathrm{T} \\
\text { APT }\end{array}$ & $\begin{array}{l}1991 \\
2004\end{array}$ & - & 2004 \\
\hline Rua B. Jaguara & - & & - & & APT & 1990 & - & - \\
\hline Al. B. Limeira & - & & - & & $\begin{array}{l}\text { APT } \\
\text { APT }\end{array}$ & $\begin{array}{l}1990 \\
2004\end{array}$ & - & 2004 \\
\hline Rua Itápolis & $\mathrm{T}$ & 1986 & TEO & 1994 & TEO & 1991 & - & - \\
\hline Cap. Morumbi & - & & NEG & 1983 & $\mathrm{~T}$ & 2005 & 1984 & - \\
\hline Avenida Rebouças & - & & - & & NEG & 1990 & - & - \\
\hline Rua Santa Cruz & $\mathrm{T}$ & 1986 & T & 1984 & $\begin{array}{l}\text { TEO } \\
\text { APT }\end{array}$ & $\begin{array}{l}1991 \\
1992\end{array}$ & 1984 & - \\
\hline R.Tomé de Souza & - & & - & & APT & 1992 & 1978 & - \\
\hline
\end{tabular}

T - Tombamento; TEO - Tombamento Ex-Ofício; NEG - Tombamento negado; APT - Abertura de Processo de Tombamento

mesmo na Resolução 04/CONPRESP/91. Na realização da tabela 3 consideramos apenas estes dois imóveis devido à indicação originada no Plano, pois todo imóvel anteriormente caracterizado como Z8-200 ou tombado pelo órgão federal, estadual ou municipal estão automaticamente enquadrados como Zepec $\left(\operatorname{art} .115^{\circ}\right)$.

Esta sobreposição cria situações estranhas, que não alteram o quadro da proteção de alguns dos bens, como a Casa da Santa Cruz, protegida pelas três esferas e duplamente pelo Conpresp, pela Resolução 05/CONPRESP/91 e posteriormente pela 44/CONPRESP/92, ou o Edifício à Barão de Limeira, duplamente protegido por APTs. Mas também mostra demandas ao órgão, como a necessidade de efetivação do tombamento deste último, há mais de duas décadas em APT ou a revisão do tombamento do conjunto da Rua Berta, que acabou por excluir os imóveis voltados à Rua Afonso Celso, entre os quais o Museu Lasar Segall.

Mas nos níveis federal e estadual não há confusão: apenas as três célebres "casas modernistas" têm espaço de reconhecimento, tendo o Condephaat acenado para a preservação da Vila Bertha e da Capela do Morumbi, mas o arquivamento dos processos fez com que se reafirmasse a supremacia das obras consagradas pela historiografia. Isto porque o universo de obras tombadas de Warchavchik já é restrito àquelas do período inicial, dos anos 1920 e 1930, com exceção da Capela - uma exceção que confirma a regra, já que sua intervenção não é a motivação do tombamento, muito pelo contrário. 
CASA DA RUA SANTA CRUZ (1927-1928)

\section{Primeira época da Residência Klabin Warchavchik}

Considerando a tríade industrialização, urbanização e imigração como chave para compreensão da emergência do modernismo enquanto expressão cultural no seio da modernização capitalista, depreende-se daí a centralidade da experiência imigratória, do exílio, do estranhamento visual e linguístico na conformação da cultura moderna. No Brasil, as novas experiências sociais contraditórias e a sociabilidade imigrante inseridas no quadro das intensas transformações conjunturais do período, demandaram um novo suporte expressivo, capaz de assimilar formas e linguagens externas e formatá-las em função das condições locais de absorção e produção ${ }^{4}$.

A vinda de Warchavchik para o Brasil foi motivada em vários níveis pelas intensas transformações geopolíticas e culturais por que passava o mundo ocidental no primeiro quartel do século XX. Sua primeira imigração, de Odessa para Roma decorreu das dificuldades que passava em seu país natal após a revolução bolchevique de 1917; A segunda, dos avanços do fascismo sobre a Itália, por um lado, e das possibilidades abertas no Brasil, por outro $^{5}$ - com o recrutamento de "rapazes de sólida formação" ${ }^{6}$ preconizado pela intelectualidade conservadora brasileira na defesa da imigração planificada em todos os extratos da sociedade.

O problema de ordem étnica, que teria impulsionado a saída de Warchavchik da Europa, seria no Brasil fator de aproximação decisivo. O judaísmo se caracterizou como elemento central de identificação cultural no novo mundo e de inserção nos círculos sociais que determinariam os caminhos de sua trajetória, evidenciando-se na amizade com Lasar Segall e no casamento com Mina Klabin.

Segall era detentor de grande prestígio nos círculos modernistas e da alta sociedade paulistana. Imigrado na condição de pintor de renome internacional, Segall casara-se com sua ex-aluna, Jenny Klabin, jovem oriunda de família pertencente à nata dos imigrantes recém enriquecidos, ampliando-lhe significativamente seu capital econômico e social, o que, aliado ao seu prestigio já trazido da Alemanha, lhe fará ser alçado ao posto informal de liderança do modernismo ${ }^{7}$. Sua amizade com Warchavchik renderá ao segundo grandes frutos - seja em termos de acesso às discussões e produção artística de fatura modernista, inserção nos círculos intelectuais e de uma elite disposta a investir e consumir essa nova arte, seja por conta de seu papel na aproximação com a família Klabin e em particular com Mina, irmã mais velha de Jenny.

Jenny, Mina e seus dois outros irmãos, Luisa e o caçula Emmanuel, eram filhos do

4 MICELI, 2003

5 LIRA, 2008

6 SIMONSEN apud MAZA, 2002

7 Em 1932 a liderança de Segall se explicitará com a sua nomeação como diretor artístico da Sociedade Pró-arte Moderna (SPAM) em 1932. PINHEIRO FILHO, 2008 
judeu lituano, industrial e proprietário de terras, Maurício Freeman Klabin e da judia russa Bertha Klabin. Maurício refugiou-se da perseguição czarista que vinha ocorrendo na Lituânia em Londres, de onde partiu para o Brasil em busca de novas oportunidades ${ }^{8}$. Inicia-se no ramo do papel com a compra da tipografia em que trabalhara, trazendo os familiares para o país quando a situação financeira já está mais confortável. Entre eles, seus pais, os irmãos Salomão, Luis, Nessel, sua própria esposa encomendada, como era costume, o tio Salmen Lafer e os primos Miguel e Max Lafer9.

Mina vivera uma infância europeia com a família, inicialmente em Londres, passando por Berlim e Bad Harzburg, na Alemanha, e por fim em Genebra ${ }^{10}$, sendo educada nos moldes tipicamente burgueses, com uma "formação humanística e cosmopolita, que incluía além do domínio de várias línguas uma passagem obrigatória pela arte, principalmente pela pintura e pela música (...)"11. Ao longo da década de 1920, Mina continuaria sua rotina de viagens até 1926, fixando-se de vez em São Paulo em 1927, quando casa-se com Gregori Warchavchik em 04 de janeiro de $1927^{12}$.

O casamento permitiu que Mina se inserisse no círculo intelectual e artístico modernista através de Gregori e possibilitou a ele o contato com o universo dos endinheirados paulistanos, a começar pela própria família Klabin, que lhe daria o lastro financeiro para as experimentações que viriam a seguir. Ademais, o ramo familiar de Maurício Klabin, que perdera espaço nos negócios industriais para os irmãos ${ }^{13}$, reconduziria seu capital para o ramo imobiliário, exigindo do arquiteto o seu envolvimento na gestão dos negócios familiares.

A primeira obra autoral de Warchavchik no Brasil será a própria residência KlabinWarchachik, projetada em 1927 e construída em 1928, em terreno herdado por Mina da gleba da Vila Mariana.

A edificação, de planta quadrada implantada isoladamente no amplo terreno, organizava-se em dois pavimentos e despia-se totalmente de ornamentos em uma composição cuja "predominância do cubo volumétrico central (...) se estende pelas asas laterais definindo a composição em simetria tripartida" ${ }^{14}$. Tal descrição se refere à fachada sul, claramente adotada como principal em detrimento das demais, entrecortada por aberturas ritmadas. As envasaduras laterais simétricas se abriam em generoso vão até as arestas do prisma, trazendo um contraponto ao caráter maciço da construção. Menos trabalhadas do ponto de vista vi-

8 Nesta época, a Lituânia era controlada pela Rússia que proibia a aquisição de terras por judeus. Denunciado, Maurício é obrigado a fugir. As informações no manuscrito redigido por Mina em 1966, "Moissi Elkana de Posselva” e REVISTA K, 200?;

9 WARCHAVCHIK, 1966

10 Cidades que proporcionaram a Maurício o aperfeiçoamento técnico e a compra de equipamento de ponta para a produção de papel

11 PERECIN, 2003, p. 78

12 PERECIN, 2003

13 Sobre os negócios industriais dos Klabin cf. MARGALHO, 2008;

14 FARIAS, 1990 
sual que a fachada frontal, as demais fachadas refletiam o programa de uma residência que, mesmo pertencendo a uma família de boas posses, era modesto. No térreo, o vestíbulo dava acesso ao escritório do arquiteto e acessava a circulação vertical e horizontal, com a sala de jantar logo em frente, a sala de estar ao lado, ambas arrematadas pela varanda. Pela fachada oeste havia a entrada de serviços, que acessava o lavabo abaixo da escada as áreas da copa, cozinha e despensa. No segundo piso, o largo corredor fazia a distribuição para o sanitário e os cinco dormitórios. Excetuando-se o dormitório de menor dimensão, localizado no que seria a janela superior central da fachada sul, destinado à governanta, os demais eram servidos por terraços, sendo um deles compartilhado por dois quartos. Um dos quartos dava acesso a outros dois, em uma dinâmica pouco compreensível para os padrões de intimidade que regem os costumes atuais.

O projeto teve participação de Mina Klabin Warchavchik, que elaborou o paisagismo que seria considerado precursor no campo, por privilegiar o uso de espécies nativas e a busca por uma identidade brasileira, em um jardim tropical que se contrapunha ao volume branco bauhauseano. O jardim obedecia ao eixo de simetria imposto à casa, reforçado pelo caminho perspéctico que ligava a casa ao portão de entrada. À medida que o jardim se afastava da construção, Mina criava volumes mais altos e livres, emoldurando-a. O estreito diálogo do paisagismo com a arquitetura estaria presente em outras obras como as casas da Rua Itápolis, Bahia, Rebouças, Berta e do edifício à Alameda Barão de Limeira. A frutífera parceria entre marido e mulher renderia elogios da imprensa.

A força dos jardins modernistas de Mina seria evidenciada ao longo do tempo, e suas várias facetas, descortinadas: primeiramente, eles seriam vistos como expressão do espírito do lugar, elemento de valorização da obra de Warchavchik na medida em que a inseria na causa modernista de nacionalização das artes; num segundo momento, reconhecendo-se o mérito de valorizar a vegetação tropical como forma de promover a própria nação; em seguida, os comentaristas passariam a valorizar uma nova maneira de operar no universo paisagístico, capaz de fundar por aí uma nova tradição $0^{15}$.

Um episódio bastante difundido pela historiografia se refere às dificuldades enfrentadas na prefeitura para a aprovação do projeto. Entretanto, a verificação do processo de aprovação leva ao questionamento do mito já consolidado. O processo, protocolado em 12/02/1927, tem como interessado o cunhado de Warchavchik, Emmanuel Klabin, inventariante do espólio de Maurício F. Klabin, falecido em 1923, e compõe-se de uma carta inicial solicitando autorização para construção, um jogo de pranchas contendo plantas, cortes e elevação principal - de fato acrescida pelos ornamentos nas envasaduras e cimalha já amplamente divulgados pela historiografia, além de memorial descritivo sucinto.

É curioso notar que as plantas não são assinadas por Warchavchik, mas sim por 
Américo Salfati e Mário Buchignani, da firma construtora A. Salfati \& M. Buchignani Arquitetos ${ }^{16}$. Naquele período não havia restrições quanto à responsabilidade técnica relacionada às construções e a profissão de engenheiro, arquiteto e agrônomo seria regulamentada somente em finais de $1933^{17}$. No entanto, o cadastro profissional na prefeitura teria levado Warchavchik a conduzir a autoria das plantas ao referido escritório. Até então, poderiam aprovar projetos na prefeitura, de acordo com a lei n 2986 de 1926, engenheiros ou arquitetos registrados na prefeitura, as firmas comerciais, companhias e sociedades e os empreiteiros de obras particulares que comprovassem competência ou tempo mínimo de três anos de experiência ${ }^{18}$. Sem tempo hábil para conseguir ele mesmo o cadastramento municipal, autuou o projeto em 12/02, mas logo solicitaria o registro de construtor em 14/02/192 ${ }^{19}$, protocolando seu diploma de arquiteto sob tradução juramentada. Entretanto, o registro de construtor não tinha o mesmo peso do registro como arquiteto diplomado ${ }^{20}$, e assim abandonava-o para abrir outro processo, solicitando registro do seu diploma de arquiteto em 30/03/192721, deferido em 30/05/1927.

O processo da Santa Cruz é primeiramente encaminhado para análise técnica da $7^{a}$ seção da Diretoria de Obras e Viação, que se detém às questões do alinhamento, desnível da soleira e muros de fechamento. Em seguida, é encaminhado à $2^{a}$ Seção, cuja manifestação é também bastante sumária: "Construcção de prédio à rua Santa Cruz no 27 p.s.u. Área do pavimento térreo: $238 \mathrm{~m}^{2}$. Área do pavimento alto: $126 \mathrm{~m}^{2}$. A firma constructora está registrada" ${ }^{22}$. Após a referida anotação, é dada ordem para expedir o Alvará. O processo tem seu despacho final favorável em 25/02/1927, ou seja, em 13 dias foi aprovado sem qualquer traço de dificuldade. Em 16/03/1927, é Warchavchik quem assina a retirada de sua via aprovada.

É difícil verificar se de fato haveria uma comissão de censura de fachadas atuante na cidade de São Paulo, pois as leis edilícias anteriores ao Código Arthur Sabóia de 1929 eram dispersas ${ }^{23}$ e os legisladores se detinham a poucos aspectos das construções, como os alinhamentos, o pé direito e alguns dimensionamentos mínimos visando a salubridade das construções. Somente após o período da construção da casa da Rua Santa Cruz é que se terá notícias de uma comissão atuante. Prevista pela seção V do Código de Obras de 1929, “Architectura das fachadas”, a "commissão de esthetica” entraria em vigor na gestão do prefeito Anhaia

16 A firma também tinha como associado o engenheiro Mário Pucci, mas não levava seu nome por ser funcionário da Prefeitura. FISCHER, 2005:282

17 Com a instituição do Decreto n ${ }^{\circ} 23.569$ de 11/12/1933

18 Lei 2986 de 7/07/1926

19 PMSP, processo 7.957/27

20 Nas intensas discussões da classe, reivindicava-se a extinção da categoria dos licenciados "práticos". FISCHER, 2005: 180

21 PMSP, Processo 16.186/27

22 PMSP, Processo 7.759/27, fl. 5

23 Foram realizadas pesquisas sem sucesso no banco de dados da Câmara Municipal de São Paulo disponível na internet, que contém toda a legislação da cidade desde sua fundação. 
Mello em 1931 com a promulgação do Ato n58, que instituía a "censura esthetica dos edifícios", objeto de polêmica na qual o próprio Warchavchik se posicionara contrário ${ }^{24}$. No breve processo relativo à casa, Warchavchik nem sequer tentou fazer passar o projeto tal como intencionava construir nem foi localizado no Arquivo Municipal qualquer outra versão que por ventura tenha sido indeferida. $\mathrm{Na}$ consulta a outros processos do período, dele e de outros construtores, também não foi localizada qualquer dificuldade neste sentido.

À exceção do projeto para a Casa à Rua Mello Alves ${ }^{25}$, de 1928, que também representava na elevação a cimalha e mostrava a ponta do telhado por trás da platibanda, os demais projetos consultados de Warchavchik foram apresentados em suas formas despojadas e geométricas, como o conjunto da Rua Berta, as residências à Rua Bahia, Itápolis e Tomé de Souza $^{26}$ ou a Sinagoga à Rua Odorico Mendes ${ }^{27}$, indeferida por estar abaixo do nível da rua e não por sua fachada fora dos padrões de época. Já o projeto para a residência à Alameda Lorena $^{28}$, de julho de 1931, quando a censura imposta por Anhaia Mello já vigia, receberia comunique-se por parte da então estabelecida Censura de Fachadas para que fosse apresentada perspectiva da construção. Atendida a solicitação, sem questionamentos o projeto foi aprovado e a construção concluída em 1932. Seja qual for a razão para a apresentação da fachada fantasiosa, censurada ou não ${ }^{29}$, Warchavchik soube utilizar o episódio muito bem, reforçando sua imagem de desbravador em um universo cultural avesso à modernização estética.

O memorial descritivo especificava:

Alicerces - Os alvéolos para a fundação terão a largura de 0,50 nas paredes de 0,30. O fundo dos alicerces será convenientemente apizoado com soquete de 70 kilos e será posta uma laje de concreto;

Alvenaria de tijolos - Toda a alvenaria de tijolos será assentação (sic) de 1:3, e entre as paredes externas, levarão montantes de concreto;

Cintas de concreto - Cada pavimento levará uma cinta de concreto na proporção de 1:3:7;

Pés Direitos - do pavimento térreo, 3,50 e do $1^{\circ}$ andar de 3,50;

Madeiramento do telhado - Será de peroba de bôa qualidade, com resistência que devem offerecer a carga do telhado que vae suportar;

Coberta - Será feita com telhas francezas typo Marselha de bôa qualidade, sendo

24 Sob título "Resguardando a Estética Arquitetônica da Paulicéia", artigo publicado em 12 de janeiro de 1931 no Diário da Noite, São Paulo, Warchavchik reconhece o mérito da iniciativa, mas opina que a escolha do estilo deve ser livre. WARCHAVCHIK apud SOUZA, 1982

25 PMSP, Processo 0.044.912/28

26 Tais projetos serão comentados adiante

27 PMSP, Processo 0.075.075/29

28 PMSP, Processo 0.032.715/31

29 Restringindo-nos às obras discutidas no capítulo 1, a aprovação é mencionada em BRUAND, 1981; CAVALCANTI, 2001; FARIAS, 1990; FERRAZ, 1965; LEMOS, 1983; LIRA, 2008; SALMONI \& DEBENEDETTI, 1981; SEGAWA, 1998. 
os espigões cobertos por cumieiras do mesmo typo da telha. As aguas furtadas serão retomadas com folhas de flandres de espessura commum, typo 26;

Revestimento das paredes - As paredes internas e externas serão revestidas com reboque de cal e areia;

Impermeabilisação - As paredes do W. C. e cosinha serão impermeabilisadas até a altura de 1,50 com barra a óleo;

Forros - Os forros serão de estuque com tela metálica;

Pavimentação - A pavimentação será feita com taboas de peroba de 0,09 por 2,5, excepto os pisos, cosinha e banheiros que serão ladrilhos com ladrilhos impermeáveis;

Esquadrias - Todas as portas internas serão de pinho do Paraná em batente de peroba, e portas externas e janellas serão de ferro com proteção de escuros de pinho do Paraná;

Venezianas - Os dormitórios levarão venezianas;

Eletricidade - Em todo o prédio haverá installação electrica, executada com material de primeira qualidade e distribuida em todos os commodos;

Pintura - A sala de jantar, sala de visitas, hall e dormitorios serão decorados e a fachada será caiada ${ }^{30}$.

Nota-se de fato a adoção de técnicas tradicionais de construção, apesar de que não se vê qualquer menção à engenhosa solução para a estruturação das janelas de canto ou sobre as esquadrias metálicas.

Outra questão incessantemente mencionada nos trabalhos sobre a casa se refere à suposta disparidade entre discurso e prática. Não vamos entrar em detalhes aqui sobre as incongruências entre fachada e planta; entre composição simétrica e correspondência no interior; entre sistema construtivo tradicional e aparência moderna (como o já apontado problema da cobertura em quatro águas escondida por um beiral), assim como as dificuldades relatadas pelo arquiteto para conseguir construir a casa, do problema da qualificação da mão de obra ao fornecimento de peças industrializadas, pois são questões já amplamente apontadas e reiteradas pela historiografia, quase um senso comum. No extremo, Carlos Lemos condena tais disparidades, chegando a não considerar a casa obra moderna ${ }^{31}$. Como vimos no capítulo 1 , apenas os trabalhos monográficos trarão abordagens que saiam da comparação com o cânone. Ferraz na sua luta para provar o pioneirismo do arquiteto; Farias, ao reconhecer a opção de Warchavchik por uma experimentação no campo visual em detrimento de técnicas ainda não disponíveis, em consonância consciente com as vanguardas; ou Lira, que assume tais contradições como constituintes do processo de "virada 
arquitetônica brasileira" ${ }^{32}$ e não uma falha do arquiteto.

Ainda no $1^{\circ}$ capítulo procurou-se retratar como a casa recebe ampla repercussão nas páginas dos diários paulistas na época de sua inauguração e torna-se palco de encontros da alta sociedade simpática ao modernismo, abrigando por exemplo atividades da SPAM. Entretanto, como também já exposto, os anos seguintes marcam uma fase de reclusão, em um contexto de tensões políticas, antissemitismo e alterações na vida familiar de Warchavchik, com o nascimento dos filhos Mauris Ilia e Anna Sonia, motivando a intervenção realizada pelo arquiteto em sua residência em 1934-35.

Apesar de realizada apenas sete anos após a inauguração da casa e sendo até hoje a figuração consolidada, a reforma foi praticamente ignorada pela historiografia. Quando mencionada, foi desprestigiada ${ }^{33}$. Atualmente aberta à visitação, é perceptível nos visitantes que a conhecem dos livros um misto de choque e decepção ao encontrar um objeto que não reconhecem ${ }^{34}$. Compreendida em um processo de reformulação ancorado nas necessidades familiares e sociais do casal Warchavchik, da chegada dos filhos aos encontros sociais refletidos na ampliação das áreas íntimas e sociais, as alterações formais e funcionais enunciavam a virada por que passava a carreira do arquiteto $^{35}$, assim como as revisões e permanências de um repertório que vinha construindo.

O processo de aprovação de reforma tem solicitação inicial assinada por Mina Klabin Warchavchik datada de 04 de setembro de 1934, acompanhada por memorial descritivo e planta. Os técnicos então encaminham o processo para comunique-se, para o atendimento de exigência de previsão de dispensa e armários conforme o artigo 213, parágrafo $2^{\circ}$ do ato 663 e de que "O requerente deve declarar nas cinco vias da planta, a cor e natureza do revestimento, que deve ser mais rico que cal e areia" ${ }^{36}$, apontamentos de 12 e 13 de setembro de 1934.

No memorial, Warchavchik especificava: "As fachadas attingidas pela reforma e augmento terão o revestimento grosso feito com argamassa mixta de cimento 1:2:7 e a segunda camada de acabamento de cal e areia fina peneirada. As paredes internas novas e reformadas com reboco de cal e areia 1:3". A lápis, anotado na prancha, Warchavchik complementa: "Revestimento simples de cal e areia. A pintura a oleo de côr branca", assinado em 25 de

\footnotetext{
32 LIRA, 2008:160

33 LIRA, 2008:325 (ver comentários à p. 113); SOUZA, 1992: 87. Ferraz não faz menção à reforma no livro sobre o arquiteto, mas em seu livro de memórias, considera-a uma reconstrução por cima da primeira versão. FERRAZ, 1983:25

34 Ao choque diante da forma desconhecida, somam-se problemas relativos à restauração dos anos 2000, comentada mais à frente. Cabe lembrar que mesmo o Guia de Arquitetura 1928-1960 descreve a casa como preservada em sua forma original.

35 Para Lira, um momento de dificuldade e hesitação, na passagem do arquiteto da vanguarda artística para o arquiteto da vanguarda do capital mediante intensas transformações no campo cultural, econômico e social em São Paulo. LIRA, 2008

36 PMSP, processo 58.806/34, fl. 1 verso
} 

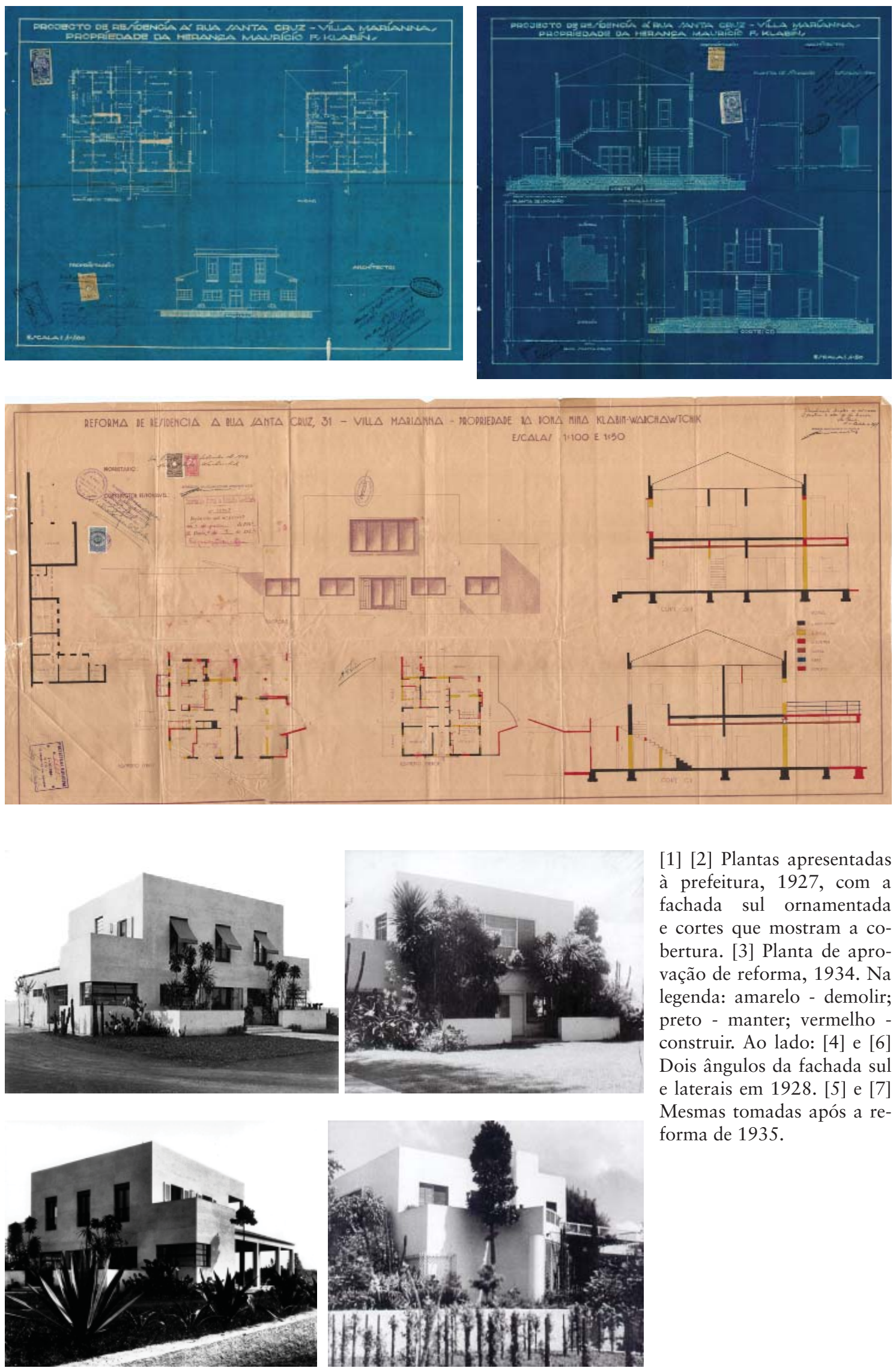

[1] [2] Plantas apresentadas à prefeitura, 1927, com a fachada sul ornamentada e cortes que mostram a cobertura. [3] Planta de aprovação de reforma, 1934. Na legenda: amarelo - demolir; preto - manter; vermelho construir. Ao lado: [4] e [6] Dois ângulos da fachada sul e laterais em 1928. [5] e [7] Mesmas tomadas após a reforma de 1935. 

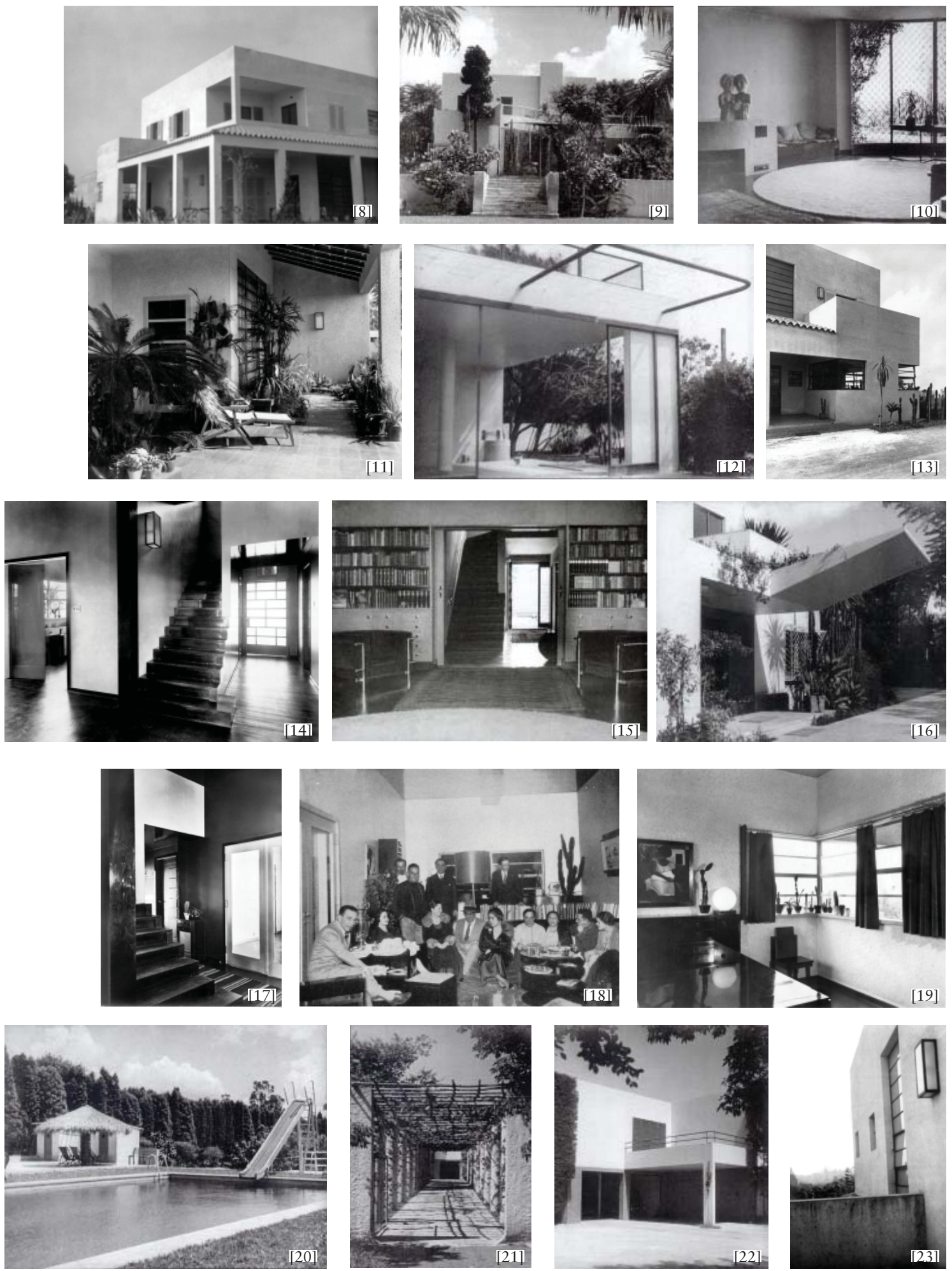

[8] Fachadas norte e leste em 1928. [9] Fachada leste após 1935. [10] Sala de estar, com escultura de Brecheret sobre lareira, após 1935. [11] Varanda em 1928, com argamassa em textura rústica. [12] varanda remanescente, mesmo ângulo, com fonte d'água ao fundo [13] Ponta da fachada oeste, com escritório ladeado por janelas de canto e entrada de serviço. [14] Escada e porta de acesso ao escritório à esq. e entrada de serviços à dir. em 1928. [15] Escada e entrada de serviço transformada em social, vista pela sala de estar após reforma de 1935. [16] Marquise sobre nova entrada social pela fachada oeste, mesma ângulo que [13]. [17] Outra vista da escada - notar tom escuro, 1928. [18] Encontro de intelectuais e artistas ligados ao modernismo, antes da reforma. [19] Escritório com mobiliário de Warchavchik. [20] Piscina construída após ampliação do terreno. [21] Entrada de automóvel, paisagismo de Mina. [22] Garagem e quarto do irmão de Warchavchik, com varanda, após 1935 (na planta de prefeitura não consta o piso superior). [23] Janela para iluminação da escada e luminária, vistas pela varanda oeste, 1928. 
outubro de 1934.

Ainda no memorial, assinalamos as especificações que alteraram as soluções do projeto de 1927:

(...) Concreto armado: A cobertura da passagem e laje dos terraços serão feitas de concreto armado (toda estructura será feita de accordo com o C.O., e serão admittidas as sobre cargas accidentaes estipuladas no mesmo Codigo"

Revestimento dos tectos: O tecto do andar térreo será abaixado - até a altura de $3,00 \mathrm{~m}$ e revestido com argamassa de cal e areia

Esquadrias: As esquadrias serão de madeira de correr, de cabreúva e jacarandá Sala de jantar e sala terão as portas corrediças até o tecto

Soalho: Soalho do andar térreo será feito em parquet de dimensões especiaes de accordo com o desenho $(\ldots)^{37}$

Entraves legais dificultaram a aprovação, em decorrência da regulamentação da profissão de arquiteto: "Sr. Eng ${ }^{\circ}$ Chefe - Tratando-se de processo entrado depois de 16/08/34,

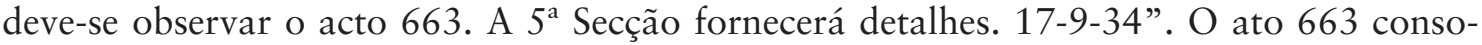
lidava o Código de obras, incorporando alterações, como as referentes aos construtores habilitados. Dizia o artigo $86^{\circ}$ :

Só podem assinar projetos e dirigir construções ou edificações engenheiros civis, arquitetos ou engenheiros arquitetos, diplomados ou licenciados de acordo com o Decreto Federal n. 23.569, de 11 de dezembro de 1933, e que registrar na Diretoria de Obras e Viação as competentes carteiras profissionais, expedidas ou visadas pelo Conselho Regional de Engenharia e Arquitetura (...)

O processo então vai para comunique-se novamente, voltando com as plantas alteradas e a anotação de Warchavchik: "apresentei certificado (na $5^{\text {a }}$ Secção) de registro no Conselho Regional de Engenharia e Arquitectura", em 8 de novembro. Mas há certa confusão no encaminhamento, pois em cota posterior, os técnicos informam: "Snr. Chefe, Gregori Warchavchik, não está licenciado", levando o processo a outro comunique-se, em 9 de novembro de 1934. Entretanto, logo percebe-se o desencontro das informações: "O interessado fez declaração no verso dessa folha por engano", cota que antecede a observação: "Sr. Chefe, O construtor e autor do projeto apresentou a carteira do CREA, nesta secção". E então é lavrado o Alvará. Em 7 de dezembro do mesmo ano, as plantas são retiradas e em 26 de dezembro de 1935, encerrando o processo, o técnico anota: "Sr. Eng. Chefe, Obra concluída. Pode ser archivado".

O desenho apresentado representava o que efetivamente foi executado. O edifício, apesar de isolado no terreno, era implantado paralelamente ao seu alinhamento, voltando-se 


\section{CRONOLOGIA CONSTRUTIVA}
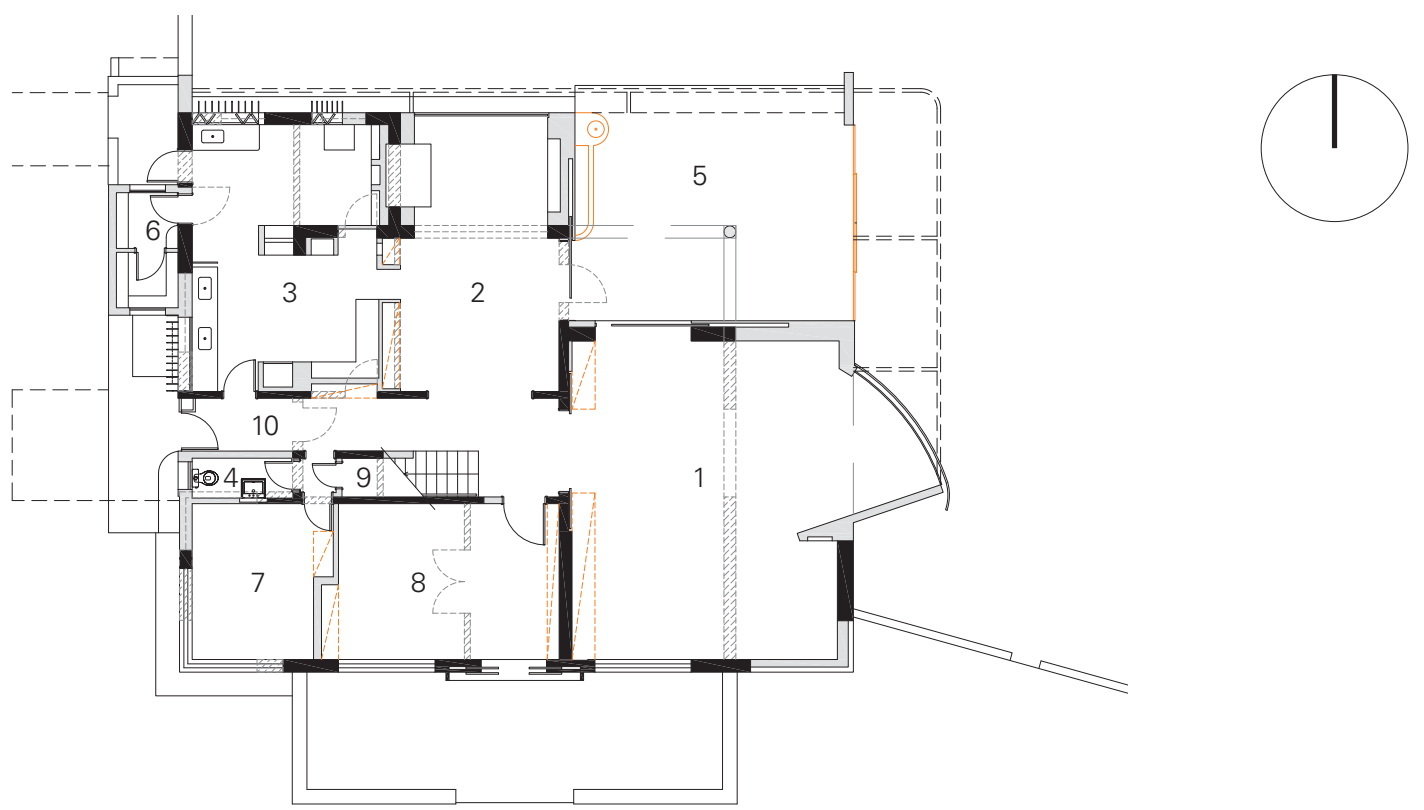

[24] PLANTA TÉRREO

Usos nos anos 1930
1. Sala de estar
6. Despensa
2. Sala de jantar
7. Quarto de estudos
3. Cozinha
8. Biblioteca
4. Lavabo
9. Depósito
5. Varanda
10. Entrada social
Atualmente todo o espaço
tornou-se expositivo, exceto: 4 .
Lavabo; 7. Sala administrativa; 6 e
9. Depósito

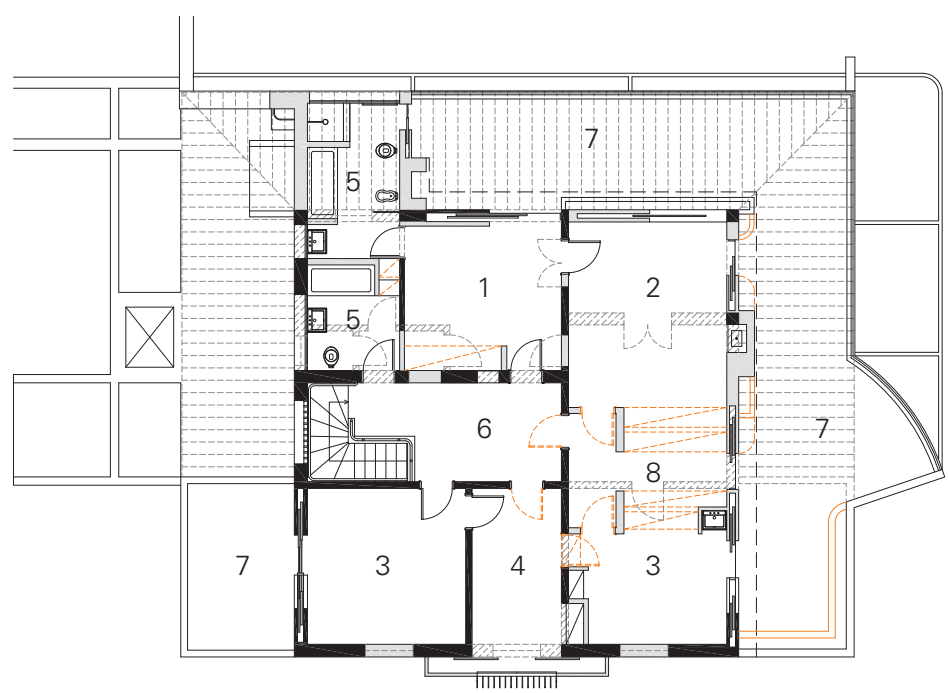

LEGENDA

Remanescente de 1928

Demolido em 1935

Construído após 1935

Demolido nos anos 2000

Reconstruído nos anos 2000

FONTES

1927 Planta de aprovação PMSP

FERRAZ, 1965

1934 Planta de aprovação PMSP

1984 GALVÃO, 1984 (levantamento)

2008 DPH, 2008 (levantamento)

[25] PLANTA PISO SUPERIOR

Usos nos anos 1930
1. Dormitório Gregori
5. Sanitário
2. Dormitório Mina
6. Circulação
3. Dormitório filhos
7. Terraço
4. Dormitório governanta
Atualmente todo o piso superior tornou-se espaço expositivo 


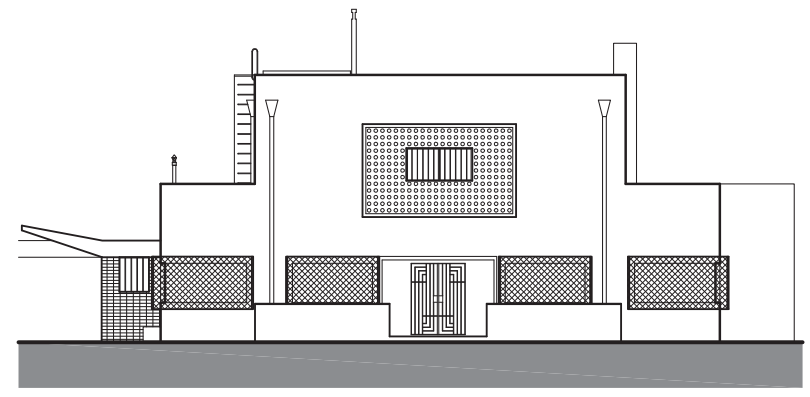

[26] ELEVAÇÃO SUL

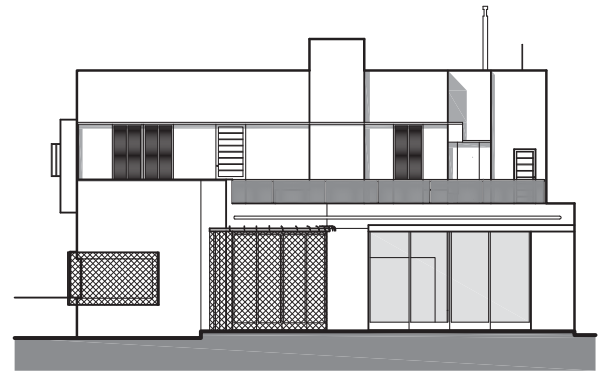

[27] ELEVAÇÃO LESTE

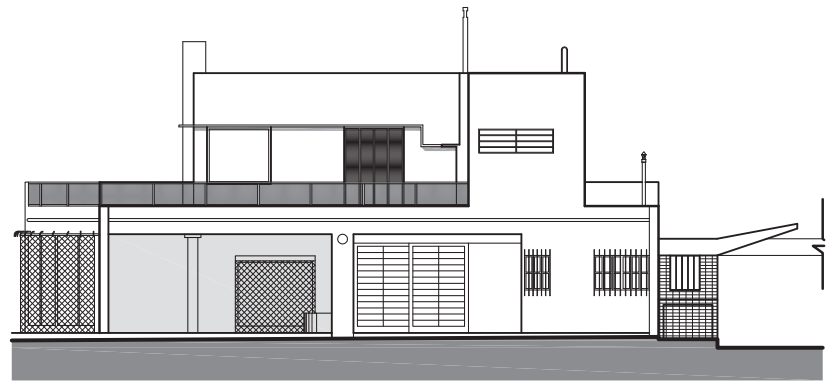

[28] ELEVAÇÃO NORTE
$0 \sqcap 1 \mathrm{~m}$

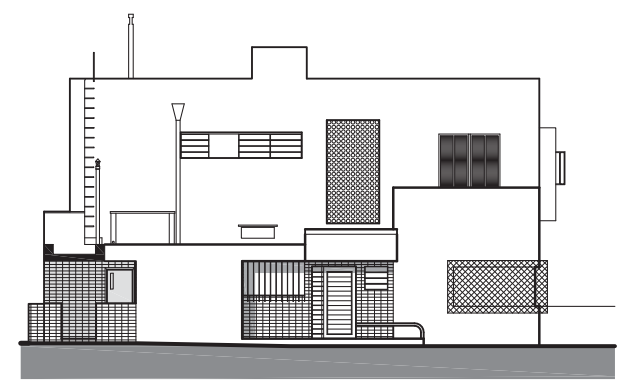

[29] ELEVAÇÃO OESTE

$0 \longmapsto 1 \mathrm{~m}$

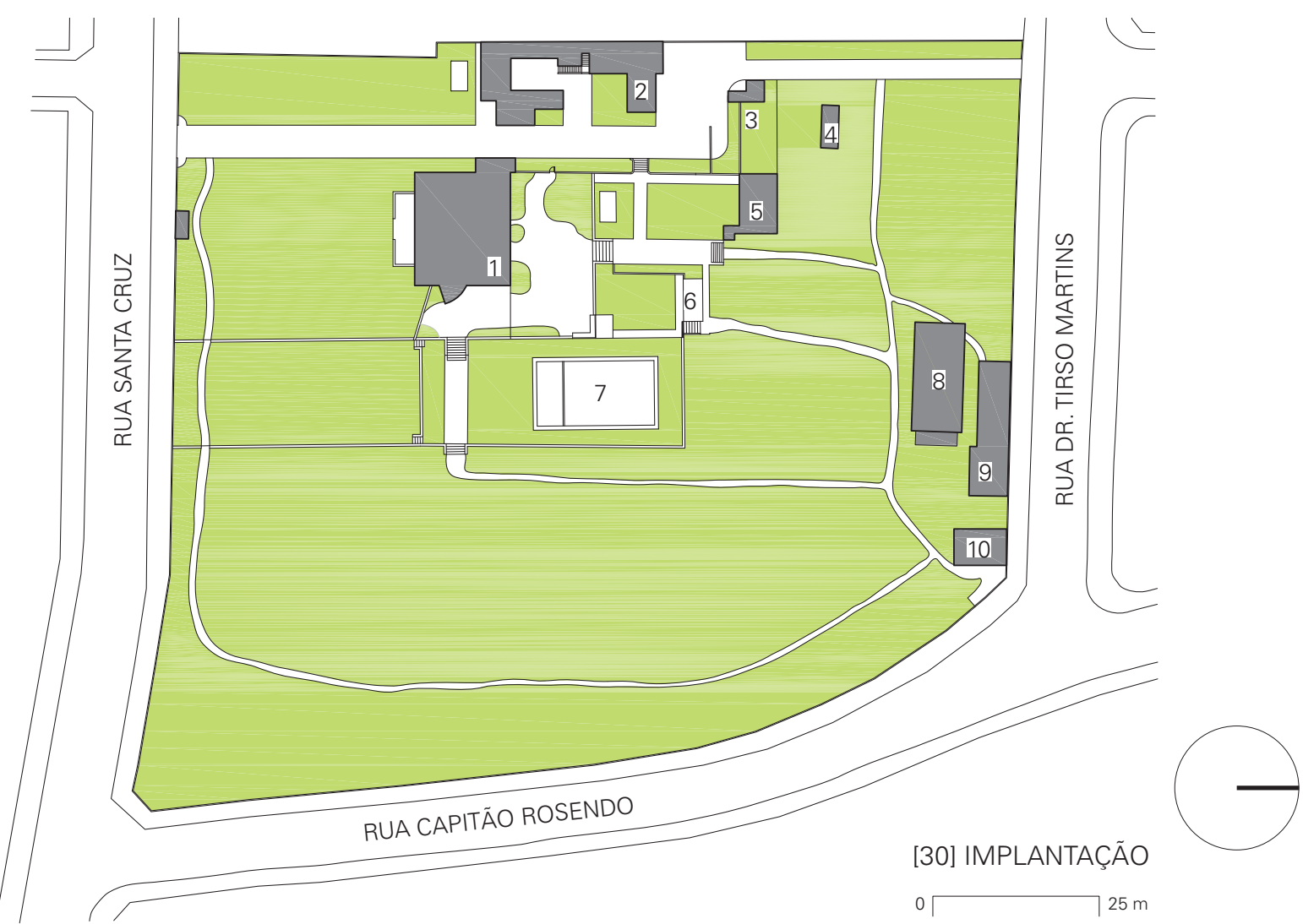

LEGENDA (uso original/ uso atual)

1. Casa modernista/ espaço expositivo

2. Serviços, garagem, irmão de Warchavchik/ Anexo serviços

3. Garagem Kart/ ruína

4. Antigo apoio jardim/ ruína
5. Salão de jogos/ruína

6. Vestiário/ruína

7. Piscina /ruína

8. Canil/galpão escoteiros

9. Laboratórios fotográfico e química /escoteiros

10. Casa do motorista /escoteiros 
para a fria orientação sul. Os quartos das extremidades tiveram seus vãos emparedados, ficando suas aberturas voltadas para os terraços laterais, enquanto o quarto central, da governanta, teve o caixilho original vertical de grandes dimensões substituído por uma abertura horizontal e menor, envolta por uma caixa sobressalente de alvenaria e blocos cilíndricos de vidro, de toque loosiano, de modo a permitir maior entrada de luz com redução de trocas térmicas. As alterações internas e nas demais fachadas mostravam a intenção do arquiteto em retirar da fachada sul sua força de fachada principal, com um tratamento equivalente às demais faces do edifício. Fato curioso é que Warchavchik preservou a sua simetria, aspecto dos mais condenados da criticada disparidade entre elevação e planta, demarcando em baixo relevo o vão emparedado da janela de canto que se abria para a antiga varanda.

Outra alteração significativa se daria na lógica da circulação. Se na configuração de 1928 o acesso era realizado pela fachada principal, reforçando seu eixo de simetria, com a intervenção de 1935, o arquiteto o deslocaria para a fachada leste, sendo enfatizado pela inserção de uma marquise em balanço, além de banco e jardim, ambientando um espaço intermediário de estar encerrado por uma nova e elegante porta em ferro e vidro, que contava com a inserção de uma engenhosa luminária em sua folha secundária.

No térreo, a referida alteração no acesso principal fez com que fosse suprimido o antigo vestíbulo, que teve sua área redividida junto com o antigo escritório, para dar lugar ao quarto de estudo ${ }^{38}$ e uma sala de leitura/ biblioteca. Na área da cozinha, substituiu-se na extremidade a cobertura em telha colonial por laje, havendo também uma ampliação a leste, alinhando-se à marquise da entrada principal, despensa e entrada de serviços. Com isso, a cozinha teve nova distribuição interna. Toda área avarandada teve a cobertura em telha colonial substituída por lajes em concreto e foi incorporada às salas de jantar e estar, restando apenas a esquina como varanda. A sala de estar, além de avançar sobre a projeção da antiga cobertura, ganhou um novo volume envidraçado obliquo de aresta encurvada, na orientação nordeste, com vista para a piscina.

Neste ponto, podemos notar o quanto o meio artístico e as aspirações do jovem casal poderiam ser determinantes para as escolhas de Warchavchik. Mina Klabin era cantora lírica e pianista, tendo sido à época da SPAM sua diretora musical. No interior da instituição, promovia concertos e eventos relacionados à música, incluindo apresentações em sua própria casa. O novo volume se configurava claramente como um pequeno auditório, cujo centro do raio de curvatura situava-se na área onde ficava seu piano $^{39}$. A eleição daquele espaço como anfiteatro se confirma em estudos para reforma não executados dos anos 1950, que chegam a propor a implantação de um palco ${ }^{40}$.

38 Os usos dos ambientes após a reforma de 1935 foram informados por Mauris Ilia Warchavchik, filho de Gregori em visita à casa realizada em 20 de junho de 2008.

39 De acordo com Mauris Warchavchik e arquitetos que visitaram a casa antes da reforma, quando ainda permanecia o trilho para uma cortina que escondia o piano.

40 Cf. Acervo FAUUSP, pasta $728.3 \mathrm{GW}$ 
No piso superior a nova laje gerou um terraço em L somado ao novo volume curvo, assim como um novo banheiro à frente do banheiro existente, que serviria o quarto de Gregori ao seu lado. Os quartos da fachada leste se rearranjaram, com a inserção de um closet e um quarto de costura, posteriormente convertido em quarto para os filhos e supressão de uma varanda. Os quartos da governanta e do filho se mantiveram e o sanitário alterou-se devido à inserção da suíte.

Foram acrescentadas à frente do terraço barras tubulares metálicas que estruturavam uma pérgola de cabos de aço para receber espécies trepadeiras, em harmonia com o jardim tropical de Mina. Outras novas inserções seriam duas lareiras, uma na sala de jantar e por algum período outra na sala de estar, posteriormente anulada, tendo o nicho da chaminé recebido um pequeno lavatório no quarto de Mina. Além disso, a varanda do térreo recebeu uma pequena jardineira arrematada por uma fonte d'água.

No que se refere às esquadrias, é notável a habilidade e a preocupação no detalhamento dos seus componentes - qualidade visível em outras obras de Warchavchik. Nos casos estudados, é perceptível a reaplicação de soluções, incluindo-se o desenho das esquadrias, denotando aprovação ao desenho realizado, ocorrendo assim um acúmulo de experiências que trará contribuições às obras seguintes. A influência bauhauseana de buscar coerência entre as escalas dos objetos era sentida na atenção dada às esquadrias, luminárias, móveis, ferragens, etc. Na reforma, as esquadrias de ferro foram substituídas por madeira no térreo, fachada sul e no $2^{\circ}$ piso, com sistemas de correr e abrir inteligentes e apuro nos acabamentos. Tais portas, assim como as demais janelas dos quartos, eram guarnecidas por venezianas de madeiras, e ambas as folhas se embutiam nas paredes, escondidas por placas de concreto. Com exceção das portas de entrada, o ferro manteve-se somente nas áreas de serviços - cozinha, despensa e sanitários, predominando o tipo basculante, por vezes combinado com sistemas de abrir e correr. A sala de jantar, que agora se ampliava, avançando sobre a antiga varanda, recebia um grande portão mecanizado de correr, que permitia a abertura total do ambiente. Destes elementos causa certa estranheza a introdução de pesado gradil à frente de todas as aberturas do térreo em uma época em que a questão da segurança talvez não fosse tão patente - se compararmos não anacronicamente com os dias atuais, mas com a própria arquitetura média praticada nos anos 1930.

Externamente, os acabamentos foram alterados de modo a substituir o aspecto rústico que alimentou as críticas positivas ao caráter tropical e nacional do projeto ainda em 1928 em nome da pureza corbusiana da nova feição dada ao volume. Além da retirada da cobertura em telhas coloniais na varanda, o volume tornou-se mais branco, pois se antes o reboco rústico de cimento branco, mica e caulim era visível em sua textura nas fotografias, depois ficou mais liso e uniforme. Nas entradas da fachada oeste, tanto a principal quanto a de serviços, a parede recebeu revestimento cerâmico vermelho da Cerâmica São Caetano, material que Warchavchik usará bastante nas construções dos anos 1940. Já o piso da varanda em litocerâmica vermelha fora substituído por mármore.

Internamente, os acabamentos das paredes se constituíam de argamassas pintadas 
nas áreas de estar e azulejadas nas áreas de serviço, com peças sem bisoteamento ou boleamento, assentadas quase à junta seca ${ }^{41}$. No térreo, as áreas de estar tinham piso em parquet e no piso superior, assoalho sobre barroteamento. Nas áreas molhadas, não se tem documentos que mostrem como eram os pisos antes da reforma. Após 1935, eram em cerâmica. Os forros eram em estuque inclusive no piso superior, pois o telhado em quatro águas mantivera-se após a reforma. Nas áreas molhadas, o forro também era azulejado.

$\mathrm{Na}$ pintura interna, os matizes escolhidos em 1928, com maior apelo às cores contrastantes e vibrantes, seriam substituídos por cores mais suaves. No relatório enviado a Giedion em 1930, Warchavchik descreve: “'entrada em cor limão claro, vermelho vivo e branco', estúdio com 'forro de esmalte prateado', sala de jantar em 'vários tons de cinza e prata, preto e branco', sala de música em 'azul-claro acinzentado', cortinas azuis, estofados roxo-violeta e cinza, móveis prateados e pretos; o primeiro andar era todo branco, portas e móveis na cor vermelho-vivo" ${ }^{42}$. Mauris Warchavchik, que tem suas primeiras lembranças da casa já após a reforma de 1935, se recorda das cores com tons de bege, verde-claro, entre outros tons mais claros ${ }^{43}$.

Entre a década de 1930 e 1950, o terreno se ampliaria e se desvincularia do restante das propriedades dos Klabin, ganhando ruas ao seu redor quando do arruamento da Vila Afonso Celso, conforme se pode observar na comparação dos Mapas Sara Brasil, de 1930 e VASP, de 1954.

A área ampliada recebera um bosque de eucaliptos, que, segundo Mauris, foram plantados para tornar o terreno menos devassado. Em fins dos anos 1930, logo em frente ao imóvel, foi construído o Hospital Santa Cruz, mantido por japoneses, que naquele momento integravam o Eixo na $2^{a}$ guerra mundial, o que causaria sentimento de insegurança na família.

As áreas externas e demais edificações têm menos documentação, talvez por serem consideradas de importância secundária. $\mathrm{O}$ anexo de serviço não foi alterado no projeto de reforma de 1934, constando no projeto o estado em que se encontrava naquele momento. Mas fotos desta época registram a construção já abrigando, além das funções de serviços, a garagem e o acréscimo do piso superior, destinado a abrigar por algum tempo o irmão do arquiteto, Paulo Warchavchik. Entre a edícula e a casa foi construída uma casa de bonecas e próximo a ela, em direção à saída dos fundos sombreada por um pergolado, uma pequena garagem de Kart.

Ainda próximo da casa, foi construído um complexo de lazer, formado pela piscina,

\footnotetext{
41 Do azulejo original restou apenas no lavabo.

42 WARCHAVCHIK apud SEGAWA, 2002:47

43 Conforme relato dado à autora em 2008. Apesar da imprecisão de tal tipo de informação, sua descrição seria confirmada pelas prospecções estratigráficas parietais realizadas em 2001 por conta do projeto de restauro então realizado.
} 
vestiário e salão de jogos, além de um pequeno anfiteatro a céu aberto. Gregori, que era fotógrafo amador, deixou registradas cenas domésticas e sociais que demonstram um pouco da vida da casa, com as brincadeiras na piscinas, as encenações teatrais, os almoços ao ar livre. A casa chegou a receber eventos artísticos para arrecadação de fundos para a cruz vermelha russa no pós-guerra.

Mais afastado do núcleo central da casa, havia ainda uma pequena construção para a manutenção do jardim, um canil, uma casa para o motorista e uma edificação que abrigava o estúdio fotográfico do arquiteto e um laboratório de química, usado por seus filhos para os estudos ${ }^{44}$.

O desapego à forma original consagrada se mostrou novamente nos anos 1950, quando o arquiteto realizou estudos para reformas não executadas, ampliando novamente as áreas íntimas e sociais, como o estudo de 1959 que expande e explicita ainda mais a vocação do estar para concertos ${ }^{45}$. Em uma das elevações, revelava-se uma nova cobertura em duas águas, o volume da ampliação do estar para frente e a recomposição dos vãos originais no piso superior.

Nos anos seguintes, a casa não se modificou e alterações pouco significativas nas áreas anexas ocorreram para atender as necessidades da família. Mina falece em 1969 e Gregori em $1972^{46}$, residindo lá apenas a filha até $1977^{47}$, quando então decide se mudar, iniciando uma nova fase na vida do imóvel. Na realidade, Gregori já não mais morava na Santa Cruz, mas sim em uma das três casas de propriedade de Mina projetadas por ele na Avenida Europa em $1940^{48}$. Sua morte foi noticiada em jornais de grande circulação ${ }^{49}$, com matérias que relembravam seu papel na renovação da arquitetura brasileira, publicavam seus $1^{\circ}$ s projetos, o manifesto de 1925 , e até uma nota sobre o dia do sepultamento. $\mathrm{Na}$ residência, compareceram figuras como Flávio de Carvalho, Ícaro de Castro Melo, Eduardo Kneese de Mello, que também assinara um artigo sobre a "contribuição inestimável" do arquiteto $^{50}$, Cicilo Matarazzo, Geraldo Ferraz e Theodor Heuberger, diretor da Pró-Arte ${ }^{51}$.

44 Interessante notar a quantidade de espaços voltados para as atividades dos filhos, o que denota a importância dada a eles.

45 Acervo FAUUSP, pasta PE W196 728.3 GW

46 Warchavchik morreu dormindo, mas já tinha problemas cardíacos e um mal de Parkinson que não o deixava trabalhar como gostaria.

47 JB, 26/08/1987.

48 PMSP, processos 0.079.634/40 (Alvará), 15.432/42 (modificativo) e 0.022.041/42(Habite-se), Acervo FAUUSP pasta PE W196 728.3rg

49 A notícia chegou a ser dada em jornal norte-americano voltado à comunidade russa, dando amostras de como Warchavchik poderia estar articulado à comunidade russa e judia imigrada.

50 OESP, 28/07/1972

51 Grupo intelectual liderado desde 1929 pelo ativista cultural e marchand Theodor Heuberger, inicialmente denominado Vereinigung Deutschsprachiger Künstler und Kunstfreunde (Associação dos Artistas e Amigos da Arte de Língua Alemã), que daria origem à PRÓ-ARTE. Segundo informações de MOREIRA, 2005, seria através da entidade que Warchavchik conheceria Alexandre Altberg, arquiteto que se responsabilizaria pela reforma do Apartamento Moderno no Rio de Janeiro. 
[31] e [32] Casa da Santa Cruz e Vila Dona Berta em destaque nos mapas Sara Brasil (1930) e Vasp (1954) respectivamente. Em 1954 já se vê o lote da Santa Cruz desmembrado do restante da gleba dos Klabin, bem como o novo arruamento e renques de casas da Vila Afonso Celso. O voo não identificou a edificação devido à densa vegetação presente no terreno. [32b] Em 1972, todo o entorno já se encontra ocupado.

Abaixo: [33] Projeto para ampliação da casa (1950). Neste, o térreo avança, as janelas do piso superior voltam à forma de 1928 e o edifício ganha cobertura em duas águas. [34] Planta do estudo, com aumento significativo da área social, com a criação de palco e separação de entrada íntima e social.
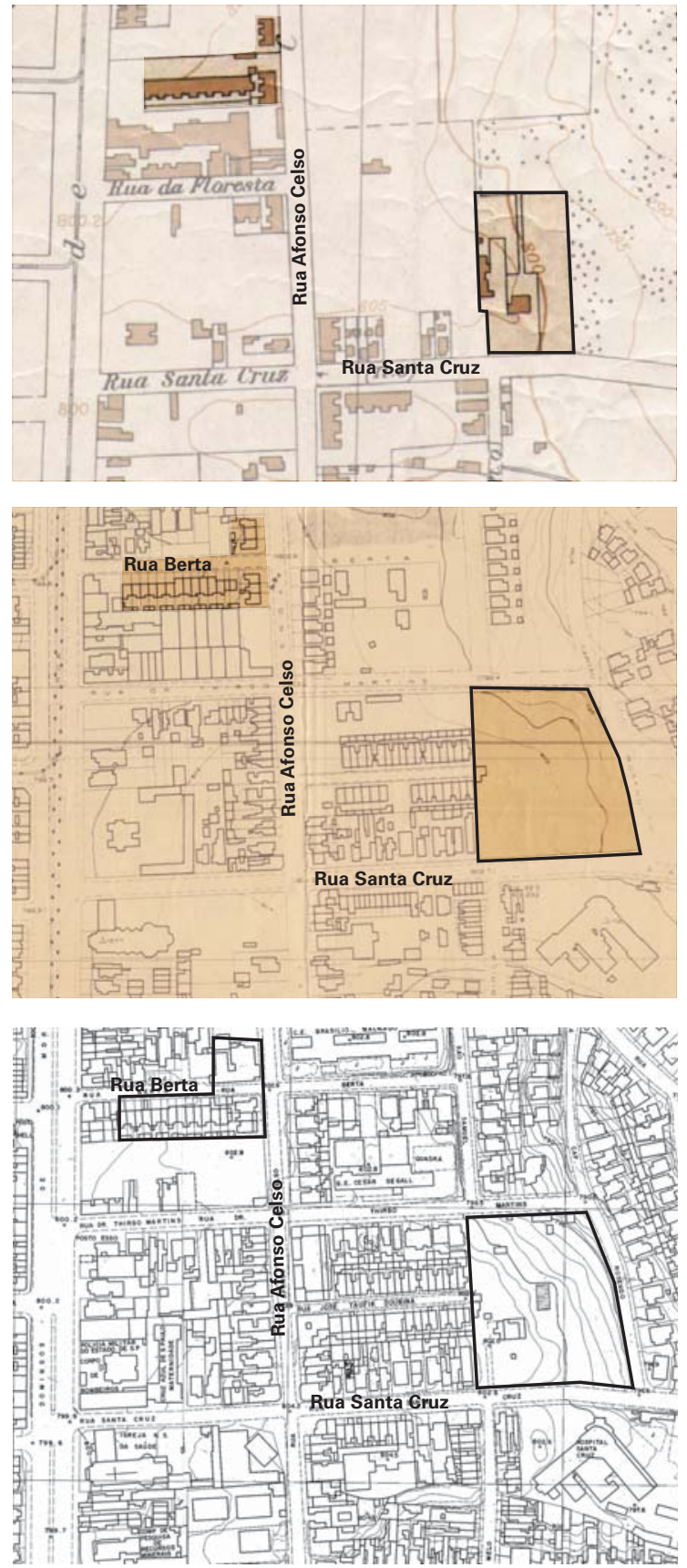
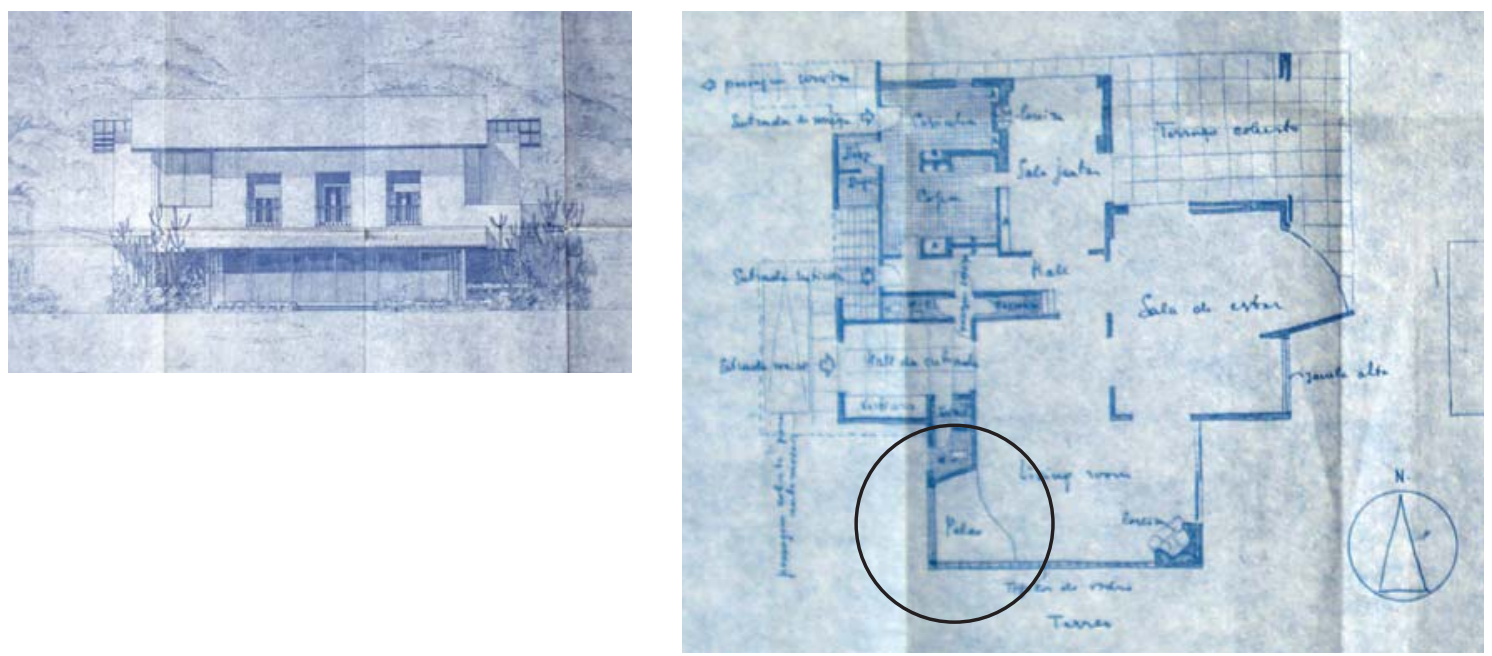
Os dois últimos discursaram após a cerimônia judaica ocorrida já no cemitério da Vila Mariana - não por acaso construído em terreno doado pela família Klabin ${ }^{52}$ - exaltando a personalidade e a contribuição de Warchavchik para a cultura arquitetônica. Na ocasião, Lúcio Costa foi requerido a dar um depoimento para a Folha de São Paulo, mas alegou que só teria "condições de recordar publicamente o grande amigo que foi Gregori Warchavchik daqui a alguns dias" ${ }^{53}$.

Com as informações sobre os presentes no velório, os depoimentos em jornais, a cerimônia fúnebre, poder-se-ia pensar que de alguma forma a morte de Warchavchik cristaliza momentos centrais de sua vida, na consagração do período precursor nos jornais, nas relações com os modernistas paulistas, os mecenas, o crítico e defensor Geraldo Ferraz, o ex-sócio Lúcio Costa e na ligação com os estoques fundiários da família Klabin. Porém o que poderia à primeira vista soar como momento de rememoração a dar nova vida após a morte, se mostrou circunstancial. Se na imprensa diária houve espaço para alguma cobertura, nos periódicos especializados não houve qualquer repercussão. É certo que o ano de 1972 se situou no interstício entre uma leva de revistas finalizadas anteriormente, como a Acrópole, Habitat, AD, AC, Arquitetura e Engenharia, BAC, Bem Estar, Forma, Módulo, etc., e outras que viriam após - como a CJ arquitetura ou a Projeto. Neste ano, poucas revistas, como a Construção São Paulo, a Casa e Jardim e outras de circulação mais restrita estavam sendo editadas, entretanto sem que houvesse nota alguma sobre o fato ${ }^{54}$.

O episódio também não se desdobrou em iniciativas de valorização da memória do arquiteto, sem que os órgãos de preservação levassem a diante qualquer ação para proteção de suas obras. As consequências seriam sentidas somente nos anos 1980.

\section{Morte e vida de um patrimônio ameaçado}

Após anos de abandono, entra em cena em 1983 a incorporadora Carmel, que instala em 24 de dezembro o plantão de vendas de seu novo empreendimento que seria erguido no local, intitulado ironicamente, Palais Versailles, um condomínio composto por quatro torres residenciais de quinze andares ${ }^{55}$. O projeto foi imediatamente combatido pela vizinhança que defendia a preservação do parque em meio à escassez de áreas verdes na Vila Mariana. A população organizou-se em torno do Movimento Pró-Parque Modernista, que se mobilizaria em defesa da área verde - a casa vindo em princípio a reboque, ganharia força a partir da adesão do Museu Lasar Segall à defesa do conjunto ${ }^{56}$ e posteriormente de entidades ligadas

52 Diário da Noite, 29/07/1972. Gregori era associado benemérito, junto com Maurício Klabin, filhos e respectivos companheiros em virtude da doação. Todos constam nominalmente do estatuto da Associação que gere o cemitério.

53 FSP, 28/07/1972

54 Conforme o Índice Brasileiro de Arquitetura - Biblioteca FAUUSP.

55 FSP, 25/12/1983.

56 Nos depoimentos publicados nos jornais, selecionamos o mais extremo, mas que representa a fala de 
à classe dos arquitetos - através de atos públicos divulgados em jornais de ampla circulação, exposições, folhetos, matérias jornalísticas ${ }^{57}$, e busca de apoios nos espaços políticos então em processo de redemocratização.

Com a denúncia da iminente concretização do empreendimento, em 27 de dezembro de 1983 o Condephaat abria o processo de tombamento ${ }^{58}$. Na realidade, o imóvel ainda não havia sido vendido pelos herdeiros de Mina e Gregori e a incorporadora não tinha autorização para instalar o plantão, pois nem sequer tinha o projeto aprovado na prefeitura. Com isso, o plantão de vendas pôde ser interditado pela municipalidade em fevereiro de 1984 . No Condephaat, a Carmel contestou a abertura de tombamento - apesar de não ser a proprietária do imóvel - questionando os méritos do tombamento, pois alegava que a casa já estava desfigurada e que se de fato fosse tão importante, já deveria ter sido tombada muito antes, e não apenas com a ameaça de sua demolição. A contestação foi julgada improcedente e a abertura de tombamento se efetivou.

Naquele momento ainda não estava certo se somente a casa ou todo o conjunto seria tombado, exercendo o Condephaat importante papel para a preservação integral do conjunto. A incorporadora chegou a propor novo projeto para aprovação no Condephaat, utilizando a casa como área social, preservando seu jardim de entorno e prevendo a compensação das árvores cortadas do bosque para dar lugar às torres. No entanto, diversas manifestações técnicas e políticas em favor da proteção integral do conjunto foram se agregando ao processo de tombamento: cartas do Movimento pró-parque Modernista, incluindo-se um abaixoassinado com mais de 3 mil assinaturas ${ }^{59}$, artigos publicados em jornais, manifestações do Instituto Astronômico e Geofísico, da Associação Brasileira de Arquitetos Paisagistas, do Instituto dos Arquitetos do Brasil, além de um estudo técnico realizado pelo Instituto de Biociências da USP, que atestava a importância ambiental do conjunto devido a beleza e diversidade de espécies vegetais nativas e exóticas. O presidente do conselho, Antônio Arantes endossava o parecer de Eduardo Kneese de Mello, de que a vegetação deveria também ser preservada. Para o arquiteto, então conselheiro pelo IPHAN, o tombamento se justificava por se tratar da residência de Warchavchik e pelo pioneirismo da casa e do jardim, devendo o conjunto ser preservado como um todo indissociável, sendo além do mais o jardim integrante do espaço envoltório da casa, dentro dos 300 metros de raio determinados pela lei. Kneese também apontava a carência de áreas verdes na Vila Mariana e a mobilização

uma parcela dos moradores do entorno: "Vamos ser realistas. Moro no bairro há 15 anos e nunca me interessei em ver essa casa. Pra mim era apenas uma casa velha e abandonada... O que vale é a área verde e por ela temos de lutar com unhas e dentes, fazer campanha para o governo desapropriar, derrubar os muros e fazer uma praça (...) Agora, quanto à casa e à piscina, é tudo uma porcaria que um cara aí construiu”. OESP, 23/01/84

57 Inclusive em meios especializados, como a matéria de Anita di Marco na revista Projeto, "DPH Procura Evitar Destruição da Casa da Rua Santa Cruz”, p.20-23

58 As informações do período do tombamento a seguir relatadas foram extraídas dos processos de tombamento CONDEPHAAT n ${ }^{\circ} 22831 / 83$ e IPHAN n ${ }^{\circ} 1121-\mathrm{T}-84$

59 Carta de SP, 27/07/1984, de Walter Troiani, pela Comissão Pró-preservação do Parque Modernista à Fundação Nacional Pró-Memória contida no processo de tombamento federal. 
da população em torno desta questão. Propunha o tombamento e a transformação da casa em Museu Gregori Warchavchik e jardim em área de lazer intitulada Parque Mina Klabin Warchavchik.

Em junho de 1984, a Prefeitura de São Paulo enquadraria o imóvel no zoneamento da cidade como Z8-200 ${ }^{60}$ no espírito da mobilização em torno do salvamento do imóvel, tendo sido assinado o ato em evento no Museu Lasar Segall e em 20 de outubro do mesmo ano, o Condephaat aprovaria o tombamento definitivo do conjunto, incluindo jardim e bosque adjacentes. Com isso, a realização do empreendimento tornava-se totalmente inviável.

Pouco antes, em 28 de setembro de 1984, os herdeiros apresentaram nova contestação, sem entrar no mérito do tombamento, mas baseando sua argumentação no fato de que o tombamento foi realizado sem que se fizesse menção ao pagamento de indenização pelo "desfalque patrimonial resultante", ferindo o direito de propriedade. Entretanto, a procuradoria do Estado argumentava que o tombamento não obriga a indenização alguma, pois não altera o regime de propriedade e ademais, a contestação não atacando o mérito do tombamento deveria ser rejeitada. Com isso, os herdeiros de Warchavchik moveriam uma ação contra Estado e prefeitura no início de outubro de 1984, alegando que o Tombamento estadual e o zoneamento municipal teriam "esvaziado irremediável e irrecuperavelmente o valor econômico" de sua propriedade. A ação foi julgada e Estado e Prefeitura seriam condenados a pagar a indenização - que teria como consequência a transferência da propriedade ao poder público. No entanto, ambos recorreram da decisão, e a ação correu longamente na justiça.

Nos debates acalorados em torno da preservação ou não do imóvel, Mauris afirmava que na venda, o empreendedor se comprometera a preservar a casa como área de lazer do condomínio, mas não tinha certeza se o faria e não estava preocupado. O engenheiro, sócio do pai na Warchavchik-Neumann, dizia que as pessoas que visitassem a casa ficariam desiludidas:

Da casa original - diz - já não existe quase nada. Ela foi inteiramente reformada em 1935 e sofreu nova reforma nos anos 70. Mais importante que ela é a casa da rua Itápolis, onde aconteceu a exposição modernista em 1930, da qual participaram Tarsila, Segall, Regina Graz e o próprio Mário de Andrade. Meu pai fez a casa da rua Itápolis para mostrar e a casa da rua Santa Cruz para morar ${ }^{61}$

De fato a casa da rua Itápolis, ainda em mãos da família, se encontrava e se encontra em bom estado de conservação, atestando o cuidado para com o imóvel. Sem que se entre no mérito da motivação econômica por trás da venda, sua visão parece corroborar o discurso de Geraldo Ferraz para quem o grande marco seria a casa modernista da Rua Itápolis: " $a$

60 Naquele momento, era a única forma de proteção em nível municipal, tendo em vista que a criação do CONPRESP só ocorreria cinco anos mais tarde.

61 Jornal da Tarde, 28/12/83 
primeira casa modernista, uma casa até certo ponto econômica, serviria para a demonstração da nova arquitetura" ${ }^{62}$. Eleita para ilustrar a capa da Habitat n ${ }^{\circ} 82$ que anunciava a publicação de seu livro sobre Warchavchik, era acompanhada pela chamada: "São Paulo, 1930. A primeira casa modernista, projetada e construída em 1930 pelo arq. Gregori Warchavchik, à rua Itápolis. Esta casa será mostrada detalhadamente no livro 'Warchavchik', a sair brevemente, em impressão de Habitat Editora Ltda.”63

De algum modo este rebaixamento da Casa da Santa Cruz estaria presente na redação final da resolução de tombamento do Condephaat. No artigo $1^{\circ}$ da resolução SC 29/84, justificava-se o tombamento: tratava-se da

primeira tentativa de implantação no Brasil de um tipo de arquitetura residencial conforme aos ideais estabelecidos pelo movimento racionalista no início do século na Europa, contribuindo assim, com uma experiência de adaptação à nossa terra dos princípios da arquitetura, gerados por aquela renovação cultural (grifo nosso).

Uma argumentação decerto hesitante ou ambígua quanto à efetiva modernidade da obra - como "tentativa" e como "experiência de adaptação". A distância entre o pioneirismo defendido por Kneese ${ }^{64}$ e a resolução de tombamento atenuante - além da ausência de menção ao valor ambiental e paisagístico do jardim e do bosque, tão defendidos e justificados ao longo do processo instruído ${ }^{65}$ e à intensa mobilização comunitária - sugere uma outra mediação compreendida pela dinâmica de efetivação do tombamento em instância decisória eminentemente política. O Conselho era composto por tarimbados e reconhecidos profissionais de áreas relacionadas à preservação, tais como Antônio Arantes na presidência, pelo SMH, Antônio L. D. de Andrade, pelo IPHAN, Murilo Marx pelo departamento de História da Arquitetura e Estética do Projeto/FAU-USP, Ulpiano Bezerra de Meneses, pelo Departamento de História/USP, a filha de Luis Saia, Helena Saia, pelo IAB, Carlos Lemos, pelo DARC, além de representantes do Departamento de Geografia e do Instituto de PréHistória da USP, representantes do IHGSP, IHGGB, CNBB, Cúria Metropolitana de SP e do Gabinete do Secretário Jorge da Cunha Lima ${ }^{66}$. Mesmo sem se conhecer as interpretações individuais dos conselheiros, não é preciso relembrar a visão radical de Lemos sobre a obra, como não seria improvável imaginar que balizasse sua atuação na votação do caso e que tivesse alguma ascendência sobre os demais. Questionado pela Revista Projeto sobre se a casa merecia ou não ser preservada, Lemos opinou: 
A casa da rua Santa Cruz é um documento da maior importância, constituindose num elo de ligação entre o passado e o presente, entre a arquitetura eclética e a arquitetura moderna. Em si, não é um exemplar de arquitetura moderna como muitos vêm alardeando, porque não possui um mínimo de requisitos identificados de modernidade (...). A casa da rua Santa Cruz, a meu ver, em vez de ser a primeira casa modernista de São Paulo, foi a última de tijolos e por isso deve ser preserva$\mathrm{da}^{67}$.

O conselheiro Antônio L. D. Andrade, então diretor da $9^{\text {a }}$ diretoria regional do IPHAN, responsável pela cidade de São Paulo, comunicava à Diretoria central sobre a APT pelo Condephaat, nos primeiros dias do ano de 1984. Em 20 de junho do mesmo ano, antes do tombamento definitivo pelo órgão estadual, enviava ofício ao subsecretário do Iphan, solicitando tombamento federal. Neste, alertava para o crescimento urbano desordenado que vinha destruindo testemunhos relevantes do processo de formação urbana.

Sua justificativa explicitava o peso da presença costiana no Instituto, em uma espécie de pedido de licença para seguir com a solicitação:

O exemplo da residência situada à rua Santa Cruz, projeto do arquiteto Gregori Warchavchik - amplamente veiculado pela imprensa - vem somar-se a tantos outros casos de destruição ou ameaças de definitivo desaparecimento, do já bastante delapidado (sic) acervo arquitetônico paulistano.

Trata-se, sem dúvida, de importante e fundamental referência para a moderna arquitetura brasileira, constituindo mesmo, respeitada a opinião do arquiteto Lúcio Costa, obra pioneira.

Cremos, portanto, ser indispensável manifestação desta Subsecretaria do Patrimônio Histórico e Artístico Nacional, correspondendo aos coletivos anseios de setores da população da cidade de São Paulo, que reivindicam a preservação da casa à rua Santa Cruz, incluindo suas áreas ajardinadas.

Entendemos, todavia, não bastar atentarmos para uma única obra de Warchavchik - não obstante seu significado e valores - importando compreendê-la no conjunto da produção do arquiteto, no qual julgamos evidenciar-se a "Casa Modernista" à rua Itápolis e a residência à rua Bahia (grifo nosso) ${ }^{68}$

O caráter exemplar das três obras está subentendido, não se explicitando ao longo do processo o porquê da seleção - e consequente exclusão do restante do legado do arquiteto. Cada uma das obras receberá um processo individual, com sua própria instrução, alimentado pela equipe técnica com pesquisa iconográfica, documental e histórica, procurando estabelecer as relações entre as três casas. No processo da Santa Cruz são anexadas cópias 
do trabalho de Geraldo Ferraz relativas à casa ${ }^{69}$, fotos do imóvel à época, realizadas pelo DPH, os processos municipais de aprovação das três obras e um histórico elaborado por Alexandre Rocha, que também será aproveitado na instrução das demais. Consideradas em perspectiva - da polêmica residência do arquiteto aos dois projetos de ampla repercussão, nos quais defendia a integração com as artes e mobiliário, o autor lança mão da periodização proposta por Ferraz - as obras até 1930, o período carioca, o retorno a SP. A referência se torna mais clara ao citar a atuação de Warchavchik na área da habitação social e a consagração da planta "V8", atribuída a ele - informação dada por Ferraz na apresentação do conjunto da Rua Barão de Jaguara ${ }^{70}$. Entretanto, seguindo Bruand, o significado do arquiteto para a história da arquitetura brasileira se restringiria à preparação de terreno para os desdobramentos posteriores, e a conclusão pareava com a historiografia hegemônica:

A figura do arquiteto Warchavchik, tão em evidência até a sua experiência carioca, deixa, entretanto, de ombrear com aqueles que deflagrariam a transformação fundamental da arquitetura brasileira, aquela cujo início se fez consubstanciado simbolicamente pela construção do Edifício do Ministério da Educação e Cultura, em 1936

Outra perspectiva será oferecida pelo ensaio realizado por Luiz Fernando Franco, posteriormente publicado na revista Gávea ${ }^{71}$, no qual o arquiteto discute a revolução estética processada pelas três casas, que para ele

constituem três etapas decisivas e quase didáticas do que poderíamos chamar de núcleo doutrinário da arquitetura moderna. Tombá-las enquanto monumentos das Belas-Artes, não acarretará uma neutralização mediante um reconhecimento acadêmico: dar-nos-emos, antes, um referencial finalmente sólido para a tarefa urgente de uma historiografia menos celebrativa e mais rigorosa de nossa arquitetura ${ }^{72}$.

A seu ver, a casa da Santa Cruz ainda apresentava hesitações, como Loos na casa Steiner, em representação unitária e simétrica - que a casa da Itápolis dissolve. Na primeira, a hesitação refletia o conflito latente entre dois sistemas de representação; na segunda, era dado o passo decisivo, a ruptura e a adoção do novo sistema simbólico. Já a casa da Rua Bahia, que não se inibia diante de um programa suntuoso, era um laboratório de experimentação dos conceitos em desenvolvimento. Se a casa da Itápolis tinha planta doméstica, a da Bahia expressava a liberdade.

Rejeitando a crítica que contrapunha o discurso de Warchavchik ao que efetivamente realizou, Franco expõe o problema: "Com Valéry, diríamos que a perenidade da obra depende menos da intenção do artista do que dos desenvolvimentos que ela recebe de outrem.

\footnotetext{
69 FERRAZ, 1965

70 FERRAZ, 1965:79

71 FRANCO, 1986:2-13

72 IPHAN, processo 1121-T-84, fl.81
} 
É essa a premissa que torna paradigmáticas as três casas de Warchavchik", independentemente da ideologia declarada pelo autor. Porém, “os desenvolvimentos recebidos posteriormente pela própria obra de Warchavchik e pela arquitetura brasileira em geral, frustraram, com raríssimas exceções, as promessas de então"73. Franco considerava que as três casas continham carga revolucionária suficiente para operar rupturas significativas nos hábitos sociais e visivos, mas as renovações daquelas promessas e surgimento de outras dependia de desdobramento do discurso sobre a cidade, abortado pela subsequente opção profissional contraditória que desembocou em obras como o edifício à Alameda Barão de Limeira, para Franco, expressão da restauração do ecletismo pelo moderno.

Dora M. S. de Alcântara, Coordenadora do Setor de Tombamento da DTC/ SPHAN, encaminha então o processo para o diretor da DTC, Augusto C. da Silva Telles, destacando o texto produzido por Franco, que comprovaria a feliz seleção proposta pela $9^{a}$ Regional. E concluía:

Fiéis a um propósito da seleção rigorosa da produção mais recente de nossa arquitetura para fins de tombamento, estamos convictos de estarmos diante de uma pequena série valiosa. Por suas características específicas, os elementos que a compõem parecem-nos insubstituíveis na página que ocupam do "álbum de família da humanidade" de que nos fala Lúcio Costa, referindo-se à ARQUITETURA, através da qual "podemos refazer, de testemunho em testemunho, os itinerários percorridos nessa apaixonante caminhada... ao encontro do tempo que ficou vivo para sempre porque entranhado na obra de arte" 74 (grifo nosso).

Telles também endossará os pareceres realizados por sua equipe, destacando não só o papel precursor de Warchavchik mas também a mobilização popular em torno do bem:

Como se depreende dos pareceres inclusos no processo, este tombamento significará o reconhecimento público do importante papel que a obra de Warchavchic assumiu na "fase heróica" da moderna arquitetura brasileira. Constituirá, também, um ato decisivo para a salvaguarda de bens de cuja importância a comunidade de São Paulo tem plena consciência, como ficou demonstrado com a campanha encetada no ano passado, para a preservação da casa da Rua Santa Cruz nº325.

Como visto anteriormente, O IPHAN vivia nos anos 1980 um momento de reformulação, no contexto da intitulada "fase moderna" marcada pela atuação de Aloísio Magalhães. É um momento de renovação dos quadros, de ampliação da noção de patrimônio e de maior permeabilidade às reivindicações da sociedade civil. No plano historiográfico é também momento de revisão, quando interpretações diversas ganham espaço. Ao considerarmos o peso de Costa na instituição e sua posição sobre a importância de Warchavchik 
para a história da arquitetura, explicitada desde a carta-depoimento de 1948, não é pouca coisa, em termos de revisão institucional, o tombamento de obras deste pelos motivos expostos pela equipe técnica do IPHAN. Tal como exposto na alteração da justificativa do tombamento dada pela equipe técnica e a versão final votada no conselho do Condephaat, aqui temos que considerar a instituição não uma entidade abstrata, mas uma estrutura dotada de agentes concretos com visões em disputa, com consequências diretas sobre as práticas. Mesmo não tendo o trabalho como foco a reflexão sobre os espaços políticos da preservação e a produção intelectual dos técnicos e dos conselhos, importa destacar a maneira como suas dinâmicas interferem e/ou definem a política preservacionista.-

Neste sentido, cabem algumas notas sobre a reunião do conselho consultivo - realizada em 13 de janeiro de 1986 - e a votação do tombamento das três casas. Eduardo Kneese de Mello, designado relator, defendeu o pioneirismo da casa da Santa Cruz, para ele, obra moderna objeto de feroz polêmica em contexto eclético e neoclássico:

Foram feitas críticas violentas ao seu estilo e à pessoa do arquiteto que a projetou, mas o tempo encarregou-se de mostrar e provar que essa casa foi a primeira casa modernista construída no Brasil, semente fértil da grande transformação arquitetônica que se operou em nosso país, a partir de então. A casa Warchavchik é o marco mais importante, histórico, do aparecimento no Brasil da arquitetura contemporânea ${ }^{75}$.

Kneese se colocou como importante defensor da preservação da obra de Warchavchik como reconhecimento da sua importância para a história da arquitetura brasileira não só perante o Iphan e o Condephaat, que teria recebido um pedido de tombamento assinado por ele há muitos anos ${ }^{76}$. O professor também convidou o arquiteto para falar dos 30 anos de "Acerca da Arquitetura Moderna" para sua turma de alunos do $5^{\circ}$ ano da FAUUSP em novembro de $1955^{77}$ e esteve presente, se não como organizador, na homenagem prestada por professores e alunos da mesma faculdade na comemoração do quadragésimo aniversário do manifesto ${ }^{78}$.

Em sua exposição de motivos, relembrava ainda o tombamento estadual e a mobilização popular para transformação da casa em museu e do jardim em área de lazer. Entretanto, com o tombamento atrelado ao das demais casas, este não ocorreu sem antes algum debate. Conforme registrado na ata da $119^{a}$ reunião do conselho, composto por nomes como José Mindlin, Gilberto Velho e Francisco Iglesias, houve quem considerasse que o tombamento de apenas uma casa - Neste caso a Santa Cruz - fosse suficiente como representativa da obra do arquiteto, como ocorrido com a obra do arquiteto Virsi, mas outros lembraram da importância das demais. Alguns recomendaram também cautela devido à

75 IPHAN, processo 1121-T-84, fl.105

76 Ver nota 64

77 HABITAT, 1955:16

78 Manuscrito original exibido na exposição "Modernista 80 anos”, 2010 
ausência de compensação financeira aos proprietários nos atos de tombamento. Entretanto, expôs-se que o proprietário não procurou impugnar a abertura do processo de tombamento; que no caso da Santa Cruz só se questionou se o tombamento federal poderia sobrepor-se ao tombamento já realizado pelo Condephaat. Lembrou-se das diferentes e complementares investigações estético-construtivas nas três casas e por fim, que já havia um grande esforço de triagem nas diretorias regionais, ou seja, que o número de pedidos de tombamento seria muito maior que aqueles que efetivamente eram encaminhados aos conselheiros. Também se considerou que a sensação de que o número de tombamentos aumentou derivava do crescente interesse que a matéria vinha proporcionando, ocupando espaço nos jornais como antes não ocupara. E assim, a votação era favorável unanimemente às três casas. O processo seguia com a homologação do tombamento e comunicação do ato aos proprietários e demais esferas competentes.

Ao fim do processo, foram juntados documentos encaminhados pela Associação PróParque Modernista, o trabalho final de especialização de Beatriz Galvão, realizado para o CECRE, reportagens diversas sobre a repercussão e continuidade da luta pela preservação do imóvel, a briga judicial e indenização aos proprietários, a denúncia da ausência de manutenção, que já se refletia em degradação da casa.

Com os tombamentos efetivados em nível estadual e federal, a ainda abundante cobertura jornalística, antes voltada à ameaça de destruição, reivindicação de tombamento e conversão do local em parque, passava a publicar, ao lado das reivindicações para conversão do imóvel em parque, denúncias não de ameaça por demolição, mas por abandono, que levava a casa a um rápido grau de deterioração e o parque ao crescimento descontrolado de sua mata. Desde 1977 vazia, mas sob cuidados de um caseiro, após o início da briga judicial, o imóvel ficaria sem qualquer tipo de manutenção, agravando a cada ano o seu estado de conservação. Em imagens de 1982 é possível identificar o estado de conservação das fachadas e da vegetação do entorno. A casa branca em local de vegetação densa e úmida faz com que as alvenarias sofram colonizações biológicas em poucos anos, mas o estado aparentemente não estava preocupante apesar de visíveis as patologias - além do que se nota que o jardim encontrava-se relativamente bem conservado. Em avaliação realizada por técnicos do Condephaat em 16/12/1983, era apontado o estado médio da estrutura, cobertura, elementos secundários e condições higiênicas e estado ruim do interior ${ }^{79}$. Já em fotos de 1984, vemos as intervenções realizadas pela incorporadora para a instalação do plantão de vendas: o imóvel recebeu nova pintura, os elementos circulares de vidro ao redor da janela superior central da fachada sul foram encobertos e pintados, foram colocados toldos e carpetes. Mas em imagens de 1986, após dois anos de abandono, tornam-se visíveis sinais de degradação, de manchas de infiltração, desplacamento do revestimento, vegetação descontrolada, depredações, confirmando o relatório realizado em 29 de julho de 1987 pelo

79 Ficha de vistoria contida no processo de tombamento estadual, $\mathrm{n}^{\circ}$ 22831/83, fls. 18-22. Na realidade, dos cinco itens avaliados, quatro foram considerados em estado médio e um em estado arruinado ou substituído inapropriadamente. 

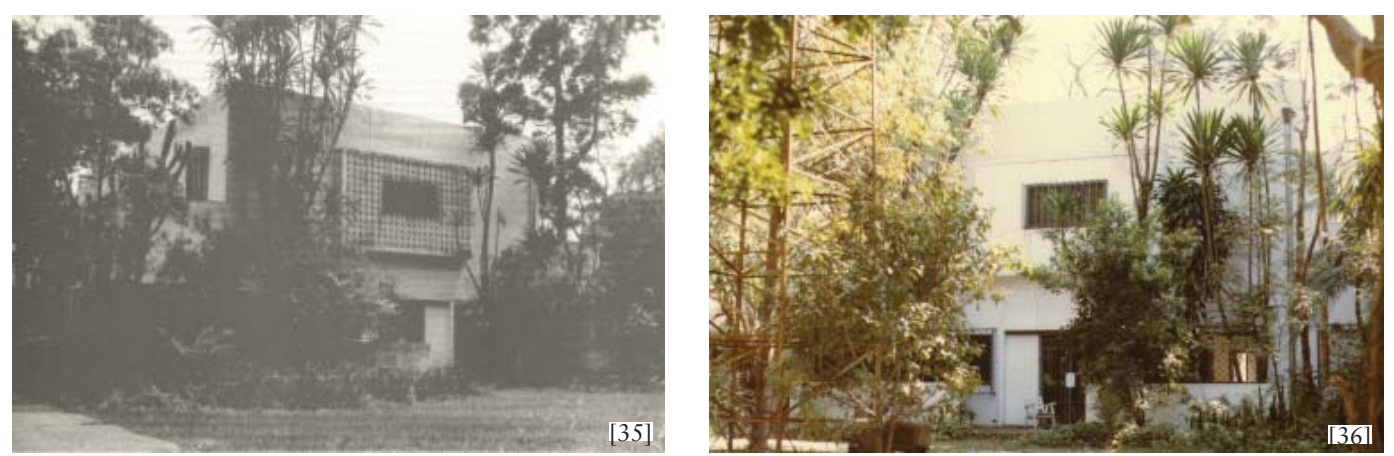

[35] Fachada sul em 1982. [36] Fachada sul em 1984, após pintura geral e fechamento dos blocos de vidro do $2^{\circ}$ piso, para a instalação do plantão de vendas das torres residenciais.

[37] Parte da fachada sul em 1986. Com o imóvel abandonado, rapidamente se deteriorou, foi depredado e o mato logo dominou o terreno.

[38] Montagem do plantão de vendas. [39] Sala de jantar, com mesa e carpete remanescentes do plantão de 1984 . Ao fundo, vê-se estante da antiga biblioteca. [40] Sala de estar em 1984. [41] Cozinha em 1984. [42] Entrada social em 1984. [43] Fachada norte em 1984, com toldo do plantão de vendas.
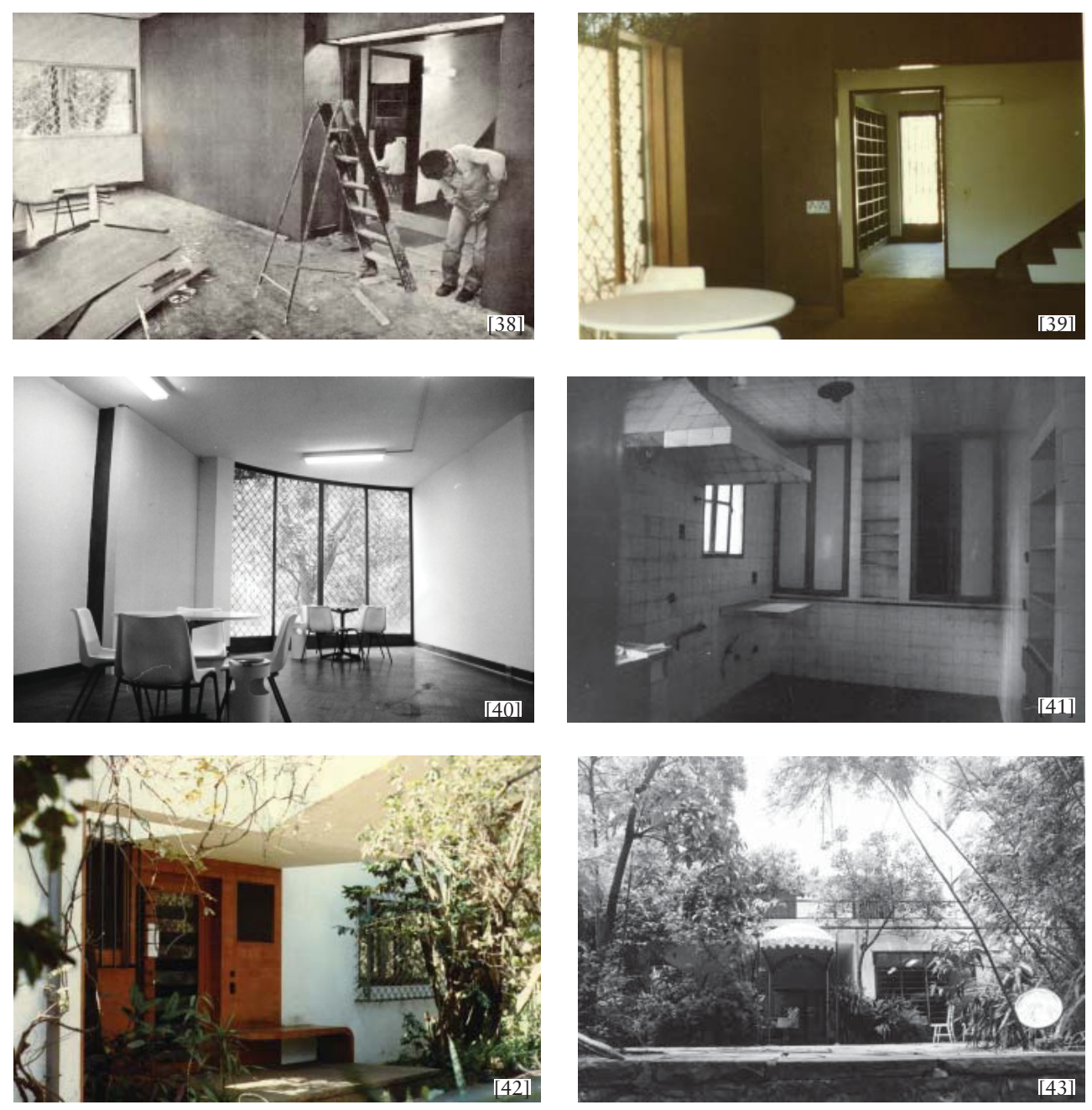

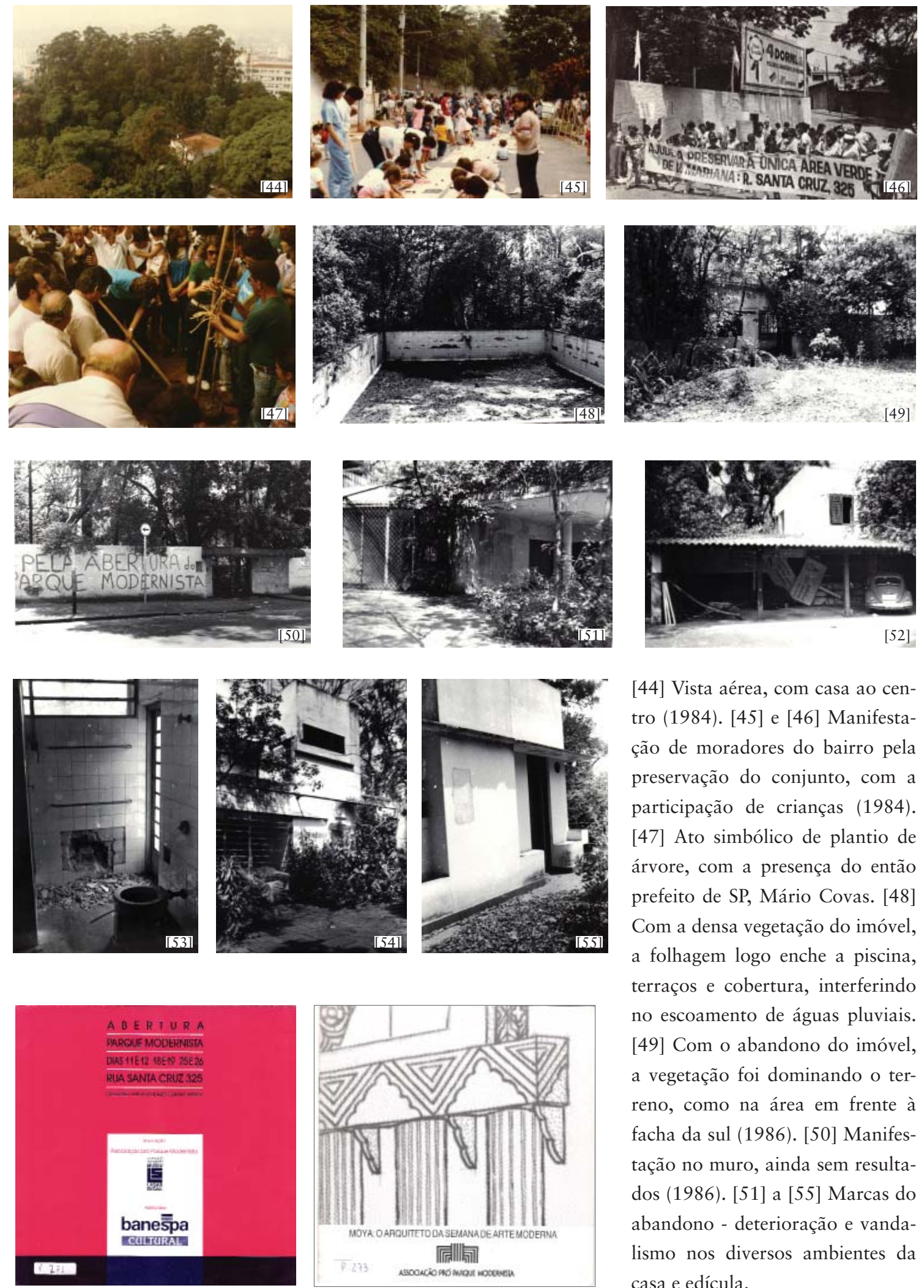

[44] Vista aérea, com casa ao centro (1984). [45] e [46] Manifestação de moradores do bairro pela preservação do conjunto, com a participação de crianças (1984). [47] Ato simbólico de plantio de árvore, com a presença do então prefeito de SP, Mário Covas. [48] Com a densa vegetação do imóvel, a folhagem logo enche a piscina, terraços e cobertura, interferindo no escoamento de águas pluviais. [49] Com o abandono do imóvel, a vegetação foi dominando o terreno, como na área em frente à facha da sul (1986). [50] Manifestação no muro, ainda sem resultados (1986). [51] a [55] Marcas do abandono - deterioração e vandalismo nos diversos ambientes da casa e edícula.

[56] Folder de divulgação da abertura da Casa Modernista em 1989, após obra de conservação financiada pelo Banespa como compensação de demolição da Vila Fornasaro, na Avenida Domingos de Morais. [57] Catálogo de exposição realizada na casa sobre Moya, organizada pela APPM e IEB. 
Condephaat ${ }^{80}$. Neste, constatou-se o mau estado de conservação da casa e da área verde, decorrente do abandono total, com infiltrações generalizadas e problemas de escoamento de água ${ }^{81}$, levando à deterioração dos revestimentos das fachadas e desabamento parcial dos forros. Os caixilhos de ferro também já apresentavam certo grau de deterioração devido à ausência de manutenção periódica.

Em agosto de 1986, a municipalidade contestava o teor da ação em favor dos proprietários, argumentando que mesmo reconhecido o inegável valor histórico e cultural do conjunto, o tombamento e a classificação como Z8-200, eles estavam deixando o imóvel se deteriorar, quando teriam a obrigação de conservá-lo. Questionavam assim se seria justo que o estado pagasse uma indenização por um imóvel que, quando recebido, estivesse completamente destruído. Na realidade, tanto Estado quanto Prefeitura afirmavam que, independentemente do resultado da ação, o proprietário tinha obrigação de manter o imóvel.

A partir de 1988 o movimento Pró-Parque Modernista, a essa altura já convertido em Associação Pró-Parque Modernista (APPM), iniciava uma nova estratégia para tornar a área do parque acessível ao público. Segundo Airton Camargo, ex-presidente da Associação ${ }^{82}$, deu-se início a uma série de atividades no entorno do parque para caracterizá-lo como uma área de "vocação" cultural. Nesta linha, foi elaborado à época um documento em conjunto com o CONDEPHAAT, intitulado "Diretrizes para utilização do Parque e da Casa Modernista”, protocolado nos processos de tombamento das duas instâncias.

Em maio do mesmo ano, a associação conseguiu uma verba junto ao Banespa, que arcaria com as despesas de manutenção da casa - cobertura, impermeabilização das lajes dos anexos, pintura, remoção de entulho, entre outros serviços, complementados com uma verba do metrô, que patrocinou a reforma das instalações elétricas ${ }^{83}$. O Banespa havia demolido nas proximidades, na Rua Domingos de Morais, um outro imóvel que estava em processo de tombamento, a chamada Vila Fornasaro, e teria que pagar uma compensação, revertida para a Casa Modernista. Com isso, entre 1988 e 1989 a casa passaria por uma primeira obra de conservação e em outubro de 1989 seria reaberta ao público ${ }^{84}$.

Em conjunto com o Museu Lasar Segall, IEB-USP e outros, a Associação organizou diversas atividades no imóvel, entre exposições, concertos musicais e encenações teatrais. Tal ocupação se consolidaria com a celebração de contrato de comodato firmado entre os herdeiros de Warchavchik e a Associação em 1990, levando esta a ocupar o espaço do anexo. Foram realizadas exposições como Anita e Oswald de volta ao parque ${ }^{85}$, Mobiliário

80 Condephaat, processo de tombamento n. 22831/83, fls. 522-523

81 Além de ausência de manutenção da cobertura, logo se acumulam folhas nas calhas subdimensionadas, em decorrência da proximidade com a densa vegetação do entorno.

82 Em depoimento dado em dezembro de 2009

83 Airton Camargo, depoimento dado em 12/12/2009

84 APPM, 1989

85 APPM, 1990a 
Modernista $1^{\circ}$ tempo/ John Graz e o Design ${ }^{86}$, Colibris ${ }^{87}$, Moya: O Arquiteto da Semana de Arte Moderna ${ }^{88}$ e São Paulo: A cidade e os trilhos ${ }^{89}$.

A associação organizava-se voluntariamente para abertura do parque, assim como as despesas ordinárias eram pagas com recursos de seus associados, sendo apenas as exposições financiadas com patrocínios e apoios culturais. Deste modo, é de se compreender que após pouco tempo, a entidade tenha perdido sua capacidade de manter um espaço daquela magnitude. Em 23 de março de 1994, o parque sofreu uma invasão e a casa foi atacada, tendo seus vidros, janelas, portas, louças e forros quebrados, assim como painéis de exposição destruídos. Em carta à Administração Regional da Vila Mariana anexada ao processo de tombamento, a Associação relata que em cinco ocasiões registraram Boletins de Ocorrência (uma em 1991, duas em 1992, uma em 1993 e esta de 1994), mas a polícia nada estava fazendo e por isso lhes solicitava maior policiamento da área.

Tal situação ficava patente em relatório de vistoria realizado pelo IPHAN em janeiro de $1995^{90}$, que denunciava o estado de abandono em que se encontrava o imóvel. O jardim havia sido dominado pelo mato e árvores ameaçavam a casa. O estado de abandono decorria da depredação de 1994 não superada e da ausência de manutenção, manifesta nas infiltrações, corrosão dos elementos metálicos, deterioração das esquadrias, desabamento de parte da cobertura do anexo. Por fim, técnicos questionavam a capacidade da APPM manter o espaço. Evidentemente, uma associação organizada em torno de trabalho voluntário e sem recursos próprios sem qualquer apoio do Estado ou outros parceiros, não tinham como dar conta de uma área de $12 \mathrm{mil} \mathrm{m}^{2}$. Nos processos de tombamento há diversas cartas solicitando colaboração e apontando os problemas de conservação que vinham ocorrendo, mas o bem não parecia constar das prioridades das instituições, ao menos enquanto o processo judicial corria.

Ainda em 1995, a ação contra o Estado de São Paulo era finalizada, fazendo com que o comodato perdesse seu valor legal e a propriedade passasse às mãos da Secretaria de Estado de Cultura. No entanto o fato não alterou a omissão da instituição para com a preservação do imóvel. No início de 1996, a APPM cobrava medidas para reverter o processo de degradação decorrente do abandono do imóvel, apresentando inclusive um orçamento para as obras de conservação, mas a associação foi colocada de lado sem que fosse substituída por qualquer ação de recuperação e revitalização do parque pelo Governo do Estado. Coincidentemente, dois dos articuladores centrais para a preservação do imóvel, o então prefeito Mário Covas e o vereador Marcos Mendonça, na qualidade de governador e secretário da cultura, se omitiram de suas responsabilidades na conservação do bem cultural que tanto fizeram para ser reconhecido.

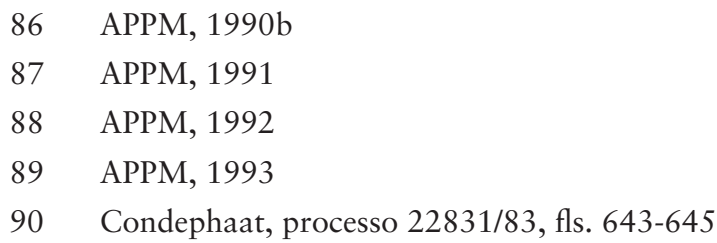


O parque ficou totalmente fechado até 1998, quando foi reaberto para abrigar as atividades das "Oficinas Culturais Parque Modernista", que se realizavam na garagem do anexo. O Estado oferecia cursos como de serralheria e mosaico. Neste período, a casa continuava fechada, pois não oferecia segurança aos visitantes em decorrência do seu estado de conservação. Na realidade, a Secretaria havia sido procurada pela Associação de Ensino de Arquitetura e Urbanismo (que gere a atual Escola da Cidade), que ocuparia o imóvel pagando em contrapartida o restauro do conjunto, mas a resistência dos moradores a um uso privado acabou fazendo com que esta desistisse. Nos fundos do parque, um grupo de escoteiros ocupou as edificações alinhadas aos limites do lote, nas áreas dos antigos laboratórios de química e fotografia e da casa do motorista, pondo abaixo um canil para dar lugar a uma cantina contígua a um galpão aberto. O grupo ocupa o local até hoje.

Mesmo com diversas denúncias a respeito do estado de abandono, somente em 1999 o quadro se reverteria, quando o Ministério Público abria Inquérito Civil para apurar denúncias de obras irregulares no conjunto. Na realidade, as obras denunciadas tinham sido aquelas realizadas pelos escoteiros, sem afetar a área principal do conjunto. Entretanto, com a questão trazida à tona, o Governo do Estado ficara obrigado a realizar obras de conservação na Casa Modernista, que nesta época estava praticamente em estado de ruína ${ }^{91}$. No ano de 2000 se iniciava uma obra sem projeto aprovado por firma sem especialização na área. Novamente com interferência do Ministério Público, ficou acordado que o Estado executaria apenas serviços emergenciais de segurança e estabilização da construção até que se elaborasse um projeto de restauro baseado em diretrizes estabelecidas pelas instituições de patrimônio e na definição de um programa de uso compatível com o imóvel.

Neste momento se colocava uma importante discussão: quais os critérios a serem adotados na intervenção?

\section{Voltar a 1928?}

Quando se abriram as discussões sobre as diretrizes de intervenção para o restauro da Casa Modernista da Rua Santa Cruz, alguns arquitetos logo se manifestaram favoráveis à "volta" a 1928. Os argumentos em favor desse "retorno" eram de que a casa que se consagrou em 1928 seria a figuração importante a ser preservada, pioneira, que foi a imagem publicada nas fotografias da época nas revistas e jornais e que se sedimentou em nossa memória. Chegouse a questionar a validade das transformações introduzidas na casa pelo próprio arquiteto, especialmente a reforma de 1934: "As alterações introduzidas trazem, portanto, uma série de dúvidas quanto à pertinência de sua adoção, o que leva a crer terem sido realizadas mais para atender as contingências da vida familiar do que com o propósito de promover revisões das concepções arquitetônicas do autor" ${ }^{92}$. 
Evidentemente que a justificativa primeira para a preservação da casa venha de sua figuração de 1928, mas além de se colocarem outros valores passadas décadas de sua origem, encontram-se alguns problemas para a execução do restauro de repristinação nesses termos, grosso modo, os mesmos apontados no capítulo anterior. Já está clara a questão das contradições existentes na obra e todas as adversidades relatadas por Warchavchik, demandando um trabalho artesanal único, sem qualquer registro, tendo se perdido grande parte com a reforma de 1935. Entre o projeto (intenção) e obra (execução) há um sem número de fatores que dão forma à realização. A casa, como se sabe, de fatura tradicional, apenas denunciava um fantasma que perseguirá a arquitetura moderna brasileira - o paradoxo entre o seu discurso modernizador e o atraso da construção civil ${ }^{93}$.

Também não há documentação precisa para sua restauração. A planta existente não tem nível executivo - o que também não garantiria que tivesse sido plenamente construída conforme o projeto, e o memorial é genérico, omitindo por exemplo a existência de caixilhos metálicos e a estruturação das janelas de canto. Além disso, a documentação fotográfica não registra todos ambientes da casa, privilegiando as áreas sociais em detrimento das áreas íntimas e molhadas. Para refazer a cobertura em telha colonial do térreo, os caixilhos, localizar as antigas envasaduras, locar os ambientes transformados, especificar os acabamentos, paginações, layouts das áreas molhadas, etc., além de destruir grande parte do edifício existente, demandaria um exercício de imaginação e invenção, nos moldes violletianos de nos colocarmos no ponto de vista do arquiteto autor da obra. Tal expediente geraria, portanto, um falso histórico em materiais contemporâneos sem conseguir voltar a 1928, afinal aquela configuração já não mais existe e nem é passível de reprodução, e destruiria as estratificações que se decantaram sobre a casa. Praticamente seria como demolir a casa existente para a construção de outra conforme a primitiva: a arquiteta Ana Beatriz Galvão ${ }^{94}$ realizou cálculo prevendo que para recompor a configuração de $1928^{95}$, seria necessário construir 52,8 metros lineares e demolir $81,4 \mathrm{~m}$ para um total de $120,9 \mathrm{~m}$ de paredes; Demolir $119 \mathrm{~m}^{2}$ de laje para deixar apenas $30 \mathrm{~m}^{2}$. Caberia perguntar o porquê de se abdicar de toda a historicidade da obra e de se naturalizar a destruição do documento como se transmitiu até o presente.

A quantidade e qualidade da documentação não é de forma alguma externa às decisões tomadas quanto ao partido de restauro. Do mesmo modo, é um instrumento poderoso de preservação. Basta notarmos que o contato que temos com a Casa da Santa Cruz em sua feição originária só é possível graças às fotos amplamente publicadas deste período. As plantas do projeto também são documentos importantes que registram as intenções do arquiteto, de modo particular e diverso da construção em si. Atualmente, aliam-se aos instrumentos já consagrados de preservação os recursos oriundos das tecnologias de modelagem virtual,

93 A impropriedade do discurso moderno frente às condições de exploração do canteiro pautaria o debate arquitetônico por volta dos anos 1960.

94 Atual superintendente da $9^{\circ}$ SR do IPHAN e autora de trabalho de especialização sobre a casa no CECRE em 1984

95 DPH, Processo 2001-0.143.169-1, p. 175 
que poderiam cumprir o papel de investigação e simulação em casos como este. A impossibilidade de reconstituição da casa de 1928 já está clara, mas caso se assumisse a extrema importância de seu retorno no tempo, no máximo se poderia cogitar a construção de uma réplica satisfazendo essa vontade de vivenciar o seu espaço perdido, não como nos falsos discutidos por Martínez ${ }^{96}$, mas em projetos didáticos, guardadas as peculiaridades, como do museu a céu aberto sueco Skansen, que expõe réplicas 1:1 de construções de diversas partes da Suécia ${ }^{97}$.

Outro problema se refere à argumentação que entra no mérito da qualidade da intervenção, julgando as intervenções posteriores a 1935 inferiores à configuração original, pioneira. Os defensores do retorno a 1928 deixam de respeitar um preceito básico do movimento moderno, que foi a busca da adequação da obra às necessidades humanas. A reforma de 1935 revela as transformações na vida familiar e social de Gregori Warchavchik, como tentamos esboçar mais acima, e tem por isso não só um valor em termos biográficos, por si só justificativa para a negação do partido repristinatório, mas também como expressão de sua trajetória arquitetônica, em um caso rico para o estudo da revisão projetual enfrentada por Warchavchik.

A questão, colocada pela reportagem da Folha de São Paulo a arquitetos que não trabalham na área do patrimônio trouxe exatamente este ponto de vista ${ }^{98}$. Carlos Warchavchik, neto de Gregori, considerou o tema polêmico, mas que haveria razões para defender 1934 - a versão de 1928 durou pouco tempo; as mudanças foram feitas pelo próprio arquiteto; para voltar ao original teria que pôr abaixo o existente e reconstruir. Eduardo de Almeida não quis opinar, destacando, entretanto, que qualquer que fosse o partido, importaria o uso, o programa a ser dado. Marcelo Ferraz, por seu turno afirmou: "Restaurar uma coisa sem saber pra que é o mesmo que nada. Não conheço as mudanças, mas, se foi ele mesmo que fez, a de 34 deve ser melhor. A gente vê muita coisa depois de uns anos”; Isay Weinfeld argumentou na mesma linha, considerando que se o autor modificou é porque percebeu que tinha alguma coisa a acrescentar. A reforma, é certo, foi muito além do que algum pequeno ajuste ou aperfeiçoamento, foi uma verdadeira transformação. Por isso mesmo merece algum reconhecimento neste sentido.

Nesta discussão fica claro o foco arquitetônico visual, em leituras impermeáveis às dinâmicas externas à intenção do arquiteto e figuração inicial da obra. Os debates giravam em torno do retorno a 1928 ou a 1934, pouco se afirmando o objeto como documento do presente, que recebeu contribuições destas e de outras épocas até sua transmissão aos dias atuais. Não se está apregoando que a obra seja intocável e que qualquer intervenção intencional ou incidental deva ser preservada, mas sim que se deva estabelecer um limite entre o que é descaracterização e o que é transformação, assumindo que toda intervenção de restau-

\footnotetext{
96 Cf. capítulo 2

97 http://www.skansen.se

98 FSP, 28/08/2001
} 
ro comporta algum grau de destruição e mesmo de repristinação, mas que a medida deva ser estabelecida através da indagação ao objeto, conforme postulado pelo restauro crítico. Assim, o próprio objeto coloca os problemas a serem enfrentados pelo restaurador, que então assume a dialética entre as instâncias histórica e estética para o desenvolvimento do projeto.

\section{O partido adotado e a restauração dos anos $\mathbf{2 0 0 0}$}

Com a intervenção do Ministério Público na condução do restauro da casa da Santa Cruz, Iphan, Condephaat, DPH e Secretaria de Estado da Cultura foram convocados para definir conjuntamente na justiça o partido arquitetônico a ser adotado. Em março de 2000 foram definidos os trabalhos emergenciais imediatamente autorizados que visavam impedir o avanço do processo de deterioração do imóvel. Os serviços consistiram no destelhamento e acondicionamento das telhas, execução de cobertura provisória em madeirit e manta plástica de modo a perpassar a platibanda, limpeza das varandas e desobstrução dos seus condutores de águas pluviais, remoção de vegetação de nascimento espontâneo por entre trincas e fissuras e remoção das porções de forros com risco de queda iminente ${ }^{99}$. Tais obras seriam concluídas em abril de 2001.

Enquanto as obras emergenciais eram executadas, as discussões a respeito do partido do restauro continuavam, contando com a participação de representantes, além dos três órgãos de preservação, da APPM, DOCOMOMO e Movimento Defenda São Paulo ${ }^{100}$. Naquele momento, o Governo do Estado não havia definido o uso para o imóvel e nesse sentido, a diretriz que se delineou procurava trazer flexibilidade na destinação, tendo como horizonte o atendimento de atividades educacionais e culturais, bem como o atendimento das exigências atuais de segurança, acessibilidade e conforto ambiental. Como norte, os órgãos de preservação concluíram: "na definição dos espaços, interiores e exteriores, o projeto deverá assumir a conformação atual da 'Casa Modernista' tendo como referência as construções em 1934” "101. Tal decisão foi ratificada no Ministério Público e a empreiteira contratada pelo Estado, Vemax, convidava o arquiteto Haroldo Gallo para elaborar o projeto.

A aprovação do projeto se deu em tempos diferentes em cada órgão de patrimônio. No DPH e no Iphan, o projetista enviou anteprojeto para apreciação em julho de 2001. Com uma proposta enxuta, procurando atender a diretriz, ambos os órgãos colocaram a exigência de documentação complementar, como levantamento fotográfico do estado anterior, concomitante e posterior às obras emergenciais, projeto paisagístico, e o condicionamento da intervenção na edícula à definição do programa ainda em aberto. Solicitadas as complementações, a Assessoria de Obras da Secretaria de Estado da Cultura encaminharia tão somente o levantamento métrico arquitetônico, assim como ao Condephaat, que só receberia o anteprojeto em julho de 2002. 
Sem atender às solicitações, no início de 2002 foi constatada obra irregular na Casa Modernista. Os serviços consistiam na demolição de toda a estrutura e entelhamento da cobertura originais, todo o forro em estuque, retirada do barroteamento do piso superior e substituição por perfis metálicos, execução de laje pré-moldadas em trecho do forro da cozinha, anteriormente em estuque, demolição das abas de concreto moldadas "in loco" sobre as envasaduras do piso superior existentes e seu refazimento, remoção de toda a argamassa de revestimento externo e revestimento cerâmico de paredes e forros interno, retirada de todas as esquadrias internas e parte das externas, implantação de nova rede de esgoto e de instalações elétricas, realização de limpeza dos blocos de vidro da circulação e retirada dos guarda-corpos metálicos do terraço para restauro e nova cromeação ${ }^{102}$. No relatório conjunto, elaborado pelos três órgãos de preservação, grande parte de tais serviços não aprovados são apontados como causadores de danos irreversíveis ao conjunto: demolição total da cobertura, forros, estruturas de madeira e concreto e revestimento, mesmo aqueles que se encontravam consolidados acarretaram na perda do material autêntico, original, que registrava as características dos materiais empregados, do tipo de fatura, "particularmente naquilo que se refere ao contraste entre a pretensão de uma arquitetura revolucionária convivendo com soluções tradicionais da arquitetura brasileira" ${ }^{103}$. A perda do material autêntico foi sentida nos diversos elementos constitutivos da construção. A remoção da argamassa, por exemplo, impediu a verificação da sua composição, tanto da mais recente quanto daquela descrita por Warchavchik, que acrescentava o pó de mica e caulim aos materiais inertes. A oportunidade de visualização das alvenarias sem os revestimentos tampouco foi aproveitada para investigação da estruturação da casa e de remanescentes das reformas - seria possível verificar, por exemplo, o emparedamento de vãos como aquelas janelas da fachada principal ou a estruturação das janelas de canto. Somada à agressiva intervenção, a ausência de registros e documentação do processo nega o acesso a um conhecimento só verificável através da construção.

Diante dos novos acontecimentos, Iphan, Condephaat, DPH, empreiteira VEMAX e Arq. Haroldo Gallo reuniram-se novamente em 15 de abril de 2002 para ajustar o projeto arquitetônico visando a regularização da obra. Os órgãos ordenaram pela recomposição do barroteamento de madeira e das vigas de concreto da estrutura primitiva do piso superior e da escadaria, permitindo a utilização dos perfis metálicos como reforços estruturais onde se fizessem necessários. Quanto aos forros, deveriam ser recompostos em estuque conforme a solução original, sendo aceita a sua substituição somente na cozinha, onde foi executada a laje pré-moldada. Ali as perdas foram consideradas como danos irreparáveis e por isso decidiu-se pela sua manutenção. Na mesma reunião, foi autorizado o alteamento do nível do piso superior em cinco centímetros "para permitir uma impermeabilização segura e confiável das varandas do pavimento superior” ${ }^{104}$. 
O projeto só seria aprovado em outubro de 2002 no Condephaat ${ }^{105}$, ainda assim com a ressalva de que o escritório teria que apresentar informações complementares. O material apresentado era bastante sucinto, composto de relatório fotográfico do estado atual (2001), levantamento fotográfico do período entre 1934 e 1940, memorial descritivo e anteprojeto de restauro. O Condephaat solicitava na aprovação do projeto, o envio do relatório referente às cores adotadas nas pinturas externas e internas das alvenarias, esquadrias, grades, telas, forros, rufos, etc., bem como a respectiva proposta cromática. Curioso é que o relatório de prospecções pictóricas parietais já havia sido realizado em junho de 2001 pela arquiteta Regina Tirello, mas não foi submetido aos órgãos.

Contratado com as obras emergenciais, o levantamento se realizou mediante baixo aporte financeiro e péssimas condições ambientais: “A degradação é tamanha que entre as grossas crostas de tinta látex aplicadas nas últimas décadas - que descolam-se em placas por causa do mofo e da umidade presentes nas superfícies - existiam até mesmo caramujos!" ${ }^{106}$. A intensa umidade, mesmo combatida com tentativas de secagem a lâmpadas especiais, fez com que em algumas paredes as tintas das superfícies ficassem cremosas, com as camadas a estudar inseparáveis. Os forros ameaçavam desabar, trazendo riscos aos operadores, fazendo com que fossem tratados em uma segunda etapa, com a retomada das obras e a retirada de amostras para análise. Além disso, com o escopo reduzido, o levantamento não incluía a caracterização dos substratos, das argamassas de revestimento e mesmo de aprofundamento sobre a composição de camadas estratigráficas que necessitariam de exames laboratoriais para precisar sua configuração - as prospecções indicavam, por exemplo, a possibilidade de diversas pinturas de 1928 terem sido realizadas sobre a tradicional técnica de "barra-lustre", recomendando a investigação mais aprofundada para confirmação ${ }^{107}$.

O relatório revelava que a casa teria tido seus ambientes em branco apenas nas pinturas recentes, tendo sido colorida na maior parte de sua vida. Da primeira fase, foram encontradas cores contrastantes, pinturas metalizadas, azul acinzentado, havana, vermelho brilhante, ocre. Entretanto, não foram localizadas exatamente as cores descritas por Warchavchik em seu relatório a Giedion ${ }^{108}$ - teria havido uma decapagem completa anterior às camadas encontradas? As condições ambientais alteraram suas características ou a qualidade das informações? O arquiteto não teria executado tal como enunciou? As cores

105 No IPHAN, o projeto foi aprovado somente em 2004 e no CONPRESP, em 2005. Nota-se que o projeto foi aprovado no IPHAN no Departamento do Patrimônio Material e Fiscalização - DEPAM e não na $9^{a}$ Superintendência Regional, que seria o caminho de praxe, porque no intervalo de tempo entre a realização do projeto e submissão ao IPHAN, assumia essa superintendência o próprio Haroldo Gallo. Os tempos de aprovação foram diferentes pelos atendimentos descompassados às solicitações de complementação documental, paralisação da obra e morosidade na análise dos processos.

106 TIRELLO, 2001:5

107 TIRELLO, 2001. Normalmente a técnica, que unia à massa pigmentada cal e pó de mármore, conferindo brilho e impermeabilidade, era adorada para imitação de pedras, mas aqui consistiria em uma faixa monocromática de $90 \mathrm{~cm}$.

108 Ver página 188 
metalizadas aparecem em paredes e caixilhos das duas fases decorativas, mas a partir de 1935, combinavam-se com tons de cinza, beges, amarelos acamurçados "que diferem significativamente em espessura, material e refletância dos amarelos do primeiro ciclo decorativo (27)" ${ }^{109}$. Algumas das paredes identificadas como do segundo período tinham somente três ou quatro camadas sobrepostas, com tonalidades mais pálidas e texturas típicas de tintas comerciais mais recentes, das décadas de 1950/60. Se tal etapa de levantamento tivesse sido aprofundada, muito desse aspecto invisível nos registros preto e branco se revelaria.

As prospecções descobriram também a existência de uma pintura decorativa mural no quarto da criança, de grande qualidade, que deveria ter sido (e não foi) objeto de proposta de restauro e incluída nos serviços contratados posteriormente. A pintura estava presente em duas das paredes e dada sua qualidade se cogitou que fosse de autoria de Lasar Segall. Deste modo, foi consultada a diretoria do Museu Lasar Segall, que no entanto, embora reconhecendo a qualidade das cenas de brincadeiras infantis, descartou a possibilidade. Em primeiro lugar porque não havia conhecimento sobre obras para ilustração infantil ou qualquer obra que tivesse alguma semelhança com esta, em segundo lugar, porque foram consultados os filhos de Segall e Warchavchik, que mesmo sem conhecer a autoria, foram unânimes em duvidar de uma possível atribuição ao artista ${ }^{110}$. Uma decapagem da pintura que a recobre talvez pudesse revelar a assinatura do autor.

O relatório não trazia fichas de todos os ambientes nem informações de prospecções nas esquadrias e grades, sendo estas apenas mencionadas. Como trabalho de subsídio, fornecia uma visão global sobre as características cromáticas nas configurações de 1928 e 1935 - caberia ao autor do projeto interpretar as informações, aprofundar as investigações, como sugerido no próprio relatório, e elaborar proposta cromática. Mas questionado pelos órgãos sobre a ausência de especificações no projeto de restauro, esclareceu que não havia informações sobre as cores pois seria dispensável repetir as informações contidas no extenso relatório, concluindo: "Destacamos que a citada peça técnica simula as situações prospectadas tanto para 1927 quanto para 1934, que deverá ser assim adotada por determinação das diretrizes de partido pelos órgãos de preservação" ${ }^{111}$. Contudo, nem todas as cores foram indicadas em escala pantone e mesmo em caso positivo, as cores simuladas na impressão destoavam destas, o que sem um acompanhamento técnico adequado e aliado a uma interpretação equivocada trouxe consequências desastrosas para a pintura dos ambientes na posterior obra de restauro.

Se a obra irregular trouxe danos irreversíveis à matéria original, tampouco o canteiro investigou e produziu documentação a respeito de vestígios de 1928 e das soluções construtivas encontradas em geral. O projeto apresentado também não levantava detalhadamente, por exemplo, as esquadrias, o desenho da cobertura, os armários e peças da cozinha, sani- 
tários, closet, vestíbulo, sala de estar, saleta, etc. O memorial descritivo mencionava a recuperação das estruturas de concreto, mas não há plantas e fotografias que identifiquem quais elementos, a sua localização, os tipos de patologias encontradas, etc. Neste sentido, outra ausência que chama a atenção se refere ao mapeamento de danos, peça básica para qualquer projeto de restauro. Evidentemente deve-se considerar o contexto absurdo em que a obra irregular ocorria simultaneamente ao projeto.

Para piorar a situação, a verba reservada pelo Governo do Estado subestimou os custos, fazendo com que os serviços, realizados entre 2002 e 2003 fossem paralisados ${ }^{112}$. A obra só seria retomada três anos depois, com a abertura da licitação em 2006. A interrupção dos serviços foi extremamente maléfica à construção, pois expôs várias partes do edifício à ação do tempo. Embora tenha sido refeita a cobertura e introduzida uma subcobertura, os topos das platibandas, as lajes sobre as janelas, os pavimentos dos terraços e os paramentos de alvenaria encontravam-se totalmente expostos, assim como as áreas internas próximas às aberturas, por conta da retirada quase total das esquadrias, causando a deterioração de seus elementos em decorrência do contato com a umidade. $\mathrm{O}$ forro de estuque havia sido refeito conforme orientação dos órgãos de preservação, assim como parte do revestimento externo e interno, de argamassa e de cerâmica, além da rede elétrica e hidráulica ${ }^{113}$.

Em outubro de 2006, a obra seria reiniciada, compreendendo os serviços de refazimento das abas de concreto; término das argamassas de revestimento das paredes e azulejamento das áreas molhadas; execução dos assoalhos, pisos litocerâmicos dos terraços, pisos cerâmicos dos sanitários do pavimento superior e parte dos tacos, chapins e soleiras, além da recuperação da outra parcela de tacos, dos mármores e arenitos; Impermeabilizações; término dos forros; execução e recuperação das esquadrias de madeira e de ferro (incluindo as ferragens); instalação dos vidros; pintura geral (exceto sobre as paredes da pintura mural encontrada); término das instalações hidráulicas e elétricas e colocação das peças e acabamentos; descupinização; inserção de cobertura em chapa metálica sobre os reservatórios de água. Para proteção contra chuva, além da subcobertura, foram substituídas as tubulações de águas pluviais por uma solução aparente que previa saída aberta da calha para o tubo, iniciada com uma espécie de funil, de modo a impedir o entupimento. $\mathrm{Na}$ varanda, foi realizada uma réplica da floreira e fonte, entretanto a partir somente de fotos, e mesmo assim visivelmente diferente nas proporções e na ausência do rodapé em mármore. Como já discutido, mesmo que fosse uma cópia fiel, sua proposição seria passível de questionamento. Outra intervenção que extrapola a conservação se refere à iluminação. Foram previstos pontos para a iluminação de emergência acima das portas, prevendo-se rotas de fuga. Para isso, foram escolhidos espelhos idênticos aos originais, de aspecto metalizado, confundindo os visitantes que ficam perplexos com o porquê do arquiteto ter previsto tomadas naquelas posições. Além disso, sem um programa de uso definido, a escolha dos pontos de iluminação se deu de modo quase aleatório, e as luminárias ordinárias, escolhidas pelo menor preço 
tornam-se uma interferência negativa nos ambientes.

Em consequência da aprovação do projeto condicionada ao conteúdo do relatório de prospecções estratigráficas parietais, sem uma clara definição da proposta cromática, o arquiteto pôde recorrer a um expediente diferente da indicação dos órgãos de preservação quanto ao partido cromático, pois ao invés de recuperar as características de 1935, buscou “conciliar” a solução de 1928 com a de 1935 - e ao que parece, se pudesse ter optado, teria feito o mesmo com a fachada:

A leitura (parcial) das duas materialidades tornou-se possível através do partido cromático, pelo artifício de um testemunho legível da solução de 27. Embora a cor dominante adotada foi a de 34, junto com essa foi aplicada em cômodos que haviam sofrido alterações espaciais a de 27 , formando-se um estado de convivência temporal nunca antes existido. Sem as imposições de critérios poder-se-ia ter aplicado algo semelhante à fachada, cuja manutenção de 34 não permitiu recuperar a imagem emblemática divulgada por toda a historiografia da arquitetura ${ }^{114}$.

Se o histórico da obra de recuperação dos anos 2000 permite visualizar o pouco apreço pelos materiais autênticos da casa, a manifestação do arquiteto autor do projeto de restauro torna evidente sua preferência por uma intervenção que recuperasse a "imagem emblemática" da casa. Nota-se que quando questionado pela Folha de São Paulo em 2001 sobre os partidos de 1928 e 1935, pendia para 1928, mas disse ter dúvidas. "Ele acha [que] o projeto de 27 registrava uma 'característica panfletária', mas concorda que a de 34 mostra um 'modernismo mais maduro"" 115 . Resta compreender em que medida uma intervenção que possibilitasse "um estado de convivência temporal nunca antes existido" contribui para a compreensão da obra a ser preservada. Em termos concretos, foram criadas situações em que ambientes criados em 1935 foram pintados com as cores de $1928^{116}$. Como o escritório e vestíbulo, que deram lugar às salas de estudos e biblioteca. $\mathrm{Na}$ sala de estudos foram reproduzidas o que seriam em teoria as cores originais, um vermelho havana (quase marrom) nas paredes e um forro cinza azulado. Mas as cores utilizadas, talvez imitando a inadequada impressão do caderno ao invés do código Pantone especificado, resultaram em um vermelho e um azul vivos, aparentemente de tintas acrílicas de distribuição comercial, quase insuportáveis para a permanência em uma área de apenas $3 \times 4 \mathrm{~m}$. Na sala de leitura/ biblioteca, ocorreu o mesmo: tentou-se imitar as cores do vestíbulo, através de paredes amarelas e forro vermelho vivo, de um acrílico fosco que não existia na época. E este problema apareceu em todos os ambientes, mesmo aqueles em que se tentou simular as cores de 1935, como no quarto de Mina, onde haveria o barra-lustre, descartado pela substituição do revestimento.

114 GALLO, 2007.

115 FSP, 28/08/2001. Enfim, novamente uma visão restrita à dimensão iconográfica da obra, na qual o restaurador opta sobre o que prefere mostrar, independente da densa discussão do campo.

116 Gallo e os arquitetos envolvidos no processo datam as fases como de 1927 e 1934, que são os anos dos projetos. Os anos de 1928 e 1935 aqui utilizados se referem aos anos de execução da obra. 
Ou a sala de jantar que, antes revestida em madeira, ganhou as cores de 1935. E por aí em diante.

Além da perda de importância do material documental, os casos das cores e da iluminação são as mais evidentes consequências da realização de uma obra sem programa de uso definido. O restauro devia conservar as características atuais tendo em vista a conformação de 1935, mas deveria imitar uma ambiência perdida? E apesar de os técnicos terem aceitado a obra como de boa qualidade naquele contexto conturbado, no qual importava salvá-la da completa destruição, a má execução seria sentida nos anos posteriores nas infiltrações em vários pontos, nos caixilhos emperrados, nos rodapés soltos.

Após o término da obra em julho de 2007, o Governo do Estado novamente se eximiu de suas obrigações, decretando permissão de uso em 2008 em favor da Prefeitura de São Paulo por tempo indeterminado, tendo como condição a criação de um centro de referência do modernismo no âmbito do projeto Museu da Cidade desenvolvido pelo $\mathrm{DPH}^{117}$. Com isso, o imóvel passou a ser gerido pelo departamento, que programou exposições e outras atividades culturais na casa e contratou equipe de educadores, que monitoram visitantes e promovem atividades com grupos escolares que passam pela casa diariamente ${ }^{118}$. A Divisão de Preservação/DPH ficou responsável pela conservação do imóvel, contratando equipe para a manutenção programada e elaborando projeto para o restante do conjunto, ainda tristemente degradado. A morosidade do processo de recuperação do conjunto é sentida nas edificações praticamente arruinadas do salão de jogos, casa do jardineiro, vestiários, piscina, edícula e na própria casa que já carece de obras de conservação. O grupo de escoteiros ainda ocupa as edificações dos fundos, realizando fogueiras e acessando o imóvel quando bem entendem, criando situações de riscos em uma relação estranha entre uma entidade privada em um bem público. Ainda no mesmo ano, SMC e SVMA passaram a compartilhar a gestão do imóvel, ficando a Cultura responsável pela manutenção das edificações e o Verde, pelas áreas do bosque e jardim ${ }^{119}$.

Embora seja necessário reconhecer que a intervenção empreendida nos anos 2000 reverteu o processo de degradação que caminhava para o arruinamento total da primeira casa de Gregori Warchavchik no Brasil, algumas perdas ocorreram nesse percurso, em virtude da pouca valorização da obra em sua materialidade e desenvolvimento ao longo do tempo. Ecos do desprestígio da intervenção de 1935 ressoaram diretamente no restauro e a supressão total de alguns de seus elementos construtivos fez com que perdêssemos a possibilidade de conhecer elementos de sua constituição física, técnicas empregadas, solução estrutural, características e composição dos materiais, procedências, modos de fatura, etc. Soma-se a isso a ausência de documentação e registro das etapas do levantamento e do restauro, procedimento básico recomendado pela Carta de Veneza de 1964. 
Neste sentido, continua mais atual do que nunca o paradigma de respeito à autenticidade material da obra arquitetônica, a qual deve ser entendida não como ícone, imagem, projeto ou intenção pura, mas como artefato vivo no tempo, produzido mediante condicionantes sociais, técnicos e culturais. Tal afirmação poderia até soar lugar comum, entretanto, é de se espantar que mesmo uma das mais emblemáticas obras de nossa arquitetura moderna continua pouco conhecida em sua consistência física, carecendo de estudos.

Se o tombamento originado pela possibilidade da perda é quase regra, a mobilização popular pela defesa do conjunto é fato significativo e infelizmente raro. De qualquer modo, o estudo da história do processo do tombamento e do restauro se mostra relevante, seja no exame das tensões sociopolíticas e econômicas, seja nas instruções dos processos como pesquisa e como objeto historiográfico. Como protagonista de diversas polêmicas ao longo de sua história, da inauguração às disputas historiográficas da qual foi objeto, passando pelo episódio do processo de tombamento e das intervenções recentes para sua recuperação, a casa da Rua Santa Cruz contém uma trajetória que escancara a necessidade de ampliarmos a discussão acerca da preservação de obras modernas no Brasil, da problemática do reconhecimento, identificação e atribuição de valores aos critérios de intervenção e restauro.
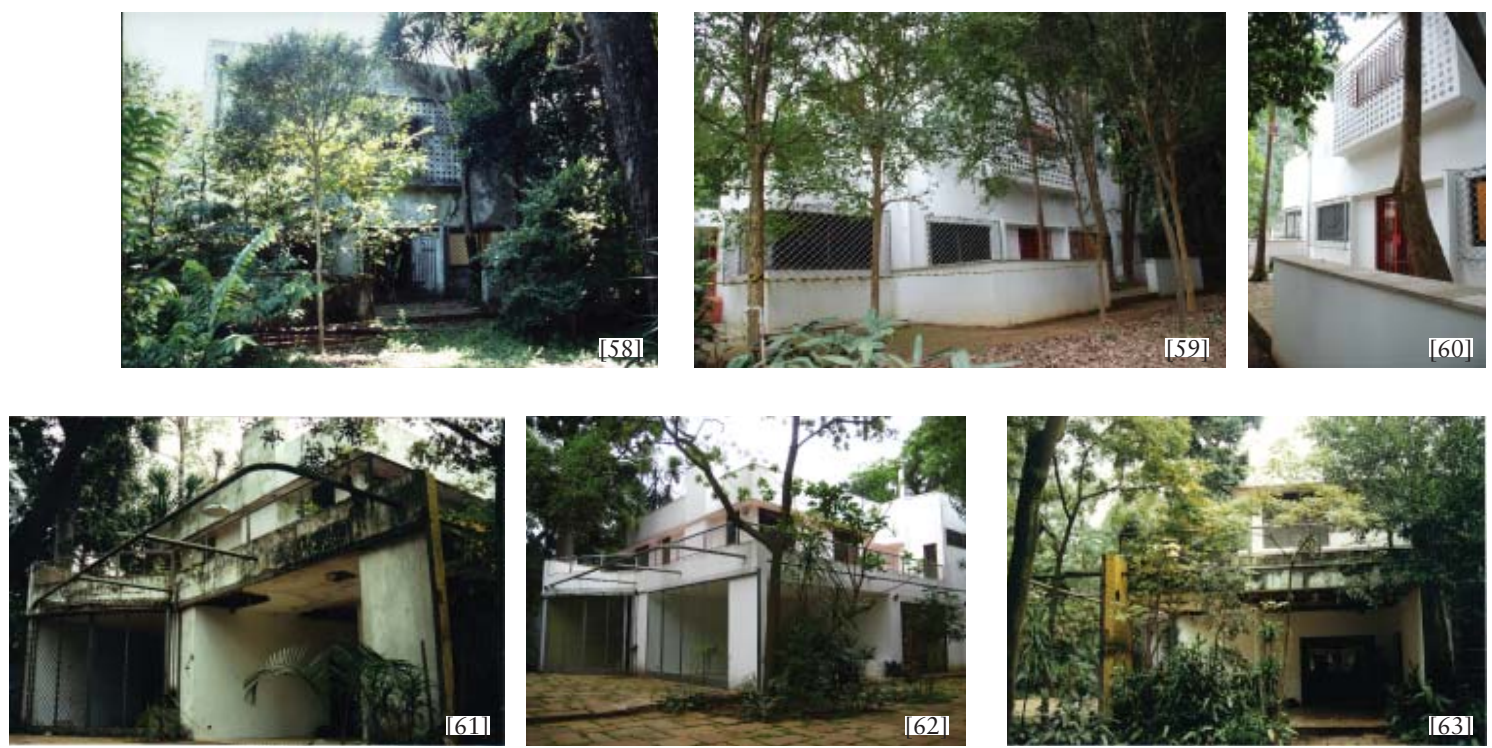

Fotos comparativas. Fachada sul em 2001 [58] e 2008 [59] e [60].

Fachada leste/ norte em 1998 [61] e [63] e em 2008 [62]. Fachada oeste em 2001 [64] e em 2008 [65]
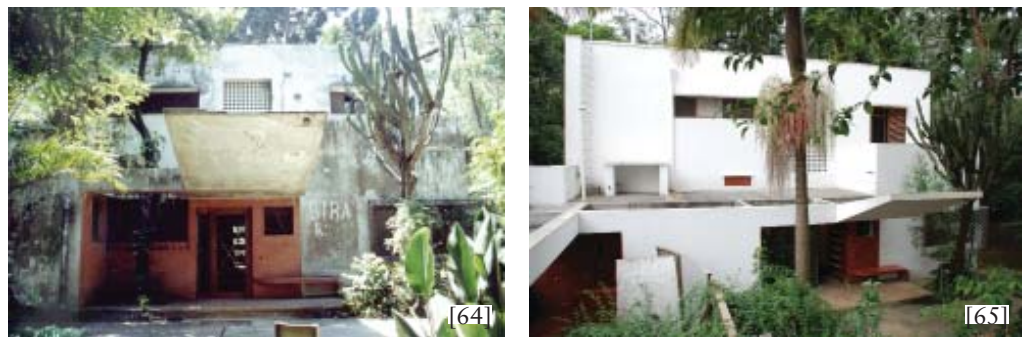

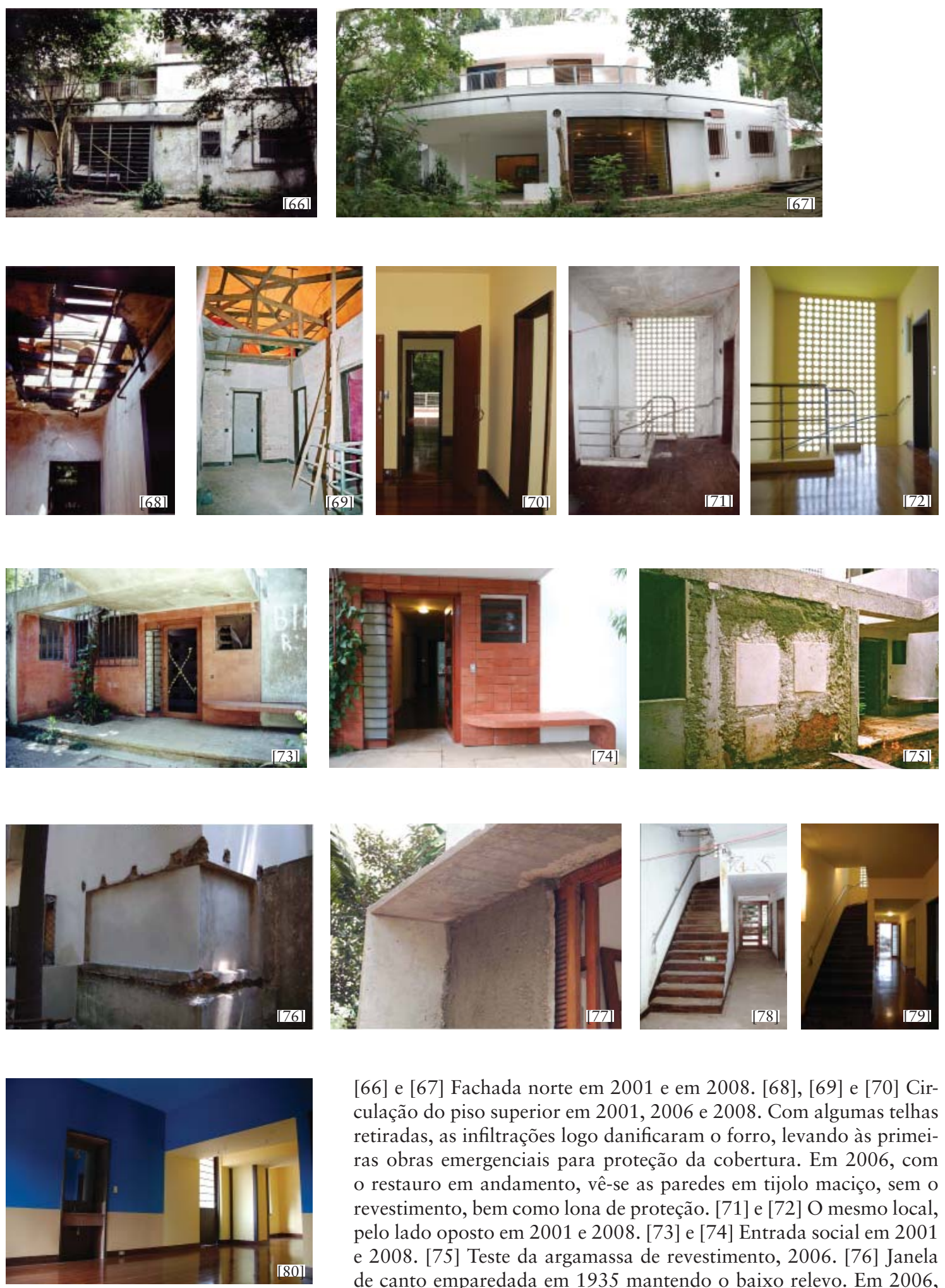

[66] e [67] Fachada norte em 2001 e em 2008. [68], [69] e [70] Circulação do piso superior em 2001, 2006 e 2008. Com algumas telhas retiradas, as infiltrações logo danificaram o forro, levando às primeiras obras emergenciais para proteção da cobertura. Em 2006, com o restauro em andamento, vê-se as paredes em tijolo maciço, sem o revestimento, bem como lona de proteção. [71] e [72] O mesmo local, pelo lado oposto em 2001 e 2008. [73] e [74] Entrada social em 2001 e 2008. [75] Teste da argamassa de revestimento, 2006. [76] Janela de canto emparedada em 1935 mantendo o baixo relevo. Em 2006, teve o gradil removido temporariamente para aplicação de revestimento e pintura da superfície e manutenção da peça. [77] Aba de

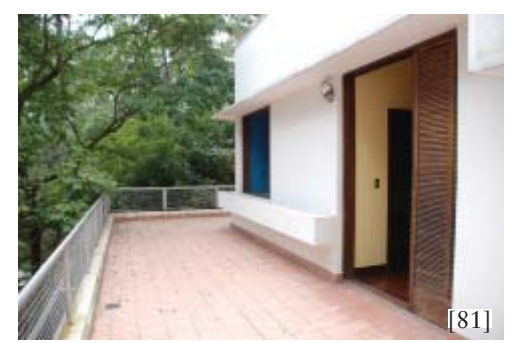
concreto refeita e placas pré-moldadas para embutimento de portas e janelas já posicionadas, 2006. [78] e [79] Circulação do térreo em 2001 e em 2008. Nas imagens de 2001, vê-se todas as paredes internas em branco. [80] Antigo quarto de Mina, com pia instalada em antigo nicho da chaminé. Com os armários demolidos, o ambiente fica incompreensível, especialmente pela utilização de cores que tentam imitar um suposto barra-lustre apenas sugerido pelas prospecções. [81] Terraço norte, com entrada do quarto de Gregori, 2008 

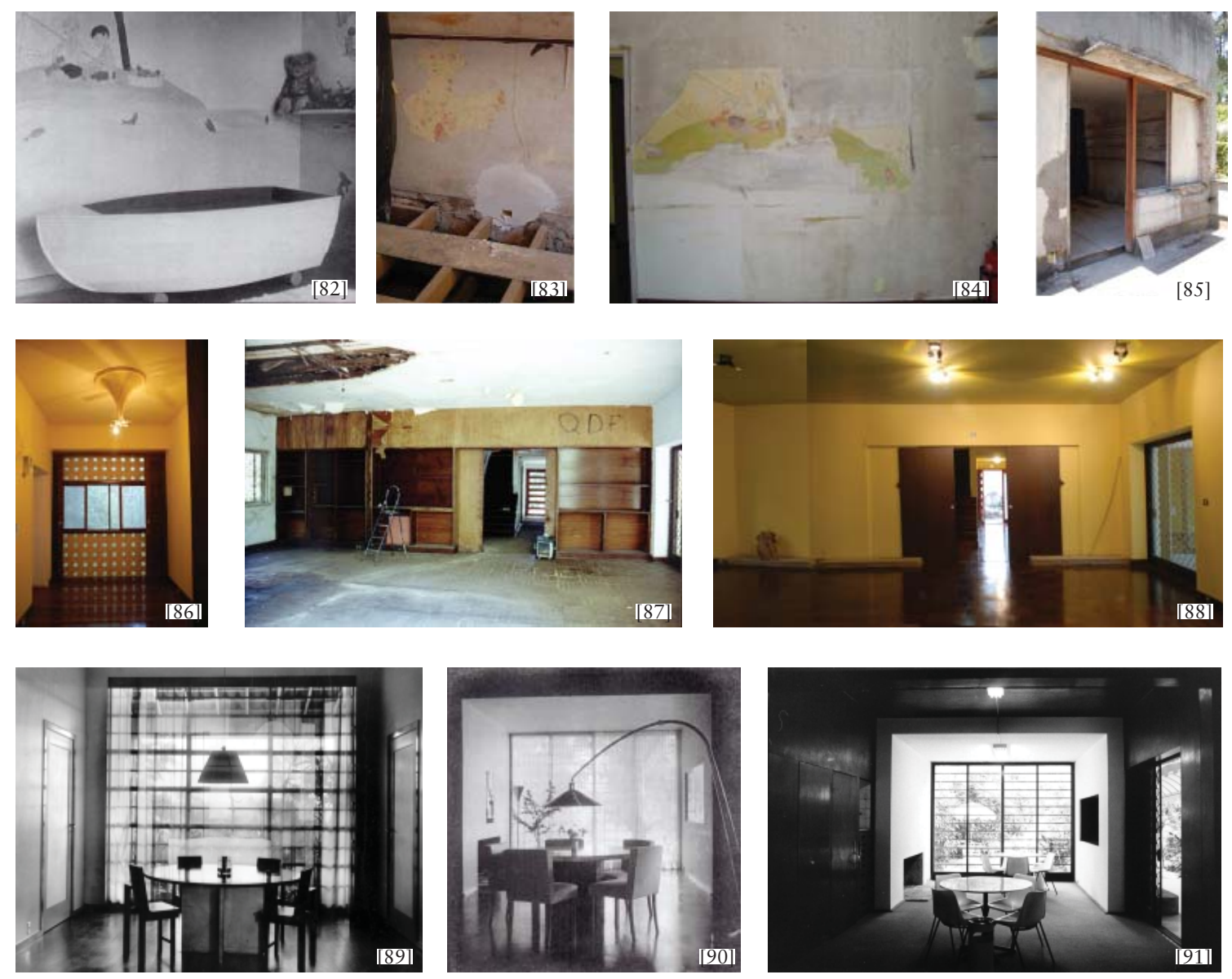
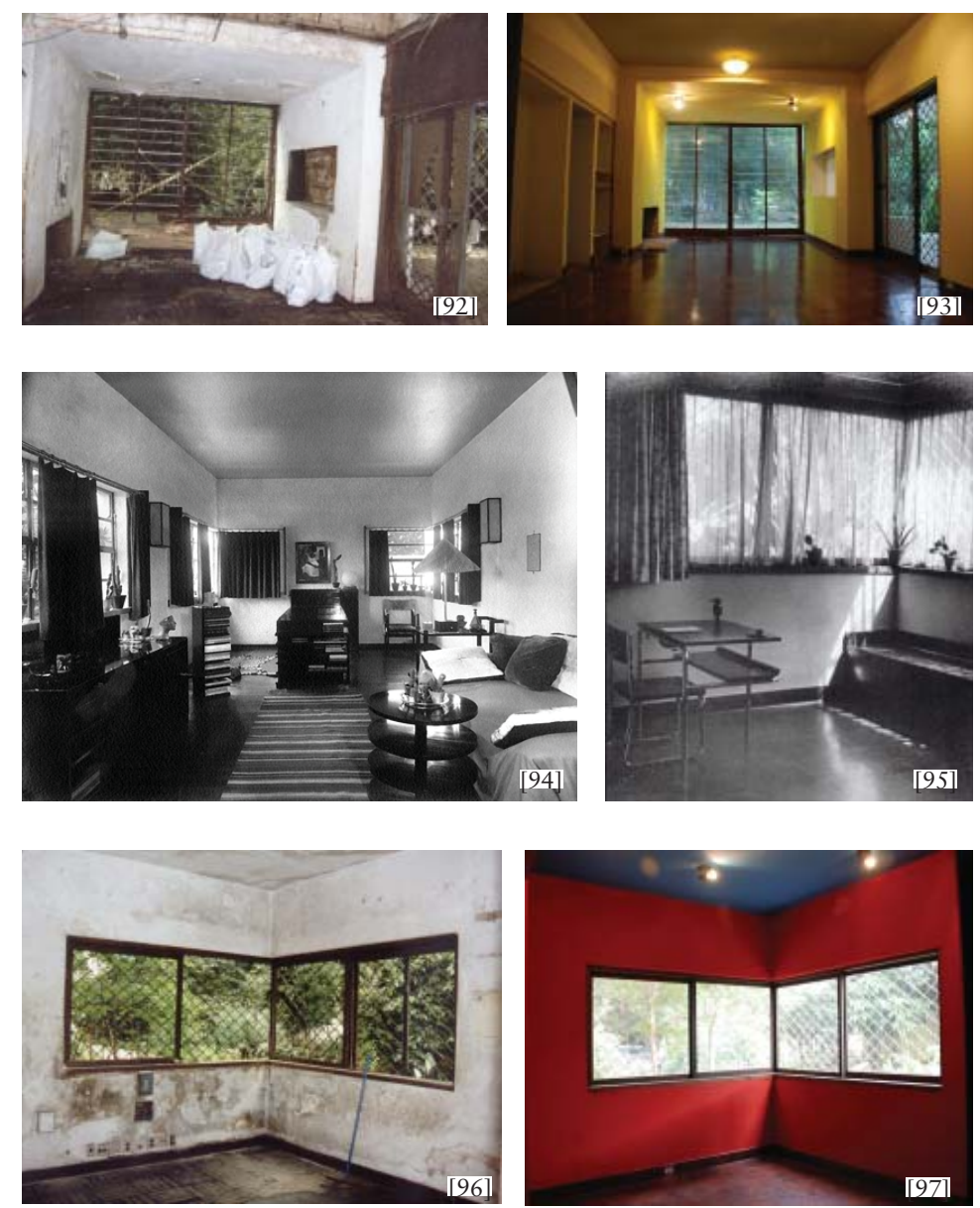

[82] Quarto do filho em 1935. [83] Serviço não autorizado por Gallo em 2006. [84] Trecho descoberto da antiga pintura mural. [85] Terraço do quarto do filho, durante recuperação dos vãos, caixilhos e painéis cimentícios em 2006. [86] Quarto da governanta, com blocos de vidro, em 2008. Sala de estar em 2001 [87] e 2008 [88]. Sala de jantar em 2001 [92] e 2008 [93]. Antigo escritório/ sala de estudos, em 1928 [94], 1935 [93], 2001 [94] e 2008 [97]. [98] Abaixo, reproduzimos a foto $97 \mathrm{em}$ preto e branco para podermos comparar os tons, contrastes e brilhos com as anteriores. Tanto em 1928 quanto em 1935 as paredes eram mais claras e o forro de 1928, apesar de mais escuro, era mais brilhante que o atual

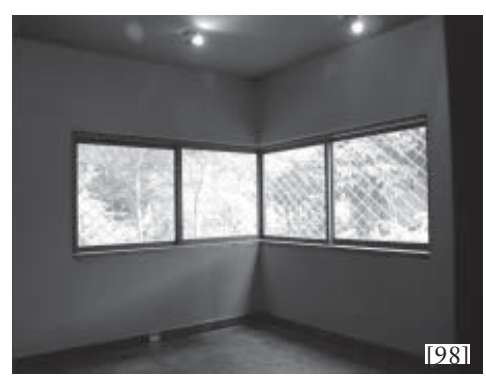



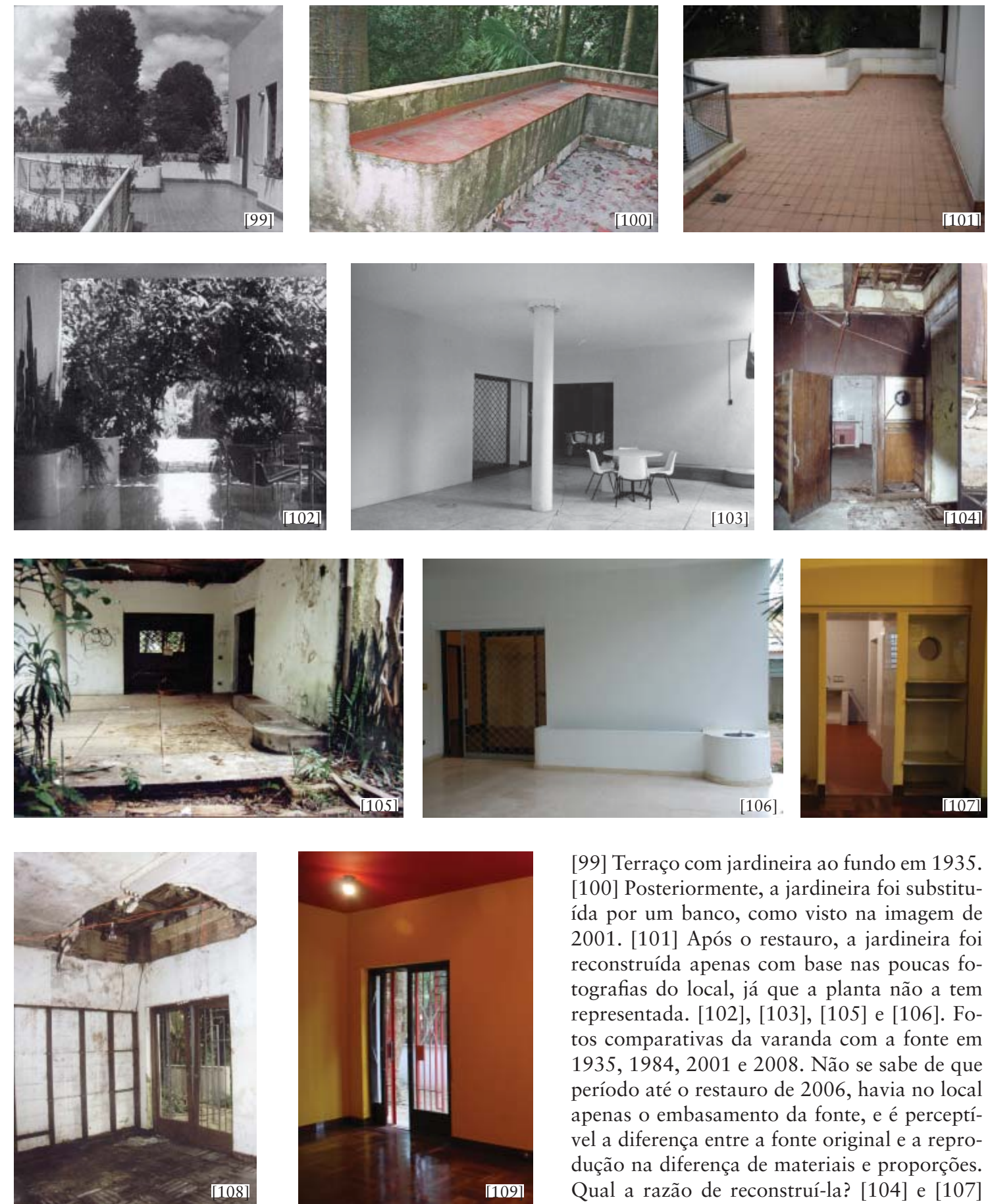

[99] Terraço com jardineira ao fundo em 1935. [100] Posteriormente, a jardineira foi substituída por um banco, como visto na imagem de 2001. [101] Após o restauro, a jardineira foi reconstruída apenas com base nas poucas fotografias do local, já que a planta não a tem representada. [102], [103], [105] e [106]. Fotos comparativas da varanda com a fonte em 1935, 1984, 2001 e 2008. Não se sabe de que período até o restauro de 2006, havia no local apenas o embasamento da fonte, e é perceptível a diferença entre a fonte original e a reprodução na diferença de materiais e proporções. Qual a razão de reconstruí-la? [104] e [107] Fotos comparativas do acesso da sala de jantar
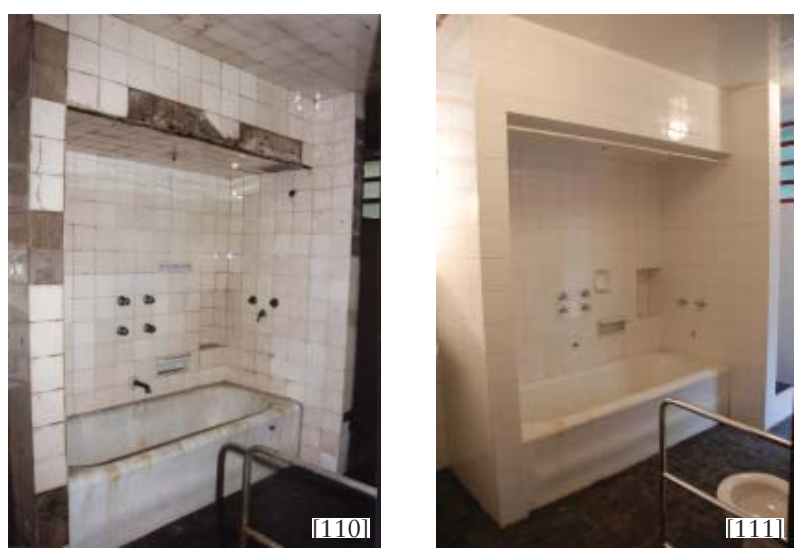
para a cozinha em 2001 e 2008. Com o restauro, todos os armários foram jogados fora e o revestimento de madeira deste ambiente foi substituído por cor que seria de outros ambientes de 1935. [108] e [109] Antiga biblioteca em 2001 e 2008. Vê-se em 2001 indícios das estantes e danos causados por infiltração no forro e no piso. Em 2008, a cor escolhida é supostamente a encontrada no vestíbulo anterior à reforma de 1935 , portanto de um ambiente não mais existente. [110] e [111] Sanitário da suíte de Warchavchik. Todos os azulejos e pisos cerâmicos dos banheiros foram substituídos, sendo preservados apenas os do lavabo. 

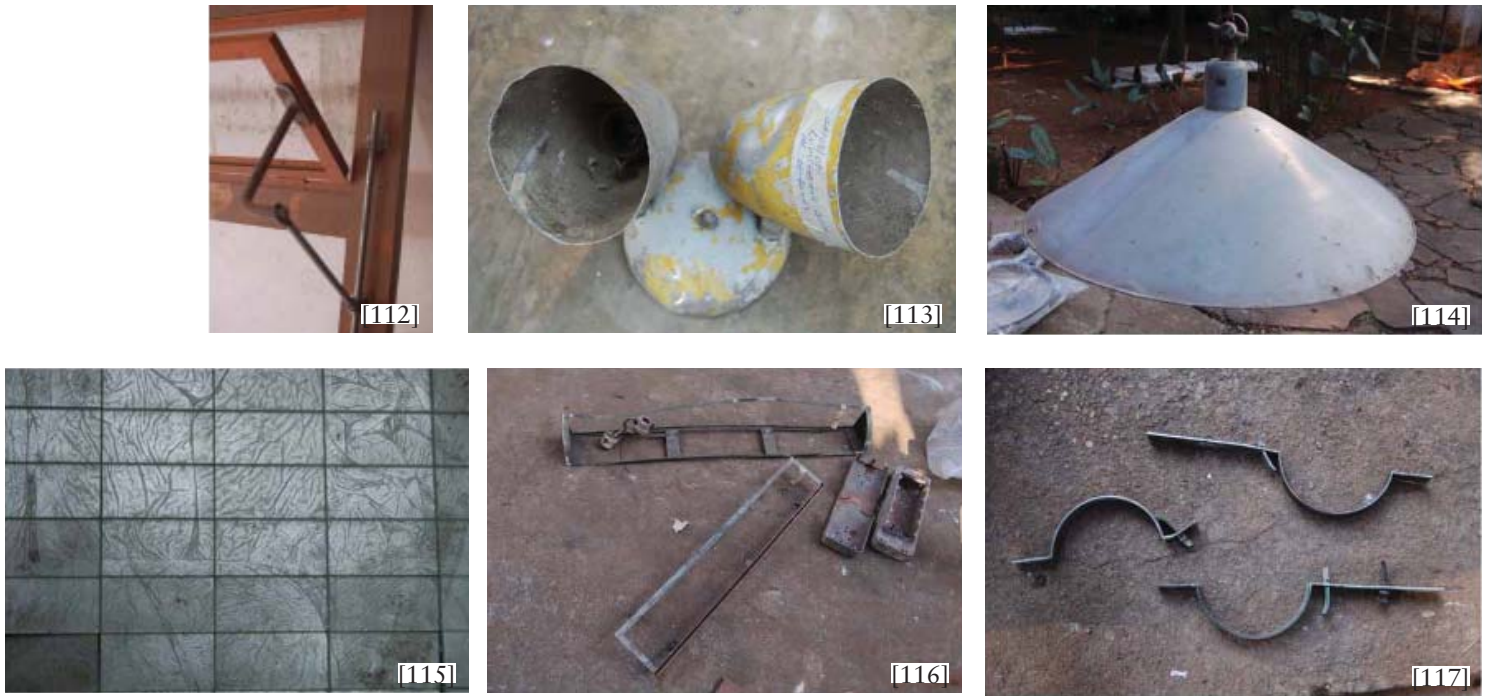

[112] Detalhe de caixilho retirado para restauro em 2006. [113] Luminária original do topo da marquise descartada em 2006 e substituída por peça comercial ordinária. [114] Luminária da sala de jantar encontrada descartada em 2006. [115] Painel espelhado com desenhos, que revestia a parede oblíqua da sala de estar, removida no restauro. Parte das peças foi guardada pela família. [116] Peças de luminárias, como a da escada, removidas e descartadas no restauro. [117] Maçanetas desenhadas por Warchavchik identificadas, restauradas e recolocadas nas portas. [118] Piscina em 2008, cercada por tapumes a meia altura, aguardando projeto de recuperação do restante do imóvel. [119] Anexo de serviços, com escada para o segundo piso, onde residiu por algum tempo o irmão de Gregori Warchavchik. Foi lá que a APPM teve seu escritório montado. Após o abandono, o forro desabou, mas era possível encontrar papéis da associação espalhados entre os escombros. [120] Outro ângulo do anexo de serviços, com destaque para a casa de boneca. [121] Galpão com cantina sobre o antigo canil e antigos laboratórios de fotografia e química, hoje ocupados por um grupo de escoteiros. [122] Cobertura em 2001, com aberturas que danificaram rapidamente o interior da construção. [123] Aspecto do anexo, com varanda da garagem incorporada por barracão em 2008, onde funcionaram as oficinas culturais do Estado. [124] Antigo espaço de jardinagem em ruína, em 2008. [125] Antigos vestiários da piscina em 2001. [126] Antigo salão de jogos em ruína em 2008. [127] Colunas que apoiavam antigo caramanchão sobre o acesso de automóveis pela Rua Dr. Tirso Martins.
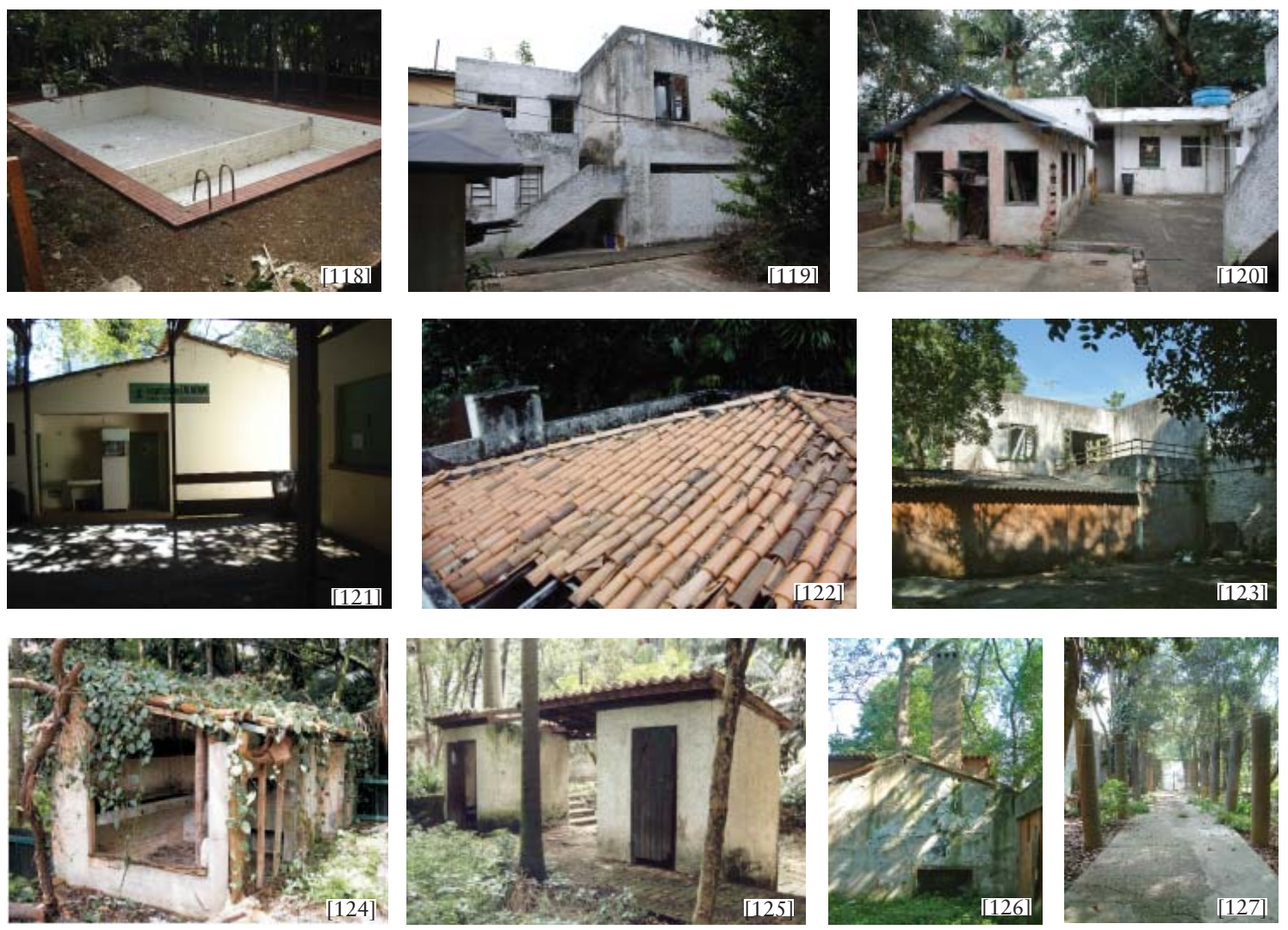


\section{VILA DONA BERTHA - BLOCOS DE CASAS ECONÔMICAS PARA CLASSE MÉ- DIA (1929 - 1930)}

\section{O problema da habitação}

Embora sempre tenha havido habitações precárias na cidade de São Paulo, o crescimento vertiginoso do número de cortiços na virada do século XIX para o XX fez com que o problema passasse a ganhar novos contornos, sob o ponto de vista do discurso higienista então em voga. Associados com a proliferação de doenças contagiosas e com a promiscuidade moral de lares sem qualquer separação da vida privada, uma comissão instituída pelo governo paulista recomendou a eliminação desse tipo de moradia em 1884, publicando-se no mesmo ano o código sanitário que proibia a construção de novos cortiços e a eliminação dos existentes ${ }^{120}$.

Entretanto, tal medida não tinha efetivamente como ser aplicada, pois não se oferecia alternativa ao modelo vigente de provisão privada para obtenção de renda. Até a década de 1930 o poder público se restringia a publicar leis que estabeleciam parâmetros de uso e ocupação e conceder incentivos fiscais e crédito facilitado aos construtores que investissem na produção de moradia popular. Entre as formas privadas, predominavam a iniciativa de empresários para provisão de moradia de seus funcionários e de particulares ou empresas construtoras de diversas naturezas para venda ou aluguel ${ }^{121}$. Os primeiros em geral destinavam as unidades de suas vilas operárias ao médio proletariado de suas empresas, por motivos estratégicos com relação à produção e como forma de controle sobre seus funcionários. Vila Maria Zélia, Vila Prudente, Vila Crespi, Vila Nadir Figueiredo em São Paulo e Vila Isabel no Rio de Janeiro são alguns exemplos ${ }^{122}$.

Já com relação aos imóveis construídos para a venda ou o aluguel, havia os pequenos investidores, as Companhias mutualistas, como a Mutua Brasil e a Economizadora Paulista, de capital aberto, cujos acionistas tinham como finalidade investir na venda ou aluguel dos imóveis e as Companhias imobiliárias e Construtoras, como a Iniciadora Predial (de Luis de Anhaia Melo e Ricardo Severo), Lar Brasileiro, Lar Paulista, City, Cia. Imobiliária Paulista e a Cia. Construtora de Santos ${ }^{123}$. Tais companhias eram geralmente comandadas por engenheiros e arquitetos formados no exterior ou nas recém-criadas escolas de engenharia de São Paulo.

O debate sobre habitação estava em alta, e empresários como Roberto Simonsen, fundador da Companhia Construtora de Santos, que trará Warchavchik ao Brasil em 1923, se engajavam em pesquisas para o barateamento da construção. Além da Companhia Construtora de Santos, Simonsen tinha diversos outros negócios, como a Cerâmica São Caetano, Cia. Brasileira de Calçamento, Cia. Frigorífica de Santos, Cia. Parque Balneário e em 1912, 
investiu na Companhia Santista de Habitações Econômicas em conjunto com o médico e higienista Guilherme Álvaro. A empresa tinha como objetivo desenvolver processos industrializados de construção visando o combate das moradias insalubres de Santos. Com o apoio do prefeito Belmiro Ribeiro ${ }^{124}$, obteve benefícios através de leis municipais santistas, tais como isenção de impostos industriais, prediais e profissionais, para a criação de um bairro modelo na Vila Belmiro.

Aproveitando condições cambiais favoráveis, Simonsen abre concorrência entre construtores e produtores de materiais industrializados nos EUA, para a construção de habitações econômicas em série, por processo "maquinizado", como o próprio engenheiro mais tarde denominou o modelo. Conhecida como "casas Ford", em referência à montadora norte-americana, em alusão à sua forma de produção industrial, a vila foi implantada em "terrenos altos, amplamente ventilados e pitorescamente dispostos, de fácil acesso", com arruamento organizado segundo projeto que obedecia "aos mais modernos preceitos da town-planning" ${ }^{125}$. A primeira unidade do bairro foi construída com estrutura independente em concreto armado, composto de elementos adquiridos de uma das empresas norte-americanas que participaram da concorrência, que seria a célula de um sistema de moradia. No entanto, logo se percebeu que a experiência realizada, mesmo buscando a economia através de aplicação dos preceitos científicos, novos processos, materiais, técnicas, etc., não estaria ao alcance da massa trabalhadora, dada sua má remuneração, e não traria retorno do capital investido. Deste modo, a vila acabou sendo concluída, por determinação da prefeitura, em casas isoladas de madeira, para o efetivo barateamento da construção.

À frente da Companhia Construtora de Santos, o engenheiro experimentou a aplicação dos princípios da gerência científica, promovendo o estabelecimento da indústria da construção civil. Seu maior encargo foi a construção de quartéis generais por todo o Brasil, nos quais trabalharam cerca de 15 mil operários simultaneamente ${ }^{126}$. Mas a modernização do processo produtivo não correspondia a novos anseios estéticos arquitetônicos. Para as residências unifamiliares, Simonsen afirmava sua predileção pelos pitorescos bungalows californianos, "sobretudo casas térreas e isoladas que se adaptavam muito bem às condições climáticas santistas" ${ }^{127}$. Para edifícios públicos monumentais, como a Bolsa do Café de Santos (1922), o Panteão dos Andradas (1923) e a Associação comercial (1924), elegia-se o eclético com influências neobarrocas. Não se constrangia em adotar também o neocolonial, o Art Nouveau, ou o classicismo francês, enfim, admitia-se a liberdade no uso dos estilos conforme o gosto do cliente ${ }^{128}$. Não se sabe como se dava a participação de Warchavchik nos quadros da em-

124 Observar que Simonsen foi chefe da Comissão de Melhoramentos do município ainda na gestão Belmiro Ribeiro. A TRIBUNA, 26/01/1939

125 SIMONSEN, 1919 apud FREITAS, 2005

126 MAZA, 2002; MEUCCI, 2009

127 SANTOS, 2007: 93

128 Mas foi a construção de diversos quartéis e equipamentos militares em todo o Brasil, em canteiros com cerca de 15.000 operários trabalhando simultaneamente, que levou a construtora a um novo patamar. Para sua execução, pioneiramente foram elaborados anteprojetos cuidadosamente revistos em 4 escritórios centrais 
presa, pois era apenas mais um salariado anônimo que, conforme sugere Lira, testemunhava a experiência de reorganização produtiva do capital, identificando o historiador no contato com o que chamou de "vanguarda do capital", um ponto fulcral: "por menor que tenha sido sua contribuição para a empresa, o trabalho de Warchavchik para Simonsen tem algo a nos dizer acerca da gênese do ideário da arquitetura moderna no Brasil" ${ }^{129}$.

Se o desenvolvimento da construção civil era uma realidade visível nos canteiros das grandes companhias construtoras, ainda que ocultado pela arquitetura de estilos, o problema habitacional pouco via iniciativas concretas para além do modelo vigente. De qualquer modo o debate estava na pauta de intelectuais de todos os espectros, direcionado por questões técnico-econômica, higiênica e moral. O ponto máximo foi o I Congresso de Habitação de São Paulo, de 1931.

Sendo organizado pela Divisão de Arquitetura do Instituto dos Engenheiros de São Paulo, por comissão composta por Alexandre Albuquerque, Dácio de Moraes (o protagonista do debate acirrado com Warchavchik nas páginas do Correio Paulistano em 1928), José Maria da Silva Neves, Gomes Cardim Filho e outros, e patrocinado pela Secretaria de Viação e pela Prefeitura de São Paulo, na gestão do engenheiro Luis de Anhaia Mello, o congresso dividia-se em seis mesas temáticas, apresentação de palestrantes, exposição paralela, da qual Warchavchik participava com uma pequena mostra de suas obras, e um roteiro de visitas, no qual se incluiu a visita à casa da Rua Bahia. A fala de abertura, proferida por Alexandre Albuquerque, dá o tom do que será o congresso:

A casa economica não resolve só o caso particular de seus habitantes. A questão deve ser encarada sob o ponto de vista social. Della, depende também o desenvolvimento da raça. Da vida promíscua em cortiços, sahe um corso de pervertidos, de delinquentes, cortejado por molestias terriveis. A casa individual, rodeada de ar e de luz, sympathica e convidativa ao repouso, é a céllula mater das raças fortes ${ }^{130}$.

Sob essa ótica foram discutidas as diversas teses - da padronização de materiais, à reivindicação pela diminuição nos parâmetros métricos para casas econômicas no código de obras, o foco era a casa individual. Uma das teses destacadas, e uma das únicas a apresentar experiências concretas, um conjunto para ferroviários em Mayrink, do engenheiro-arquiteto e civil Bruno Simões Magro ${ }^{131}$, não ia por direção diferente. Apesar de demonstrar conhecimento sobre o trabalho de Ernest May, dizia que casa coletiva devia ser evitada, devido aos perigos de ordem social e à ausência de espaço para cultivo de plantas e animais. Para ele,

da empresa, praticou-se abundante documentação contábil tendo em vista os complexos procedimentos de compras e pagamentos, utilizou-se materiais padronizados e pré-fabricados visando a construção em série. MAZA, Fábio, 2002; MEUCCI, 2009

129 LIRA, 2008:126

130 CONGRESSO DE HABITAÇÃO (SÃO PAULO), 1931:22

131 Para Bruno Simões Magro, havia no período os passadistas, futuristas e os moderados (protomodernos ou art déco), grupo com o qual se identificava. Ver FREITAS, 2005; FISCHER, 2005. 

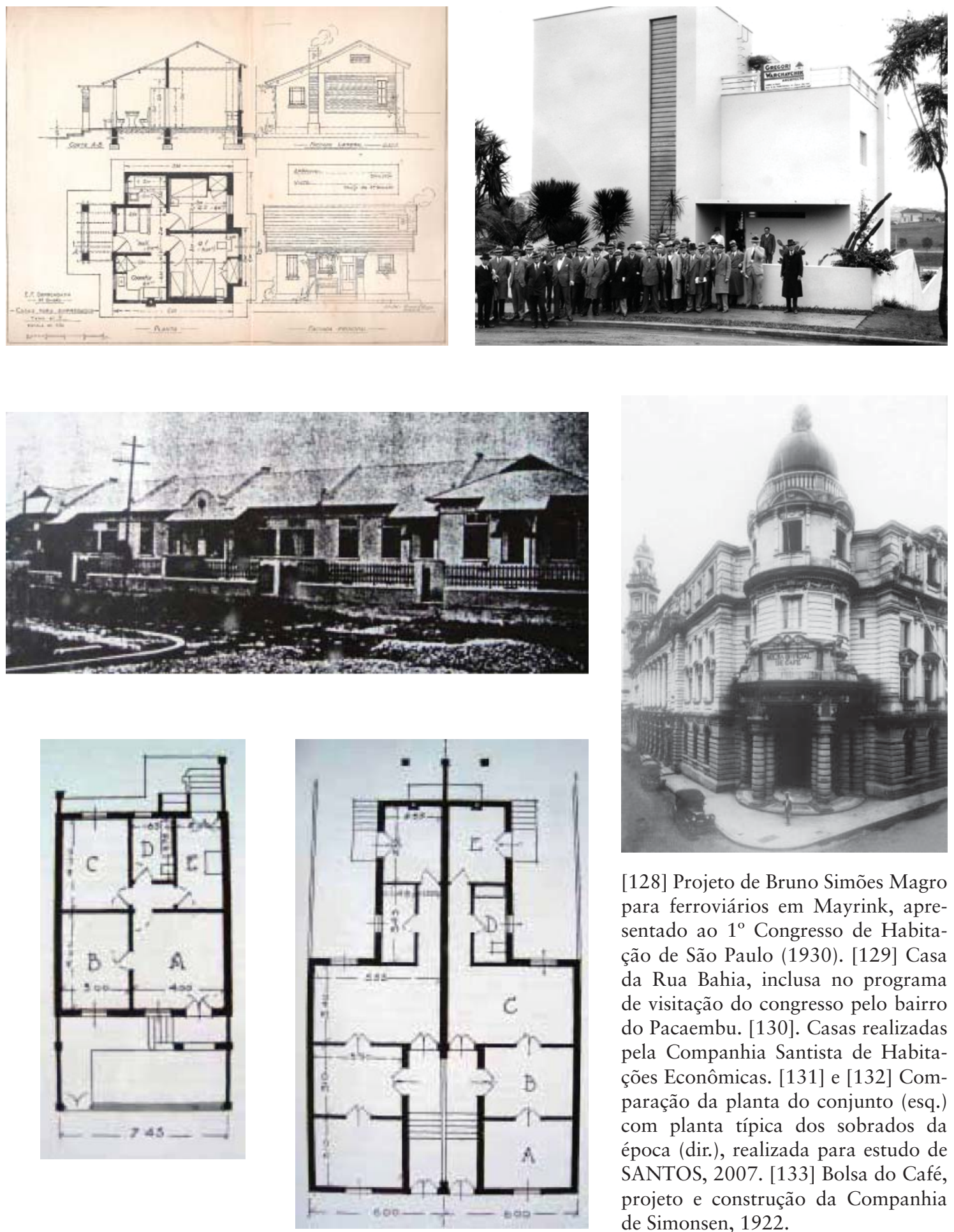

[128] Projeto de Bruno Simões Magro para ferroviários em Mayrink, apresentado ao $1^{\circ}$ Congresso de Habitação de São Paulo (1930). [129] Casa da Rua Bahia, inclusa no programa de visitação do congresso pelo bairro do Pacaembu. [130]. Casas realizadas pela Companhia Santista de Habitações Econômicas. [131] e [132] Comparação da planta do conjunto (esq.) com planta típica dos sobrados da época (dir.), realizada para estudo de SANTOS, 2007. [133] Bolsa do Café, projeto e construção da Companhia de Simonsen, 1922. 
seria aceitável grupos de quatro a até seis casas geminadas, se inexequível o tipo isolado.

Exceto pela evidente aproximação quanto à necessidade de padronização e barateamento da construção, são gritantes as divergências entre Warchavchik e os profissionais atuantes na cidade naquele período.

Apoiado no jargão de Le Corbusier, Warchavchik considerava necessário aplicar a mesma lógica da indústria às "máquinas para habitação". Informado sobre as experiências desenvolvidas em Frankfurt, Stuttgart e a produção dos mestres do modernismo internacional, como bem demonstrado na série Arquitetura do século $X X^{132}$, defendia a racionalização, padronização e serialização da arquitetura, assim como o conceito de casa tipo, e criticava o alto custo dos materiais de construção e a falta de incentivos. Warchavchik diferia do discurso hegemônico com relação à hierarquia estilística entre tipos de construção, mal sendo a casa econômica considerada arquitetura para arquitetos como Christiano Stockler das Neves ${ }^{133}$. Outro ponto importante se referia à aceitação de diversas soluções, a casa isolada, agrupamentos de casas, prédios isolados e em altura, etc., ao contrário dos congressistas, que elegiam a casa individual ante o que consideravam problema moral da vivência coletiva - sem contar a óbvia divergência no campo estético.

É neste clima que será construída a Vila Dona Bertha.

\section{Entre a vanguarda e os negócios familiares}

Apesar de significativos no conjunto de sua produção, os projetos para casas econômicas de Warchavchik são pouco retratados pela historiografia, pois, destituídos de aura modernista e voltados para o melhor rendimento do capital imobiliário, escapam ao interesse para estudos em história da arquitetura moderna. Tais projetos serão exclusivamente realizados em âmbito privado, estando a produção para o Estado definitivamente ausente da obra do arquiteto. Contudo, devemos lembrar que somente a partir dos anos 1940, após o golpe de 1937 que culminaria no Estado Novo, a habitação passava a ser entendida como direito social sob tutela do Estado e a produção privada rentista somente seria desestimulada com a promulgação da lei do inquilinato de $1942^{134}$.

Maurício Freeman Klabin foi um dos compradores das grandes glebas resultantes do parcelamento da Colônia da Glória, uma das três colônias agrícolas e de povoamento empreendidas pelo Império no início do século XIX ${ }^{135}$. Também tinha terras na Mooca, no Belenzinho e outros locais pela cidade. Seus herdeiros deram prosseguimento aos investimentos fundiários e imobiliários - aquisição de terras, parcelamento, urbanização, construção, etc., para venda e aluguel. Nesse sentido, Warchavchik tornar-se-ia peça fundamental para a 
gestão dos negócios familiares, com a elaboração de estudos de viabilidade, projetos e gerenciamento de obras. O arquiteto participava dos desenhos dos arruamentos, implantação dos loteamentos, cálculos de drenagem e divisão das áreas para destinação a cada um dos herdeiros, que eram partilhadas através de sorteio, com registro em ata. Quando a divisão não era exata, os terrenos excedentes passavam a ser de propriedade de todos os herdeiros ${ }^{136}$. O resultado pode ser visto, por exemplo, na planta de loteamento da Vila Afonso Celso, disponível no acervo da biblioteca da FAUUSP, na qual as quadras são assinaladas com a divisão dos proprietários. A Vila Afonso Celso se situava na ponta inicial da gleba dos Klabin, que descia rumo ao Ipiranga, e serviu de cenário a inúmeros projetos residenciais assinados por Warchavchik destinados à locação ${ }^{137}$.

Em levantamento realizado no acervo da FAUUSP, verificamos que dos 30 projetos residenciais não unifamiliares localizados, 17 são da família Klabin (destes, 11 de Mina e Gregori), 5 de terceiros e 5 de proprietários não identificados. Os 3 restantes são outras versões para projetos já contabilizados. Por seu turno, os projetos de residências unifamiliares totalizam 77 de terceiros, 13 da família Klabin e 1 sem proprietário identificado (repetindose algumas reformas); os projetos de residências unifamiliares de veraneio, 25 de terceiros e 2 da família, e os de casa de campo, 2 de terceiros e 3 da família. Os edifícios residenciais ou mistos coletivos também têm a maioria da clientela particular de terceiros: 24 contra 4 da família e 1 não identificado, incluindo-se na contagem edifícios de apartamento de veraneio.

Também é possível notar a predominância de projetos residenciais sobre comerciais, institucionais ou de serviços. Enquanto os primeiros totalizam 173 projetos, os restantes são em 63, sendo 18 comerciais, 2 industriais e 31 institucionais ou de serviços. Não fazem parte desse cálculo os projetos realizados em parceria com Lúcio Costa nem no período da construtora Warchavchik-Neumann.

Tal estatística permite concluir que dos 239 projetos contabilizados, sendo 12 de proprietário não identificado, descontando-se reformas para os mesmos imóveis, 40 foram encomendadas pela família Klabin - Warchavchik, totalizando cerca de $18 \%$ dos imóveis. Mas com relação aos projetos residenciais de conjuntos de casas, sobe para $68 \%$ a participação da família sobre os demais clientes.

O conjunto da Rua Berta e Afonso Celso não foge à regra. Projetada em 1929, a Vila Dona Bertha - como denominada no projeto de aprovação municipal - previa a construção de 34 casas com quatro tipologias, sendo 6 unidades do tipo "A", de maior porte, voltadas para a Rua Afonso Celso, 9 do tipo “B”, voltadas para a Avenida Domingos de Morais, 13

136 Acervo particular José Antônio Domingues. O advogado possui as correspondências, atas e plantas que documentam tal procedimento. De acordo com Domingues, todas as etapas passavam pelo crivo de Warchavchik. Sobre a divisão das propriedades, Warchavchik propunha a disposição dos lotes, a divisão equânime de áreas, era realizado o sorteio e dona Bertha registrava as atas. A título de curiosidade há inclusive uma carta que documenta a queixa de Emmanuel Klabin de que sempre ficava com os piores terrenos, de maior declividade só porque era engenheiro.

137 Como os diversos projetos localizados no AHMWL e na FAU. Cf. Listagem ao fim. 

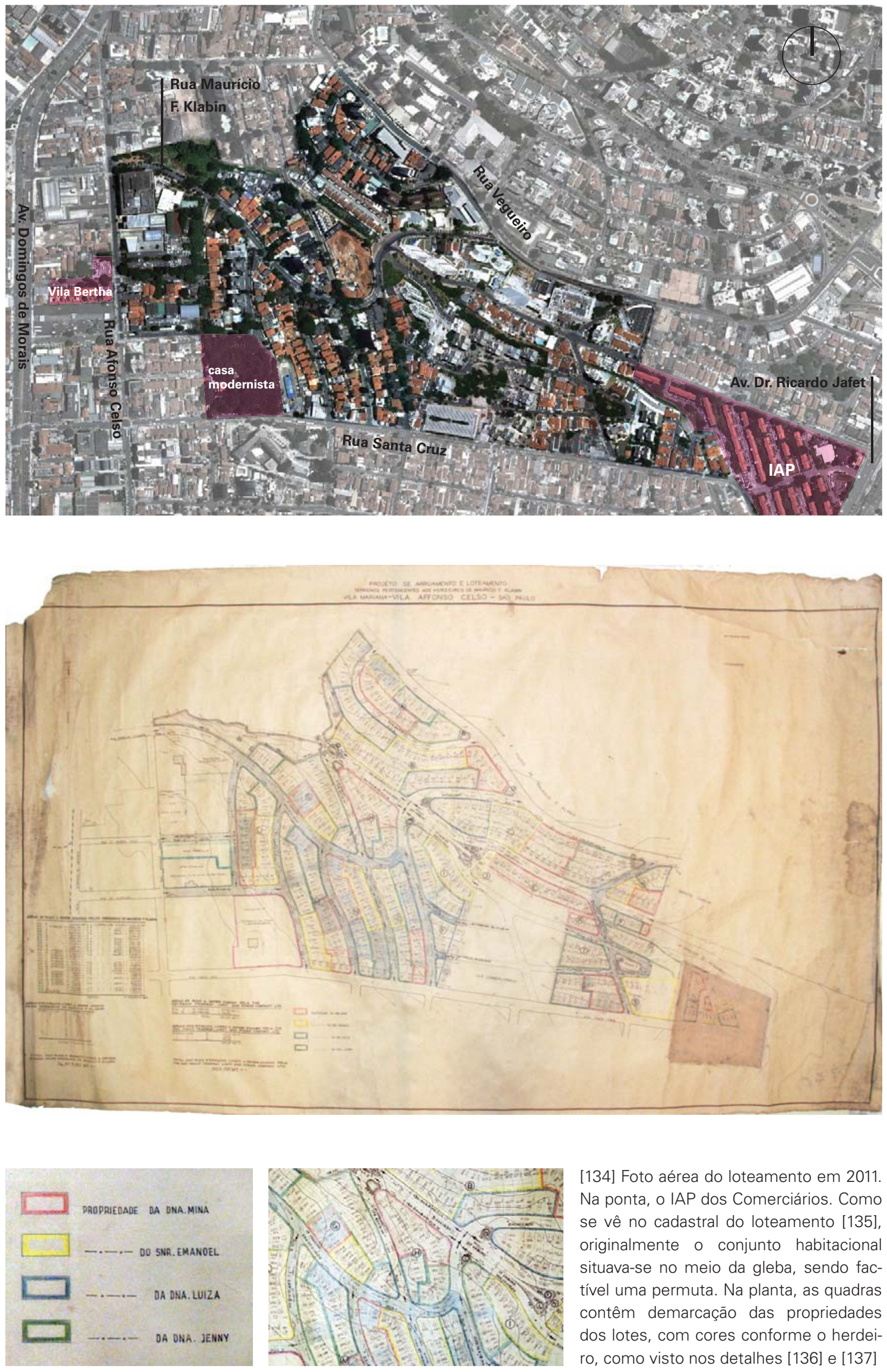

[134] Foto aérea do loteamento em 2011. Na ponta, o IAP dos Comerciários. Como se vê no cadastral do loteamento [135], originalmente $\mathrm{O}$ conjunto habitacional situava-se no meio da gleba, sendo factível uma permuta. Na planta, as quadras contêm demarcação das propriedades dos lotes, com cores conforme o herdeiro, como visto nos detalhes [136] e [137] 

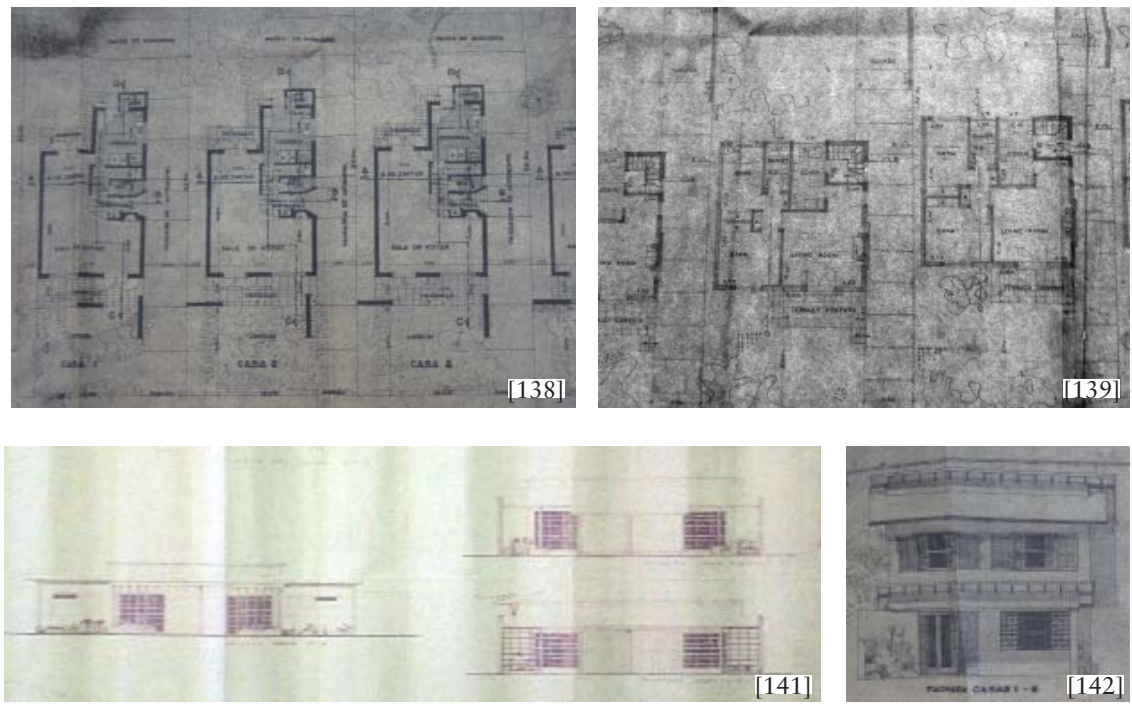

42]

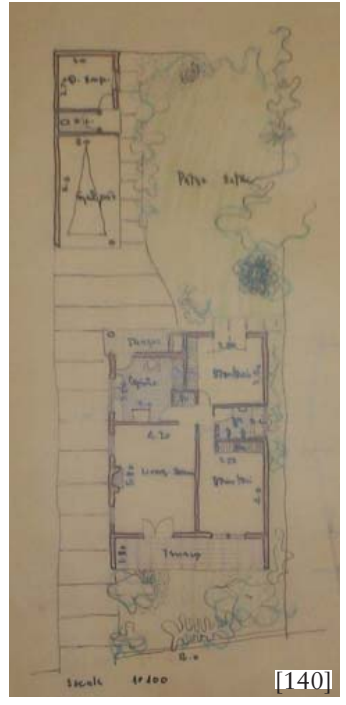

Alguns projetos de Warchavchik para a Vila Afonso Celso: [138] 7 casas para Mina, Rua 7. [139] 5 casas para Jenny, Rua 8. [140] 5 casas para Luísa, Rua 9. [141] 14 casas para Mina à $R$. Desembargador Aragão (antiga Rua 6). [142] 8 casas para Mina. Não há nos arquivos projetos para Emanuel, pois ao que consta, construía por conta própria. [143] Implantação da Vila Dona Bertha, 1929. [144] Planta da tipologia "A", voltada para a Rua Afonso Celso.

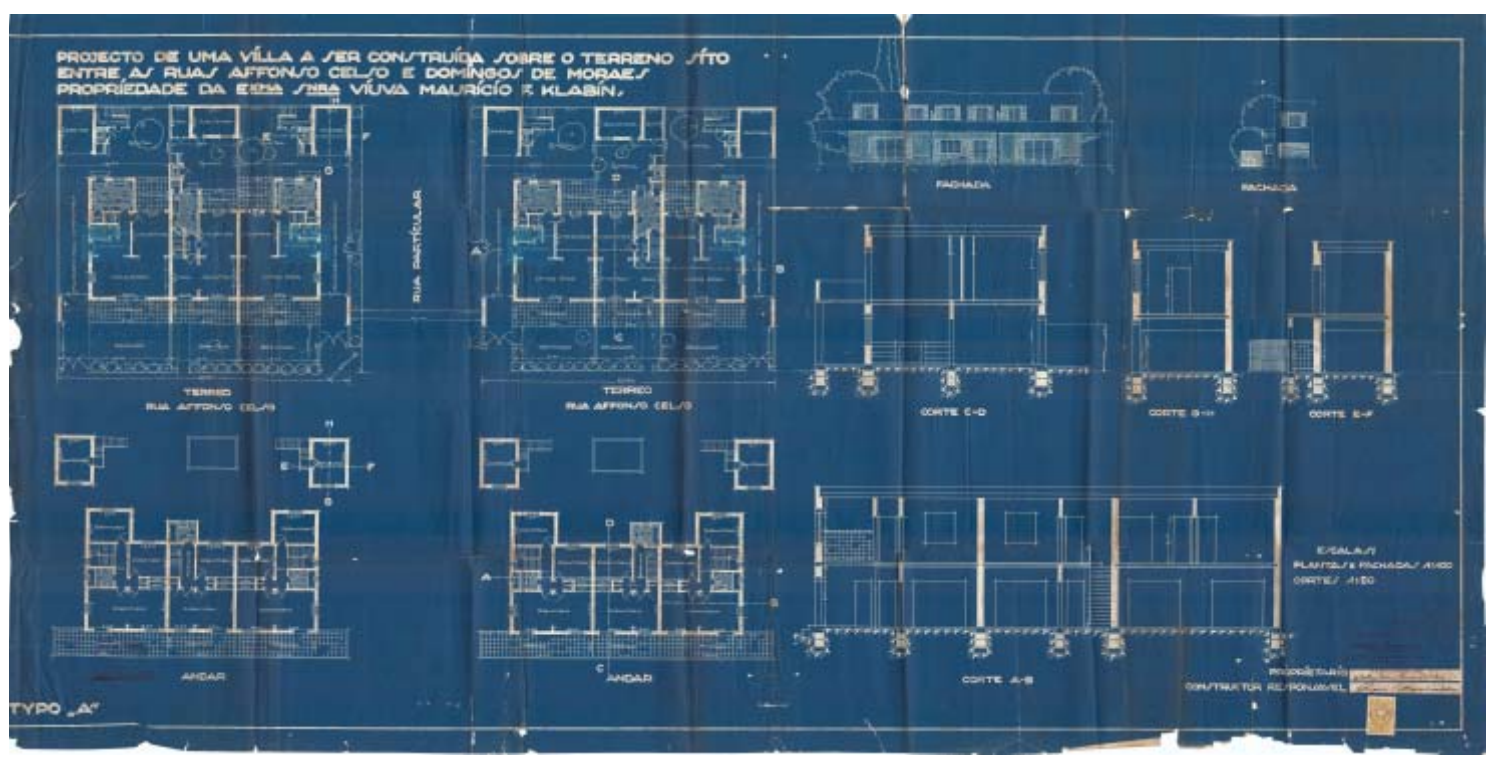


do tipo "C", implantadas à Rua Berta lado par e 6 unidades em uma variação denominada "C1", entremeadas por uma praça, ao lado ímpar da nova rua. A variação das tipologias obedecia à leitura que Warchavchik fazia do contexto de implantação do projeto. O tipo “A”, previsto para a Rua Afonso Celso, era o único a ter garagem. De maiores dimensões, comportavam famílias em melhor situação financeira como pano de fundo para a mansão Klabin, a residência do arquiteto e a Vila Afonso Celso, do outro lado da rua, sendo admissível para o estabelecimento de seus cunhados Jenny Klabin e Lasar Segall, ainda que utilizando duas unidades e incorporando o lote vizinho para a construção do atelier do pintor em 1932. A reforma adaptou as unidades às necessidades do casal e seus dois filhos, e o atelier foi "diretamente inspirado nas residências-ateliê que concebera experimentalmente entre 1929 e 1930, a partir de projetos similares de Le Corbusier no início da década" ${ }^{138}$. Já o tipo "B", localizado à Avenida Domingos de Morais, era o mais compacto e previa um "armazém" aberto para a avenida, conforme a vocação comercial do corredor viário. O tipo “C”, e sua variação "C1", que apenas tinha o quintal diminuído, seria a versão de padrão médio, constituindo-se no grosso do conjunto. Todos os tipos previam, em maiores ou menores dimensões, um espaço para galinheiro no fundo do lote, revelando as reminiscências de um modo de vida rural ainda presente na cidade, em um momento anterior à revolução doméstica causada pela fabricação de geladeiras no Brasil ${ }^{139}$.

No memorial descritivo estavam especificados técnicas e materiais correntes, como a alvenaria de tijolos assentados e revestidos com argamassa de cal e areia, mas também o uso de laje de cobertura, a apenas um ano da execução da casa da Santa Cruz:

Terreno - O terreno será todo nivelado.

Alicerces - Em concreto de pedregulho e cimento.

Paredes - Alvenaria de tijolos assentes com argamassa de cal e areia.

Revestimento - Interna e externamente as paredes serão revestidas de cal e areia.

Cobertura - Lages de tijolos furados intercalados com ferro de 1/4 impermeabilizado.

Soalhos - Taboas largas de embuia sobre madeiramento de peroba.

Alturas - Pavimento terreo 2,80 - andares 3 metros.

Esquadrias - Porta de embuia e janellas de cedro, os quartos de dormir serão providos de venezianas.

Camada isoladora - Constituida de tres fiadas de tijolos assentes com argamassa de cimento. As paredes tanto interna com externamente, n'uma faixa de $0,30 \mathrm{cms}$. (Sic) serão cimentadas. 
Cosinhas e banheiros - Com pizo revestido de ladrilhos, assentes sobre pavimento de cimento armado. Em redor das paredes serão collocados azulejos brancos.

A rua particular terá 10 metros de largura com passeio de 2 metros.

O centro da rua será ajardinado. Será feito abaulamento e o cahimento das aguas será para a rua Affonso Celso ${ }^{140}$.

O processo municipal para obtenção do Alvará de construção foi protocolado em 12/07/1929, sendo inicialmente encaminhado ao Departamento de Patrimônio para emissão de parecer quanto ao título apresentado, tendo em vista a abertura de rua. Comprovada a propriedade, o técnico conclui: "as plantas podem ser approvadas nos termos do projecto de lei sobre construcção de 'casas populares'. Área da rua e praça $-2370 \mathrm{mts}^{2}$. Prazo: 3 annos. Zona suburbana" ${ }^{141}$. Em seguida, era encaminhado para análise técnica. A informação do Eng. Lúcio M. Rodrigues filho: “As paredes no andar terreo com carga deve ter 1 tijolo de espessura. As garages devem ter tecto de cimento armado. Os W.C internos no pavimento terreo devem ter area minima de $2 \mathrm{~m}^{2}$ (art. 143 do padrão). Os corredores dos armazens devem ter largura minima de $1 \mathrm{~m}$ (art. 136 do padrão)" ${ }^{142}$. No comunique-se era ainda apontado que Warchavchik não estaria licenciado. Após a retirada e devolução das plantas alteradas, confirmava-se o licenciamento do arquiteto.

Com o retorno das plantas, Lucio M. Rodrigues filho dava seu parecer: "Não foi satisfeita a $3^{\text {a }}$ exigencia da minha informação anterior. não podendo ser incluido nas areas da latrina o pequeno 'lavabo' anexo. As rectificações serão feitas de accordo com o art. 31 padrão. Peço para ser comunicado mais uma vez". Deste modo, as plantas novamente são trocadas e em 05/09/1929, o alvará é lavrado.

Do projeto aprovado, apenas as 13 casas de tipo "C" e as 6 casas de tipo " $\mathrm{A}$ ” foram executadas. Entretanto, as demais áreas se mantiveram em propriedade dos Klabin. As casas do conjunto foram divididas pelos herdeiros de Maurício e no entorno foram construídos outros edifícios para a família. Foi construído por Warchavchik, por exemplo, um edifício de três andares voltado para a Avenida Domingos de Morais no espaço equivalente a duas casas da tipologia "B" e uma casa à Rua Berta lado ímpar ${ }^{143}$ para Jenny e Lasar Segall. Além disso, o conjunto era vizinho ao loteamento da Vila Afonso Celso, que se iniciava do outro lado da rua de mesmo nome.

É certo que o empreendimento visava não um público operário, mas sim uma nova classe média urbana - neste caso formada por imigrantes, pois ao que consta, os primeiros moradores da Vila eram todos estrangeiros, judeus ashkenazi ${ }^{144}$. Mas vilas econômicas nor-

140 PMSP, processo 43.171/29, fl. 3

141 Idem, fl. 12 verso

142 Idem, fl. 11

143 PMSP, processos 26.589/39; 65.275/39; 74.788/40

144 Como a austríaca Anna Zauser, que em 1989 defendeu a preservação do conjunto em reportagem de jornal, moradora da casa ${ }^{\circ} 48$. José Antonio Domingues, proprietário do imóvel a partir de 2003 a conheceu 
malmente ocupavam o máximo permitido pela legislação, implantando-se no alinhamento frontal, ao contrário do presente conjunto, que previa um generoso recuo de 6 metros constituído por um jardim projetado por Mina que criava um agradável espaço intermediário entre a massa construída e o largo arborizado que se formava na nova rua. Composto por agaves, primaveras e ciprestes, o jardim era supervisionado diretamente por Mina, que enviava um jardineiro na troca de inquilinos. Seus jardins tropicais já estavam incorporados ao imaginário da arquitetura de Warchavchik e se constituíam como forma de valorização das iniciativas imobiliárias do casal ${ }^{145}$. Este também desempenhava um importante papel para resguardar a visibilidade do interior das unidades, providas de generosas aberturas e porta envidraçada.

As amplas aberturas, aliadas ao espaço contínuo entre sala de estar e jantar, promoviam a integração visual entre interior e exterior. Iluminação e transparência foram elementos valorizados, perceptíveis na utilização de portas envidraçadas na entrada, na saída da sala de jantar e da cozinha para o quintal, na claraboia da escada, acima do volume do sanitário e evidentemente nas amplas aberturas. A luminosidade aparentemente tornou-se elemento ativo de projeto, sendo o jogo contrastante de luz e sombra intencionalmente expresso nas elevações contidas nas peças gráficas do processo de aprovação. Neste sentido, a marquise passa a ser central na obra, pois além dos agradáveis terraços e varandas criados articulando-se com o jardim e com as transparências para o estabelecimento de um espaço de transição entre dentro e fora, pôde marcar nos escuros o ritmo dos nichos representados pela individualidade das unidades ao mesmo tempo em que permitiu uma integração visual entre as unidades, proporcionando uma leitura contínua e total do conjunto. A marquise seria um elemento muito bem explorado plasticamente em uma série de projetos, dos quais se destacam a casa da Rua Itápolis (1930), a casa da Rua Melo Alves (1929) ou a casa da Rua Estados Unidos (1931) e no conjunto da Barão de Gamboa (1933), último projeto realizado na sociedade com Lúcio Costa no Rio de Janeiro, no qual a passarela em laje contínua permite dar unidade às células implantadas de modo escalonado para acompanhar o terreno.

De fato, não só as aberturas, mas os próprios caixilhos receberão atenção, pois mesmo constituídos de desenhos simples, terão detalhes construtivos interessantes, considerando-se o contexto de produção - detalhes, como outros, revelados in loco e especialmente na obra de restauro, que será comentada mais adiante. $\mathrm{Na}$ janela voltada para a rua, combinavam-se folhas fixas e folhas de correr com vitrôs basculantes. No vão voltado para o espaço externo dos fundos, o caixilho de ferro conjugava janelas de peitoril baixo e largo e porta ao centro formando um “T”, solução que também será encontrada, por exemplo, nas casas da Rua

e soube de outro antigo morador alemão o nome de todos os vizinhos. A historiadora Sheila Schwartzman obteve a informação de Maurício Klabin Segall, filho de Jenny Klabin e Lasar Segall de que inicialmente as casas abrigavam a parentela da família Klabin. Foi localizado no Arquivo Geral da Prefeitura, um processo de 1961 de pedido de cópia da planta da casa n 106 da reforma de 1950, em nome de Mendel Klabin "para fins de defesa judicial que move contra o proprietário" - processo n 169.422/61.

145 PERECIN, 2003 
[145] Tipologia C, executada sobre a Rua Berta.
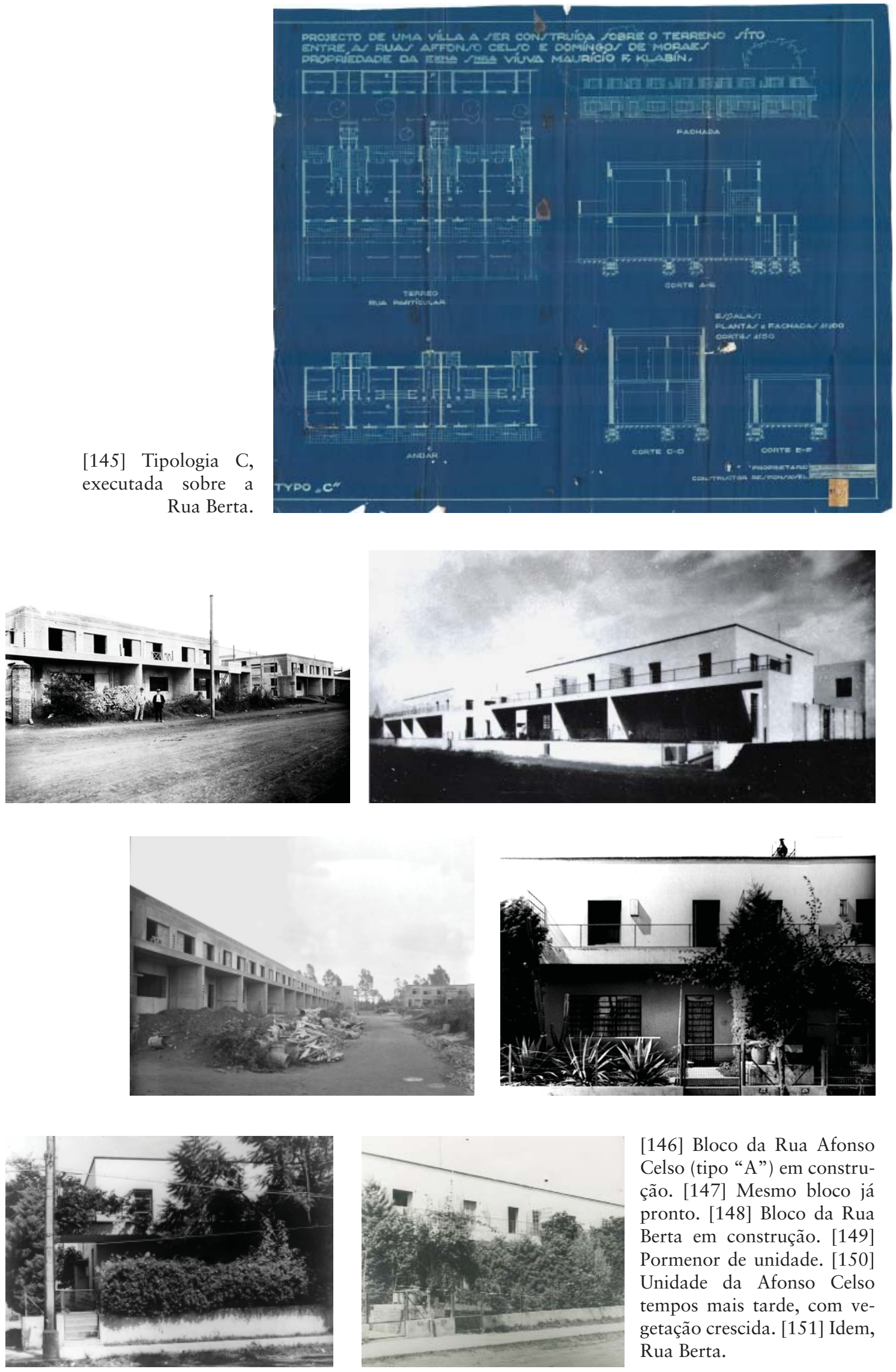

[146] Bloco da Rua Afonso Celso (tipo “A”) em construção. [147] Mesmo bloco já pronto. [148] Bloco da Rua Berta em construção. [149] Pormenor de unidade. [150] Unidade da Afonso Celso tempos mais tarde, com vegetação crescida. [151] Idem, Rua Berta. 


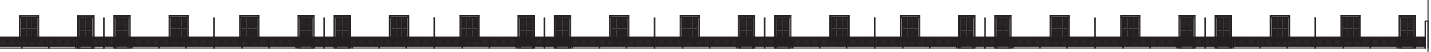

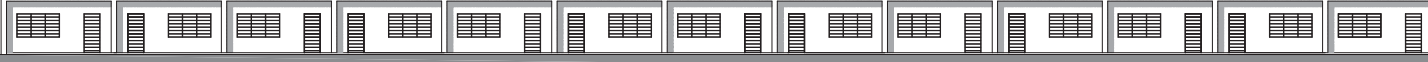
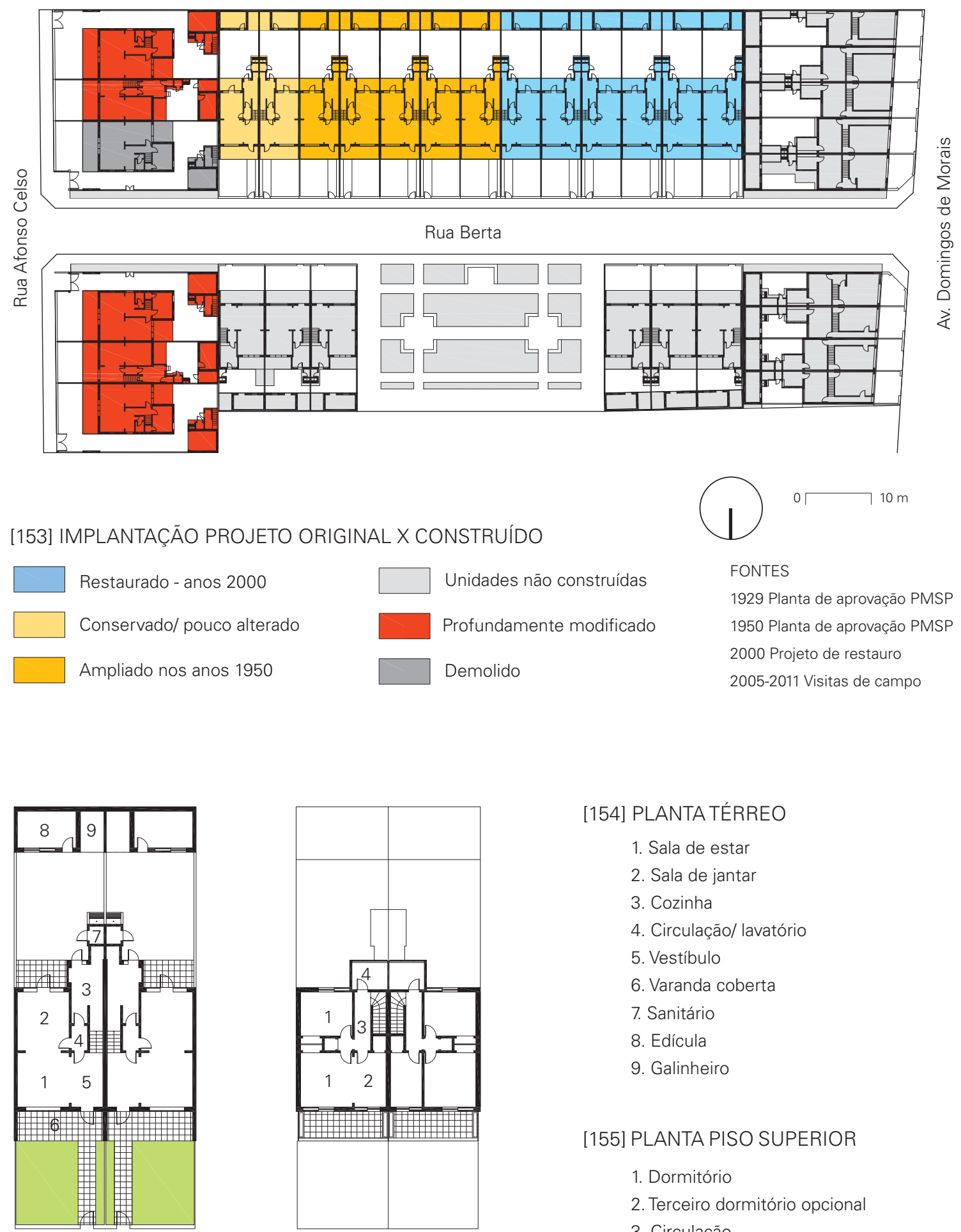

[154] PLANTA TÉRREO

1. Sala de estar

2. Sala de jantar

3. Cozinha

4. Circulação/ lavatório

5. Vestíbulo

6. Varanda coberta

7. Sanitário

8. Edícula

9. Galinheiro

[155] PLANTA PISO SUPERIOR

1. Dormitório

2. Terceiro dormitório opcional

3. Circulação

4. Sanitário 
Itápolis e Tomé de Souza. Já as janelas dos dormitórios, da edícula e a porta de acesso ao terraço do piso superior eram todas de correr com suas folhas embutidas, escondidas entre placas de argamassa armada e tijolos assentados em espelho. Como não havia peças disponíveis no mercado, Warchavchik utilizou para o trilho, cantoneiras de ferro, uma voltada para a frente da outra e uma régua de madeira no meio como baliza. Todas as estruturas e pisos em madeira da casa eram de peroba, portas em embuia e janelas em cedro, exceto esta guia, que era de Cabreúva, por ser uma madeira oleosa, apropriada para a fricção constante. A própria caixa que servia de forma para as vergas era própria para parafusar os trilhos. E então é perceptível o esforço de serialização - implicando na diminuição do tempo de execução e no barateamento da obra - nos caixilhos repetidos, no fechamento em placas de argamassa armada - também utilizada nos armários embutidos -, nas portas de compensado, etc., que produzidos em escala trariam rendimentos consideráveis.

Vale ainda destacar a postura do arquiteto naquele período, também presente no conjunto, de integração entre arquitetura e design nas diversas escalas, resultando no desenvolvimento de soluções não só para as esquadrias, mas também para gradis, painéis divisórios, luminárias, ferragens, etc. Se por um lado isto decorria da ausência de componentes industrializados, por outro a obra se mostrava como oportunidade de aplicação dos conceitos que vinha experimentando e do repertório que vinha construindo. Mesmo com a produção de elementos artesanais, mas para uma escala de conjunto, era necessário organizar oficinas de argamassa armada, serralheria, marcenaria para fabricação dos componentes:

Eu, abaixo assignado, architecto Gregori I. Warchavchik, declaro que o barracão coberto com folhas de zinco, que construi na Rua Afonso Celso n³1, na frente das minhas obras (Villa Da. Bertha), foi feito para servir de deposito e officinas das referidas obras e será demolido logo que as mesmas estejam terminadas ${ }^{146}$

Nota-se também algumas experimentações do ponto de vista da planta. Além da integração e continuidade dos ambientes do térreo, Warchavchik demonstra a preocupação de desenvolver uma solução mínima na área da cozinha, bem reduzida com relação aos padrões vigentes. Com 2,15m de largura por um comprimento livre de 2,80m, acrescido de dois nichos nas extremidades - um abaixo da escada e outro junto do bloco do sanitário externo -, a cozinha mostra o quanto o arquiteto estava bem informado das discussões modernas internacionais sobre os espaços mínimos, a exemplo dos trabalhos de Frankfurt. A cozinha de Warchavchik permite apenas uma área de circulação reduzida, ditada pelo alinhamento das portas de ligação com a sala e área externa, e uma linha de bancada de trabalho, possivelmente calculada de acordo com as peças usuais daquele período. E isso é percebido como intenção, pois os lotes não tinham restrições de área que justificassem a redução extrema de espaço.

Já no piso superior, está presente, ainda que de maneira tímida, a intenção de flexi- 
bilizar a planta. O conjunto foi construído por meio de alvenaria autoportante coroada por cintas de amarração, cobertura em laje de concreto e piso em assoalho. No entanto, há uma viga apoiada sobre duas espécies de pilares que pode ser notada nos dois pavimentos, no térreo sugerindo uma divisão entre um vestíbulo e a sala, se assim desejasse o morador, e no piso superior, a divisão ou não do quarto voltado à frente - no projeto já foram inseridas duas portas, aguardando o fechamento da parede e criação de um terceiro quarto.

Em termos compositivos, se na fachada voltada para a rua, os blocos se apresentavam como um grande prisma contínuo articulado pela marquise, nos fundos pequenas saliências quebravam a monotonia da superfície contínua. Tratava-se do volume representado pela cozinha no térreo e pelo banheiro no piso superior, que pela distribuição da planta encontrava-se em posição coerente e tecnicamente facilitavam a construção, pois era o único ambiente a necessitar de laje e instalações hidráulicas. Além disso, espelhados em planta nos sobrados, simplificavam a execução. O pé direito exigido menor possibilitava ainda jogar com a iluminação da circulação, com a claraboia já comentada. A associação a exemplares do Weissenhof, como o conjunto de J. J. P. Oud e o Kiefhoek, de Rotterdam, do mesmo arquiteto é imediata, mostrando um Warchavchik não só bem informado, mas desenvolto na tendência que vinha investigando.

De modo geral, é notável a busca por economia e conforto, em conformidade com os preceitos modernos. A solução encontrada no conjunto aparentemente era bem satisfatória ao arquiteto, pois é possível encontrar variações em outros trabalhos, como na quase repetição da tipologia "C" no projeto para 9 casas à Rua Turiassú para Maria das Neves Sampaio Moreira e nas 5 casas para Mina Klabin Warchavchik à Rua Dona Ignácia Uchôa ${ }^{147}$.

Passados alguns anos, confirmou-se o receio de Warchavchik, de que o sistema de impermeabilização ainda não era adequado, ocasionando constantes reclamações de infiltração por parte dos inquilinos, até que nos anos 1950, o conjunto passa por uma importante reforma. Emmanuel Klabin, proprietário das casas n 2 a 10, atualmente $n^{\circ}$ 48, 58, 60, 70 e 72 , decide inserir um novo telhado sobre a laje, resolvendo de vez o problema. Warchavchik aproveita a ocasião para construir um terceiro andar nas cinco casas pertencentes à sua esposa, atualmente de $\mathrm{n}^{\circ} \mathrm{s} 84,94,96,106,108$, entre 1950 e 1951. A reforma previa no térreo a diminuição do quarto da empregada, no $2^{\circ}$ andar, a abertura de um armário voltado para o corredor e divisão do quarto voltado para a rua em dois, e no novo $3^{\circ}$ andar, construído na área equivalente à metade dos fundos da casa (sala de jantar, circulação e cozinha), um novo dormitório, sanitário, armário e closet. A divisão obedecia a linha das paredes dos demais andares, seguindo a lógica da estrutura de alvenaria autoportante. O projeto foi submetido à prefeitura em 14/03/1950 ${ }^{148}$, tendo algumas observações para a oficialização da Rua Dona Berta e um comunique-se relativo à representação gráfica, destinação de usos e dimensionamento do "quarto da creada", sendo a aprovação publicada em 22/05/1950. A obra correria 

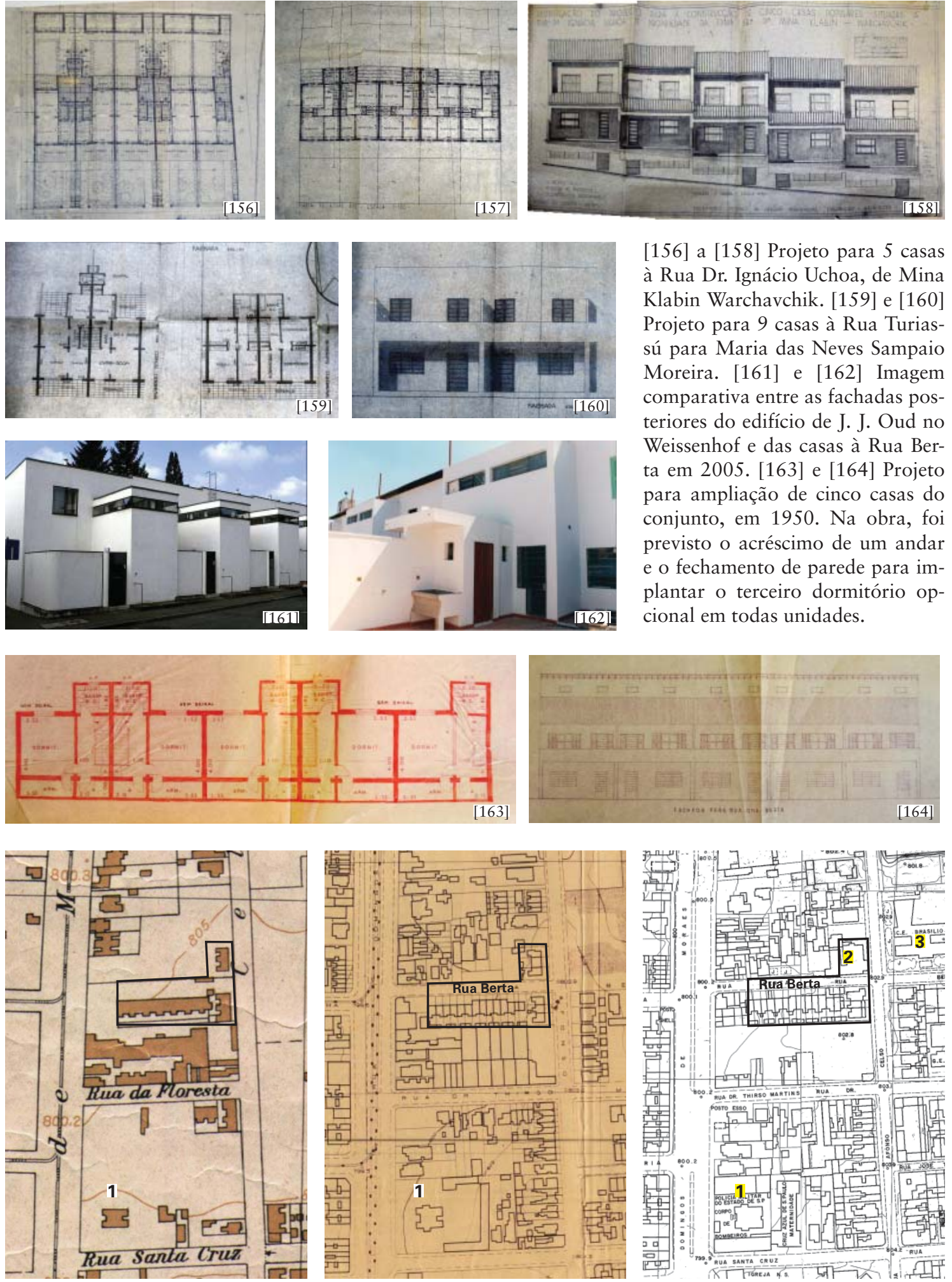

1. Quartel da Polícia Militar 2. Museu Lasar Segall 3. Colégio Brasílio Machado

[165] a [167] Evolução urbana do entorno do conjunto, de baixíssima densidade em 1930 à ocupação em 1954 e consolidação em 1972. Em 1930 a R. Berta não estava oficializada e o mapa registra uma pequena edificação no meio da rua, que cogitamos ser os tais barracões autorizados para a obra. Em 1954, a R. Berta já consta e a R. da Floresta tem nome trocado para Dr. Thirso Martins, prosseguindo rumo à Vila Afonso Celso. Em 1972 o bairro está plenamente ocupado, abrigando diversos equipamentos. [168] A área do conjunto nos dias atuais.

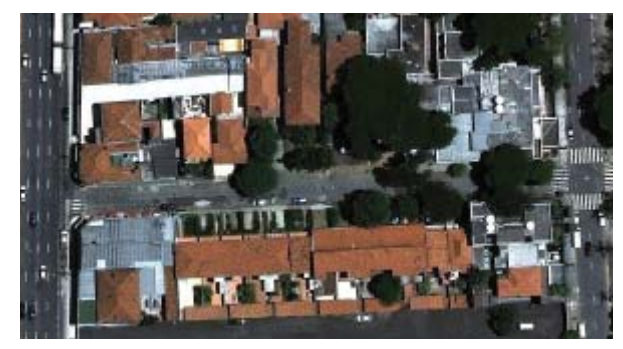

[156] a [158] Projeto para 5 casas à Rua Dr. Ignácio Uchoa, de Mina Klabin Warchavchik. [159] e [160] Projeto para 9 casas à Rua Turiassú para Maria das Neves Sampaio Moreira. [161] e [162] Imagem comparativa entre as fachadas posteriores do edifício de J. J. Oud no Weissenhof e das casas à Rua Berta em 2005. [163] e [164] Projeto para ampliação de cinco casas do conjunto, em 1950. Na obra, foi previsto o acréscimo de um andar e o fechamento de parede para implantar o terceiro dormitório opcional em todas unidades. 
até o ano seguinte, tendo sido concedido o Auto de vistoria em 14/11/1951 ${ }^{149}$.

Neste período a região já não era tão distante quanto a considerada zona suburbana de 1930, mas tampouco era um bairro consolidado, havendo ainda glebas da própria família Klabin por parcelar. É dali em diante que a cidade sofre um intenso processo de urbanização, adensamento, verticalização, metropolização. A cidade extrapola o centro e se expande por todas as direções, mas de modo seletivo: as classes mais abastadas rumam ao vetor sudoeste, enquanto a zona leste, extensão dos bairros operários, e o "lado de lá" dos rios Tietê e Pinheiros tornam-se de menor interesse para o mercado ${ }^{150}$. A Vila Mariana constituiu-se como bairro de classe média, mas já vinha abrigando instituições de referência, como a Escola Paulista de Medicina, nos anos 1930, o Liceu Pasteur na década de 1920, o colégio Arquidiocesano, na 2a metade do século XIX. Em 1951 seria construído o colégio Brasílio Machado em frente ao conjunto, do outro lado da Rua Afonso Celso e em 1955 se instalaria na Avenida Domingos de Morais a Caixa Beneficente da Guarda Civil ${ }^{151}$. Em 1957 falece Lasar Segall, fazendo imediatamente com que Jenny Klabin concebesse um museu em sua homenagem na própria casa do casal.

Jenny, tradutora de clássicos da literatura alemã e francesa, como as respeitadas versões de Goethe, Molière, Racine e Corneille ${ }^{152}$, começou a realizar extenso trabalho de catalogação e conservação, viajou ao exterior para adquirir quadros de Segall, e chegou a abrir provisoriamente o museu em 1967, paralelamente à VIII Bienal de São Paulo. Após fechamento para reforma final de adequação do espaço, entretanto, não assiste à inauguração do Museu, falecendo a menos de dois meses da abertura em 21 de setembro de $1967^{153}$. Os filhos, Oscar e Maurício Segall então assumiram a condução do empreendimento, criando uma associação sem fins lucrativos em 1970, para a qual doaram o imóvel e a coleção de Lasar. A abertura oficial ao público ocorreu em 1973 e a partir de 1975 o museu passou a receber auxílio estatal. Mas o local era ainda considerado distante, sendo alvo de críticas do próprio concunhado Warchavchik. Em depoimento de 1972, considerava o museu mal localizado, devendo estar em espaço mais acessível, como uma Avenida Paulista, o que poderia ocorrer com auxílio do crítico Geraldo Ferraz, amigo e bom conhecedor da vida de Segall ${ }^{154}$. Mas em pouco tempo, a linha azul do metrô começaria suas obras, inaugurando a estação Santa Cruz em 1974, encurtando a distância e dando um novo impulso à dinâmica imobiliária da região.

149 PMSP, processo 152.691/51. Na reforma, o terraço passa a ser coberto, contanto como área construída, o que fica demonstrado no mapa Vasp de 1954.

150 VILLAÇA, 1998

151 Sistema previdenciário próprio da corporação, hoje Polícia Militar do Estado.

152 A publicação Jenny K. Segall compilou uma série de críticas e notas publicadas em jornais de grande circulação sobre as traduções

153 Informações em exposição permanente e site do Museu e em O Dia, 31/08/1966; Diário da Noite, 31/08/1966; FSP, 16/11/1966; A Gazeta 22/11/1966. Os filhos passam a cuidar do museu, instituindo legalmente a associação Museu Lasar Segall em 1970 e em 1984 doam-no para a Fundação Pró-Memória, atualmente IBRAM.

154 WARCHAVCHIK apud BECCARI, 1979:98-101 


\section{Patrimônio cultural x patrimônio imobiliário}

Em 5 de maio de 1989, Maurício Segall encaminha carta ao Conpresp denunciando o pedido de demolição em análise na prefeitura, das casas de $n^{\circ} 48$ a 72, para dar lugar a um edifício de escritórios. Diante da ameaça iminente de destruição, solicita tombamento urgente do conjunto. Em carta acompanhada de abaixo-assinado, assinalava sua justificativa:

Como se sabe, esta vila, cujo projeto de 1931 (sic) é de autoria do arquiteto Gregori Warchavchik, pioneiro da arquitetura moderna entre nós, é a primeira vila de caráter moderno na cidade de São Paulo e guarda até hoje a maioria das características originais. As alterações mais significativas são as dos telhados e, em cinco casas, a adição de mais um andar, mas tudo projetado e executado pelo próprio Warchavchik na década de 50. Cabe assinalar que a planta e a fachada destas casas constam da página 82 do livro de Geraldo Ferraz sobre o arquiteto ${ }^{155}$

O processo correu em caráter de urgência, sendo aprovada a resolução de APT 6/ CONPRESP/89, em 29 de junho de 1989. Paralelamente, pedido semelhante entrava no Condephaat, em nome dos moradores da Rua Berta, que se mobilizaram ao saber que os locatários das casas de $\mathrm{n}^{\circ} 48$ a 72 haviam recebido notificação dos proprietários de que deveriam desocupá-las porque seriam demolidas. Solicitavam assim, medidas urgentes para impedir a demolição "por se tratar da primeira vila modernista do Brasil, ainda intacta, projetada pelo arquiteto WARCHAVCHIK em 1930, que consideramos de extremo valor arquitetônico" ${ }^{156}$. A arquiteta Diana Danon do STCR logo acatou a solicitação, lembrando que Warchavchik foi pioneiro ao compatibilizar o problema da habitação com a nova arquitetura, resultando em um conjunto de casas atuais mesmo para uma família dos anos 1980. O professor e crítico de arte Jorge Coli, conselheiro designado relator do processo, também dava seu parecer favorável à abertura de tombamento, que se efetivaria em 26 de junho do mesmo ano:

As casas da Rua Dona Berta foram projetadas por Gregori Warshavchik. É inútil insistir aqui sobre a extraordinária importância desse arquiteto na nossa história. Relevemos apenas que, construídas nos anos 1930, essas casas constituem o primeiro conjunto de habitações de caráter moderno destinado à população de média e baixa renda. Representam, portanto, um marco arquitetural da maior importância.

Acrescente-se que elas guardaram suas características originais. As alterações nelas realizadas - telhados, e em algumas, adição de um andar - em realidade só as tornam mais preciosas. Pois estas modificações foram realizadas pelo próprio arquiteto (grifo do autor) nos anos 1950, o que nos deixa o testemunho de uma 
reflexão do autor sobre sua própria obra, segundo as exigências de adaptações às novas circunstâncias.

Entretanto, esse tipo de argumentação não foi levado em consideração pela equipe do DPH. Para os arquitetos responsáveis pelo parecer, Roberto Pinheiro e Yara Carvalho, as unidades voltadas para a Rua Afonso Celso e Domingos de Morais estariam demasiadamente descaracterizadas para justificar o tombamento ${ }^{157}$, concluindo que

Resta então o conjunto central da Rua Berta que constitui um todo harmonioso de linhas sóbrias e despojadas e que mantém muitos de seus elementos originais tais como gradis, caixilhos e luminárias desenhadas pelo arquiteto ${ }^{158}$

Entretanto, ao descreverem as alterações realizadas por Warchavchik, consideraram que a cobertura em duas águas alterava profundamente a principal característica do conjunto, que seria a ortogonalidade do volume geométrico. Com isso, opinavam que

Então que a maior importância da vila se dá pelo seu valor ambiental já que ela se integra harmoniosamente na paisagem local composta quase que exclusivamente de construções residenciais unifamiliares de pequeno porte dotadas de significativa arborização.

Dentre todo o conjunto da obra do arquiteto Gregori Warchavchik há que se questionar a importância das casas da Rua Berta em relação a outras edificações ainda existentes, entre as quais o conjunto de casas operárias situado à Rua Barão de Jaguara executadas de acordo com o projeto original, o prédio de apartamentos à Alameda Barão de Limeira vencedor de concurso realizado por Prestes Maia, além da Casa Modernista da Rua Santa Cruz, já tombada pelo Condephaat ${ }^{159}$.

Respaldados pela chefia da Seção de Crítica e Tombamento (STCT), seção responsável pela instrução, propunham apenas o enquadramento na Z8-200, dado o valor ambiental do conjunto. Mas com a APT os estudos prosseguem e são também sugeridas as APTs do conjunto da Barão de Jaguara, do edifício da Barão de Limeira e da casa da Avenida Rebouças. A diretora da Divisão de Preservação solicitava o estudo do conjunto de obras remanescentes de Warchavchik, mas o chefe da STCT, Eudes Campos, orientou sua equipe técnica a restringi-los. Para ele,

A produção do arquiteto Warchavchik deverá se limitar, salvo se os estudos demonstrarem o contrário, às obras das décadas de 20 e 30, período realmente significativo da atividade profissional do arquiteto, tanto em nível nacional quanto aos 
níveis regional e local ${ }^{160}$. (grifo nosso).

Vemos aí entrar em cena mais uma vez o poder de uma historiografia que aprioristicamente já selecionou os exemplares dignos de preservação. Destaca-se o livro de Geraldo Ferraz, que será sempre citado e copiado nos processos de tombamento de obras de Warchavchik como prova ou atestado de relevância. O livro reivindica o papel fundamental do arquiteto na constituição da arquitetura moderna no Brasil, mas ao restringir o período abordado no livro para 1925-1940, deixa subentendido que a produção restante não é importante. Como única obra disponível sobre o arquiteto naquele momento, sendo ausente qualquer estudo que levantasse as obras posteriores, esta contribuiu para moldar uma valoração focada no pioneirismo das obras iniciais. O reverso da rememoração das obras pioneiras era o decretado esquecimento das obras posteriores a 1930, desconhecidas do órgão de preservação.

Chama a atenção o entendimento dos técnicos sobre o que seria descaracterização. Fundada no problema visual, a argumentação claramente entendia qualquer alteração com relação ao aspecto primitivo do imóvel um valor negativo. Por que não considerar a reforma dos anos 1950 como um novo estágio figurativo do conjunto? Porque descartar as casas voltadas para a Rua Afonso Celso? Quanto a essas, o valor simbólico e projetual da casa-atelier de Segall por si só justificaria o tombamento; $\mathrm{Na}$ outra quadra, das três casas, apenas a da esquina se encontra com alterações, pois apesar de não ficar claro nos registros fotográficos, aparentemente preservava-se a volumetria, o posicionamento dos vãos e alinhamento. Quanto às outras duas, exceto pelo estado de conservação da casa à esquerda, ambas aparentam estar no mesmo estado das casas voltadas à Rua Berta.

O conteúdo referente às demais indicações de APT passou a ser tratado em processo à parte, que daria origem à resolução 14/CONPRESP/90. Sobre a Vila Dona Bertha, o parecer final de STCT reiterava os argumentos anteriormente colocados, mas ressaltava a necessidade de proteção como forma de garantir a qualidade ambiental, combater a especulação imobiliária e futuras descaracterizações. A proposta do DPH incluía uma área envoltória formada pelas duas quadras que englobavam as casas e a proposta de resolução criava mecanismos para o controle urbanístico da configuração desejada, com a proibição de remembramentos e a fixação de gabaritos baixos no entorno, de modo a não perturbar o valor ambiental atribuído ao conjunto. Deve-se assinalar a relação paradoxal entre uma visão contemporânea na qual emergia o valor ambiental como fundo para o tombamento de bairros e uma visão conservadora, na qual primava a originalidade da obra.

O processo é então encaminhado ao conselheiro relator, mas este o devolve para esclarecimento quanto à proteção proposta - tombamento ou Z8-200. Neste caso, Eudes Campos responde assumindo hesitação inicial e elegendo o tombamento por considerar um instrumento mais técnico que a Z8-200, mais suscetível à dinâmica política, por depender 
de aprovação na Câmara de vereadores. E assim, o tombamento final é votado em 5 de abril de 1991.

Apesar de não ter contestado o tombamento em 1991, Tito Chrostowski Gornick, proprietário das casas de $\mathrm{n}^{\circ} 48$ a 72, irá fazê-lo em $1994^{161}$. Tito era afilhado de Anna Theresia Hamburguer, que doou a ele as casas com usufruto vitalício em 1988, mas com seu falecimento em 1989, foram logo transferidas em definitivo ${ }^{162}$. Já Anna Theresia viveu com Emmanuel Klabin por anos ${ }^{163}$, que mesmo não tendo se casado oficialmente nem terem tido filhos, herdou os imóveis do irmão caçula de Mina Klabin Warchavchik. Inconformado com o tombamento, Tito tentou vendê-las a uma incorporadora, que pagaria um bom preço, em um momento em que acreditava ser possível reverter o tombamento. Naquela época, seu advogado, José Antonio Domingues chegou a declarar na imprensa que pouco viam valor no conjunto, que "são casas em situação precária e que estão ultrapassadas hoje em dia" 164 . Foram algumas tentativas para viabilizar uma saída comercialmente mais interessante, chegaram a contratar o arquiteto Carlos Faggin para um projeto de reciclagem, mas nada vingava. Cansado da relação difícil com seu cliente, que insistia no destombamento e em subterfúgios duvidosos, Domingues parou de advogar para ele.

Em 28/09/1999, era aprovado o tombamento estadual, "das fachadas dos imóveis situados na Rua Dona Berta” dos nº 48 ao 120, com a recomendação de preservação integral do $n^{\circ} 96^{165}$. A unidade é uma das 5 reformadas nos anos 1950, o que demonstra que o Condephaat de fato assumiu a valorização das intervenções posteriores ao período de inauguração da obra. O processo foi levado à relatora, a arquiteta e professora da Unesp Rosio Fernández Salcedo, sem que houvesse uma posição fechada pela equipe técnica do Condephaat quanto à proteção a ser dada ao conjunto. A arquiteta Diana Danon era favorável à preservação apenas das características externas pois o Estado não oferecia qualquer tipo de benefício ao usuário como contrapartida às restrições. Já a historiadora Sheila Schwartzman defendia que ao menos um imóvel fosse preservado integralmente, além de defender, sem sucesso, a APT da casa de Lasar Segall, não com o acervo do museu, mas apenas sua arquitetura. Sua posição ia especialmente contra a leitura realizada pelo DPH que considerava que a suposta descaracterização teria tirado o valor do conjunto:

Se caixilhos foram alterados, gradis trocados, se houve acréscimos ou não, continuam de pé as concepções racionais de espaço, as aberturas das fachadas, a distribuição interna, os acabamentos e o material original. Assim, somos contrários a Preservação de um “Cenário”. Estas casas não são apenas uma "vista moderna”.

161 Conforme descrito no processo de tombamento, 1989-0.002.598-8, fl. 110 verso.

162 Conforme registro em cartório anexado ao processo de tombamento, fls. 66 e 67.

163 E que segundo seu antigo advogado, por ser católica foi alvo de hostilização por parte da família.

164 VEJA SP, 24/05/1989

165 Notificação - Processo 27.030/89 
São testemunho e ensinamento e como tal devem ser preservadas, Tombar apenas a fachada contradiz a própria natureza do objeto em estudo, uma vez que trata-se da própria história da arquitetura moderna em São Paulo, seus espaços, concepções estéticas, econômicas, e sociais, os materiais utilizados e a própria idéia contida na concepção de "máquina de morar". Mesmo que estes espaços não estejam hoje íntegros como há 60 anos, terão as marcas cabíveis desta história.

Entre preservar apenas as características externas ou também incorporar as internas, a relatora optou pelo segundo caminho:

Apenas tombamento das fachadas não mostra a tipologia residencial de um determinado grupo social e faze sua leitura incompleta aos olhos do observador (...). O tombamento integral de uma das casas pode mostrar a nossa geração como a gerações futuras o projeto do arquiteto Warchavchik, precursor do modernismo na cidade de São Paulo, assim como o habitat da população de classe média na década de trinta ${ }^{166}$.

Apesar de aprovado o tombamento em 1999, a resolução seria aprovada apenas em 2003 pelo conselho ${ }^{167}$. A resolução já incluía a regulamentação da área envoltória, pesquisa esta realizada em conjunto com arquitetos do DPH, no intuito de se adotar uma linguagem única e critérios comuns entre os dois órgãos. Entretanto, o processo seria encaminhado para relatoria de dois conselheiros e entre a apreciação da minuta pelo primeiro, o arquiteto Jon Maitrejean, um dos professores junto com Vilanova Artigas e Paulo Mendes da Rocha, afastados compulsoriamente dos quadros da FAUUSP nos anos de chumbo da ditadura militar, e o segundo, padre José Rodolpho Perazzolo, ambos favoráveis à redação proposta, foi sancionado o decreto 48.137/03, que alterava a forma de definição das áreas envoltórias, levando à necessidade de revisão do texto inicial da Resolução. O processo se estendeu por anos, por inúmeros percalços, desde a demora na obtenção de documentos, os tempos em que ficou parado, as denúncias de descaracterizações, as pesquisas, as idas e vidas às reuniões do conselho, problemas no Ministério Publico, entre outros. Após a modificação nas considerações iniciais da Resolução, esta seria somente aprovada novamente em 2005, mas o tombamento não foi imediatamente homologado. Em 2006, novamente o jurídico aconselharia alteração no texto em decorrência de novo decreto de $n^{\circ}$ 50.941, de 05/07/2006, que reestruturava o Condephaat, criando a Unidade de Preservação do Patrimônio Histórico (UPPH). Com isso o processo enfrentaria nova rodada de tramitação, chegando a 2007 às mãos do conselheiro Maitrejean, que então propunha uma nova reflexão: "nestes quase vinte anos em que o processo perambulou pelo CONDEPHAAT e após inúmeras vicissitudes e mudanças, chega a nossas mãos a redação final da resolução de tombamento a ser enviada ao Sr. Secretário da Cultura, para a devida homologação”. E continua: 
Já estávamos prestes a aprovar o texto apresentado, quando por curiosidade intelectual resolvemos ler as matérias de publicações da época, que compõem o processo, que por sinal é muito rico e esclarecedor das teses da arquitetura moderna, caramilhoras aqui, caramilhoras lá, uma dúvida vai tomando vulto: "o que afinal estamos tombando"? ${ }^{168}$

Perguntando-se se o tombamento preserva o bem nas condições que se encontra na data da APT ou se é o projeto do autor que está sendo tombado, relata, começa a consultar a planta original e as fotos da época da inauguração contidas no livro de Ferraz, de "quando o normal era morar em casa de aluguel e quando o sonho do carro próprio ainda estava em gestação”. Mas cinquenta anos depois, quando os estudos para o tombamento se iniciaram, o carro já era uma necessidade, dando lugar o jardim frontal às garagens, a laje plana, que dava forte característica de modernidade, era substituído por telhado com beiral, "e a algumas casas foi acrescentado um novo andar, eram pequenas para acomodar as novas famílias de classe média em ascensão", e assim por diante. Indagava-se:

E do projeto do autor o que sobrou? Muito pouco diríamos. Talvez a volumetria das fachadas, as proporções dos vãos de abertura (portas e janelas), as divisórias em ferro e vidro que dividem os terraços superiores, individualizando as residências, a massa de revestimento original, algumas grades que parecem ser originais ou reproduzem o tipo das mesmas, que nos parecem, poderiam ser preservados.

Depois desses devaneios causados pela leitura das 450 páginas do processo, nos levaram a concluir que após vinte anos de discussão, o tombamento não seja a solução, especialmente se considerarmos que as casas em questão e a rua Berta em particular já se encontram tombadas pelo COMPRESP desde 1991 (...).

Nestes termos, entendemos que o bem em questão está suficientemente protegido e nos parece ilógico que um mesmo bem tenha graus de proteção distintos (...), assim propomos que o estudo de tombamento das casas da Rua Berta seja ARQUIVADO 169 .

Ou seja, depois do longo percurso em que a própria burocracia impedia a conclusão do processo - algo de dar inveja a Kafka, diga-se de passagem, o mesmo conselheiro que aprovou o tombamento lá atrás propunha o arquivamento pelos mesmos motivos que os arquitetos do DPH tombaram os imóveis exclusivamente pela conformação ambiental do conjunto. Com isso, renegou a própria ideia contida no parecer de Jorge Coli, que originou a abertura do processo, de que as alterações realizadas tornavam as casas ainda mais valiosas por se tratarem de intervenções do próprio arquiteto. A comparação entre as visões de arqui- 
tetos e profissionais formados em outras áreas parece ser inevitável. A visão de um arquiteto que faz parte da história do modernismo brasileiro (Maitrejean) parece confrontar-se com a de um crítico de arte (Coli) - cujo campo de conhecimento tende a ver a obra como um objeto mais aberto, uma historiadora (Schwartzman) ou uma profissional, embora arquiteta, mas formada no Peru, pós-graduada em geografia e no PROLAM (Salcedo), no que se refere à evolução da obra no tempo, na relevância das contribuições posteriores à concepção original, na ideia da obra como testemunho de uma forma de morar. A arquitetura do eterno presente fez com que sua forma sedutora original se sobrepusesse ao presente decantado. $\mathrm{E}$ assim, a proposta de arquivamento do processo era acatada pelo conselho em 26/11/2007170. Houve novo abaixo-assinado dos moradores pela reversão do arquivamento, no qual expressavam temor com relação à ocupação do entorno, já que nos fundos da quadra da Rua Berta lado ímpar havia sido construída uma Igreja Universal do Reino de Deus de grandes proporções e o terreno baldio nos fundos do conjunto protegido havia se tornado um imenso estacionamento para os fiéis. Mas a leitura do setor jurídico do Condephaat era de que os pontos apresentados não ofereciam subsídios para a reabertura do tombamento e que o parecer do conselheiro respondia aos questionamentos apresentados, não aceitando assim o recurso.

O receio não era à toa. Alguns anos antes, enquanto corria o processo de tombamento estadual, percebendo uma movimentação de tratores nos fundos dos sobrados, o diretor do Museu Lasar Segall, Marcelo Mattos Araújo, acionava a polícia no dia 18/02/2000 para suspender a demolição em curso ${ }^{171}$. Segundo funcionários da Hidroservice que trabalhavam no local, a empresa estaria realizando apenas serviços de limpeza na área, que já havia sido demolida. Foram derrubadas as edículas, os muros de divisa, os pisos dos quintais das cinco casas de Tito, $\mathrm{n}^{\circ} 48$ a 72 e parte da fachada posterior da de $\mathrm{n}^{\circ} 48$ (a mais próxima da Avenida Domingos de Morais) - as mesmas que em 1989 tiveram o pedido de demolição como motivação para a abertura dos tombamentos. Em poucos dias, o DPH abria processo para apurar o caso e rapidamente a Administração Regional da Vila Mariana era acionada, aplicando multa por execução de reforma com decréscimo de área sem Alvará e embargo às obras. O passo seguinte foi intimar o proprietário a restaurar os imóveis conforme as diretrizes estabelecidas pelo órgão preservacionista ${ }^{172}$.

Antecedia a intimação um relatório realizado por técnicos do DPH, de 23 de junho de 2000, contendo fotografias, relato de vistoria e proposta de diretrizes. Segundo eles, as fachadas frontais estavam em geral bem conservadas e pouco alteradas, sendo os problemas mais comuns: alterações das envasaduras das fachadas posteriores; alterações internas, especialmente cozinhas e banheiros; infiltrações por águas pluviais; danos nos pisos internos, de tábua corrida; fissuras superficiais na argamassa de revestimento; degraus soltos nas casas 

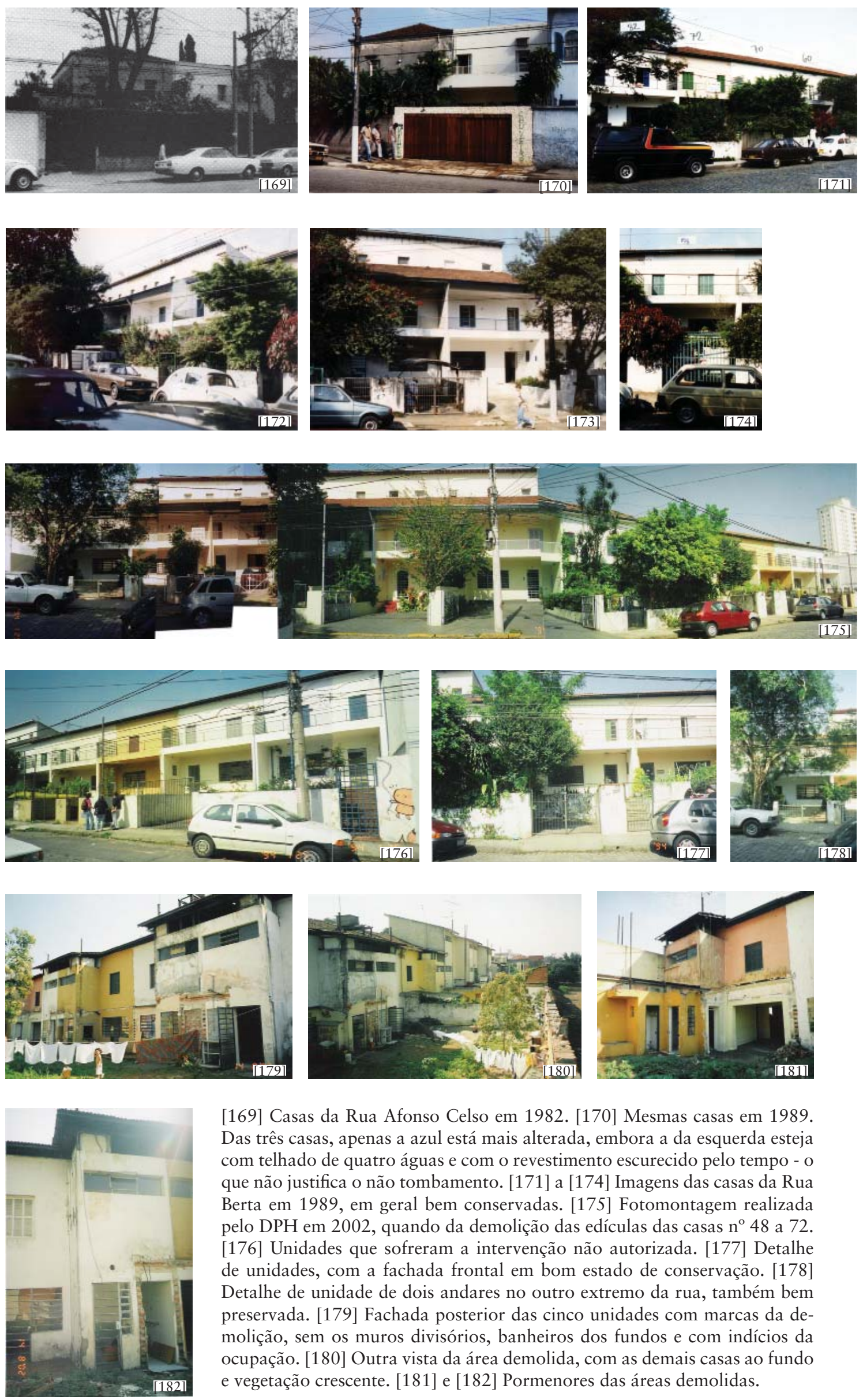

[169] Casas da Rua Afonso Celso em 1982. [170] Mesmas casas em 1989. Das três casas, apenas a azul está mais alterada, embora a da esquerda esteja com telhado de quatro águas e com o revestimento escurecido pelo tempo - o que não justifica o não tombamento. [171] a [174] Imagens das casas da Rua Berta em 1989, em geral bem conservadas. [175] Fotomontagem realizada pelo DPH em 2002, quando da demolição das edículas das casas n ${ }^{\circ} 48$ a 72 . [176] Unidades que sofreram a intervenção não autorizada. [177] Detalhe de unidades, com a fachada frontal em bom estado de conservação. [178] Detalhe de unidade de dois andares no outro extremo da rua, também bem preservada. [179] Fachada posterior das cinco unidades com marcas da demolição, sem os muros divisórios, banheiros dos fundos e com indícios da ocupação. [180] Outra vista da área demolida, com as demais casas ao fundo e vegetação crescente. [181] e [182] Pormenores das áreas demolidas. 
$\mathrm{n}^{\circ} 58$ e 60 ; presença de cupim de solo detectável visualmente na casa $\mathrm{n}^{\circ} 48^{173}$. E então propunham diretrizes:

- Reconstrução das edículas e dos muros divisórios dos fundos dos lotes;

- Restauração das envasaduras das fachadas posteriores (portas e janelas);

- Recuperação da cobertura;

- Retirada do anteparo para chuva na soleira da porta do terraço superior da casa 60

- Recuperação dos elementos divisórios do terraço superior (vidros aramados);

- Recuperação dos jardins e áreas livres de cada lote

O projeto deverá ser efetuado por profissionais especializados e submetido à apreciação do Conpresp ${ }^{174}$.

Não tendo sido a intimação cumprida, em novembro de 2000 e janeiro de 2001 a Administração Regional multou o proprietário. Em setembro de 2001, com os imóveis em estado de completo abandono, o DPH encaminha o processo para o Departamento judicial para adoção de medidas cabíveis. Paralelamente, já corria um Inquérito Policial em decorrência do registro de Boletim de Ocorrência realizado pela equipe do MLS, remetido ao Fórum Regional do Jabaquara. Foi então aberto Inquérito Civil pela Promotoria de Justiça do Meio Ambiente da comarca de Barra Velha, comarca de Santa Catarina, estado onde residia o proprietário. Enquanto Tito Gornick firmava um Termo de Ajustamento de Conduta (TAC) no MP catarinense, o MP paulista abria outro processo, solicitando ao DPH que detalhasse as diretrizes e fornecesse elementos para o embasamento do restauro. No TAC, Tito comprometia-se, no prazo de 90 dias a partir da aprovação do projeto de restauro, recebimento do projeto original e dos processos de tombamento, a "efetuar a reconstrução dos imóveis de sua propriedade, com base nas plantas originais a serem apresentadas pelos órgãos competentes” ${ }^{175}$. Foram então providenciadas cópia do projeto original, levantamento métrico arquitetônico e plantas contendo as diretrizes, que também foram detalhadas e complementadas. Os itens anteriormente citados foram reiterados, acrescentando-se a recuperação de pisos e soleiras, reposição de vidros e manutenção na caixilharia, recuperação geral da pintura das paredes e esquadrias metálicas, reconstrução do compartimento que originalmente abrigou despensa e banheiro externo. Foram liberadas as vagas de estacionamento realizadas anteriormente ao tombamento e as alterações internas, pois não interferiam nas fachadas.

O advogado Domingues, desde o contato com o arquiteto e professor Faggin foi incentivado a cursar arquitetura, dado seu processo de sensibilização para o problema. Além 
disso, lhe interessava adquirir conhecimentos na área, tendo em vista seu trabalho com parcelamentos urbanos e o problema que tinha por vezes com perícias, quando lhe faltava o repertório técnico. Deste modo, enquanto corria a ação, começou a cursar graduação em Arquitetura e Urbanismo e passou a defender a preservação das casas. Com isso, foi atrás de investidores que assumissem o compromisso judicial da recuperação do conjunto, atraindo um casal de amigos que pretendiam comprar um imóvel no Planalto Paulista, convencendoos a comprar no lugar de um, quatro imóveis na Vila Mariana. A quinta casa objeto da ação, ele mesmo compraria, tendo parte do valor descontada como pagamento por seus honorários. Inicialmente, orçou a restauração com arquitetos e restauradores que estimavam a obra de R\$150 a R \$200 mil por imóvel em média, chegando ao ponto absurdo de um profissional sugerir que lhe doassem as casas para que os livrassem do processo-crime. Concluindo a graduação em arquitetura e tendo tido escritório na casa ${ }^{\circ} 72$, quando já realizara pequenos reparos, havia notado que o conjunto não tinha qualquer técnica ou material mais rebuscado. Como também tinha grandes conhecimentos de serralheria e carpintaria, hobbies cultivados em sua oficina particular e ofícios aprendidos com seu próprio pai, serralheiro, de família de artesãos, percebeu que também neste quesito conseguiria se sair bem e decidiu assumir ele mesmo a obra de restauro ${ }^{176}$.

Já em janeiro de 2003, era comunicada à justiça a venda dos imóveis ao casal, que assumia os compromissos firmados pelo antigo proprietário no TAC. A primeira etapa, comandada pelo advogado e arquiteto José Antonio Domingues, consistiu na solicitação para limpeza do terreno, logo autorizada, enquanto era desenvolvido o projeto de restauro para aprovação pelo Conpresp. O projeto tinha desenhos e especificações em memorial descritivo que visavam o atendimento das diretrizes, aproveitando bastante dos desenhos já realizados pelo DPH. Sua proposta detalhava os procedimentos para a edícula a ser construída conforme a demolida - fundações, alvenarias, coberturas, caixilhos, instalações, etc. Visualmente, deveriam se igualar às edículas das casas de $\mathrm{n}^{\circ} 82,84$ e 94 , que se mantinham originais. $\mathrm{O}$ mesmo expediente foi utilizado para a orientação de outros serviços, como o tanque a ser refeito conforme o existente na casa $\mathrm{n}^{\circ} 82$; as portas e portões, conforme o $\mathrm{n}^{\circ} 58$; os guardacorpos, conforme o $\mathrm{n}^{\circ} 48$; as portas com vitrô da cozinha e sala de jantar, conforme o $\mathrm{n}^{\circ} 70$; as escadas externas de acesso, conforme os $\mathrm{n}^{\circ} \mathrm{s} 58$ a 72, revestidas pelo mesmo piso litocerâmico de 24 x $39 \mathrm{~cm}$ utilizado nas varandas e pisos externos. A obra também previa o refazimento do muro de divisa com altura de $2,10 \mathrm{~m}$, a demolição da caixa d'água que ficava visível, sobre o volume dos sanitários, para instalação de novas peças no volume principal, sob os telhados, a revisão da cobertura, a recomposição dos revestimentos desagregados. Além disso, Domingues havia notado que no assentamento das peças cerâmicas, o rejunte era rebaixado para o arremate em cimento queimado, para o acabamento ficar bem liso e nivelado. Tendo sido consideradas contempladas as diretrizes, o DPH sugeriu aprovação do projeto, entretanto com a diretriz de que as juntas do piso litocerâmico especificadas injustificadamente em verde deveriam ser substituídas por cor natural. Em 19 de agosto de 2003 
o projeto era então aprovado pelo Conpresp.

\section{Conhecendo a obra através do canteiro}

Iniciado o restauro, logo surgiriam imprevistos e informações oriundas da própria interação com a obra, fazendo com que os proprietários solicitassem revisão das diretrizes em $21 / 11 / 2003^{177}$. Além de boa parte do piso dos fundos ter sido demolida, muito do piso litocerâmico remanescente deveria ser retirado para a reimpermeabilização do terraço ou para a substituição de condutores de águas pluviais e esgoto, que tinham as manilhas cerâmicas avariadas. Mesmo retirado com cuidado, não se salvaram peças o suficiente para serem reassentadas nem em apenas uma casa inteira e o piso fabricado pela extinta Cerâmica São Caetano não era mais encontrado no mercado, nem havia peças maiores na mesma coloração que pudessem ser cortadas. Além disso, para a fabricação por encomenda, o custo exorbitante inviabilizaria o restauro, levando à proposição de substituição por peças de 31 x $31 \mathrm{~cm}$ na mesma coloração, que no mais, argumentavam, era bastante utilizado em outras obras de Gregori.

No trabalho de troca de reboco da parte frontal, constatou-se a existência de rede de eletrodutos e caixas de passagem que partiam da casa $n^{\circ} 48$ e alimentavam o conjunto. Foi solicitado o restabelecimento deste modelo de distribuição de energia, pois além de os medidores já terem sido furtados das casas nos anos de abandono, a retirada das fiações e dos postes individuais que competiam com a estreita calçada promoveria significativa redução da poluição visual. Restaria somente um poste, servindo a casa 48, que teria um abrigo onde concentraria todos os medidores, como em uma vila. A ação no MP contribuiu para a aprovação nas concessionárias, que em princípio eram contrárias à solução.

Os gradis também tiveram a diretriz revista, quando foi comprovado que a solução original não era o gradeado da casa $\mathrm{n}^{\circ} 58$, mas sim perfis tubulares fechados por telas, como visto nos guarda-corpos dos terraços, em casas vizinhas e mesmo nas demais casas, nos quais era possível observar os furos presentes nos tubos.

Por último, durante a execução dos serviços de reparação nos condutores de águas pluviais, notou-se o estado bem conservado da laje, apenas encoberta por entulhos e com grossa camada de regularização. Quando realizado orçamento, constatou-se que possivelmente a manutenção do telhado seria mais custosa e demorada que a sua retirada, impermeabilização e regularização da laje, levando o proprietário a propor a adoção da $2^{a}$ opção. Como este item era mais polêmico, passou a ser tratado em processo à parte ${ }^{178}$, e os demais, aprovados imediatamente. $\mathrm{Na}$ ocasião do protocolamento do pedido, acompanhado por desenhos e memorial detalhado, Domingues entrou com pedido de restauro para a casa 
$\mathrm{n}^{\circ} 82^{179}$, de propriedade dos espólios de Mina Klabin Warchavchik, Emmanuel Klabin e Oscar Abel Klabin Segall, conforme mesmas diretrizes das demais.

Para a realização da obra, Domingues organizou o canteiro implantando o depósito em uma casa, a serralheria em outra, a marcenaria em outra, e como a equipe da obra brincava, a "creche" em outra. Quando foi dada autorização para o início dos trabalhos, havia uma família ocupando uma das casas. Para não haver problemas, Domingues realizou contrato de comodato permitindo a ocupação por parte do casal e sua filha no local. Capacitou o rapaz, pintor automotivo, para realizar as pinturas dos gradis e caixilhos e designou sua esposa para produzir o almoço para os trabalhadores. A enxuta equipe foi montada visando o menor preço, e assim, não se contratou técnicos especializados, mas sim uma mão de obra que precisou ser treinada ${ }^{180}$.

Os anos em que as casas ficaram abandonadas após a demolição foram extremamente danosos. Com o entulho e a ausência de manutenção e limpeza diária, as saídas de água pluvial ficaram entupidas, fazendo com que o assoalho de peroba do térreo apodrecesse, a umidade deteriorasse parte da argamassa de revestimento e atraísse cupins. Antes mesmo deste período a condução da água da chuva não tinha uma solução adequada, pois não havia calhas, fazendo com que os respingos danificassem as bases das alvenarias e portas, especialmente na fachada dos fundos, por onde a água caía de uma altura de dois pavimentos. Além disso, com um volume de água acima do dimensionado para o ralo do terraço, ocorriam transbordamentos que levaram moradores a executar soluções infelizes, como pequenas muretas de contenção no pé da porta.

Após a retirada do entulho, todo o assoalho e rodapé do térreo foram removidos para restauro ou substituição. As tábuas em condições de serem recuperadas tiveram os pregos retirados, foram lavadas com água sob pressão e secadas à sombra. Para a aquisição de novas peças, foi necessário recorrer a obras de demolição, pois a largura atual das tábuas é maior do que o padrão antigo (10 e $9 \mathrm{~cm}$ respectivamente), e ainda por cima a paginação das tábuas de $9 \mathrm{~cm}$ encaixava exatamente na largura dos ambientes. No sentido longitudinal havia abaixo das portas, ao invés de soleiras, cantoneiras arrematando o assoalho. O entarugamento apodrecido foi retirado com serra, para se preservar ao máximo o preenchimento de argamassa sobre o contrapiso. Inicialmente achou-se que havia problema de irregularidade no nível do piso, mas ao se constatar que todas as casas tinham as mesmas características, notou-se que foi planejado um suave caimento da entrada principal até a saída da sala de jantar para o quintal. Pisos e barrotes eram banhados a piche, e o madeiramento tratado com o banido PHC, fazendo com que o material resistisse por muito tempo, não suportando apenas a agressividade desses anos de abandono, quando a água transbordante penetrou e permaneceu nos ambientes. O madeiramento do forro em estuque, por exemplo, não contava com nenhum cupim e no piso superior todo o assoalho foi recuperado, não carecendo de 
substituições, excetuando-se a casa $\mathrm{n}^{\circ} 72$, que teve o trecho do dormitório correspondente à passagem para o terraço substituído por laje.

Os pisos externos, como já comentado, também foram inteiramente retirados para a reimpermeabilização do terraço no $2^{\circ}$ pavimento, para a substituição das instalações de esgoto e águas pluviais no térreo e para a recomposição da forma original, pois além dos trechos indevidamente demolidos, cada casa tinha uma solução diferente. Nos fundos, aproveitou-se a ocasião para demolir os diversos puxadinhos e soluções improvisadas existentes em nome de uma uniformidade do conjunto e no terraço, demoliu-se as soluções improvisadas de contenção de água.

Nas movimentações de terra e substituições de argamassas soltas, notou-se que o baldrame corrido e a base da alvenaria havia sido todo impermeabilizado por uma espessa camada de piche, fazendo com que nenhuma casa sofresse problemas de umidade ascendente. Com a exposição dos tijolos, também revelou-se a marca utilizada: a própria "Emefka", pertencente aos Klabin. As argamassas de cal e areia foram substituídas por argamassas cimentícias, que preenchiam lacunas de revestimento e áreas onde houve substituição de conduítes ${ }^{181}$ e tubulações nas áreas internas e foram utilizadas integralmente nas fachadas frontais. Nas cozinhas e banheiros todos os revestimentos foram substituídos, exceto na casa $\mathrm{n}^{\circ} 48$, que assentou piso de ladrilho hidráulico xadrez como o original encontrado sob um armário instalado pela $1^{a}$ moradora. O layout do banheiro foi alterado, eliminando-se as antigas banheiras e mudando a posição das demais peças e do novo box. Já na cozinha não houve alteração, tendo sido realizado na oportunidade das quebras, reforço estrutural nas escadas.

Com a retirada da argamassa pôde-se visualizar melhor a estrutura das construções, já descrita, revelando-se fissuras amarradas com grampos na casa $n^{\circ} 48$, que é a mais próxima da Avenida Domingos de Morais. As fissuras estão em sentido diagonal revelando possíveis acomodações da construção ao impacto de obras como do Metrô nos anos 1970, ao tráfego intenso da avenida e de caminhões pesados que passam pela rua. Ao que consta do memorial descritivo, o caimento da rua foi projetado inicialmente no sentido Domingos de Morais - Afonso Celso, tendo o conjunto acompanhado este movimento, mas atualmente a inclinação da rua é no sentido oposto. Possivelmente, com a ampliação da linha do Bonde, da Sena Madureira em sentido ao Jabaquara, cortes para ajustar a inclinação da avenida tiveram de ser feitos, rebaixando seu nível na altura da Rua Berta. Com isso, as casas mais próximas da Domingos de Morais ficaram algo acima da cota da rua, chegando a um desnível de pouco mais de 1,60m ao passo que os imóveis vizinhos foram já implantados em nível, e assim, a ausência de um reforço estrutural adequado pôde contribuir para a desestabilização das fundações.

A equipe de pedreiros incluía um operário que trabalhou em diversas obras de Ema-

181 Os conduítes originais americanos foram apenas substituídos onde necessário. O layout dos pontos não foi modificado, substituindo-se apenas fiação, caixinhas, tomadas e interruptores, quadro, enfim o sistema. 
nuel Klabin e quando jovem esteve na reforma dos anos 1950. Enquanto se ocupavam da reconstrução das edículas e do pequeno bloco de depósito, banheiro e tanque anexo ao bloco da cozinha, carpinteiros e serralheiros cuidavam da restauração de caixilhos, gradis e divisórias. Algumas das janelas e portas de madeira foram encomendadas em Santa Catarina, mas em grande parte os componentes existentes estavam em bom estado de conservação, podendo ser reaproveitados. Quanto às portas de compensado, feitas na própria oficina de Warchavchik, estavam fora do padrão atual, tendo o arquiteto restaurador encontrado dificuldade de encontrar peças para compra. As placas de argamassa foram retiradas para manutenção e as portas e janelas de correr passaram por reparos, como a manutenção nos rodízios e trilhos, inserção de próteses nas áreas danificadas, decapagem das folhas, lixamento, preparação para pintura, etc. Para a fixação dos batentes e guarnições, percebeu-se o cuidado com o alinhamento e o nível da argamassa de revestimento da alvenaria que chegava às peças, como também nos rodapés, para os arremates ficarem discretos.

Com os caixilhos de ferro ocorreram procedimentos correlatos, em serviços de manutenção e conservação compatíveis com o material, tendo nas peças externas - gradis, guarda-corpos e divisórias e portas de entrada - um trabalho mais intenso de substituição. Cada casa tinha uma solução diferente para os gradis de fechamento, e conforme definido em diretriz, deveriam voltar à solução dos perfis tubulares e telas, como em geral se encontravam os guarda-corpo dos terraços, por sua vez também retirados para manutenção. As portas de entrada e dos fundos também estavam bem alteradas, tendo sido refeitas. E as peças divisórias fixadas nos terraços estavam em um estado de corrosão avançado, sendo quase integralmente substituídas e os vidros aramados originais também substituídos por outros de características similares. Na serralheria foram restauradas e executadas as clássicas luminárias prismáticas de Warchavchik. Trincos, dobradiças, maçanetas permaneceram todos originais, com reparos, banhos de zinco, troca de componentes, mas sendo possível notar seu aspecto artesanal, através das marcas deixadas pelos artífices nas maçanetas forjadas, sem haver uma igual à outra ou nos trincos marcados por pontinhos que identificavam cada peça com quais deveriam se encaixar. Evidentemente, esse tipo de detalhe só foi possível ser percebido pelo olhar do arquiteto e advogado Domingues, bastante familiarizado com a linguagem, identificando as mensagens deixadas por esses ferreiros do passado, confirmando mais uma vez a necessidade do alto conhecimento das técnicas construtivas empregadas para a realização de restauro.

Quando o conjunto foi construído não havia problemas de abastecimento naquela região alta da cidade e o projeto não previa a presença de caixa d'água. Com o tempo, cada locatário instalou a sua na laje do banheiro, resolvendo cada um ao seu modo a forma de protegê-la das intempéries. Em geral, estendiam o telhamento do volume principal e fechavam verticalmente com placas, telhas de fibrocimento e outros, ou deixavam-nas expostas. O posicionamento da caixa não trazia boa pressão para o banheiro, seu fechamento obstruía a claraboia e trazia perturbações de ordem estética, anulando o destaque do volume do banheiro e cozinha em suas soluções improvisadas. 
O passo inicial era resolver o problema do escoamento de água pluvial e da caixa d'água, que ademais já se encontrava subdimensionada para os padrões atuais de consumo. A laje de concreto se encontrava em ótimo estado, mesmo considerando sua fabricação com técnicas arcaicas. A estrutura era em madeira com espaçamento pequeno e sobre o lastro de concreto, segundo descrição do arquiteto restaurador, foi usado carvão coque queimado, refugo da cerâmica Klabin, recoberto por outra camada de concreto. Por cima da laje de $16 \mathrm{~cm}$, apenas a pintura betuminosa não resistiu bem ao tempo, levando à intervenção dos anos 1950. O madeiramento do telhado estava relativamente bom, então a ideia de restabelecer a cobertura em laje foi deixada de lado para a realização de manutenção na atual cobertura, retirada da porção posterior que cobria o volume do banheiro e instalação de calhas e condutores de águas pluviais. A nova caixa d'água foi instalada sobre o bloco principal, escondida pelo telhamento, e a laje do banheiro, reimpermeabilizada. Na edícula que estava sendo reconstruída a partir dos testemunhos das paredes demolidas e com referência nas edículas vizinhas originais, foi também instalada outra caixa d'água servindo a área do antigo galinheiro, que poderia ser convertida em área de serviço com saídas previstas para a instalação de máquina de lavar roupa.

Com relação à pintura, toda a superfície das fachadas recebeu pintura em látex sobre a nova argamassa de revestimento. Internamente, as muitas camadas de látex que encobriam a pintura à cal foram extraídas na espátula, mas sem recursos e tempo para realizar prospecções pictóricas, as cores propostas surgiram de uma releitura do local. O branco dos panos de alvenaria contrastando com o preto dos caixilhos metálicos, o prata nos gradis e guardacorpos combinavam-se com o verde claro e o lilás das esquadrias de madeira e ambientes internos alternadamente nas casas. Por fim, além de removido um Fícus, cujas raízes vinham comprometendo tubulações e piso da entrada da casa $n^{\circ} 82$, foi contratado um arquiteto paisagista, Marcelo Faisal, para implantação do paisagismo nos canteiros frontais e quintal posterior, adotando-se proposta contemporânea.

Por volta de abril de 2005 a obra se encerrava e as unidades eram colocadas para locação. Ante aos estimados R $\$ 200$ mil, a obra custou cerca de $\mathrm{R} \$ 50$ mil por unidade, em uma união da filosofia de reaproveitamento máximo do existente com as ótimas qualidades de conservação da construção - a despeito dos anos de abandono ao tempo - e a supervisão atenta de José Antônio Domingues ${ }^{182}$. O restauro demonstrou que a construção não tinha qualquer técnica mais arrojada, mas buscava justamente a simplificação, a repetição, a serialização para o barateamento e diminuição de tempo de obra, questões que o próprio canteiro de restauro teve de enfrentar. Também tornou evidente os cuidados nos mais diversos detalhes e soluções construtivas, manifestações de uma presença de Warchavchik, mas também de um saber-fazer tradicional anônimo que deixou suas marcas silenciosas, sem aura, reveladas anos após, quando indagadas. Assim como a produção rentista e a face urbanista de Warchavchik, tais questões transcendem a história da arquitetura moderna evocando 

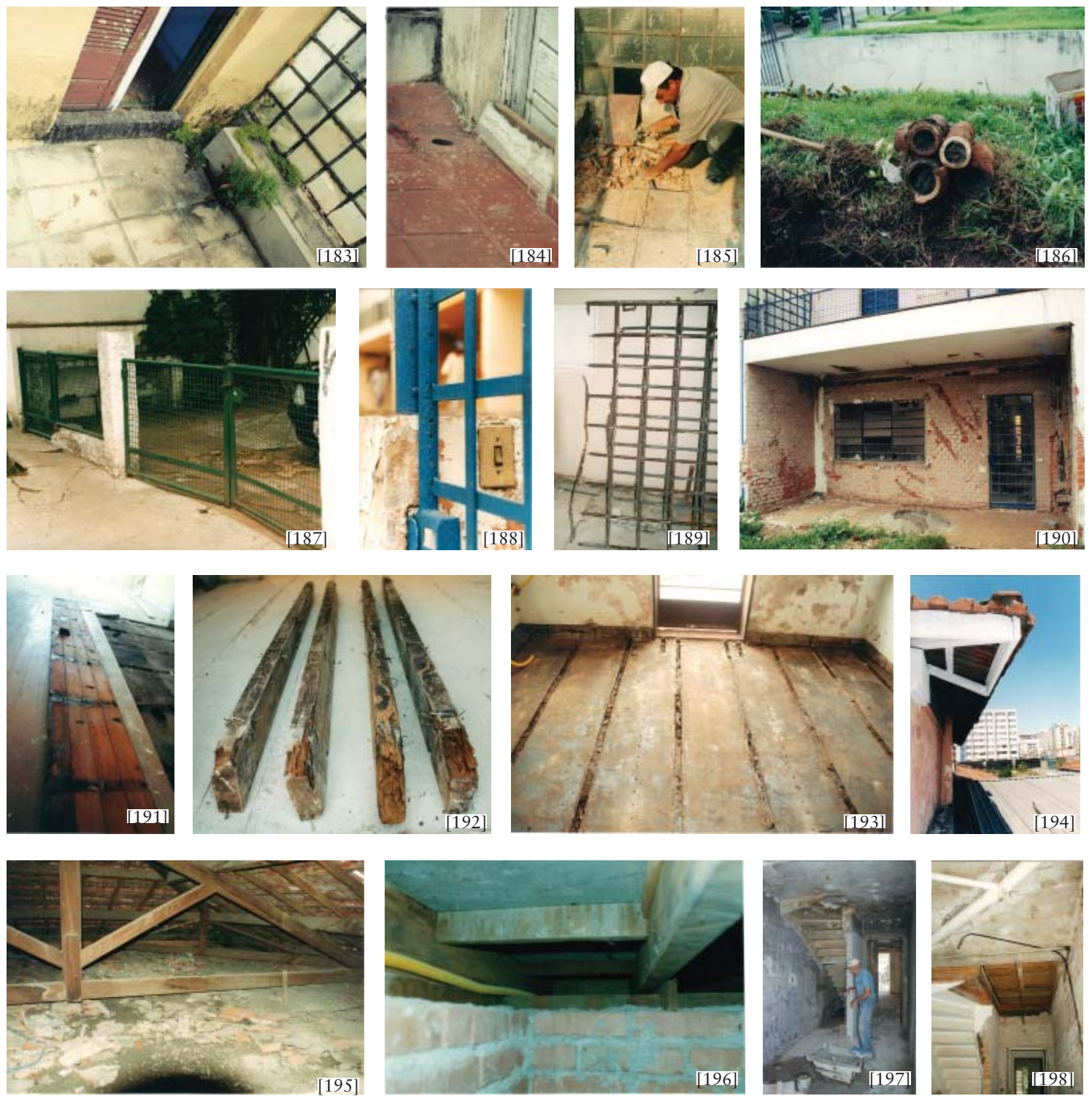
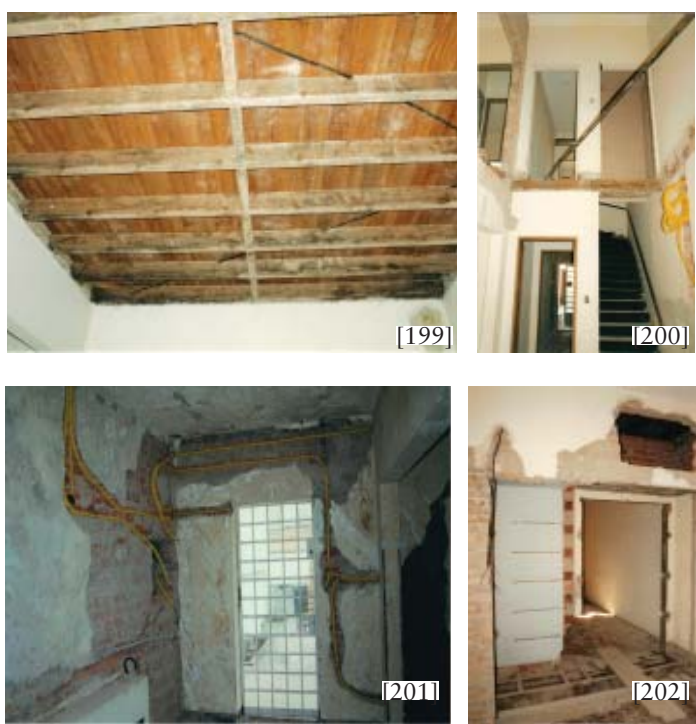

[199] Assoalho visto por baixo, após retirada do forro. [200] Área de assoalho substituída por concreto em uma das unidades. [201] Instalação de conduítes. [202] Retirada de painéis de argamassa da divisão dos armários.
[183] e [184] Soluções improvisadas para contenção de água. [185] Retirada das lajotas de 24 x $90 \mathrm{~cm}$, fora de fabricação, para impermeabilização do terraço. [186] Manilhas retiradas e substituídas por nova tubulação de esgoto. [187] Portão de casa do outro lado da rua, com desenho supostamente original. [188] Furos nas barras dos portões das casas em obra, que comprovaria a existência da tela originalmente. [189] Divisória do terraço danificada e sem os vidros, para restauro. [190] Parede sem revestimento. Com a tubulação de elétrica exposta, viu-se como era o sistema de distribuição de energia. Nota-se também a presença de grampos colocados anteriormente para tentar conter as fissuras no local. [191] a [193] Aspectos do assoalho - tabuado, barroteamento e contrapiso/ rodapé. [194] Detalhe do beiral. [195] Telhado sobre a laje, ambos em bom estado. [196] Face inferior da laje, com barroteamento em madeira. [197] e [198] Obra na cozinha - instalações elétricas e hidráulicas (além do esgoto do banheiro) e revestimentos. 

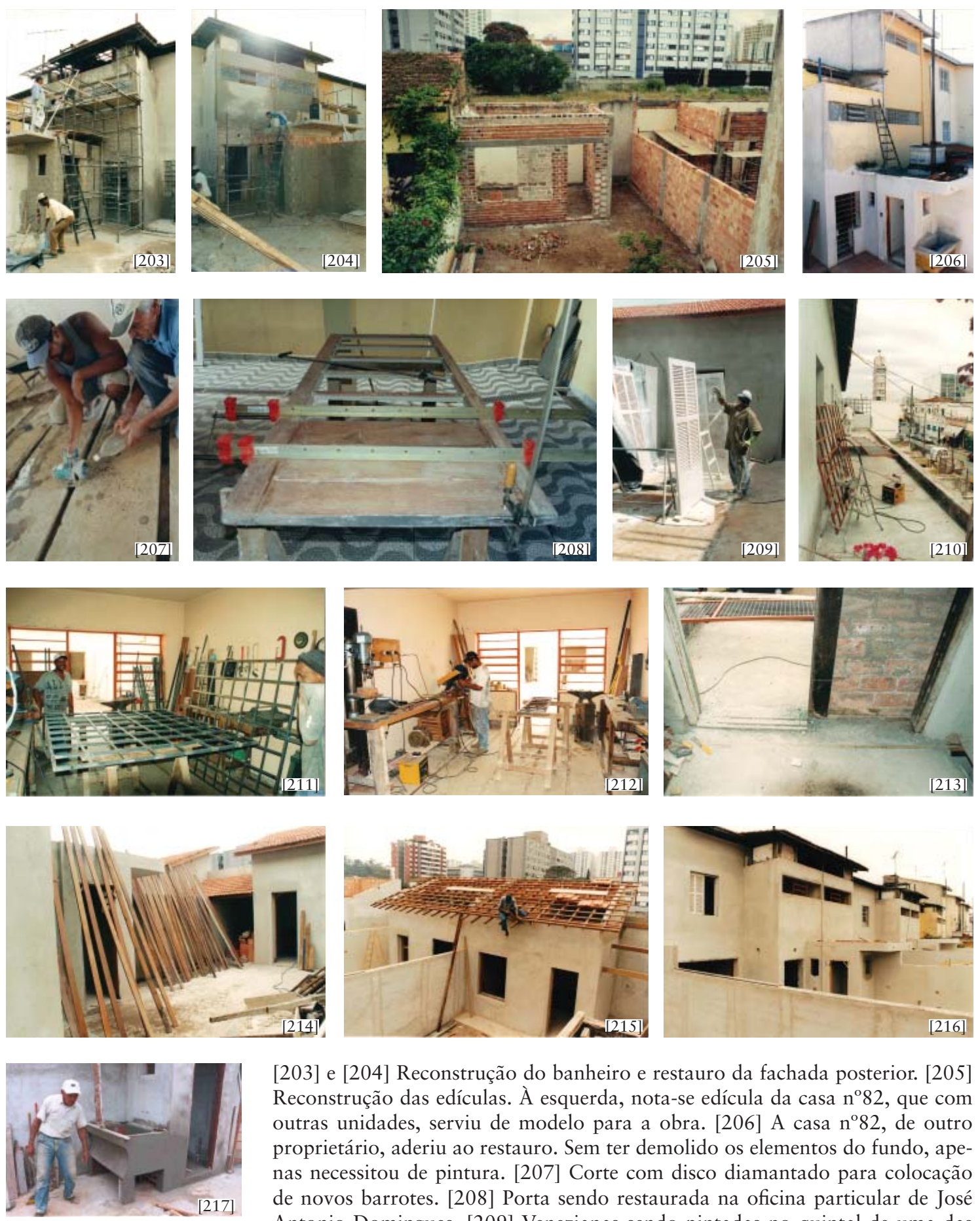

[203] e [204] Reconstrução do banheiro e restauro da fachada posterior. [205] Reconstrução das edículas. À esquerda, nota-se edícula da casa n 82 , que com outras unidades, serviu de modelo para a obra. [206] A casa n ${ }^{\circ} 82$, de outro proprietário, aderiu ao restauro. Sem ter demolido os elementos do fundo, apenas necessitou de pintura. [207] Corte com disco diamantado para colocação de novos barrotes. [208] Porta sendo restaurada na oficina particular de José Antonio Domingues. [209] Venezianas sendo pintadas no quintal de uma das casas em obra. [210] Terraço com contrapiso pronto, sobre impermeabilização,

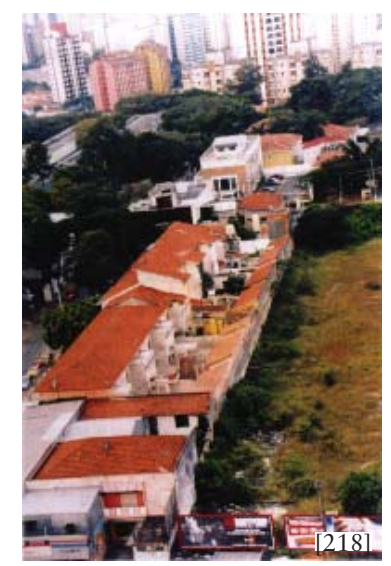
para receber novo piso, guarda-corpo e divisórias metálicas. [211] Oficina de serralheria, instalada em uma das casas [212] Oficina de marcenaria, instalada em outra das casas. [213] Porta de correr retirada para restauro. Com o painel de argamassa retirado, vê-se o lado interno dos tijolos assentados em espelho para embutimento dos caixilhos. [214] Secagem das tábuas. [215] Edículas reconstruídas, com telhamento em execução. [216] Aspecto da construção, com argamassa finalizada, ainda sem modificação do telhado. [217] Reconstrução do tanque em versão fac-símile dos existentes nos vizinhos. Para a execução dos serviços, esteve presente o pedreiro Raimundo, que trabalhou na reforma dos anos 1950 e comumente trabalhava para Emanuel Klabin. [218] Vista aérea do conjunto em 2004, no qual se vê as edículas reconstruídas e a uniformidade do conjunto, mesmo com variações nas tipologias. Ao fundo, em primeiro plano, a arborização da Vila Afonso Celso e em segundo plano, a verticalização que ameaçou o bem. 

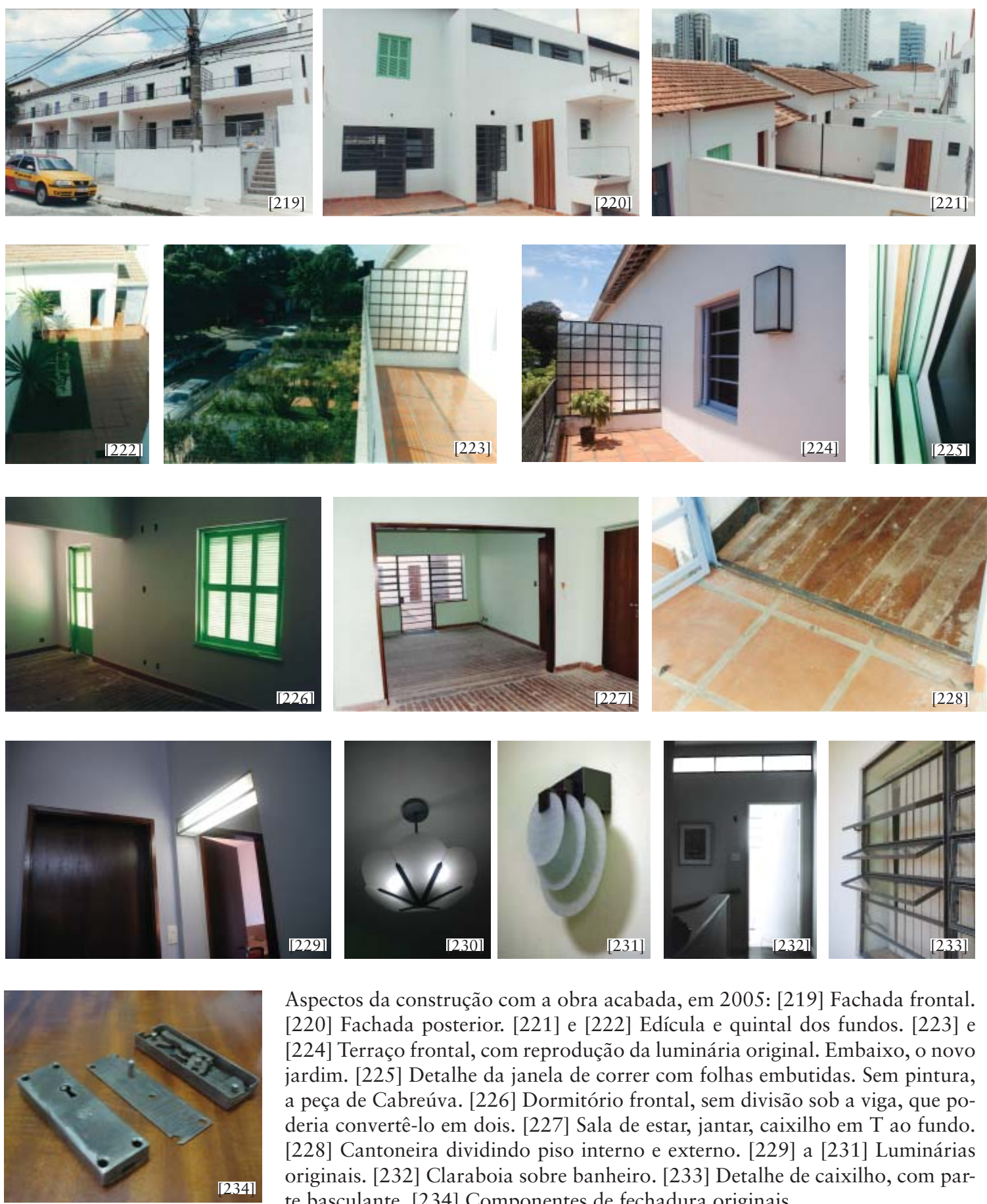

Aspectos da construção com a obra acabada, em 2005: [219] Fachada frontal. [220] Fachada posterior. [221] e [222] Edícula e quintal dos fundos. [223] e [224] Terraço frontal, com reprodução da luminária original. Embaixo, o novo jardim. [225] Detalhe da janela de correr com folhas embutidas. Sem pintura, a peça de Cabreúva. [226] Dormitório frontal, sem divisão sob a viga, que poderia convertê-lo em dois. [227] Sala de estar, jantar, caixilho em T ao fundo. [228] Cantoneira dividindo piso interno e externo. [229] a [231] Luminárias originais. [232] Claraboia sobre banheiro. [233] Detalhe de caixilho, com parte basculante. [234] Componentes de fechadura originais.
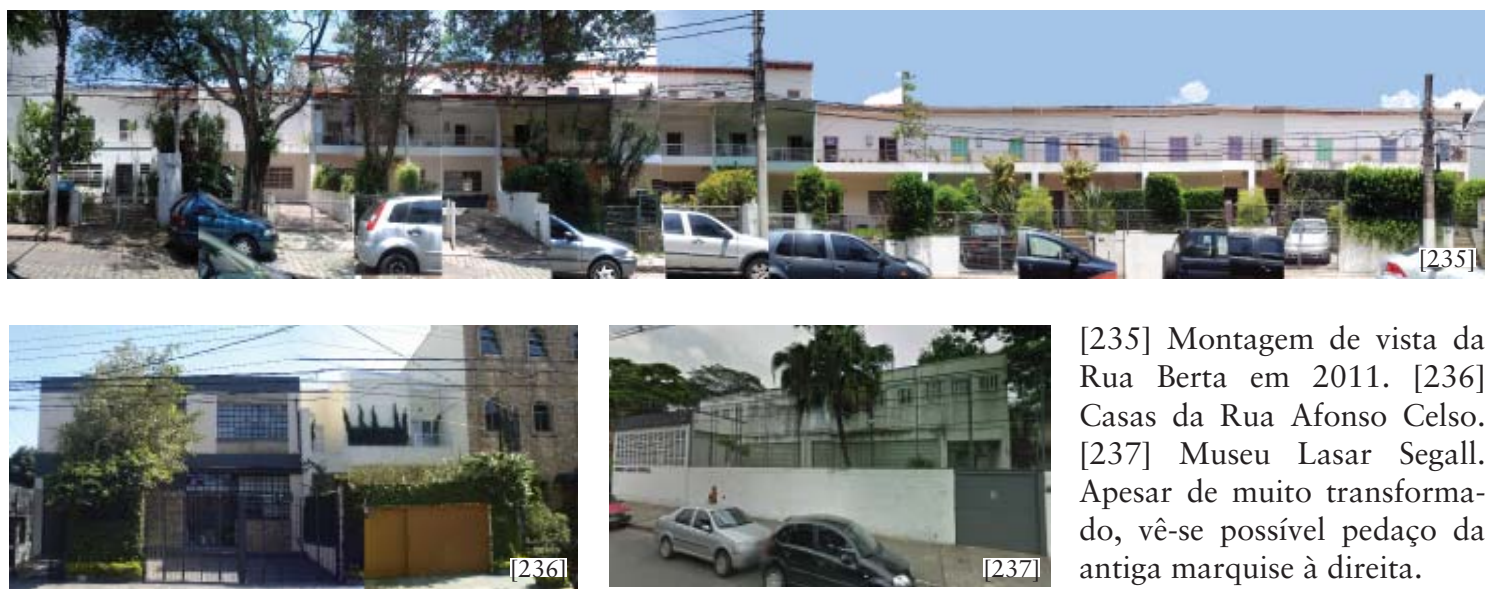

[235] Montagem de vista da Rua Berta em 2011. [236] Casas da Rua Afonso Celso. [237] Museu Lasar Segall. Apesar de muito transformado, vê-se possível pedaço da antiga marquise à direita. 
outras perspectivas historiográficas.

O conjunto como um todo traz unidade na diversidade. A história do espaço do MLS não pode ser pensada dissociada dos sobrados, mesmo que tenha tido um desenvolvimento próprio, assim como os sobrados não mais estariam em pé sem a ação do museu. As casas voltadas para a Rua Afonso Celso se descaracterizaram apesar de manter volumetria coerente com o conjunto, destoando apenas a edificação da esquina, substituída por um hotel de três andares. Mas as casas da Rua Berta formam realmente um bloco. As seis primeiras restauradas, pintadas uniformemente de branco, com mesmos caixilhos e elementos divisórios formam um primeiro trecho homogêneo; o segundo, das unidades de três andares, demarcam as diferenças de propriedade entre herdeiros e assinalam uma outra fase figurativa, sendo impensável a recomposição conforme as unidades restauradas; e então, mais duas casas que mesmo sem restaurar se mantêm mais originais. Neste sentido, seria interessante que a proteção conferida pelo Conpresp não incidisse somente nos sobrados da Rua Berta, mas se estendesse e passasse a abarcar a Vila Dona Berta em sua totalidade.

Todo o percurso de conflitos entre as pressões do mercado imobiliário e a preservação do conjunto revelou que esta só se realiza mediante apropriação social do valor cultural. Em um primeiro momento, os moradores da vila e o Museu Lasar Segall foram protagonistas na luta pelo tombamento. Este último, instituição cujo papel na preservação da memória de Lasar Segall vai além de sua própria obra ou da casa onde morou, mas também se dá no âmbito da preservação da história familiar, que perpassa a história de Warchavchik e dos empreendedores Klabin, que por seu turno definiram as feições daquele trecho de cidade. Em um segundo momento, com a demolição não levada a cabo novamente graças ao Museu, o advogado que defendia o destombamento do conjunto torna-se arquiteto e passa a atuar pela sua preservação, aprendendo o seu valor e responsabilizando-se pelo restauro das 6 primeiras casas da Vila. Aí fica claro o quanto um trabalho educativo e de sensibilização é necessário em toda a sociedade, dos técnicos públicos e privados aos usuários, da vizinhança aos agentes por trás do abstrato "mercado imobiliário". 


\section{CASAS ECONÔMICAS DA RUA BARÃO DE JAGUARA (1927-1929)}

A ocupação fabril crescente e suas consequências contribuíram para a segregação em "lado de lá" e "lado de cá" da cidade entre os fins do século XIX até metade do século XX, cujas barreiras eram representadas pelo rio Tamanduateí e pela linha do trem, consistindo no primeiro e mais consistente imaginário que São Paulo produziu de si mesma como cidade moderna e industrial, expresso nos romances sobre a vida da cidade e em crônicas de jornal ${ }^{183}$.

Entre a cidade e o Brás, aparentemente apenas há um riozinho, o Tamanduateí, prosaico e barrento, correndo em um canal. Mas na verdade, entre a cidade e o Brás, há separações mais profundas. É como se fossem duas cidades distintas. Quem vive no Brás nada sabe da cidade, de suas belezas e de seus confortos. Quem vive na cidade, isto é, do lado de cá do Tamanduateí, nada sabe da vida trabalhosa e infatigável do Brás, célula poderosa que produz para o consumo da cidade, do estado, do país - e nada pode saber das necessidades e incertezas desses anônimos operários que consomem a mocidade e depois a vida no calor das fornalhas e dos teares, nas fábricas ${ }^{184}$.

O mesmo se poderia dizer da vizinha Mooca. E no reverso desse mundo privado do trabalho, da ordem e do silêncio no chão das fábricas, situava-se o mundo público da palavra da moradia. As pequenas casas geminadas, dispostas no alinhamento do lote, a ocupação da rua em seu ciclo cotidiano, promoviam uma relação diversa com o urbano ${ }^{185}$. O conjunto da Barão de Jaguara não diferia muito das demais vilas do entorno, como morfologia e tipologia, integrando-se àquela paisagem industrial formada por fábricas, vilas operárias e aquela várzea indesejada pelo mercado imobiliário. Igualava-se também em sua finalidade econômica, consistindo em mais um empreendimento para renda da família Klabin, totalizando 20 imóveis à Rua Barão de Jaguara entre as ruas Odorico Mendes e Xingú ${ }^{186}$. A planta previa sala de estar à frente, cozinha e banheiro ao fundo e no piso superior, um quarto à frente e outro ao fundo, chamada por Ferraz de "planta V-8"187. Erguida com técnicas construtivas tradicionais - alvenaria de tijolos, cobertura de telha francesa em duas águas, revestimento de cal e areia, pintura a cal, assoalho de madeira e ladrilhos nas áreas molhadas, forro em estuque, caixilharia de madeira, a fundação previa estaqueamento em madeira sobre vigamento de concreto ${ }^{188}$.

Em novembro de 1927, Emmanuel Klabin, como representante dos herdeiros de Maurício Klabin, protocolava junto à prefeitura projeto para obtenção do Alvará de Construção. A planta apresentada, assinada por Warchavchik como "construtor responsável” foi 
objeto de um comunique-se solicitando a diminuição da área de armários na cozinha para o aumento de área útil da mesma. De resto, foi aprovada rapidamente, estando o Alvará disponível em $1^{\circ}$ de dezembro de 1927 . O projeto muito se assemelha ao que de fato foi construído em 1929, apresentando uma fachada limpa, com modenatura marcada pelo contraste entre pilastras e cimalha de tijolo aparente escuro, os panos das alvenarias revestidos por uma argamassa clara de textura grossa caiada e a caixilharia de madeira escura. Com estrutura autoportante, tais elementos revelam a preocupação clássica com a composição da fachada, com a marcação de ritmo e com a divisão das unidades. A floreira presente no peitoril da janela superior conferia dimensão doméstica às casas.

Embora a Mooca hoje se ressinta do processo de desindustrialização e especulação imobiliária que vem substituindo os grandes galpões industriais por edifícios residenciais de alto padrão, o entorno imediato do conjunto permeado por casas, pequeno comércio, gente na rua e fábricas mantém-se, e o conjunto, até recentemente bem preservado, se integra bem à vizinhança. Até 2002, a maior parte das casas apresentava poucas alterações, apesar de um estado de conservação nem sempre satisfatório. Mas em imagem de 2009 já é registrada a profunda alteração sofrida, ao menos realizada em todo o conjunto - excetuando-se as unidades das duas esquinas - conferindo-lhe unidade. Um revestimento texturizado encobriu toda a fachada, amarelo claro nos panos de alvenaria e branco na modenatura. A telha francesa foi substituída por placas de fibrocimento. Todas as envasaduras foram alteradas, tendo os vãos diminuídos e as caixilharias substituídas. As simpáticas portas duplas foram trocadas por outra de uma folha e qualidade inferior e as janelas lamentavelmente por janelas de alumínio de padrão popular. Apesar de recente, a reforma já dá sinais de envelhecimento pois o revestimento escolhido promoveu o encardimento das platibandas e panos de alvenaria, visivelmente marcados também por manchas de lavagem da água da chuva, com o curso alterado pelos peitoris, floreiras e novas bordas das envasaduras. $\mathrm{O}$ material aderente do revestimento e a retirada da cornija fizeram com que em poucos anos as casas fossem mais afetadas pela sujeira e pela chuva do que anos na forma original.

E tudo isso ocorreu à revelia da proteção conferida pela APT do CONPRESP desde 1990. O conjunto foi indicado para tombamento juntamente com o edifício da Alameda Barão de Limeira e a casa da Avenida Rebouças, mas destes apenas os dois primeiros foram incluídos na resolução de APT 14/CONPRESP/1990. Como já relatado, o processo surge como desdobramento do tombamento das casas econômicas da Rua Berta, que foram consideradas descaracterizadas e menos significativas que estas. Para o arquiteto José Roberto Pinheiro, de STCT,

Este pedido se justifica por serem as únicas obras em São Paulo do arq. Gregori Warchavchik, projetadas durante as décadas de 20 e 30, em razoável estado de integridade, que ainda não se encontram protegidas por nenhum dispositivo legal.

Além do significado próprio de cada um dos bens citados o tombamento conjunto adquire maior importância na medida em que estende a salvaguarda legal às obras 
restantes produzidas no período mais fértil do arquiteto, quando muito contribuiu para a introdução e a consolidação da linguagem da Arquitetura Moderna no Brasil. Ação protetora que complementará a iniciada por outros órgãos de preservação cultural ${ }^{189}$.

E o chefe de STCT, Eudes de Mello C. Junior, recuperava o histórico:

Conforme orientamos no Proc. 16.002.717.89*62, referente ao tombamento do conjunto da Rua Berta, de autoria de Warchavchik, foram analisadas todas as obras remanescentes do arquiteto projetadas durante a década de 20 e 30, período realmente significativo de sua atividade profissional. De toda a produção daquela fase, foram selecionados os bens anteriormente mencionados, para os quais a STCT solicita a respectiva abertura do processo de tombamento ${ }^{190}$ (grifo nosso).

Vemos aí o evidente esforço de tombamento conjunto de obras do período inicial de Warchavchik, já descartando as casas da Rua Avanhandava, Melo Alves e Estados Unidos, por estarem demolidas ou descaracterizadas ${ }^{191}$. A fonte histórica é Geraldo Ferraz, com seu livro xerocopiado e transcrito nos conteúdos relativos aos três imóveis.

O processo segue para o Conselheiro do CONPRESP, Roberto Heitor Ferreira Lima, que relata estarem os imóveis em razoável estado de conservação, exceto a casa ${ }^{\circ} 320$, bastante alterada ${ }^{192}$. Entretanto Benclowics percebe os imóveis de outra maneira, considerandoos com mau estado de conservação mas com grau de alteração pequeno ${ }^{193}$. Uma passagem interessante da manifestação do conselheiro se refere à sua concordância com o parecer dos técnicos do DPH quanto ao interesse em tombar o conjunto como forma de garantir a fixação das famílias que lá residiam ante a ameaça de verticalização, dada sua inserção na área de influência da linha leste-oeste do Metrô. As discussões sobre uso, patrimônio e relação com a dinâmica econômica da cidade e problemática social do tombamento seriam marcantes da década de 1980 em diante ${ }^{194}$.

Em 9 de novembro de 1990 o processo de tombamento foi aberto no CONPRESP, mas sua instrução final está paralisada. Mesmo assim, o proprietário realizou importante alteração figurativa sem a obrigatória prévia anuência do conselho, colocando a obra em

189 Processo PMSP 1990-0.004.774-9, fl.03

190 Processo PMSP 1990-0.004.774-9, fl.04

191 Apesar de que não é inserida nenhuma documentação que registre os imóveis - ou os lotes no estado atual, sem que confirme a afirmação. Também não foi considerada a casa da Rua Tomé de Souza, protegida apenas em 1992, por já se enquadrar na zona Z8-200 nem verificada a localização de obras como a residência Maestro Souza Lima ou casa da Alameda Lorena, tratando-se do período 1920-1930

192 Há que se considerar que estado de conservação e grau de alteração são elementos diversos, podendo um imóvel estar bem conservado, mas completamente descaracterizado e vice-versa.

193 BENCLOWICS, 1989

194 Especialmente a partir dos anos 1990, mas por um viés negativo, na sua assimilação pelo Planejamento Estratégico e pelas políticas de gentrification, como comentadas anteriormente. 
uma irreversível nova feição. Desde 2006 foi regulamentado o FUNCAP, orientando os procedimentos para aplicação de multa e aplicação dos recursos reunidos no fundo. Entretanto a ausência de fiscalização aliada ao não reconhecimento de valor por parte dos proprietários e da população levam casos a esses termos, aqui e pela cidade. Seria impensável propor uma repristinação do conjunto tendo em vista tamanha a transformação quantitativa e qualitativa. Mas ao mesmo tempo, é difícil para os olhos contemporâneos aceitar uma agressiva e questionável intervenção, aguardando que se historicize. Caberia repensar os valores atribuídos às casas conjugadas da Rua Barão de Jaguara? Ao que parece, como bem integrante de um tecido que fala de uma vida fabril e operária na cidade de São Paulo, a vila pode ser reconhecida sob perspectiva da história urbana, social, da habitação, do trabalho, etc., dentro de um estudo mais amplo sobre a tipologia no bairro e sua relação com a paisagem industrial e não somente por seu valor autoral. Ou seja, ainda que tenha sofrido perdas irreversíveis, guarda uma memória que vai além do seu aspecto visual.
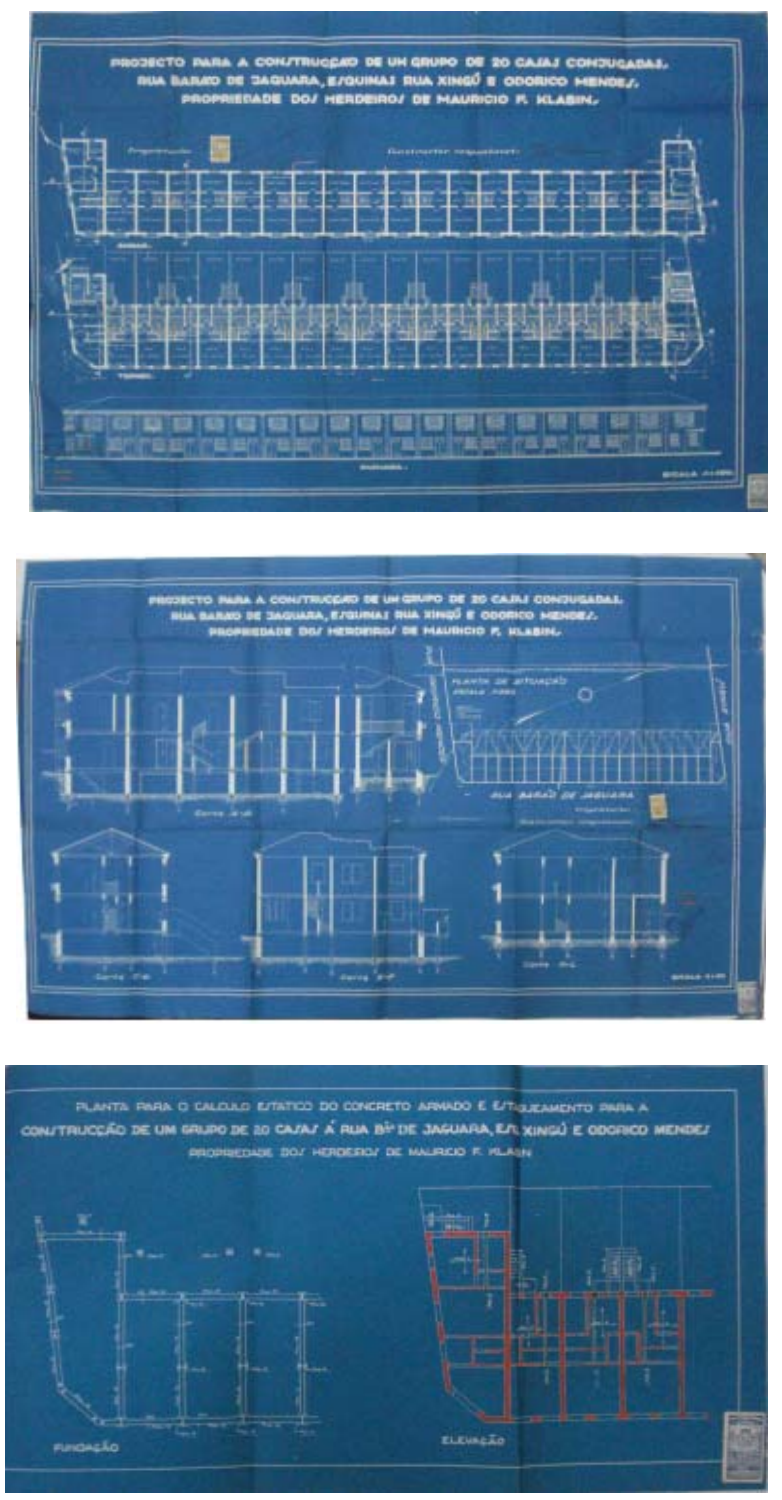

Ao lado [238] a [240] Pranchas do projeto de aprovação municipal. Além de plantas, cortes e implantação, foi encaminhado cálculo estrutural em planta e memória de cálculo. Abaixo, [241] e [242] fotos do conjunto à época de sua inauguração.
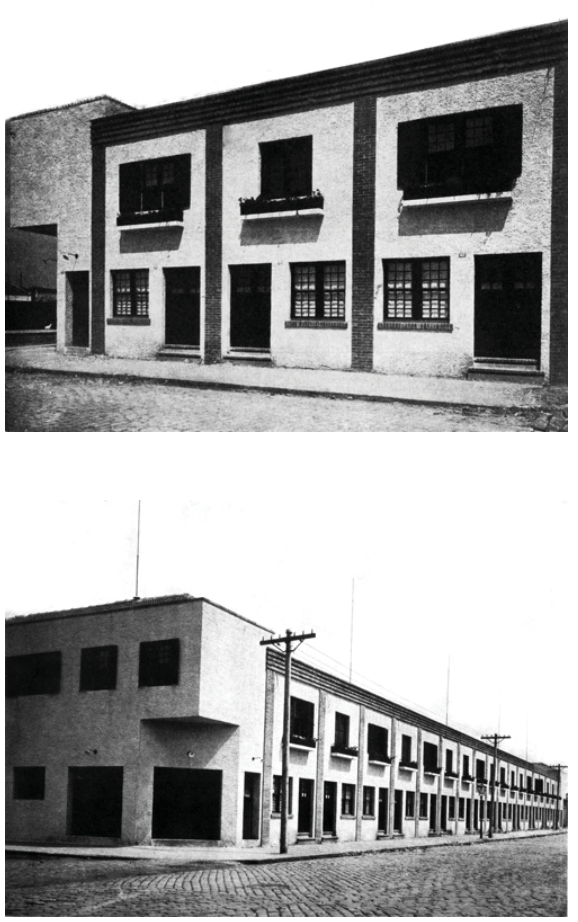

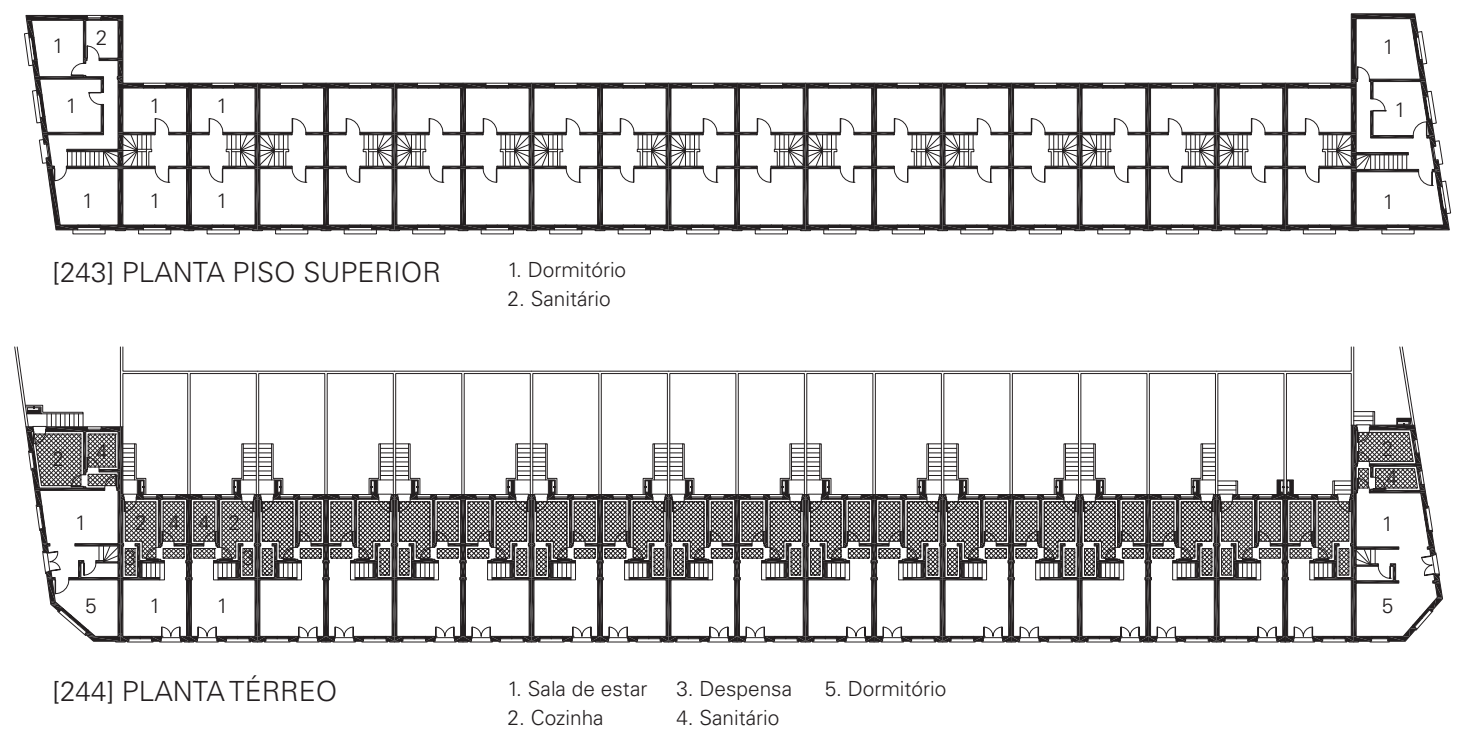

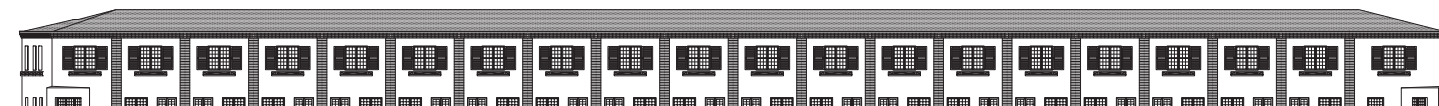

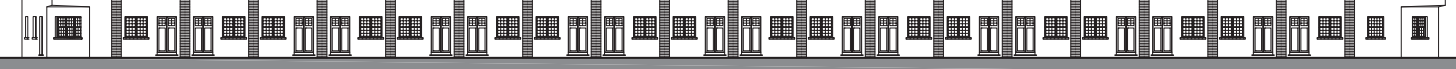

[245] ELEVAÇÃO
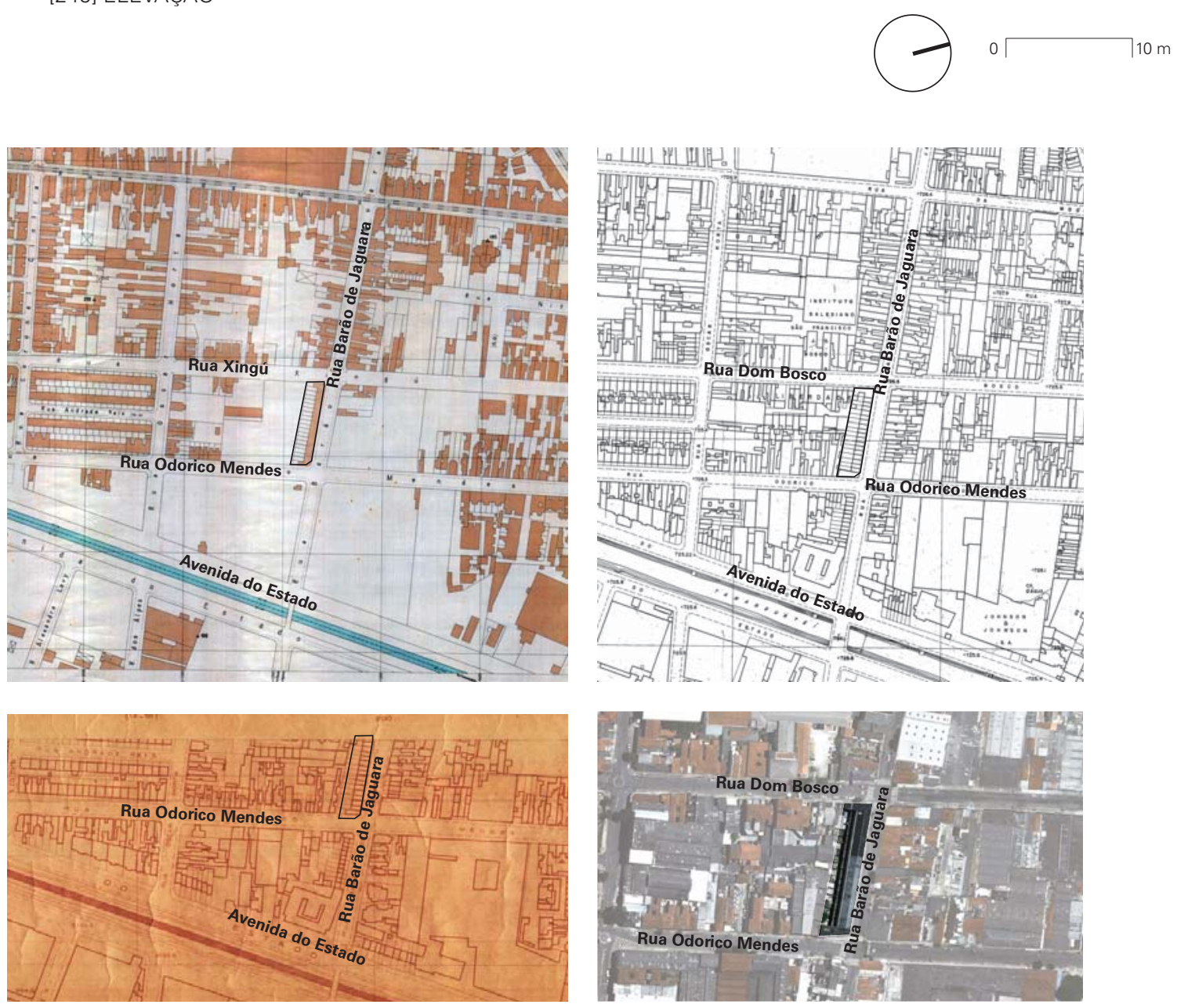

[246] a [249] O local em 1930, 1954, 1972 e 2011. Nota-se a mistura de usos, com galpões industriais, vilas e construções de pequeno porte no alinhamento. 

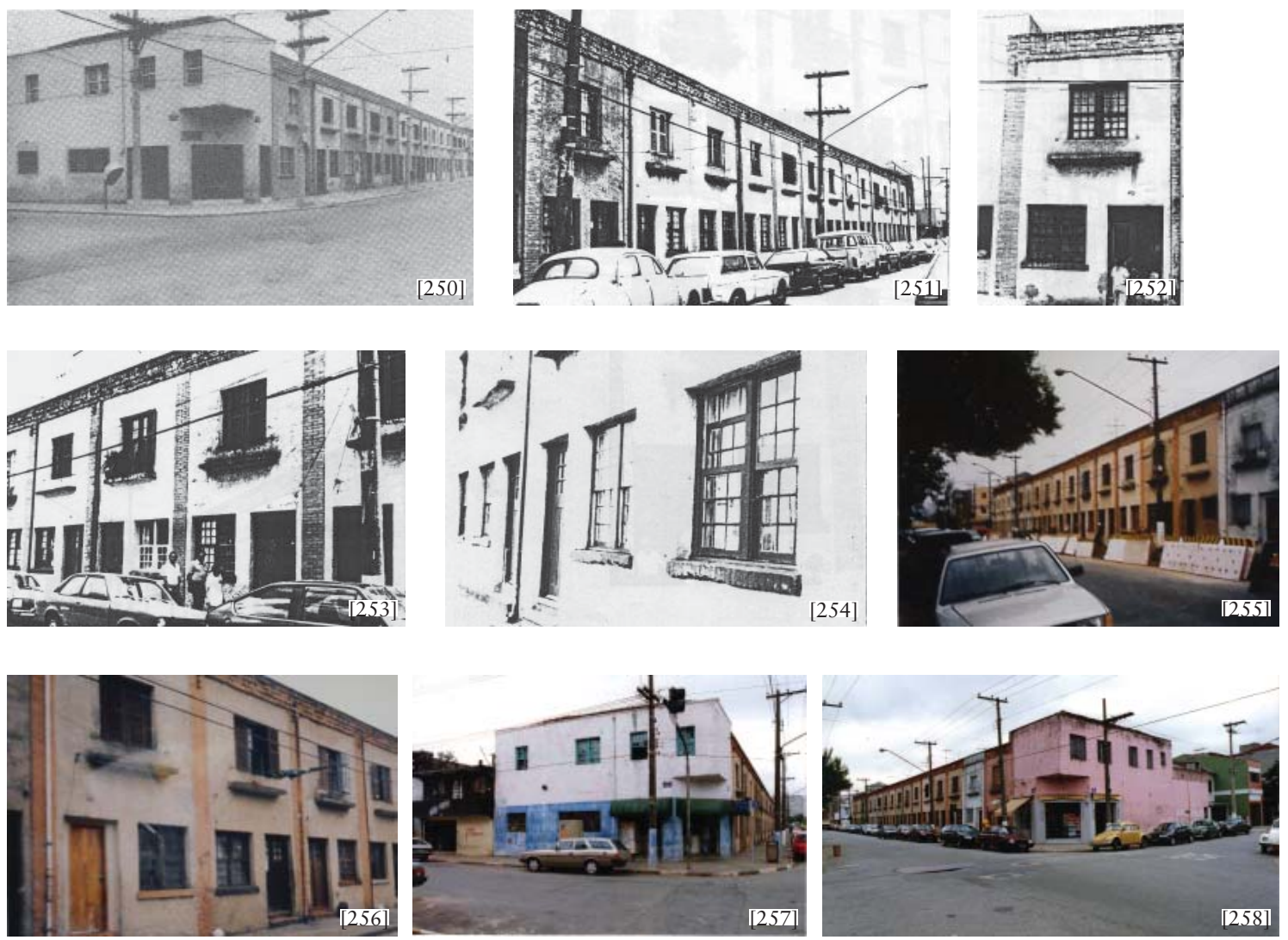

Imagens do conjunto em diversas épocas: em 1982 [250]; em 1989 [251] a [254]; em 2002 [255] e [256]; em 2004 [257] e [258]. Apesar de algumas unidades terem modificado o revestimento, no geral o conjunto está pouco alterado, embora não necessariamente bem conservado. Poucos anos depois, ocorreria uma transformação radical dos revestimentos, caixilhos, cobertura, como vimos em imagens de 2009 divulgadas na internet. Abaixo, o registro da vila em 2011 - figuras [259] a [262], com o revestimento já sendo marcado por sujidades decorrentes da poluição. Nota-se na figura [261] a mancha do escorrimento na fachada, contornando as envasaduras.
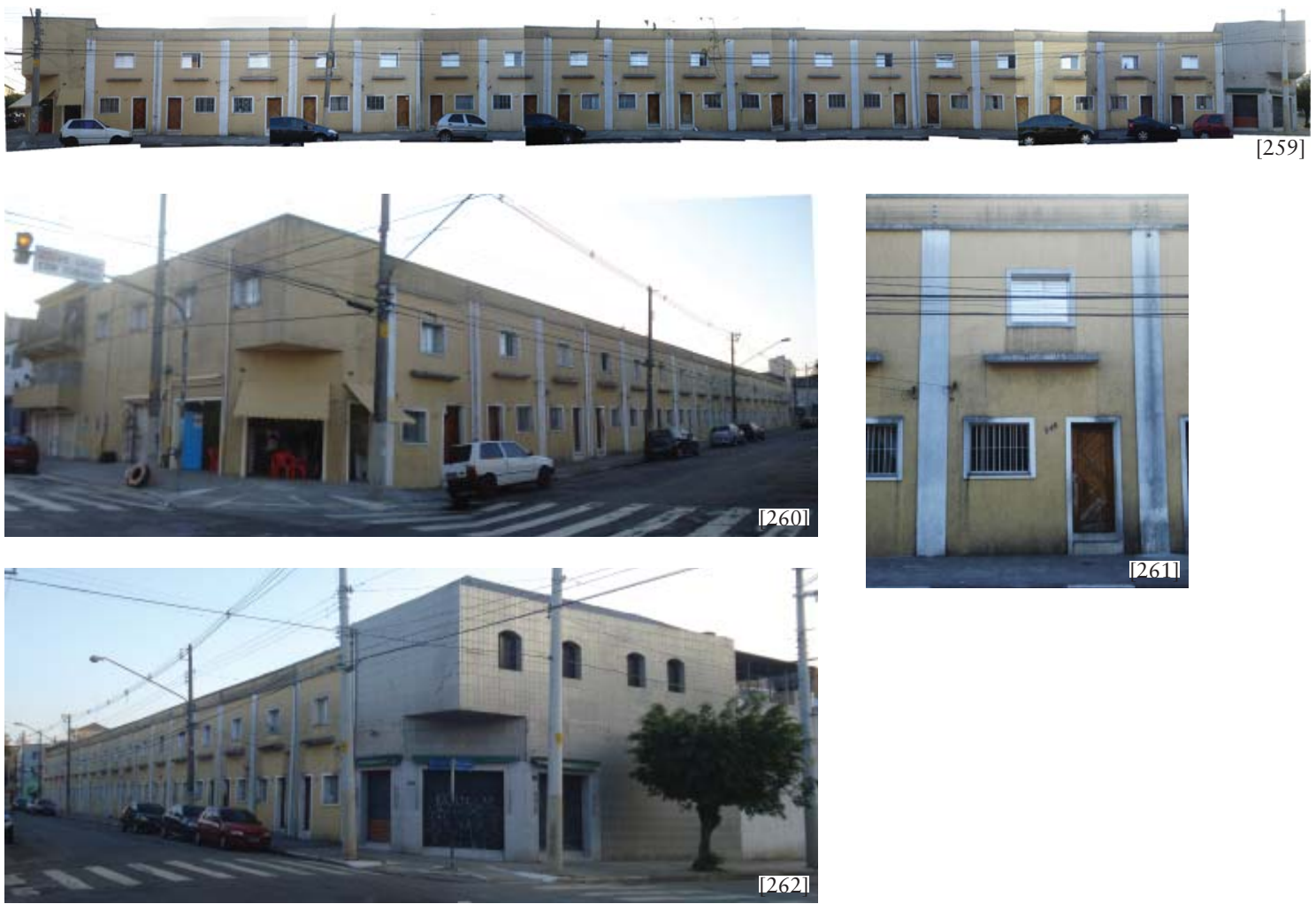


\section{CASA DA RUA ITÁPOLIS (1928-1930)}

No período em que a casa da Rua Itápolis era construída, Warchavchik trabalhava na Vila Bertha, na casa para o sr. Cândido da Silva à rua Tomé de Souza e já havia construído, entre outros, o conjunto da Barão de Jaguara, sua própria residência e a residência Max Graf à Rua Mello Alves. Mas a Casa Modernista da Rua Itápolis é considerada o ponto de virada da poética warchavchikiana, onde supera os conflitos formais e construtivos presentes na Casa Modernista da Rua Santa Cruz e desenvolve elementos já presentes na Mello Alves, que para Farias funcionou como balão de ensaio para esta, que "conseguiu ser a expressão plena dos princípios norteadores da arquitetura moderna defendidos por Gregori Warchavchik" ${ }^{195}$. E não só em termos da composição, que partia do prisma puro, esculpido com a adição de elementos como marquises e terraços e com a subtração de massa para dar lugar às aberturas, conferindo dinâmica ao edifício, mas também em termos de planta, pois a solução compacta em consonância com os preceitos da habitação mínima se fazia valer e se repetir em outros projetos, como notado por exemplo no conjunto de apartamentos econômicos à Rua Barão de Gamboa, no Rio de Janeiro ou as casas para Mina Klabin Warchavchik à Rua $1^{196}$, na Vila Afonso Celso ${ }^{197}$, que utilizavam o acesso aos dormitórios a $45^{\circ}$.

Também é com a casa da Rua Itápolis que Warchavchik conquistará nova visibilidade com a realização da Exposição de uma Casa Modernista (1930), angariando clientela de maior calibre e reafirmando seu papel vanguardista junto aos artistas e intelectuais identificados com o modernismo ${ }^{198}$. Projetada para si mesmo como imóvel para aluguel, a obra não sofreria restrições programáticas, formais, orçamentárias decorrentes de uma interlocução com clientes, podendo ser lida como plena intenção do arquiteto.

Atraído pelas condições vantajosas para construir no recém-inaugurado loteamento City do Pacaembu, Warchavchik decide construir um imóvel para renda, encaminhando o projeto para aprovação junto à Prefeitura em 14/11/1928, obtendo em uma semana o Alvará de construção ${ }^{199}$. A obra dura pouco mais de um ano, tendo Le Corbusier visitado-a ainda em construção quando de sua primeira viagem ao Brasil em novembro de $1929^{200}$, elogiando a plasticidade do muro curvo que separa o jardim social do quintal de serviço. E em 24/03/1930 é inaugurada a "Exposição de uma Casa Modernista", com a data de término prevista para 20/04/1930 prorrogada por conta do enorme sucesso de público, estimado em

195 FARIAS, 1990:211. Para FERRAZ (1965), a casa encerra o ciclo de combate e difusão do modernismo; para LIRA (2008), abre uma nova etapa de reconhecimento; SEGAWA (1998) afirma que a casa e sua exposição finalmente cumprem a ideia de aproximação com a Bauhaus.

196 Atualmente Rua Maurício Klabin. Acervo FAUUSP, tubo P W196/728.3 MW

197 Acervo FAUUSP, tubo P W196/728.3 MW

198 LIRA, 2008. Lira dedica um capítulo de sua tese de livre-docência à casa, intitulado "Visibilidade da Casa Modernista", no qual investiga a fundo a Exposição e sua repercussão, o projeto e sua relação com o cubismo, com a estética industrial, com o tema do rústico e a crítica de época, sugerindo a mudança de patamar na carreira de Warchavchik a partir do sucesso e projeção da Casa Modernista da Rua Itápolis.

199 Processo PMSP 66.515/28

200 FERRAZ, 1965:91 
20 mil visitantes. O grande acontecimento artístico que nas palavras de Oswald de Andrade, encerrou "o ciclo de combate à velharia, iniciado por um grupo audacioso, no Teatro Municipal, em fevereiro de 1922 "201, abria as portas tanto para a receptiva crítica alinhada ao modernismo quanto para as visões contrárias, tão bem ilustradas pela polêmica travada com Christiano Stockler das Neves, que provocativamente considerava a casa uma extensão do Cemitério do Araçán 202 .

Neste sentido, não seria de estranhar que em 08/04/1930, durante o período da exposição que movimentou a cidade, um engenheiro da prefeitura solicita por memorando o processo de aprovação do projeto para consulta ${ }^{203}$, imaginamos que para comparar o que foi visto com o que foi aprovado. A seguir aponta irregularidade na construção, que não seguiu o desenho aprovado, mas que não poderia ser embargada, pois já estava concluída. É então expedido Auto de Intimação em 05/04/1930 para que fosse apresentado projeto substitutivo retirando a escada interna da garagem e tornando o seu forro incombustível. Não sabemos o quão generalizado era o rigor da fiscalização, mas de qualquer modo a solicitação feita durante o período da exposição não deixa dúvida quanto ao impacto da mesma, merecendo de um engenheiro municipal, não se sabe com que opinião sobre o acontecimento, a atenção sobre a dimensão legal da obra construída. Em 29/04/1930 é apontado que a intimação não foi cumprida, sendo o processo encaminhado à procuradoria fiscal. Warchavchik submete à prefeitura o projeto substitutivo em 31/05/1930, alterando a edícula:

A escada - para acesso ao quarto de cima da garage será fechada por uma parede de tijolos; O forro - da garage será impermeabilizado com argamassa incombustível; As paredes - levarão barra a óleo até a altura de 1,50 mts; Porta - Será aberta uma porta para communicação independente para o quarto de cima; O piso - da garage será cimentado 204

O Alvará de substituição é lavrado em 23/06/1930, mas Warchavchik não executa as alterações, como notado em vistoria em 20/07/1931. São realizadas diversas tentativas de vistoria sem sucesso, até que em 1933 é constatado que nenhuma obra fora executada. Já em 1936, o técnico observa: "permanecem as infrações apontadas na informação de 27-12-33. Por se tratar de pequenos desacordos com o Código de Obras e ser obra antiga, proponho a tolerância da mesma. Não há emolumentos a pagar, por não ter havido augmento de área. O proprietário é o mesmo" ${ }^{205}$. Ou seja, o processo se desenrola por anos, para um assunto irrelevante, a partir de uma inicial que pode ter tido cunho persecutório.

Em setembro de 1940 o já marcado Warchavchik é novamente notificado por ter au-

201 No artigo “A casa modernista, o pior crítico do mundo e outras considerações”, Diário da Noite, julho de 1930.

202 NEVES apud FERRAZ, 1965:90

203 Processo PMSP 20.013/30

204 Processo PMSP 28.266/30, fl. 6

205 Processo PMSP 28.266/30, fl.12 
mentado a edícula sem o devido Alvará de construção. O quarto anexo ao quarto superior renderia um Auto de multa e Infração, gerando a cobrança de emolumentos em 24/09/1940 e a submissão de novo processo de aprovação do projeto de ampliação, com o Alvará de aumento de área $\left(18 \mathrm{~m}^{2}\right)$ lavrado em 14/10/1940.

De modo geral, a casa passou por pequenas alterações até os dias de hoje, sem comprometer seu aspecto figurativo e material geral. Na sala de estar observamos na planta original e na planta ilustrada publicada por Ferraz ${ }^{206}$ a inserção de janela voltada para a fachada oeste (lateral oposta à entrada). Entretanto nos registros fotográficos da Exposição de uma Casa Modernista a parede é inteiramente fechada, apoiando um quadro de Tarsila do Amaral. Por outro lado, Carlos Warchavchik não se lembra do local sem a janela, colocando-se a dúvida sobre se houve janela na obra em seu estado inicial, fechada - temporariamente ou não - para a exposição e posteriormente aberta ou reaberta. Em algum momento, talvez mais recente, foi construída uma lareira, um acesso frontal por escada, alinhada à rampa de acesso, um guarda-corpo em madeira acima do peitoril em alvenaria do terraço superior, uma barra em madeira no mesmo padrão na borda superior do muro frontal, eliminando a luminária de canto junto ao portão e um fechamento da varanda frontal com caixilho de madeira, conforme se vê em foto de $1982^{207}$. Estes dois últimos elementos, contudo, foram retirados entre 1982 e 1984, quando o Iphan abre o processo de tombamento e fotografa o local.

Como já tratado no estudo sobre a casa da Rua Santa Cruz, a ameaça de destruição no final de 1983 levou ao seu tombamento estadual em 1984 e o Iphan decide, na esteira do Condephaat, realizar o tombamento federal, contudo abarcando também as casas modernistas das Ruas Itápolis e Bahia. O processo relativo à Itápolis tem os encaminhamentos e textos históricos semelhantes ao da Santa Cruz, complementado por dados específicos do imóvel, como fotos comparativas do local, cópias dos processos municipais de aprovação do projeto original, cópia das páginas do livro de Ferraz sobre a casa, registro do imóvel e dados do proprietário, Mauris Ilia Klabin Warchavchik. Mauris é notificado do processo de tombamento, mas não tenta impugná-lo. Nos conflitos acerca do tombamento da casa da Santa Cruz, o filho de Gregori Warchavchik opina na imprensa que a casa da Santa Cruz já tinha sido descaracterizada, não valendo à pena preservá-la e que ela havia sido feita para morar, enquanto que a verdadeira casa modernista era a da Rua Itápolis, feita para mos$\operatorname{trar}^{208}$.

Por fim, o processo segue para parecer, de Eduardo Kneese de Mello, para ser votado no conselho consultivo:

A casa da Rua Itápolis 961, São Paulo, foi projetada pelo arquiteto Gregori Warchavchik em 1930, época em que, predominava em nosso país o ecletismo. Trata-se 
de exemplo revolucionário, precursor, sem dúvida, da atual arquitetura contemporânea do Brasil.

Em homenagem ao seu projetista e como reconhecimento do seu pioneirismo, recomendo com entusiasmo seu registro no livro de tombo, como monumento histórico e artístico de nosso país ${ }^{209}$.

No conselho, há inicialmente resistência por parte de alguns conselheiros em realizar o tombamento dos três imóveis, mas Kneese, Dora Alcântara e Augusto da Silva Telles expõem a importância específica de cada imóvel, enfatizando neste a importância da histórica exposição e a busca pela integração das artes. Com votação unânime, o processo é então homologado em 27/06/1986.

Por um período de 25 anos a casa fora alugada a Dulce Horta ${ }^{210}$, quando Carlos Warchavchik decide reformá-la e colocá-la em exposição nos 80 anos da "Exposição de uma casa modernista”, em 2010. A intervenção já vinha sendo idealizada desde 2008, quando tivemos a oportunidade de visitar o imóvel vazio. Do quadro de alterações descrito, pode-se acrescentar que no interior da casa pouca coisa mudou, tendo sido substituído o pergolado de madeira por concreto; alterado o acabamento do lavabo, com desenho e tipo visivelmente dos anos 1970; colocados carpetes no piso superior e portãozinho de madeira no acesso à escada (provavelmente impedindo a passagem de crianças); instalado boiler aparente na fachada posterior. Algumas das luminárias originais já haviam sido removidas, o armário embutido da sala de jantar tinha algumas das placas empenadas por umidade, o mecanismo da veneziana de recolher da janela de canto estava danificado e o forro do piso superior encontrava-se manchado por infiltrações na cobertura. Externamente, uma árvore ameaçava cair sobre a varanda frontal.

Sem grandes alterações ou patologias encontradas, a obra realizada por Carlos Warchavchik entre 2008 e 2010 pode ser considerada como de conservação, com algumas intervenções caracterizadas por uma intenção de restaurá-la. Instalações, pisos, acabamentos, ferragens e metais, portas e janelas, forros e coberturas passaram por obras de conservação e manutenção. Mesmo sem projeto, Carlos procurou através de fotografias reproduzir as luminárias retiradas e restabelecer o desenho original do jardim frontal, retirando a escada de acesso rente à rampa. O lavabo foi alterado em layout e acabamentos, substituindo a démodé configuração setentista. Não dispondo de levantamento estratigráfico das pinturas parietais, o arquiteto encontrou em remoção de pintura na escada uma tonalidade vinho, reproduzida na obra, contrastando com a brancura geral das paredes e forros ${ }^{211}$. A intervenção que talvez seja mais polêmica se refere à abertura da edícula para o jardim social, podendo ser acessada

209 Processo $\mathrm{n}^{\circ} 1.154-\mathrm{T}-85$, fl.85

210 A família Horta se situa no ramo familiar materno de Carlos, neto de Gregori. OESP, 25 mar. 2010

211 Apesar de que originalmente Warchavchik trabalhava com cores, contrastes, referências à estética industrial, ao neoplasticismo e outros, fazendo com que a realização de prospecções pictóricas e cromáticas no imóvel tenham grande potencial investigativo sobre este aspecto ainda pouco explorado pelas pesquisas. 
pela varanda posterior da casa. A porta se situa na empena cega imortalizada pela foto da Exposição, como pano de fundo para uma escultura de Brecheret. $\mathrm{O}$ arquiteto propôs uma solução para a escada que alude ao repertório formal Warchavchikiano. O desenho é similar a uma escada existente na casa da Rua Bahia, não se distinguindo da estrutura original.

De qualquer modo, o esforço de manutenção da memória familiar é claramente visível na exposição promovida em 2010. Além da própria casa como tema, foram dispostos projetos, luminárias e móveis executados por Gregori Warchavchik. Também foram exibidos textos e vídeos com depoimentos de arquitetos contemporâneos sobre o arquiteto, os históricos filmes da Rossi Film sobre a exposição e Die neue Wohnung do cineasta da vanguarda alemã, Hans Richter, sobre arquitetura e vida moderna, bem como uma interessante exposição de retratos realizados por Warchavchik, fotógrafo amador, colecionador de máquinas fotográficas e integrante do Foto Cine Clube Bandeirante ${ }^{212}$, sob curadoria de Ricardo Mendes. Paralelamente, foi organizada exposição com a curadoria de Ilda Castelo Branco no Museu da Casa Brasileira, que também disponibilizou monitores para realizar visitas guiadas à casa. Além da exposição, Carlos Warchavchik organizou debate, convidando Carlos Martins e José Lira para a mesa. A exposição, bem divulgada na imprensa diária, contou com intensa visitação, fazendo com que a exposição fosse prorrogada, assim como aquela de 80 anos atrás.

Deste modo, mesmo com alguns detalhes da reforma passíveis de crítica, deve ser reconhecido o empenho da família Warchavchik na preservação da memória da Casa Modernista da Rua Itápolis - do imóvel bem preservado, chegando aos dias de hoje sem alterações significativas, demonstrando o reconhecimento que tiveram de seu valor histórico e arquitetônico ao longo dos anos à mobilização pela realização da exposição, resgatando-se móveis e objetos espalhados pelos diversos ramos herdeiros. E tal ímpeto fez com que a exposição de 2010 reavivasse o interesse sobre a obra e seu arquiteto, certamente reafirmando o seu vigor.

212 Para Helouise Costa, “a fotografia moderna no Brasil surgiu e se desenvolveu no Foto Cine Clube Bandeirante", que rompeu com o padrão pictórico e acadêmico reinantes. COSTA, 2004:36-47. O clube contou com nomes como Geraldo de Barros, Thomaz Farkas, German Lorca e José Yalenti, que trouxeram novos caminhos à Escola Paulista. Warchavchik teve um autorretrato escolhido como capa do III Salão Paulista de Arte Fotográfica e cultivava a fotografia de retrato, registrando cenas familiares, desconhecidos e amigos intelectuais e artistas, como o casal Bardi, Lasar Segall, Lucjan Korngold, Mário de Andrade, Camargo Guarnieri. 

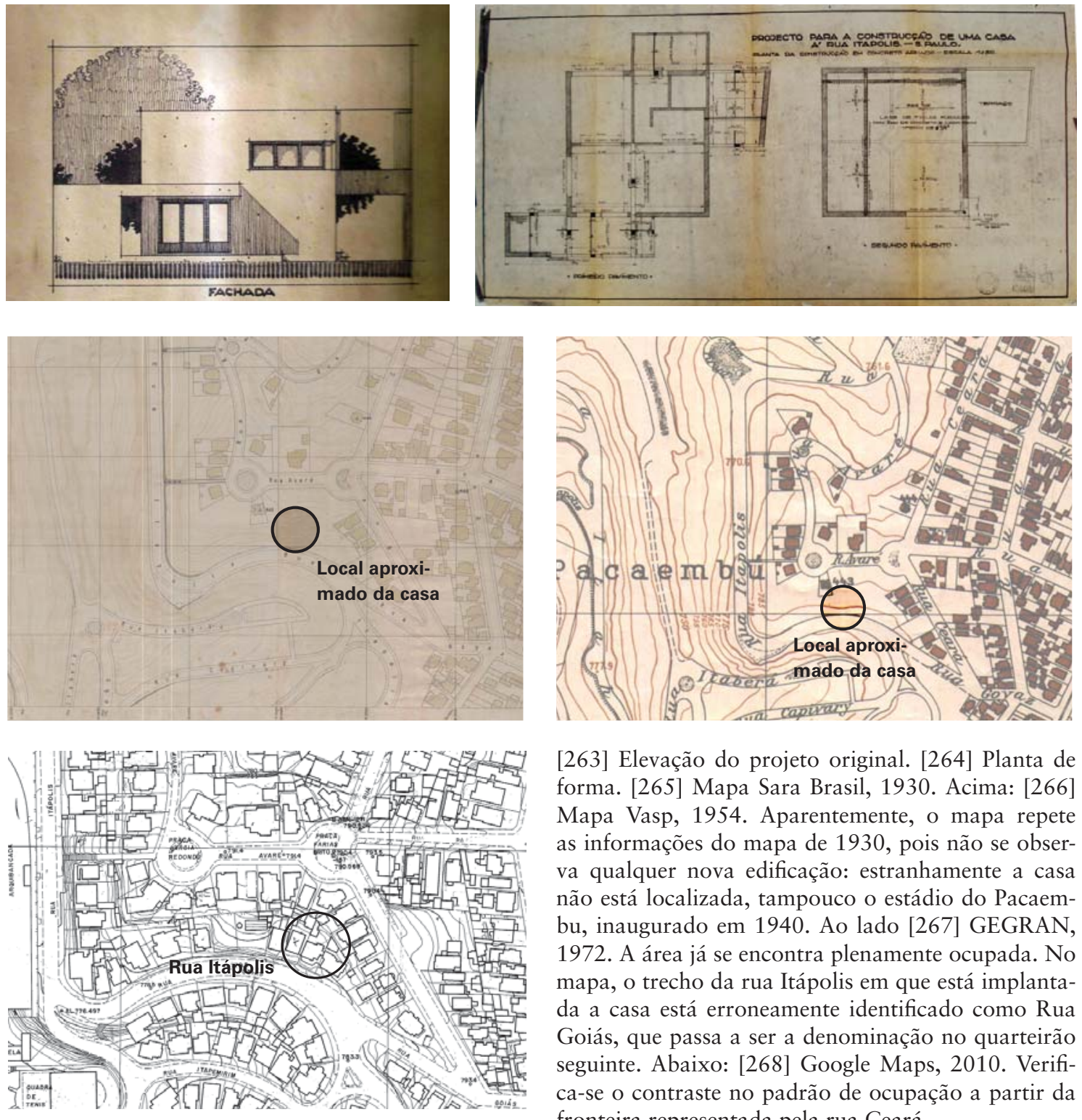

[263] Elevação do projeto original. [264] Planta de forma. [265] Mapa Sara Brasil, 1930. Acima: [266] Mapa Vasp, 1954. Aparentemente, o mapa repete as informações do mapa de 1930, pois não se observa qualquer nova edificação: estranhamente a casa não está localizada, tampouco o estádio do Pacaembu, inaugurado em 1940. Ao lado [267] GEGRAN, 1972. A área já se encontra plenamente ocupada. No mapa, o trecho da rua Itápolis em que está implantada a casa está erroneamente identificado como Rua Goiás, que passa a ser a denominação no quarteirão seguinte. Abaixo: [268] Google Maps, 2010. Verifica-se o contraste no padrão de ocupação a partir da fronteira representada pela rua Ceará.

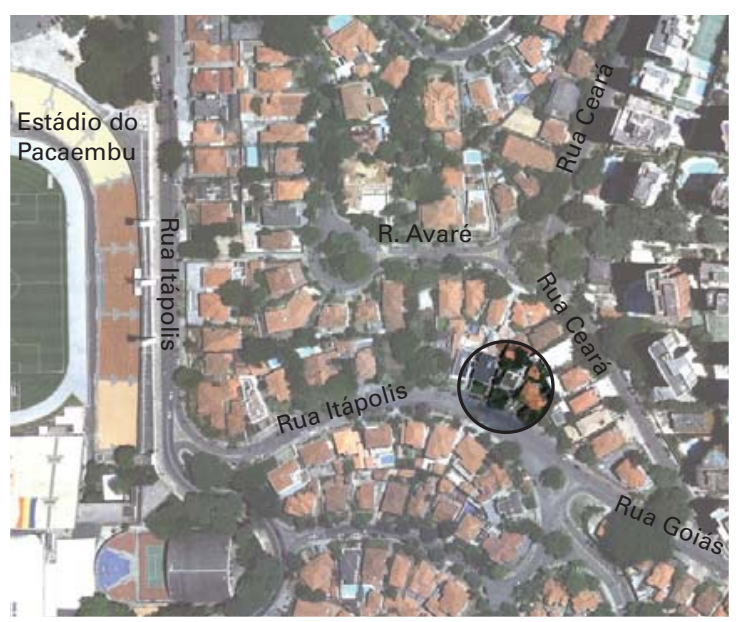




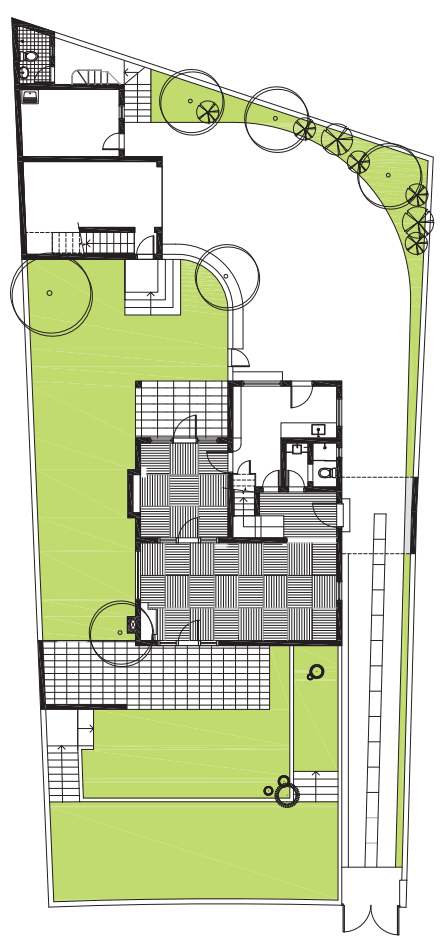

[269] PLANTA TÉRREO

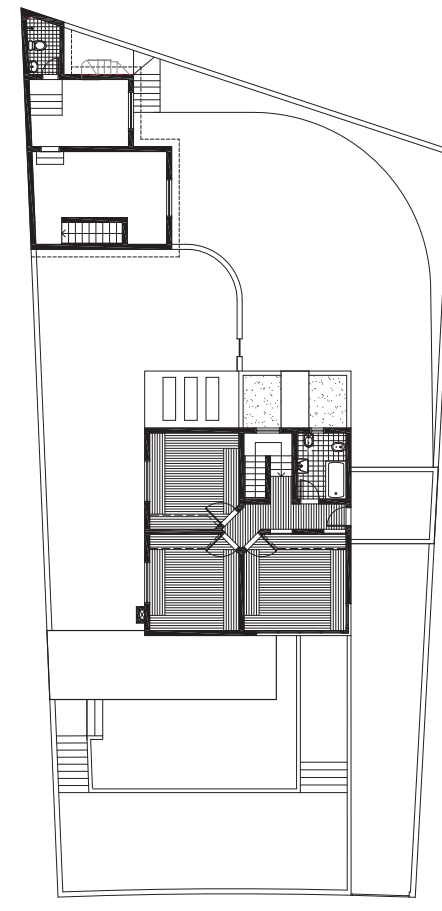

[270] PLANTA PISO SUPERIOR

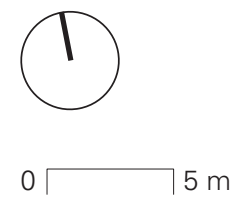

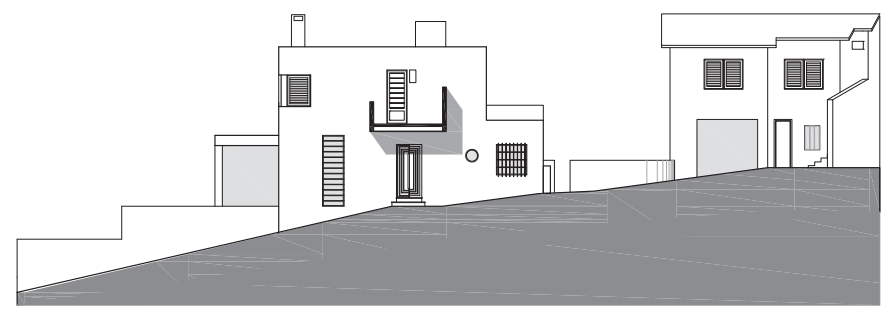

[271] ELEVAÇÃO LESTE

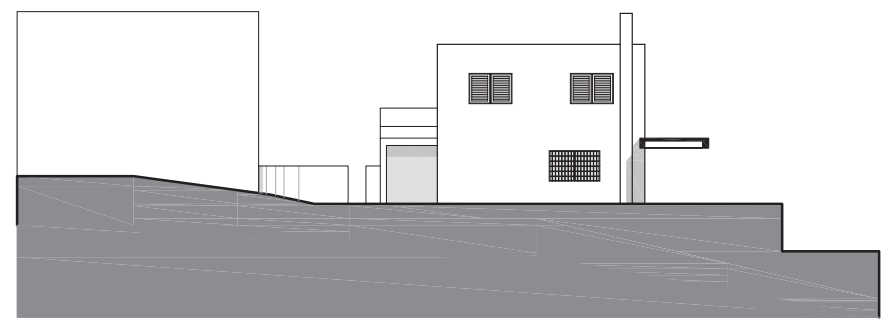

[273] ELEVAÇÃO OESTE

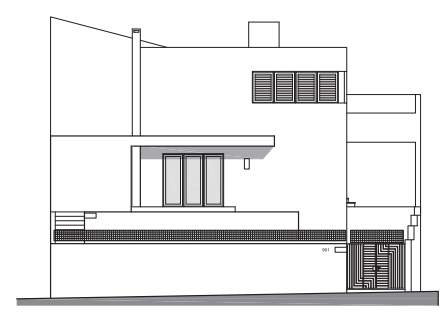

[272] ELEVAÇÃO SUL

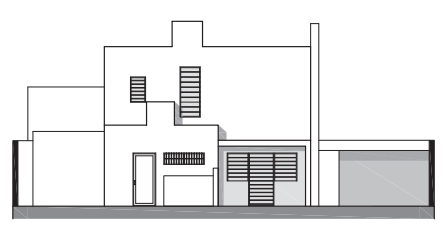

[274] ELEVAÇÃO NORTE 

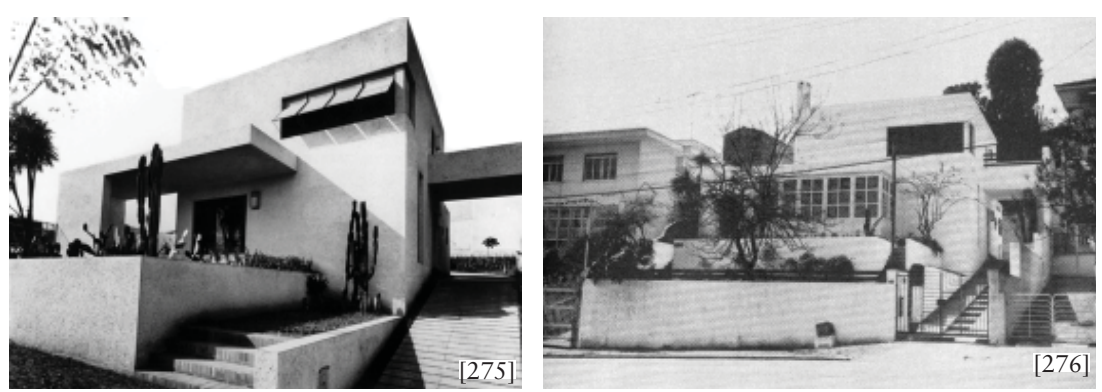

[275] a [279] Fachada frontal em 1930, 1982, quando a varanda é fechada, 1984, em registro para o tombamento federal, com a varanda já reaberta, 2008 e 2010, após reforma para lançamento da exposição "Modernista 80 anos".
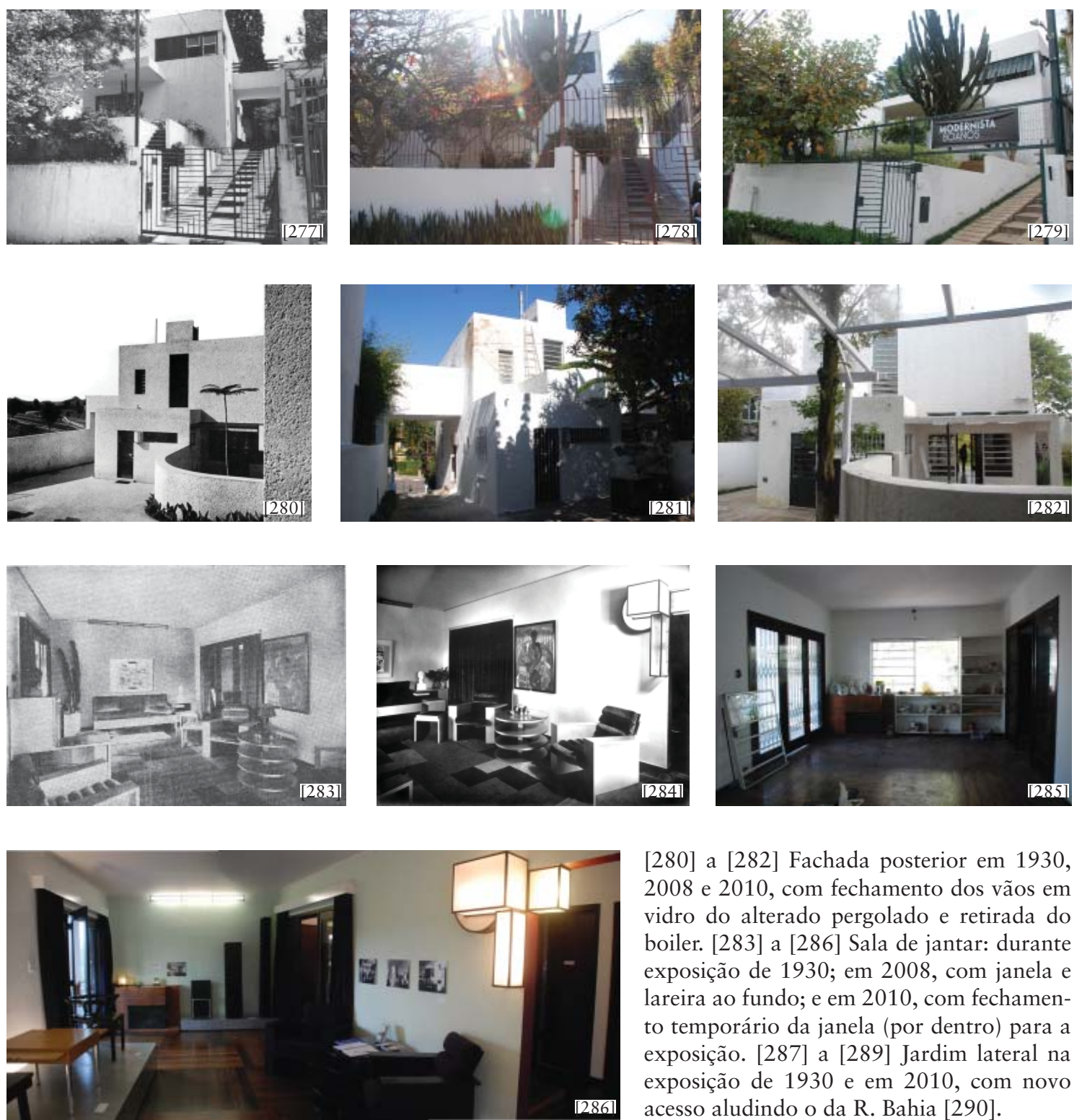

[280] a [282] Fachada posterior em 1930, 2008 e 2010, com fechamento dos vãos em vidro do alterado pergolado e retirada do boiler. [283] a [286] Sala de jantar: durante exposição de 1930; em 2008, com janela e lareira ao fundo; e em 2010, com fechamento temporário da janela (por dentro) para a exposição. [287] a [289] Jardim lateral na exposição de 1930 e em 2010, com novo [286] acesso aludindo o da R. Bahia [290].
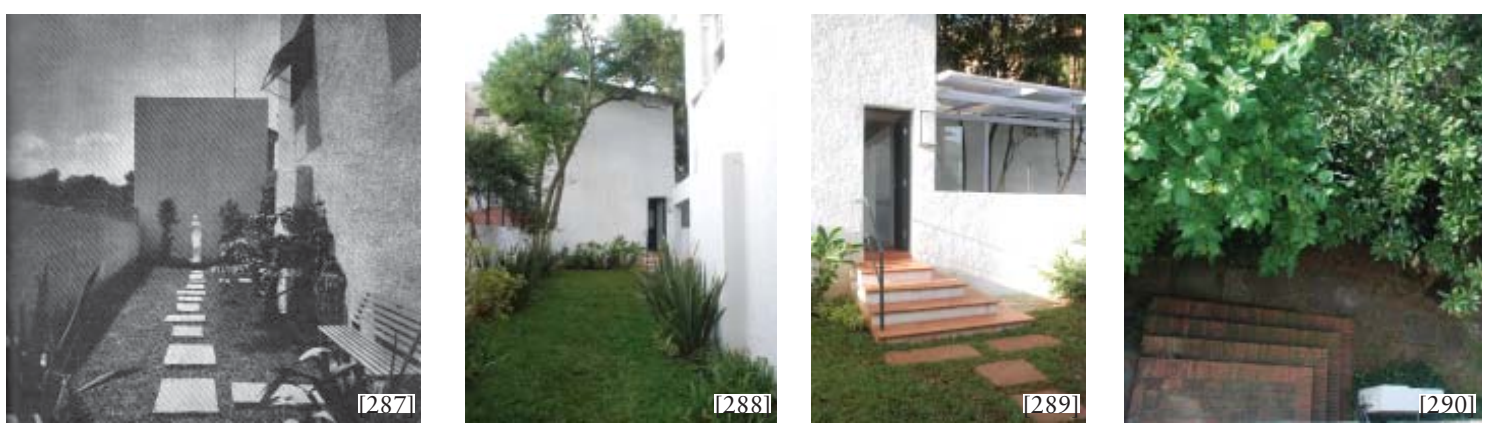

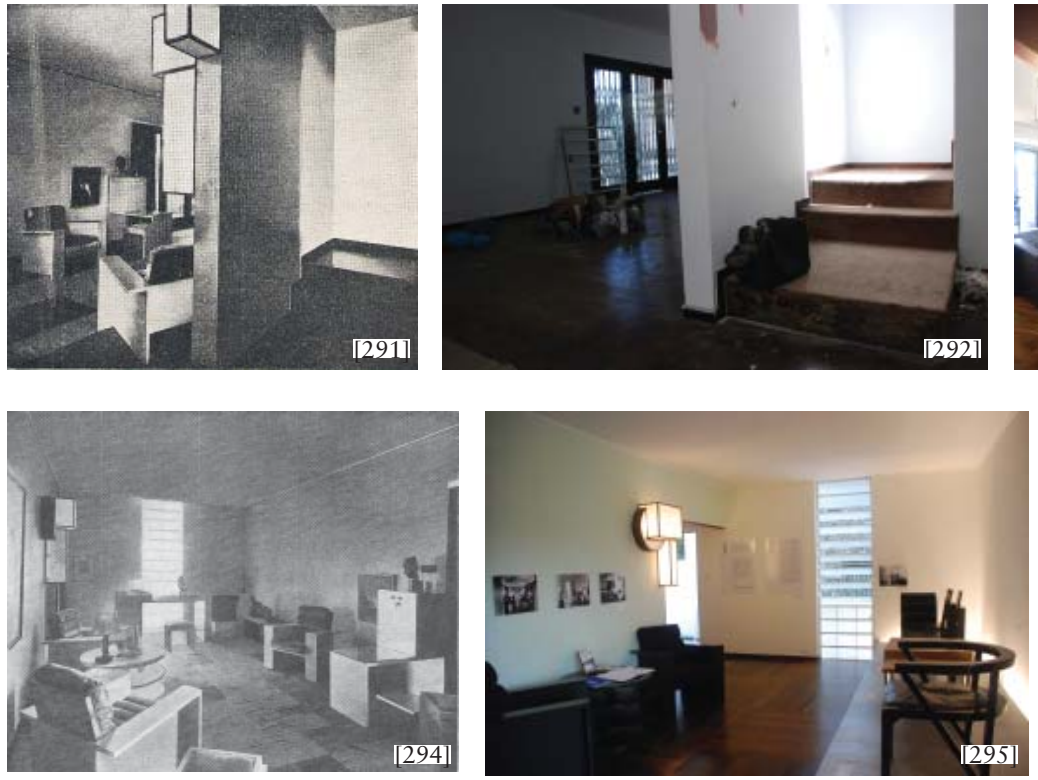

Fotos comparativas 1930, 2008 e 2010: [291] a [293] Escada, com estar ao fundo. A cor escura volta à parede em 2010, após prospecção. O carpete é removido e as luminárias reconstruídas. [294] e [295] Sala de jantar em 1930 e 2010. [296] a [298] Sala de jantar, com caixilho em "T" ao fundo e o piso tratado.
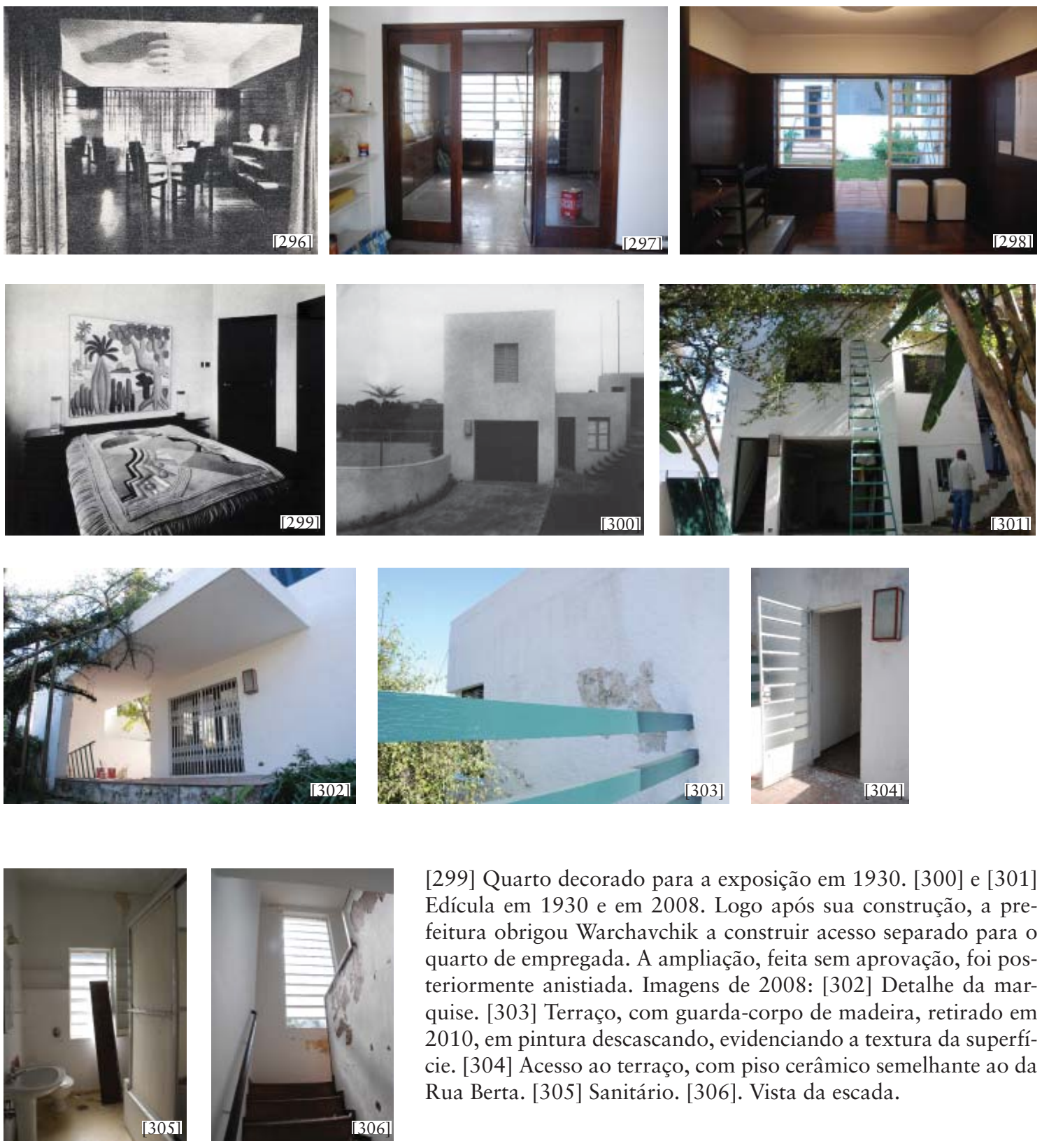

[299] Quarto decorado para a exposição em 1930. [300] e [301] Edícula em 1930 e em 2008. Logo após sua construção, a prefeitura obrigou Warchavchik a construir acesso separado para o quarto de empregada. A ampliação, feita sem aprovação, foi posteriormente anistiada. Imagens de 2008: [302] Detalhe da marquise. [303] Terraço, com guarda-corpo de madeira, retirado em 2010, em pintura descascando, evidenciando a textura da superfície. [304] Acesso ao terraço, com piso cerâmico semelhante ao da Rua Berta. [305] Sanitário. [306]. Vista da escada. 

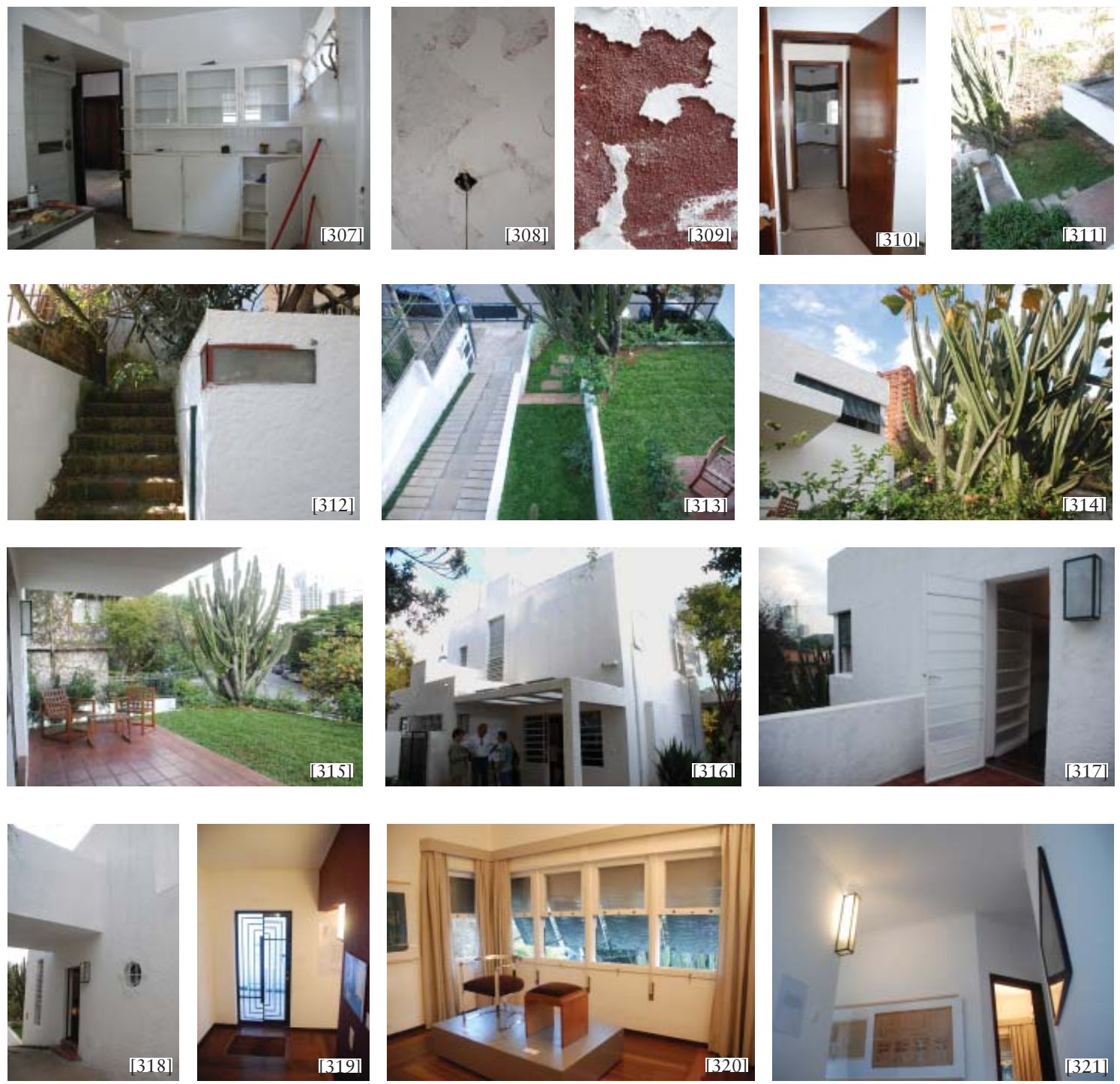
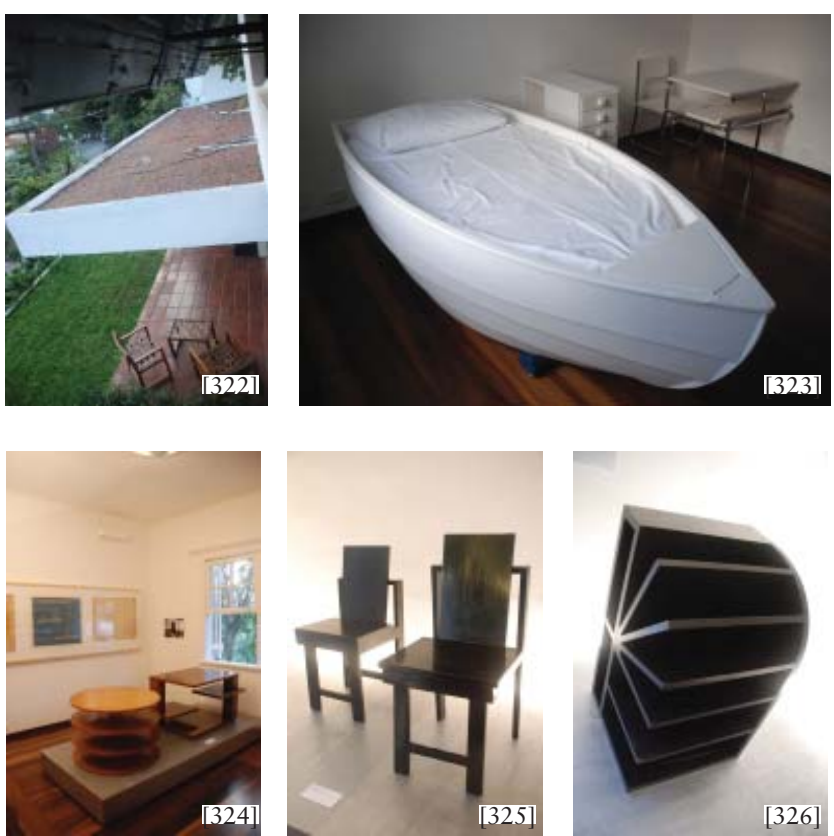

[307] a [312] Imagens de 2008: Cozinha; marcas de infiltração na laje. Parede descascada para obtenção da cor; Vista de um quarto para aquele da janela de canto; acesso à varanda pelo jardim, em algum momento alterado, e em 2010 repristinado [313]; acesso preservado, pelo lado oposto do jardim. Imagens da casa em 2010: [314] Detalhe de remanescente do jardim original. [315] Varanda sob marquise. [316] fachada posterior. [317] Terraço após a intervenção, sem o guarda-corpo de madeira, com revestimento recomposto, piso lavado e luminária acabada. [318] Vista da entrada lateral sob o terraço. [319] Detalhe da porta de acesso. [320] Janela de canto do quarto frontal. [321] Vista da circulação, donde se vê o acesso a $45^{\circ}$ aos quartos. [322] Detalhe da marquise. [323] a [326] peças em exposição: mobiliário do quarto do filho de Gregori, visto em foto da casa da Santa Cruz em 1935; mesinhas e projetos, em um dos quartos; cadeiras e revisteiro, dentre muitos outros objetos em exibição. 


\section{CASA DA RUA TOMÉ DE SOUZA (1929-1930)}

A singela residência José Cândido da Silva à Rua Tomé de Souza foi projetada em 1929 para o médico, esposa e filha no recente loteamento da Cia. City Alto da Lapa e Bella Aliança. Tendo contratado o arquiteto Barry Parker para desenhar o loteamento de $2.126 .653 \mathrm{~m}^{2}$ em 1921, a companhia focava originalmente o operariado que trabalhava nas fábricas das redondezas, a exemplo da Vila Romana e do Grão Burgo da Lapa (Lapa de Baixo), de 1888 e 1891 respectivamente, mas em virtude do padrão Jardim e da infraestrutura que se consolidava no local, passou a se destinar a uma classe média mais bem remunerada ${ }^{213}$. Com anúncios nos jornais paulistas e ligados a comunidades de imigrantes em língua italiana, russa, alemã, espanhola, eram oferecidas condições atraentes de compra com facilidade de financiamento: "Não pague aluguel, uma vez que V. S. pode adquirir em prestações equivalentes qualquer uma das excellentes casas que lhe offerecemos" ${ }^{214}$, dizia o reclame de julho de 1930 no Estado de São Paulo.

No mapa de 1930 é possível notar que o loteamento contava ainda com pouquíssimas construções, e a própria casa do dr. Cândido era a única construída em seu quarteirão. Com o terreno comprado em 13/08/1929215, o projeto de Warchavchik é submetido à prefeitura em 22/08/1929 para obtenção do Alvará de Construção, com anuência da Cia. City. Do projeto foi solicitada pelos engenheiros municipais apenas uma alteração quanto à iluminação e ventilação da copa, sendo rapidamente aprovado ${ }^{216}$. Com recuos bem mais generosos que aqueles impostos pela loteadora ${ }^{217}$, a casa térrea de dois dormitórios era construída em alvenaria de tijolos e argamassa de cal e areia, com assoalho em canela sobre madeiramento de peroba, portas internas de embuia, portas de acesso de caixilho de ferro na sala de estar e de jantar, sendo utilizado nesta última o caixilho em "T" que conjugava janela com porta centralizada, como nas casas da Vila Bertha e na Itápolis -, janelas de cedro - exceto na sala de estar e de jantar, pisos em ladrilhos sobre contrapiso de cimento e azulejos brancos na cozinha e banheiro ${ }^{218}$ e laje de cobertura de tijolos furados intercalados com ferragem de $1 / 4^{219}$.

Com a cultivada janela de canto, marquise em balanço e teto-jardim, o apreço de Warchavchik por essa obra se revelava na seleção realizada por ele para as duas publicações internacionais que retratariam a sua arquitetura e por extensão a arquitetura moderna bra-

\footnotetext{
213 Histórico disponível no site da Cia. City, <http://www.ciacity.com.br/ep/index.html>.

214 Anúncios de 1928 a 1930 disponíveis no site da Cia. City.

215 Escritura de compra e venda disponível no acervo do CCAP. A escritura definitiva é de 13/08/1930.

216 Alvará expedido em 26/09/1929. Processo PMSP 0.052.163/29

217 Para garantir o padrão ambiental desejado, a companhia incluía na escritura obrigações contratuais relativas à ocupação do terreno: recuo frontal de $8 \mathrm{~m}$, laterais de $2 \mathrm{~m}$, uso exclusivamente residencial, dependências com mesmas restrições que construção principal.

218 Esta informação consta do memorial descritivo do projeto original. Hoje em dia o banheiro e a circulação são em granilite, devendo ser posteriores à década de 1940, quando o material passa a ser maciçamente empregado.
}

219 Memorial descritivo, Processo PMSP 0.052.163/29, fl. 3 
sileira pela primeira vez ${ }^{220}$, a revista Cahiers D'art, editada por Giedion, cuja matéria aproveitava o relatório enviado por Warchavchik como representante sulamericano dos CIAM e o livro Gli Elementi dell'architettura funzionale de Sartoris. Aliás, através das plantas publicadas nesses trabalhos se nota que a copa transformou-se em quarto de costura, como depois identificado por Ferraz, mas também a ausência da escada caracol representada no livro deste último ${ }^{221}$, deixando a dúvida quanto à intenção original do arquiteto em tornar acessível a laje de cobertura.

Além do projeto, a construção ficou a cargo de Warchavchik, como era de costume em uma época em que não existiam escritórios dedicados exclusivamente à prancheta ${ }^{222}$. Antes mesmo da oficialização da compra do terreno, projetista e cliente já tratavam da construção, como se vê em documento de 6/06/1929, que visava formalizar o encargo, remetido por Warchavchik ao Dr. Cândido:

De accordo com nossa combinação verbal, comunico a V. S. que posso executar a construcção cujo projeto está em seu poder, completa, com garage usando material todo de boa qualidade, pelo preço de 38:000\$000 223

Já em 28/09/1929, dois dias após a aprovação do Alvará de Construção, é paga a primeira prestação da construção da casa no valor de 9:300\$000 (nove contos e trezentos mil reis), para dar início à obra. No mesmo valor, são pagas mais três parcelas em 11/11/1929, 20/01/1930 e 11/06/1930 e por fim, em 12/08/1930 Warchavchik emite um documento atestando que todo o valor contratado foi quitado ${ }^{224}$. Entretanto, tais parcelas não correspondem a etapas da obra, pois esta se encontrava concluída externamente, quiçá totalmente, em maio de 1930. Warchavchik presenteia o Dr. Cândido com duas das fotos utilizadas nas publicações sobre a casa realizadas pelo Foto Studio Hugo Zanella, com dedicatória datada de 5/05/1930. Pouco antes, em 14/04/1930, a prefeitura embarga a obra em razão de a edícula estar sendo construída em desacordo com a planta aprovada e com o código de obras e intima Warchavchik a pagar multa e apresentar nova planta regularizando a construção em uma situação similar à ocorrida na Rua Itápolis. Esta abrigava garagem no térreo e quarto de empregada no piso superior e tinha originalmente escada externa, tornando-se interna com acesso direto pela garagem, levando a prefeitura a exigir o acesso independente. O projeto substitutivo é apresentado em 26/05/1930 e o processo se encerra em julho daquele ano.

Quando a família decide vender o imóvel, em 1959, já não mais lá reside. A compradora, dona Mariette Lorensini, arrematou-o por 1 milhão de cruzeiros, pagos com sinal de $35 \%$ e 60 prestações mensais. Enquanto corria o prazo de cinco anos para quitação da compra, Mariette decide reformar a casa em 1962, aprovando na prefeitura projeto que

221 A planta de prefeitura também não representava a escada caracol.

222 Prática sobre a qual o colega Rino Levi terá fundamental importância.

223 Acervo CCAP

224 Recibos arquivados no CCAP 
previa a demolição da edícula e substituição por outra encostada no fundo do lote, a incorporação da área da lavanderia à cozinha, a ampliação da casa, prevendo uma nova e maior lavanderia com depósito, quarto e banheiro de empregada e banheiro servindo o dormitório dos fundos, e a construção de garagem no alinhamento frontal do terreno.

Da proposta aprovada, apenas a garagem foi executada, mas a planta registrava também o estado da construção naquele período. A rampa para automóvel já havia sido eliminada e o acesso frontal já se encontrava na sua forma atual. As novidades da construção original também já se apagavam, pois a marquise em balanço havia sido fechada em caixilharia com linguagem semelhante à usada por Warchavchik, aproveitando a varanda como uma pequena saleta e o terraço jardim eliminado por uma cobertura em quatro águas.

Findo o prazo de quitação em 1964, ao invés de se outorgar a escritura definitiva do imóvel, Cândido da Silva transfere-o diretamente a Aúthos Pagano e esposa, com a anuência de Mariette Lorensini, que já não mais morava no local225. É possível que o casal Pagano já estivesse lá morando sem que Mariette pudesse oficialmente vender-lhes o imóvel, o que confere com a informação dada pela diretora do atual centro cultural lá instalado, de que a cobertura teria sido construída por eles quando entraram no imóvel, pois a ausência de beirais incomodava a Sra. Pagano ${ }^{226}$.

Em 1976 falece Aúthos Pagano, motivando imediatamente Carmela Pagano a criar um centro de estudos em sua homenagem. Aúthos foi professor e diretor da Faculdade de Ciências Econômicas da Fundação Álvares Penteado, professor de demografia, matemática, estatística geral e aplicada na Faculdade de Ciências Econômicas da Universidade Mackenzie, diretor da Divisão de Estatística do Departamento de Cultura da Prefeitura de São Paulo e produziu uma série de trabalhos acadêmicos, livros e artigos nas áreas de economia, direito e correlatos, deixando uma biblioteca com mais de 7 mil títulos. A viúva era advogada atuante na OAB e na associação de Advogados da Lapa, tendo se formado pelo Mackenzie e se aperfeiçoado em diversos cursos no Brasil e no exterior. Sua admiração pelo marido, bem expressa no livro que publicou a seu respeito, Aúthos Pagano: O intelectual, a obra, o ho$m^{2} m^{27}$, logo levou-a a propor a doação da casa com seu acervo, mobiliário, etc. ao Governo do Estado de São Paulo, para viabilizar a criação do centro de estudos.

Nas tratativas iniciais, a ideia era que a casa fosse doada à USP, sob responsabilidade do Instituto de Matemática, mas o receio de que as obras se espalhassem pelos diversos departamentos da Universidade, fez com que Carmela Pagano escolhesse a Secretaria de Estado da Cultura como responsável pela sua guarda ${ }^{228}$. Inicialmente, o empecilho vinha do

\section{Cf. escritura de compra e venda, 1964. CCAP}

226 As informações são da diretora do CCAP, que mantém contato direto com Carmela Pagano, mentora do Centro Cultural, que teve contato direto com Cândido da Silva e Mariette Lorensini para a compra do imóvel.

227 PAGANO, 2010

228 Informação no site do CCAP, <http://www.apaacultural.org.br/authospagano/espaco.php>, acesso em 15/01/2010 
zoneamento municipal, que classificava o City Lapa como zona exclusivamente residencial, não permitindo a instalação de uso institucional. Mas, diante de um caso tão específico, a Administração Regional da Lapa, consultada a respeito, sugeriu o encaminhamento da questão à Comissão de zoneamento municipal para uma decisão final ${ }^{229}$. A solução encontrada se concretizou em 7 de julho de 1978, com a promulgação da lei $n^{\circ} 8.759$, que enquadrava o imóvel na Z8-200. Neste momento a doação ainda vinha sendo tratada com a Universidade de São Paulo, a quem a Sra. Pagano comunicara a estratégia de viabilização adotada:

Tendo o Sr. Prefeito da Capital tomado conhecimento da consulta formulada pelo Instituto de Matemática à Regional da Lapa, assinada por V. Excia. quando diretor da unidade, após visita que fez em minha residência à Rua Tomé de Souza, 997, sobre a possibilidade de instalação de um CENTRO DE CULTURA com a doação acima mencionada e inteirando-se da finalidade pretendida pela signatária desta, houve por bem o Sr. Prefeito sancionar lei preservando o imóvel a fim de dar solução satisfatória sem desrespeitar a lei de zoneamento, tendo em vista a importância cultural da doação, segundo carta em anexo ${ }^{230}$.

Ou seja, tal medida se deu mais como subterfúgio para driblar as restrições impostas pelo zoneamento do que como forma de reconhecimento do valor cultural da obra, que viria a reboque. Assim como a instrumentalização do tombamento e das políticas culturais para finalidades econômicas vista no capítulo anterior, o seu uso como forma de driblar a legislação urbanística ou inviabilizar empreendimentos que coloquem obras em perigo tornarse-iam práticas frequentes, em um contexto no qual os órgãos de preservação enxutos, para não dizer carentes de equipe, estrutura e recursos, acabavam por atuar na salvaguarda do patrimônio cultural em caráter de urgência, apagando incêndios sem antever claramente as políticas de preservação e sem conseguir realizar os inventários de que acreditavam serem os instrumentos eficazes disponíveis para reconhecimento, registro e tutela dos bens culturais.

Ao menos a classificação como Z8-200 trouxe alguma repercussão na imprensa quanto ao valor cultural da casa, sendo rememorada não só a história recente da instalação do Centro Cultural, mas também as suas origens. Destacou-se, por exemplo, o fato de que estava em curso a ampliação dos critérios de preservação dos bens culturais, não se considerando apenas a antiguidade, mas também outros aspectos que justificassem a proteção de uma obra de arquitetura contemporânea ${ }^{231}$.

Confirmada a possibilidade da mudança de uso, o processo de doação correu por

229 Ofício assinado pelo Diretor do Instituto de Matemática, Waldyr Muniz de Souza ao Administrador Regional da Lapa, Carlos Alberto Teixeira Bataline. Of. D/1065/77, de 26/08/1977. Acervo CCAP

230 Carta de 01/12/1978 de Carmela Pagano ao Reitor da USP, o ex-diretor do Instituto de Matemática Waldyr Muniz de Souza. A carta a que faz referência é do prefeito Olavo Setúbal a ela endereçada, de 17/08/1978. Acervo CCAP

231 Diário da Noite, 24/06/1978. Também publicaram a respeito: OESP, 20/11/197?, Diário Popular, 12/05/1982, Diário de São Paulo, 23/07/1978. Anexos a PAGANO, 2010 
mais alguns anos, até que em fevereiro de 1982 o governador Paulo Maluf publicaria o decreto $\mathrm{n}^{\circ} 18.453$ que autorizava o recebimento por doação do imóvel e seu acervo mediante implantação de Centro Cultural a cargo da Secretaria de Cultura. Em maio do mesmo ano, a Secretaria de Estado da Cultura publicava a Resolução 52, que convidava Carmela Pagano a colaborar na direção do "Centro Cultural e de Estudos Superiores Aúthos Pagano", desde que sem ônus para o erário. A escritura de doação incluía cláusulas referentes às condições da doação: "o imóvel destinar-se-á exclusivamente a instituição de Centro Cultural, de nível superior, a cargo da Divisão de Arquivo do Estado da Secretaria de Estado da Cultura, a ser denominado 'Centro Cultural e de Estudos Superiores Aúthos Pagano', seu patrono perpétuo". Havia também uma cláusula que proibia a saída de qualquer componente da biblioteca, formada por 7.096 obras, e demais pertences, mesmo a título de empréstimo ${ }^{232}$.

O passo seguinte era reformar o imóvel para a instalação do Centro. O projeto substitutivo apresentado em $1988^{233}$ daria a feição atual do Centro, com a criação de um galpão multiuso de $60 \mathrm{~m}^{2}$ no fundo do lote, somando-se a outras adaptações anteriormente realizadas para o funcionamento do centro cultural. O imóvel já contava com a instalação de dois pequenos sanitários junto à edícula e de uma área de depósito e copa localizada ao fundo do lote, faceando a lateral voltada para a viela.

Atualmente, o Centro Cultural Aúthos Pagano é gerido por uma Associação através de convênio com a Secretaria de Estado da Cultura, e mantém programação diversificada, com cursos de teatro, canto, coral, música, cinema, palestras em diversas áreas culturais, shows, exibição de filmes, etc., ao lado da biblioteca de Aúthos Pagano. Para o funcionamento do espaço, além dos acréscimos descritos na área externa da casa, a biblioteca se espalhou por todos os cômodos da casa, exceto sala de estar e banheiro, ficando a maior parte do acervo no dormitório dos fundos, duas salas foram destinadas à administração, uma no antigo quarto de costura e o outro no dormitório em frente à sala de jantar. Tendo o acompanhamento direto da viúva Pagano, que até hoje visita com alguma frequência o Centro, a construção sempre teve boa conservação ao longo dos anos. Como previsto na escritura de doação, o mobiliário e a decoração da casa permanecem os mesmos de quando o casal Pagano habitava o local, permitindo a vivência da atmosfera de então, conferindo ares domésticos aos interiores. Exceção feita ao dormitório do casal, cuja intimidade fora suprimida para a instalação do coração do acervo. Carmela admitiu que a compra da casa se deu como oportunidade de retornar ao bairro que tanto apreciavam e que eles descobriram apenas anos mais tarde a autoria do projeto ${ }^{234}$. Observando o mobiliário em mogno, a tapeçaria, os quadros, as luminárias e objetos de feições clássicas, sóbrias e conservadoras logo se entende a necessidade de colocação de telhado em quatro águas anulando os ares de modernidade da pequena edificação. É certo que as principais alterações realizadas na casa - a colocação do telhado e o fechamento da marquise frontal - são totalmente reversíveis, sendo 
possível a retirada. Mas as marcas dessa biografia recente incorporada ao edifício se dão nos interiores, que efetivamente imprimem a domesticidade e a ambiência da fase Pagano. Sobre este aspecto, fica claro o quanto a memória tem de processo em construção, já que graças aos esforços da viúva Pagano, o que seria uma memória pessoal e afetiva tornou-se pública, coletivizou-se, transformando-se em mais um capítulo da história desta casa.
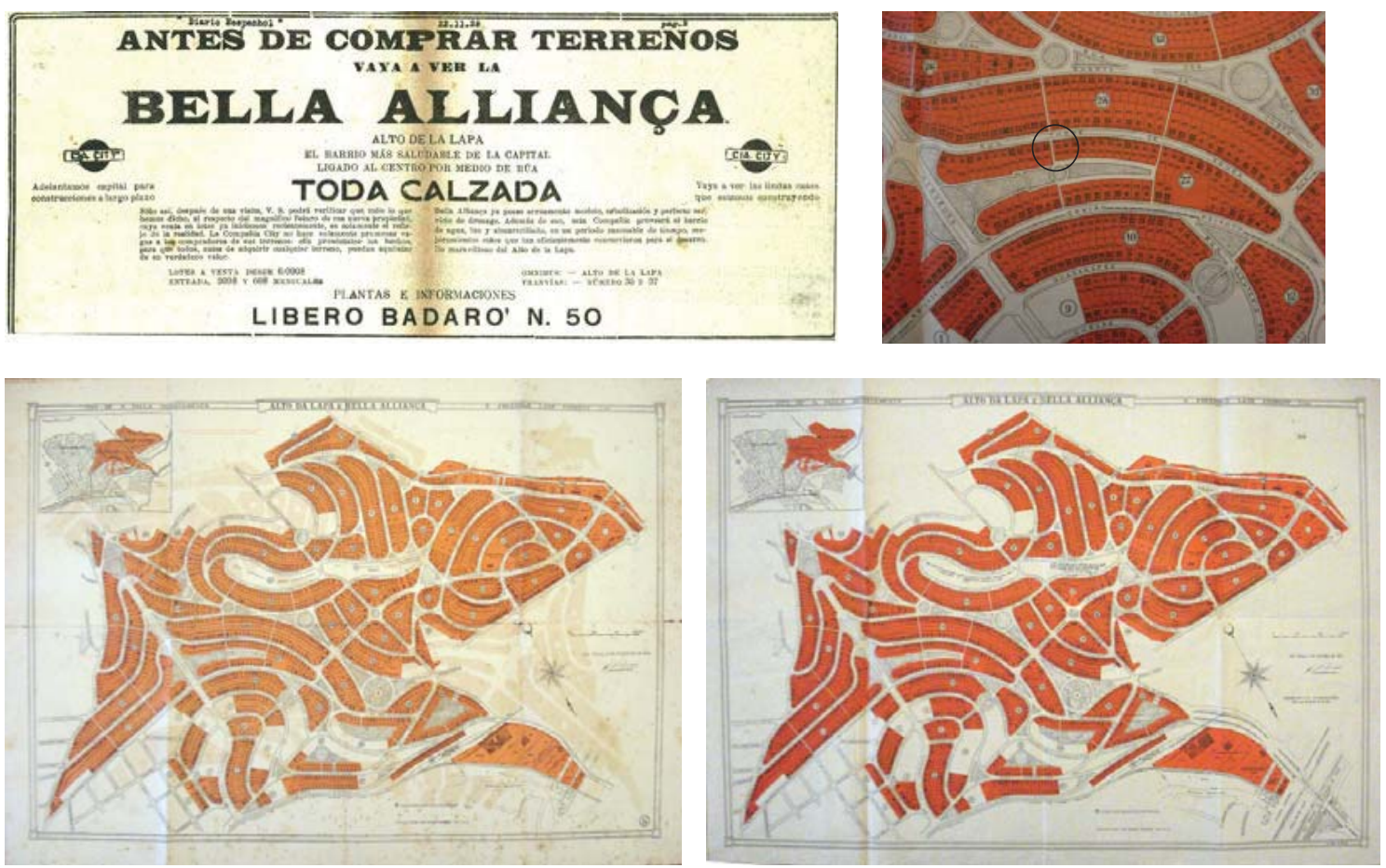

Acima: [327] Anúncio da Cia. City em espanhol, para atrair imigrantes. [328] Detalhe de planta da Cia. City com a localização do terreno. [329] e [330] Planta do loteamento City Lapa e Bela Aliança em 1946 e 1955 , com a indicação dos terrenos ocupados. Abaixo: [331] a [334] Localização da área em 1930, 1954, 1972 e 2010 .
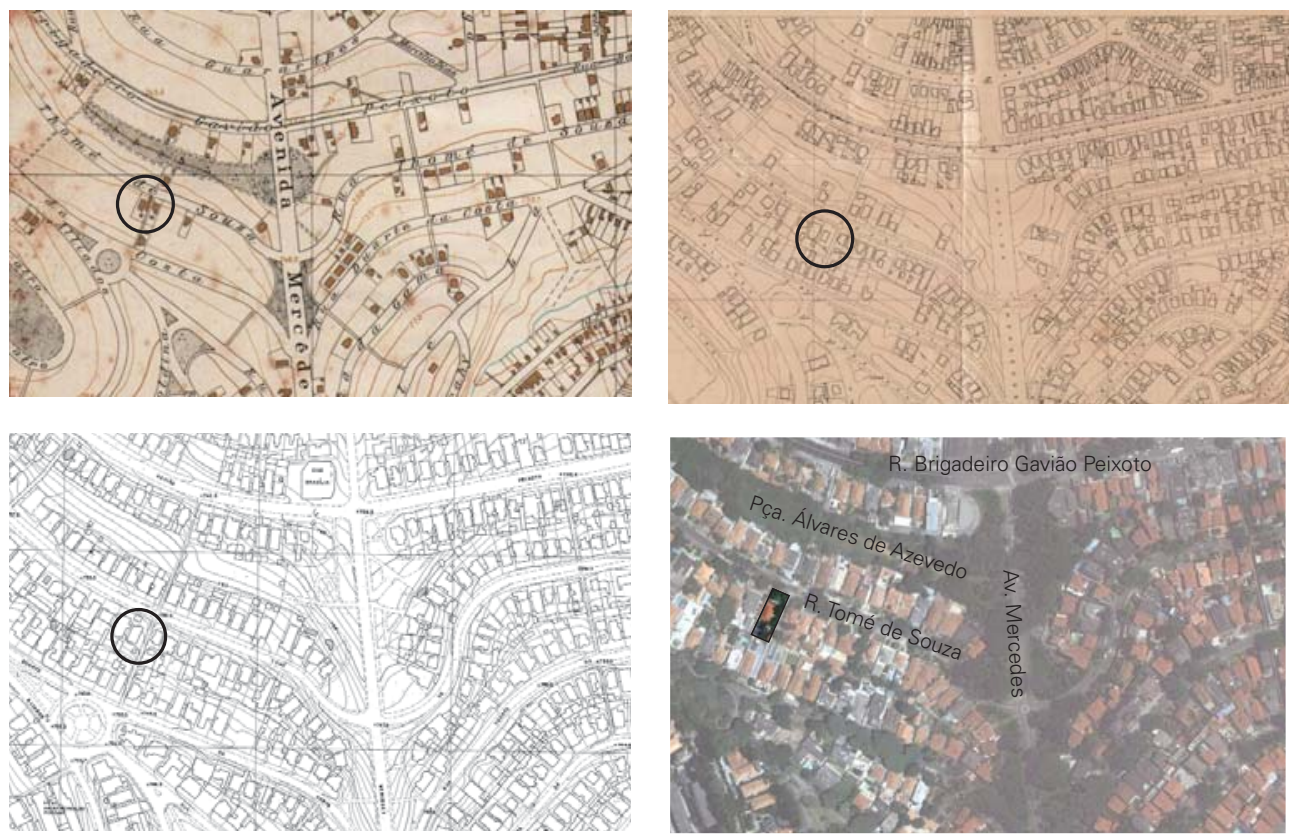

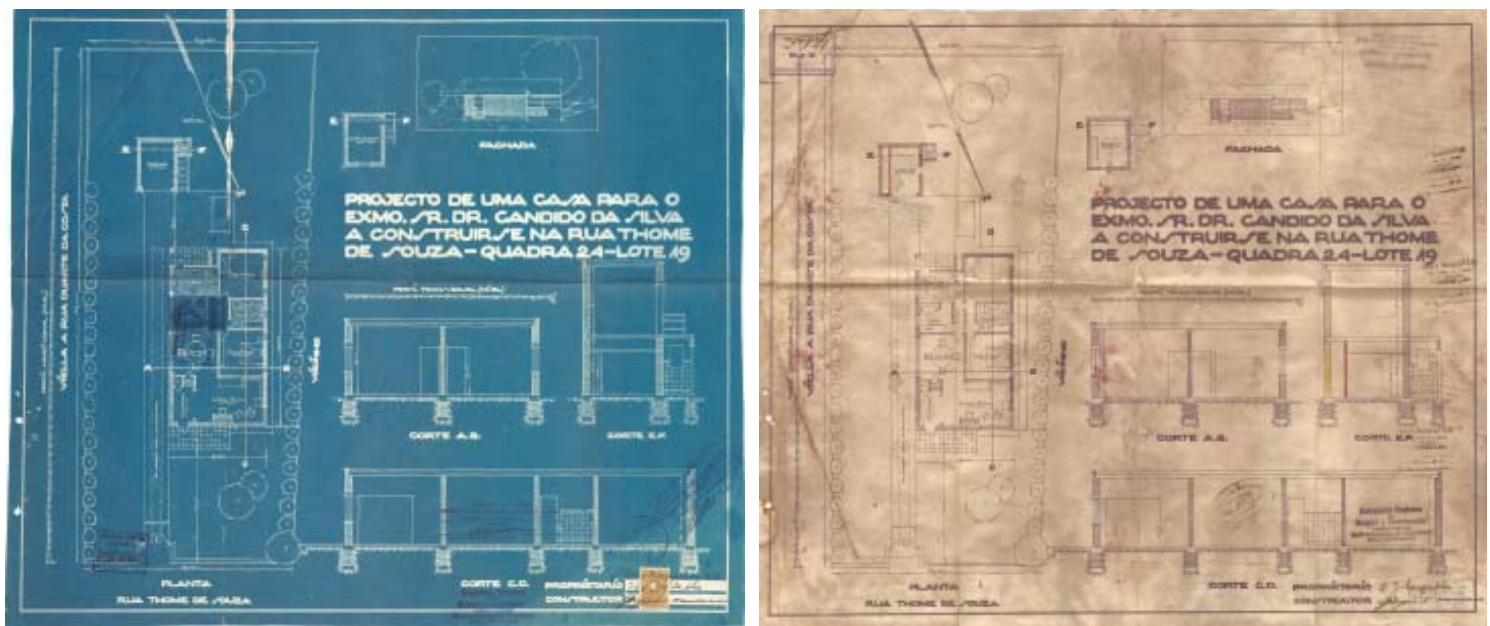

[335] e [336] Planta do processo de aprovação (1929) e do modificativo (1930).
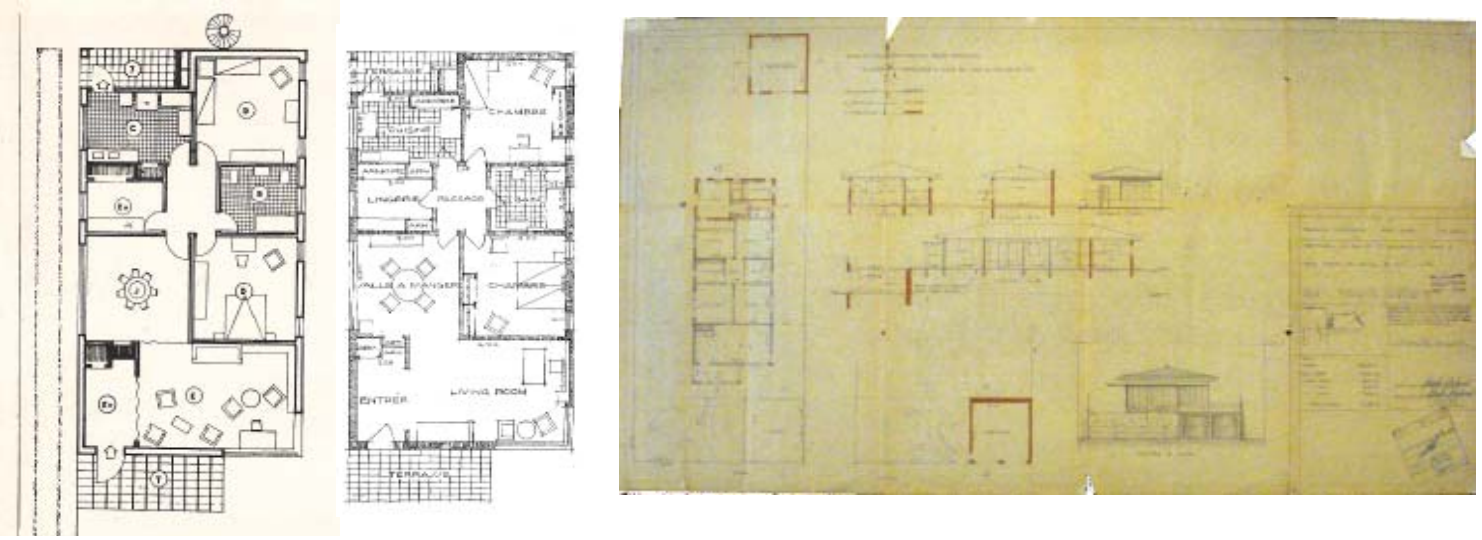

[337] Planta com layout, constando escada helicoidal publicada em FERRAZ, 1965. [338] Planta com Layout publicada em SARTORIS, 1932. [339] Projeto de reforma, 1962, para Mariette Lorensini. Abaixo: [340] Projeto de conversão da casa em centro cultural, de 1988.

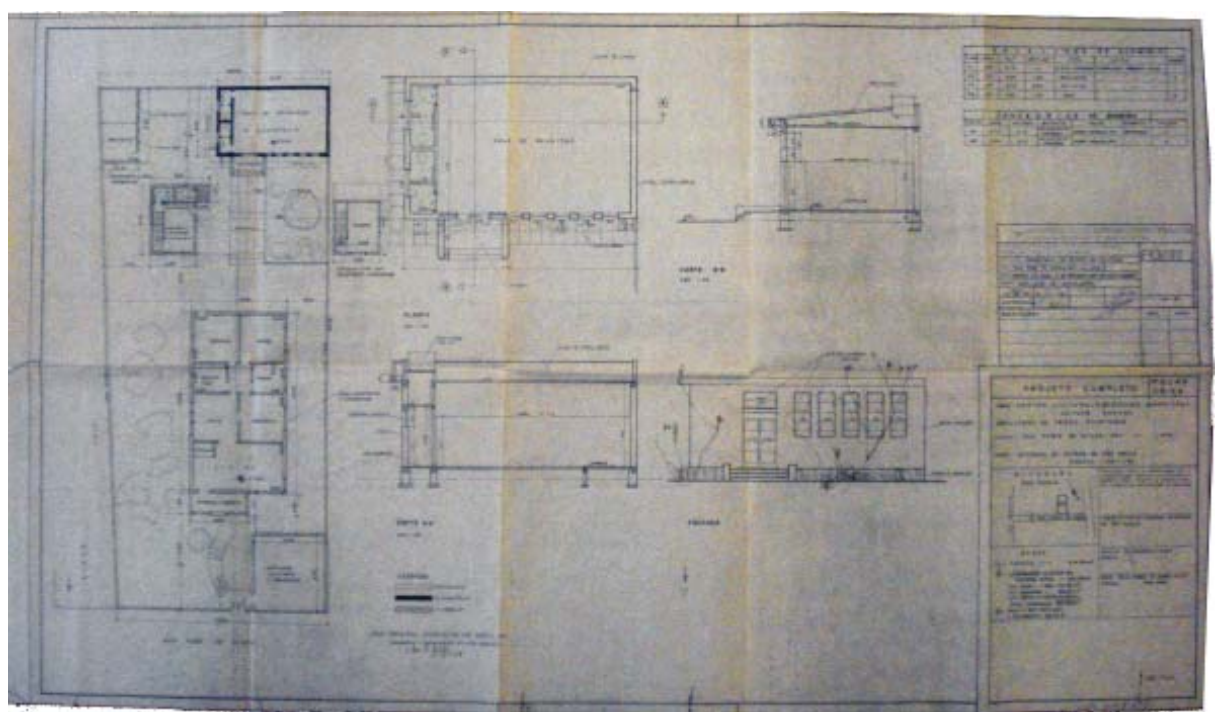




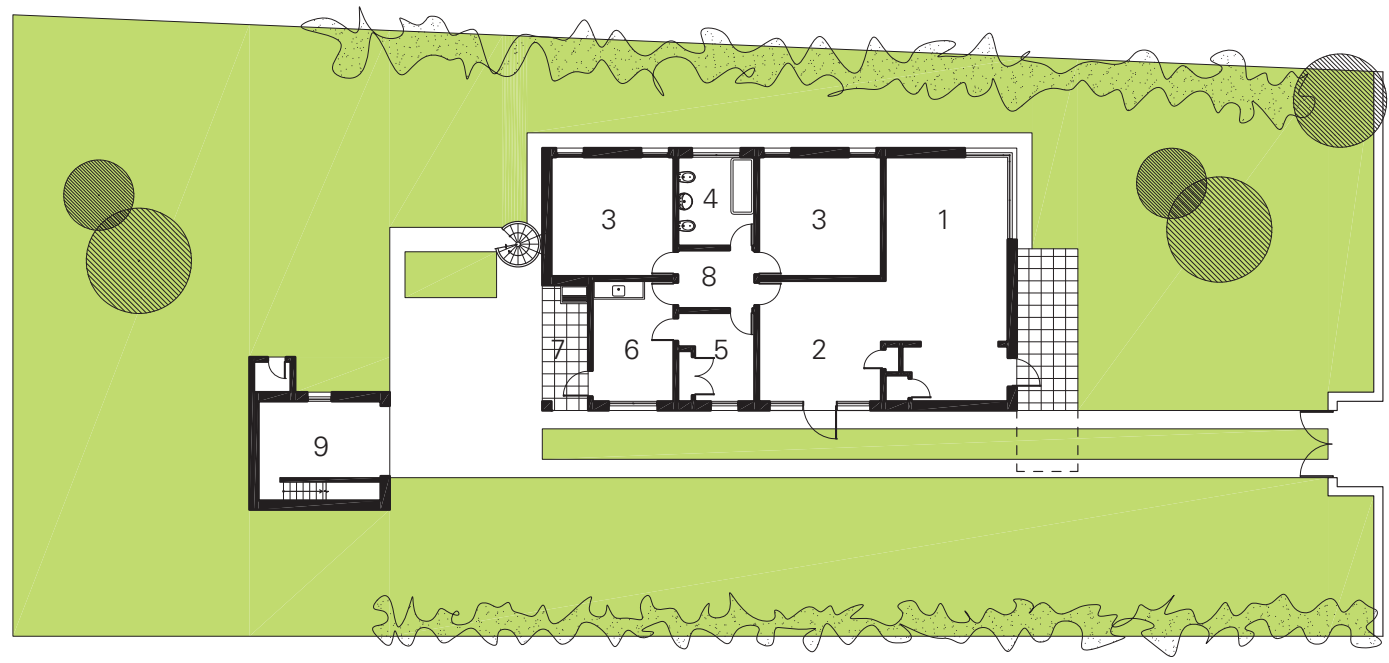

[341] PLANTA TÉRREO
Uso original
1. Sala de estar
2. Sala de jantar
3. Dormitório
4. Sanitário
5. Quarto de costura
6. Cozinha
7. Lavanderia
8. Circulação
9. Garagem
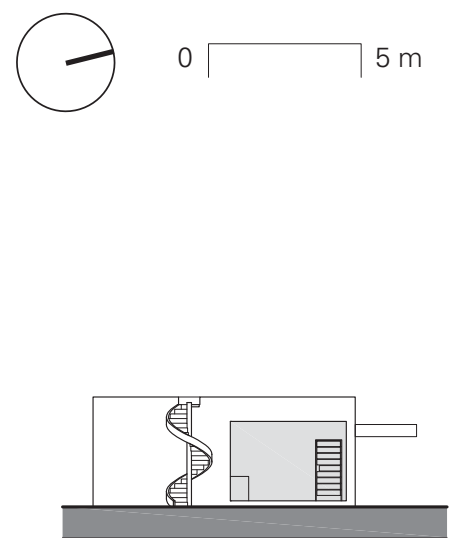

[344] ELEVAÇÃO SUL

[342] $2^{\circ} \mathrm{PAV}$.

[343] ELEVAÇÃO LESTE

EDÍCULA

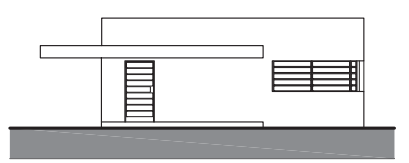

[345] ELEV. NORTE

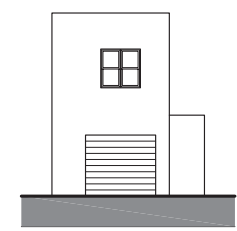

[346] ELEV. NORTE

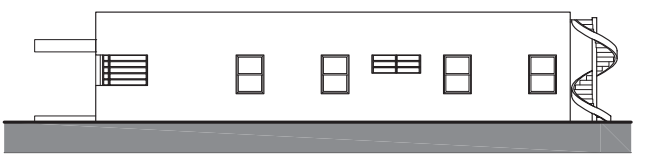

[347] ELEVAÇÃO OESTE

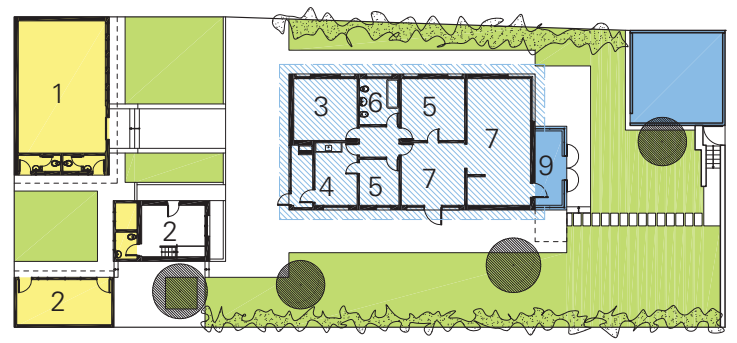

$\begin{array}{ll}\text { 1. Sala multiuso } & \text { 6. Sanitário } \\ \text { 2. Depósito } & \text { 7. Área expositiva } \\ \text { 3. Biblioteca } & \text { 8. Garagem } \\ \text { 4. Copa } & \text { 9. Varanda } \\ \text { 5. Administração } & \end{array}$

Reforma de 1962: Novo telhado, fechamento da varanda, nova garagem
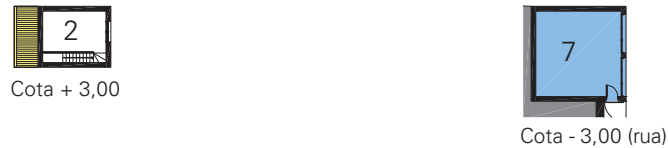

[348] PLANTA CRONOLOGIA/ USO ATUAL

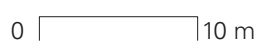

Plantas de aprovação PMSP 1929, 1930, 1962, 1988 FERRAZ, 1965

Visitas de campo 2010 


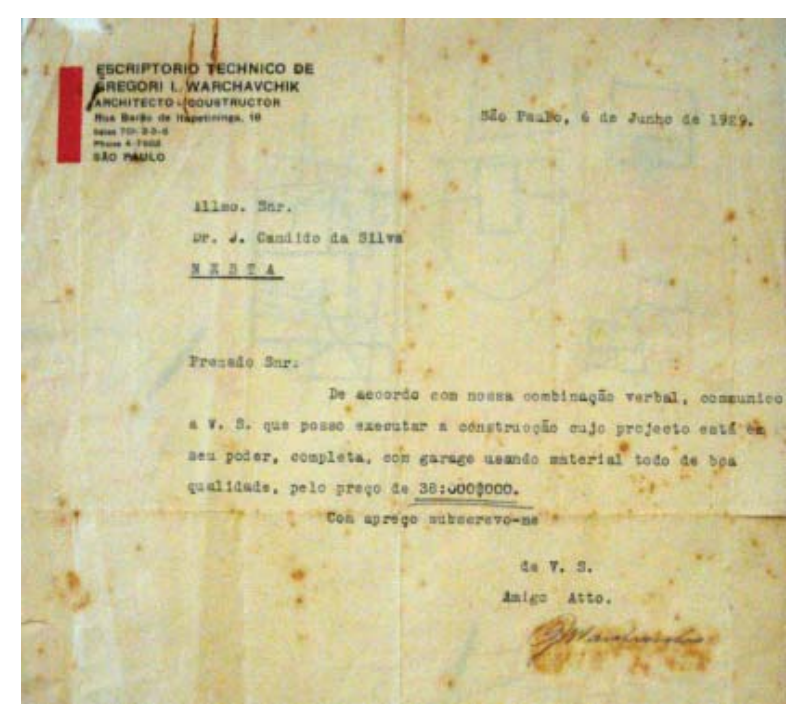

Ao lado: [349] Proposta financeira de Warchavchik para execução da obra. Abaixo: [350] a [353] Vistas frontais dentro e fora do lote em 1930. [354] A casa alguns anos depois, com vegetação crescida. [355] A casa em 2010.
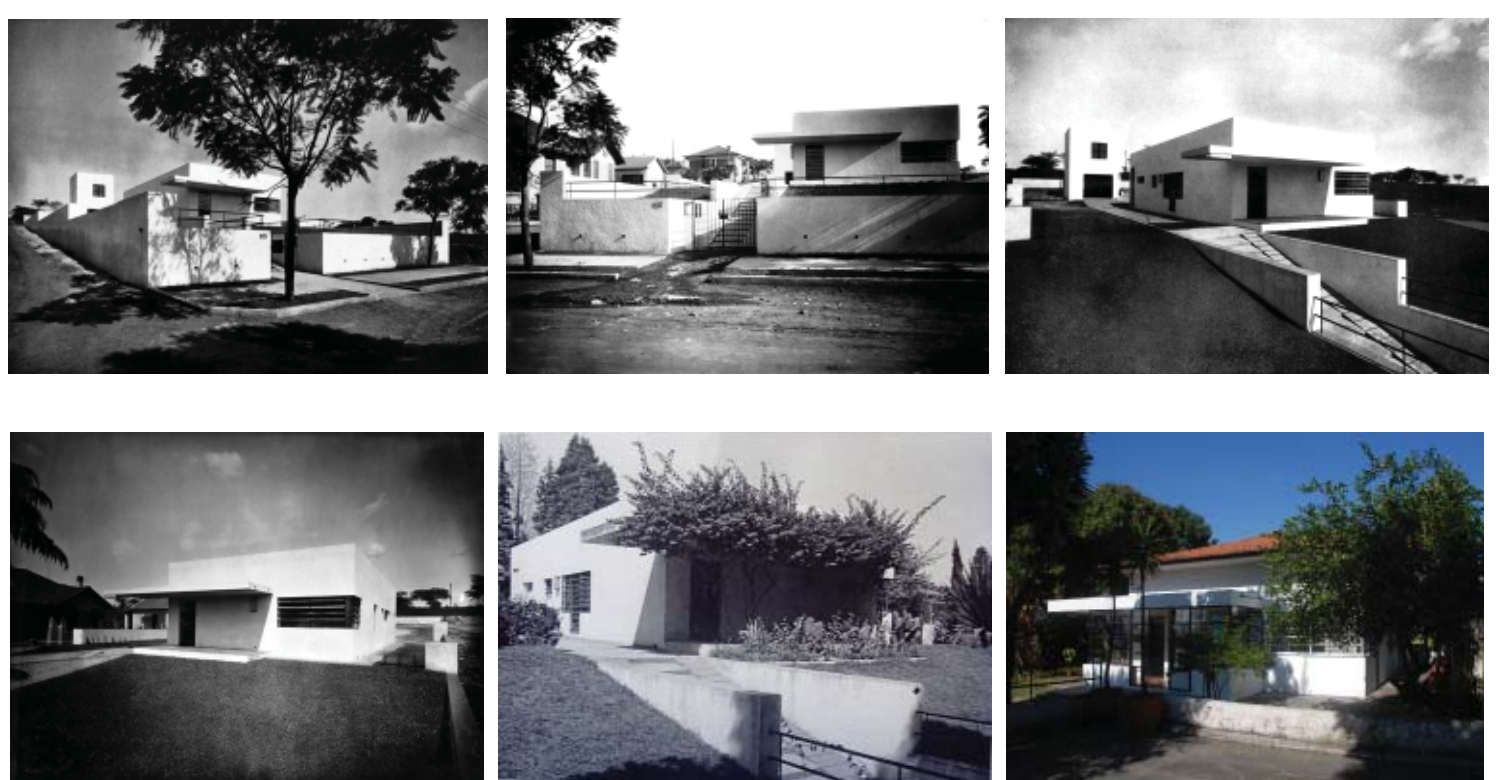
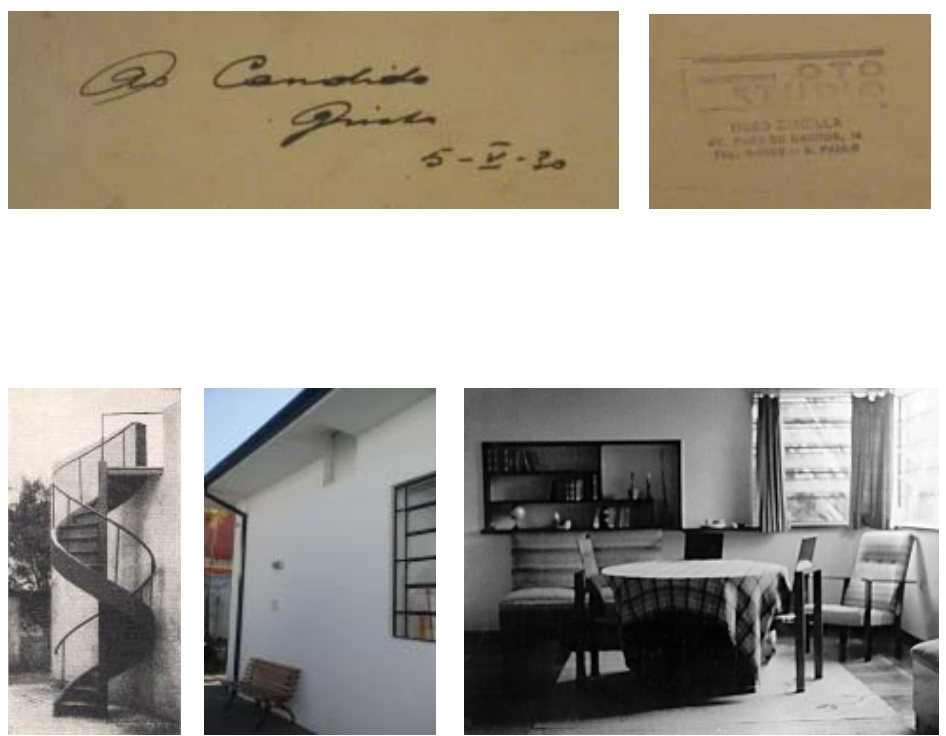

Ao lado: [356] e [357] Verso de foto de Hugo Zanella da casa dada por Warchavchik a Cândido da Silva em 1930. Abaixo: [358] e [359] Fotos comparativas do local da escada helicoidal. [360] e [361] Foto comparativa de detalhe da sala de estar, com prateleira embutida e janela de canto.

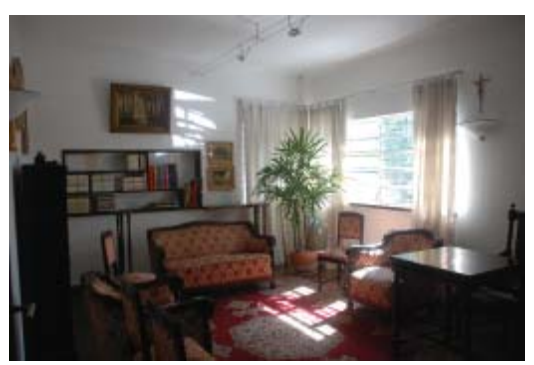



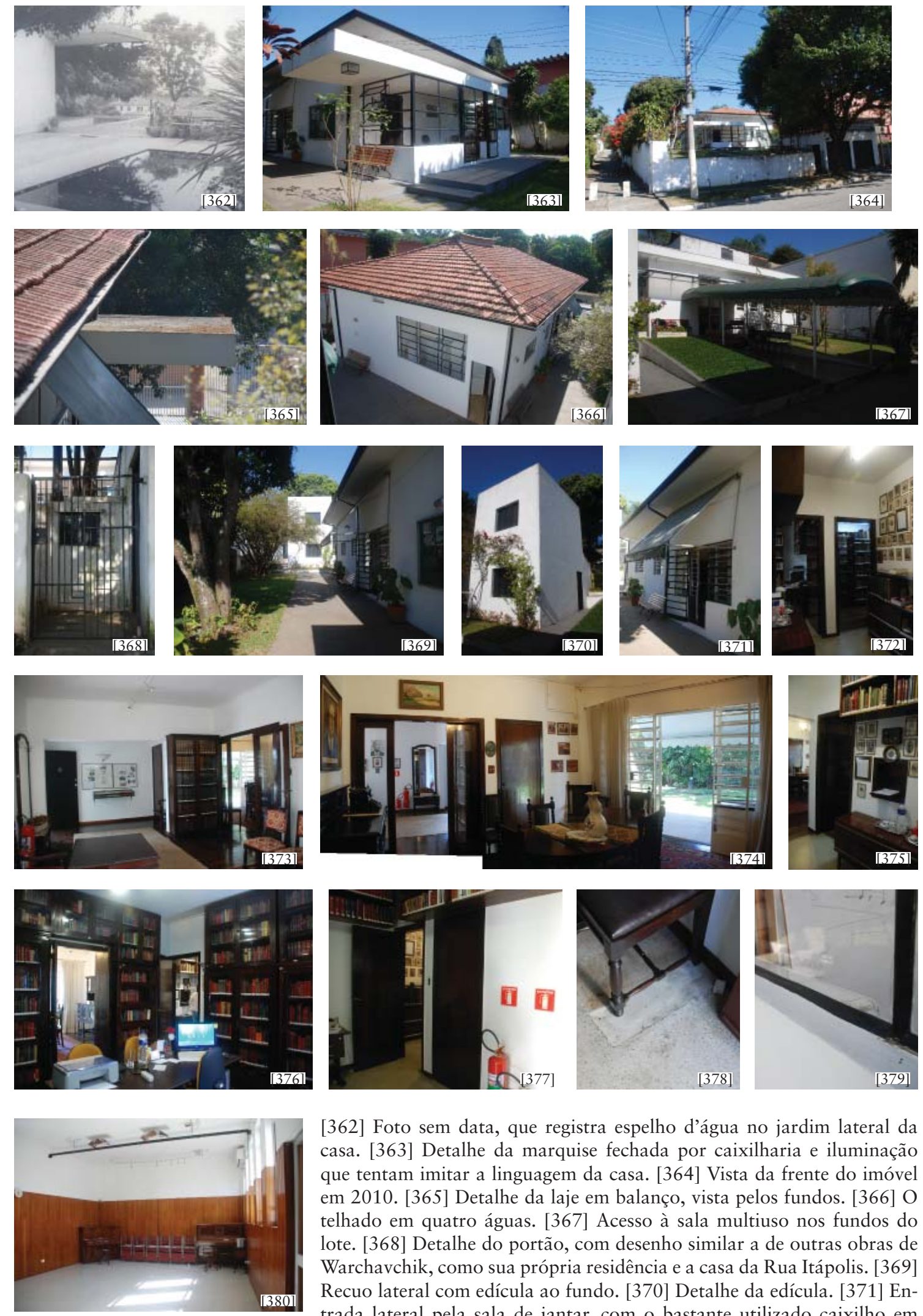

[362] Foto sem data, que registra espelho d'água no jardim lateral da casa. [363] Detalhe da marquise fechada por caixilharia e iluminação que tentam imitar a linguagem da casa. [364] Vista da frente do imóvel em 2010. [365] Detalhe da laje em balanço, vista pelos fundos. [366] O telhado em quatro águas. [367] Acesso à sala multiuso nos fundos do lote. [368] Detalhe do portão, com desenho similar a de outras obras de Warchavchik, como sua própria residência e a casa da Rua Itápolis. [369] Recuo lateral com edícula ao fundo. [370] Detalhe da edícula. [371] Entrada lateral pela sala de jantar, com o bastante utilizado caixilho em “T”. [372] Circulação, com vista para biblioteca (antigo quarto do casal) e arquivo (antiga cozinha). [373] Antiga sala de estar, com porta de entrada à esquerda. [374] Antiga sala de jantar. [375] Circulação, com vista para antigo quarto de costura e sua janelinha. [376] Acervo/ administração (antigo quarto). [377] Antiga cozinha. [378] Detalhe de piso da cozinha, com marca da bancada removida. [379] Detalhe de peitoril, com face interna testemunhando antiga divisão. [380] Sala multiuso. 


\section{CASA DA RUA BAHIA (1930-1931)}

Terceiro pé da tríade considerada como as obras mais importantes de Warchavchik ao lado das casas da Rua Santa Cruz e Itápolis, a casa da Rua Bahia é comumente vista como etapa final da evolução projetual de Warchavchik. Na Santa Cruz as pesquisas vanguardistas são iniciadas convivendo com elementos da arquitetura tradicional; na Itápolis a linguagem moderna é plenamente atingida como intencionado, em termos visuais e construtivos e na integração com as artes; e na Bahia as conquistas anteriores contribuem para o enfrentamento do programa residencial expandido, permitindo experimentações que dissolvem a geometria dura do cubo em topografia favorável à articulação dos volumes. Para Lira, "Warchavchik resolve com enorme habilidade a implantação e o programa, decompondo pela primeira vez o cubo único em dois volumes prismáticos que se interpenetram" ${ }^{235}$. Farias considera que o terreno "obriga ao arquiteto um equacionamento muito feliz e que se pode ser aferido pelo zoneamento equitativo da casa, articulado em torno do eixo formado pela caixa de escada" ${ }^{236}$. O crítico conclui ainda que a casa fecha um ciclo de investigações de Warchavchik pois pontos por ele defendidos são virtualmente realizados. Tal percepção também fundamentará a proposição do tombamento conjunto das três casas pela equipe técnica do Iphan $^{237}$.

Não só o programa suntuoso ou terreno em declive diferenciam a casa da Rua Bahia, em termos de demandas para o projeto, com relação às demais. Como projeto contratado por terceiro, ao contrário dos anteriores, realizados para o próprio arquiteto, sofreu alterações suscitadas pelo diálogo com o cliente, o quatrocentão Luis da Silva Prado, podendo ser vistas através dos estudos disponíveis no acervo de projetos da FAUUSP, que documentam a evolução do projeto até a sua solução final238.

Em 15/05/1930 é dada entrada no pedido de Alvará de Construção, protocolandose planta e memorial descritivo que especificava soluções correntes, como as alvenarias de tijolos assentadas e revestidas por argamassa de cal e areia, assoalhos de peroba, esquadrias de madeira, pisos ladrilhados e paredes azulejadas nos banheiros e cozinha. Apenas a cobertura em laje seria ainda pouco frequente na arquitetura residencial daquele período. Antes de ser aprovado, o processo sofre um comunique-se, que solicita alteração nos acessos para os dormitórios dos empregados. Atendido isso, o projeto é aprovado em 20/06/1930. Ao longo da obra, são pedidos alvarás em processos separados para a abertura de valas para as instalações de água, pela Rua Bahia, e de esgoto, pela Itápolis, nos fundos do lote, em 26/06/1930 e 5/01/1931, respectivamente ${ }^{239}$. Em 27 de novembro de 1931 é proposto o

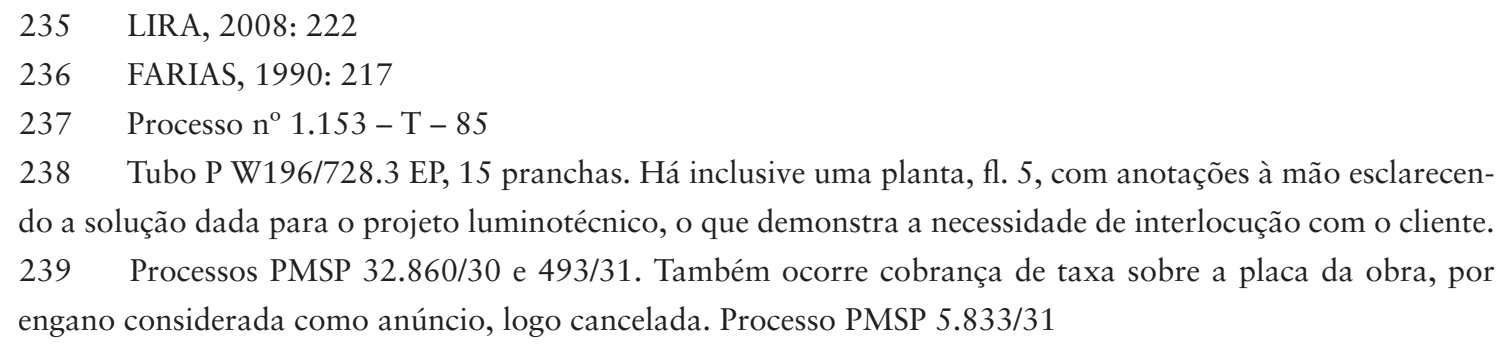
do a solução dada para o projeto luminotécnico, o que demonstra a necessidade de interlocução com o cliente. 239 Processos PMSP 32.860/30 e 493/31. Também ocorre cobrança de taxa sobre a placa da obra, por engano considerada como anúncio, logo cancelada. Processo PMSP 5.833/31 
arquivamento do processo, tendo em vista a conclusão da obra. Além da construção, Warchavchik se encarregara do mobiliário, luminárias e demais detalhes, como o colorido forro que evoca o neoplasticismo holandês. Apesar da dificuldade na identificação de cores nas fotografias preto e branco, é possível perceber nas elevações a diferença de tonalidade entre os dois blocos vistos pela fachada norte. $\mathrm{Na}$ legenda do livro de Sartoris ${ }^{240}$, diz-se que as fachadas eram pintadas em creme e verde pálido.

Como se sabe, a casa teve imediata repercussão, sendo incluída no programa de visitas ao loteamento City do Pacaembu, promovido pelo $1^{\circ}$ Congresso de Habitação de São Paulo, em 1931. No relato da visita publicado nos Anais, são destacadas a sua iluminação e a ventilação, temas centrais na pauta higienista do Congresso, mas o restante do texto é ambíguo. Construída "de acordo com a sua estética pessoal (...) a casa de Warchavchik apresenta todas as características desta arquitetura que está procurando destruir toda a tradição" ${ }^{241}$ - qual o juízo dos congressistas com relação a isso?

Mas poucos anos depois os moradores já queriam alterações. Dois estudos sem data, um em nome de Luis da Silva Prado e outro em nome de Esther da Silva Prado, disponíveis no acervo FAUUSP, devem ser posteriores a 11/11/1935, quando a numeração da casa passa de 114 para $1.126^{242}$ e anteriores a 1950, quando há um projeto de reforma em nome de Túlio Misasi. A fachada norte é mostrada em seu aspecto anterior à intervenção em Brazil Builds, mas não há como datá-la, pois o livro não traz informações sobre a fotografia. Sabese apenas que é posterior ao período inaugural pelo porte da vegetação do jardim concebido por Mina Klabin Warchavchik ${ }^{243}$ que cerca o enquadramento. Porém, não tendo sido aproveitados os registros fotográficos disponibilizados por Warchavchik na obra de Sartoris, aparentemente a foto foi realizada especialmente para o livro, ou seja, próximo a 1943. As duas propostas previam a ampliação da garagem e da sala de jantar, que passaria a alinhar-se com a sala de estar, bem como o fechamento do terraço lateral do térreo como "terraço de estar", diferenciando-se apenas pela instalação de elevador na primeira, que não se concretizou. De fato, em 13/12/1943 Warchavchik solicita o Habite-se de reforma realizada para Esther da Silva Prado, sendo parcialmente detectada nos estudos para reforma para Túlio Misasi, nos quais se vê a supressão do terraço frontal à sala de jantar para seu alinhamento à sala de estar. Nesta última estavam previstos um prolongamento da copa alinhado ao terraço lateral, comunicando-os, e a substituição da escada de madeira por escada metálica com pisos de vidro, eliminando-se também o bar que acoplava-se a ela no piso térreo. Uma alteração que visava tornar mais glamourosa e iluminada a circulação rasgada pela abertura vertical, como se vê na perspectiva artística da intervenção, cujas escalas humanas estão prontas para ir a uma festa de gala. O projeto chegou à escala 1:1 para detalhar a fixação do

240 SARTORIS, 1932:157

241 CONGRESSO DE HABITAÇÃO (SÃO PAULO), 1931:325

242 AHMWL, emplacamento, livro 20, p.167

243 Que faz claras referências ao jardim cubista de Gabriel Gevrekian executado para a Villa Noilles, de Robert Mallet-Stevens. PERECIN, 2003 
piso de vidro à estrutura metálica ${ }^{244}$.

Esta e outras alterações são apontadas em vistoria realizada por técnico do Iphan, quando é iniciado o estudo para o tombamento federal do imóvel, em 1985 e ocorre uma denúncia de obras irregulares. O relatório, elaborado em 16/10/1985, distingue as alterações em curso, de menor importância com relação a intervenções de maior monta, principalmente no térreo, ocorridas há dez anos ou mais, identificadas, segundo o texto, graças à documentação disponível da obra. $\mathrm{Na}$ fachada sul, voltada para a Rua Bahia, ocorreu a retirada do muro frontal com sua luminária e o fechamento parcial da cobertura de entrada. $\mathrm{O}$ terraço transformou-se em jardim de inverno, fechado, a sala de jantar ganhou a área do terraço, alinhando-se com o bloco da sala de estar, a escada com bar foi substituída por estrutura metálica e piso de vidro temperado e no $3^{\circ}$ pavimento as envasaduras ganharam a forma de arcos no quarto originalmente destinado à filha e governanta. Ou seja, excetuando-se a última, as demais alterações no interior da construção já datavam de 1950 e 1943.

Até a época do estudo de tombamento a propriedade ainda estava em nome da família Misasi, partilhada pela viúva Marina Medici Misasi, filhos e respectivos cônjuges. Entretanto, alertava o relatório sobre os danos potenciais que o uso de escritório pretendido após a reforma em curso poderia trazer à preservação do imóvel. Este localiza-se em trecho da Rua Bahia que faz divisa com o bairro de Higienópolis e está próximo da Avenida Angélica, tornando-se ótima localização para usos de serviços.

O tombamento, já relatado nos casos da Santa Cruz e Itápolis, segue com o parecer curto e grosso de Eduardo Kneese de Mello:

No mesmo ano em que foi construída a casa da Rua Itápolis 961, seu projetista, o arquiteto Gregori Warchavchik realizou a obra da Bahia 1126, outro exemplo de arquitetura contemporânea precursora da renovação arquitetônica realizada, a partir de então, em nosso país.

Pelas mesmas razões e com o mesmo entusiasmo, recomendo a inscrição da casa $\mathrm{n}^{\mathrm{o}} 1.126$ da Rua Bahia no livro do tombo como monumento histórico e artístico nacional ${ }^{245}$.

Mas na reunião do conselho, a votação é antecedida por algum questionamento quanto ao tombamento da casa da Rua Bahia. Foram lembrados os problemas da falta de compensação aos proprietários, a hostilidade aos tombamentos em Ouro Preto e o tombamento de uma edificação de Virsi como representativa do conjunto de sua obra. Se a casa da Santa Cruz era a primeira e a da Itápolis ocorrera a Exposição da Casa Modernista, o que justificaria o tombamento da casa da Rua Bahia? Técnicos e diretores foram chamados a opinar, lembrando que não houve contestação da abertura do processo de tombamento e que cada casa tinha características especiais e retratavam as pregações de Warchavchik do 
Manifesto e de escritos posteriores.

Após o tombamento efetivado em 1986 a casa aparentemente comportou bem o uso de serviços, chegando aos dias de hoje com as mesmas características relatadas àquela época, tendo sido inseridos apenas elementos leves, como divisórias em Dry-Wall na sala de estar e toldo no teto-jardim.
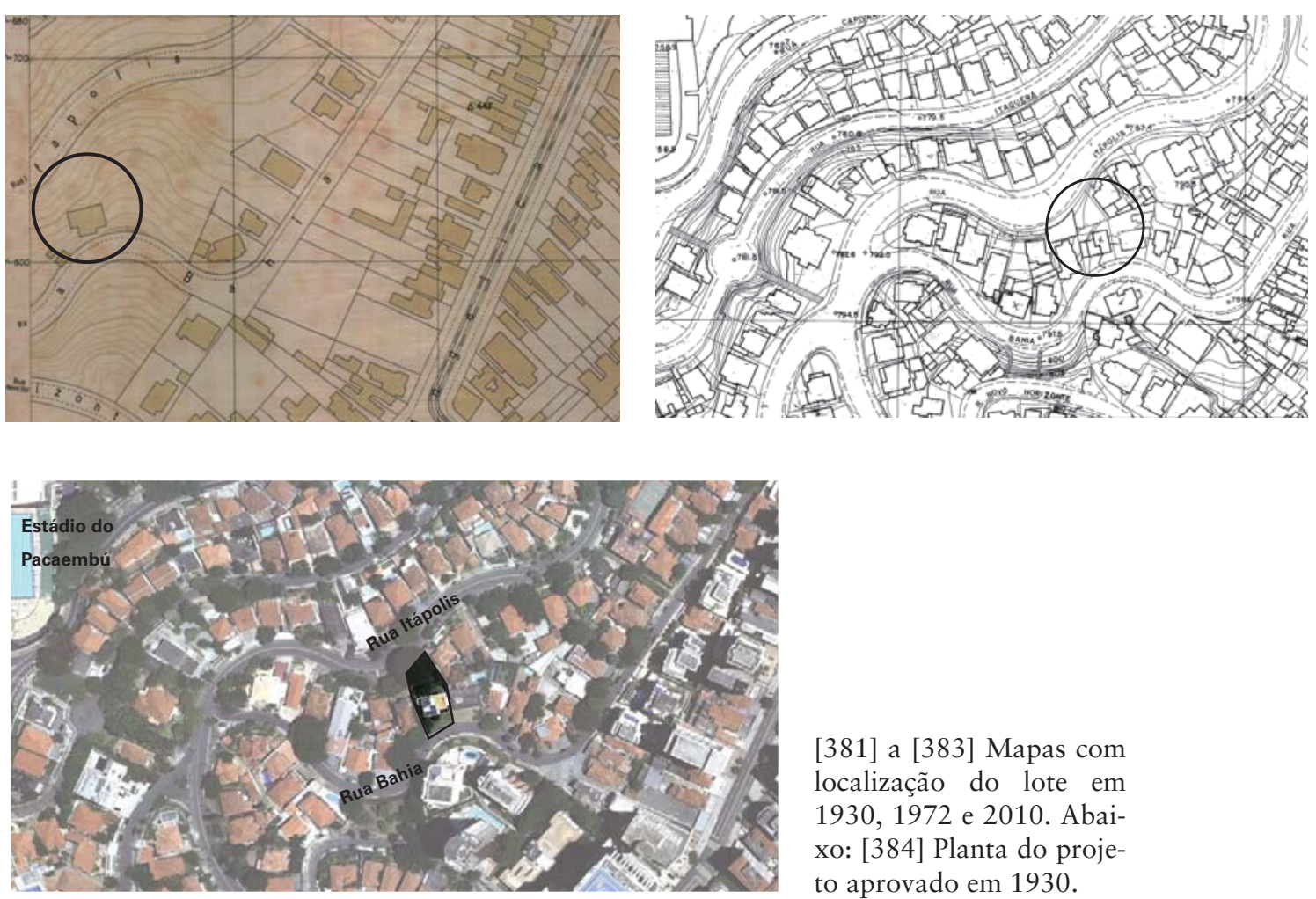

[381] a [383] Mapas com localização do lote em 1930, 1972 e 2010. Abaixo: [384] Planta do projeto aprovado em 1930.

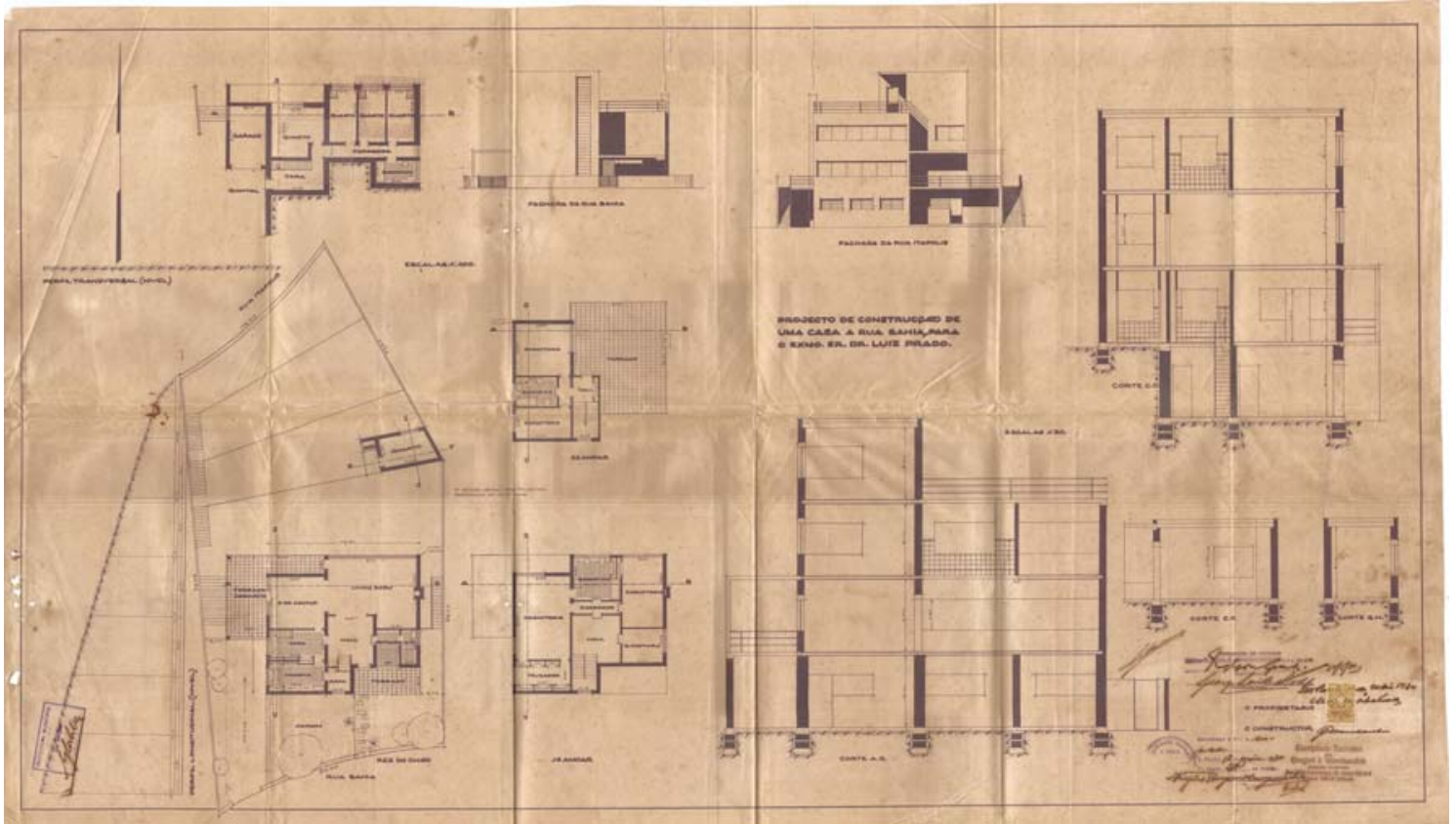



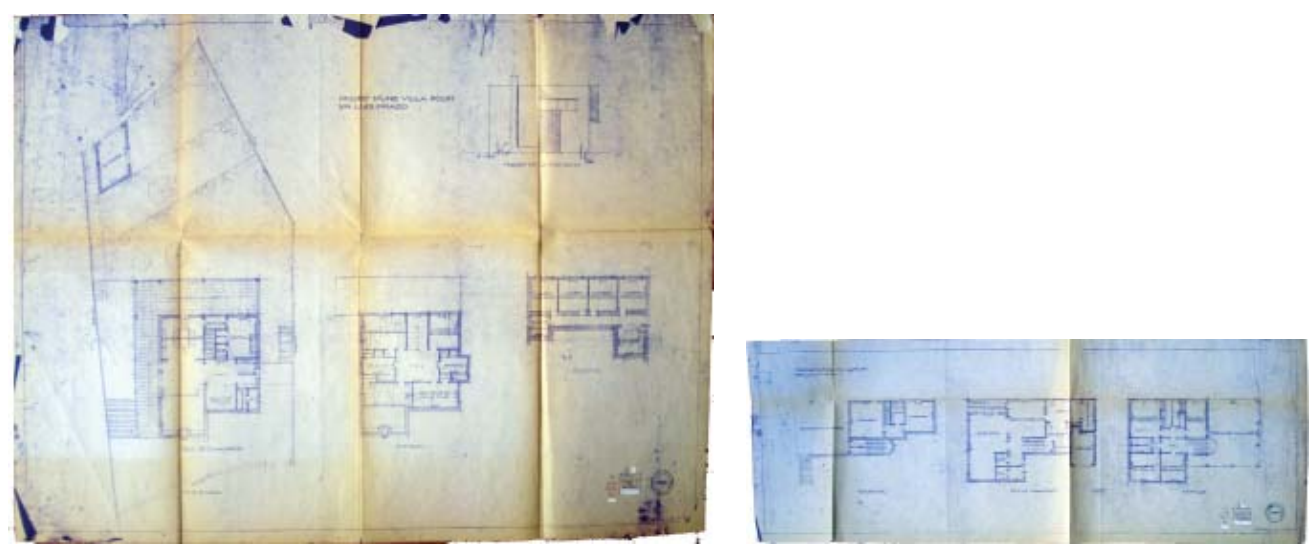

[385] e [386] Estudos anteriores para o projeto.

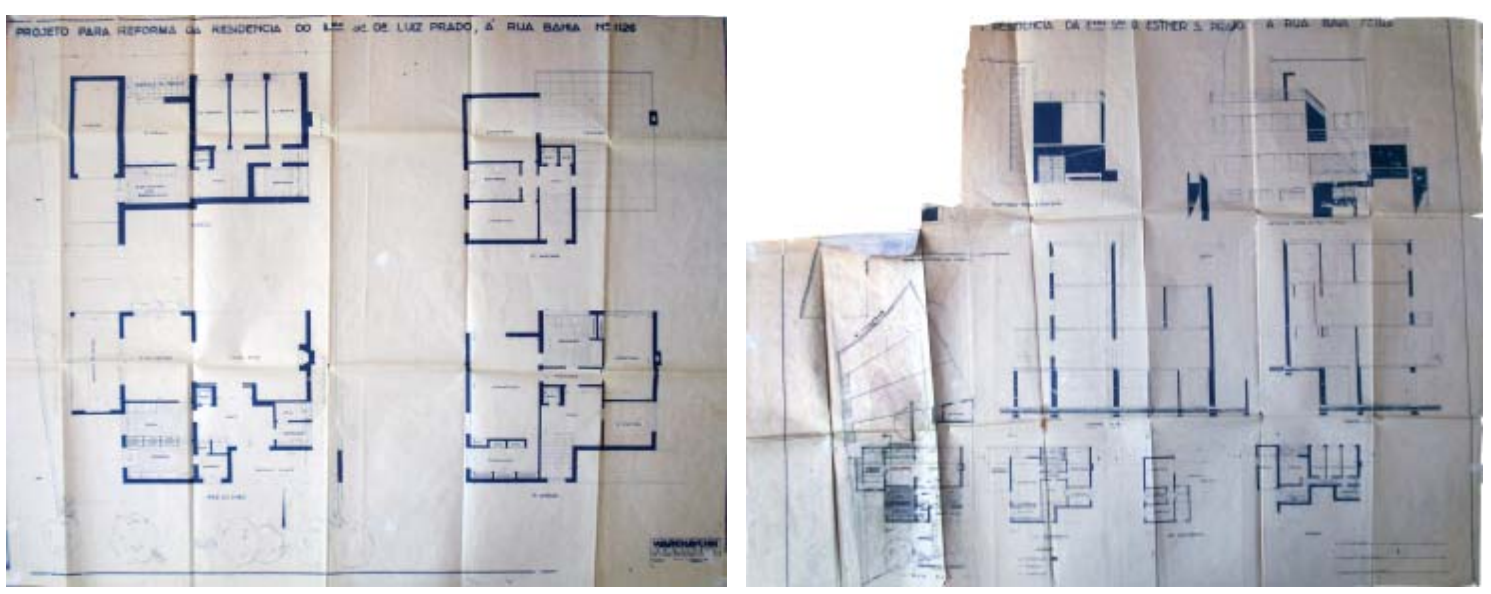

[387] Estudo para reforma em nome de Luiz da Silva Prado. [388] Outra proposta de reforma, para Esther da Silva Prado, similar à primeira, mas sem elevador.
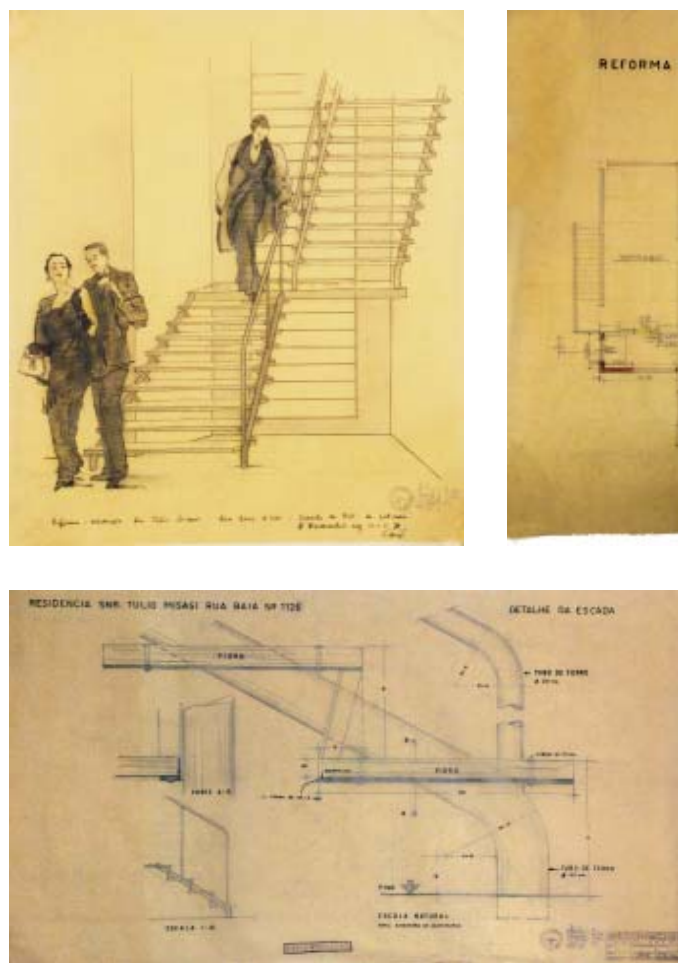

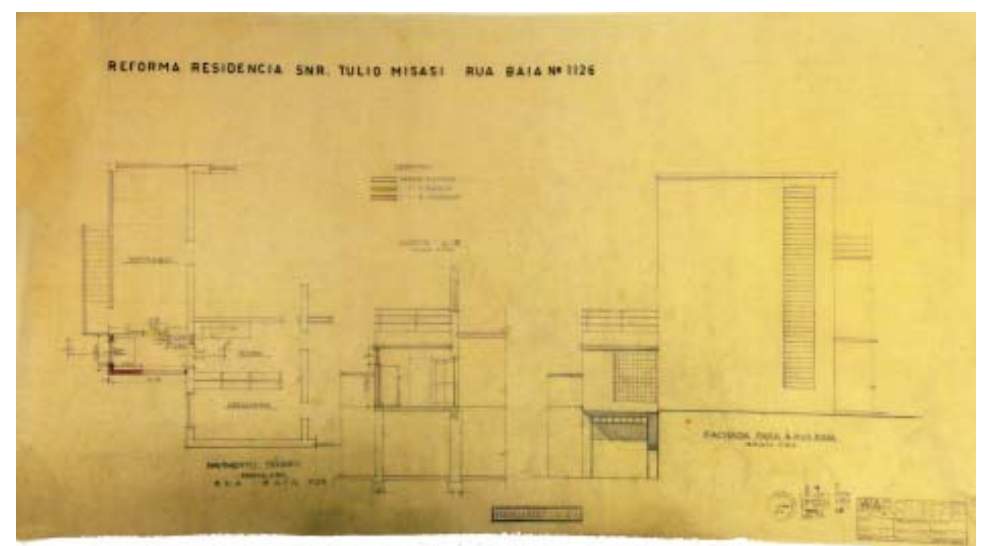

[389] a [391] Reforma para Túlio Misasi. Pelos desenhos, nota-se a importância dada para a reforma da escada no piso térreo, que retirou o bar e substituiu a madeira por estrutura de aço e piso de vidro. O projeto chega ao nível de detalhamento 1:1. 


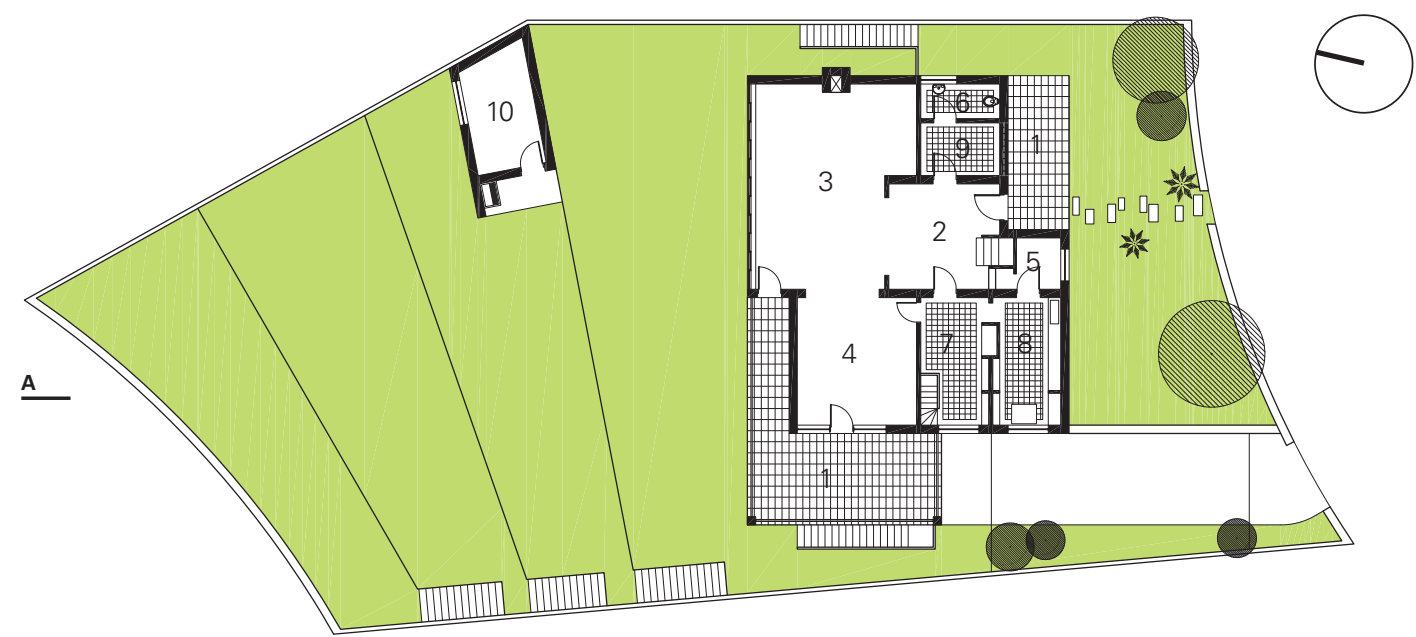

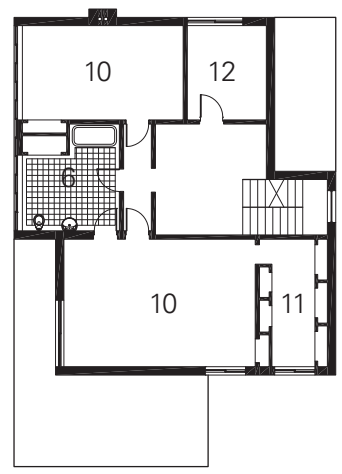

[393] PLANTA $1^{\circ}$ PAV.

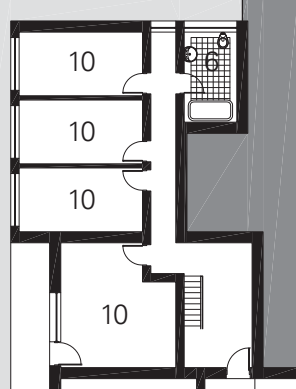

13

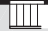

$\underline{\underline{111}}$

[395] PLANTA SUBSOLO

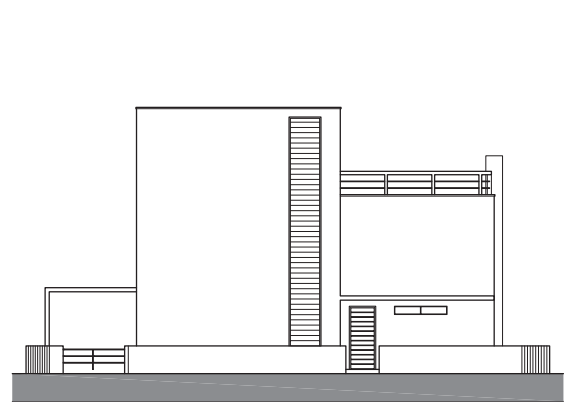

[397] ELEVAÇÃO SUL

[392] PLANTA TÉRREO

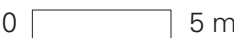

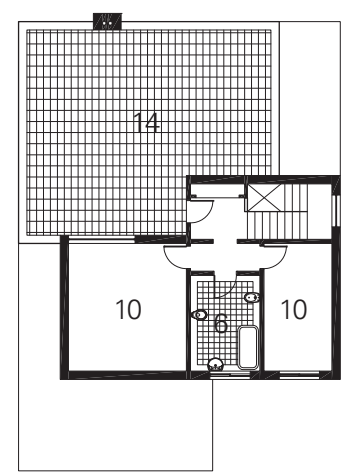

[394] PLANTA $2^{\circ}$ PAV.

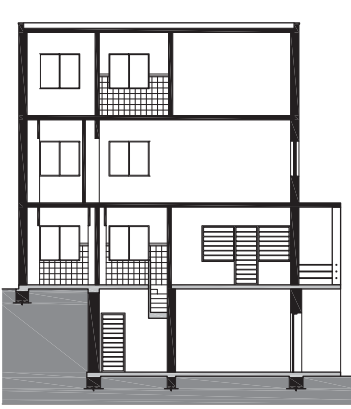

[396] CORTE AA
Uso original

1. Terraço coberto

2. Hall

3. Sala de estar

4. Sala de jantar

5. Bar/ despensa

6. Sanitário

7. Copa

8. Cozinha

9. Vestiário

10. Dormitório

11. Toucador

12. Quarto de costura

13. Garagem

14. Terraço descoberto

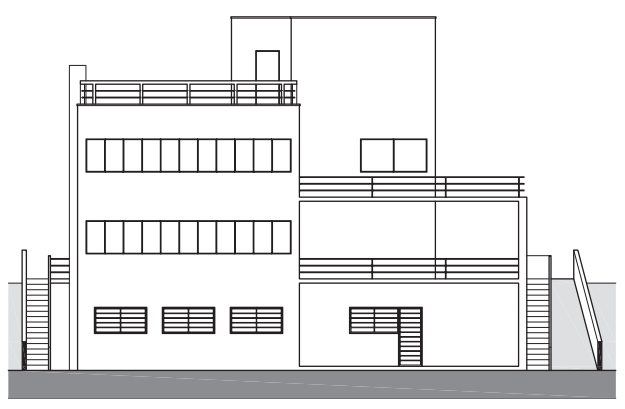

398[ ELEVAÇÃO NORTE 

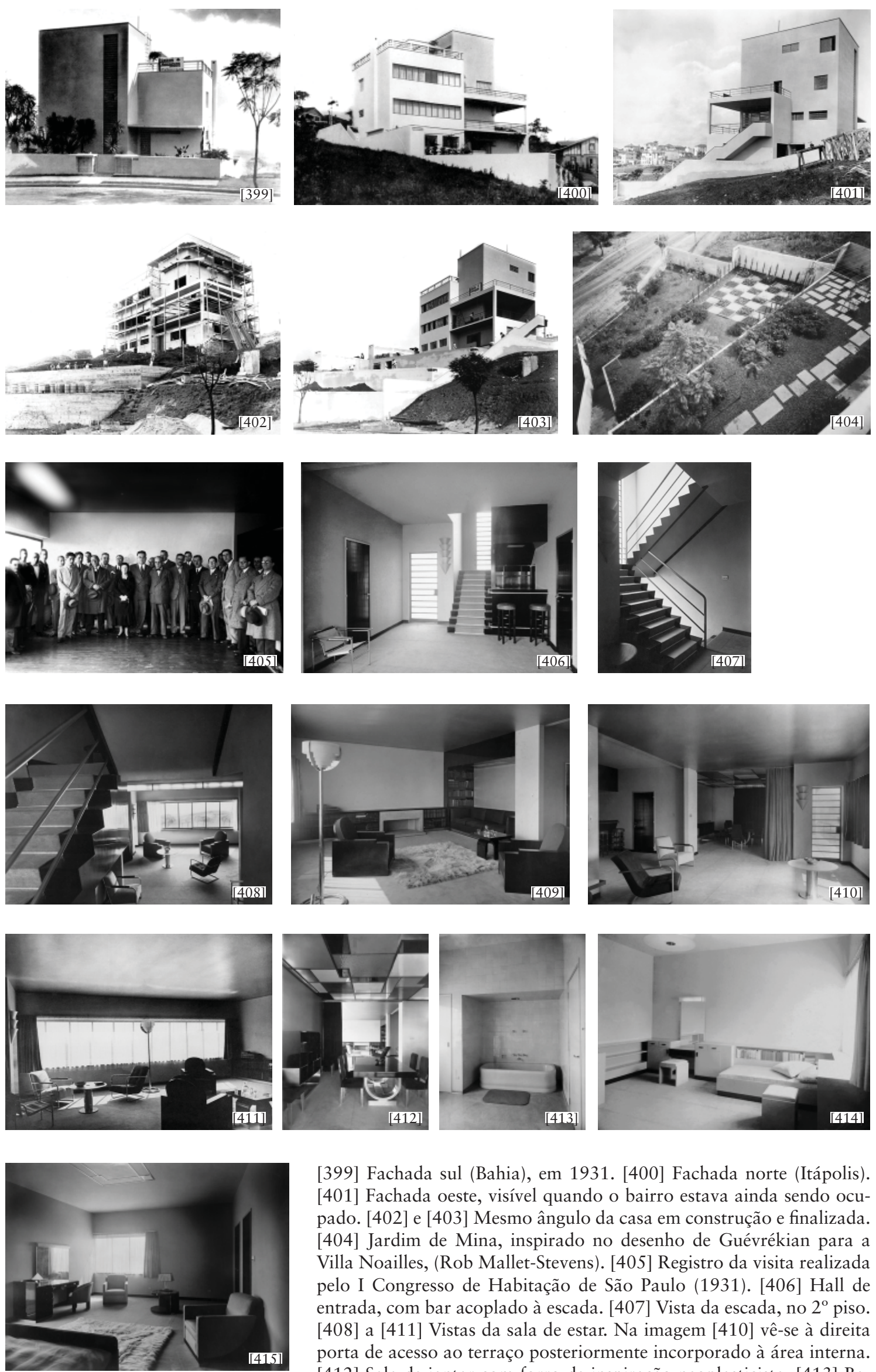

[399] Fachada sul (Bahia), em 1931. [400] Fachada norte (Itápolis). [401] Fachada oeste, visível quando o bairro estava ainda sendo ocupado. [402] e [403] Mesmo ângulo da casa em construção e finalizada. [404] Jardim de Mina, inspirado no desenho de Guévrékian para a Villa Noailles, (Rob Mallet-Stevens). [405] Registro da visita realizada pelo I Congresso de Habitação de São Paulo (1931). [406] Hall de entrada, com bar acoplado à escada. [407] Vista da escada, no $2^{\circ}$ piso. [408] a [411] Vistas da sala de estar. $\mathrm{Na}$ imagem [410] vê-se à direita porta de acesso ao terraço posteriormente incorporado à área interna. [412] Sala de jantar com forro de inspiração neoplasticista. [413] Banheira. [414] e [415] Dormitórios. 

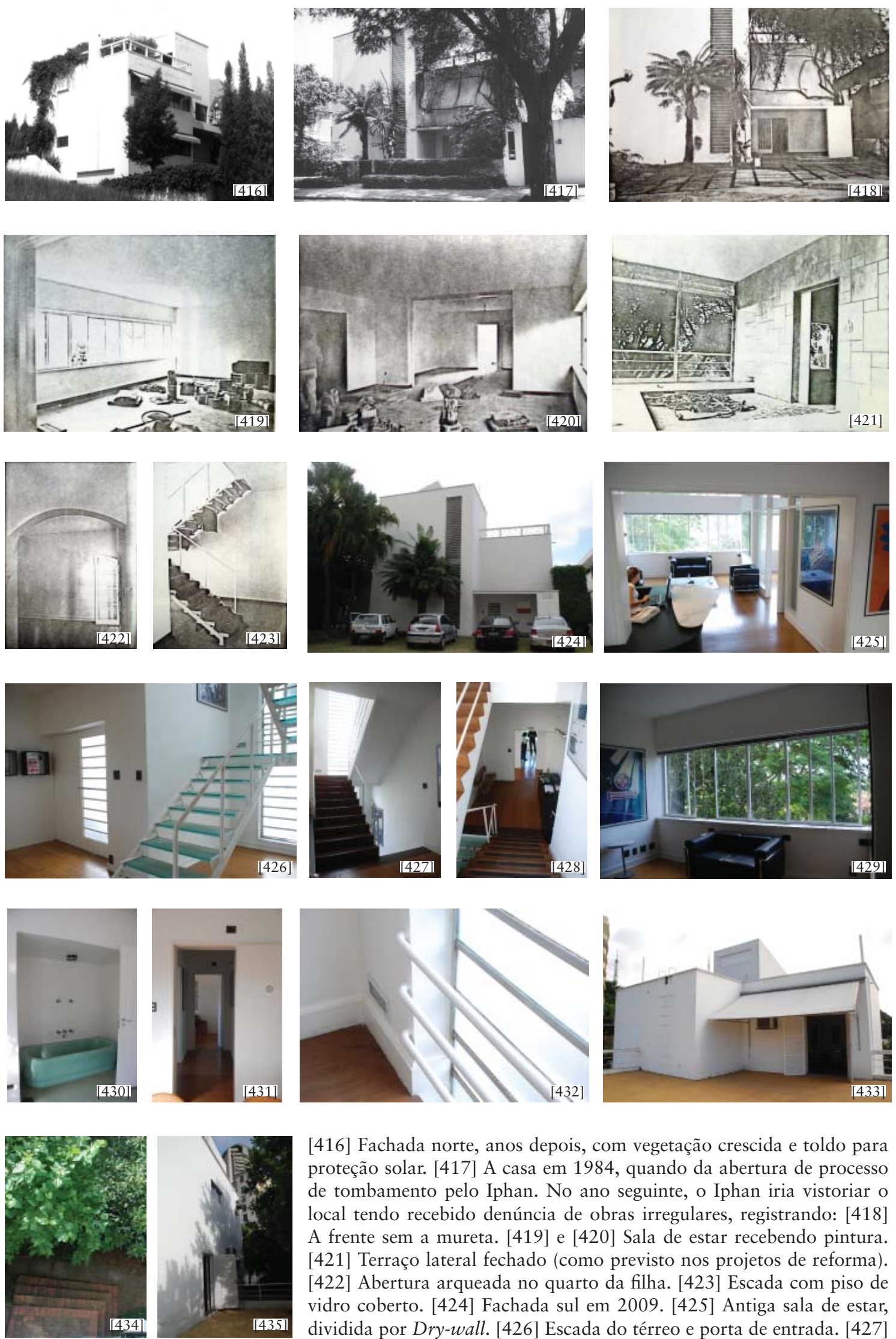

[416] Fachada norte, anos depois, com vegetação crescida e toldo para proteção solar. [417] A casa em 1984, quando da abertura de processo de tombamento pelo Iphan. No ano seguinte, o Iphan iria vistoriar o local tendo recebido denúncia de obras irregulares, registrando: [418] A frente sem a mureta. [419] e [420] Sala de estar recebendo pintura. [421] Terraço lateral fechado (como previsto nos projetos de reforma). [422] Abertura arqueada no quarto da filha. [423] Escada com piso de vidro coberto. [424] Fachada sul em 2009. [425] Antiga sala de estar, dividida por Dry-wall. [426] Escada do térreo e porta de entrada. [427] Escada do $1^{\circ}$ andar. [428] Vista da circulação com banheiro ao fundo. [429] Antiga sala de jantar. [430] Banheira conservada. [431] circulação entre quartos. [432] Detalhe de proteção do caixilho na escada. [433] Antigo quarto na cobertura, visto pelo terraço. [434] Escada de acesso ao jardim. [435] Acesso ao terraço aberto posteriormente no $1^{\circ}$ piso. 


\section{CASA DA AVENIDA REBOUÇAS (1937-1940)}

Nas principais fontes pesquisadas sobre o conjunto de projetos assinados por Warchavchik não há qualquer registro de atividades entre os anos de 1935 e 1936, embora algumas informações estejam desencontradas. O livro de Ferraz dedicado ao arquiteto ${ }^{246}$, apesar de ser um extenso documento sobre o legado do arquiteto em sua produção inicial, não tem como proposta inventariar suas obras, mas sim selecionar aquelas adequadas ao perfil concebido para o trabalho. Com isso, dentro do recorte temporal proposto - 1925 a 1940, algumas obras ficaram de fora, como a residência da Alameda Lorena (1931-32), a residência Victor Brecheret $^{247}$ (1937) ou a Sinagoga à Rua Odorico Mendes (1929), para a Sociedade Talmud Torah da União Israelita de São Paulo ${ }^{248}$. Por outro lado, o acervo de projetos da FAUUSP não identifica a data de todos os projetos e tampouco é composto pela totalidade da produção de Warchavchik, fato verificável em uma rápida e aleatória busca. Projetos como da residência Cândido da Silva (1929-30, Rua Tomé de Souza), da Sociedade Paulista de Tênis (1931), da casa da Rua Avanhandava, da própria casa da Avenida Rebouças e de uma série de projetos catalogados no Arquivo Municipal ${ }^{249}$ não constam da listagem.

De outra parte, um conjunto de processos municipais tramitados entre 1934 e 1938 oferece uma outra faceta do problema. Trata-se de processos movidos contra Warchavchik pela municipalidade em decorrência da execução de obras sem a aprovação dos projetos e respectivos alvarás de construção e de solicitações de cancelamento de tais cobranças. São diversas obras no Ipiranga, Vergueiro e Vila Klabin. As denúncias iniciais da fiscalização são de 1933, mas os processos se iniciam em fevereiro de $1934^{250}$. Warchavchik recorre em 1934, mas o processo é indeferido, fazendo com que abra um novo processo de reconsideração de despacho em $1935^{251}$. Neste, Warchavchik justifica a solicitação:

Dizem, Viuva e Filhos de Mauricio F. Klabin representados por seu procurador, Dr. Gregorio Warchavchik, que sendo proprietários de uma grande área de terra no Ypiranga, nesta Capital, iniciaram já ha tempos e ainda estão continuando a venda de terrenos á prestações, com fornecimento de algum material para quem queira construir; bem de vêr-se que, quem adquire lote de terreno e constroe, o faz por sua conta e risco, porquanto, os Supplicantes só fornecem o terreno e tijolos, conforme contractos usuaes que poderão ser exhibidos se necessario a qualquer momento; acontece, que, proprietarios prestamistas ou não e mesmo constructores talvez de

\footnotetext{
246 FERRAZ, 1965

247 Obra citada por LIRA, 2008

248 Processo PMSP 0.075.075/29.

249 Como a casa Charles Gutmann à Rua Holanda (1939), a casa Julian Altman à Rua dos Tamanás, 287 (consta apenas outra casa à Rua Quilombo), Casa Rolf Saenger à Rua Bitencourt Sampaio, 48, O galpão de Eugênio Bognor à Rua Juréia, a construção para Petro Antonoff à Rua União, 18, casa Siegfried Adler à Rua Noruega, 226.

250 Processos PMSP 19.438/34, 19.442/34, 19.443/34, 19.444/34, 19,448/34

251 Processos 64.617/34 e 19.674/35, respectivamente
} 
má fé e para fugirem ás consequecias dos seus actos, contra as prescripções legaes, por vezes affirmam aos Snrs. Fiscaes, Engenheiros e demais Autoridades desta Prefeitura, que os proprietarios das constrcções são os Supplicantes ou seja Viuva e Filhos de Maurcicio F. Klabin, o que é falso ${ }^{252}$.

No processo é anexado um modelo de contrato de compromisso de compra e venda, que previa o pagamento em até 150 prestações e onde de fato consta cláusula informando o fornecimento de tijolos para a construção, "de accordo com planta aprovada pela prefeitura (...). Os tijolos serão postos no local da construcção em parcella, acompanhando a marcha da edificação" 253 . Ao que parece, a própria família dispunha de uma olaria chamada "Emefka”, situada à atual Avenida Ricardo Jafet, apoiando a sua intensa atividade imobiliária. Mas o processo é igualmente indeferido conforme argumenta o procurador:

Os requerentes, na qualidade de proprietários e compromitentes - vendedores de grande área de terrenos, deveriam ser os primeiros a exigir o cumprimento da lei, estimulando em seus contratos de compromisso a proibição de serem feitas construcções sem que os respectivos projetos e plantas lhe fossem submetidos afim de serem por êles assinados conjuntamente com o dono da construção e o constru$\operatorname{tor}^{254}$

Paralelamente é aberto processo em 30/10/1934 visando a suspensão da licença de construtor do arquiteto ${ }^{255}$, com base no artigo $90^{\circ}$ do Código de Obras Arthur Saboya (Ato 663 de 1934), que previa sanções previstas pelo Decreto Federal no 23.569/33, que regulamenta o exercício profissional de engenheiros e arquitetos aos construtores que, entre outros, construíssem sem o necessário Alvará. Era relatado na inicial:

Solicito a V. S. as providencias necessarias junto ao Conselho Regional de Engenharia, para que seja suspenso, de accordo com o art. 90, letra F. do acto 663, de 10 de agosto de 1934, o constructor Gregorio Warchavchik, burlador reincidente das leis municipaes e responsavel pelas centenas de construcções feitas sem licença e em desaccordo com o nosso codigo, nos terrenos Klabin, no Alto do Ypiranga.

Estas construcções deram causa á cerca de trezentos processos de infracção, já inciiados, havendo outros tantos a iniciar, pois não são respeitados os embargos e intimações desta secção.

Mas o processo correu até 1937, sendo julgado improcedente, devendo a municipalidade apenas prosseguir com as ações já iniciadas. O que se altera é que a parte processada inicialmente deixa de ser Warchavchik e passam a ser os proprietários dos terrenos, herdei- 
ros de Maurício F. Klabin. Com isso, são geradas novas guias para recolhimento dos emolumentos referentes às obras executadas, mas Warchavchik, então como representante dos proprietários, abre novo processo solicitando cancelamento das cobranças. Na solicitação inicial, diz:

VIUVA E FILHOS DE MAURICIO F. KLABIN, representados pelo seu procurador, Snr. Dr. Gregori Warchavchik, com escriptorio á rua Barão de Itapetininga, 120, foram suprehendidos com o aviso publicado no Diario Official de 23/2/37, para pagamento de emolumentos de construcções, referentes a 225 processos sobre edificações de casas no bairro do Alto Ypiranga, sem licença. São os requerentes nesse local unicamente os compromissarios pelos respectivos adquirentes, que são dellas exclusivos proprietarios

Anexam ao processo listagem com a relação de todos os compradores, mas a procuradoria administrativa entende que o assunto já foi tratado no outro processo, com indeferimento proposto pelo prefeito, devendo apenas ser encaminhadas as guias para pagamento dos emolumentos. A tramitação ocorre com questionamentos sobre a forma da cobrança, a necessidade de localizar os endereços de cada imóvel notificado, surgindo o problema de que o assunto se iniciou há anos, com técnicos não mais envolvidos no assunto, até que chega um ponto em que a cobrança prescreveu e o processo foi arquivado em março de 1938.

Como há menção nestes a outros processos de cobrança não localizados pela pesquisa, não sabemos também se após este arquivamento novo processo tenha concretizado tal pagamento, mas de qualquer forma esta maratona processual conduzida de 1934 a 1938, independente dos seus meandros jurídicos, já levanta algumas questões. Primeiramente, mostra um outro universo de atuação de Warchavchik, não só projetando para empreendimentos familiares, mas participando da sua implementação, da construção à trabalhosa defesa perante a municipalidade. Não há como saber se enquanto corria o processo que propunha a cassação da licença de Warchavchik ele continuou a atuar, nem como se dava sua participação nas obras de urbanização dos estoques fundiários dos Klabin e na construção de unidades nessas áreas. Tanto o arquiteto pode ter atuado sem que se registrasse qualquer documentação como pode ter substituído a prancheta pelo canteiro nas imensas glebas da região do Ipiranga em um trabalho que pode ter consumido muito de seu tempo por anos. O fato é que não foi encontrado qualquer projeto datado entre 1935 e 1936 nas principais fontes bibliográficas e arquivísticas a respeito do arquiteto.

Qualquer que seja a razão, e mesmo tendo a certeza da falibilidade dos documentos, somente em 1937 Warchavchik volta a projetar. Como lembrado por Lira ${ }^{256}$, o interlúdio do biênio 1935-36 coincidentemente ou não é marcado por um contexto de ascensão do integralismo e do antissemitismo, por vezes associado ao governo Vargas; pelas consequências da Revolução constitucionalista de 1932 para a vida na cidade e na relação de São Paulo 
com o Brasil; pelo que Lira chamou de "alteração da geografia das vanguardas”.

Em 13 de agosto de 1937, era solicitado o alvará de construção para a casa da Avenida Rebouças, em nome da Companhia Melhoramentos Gopouva, que contratara diversos escritórios de renome para a construção de casas ao longo do novo prolongamento da Avenida Rebouças que viria a ser executado em $1938^{257}$, de modo a dar visibilidade ao novo empreendimento imobiliário. Nomes como Moya \& Malfati; Lindemberg, Alves e Assumpção; Olavo F. Caiuby; Vicente Nigro Jr.; Sociedade Commercial e Constructora; Oscar Americano; Eduardo Kneese de Mello; Bratke \& Botti figuravam na lista de construtores ao lado de Warchavchik. Entre os projetos, reinava a arquitetura de estilos, predominando o neocolonial, incluindo-se as realizações de Kneese, Bratke e Botti, ainda não "convertidos" ao modernismo. Assim, eram exceções as casas projetadas por Warchavchik e pelo engenheiro Oscar Americano, despojadas e de fatura moderna.

O volume branco solto no lote sugeria novas experiências formais e construtivas no repertório de Warchavchik, com o uso de volumes curvos e o terraço em balanço, emoldurados pelo jardim tropical de Mina Klabin Warchavchik. É digno de nota que o projeto enviado para aprovação municipal previa a utilização do concreto armado nas lajes de cobertura e dos pisos dos dormitórios frontais, sanitários e terraço do $1^{\circ}$ andar, que deveria ainda contar com um pilar de seção circular em seu centro ${ }^{258}$, entretanto não executado. Por outro lado, a planta não apresentava qualquer novidade, seguindo agenciamento tradicional da arquitetura residencial. O Alvará de Licença é concedido em 14 de dezembro de $1937^{259}$ e o Auto de Vistoria em 31 de janeiro de $1940^{260}$.

A avenida erma, na fronteira entre Pinheiros e Jardim América logo tornou-se importante corredor para a ligação do centro com os bairros da zona oeste. Com o tempo, as residências foram dando lugar ao comércio e serviços, e a casa de Warchavchik chegou a ser de propriedade de alguma instituição ligada à Marinha, que a deixou abandonada por anos, até o momento da proposta de Abertura de Processo de Tombamento, em 1990. Como desdobramento do tombamento do conjunto da Rua Berta, o processo inicialmente visava proteger a casa da Avenida Rebouças juntamente com o conjunto da Barão de Jaguara e o edifício à Barão de Limeira, mas uma leitura invertida sobre o papel dos órgãos de preservação fez com que fosse descartada da APT.

Em seu parecer, o arquiteto de STCT, José Roberto Pinheiro, defende a preservação da casa, descrevendo sua vistoria:

257 FERRAZ, 1965: 208. Até então, a Avenida era uma espécie de continuação da Rua da Consolação terminando na Avenida Brasil. De lá bifurcava-se como Rua Pinheiros e Rua Itapirussú. Cf. Mapa SARA Brasil, 1930, fl. 50.

258 Processo PMSP 58.674/37.

259 Processo PMSP 78.044/37. O presente é aberto porque o processo de $n^{\circ} 58.674 / 37$, que contém o projeto aprovado foi arquivado por abandono.

260 Processo PMSP 13.746/40 
Visitando-a, encontramos o portão trancado a cadeado, mas notamos que alguns móveis residenciais ocupam a área do antigo terraço, atualmente fechado com vidraças.

Exceto por este fechamento e pela modificação do muro de fecho, atualmente revestido de pedra e tendo sido substituído o portão, a casa mantém-se como construída, apesar de razoavelmente deteriorada. Mesmo a jardineira que aparece nas cópias em anexo das páginas 19, 20 e 21 do periódico 'Acrópole' de dezembro de 1938 permanece no seu local de origem.

Situada em um corredor de uso restrito, onde predominam os 'Show Rooms', a casa integra-se ao local em volume e gabarito. Mesmo que tenha seu uso alterado, como acontece com a vizinhança, seu tombamento não seria um entrave à sua utilização já que comporta perfeitamente um uso 'S' (serviços) que é permitido na zona. A preservação desta obra seria indispensável como complementação do tombamento de toda obra existente do arquiteto Gregori Warchavchik das décadas de 20 e $30^{261}$

Ocorre que o relator do processo no Conpresp, Roberto Heitor Ferreira Lima, mesmo admitindo que o imóvel tenha se mantido no geral conforme sua forma original, viu no mau estado de conservação um impeditivo ao seu tombamento:

Embora o laudo técnico tenha se posicionado pela preservação dessa obra por ser indispensável como complementação do tombamento de toda a obra do renomado arquiteto, entendemos, salvo melhor juízo, que as péssimas condições do imóvel aliado a seu total e completo abandono, acabarão por descaracterizá-lo, levando a sua total destruição, comprometendo o intuito desta Municipalidade em preservá$10^{262}$.

O procurador assim revelava um entendimento diminuto da preservação em que o tombamento só pode se realizar mediante afirmação do status quo das edificações, sem considerar a responsabilidade que os órgãos de preservação têm na salvaguarda dos bens sob sua tutela. Tampouco se lembrou que o Conpresp teria a competência de formular políticas e instrumentos, bem como agir para sua aplicação e fiscalização, de modo que o tombamento abriria portas para a preservação do imóvel mais do que o deixando relegado ao esquecimento e ao abandono. E por último, não levou em consideração que um imóvel em mau estado de conservação pode ser restaurado, assim como o uso e propriedade alterados.

Por sorte, apesar da negativa a casa se preservou por sua adequação aos usos requeridos pelo local, como bem apontado pelo parecer do DPH. Hoje funciona no imóvel uma revenda de motocicletas que usufrui de alterações realizadas por estabelecimentos que 
anteriormente ocuparam o ponto ${ }^{263}$. O volume principal continua preservado, com algumas alterações nas divisões internas e envasaduras, mas toda a área livre, excetuando-se o recuo frontal, utilizado como estacionamento, foi ocupada com uma cobertura em estrutura leve, embora facilmente removível. Caberia talvez uma revisão da APT, repensando o valor desta obra não só no conjunto das obras iniciais de Warchavchik, mas na dinâmica de urbanização da Avenida Rebouças.

SOLICITO A V.S. AS PROVIDEICIAS NECESSARIAS JUNTO AO CONSELHO REGIONAL DE ENGEIHARIA, PARA QUE SEJA SUSPENSO, DE ACCORDO COM O ART. 90, LETRA F., DO ACTO C63, DE 10 DE AGOSTO DE 1934, O CONSTRUCTOR GREGORIO WARCHAVCHIK, BURLADOR REINCIDENTE DAS LEIS MUNICIPAES E RESPONSAVEL PELAS CENTENAS DE CONSTRUCÇÕES FEITAS SEM LICENĢA E EM DESACCORDO COM O NOSSO CODIOO, NOS TERRENOS KLABIN, NO ALTO DO YRIFANGA.

ESTAS CONSTRUCÇÕES DERAM CAUSA T CEFCa DE TREZENUTOS PROCESSOS DE INFRAÇ⿻̄̄o, JÁ INICINDOS, HANENDO OUTROS TANTOS TINICIAR, POIS NÃO SÃO RESPEITADOS OS EMBARGOS E INTINAÇÕES DESTA SECÇÃO.

$$
\text { AGUAROANDO AS PROVIDENCIAS DE V.S., APRESEN- }
$$
TO AS MIKHAS RESPEITOSAS SAUDAÇÕES.

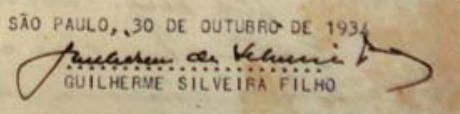

[436] Inicial de processo que propunha suspensão do registro no CREA de Warchavchik em decorrência das construções irregulares no loteamento do Ipiranga, de 1934. [437] Foto aérea com a localização do loteamento e da fábrica de cerâmica/ olaria "Emefka" (de MFK, iniciais de Maurício Freeman Klabin) de propriedade dos Klabin. [438] Capa do contrato de compra e venda de terrenos na área, pago em prestações e que previa o fornecimento de tijolos. [439] Projeto do loteamento.
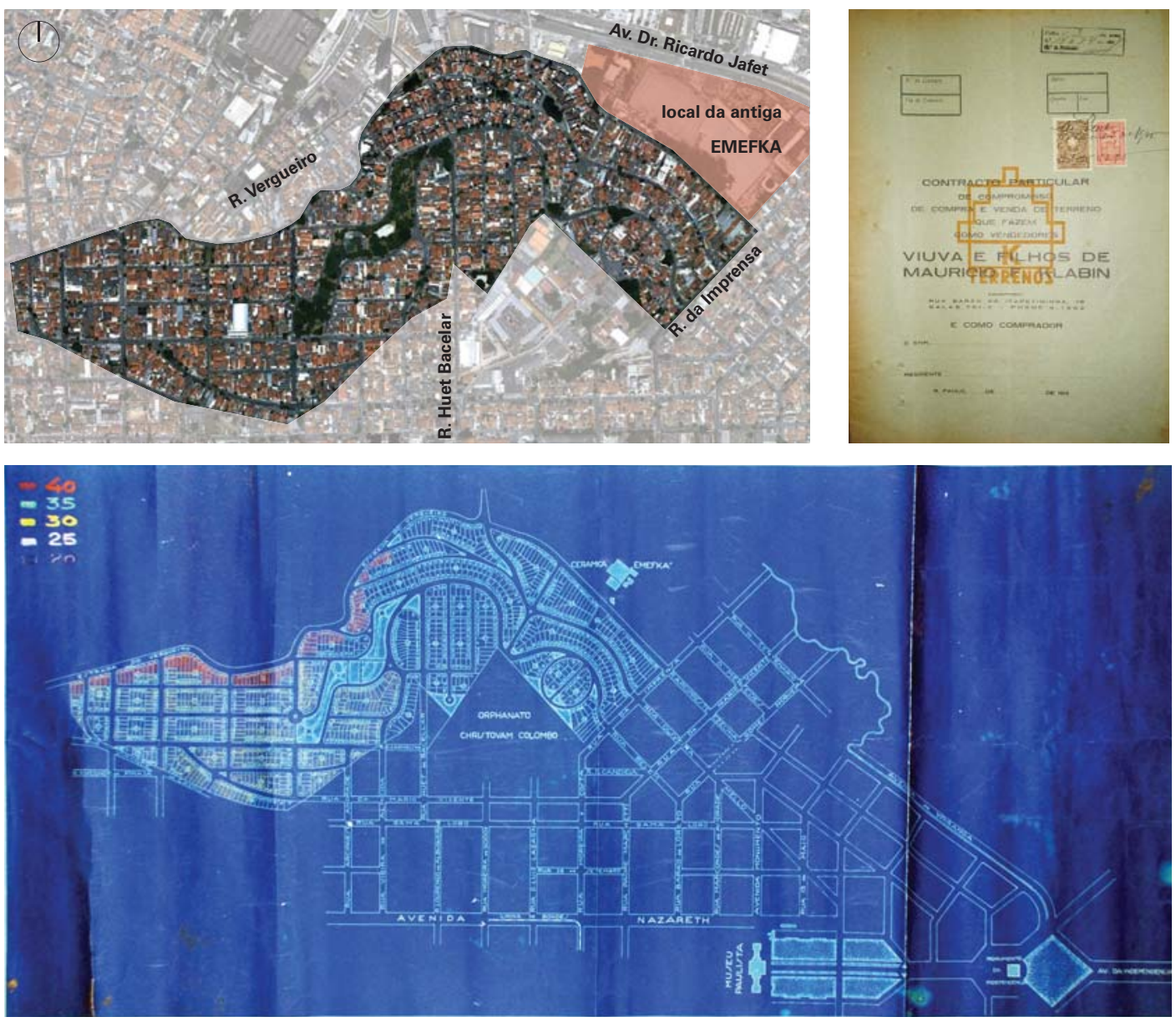


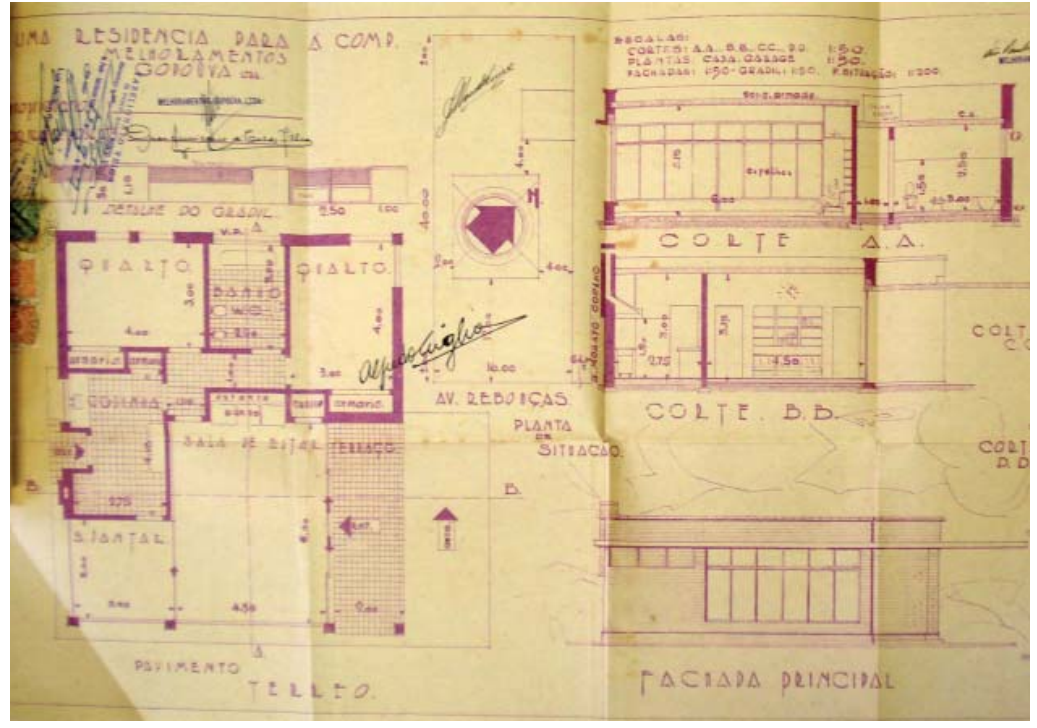

Projetos realizados por renomados escritórios para a Cia. Gopouva na Avenida Rebouças. Dos projetos localizados, apenas os desenhos de Warchavchik e do engenheiro Oscar Americano [440] (ao lado) seguiam linhas mais arrojadas. Mesmo seu futuro parceiro, Oswaldo Bratke, apresenta projeto de desenho neocolonial pela Bratke \& Botti, assim como Eduardo Kneese de Mello.
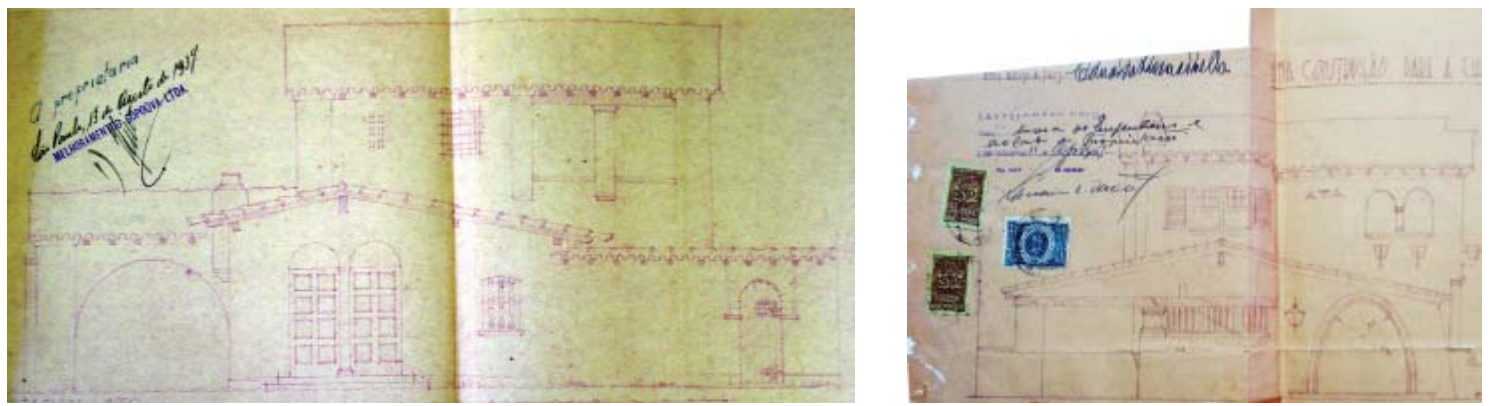

[441] Bratke \& Botti (esq.). [442] Eduardo Kneese de Mello (dir.).
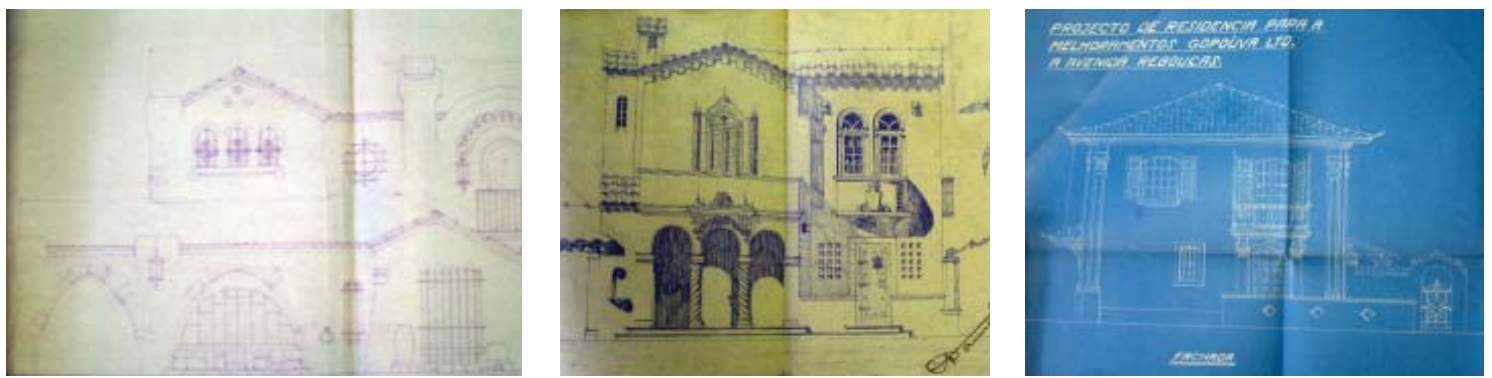

Da esq. para dir. [443] Sociedade Construtora e de Imóveis. [444] Lindemberg, Alves \& Assumpção. [445] Olavo F. Caiuby.
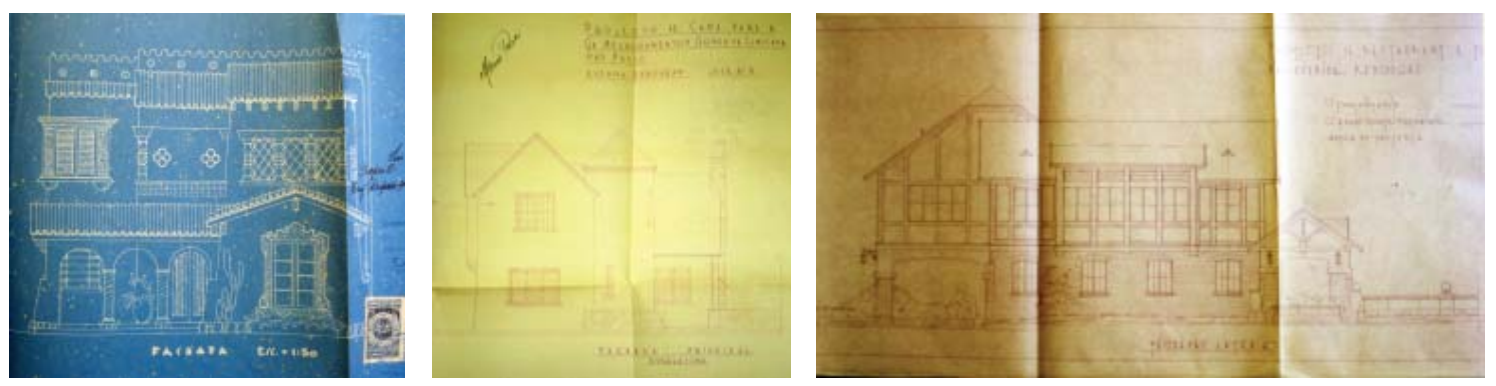

Da esq. para dir. [446] Vicente Nigro Jr. [447] Moya \& Malfatti. Antonio Garcia Moya foi um dos arquitetos participantes da Semana de 22. [448] Projeto de Bar-restaurante "campestre", "tipo Lido", da Sociedade Construtora e Comercial. 

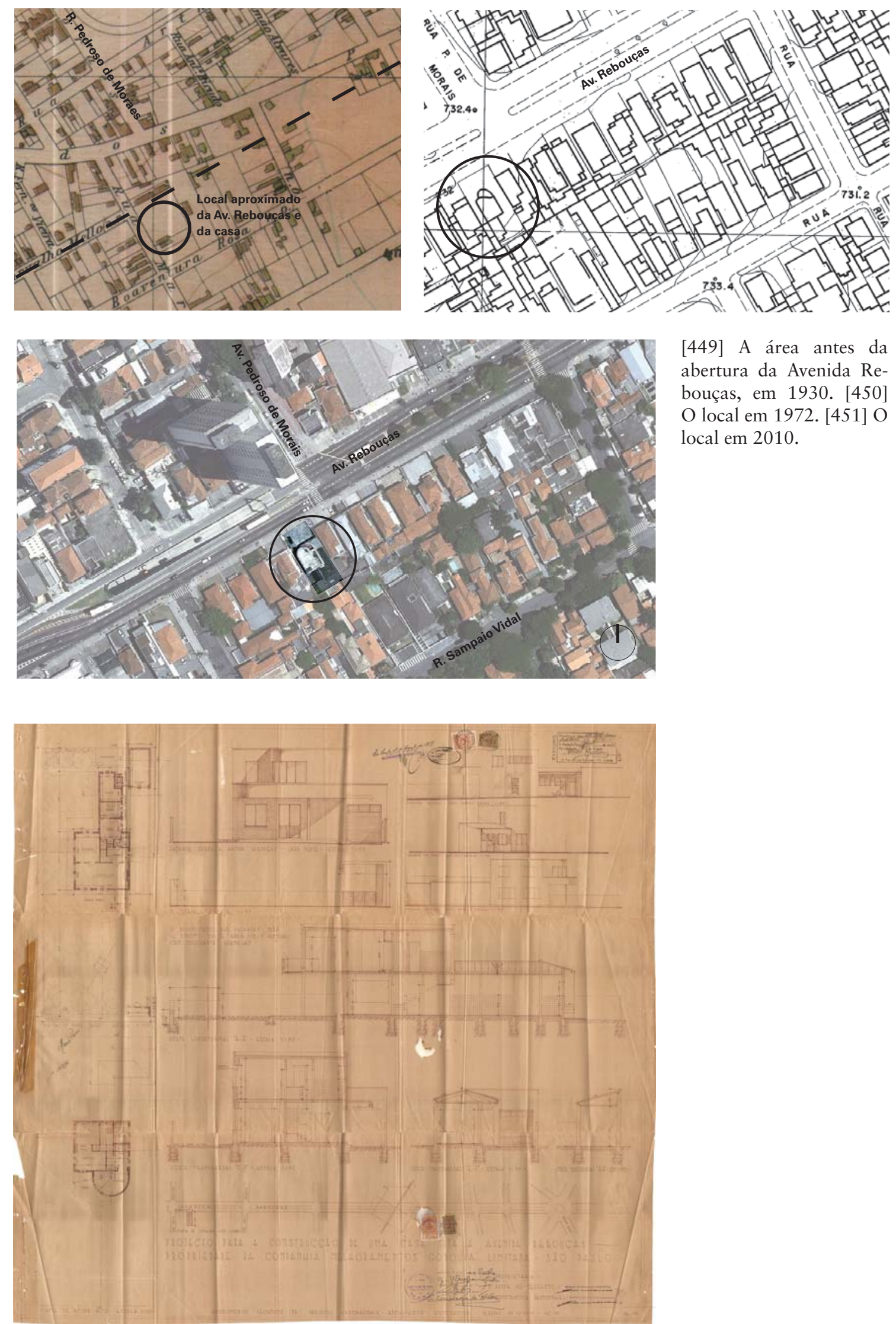

[452] Planta de prefeitura do projeto, 1937.
[449] A área antes da abertura da Avenida Rebouças, em 1930. [450] O local em 1972. [451] O local em 2010. 


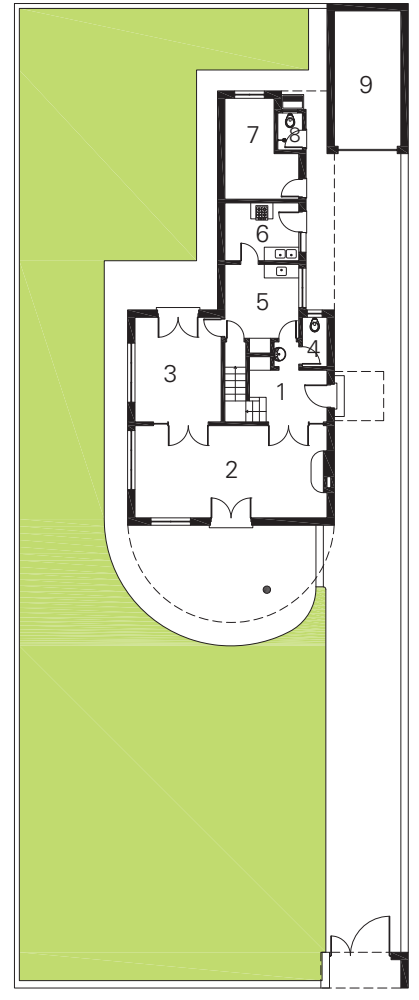

[453] PLANTA TÉRREO

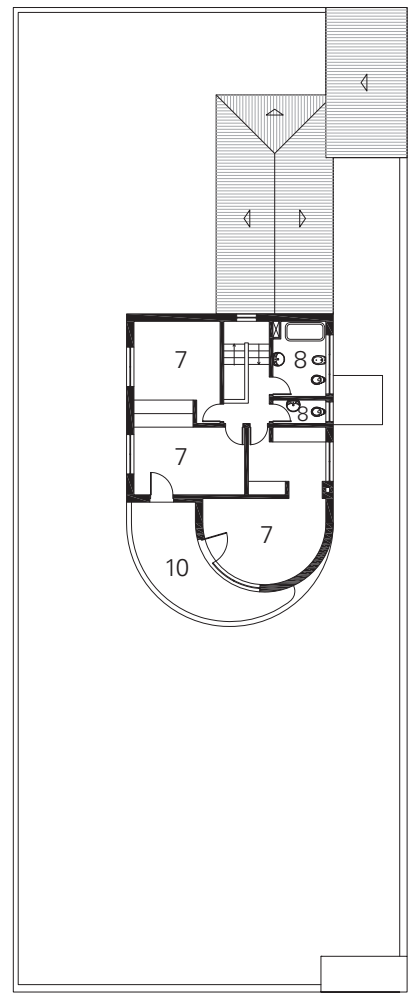

[454] PLANTA $2^{\circ}$ PAV.
Uso original

1. Entrada

2. Sala de estar

3. Sala de jantar

4. Lavabo

5. Copa

6. Cozinha

7. Dormitório

8. Sanitário

9. Garagem

10. Terraço
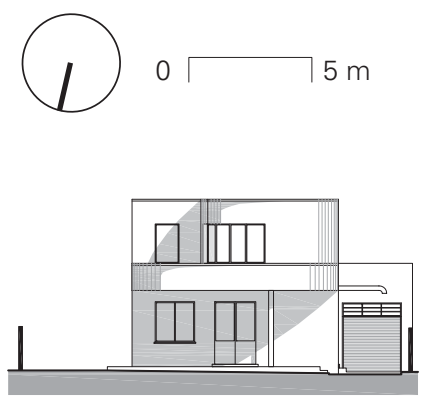

[456] ELEVAÇÃO NORTE

[455] ELEVAÇÃO LESTE
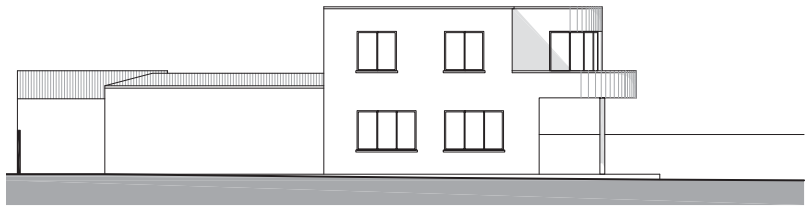

[457] ELEVAÇÃO OESTE
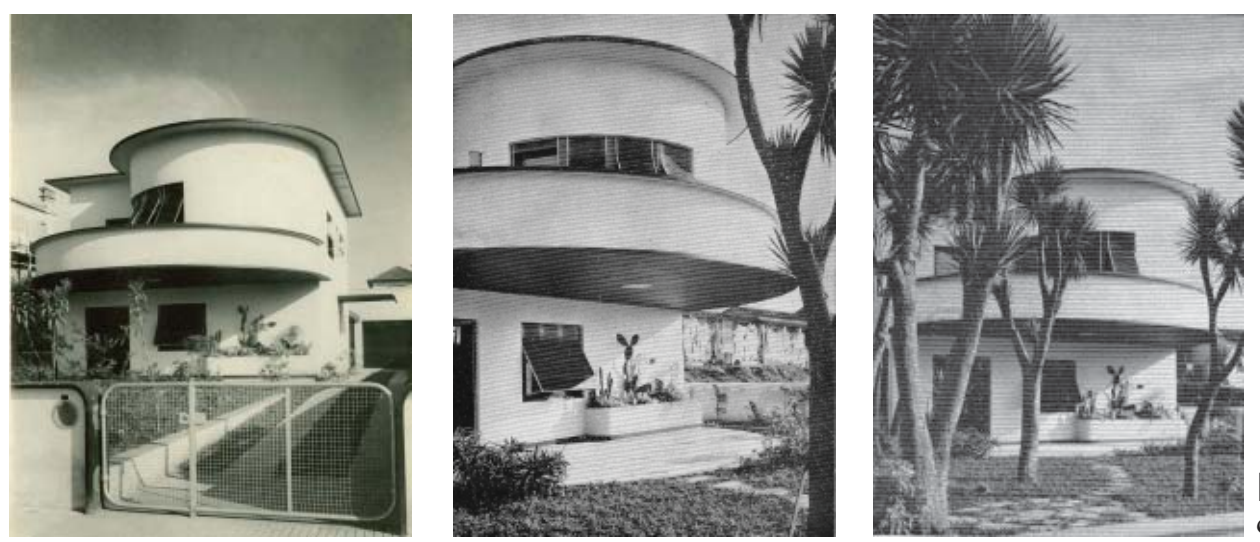

[458] a [460] A casa em 1938 

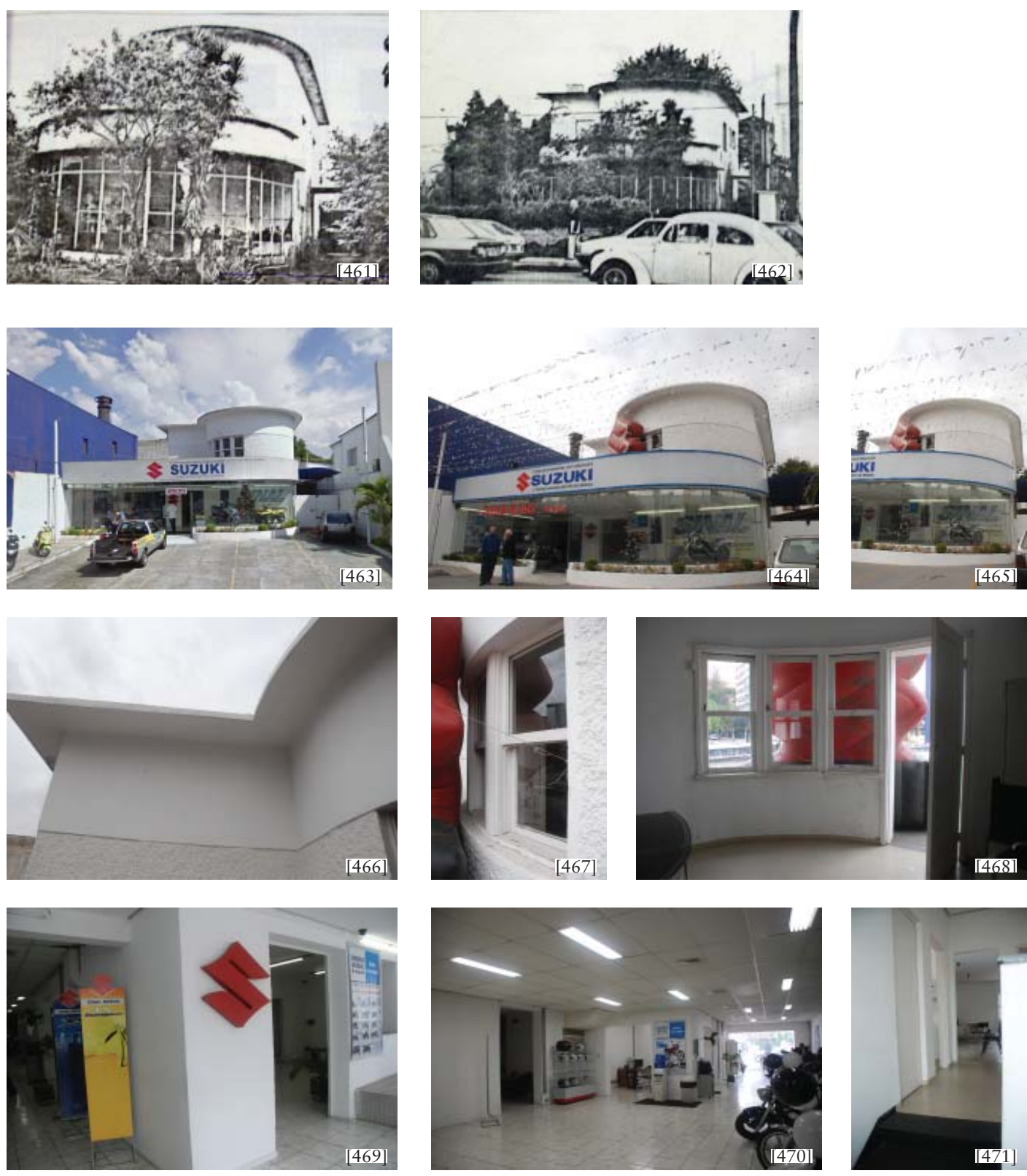
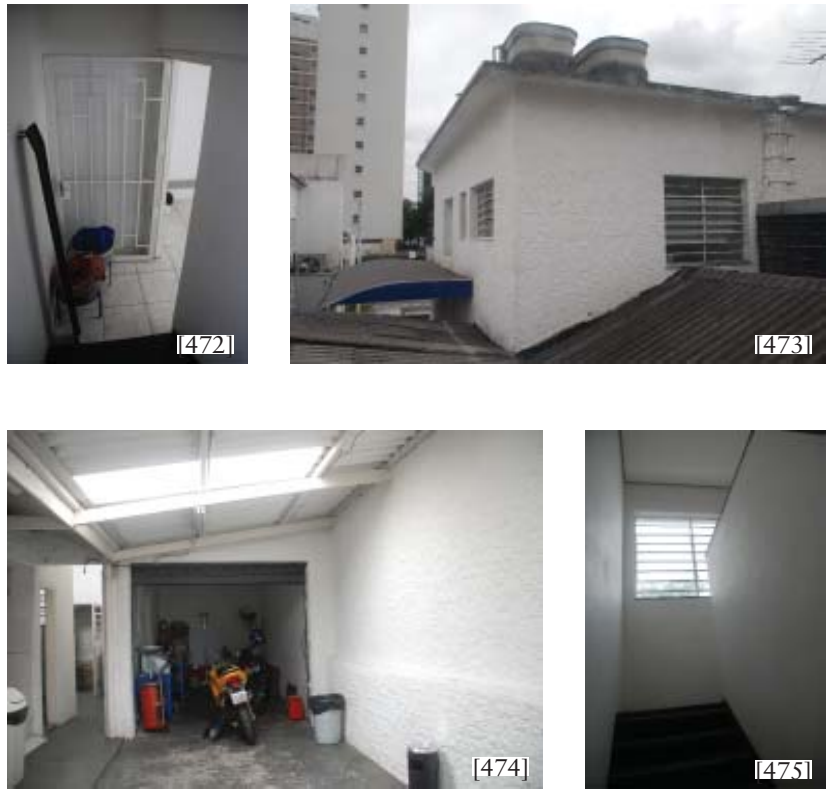

[461] e [462] A casa em 1990, com a varanda fechada por caixilharia. [463] a [465] Fachada frontal em 2010. O volume principal continua preservado, mas toda antiga área livre foi incorporada à área da loja, por meio de estrutura leve. [466] Detalhe da aba que arremata a laje. [467] e [468] Detalhes da caixilharia do dormitório curvo. [469] Vão original, do acesso frontal. [470] Vista do fundo do lote para a frente. é possível notar a implantação original. [471] Circulação, de onde se vê entrada para os cômodos. [472] circulação vertical, com porta original. [473] Volume principal visto pela edícula. Mais uma vez se vê a área livre ocupada, com fechamento em telha de fibrocimento ondulada. [474] Antiga garagem. [475] Escadaria. 


\section{EDIFÍCIO DA ALAMEDA BARÃO DE LIMEIRA (1939-1940)}

O edifício Mina Klabin é, ao lado das casas da Santa Cruz, Itápolis e Bahia, uma das obras mais consagradas de Warchavchik. Já vimos como sua premiação e sua aparição no catálogo de Brazil Builds fará com que o arquiteto retorne às páginas da imprensa nacional e seja publicado por periódicos especializados nacionais e internacionais. Os primeiros estudos datam de 1938, quando Warchavchik projeta quatro edifícios para o local. No acervo da FAUUSP, existem duas versões anteriores à executada. Ambas espelham frente e fundos em apartamentos de um dormitório separado da sala por cortina, mas o posicionamento da circulação as diferenciam. Na primeira, a circulação é centralizada, em uma espécie de passarela entre os dois blocos, servida por um elevador envolto à escadaria. Esta circulação central determina também o agenciamento interno dos apartamentos, separando cozinha/ serviços do sanitário. Nesta solução, entra-se por um corredor que distribui para tais ambientes ou acessa a sala, que é ladeada pelo dormitório, por sua vez servido por closet. Na outra proposta, a circulação se situa em um dos alinhamentos laterais do lote, fazendo com que as unidades concentrem as áreas molhadas e o closet abra para a área de serviço. A solução final partirá do $2^{\circ}$ esquema, mas abolirá a passarela. Outra diferença notada se refere à eliminação do térreo comercial em favor de mais unidades residenciais. Inicialmente os blocos deveriam ser repetidos e rebatidos em 4 edifícios, que em elevação apareceriam como um.

O projeto se enquadra no grupo de empreendimentos imobiliários da família Klabin destinados ao aluguel, e o estudo para quatro edifícios visava justamente atender aos quatro herdeiros. Mas apenas o casal Mina e Gregori segue em frente com o investimento, solicitando o Habite-se em 1940264. Emmanuel Klabin chegou a ter aprovado um projeto para construção de um barracão que serviria de estacionamento e apoio para obra nos prédios vizinhos em $1941^{265}$. Entretanto em 1943 pede revalidação do Alvará, pois o barracão não fora executado pela situação anormal de falta de materiais causada pela guerra. Mas ao que parece, o barracão foi construído mesmo sem a autorização, levando a prefeitura a intimar o proprietário a demoli-lo em 1946, o que ocorre alguns anos depois ${ }^{266}$.

A obra insere-se no fenômeno de verticalização que vinha transpassando o triângulo histórico a partir de empreendimentos para renda. Como Pinheiro aponta, mesmo sancionada lei de criação de condomínios em 1928, apenas com a lei do inquilinato de 1942 aparecerá o primeiro edifício constituído por esta modalidade ${ }^{267}$. Até então, comumente um edifício inteiro pertencia a um único proprietário, e o edifício Mina Klabin não era exceção ${ }^{268}$. Assim como a cidade expandia-se, verticalizava-se e elegia o transporte individual como modelo de mobilidade urbana, o edifício originalmente recuado tendo em vista o projeto de alargamento da via, perdia seu jardim frontal projetado por Mina Klabin, passando a acompanhar o

264 Segundo informações de BRANCO, 1989. O processo não foi localizado no Arquivo Municipal.

265 Processo PMSP 0.022.691/41. Não fica claro que a que outras obras se refere a solicitação

266 Processos PMSP 0.029.008/41, 0.078.983/43, 0.078.300/44, 0.060.073/44, 0.048.625/46

267 PINHEIRO, 2008:110

268 Processo PMSP 2010-0.018.748-5. 
novo alinhamento do lote acomodado pelo perfil viário então ampliado.

E tal como praticado, o edifício privilegiava a fachada voltada para a rua. Mindlin já observava o modo engenhoso como era explorado o melhor aproveitamento do lote, enfrentando o comum problema da exiguidade de suas dimensões ${ }^{269}$. Dotado de seis andares (térreo + 5), ou 12 unidades, o projeto investia no enxugamento da circulação vertical e horizontal, eliminando circulação de serviços e criando um bloco concentrando elevador - hall - escada. As plantas também obedeciam a um programa ainda pouco usual para os costumes da época, eliminando o quarto de empregada e trazendo duas tipologias. Os apartamentos voltados para a Barão de Limeira tinham dois dormitórios, ao passo que os apartamentos dos fundos eram kitchenettes. As áreas de serviço eram mínimas e juntamente com cozinha e sanitário eram projetadas de acordo com layouts funcionais que aproveitavam nichos, embutimentos e otimização da circulação. $\mathrm{Na}$ entrada dos apartamentos, um vestíbulo dotado de armário embutido e um forro rebaixado em sanca, com iluminação indireta resguardavam o estar. O armário embutido estava presente também nos dormitórios. Ambos os tipos contavam com terraço, sendo o frontal servido por uma jardineira de toques Déco. A implantação em L permitia iluminação e ventilação direta de todas as faces do edifício, ao contrário de plantas bastante praticadas à época, que na ganância pela máxima ocupação do lote, criavam fossos para atender aos serviços. Warchavchik descrevia:

Construção de concreto armado, sobre colunas reforçadas e divisões em lâminas de concreto. Os apartamentos sobre a Alameda Barão de Limeira são destinados a pequenas famílias, dispondo de um living e de dois dormitórios. Os apartamentos dos fundos destinam-se a solteiros ou casais sem filhos, pois dispõe de um único, mas grande ambiente com cozinha e banho dotadas de todo o conforto, armários embutidos, trilhos para cortinas, cozinhas completas, inclusive geladeira. A residência do zelador é nos fundos do terreno, ajardinado para os brinquedos dos filhos dos inquilinos. As janelas de metal, são do liceu de Artes e Ofícios ${ }^{270}$

Os vãos se estendiam por toda a largura dos dormitórios e com a parede divisória recuada em relação às paredes de vedação externa, criavam a sensação do pano de vidro contínuo, que acabava no movimentado terraço. As janelas desempenhavam importante papel nesta composição, pois tinham perfil esbelto e a veneziana de recolher, imprimindo leveza à fachada. Os trincos tinham um sistema de travamento inteligente e delicado e condizia com outros detalhes especificados ou desenhados por Warchavchik - maçanetas, plafons, puxadores, etc. Outro detalhe que vale destacar se refere ao arremate do peitoril. Para evitar o escorrimento e a impregnação de sujidades em decorrência da chuva na fachada, este foi desenhado inclinado para dentro, conduzindo a água a uma canaleta servida por pequenos buzinotes para descartá-la. Os pisos dos terraços e áreas de serviço eram em cerâmica verme- 
lha, os internos nas áreas secas em parquet ${ }^{271}$. Na cozinha, o granilite deixa dúvidas quanto à execução, se são peças de granilite pré-fabricadas rejuntadas por massa pigmentada ou se todo o piso teria sido executado in loco. Já no banheiro, uma reforma dos anos 1970 substituiu todo o revestimento original, sem que haja documentação. Nas fachadas, os panos de argamassa acrescida de pó de mármore cinza ${ }^{272}$ são substituídos no térreo por peças em litocerâmica, conferindo especial beleza. As peças têm profundidades diferentes, criando frisos horizontais no embasamento do edifício. E o mais curioso é que o arremate encurvado da fachada é acompanhado pelas peças. Produzidas pela Cerâmica São Caetano, companhia de propriedade do ex-patrão de Warchavchik, Roberto Simonsen, estas eram uma verdadeira vitrine das possibilidades de aplicação do acabamento, estampando propagandas na revista Acrópole ${ }^{273}$. O cuidado com os detalhes também é notado nas áreas comuns do edifício, nos espelhos inclinados dos degraus, na porta de entrada, no balcão da portaria, no caixilho e na escada da circulação vertical, etc. Vale ressaltar que todos os aspectos descritos foram verificados no local, que pouca alteração sofreu até hoje e ainda é de propriedade da família. Repetimos aqui que isto demonstra a importância do contato direto com a obra arquitetônica para seu estudo, pois só assim é possível o contato com certos elementos e detalhes ausentes ou imperceptíveis nos desenhos, registros fotográficos e outros documentos, tanto em termos das soluções propostas como das técnicas construtivas, que ainda estamos longe de mapear plenamente.

Sob a estrutura de concreto armado, a fundação era das convencionais estacas de madeira. Seu recente apodrecimento gerou recalques diferenciados, provocando fissuras e rachando até os mármores do hall de entrada. Para os anos por que passou sem manutenção, até que o edifício se comportou bem. Exceto pelo problema infraestrutural, poucos problemas eram perceptíveis. Algumas peças da litocerâmica se desprenderam e alguns apartamentos estavam com a pintura descascando na área externa, mas de resto, nenhum problema maior decorrente do uso. Talvez o mais impactante sejam as pichações e a grade colocada na entrada expondo a interface cruel com a cidade. Quanto às patologias, cabe observar que estas mostram também outro tipo de informação não perceptível de outra forma, dedutíveis a partir dos comportamentos dos materiais. Por exemplo, o desprendimento dos revestimentos cerâmicos permitiu a observação da maneira como eram assentados, bem como a identificação do fabricante, estampada na argamassa residual; o descascamento da pintura em uma das unidades, que mesmo sem prospectar suas superfícies, deixou à mostra as tonalidades utilizadas naquele apartamento, até sua primeira camada; ou a lacuna em um dos balcões que revelou ser o fechamento parcialmente em estuque telado e entarugado tradicionalmente. Deste modo, o levantamento arquitetônico conduzido pelo olhar do res-

271 Na Acrópole a revista anuncia o fabricante das portas compensadas e do parquet, na edição de março de 1941.

272 Cf. Acervo FAUUSP, tubo P W196/728.1 BL

273 Notamos que no período consultado, as obras que recebiam maior destaque na revista eram utilizadas em anúncios da Cerâmica São Caetano, incluindo outras casas de Warchavchik. 
taurador mostra-se capaz de produzir novos conhecimentos sobre as obras, especialmente se dispondo de técnicas próprias e ensaios laboratoriais. Atualmente, o edifício passa por reforma e conservação, com a realização de obras de reforço estrutural, manutenção dos pisos e caixilhos, pintura geral, substituição dos revestimentos dos banheiros e colocação de Dry-Wall nos apartamentos dos fundos, separando dormitório da sala de estar. Tal medida parece ir de encontro com estudo de reforma realizado por Gregori em 1953, no qual anotava em um dos croquis: "Apartamento dos fundos - aumentar e transformar nicho em verdadeiro dormitório". A ideia era dividir e estender o dormitório até o alinhamento do terraço, o que não foi levado adiante, assim como o proposto para o apartamento da frente: "construir um quarto de empregada e uma toilette, desistir da despensa, fazer canto do tanque, embutir janela cozinha e banheiro" ${ }^{274}$. Ambas as intervenções se mostravam dispendiosas, dado que teriam que se servir de toda uma nova estrutura para um aumento mínimo de área. De qualquer modo, demonstram que aquilo que tornava o edifício fora do padrão da época não devia estar satisfazendo às exigências de mercado, que pautou o programa desta reforma: o quarto para empregada e o quarto individualizado.

Como já dito, o edifício da Alameda Barão de Limeira integra processo de APT em conjunto com a vila da Rua Barão de Jaguara e a preterida casa da Avenida Rebouças, excluída da resolução. As motivações gerais já foram expostas no caso da Barão de Jaguara, mas o que assinalaríamos de específico quanto a este caso se refere à sua visibilidade nos anos 1940, com sua premiação e publicação, tendo sido xerocopiadas páginas a seu respeito, citadas integralmente passagens de Geraldo Ferraz e comparado ao contemporâneo Edifício Esther (1938) quanto à sua modernidade, apresentando as "principais características do modernismo: estrutura independente, janelas contíguas e purismo nas linhas geométricas da fachada. Destacam-se as lajes curvas e em balanço que formam os amplos e confortáveis terraços que já foram providos de cortinas (...)”275.

Apesar de ainda hoje o edifício estar protegido somente por uma $\mathrm{APT}^{276}$ sua preservação, mesmo que com algum grau de degradação, permitiu a verificação de elementos construtivos, detalhes arquitetônicos, fenômenos patológicos que comprovam a importância da experiência direta com a obra e a potência do instrumental da restauração para aquisição de conhecimentos sobre a arquitetura. 

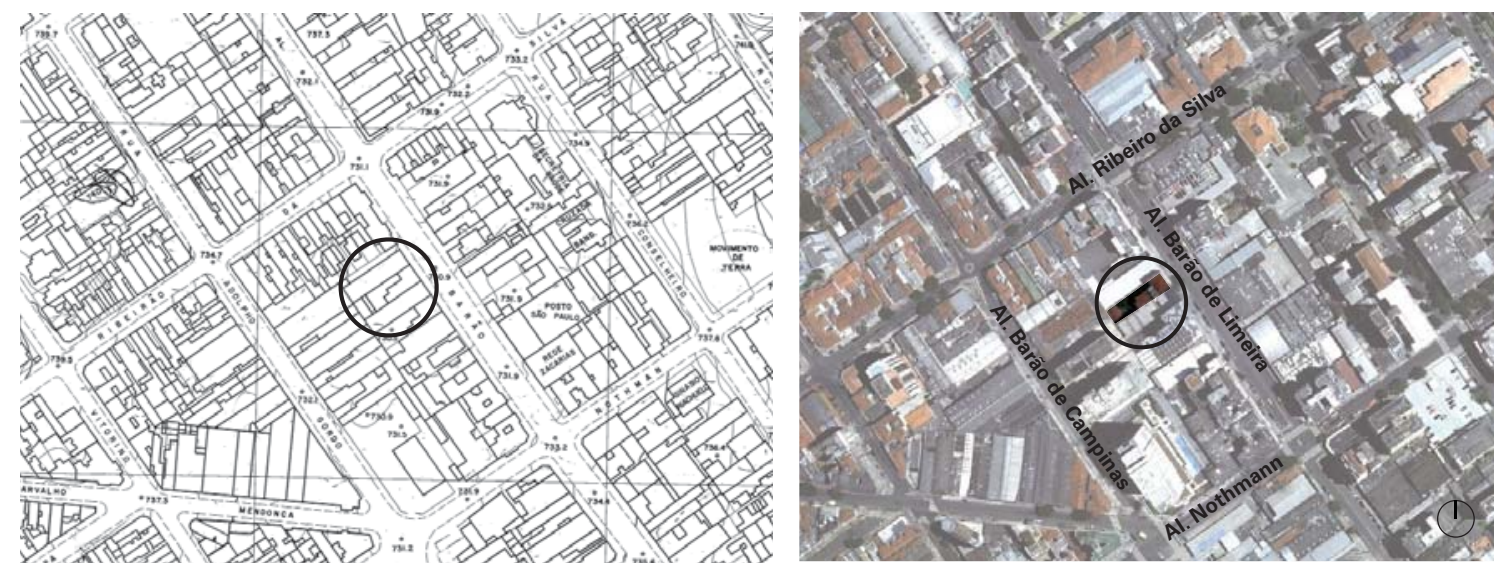

[476] e [477] A área em 1972 e 2010.
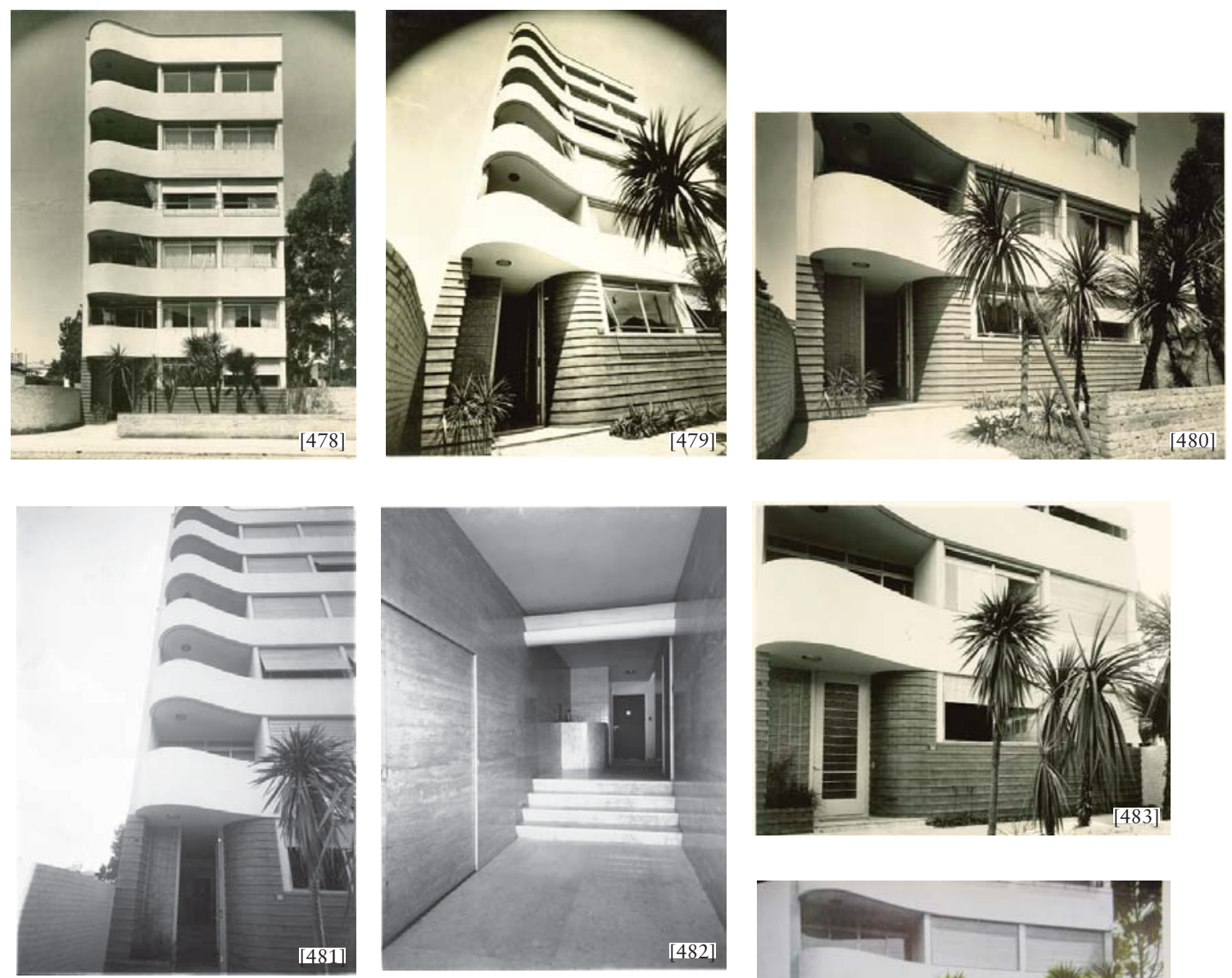

[478], [479] e [481] Vistas da fachada frontal. Com a lente angular, Hugo Zanella (foto 479) constrói uma perspectiva que explora o elemento estético mais expressivo do edifício. [480] e [483] Detalhe da entrada do edifício, com jardim de Mina, depois eliminado pelo alargamento da via, e embasamento em peças da cerâmica São Caetano. [484] Anúncio da Cerâmica São Caetano na Acrópole. Por alguns números a empresa usou em suas propagandas obras destacadas na revista, para mostrar a aplicação de seus produtos.

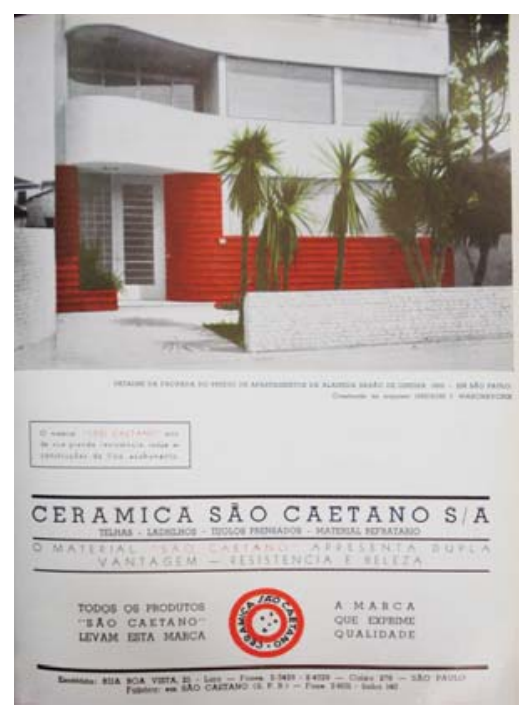



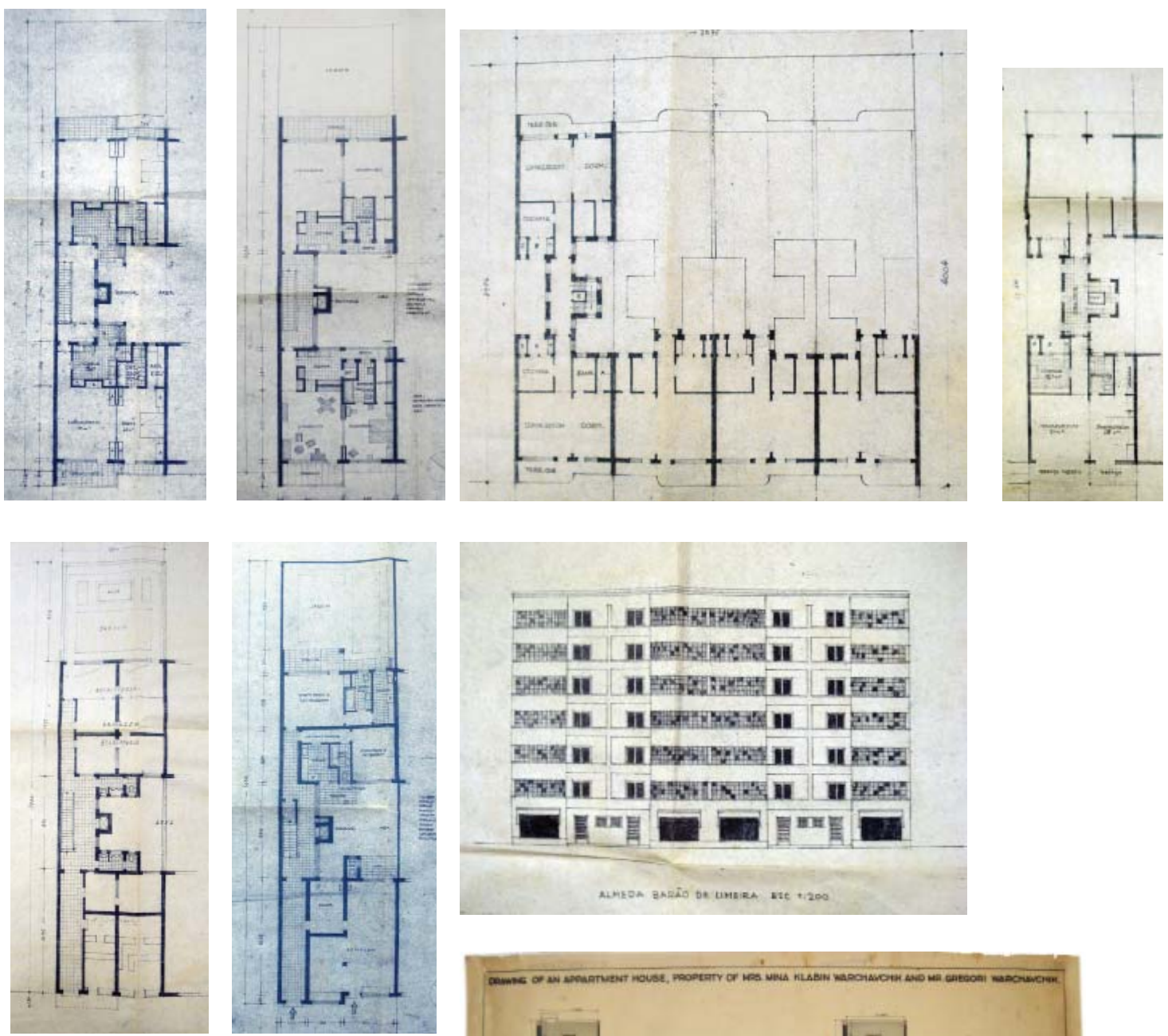

Acima: [485] a [491] Estudos para construção de 4 prédios na Barão de Limeira, com diferentes versões para as tipologias e esquemas de circulação. Ao lado: [492] Planta com desenho definitivo dos andares, em inglês, possivelmente para divulgação nas revistas estrangeiras que publicaram a obra. Abaixo: [493] Planta definitiva do projeto.
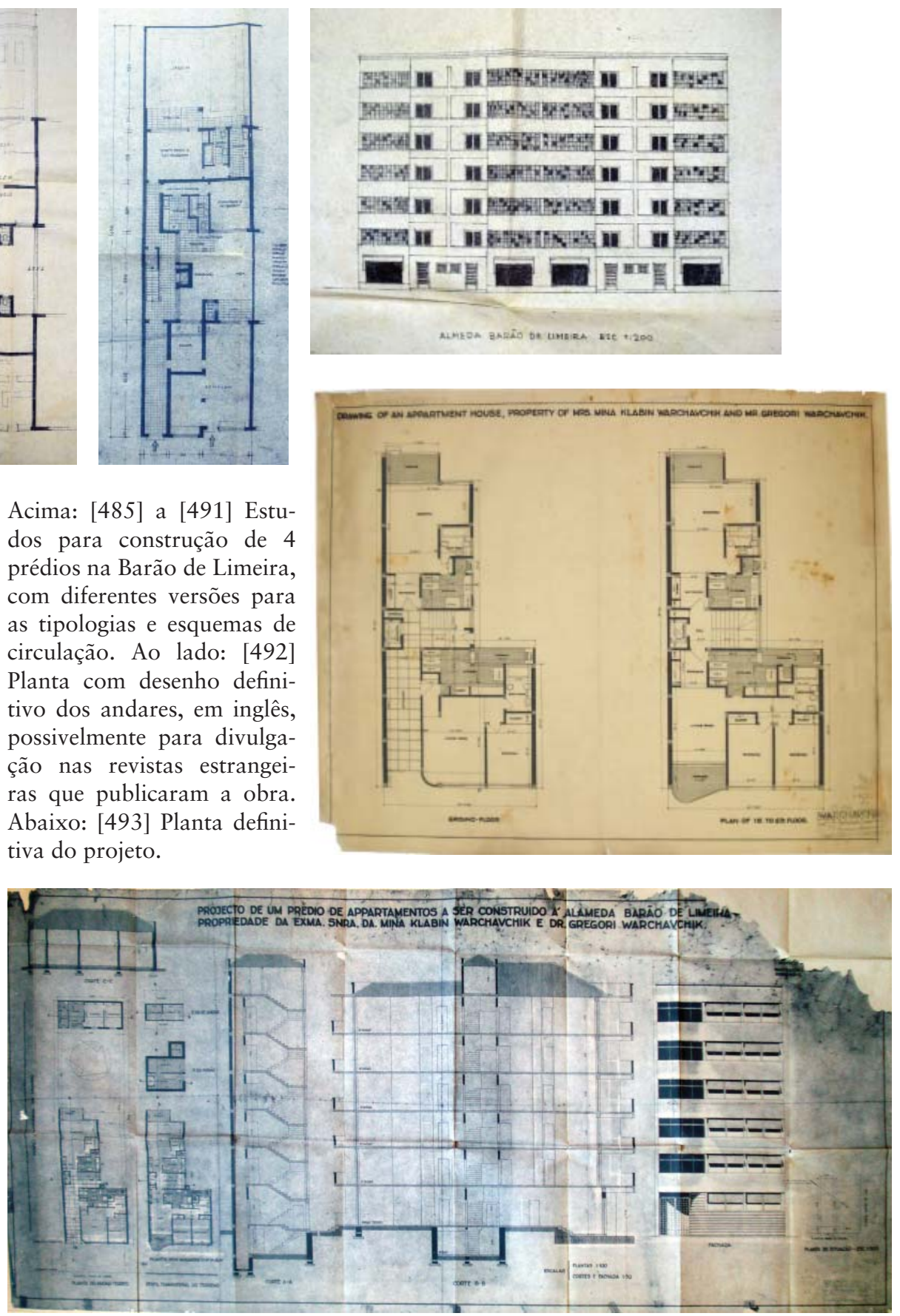


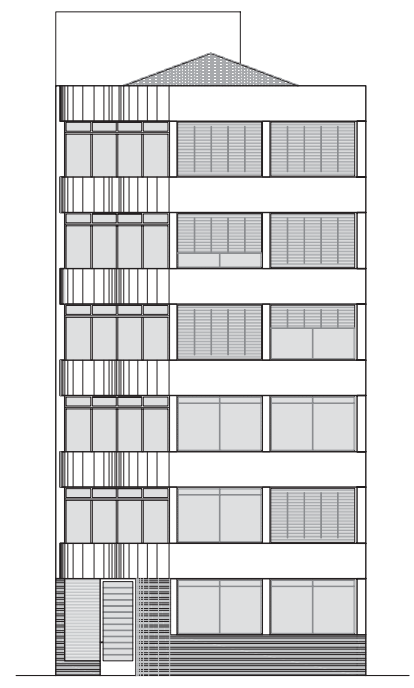

[494] ELEVAÇÃO
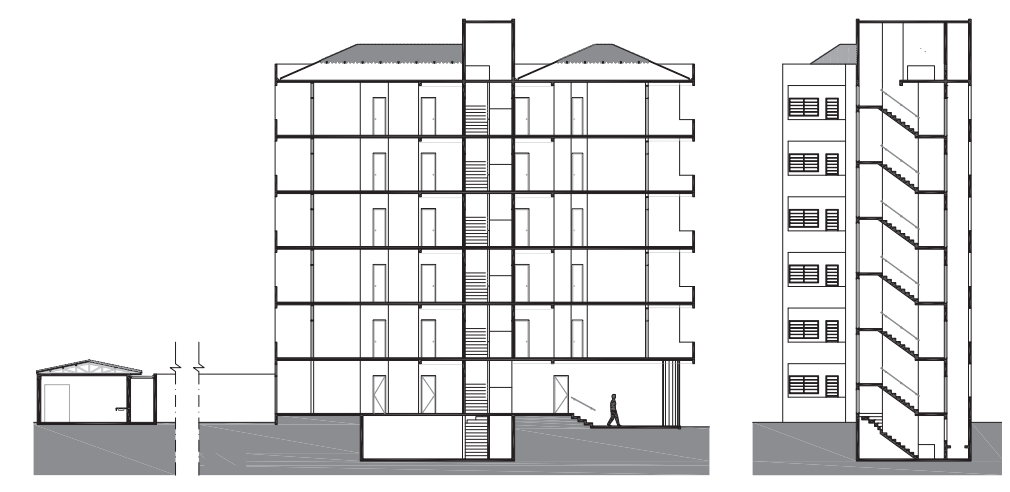

[495] e [496] CORTES LONGITUDINAL E TRANSVERSAL

$0 \lcm{5 \mathrm{~m}}$

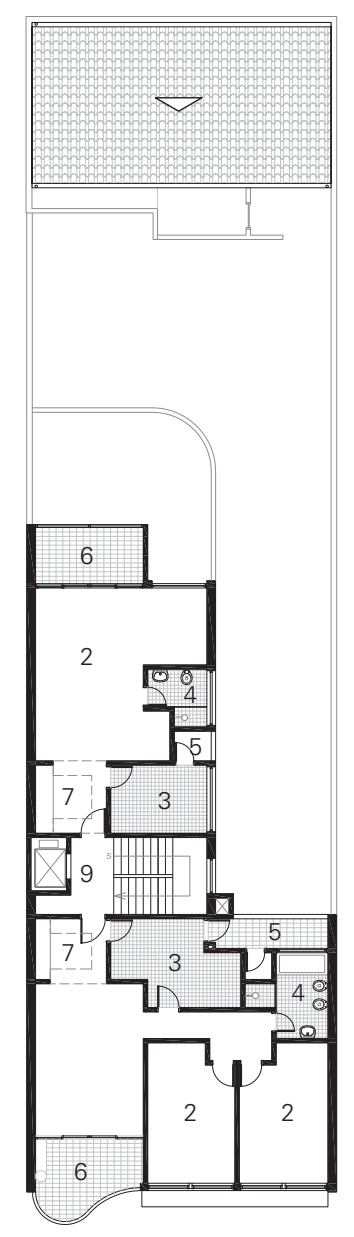

[498] PLANTA PAV. TIPO
1. Sala de estar

2. Dormitório

3. Copa/ cozinha

4. Sanitário

5. Área de serviço

6. Terraço

7. Vestíbulo

8. Entrada

9. Hall 

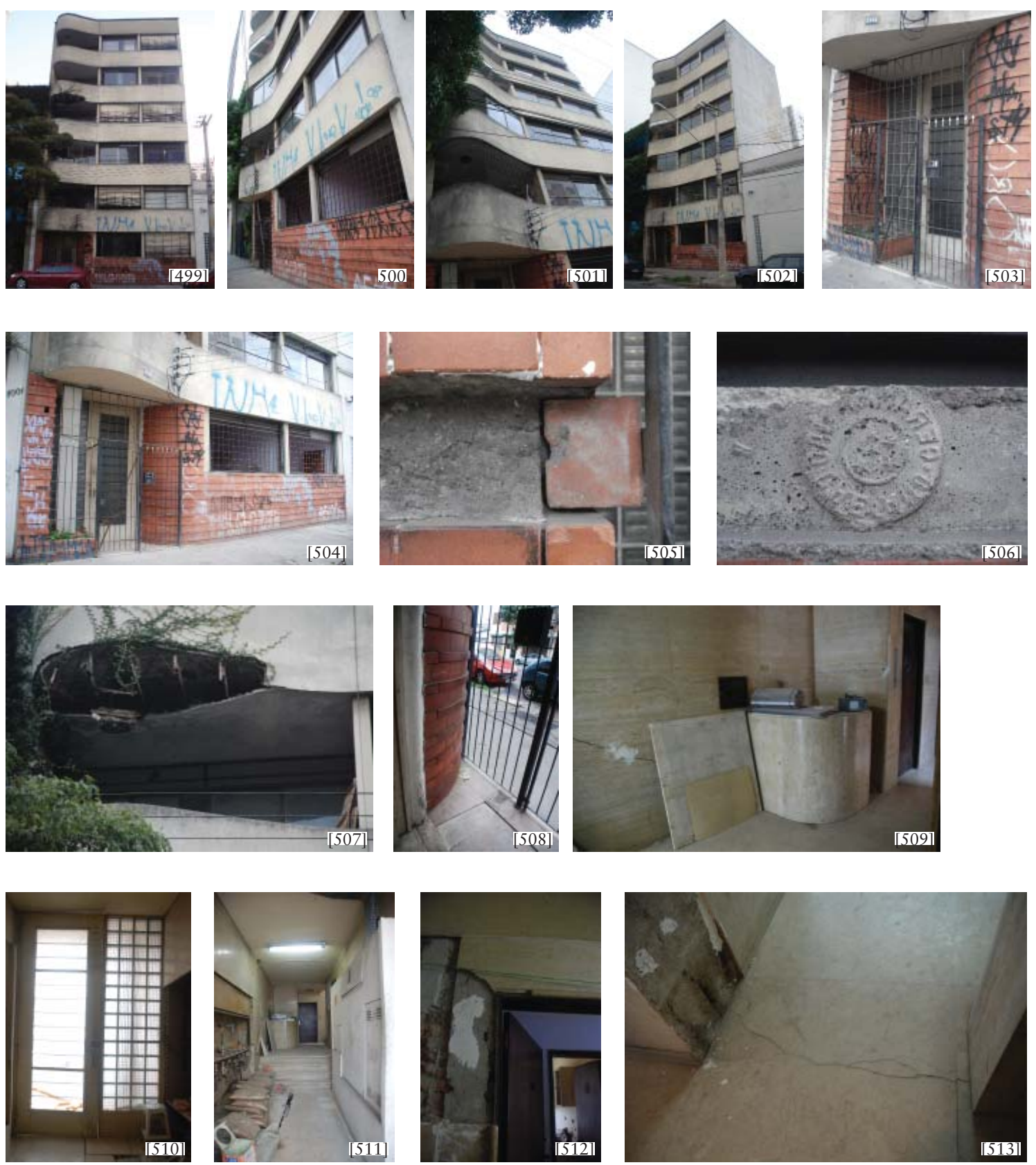
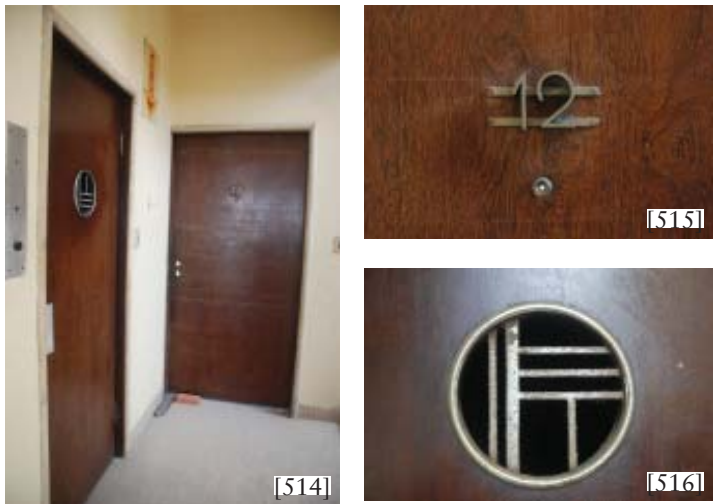

[515]

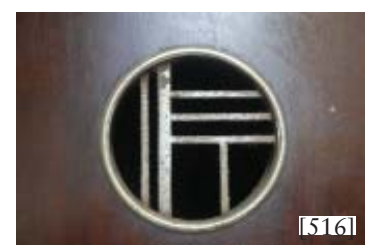

[499] a [502] Vistas da fachada frontal. [503] Detalhe da entrada, fechada por grades. \{504] Detalhe do embasamento do edifício, com marcas de pixação e entrada gradeada. [505] Detalhe de lacuna do revestimento, por onde é possível observar o assentamento das peças. [506] Outra marca do desprendimento de peças, desta vez revelando a marca da Cerâmica São Caetano na argamassa. [507] Trecho do balcão no qual a lacuna revela que o arremate do balcão é na tradicional técnica do estuque. [508] Outra vista da entrada, onde se vê as peças cerâmicas curvas e o nicho para o capacho. [509] Balcão da portaria em mármore, ao lado de placas danificadas. Vê-se à esquerda selo de gesso para o monitoramento das fissuras. [510] Portão de entrada, visto por dentro. [511] Corredor de entrada, com material da obra de conservação. [512] e [513] Peças de mármore trincadas pelo recalque. [514] Hall. [515] Numeração dos apartamentos. [516] Visor do elevador. 

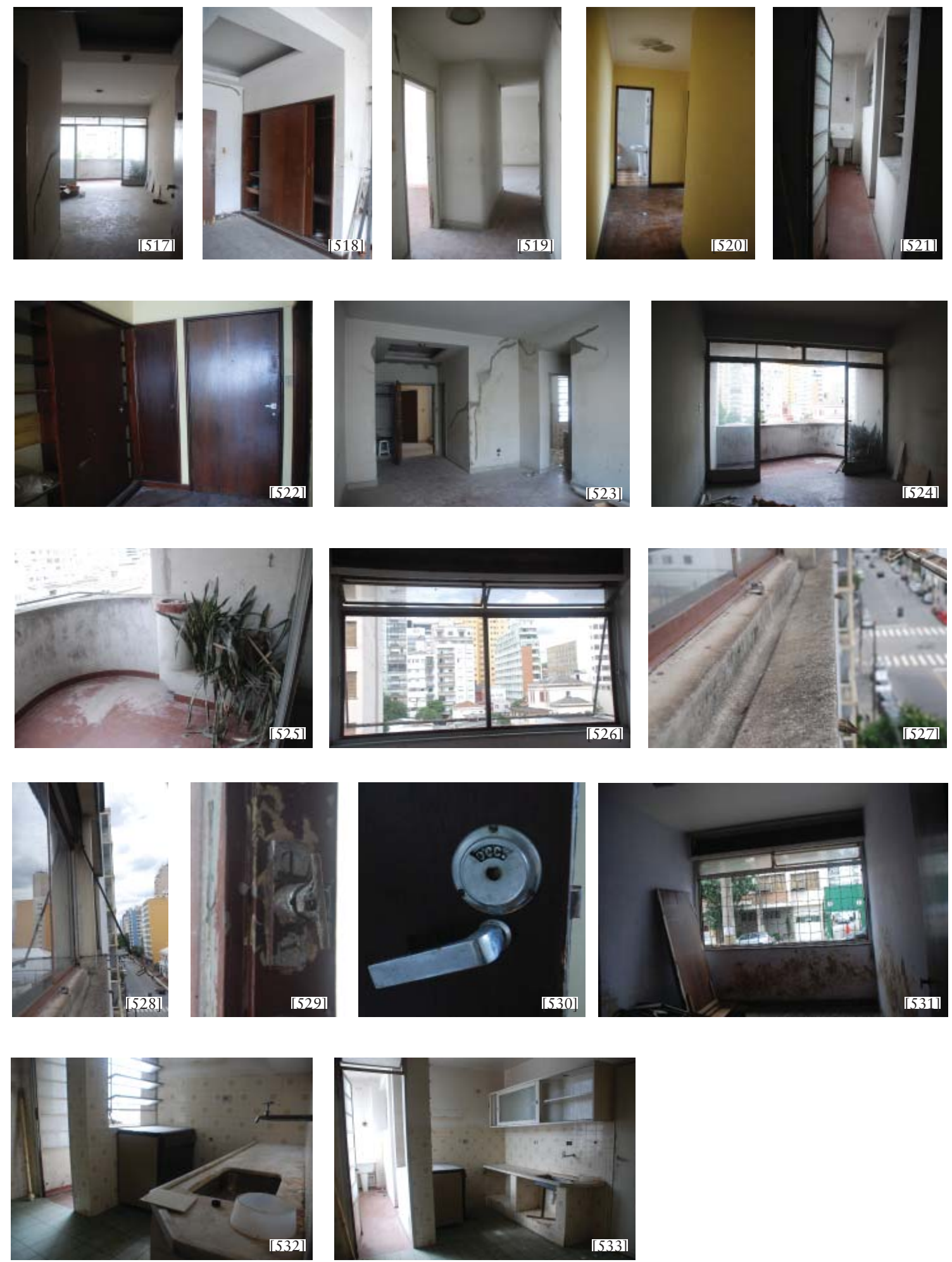

[517] Vista da sala, pela entrada, da unidade voltada para a rua. [518] Vestíbulo. [519] Circulação, em direção à sala. [520] Circulação, em direção aos dormitórios e sanitário. [521] Área de serviço. [522] Armários embutidos do vestíbulo. [523] Vista da sala de estar para entrada. [524] Vista oposta, em direção ao terraço. [525] Terraço, com floreira no canto. [526] Caixilho dos dormitórios, com vista para a região verticalizada. [527] a [529] Detalhes da janela, com peitoril inclinado para dentro, calha e buzinote para escoamento da água; armação da veneziana; trinco dos caixilhos fabricados pelo Liceu. [530] Fechadura importada (“occ.”.) [531] Sala de estar da unidade térrea, de apenas 1 dormitório. [532] e [533] Vistas da cozinha, ladeada pela área de serviço (apartamentos voltados para a rua). Praticamente todas as unidades conservam o balcão, armários, piso e azulejos. Os últimos estavam sendo trocados durante a visita. 

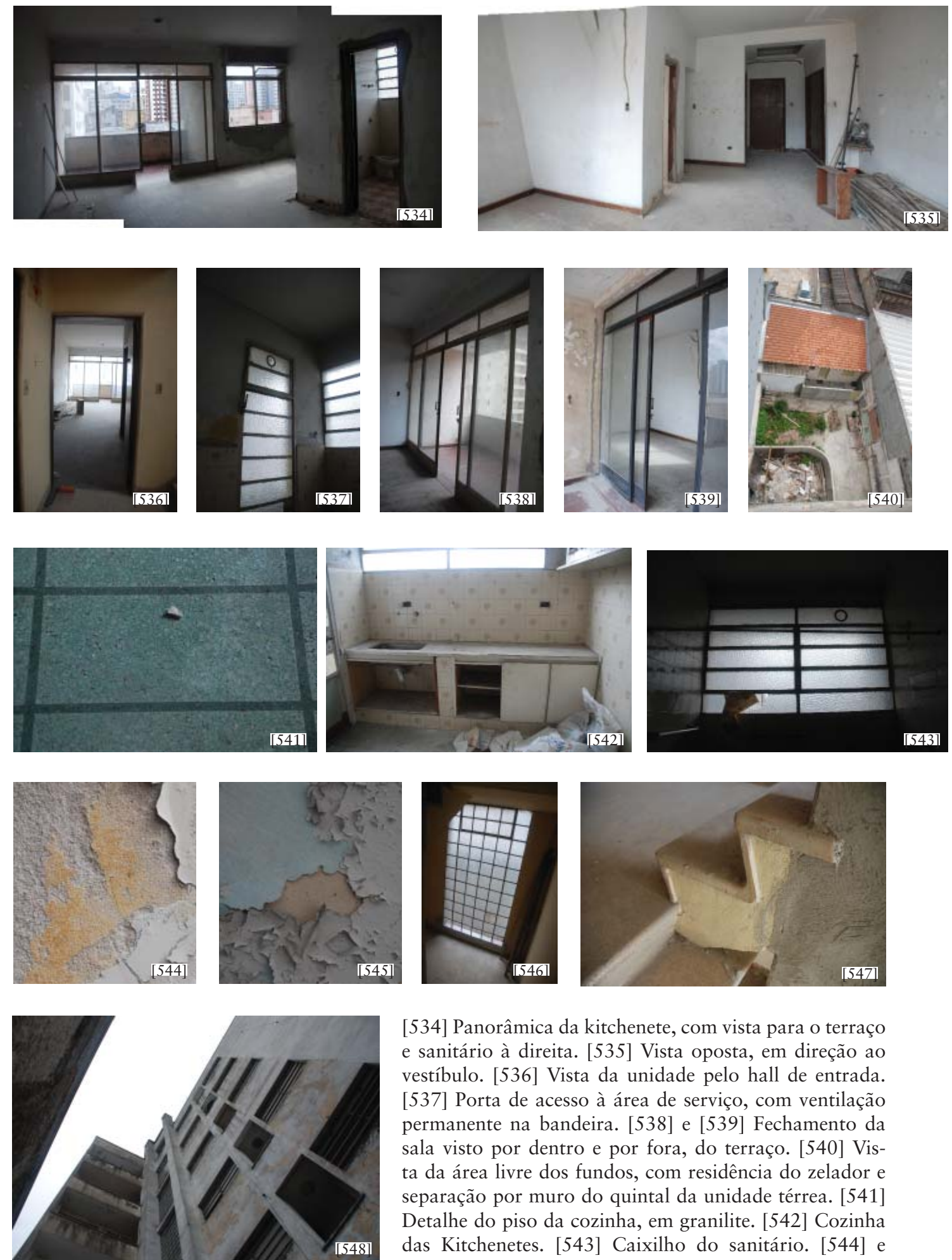

[534] Panorâmica da kitchenete, com vista para o terraço e sanitário à direita. [535] Vista oposta, em direção ao vestíbulo. [536] Vista da unidade pelo hall de entrada. [537] Porta de acesso à área de serviço, com ventilação permanente na bandeira. [538] e [539] Fechamento da sala visto por dentro e por fora, do terraço. [540] Vista da área livre dos fundos, com residência do zelador e separação por muro do quintal da unidade térrea. [541] Detalhe do piso da cozinha, em granilite. [542] Cozinha das Kitchenetes. [543] Caixilho do sanitário. [544] e [545] marcas de descascamento, mostrando a argamassa

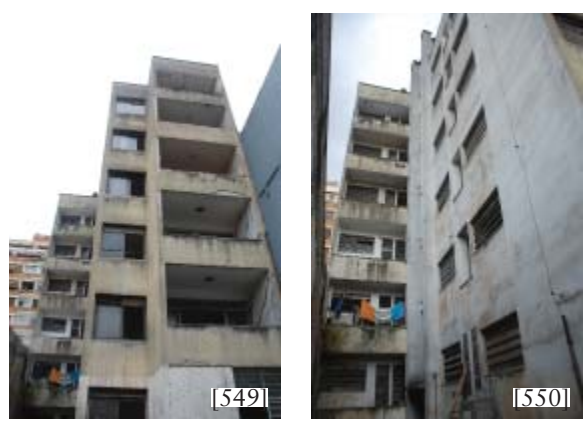
e as camadas de pintura látex. [546] Iluminação da escadaria do edifício. [547] Detalhe da escada, cujo desenho consta do acervo da biblioteca da FAUUSP. [548] a [550] Vistas das fachadas posteriores, nunca divulgadas pelas revistas especializadas. 


\section{CAPELA DO MORUMBI (1948-1950)}

A Capela do Morumbi é certamente obra de exceção no repertório de Warchavchik. Tratase de intervenção sobre uma ruína existente que evoca o partido religioso original, mas sem falsear seu caráter contemporâneo.

A intervenção inseria-se nas ações de valorização do novo loteamento Jardim Morumbi, de modo a dar feições pitorescas ao empreendimento erigido sobre a antiga Fazenda do Morumbi. O Jardim Morumbi inspirava-se no modelo urbano da cidade-jardim, que a exemplo dos bairros-jardins já existentes, visava o público de alto poder aquisitivo. A Companhia Imobiliária Morumby iniciou o loteamento da última gleba remanescente em 1949, contratando Warchavchik em 1948 para elaborar projetos para a ruína da antiga Capela de São Sebastião do Morumbi e para a casa-sede da Fazenda, convertida em clube do loteamento.

O empreendimento foi festejado pelos Bardi na revista Habitat. Em 1951, a revista dedicava duas páginas para falar do loteamento e da Igreja, alertando para o risco das novas edificações caírem no mau gosto reinante nos Jardins. Já em 1953, “O Jardim Morumbí Arquitetura Natureza", as notas elogiavam o respeito à paisagem, informando que a CNI - Companhia Nacional de Investimentos, encarregada das vendas, já teria vendido grande parte dos lotes. Relatavam também o asfaltamento das ruas em um bairro destinado a ser "prolongamento natural de São Paulo residencial”, dando sequência aos Jardins Paulista, América e Europa; concluíam: "No Morumbí o progresso é palpável”277. A vontade de transformar o bairro em residência de uma elite esclarecida transparece tanto nesses alertas sobre o mau gosto quanto nas publicações de casas como a própria residência Bardi e a residência Bratke na mesma edição, na sequência da matéria.

Oswaldo Bratke foi um dos protagonistas da urbanização do Morumbi, adquirindo terras nos anos 1930 e incentivando amigos e empresários a fazerem o mesmo, como o engenheiro Oscar Americano e o prefeito Fábio Prado, dando origem aos loteamentos do Jardim Leonor, Paineiras do Morumbi, Vila Susana e Vila Andrade ${ }^{278}$. Fabio Prado era um dos diretores da Companhia Imobiliária do Morumbi, e sua esposa, Renata Crespi da Silva Prado, responsabilizou-se pelas obras na Capela - informações que tornam mais compreensível como teria surgido o nome de Warchavchik para realização do projeto. O arquiteto já era conhecido das famílias Prado e Crespi, tendo realizado projetos como as residências de Luis da Silva Prado (R. Bahia), Antonio da Silva Prado Neto (R. Estados Unidos), o rancho de Marjorie e Jorge da Silva Prado na praia de Pernambuco/ Guarujá, a casa de veraneio na Enseada/Guarujá e a Fazenda Santa Maria Calunga do conde Raul Crespi.

Os primeiros documentos relativos à Fazenda do Morumbi datam do início do século XIX, passando ela por vários proprietários. Mas ao que parece, capela e casa-sede foram 
construídas por John Rudge, que lá cultivava chá da Índia ${ }^{279}$ no primeiro quartel do século. A casa-sede foi alterada diversas vezes, sofrendo reformas a cada proprietário que nela residia. A Gazeta de Santo Amaro, de 03/05/1935, publicou um artigo lamentando a modernização realizada pelo então proprietário, Hans Müller Carioba, tirando a feição colonial e assim, para o jornal, sua importância histórica. E descreviam: “A casa residencial, que se vê no clichê $\mathrm{n}^{\circ} 1$, era de feição colonial, acaçapada e enorme. Tinha paredes de pilão e onze commodos no pavimento térreo e 12 no superior. Foi reformada e modificado o seu exterior pelo actual proprietário, dr. Hans Muller Carioba" ${ }^{280}$. O mesmo problema é relembrado em reportagem do Estado de São Paulo de 29/08/1979, que relata que a casa já havia passado por sete proprietários, sofrendo constantes descaracterizações ${ }^{281}$. Provavelmente concordando com a consensual ideia de descaracterização e perda de valor histórico, Warchavchik realiza um projeto bem mais livre sobre a preexistência que na Capela, prevendo acréscimo de $95 \mathrm{~m}^{2}$, mas sem distinguir as marcas de sua intervenção. Nos projetos localizados no acervo da biblioteca da FAU e no processo de aprovação municipal ${ }^{282}$, apesar de em planta serem identificadas as áreas a conservar, demolir e construir, em elevação não o são, portanto em um primeiro momento, não é possível perceber quais as intervenções de Warchavchik. Deste modo, focaremos o trabalho na Capela, ainda que se observe a necessidade de um estudo profundo sobre o complexo caso da casa-sede.

A Capela, provavelmente construída por Rudge, aparece em documento de 1886 que se refere a ela como sede de cemitério localizado dentro da fazenda, na época pertencente ao alemão Bernardo Diederisken. Em estudo publicado por SCHMIDT em 1946, o autor analisa a ruína da "antiga igreja do morro do Morumbi", descrevendo a engenhosidade e execução apurada de sua taipa, que tinha seus blocos iniciados pelos cantos, através da montagem dos taipais em ângulo reto e amarração a $45^{\circ}$ nos vértices das paredes, visíveis nos cabodás existentes. Mesmo sendo obra particular, o vigário da paróquia de Santo Amaro pediu em 1912 que fosse emitida provisão por parte do Arcebispo D. Duarte Leopoldo e Silva autorizando a celebração de missas, por cinco anos, na capela. Entretanto, em visita ao local, o vigário da Freguesia de Santo Amaro, padre Aurélio Fraissat, disse: “(...) certifico que tendo visitado a capela, achei-a paupérrima, inteiramente desprovida de tudo que se requer para as funções sacras, possui apenas uma imagem de São Sebastião, duas pequenas imagens de outros Santos em um crucifixo" ${ }^{283}$. Para Haskel, possivelmente nunca se tenha celebrado uma missa na capela, dada a precariedade 284 . Quando a Companhia Imobiliária Morumby decide pelo empreendimento, a capela está totalmente arruinada.

279 Pesquisa cartorial realizada por Vilma Gagliardi para o processo municipal de tombamento. Rudge adquiriu a fazenda pela primeira vez em 1813, vende-a e depois a recompra em 1825.

280 Processo PMSP 1992-0.007.730-7, fl. 84

281 Idem

282 Pasta $725.85 \mathrm{fm}$ e processo PMSP 4662/51, respectivamente

283 Processo PMSP 1992-0.007.730-7

284 Idem 
Quando Warchavchik é contratado em 1948, realiza detalhado levantamento, chegando a desenhar as elevações das paredes arruinadas em 1:10 ${ }^{285}$. Aziz Ab'Saber define bem o resultado da intervenção do arquiteto, compreendendo o edifício como um híbrido, duplamente histórico:

As velhas paredes de taipa, sob cujos ombros arruinados Warchavchik iria reconstruir simbolicamente o edifício do pequeno templo - tal como nós o vemos hoje - representou um dos mais bizarros sistemas construtivos, pela técnica da chamada taipa de pilão, conhecida em todo o Brasil. O edifício de hoje é duplamente histórico: incorpora uma estrutura basal, da mais arcaica de nossas paredes de taipa; e é completado, em estilo livre pseudo colonial por uma arcabouço de paredes de tijolo rebocadas, madeirame de cobertura renovado e telhas de calhas opósitas, de tipo clássico amorfo. A base da capela é o passado; as paredes superiores e o telhado representam um estilo pseudo-colonial livre e simbólico, formando um conjunto de inusitada beleza estética. Uma concepção do passado, em estado de ruínas, acaba por ser aviventada por uma concepção reconstrutiva da lavra de um modernista sensível e criativo. Warchavchik acrescentou modernidade estilizada independente apenas na amurada de pedras e na escadaria lateral assimétrica, ao mascarar o velho barranco existente entre o patamar suspenso em que foi construída a capela e a rua e avenida de hoje, situada a alguns metros abaixo (...). Um caso de leitura complexa, que envolve concepções sobrepostas de admirável efeito final. Uma obra de escravos reconstruída por trabalhadores livres ${ }^{286}$.

Certamente a formação italiana de Warchavchik o orientou a respeitar o elemento existente, distinguindo sua intervenção, que valorizava e deixava à mostra a beleza bruta das paredes arruinadas. De planta singela, a Capela receberia um afresco no batistério de autoria de Lúcia Suanê, que encenava um batismo de Cristo no qual os anjos tinham feições indígenas. Além de Warchavchik para o projeto de arquitetura, Renata Crespi confiaria a P. M. Bardi a decoração. Em carta à comitente, Bardi, "na qualidade de superintendente da decoração", informava que estivera em visita ao local com a crítica de arte norte-americana Florence Arquim, que elogiou o mural de Suanê e que Alcides da Rocha Miranda, do Sphan, “confirmou, entusiasticamente, o acerto da escolha do nome da pintora (...)". Por fim sugeria uma visita à capela junto com Warchavchik ${ }^{287}$. Anteriormente, Warchavchik teria convidado seu concunhado Lasar Segall a realizá-lo, mas um desentendimento com Bardi em visita ao local teria inviabilizado o trabalho. Bardi questionou se não soaria estranho às pessoas um judeu realizar uma pintura em uma igreja e Segall, insultado, recusou-se a fazê-la ${ }^{288}$.

Para a obra, Warchavchik estipulava uma equipe de dois pedreiros e três serventes 
e arrolava os materiais e quantidades necessários - tijolos, telhas, tesouras, janelas, portas, dobradiças, fechaduras, forro, tábua para assoalho, paus roliços, ripas, areia, saibro, cal, cimento e barras de ferro de seção 5/16" 289 . Imaginamos que as 12 barras de ferro e os 10 sacos de cimento especificados teriam sido utilizados apenas na execução de cintas de amarração ou vergas, pois além de a quantidade de cimento ser insuficiente para assentar e revestir toda a superfície nova, a argamassa de revestimento existente não apresenta coloração compatível com o uso deste material, provavelmente sendo composta de cal, areia e saibro, materiais que constam do memorial em quantidade de 50 sacos, $4 \mathrm{~m}^{3}$ e $10 \mathrm{~m}^{3}$ respectivamente.

O projeto foi submetido à prefeitura em 6/05/1949, apresentado como projeto de restauro. Nas plantas, são identificadas as paredes existentes e as a construir e no memorial explicita-se a intenção do arquiteto:

Preliminares - Características da Ruína: As paredes são de terra batida, variando sua espessura entre 0,45 a 0,60 .

\section{$\underline{\text { Restauro }}$}

Paredes de elevação - Sobre as ruinas de terra batida, serão levantadas paredes de alvenaria de tijolos, recuados 0,08 da existente, sem rejuntamento até atingir o respaldo.

Cobertura - A cobertura será de telhas comuns sobre madeiramento de pau roliço. O forro será de madeira.

Pisos - Todos os pisos serão de tijolos requeimados e rejuntados de cimento.

Esquadrias - Janelas de 2 folhas, tipo calha, de abrir para dentro. Externamente grade de proteção de pau roliço. As portas serão de Cabreuva, em 2 folhas com taboas largas.

Pinturas - Todos os comodos serão caiados, exceptuando as paredes existentes. Os forros serão pintados a oleo ${ }^{290}$

O recuo de $8 \mathrm{~cm}$ e a utilização de tijolos aparentes visavam não dissimular a técnica. A alvenaria acabou sendo revestida, mas seu pano rebaixado e o revestimento ainda contrastavam claramente com as grossas e aparentes paredes de taipa. A aprovação sairia no início de agosto do mesmo ano, mas antes mesmo disso, servindo-se do artigo $67^{\circ}$ do código de Obras Arthur Saboia, Warchavchik comunicava o início da obra em 31/05/1949291 . O código estabelecia o prazo de 20 dias para aprovação dos projetos, contados da data de entrada no protocolo. Passado este prazo, o requerente poderia iniciar a obra mediante comunicação prévia. 
Inevitável é a comparação da Capela do Morumbi com os restauros de linhagem violletiana praticados pelo Sphan no mesmo período ${ }^{292}$. Em certo sentido, em ambos há um quê de invenção. Entretanto, na capela a distinção com relação ao existente faz da nova camada uma clara releitura contemporânea, que recupera simbolicamente a sua função religiosa. O grau de intervenção faz com que esta não possa ser chamada de restauro e, sem querer dissimular seus traços novos, não tem como princípio a volta no tempo e a pureza da obra original, colocando-se em oposição aos restauros do Sphan. Chega a ser irônico que no trato da preexistência histórica, Warchavchik se difira do cânone estabelecido pelo Sphan do mesmo modo como suas obras vanguardistas de toques internacionais em relação aos cariocas afeitos às curvas de nossa tradição colonial.

E será esta concepção diversa que causará estranhamento aos preservacionistas do Condephaat, que por duas vezes negará seu tombamento.

A argumentação do relator do processo, o arquiteto Carlos Lemos, é clara:

Tal tombamento, portanto, teria como justificativa o maior interesse turístico, o qual, evidentemente não pode ser atribuído somente a uma construção - sem que se atente à paisagem envoltória. Conclui-se que urge um estudo detalhado das condições paisagísticas do local, que vão desde a vegetação, as construções e, principalmente, até a vista que se descortina daquele sítio.

Sob o ponto de vista histórico, artístico ou arquitetônico nada podemos descobrir de importante que possa justificar de modo plausível o pretendido tombamento. Da arquitetura antiga de taipa de pilão praticamente nada mais há, devido às sucessivas reformas e adaptações. A principal intervenção, feita pelo arquiteto Warchavchik, desfigurou-a completamente, impedindo, praticamente, a reversão ao feitio original. Quanto ao valor histórico, ignoramos fatos ou eventos de interesse social ou cultural que realmente justifiquem a inserção daquela construção rural nos livros do tombo deste Condephaat (grifo nosso).

A votação do primeiro processo, de 1974, aberto por solicitação da Sociedade Amigos da Cidade Jardim, ocorrida em abril de 1975, foi empatada, cabendo ao presidente, Luis Saia, o voto de desempate. O perfil intelectual de ambos, Lemos e Saia, não pode ser descartada para o entendimento sobre a negativa dada. A purificação ao original tornara-se inviável na casa-sede e a capela era pura invenção, não merecendo, portanto, a proteção estadual.

A um só tempo, o arquivamento do processo silenciou sobre uma demanda da sociedade civil com relação a um elemento referencial para o bairro, descartou a intervenção de Warchavchik, considerando-a descaracterização - que inviabilizara a "reversão ao feitio original” - e assumiu uma noção antiga de patrimônio, na qual o valor histórico se resume a fatos ou eventos testemunhados pelo bem material. 
Em 1975, preocupado com a conservação da Capela, o antigo Departamento de Cultura solicita e obtém a guarda do imóvel. Tendo em vista a adequação ao intencionado programa expositivo, o DPH promove uma reforma em 1979, retirando o altar, inserindo ambientes de apoio - copa, depósito e sanitários - na antiga sacristia da nave lateral, em linguagem claramente contemporânea. A inauguração da Capela ocorreu em 25/01/1980, ficando aberta para visitação desde então. O projeto foi posteriormente criticado por membros da STPRC por trazer instalações hidráulicas para o interior da construção, convertendo-se em risco potencial para as paredes de taipa ${ }^{293}$. O espaço seria dedicado a concertos musicais e exposições, privilegiando-se a arte contemporânea e a realização de instalações especialmente para o local ${ }^{294}$. A própria secretaria da cultura considerava interessante o tombamento da Capela que, não estando sob qualquer ameaça de demolição, significaria tão somente o reconhecimento de seu valor cultural.

Em 1982, a Secretaria Municipal de Cultura solicitava ao Condephaat o tombamento da Capela do Morumbi, quando o Conpresp ainda não havia sido criado. O pedido assinado pelo secretário municipal Mário Chamie englobava também a Casa do bandeirante (Butantã) e a Casa do sertanista (Caxingui), que expunha suas razões:

Considerando o alto valor histórico e cultural desses imóveis, todos devidamente restaurados e transformados em Casas Museu, cuja manutenção e preservação está a cargo desta Pasta, solicito, como medida de interesse público, que seja iniciado por esse prestigioso órgão, o competente processo de tombamento desse precioso patrimônio documental ${ }^{295}$.

Contudo, Carlos Lemos novamente é designado relator, e seguindo as trilhas do parecer dado ao processo de 1974, sugere o arquivamento deste. Para ele,

Aquele renomado arquiteto, no entanto, não teve preocupação alguma, nas duas intervenções, em ater-se às regras técnico-construtivas próprias da arquitetura tradicional paulistana, fazendo ali verdadeiras invenções que agora não vale a pena comentar, ficando assinalado somente que a capela, em sua conformação atual, não filia-se a qualquer corrente arquitetônica do passado, parecendo ter sido inspirada em exemplares hispano-americanos ${ }^{296}$.

Mas o argumento contradiz o seguinte, pois se aqui o problema é o fato de a intervenção não buscar dissimular as técnicas construtivas próprias da arquitetura tradicional paulistana nem filiar-se a qualquer corrente arquitetônica do passado, o relator vai então

293 Desde a inauguração, a equipe de projeto do DPH tornou-se responsável pela conservação do imóvel. Já em 1987, o DPH faria uma grande obra de conservação, incluindo a recuperação da cobertura, e até hoje faz manutenção periódica.

294 A proposta de uso do local como site specific permanece até hoje.

295 Condephaat, processo 22263/82, fl. 01

296 Condephaat, processo 22263/82, fl. 35 
condenar a adoção da "unidade estilística":

Sabemos, também, que hoje as recomendações internacionais não toleram o aproveitamento de ruínas no intento de valorizá-las criando novos espaços úteis, ainda mais quando nessa intervenção recorre-se à "unidade estilística”, isto é, apela-se à imitação de soluções próprias do tempo do monumento aproveitado.

Quanto ao tratamento contemporâneo da ruína, haveria que se levar em consideração o contexto de realização da obra e o quanto esta intervenção também se historicizou. $\mathrm{O}$ argumento final era de que o imóvel sendo próprio municipal estaria naturalmente preservado, “fato a nosso ver já suficiente à salvaguarda das taipas históricas”. Com isso, em novembro de 1983 o processo era arquivado.

Apesar de a Secretaria Municipal da Cultura ter tomado a iniciativa do tombamento estadual em 1982, somente 10 anos depois o CONPRESP abriria processo para o tombamento municipal, a partir de pedido formulado pelo então vereador Eduardo Matarazzo Suplicy, que também apoiou a iniciativa da Associação de bairro no primeiro pedido de tombamento estadual. O processo é instruído com ampla pesquisa, aproveitando material realizado para uma exposição na Capela, "Taipa, tijolo e fantasia”, produzindo estudos históricos recorrendo a fontes cartoriais primárias, periódicos e documentos diversos, levantamentos de projetos, levantamento da vegetação, entre outros. Entretanto as leituras e diversas descobertas realizadas pelos estudos parecem não ter sido consideradas pela técnica do DPH responsável pelo parecer final que levaria o processo à votação no CONPRESP, já em 2005. Em sua redação da minuta de Resolução de tombamento, era proposta a preservação apenas da taipa e vegetação na casa-sede, embora já houvesse proteção por legislação específica de vegetação significativa da cidade, e dos afrescos e taipa na Capela. Felizmente a versão final, alterada pelo Conpresp, consideraria as construções como um todo. Ou seja, no conjunto das obras tombadas de Warchavchik, a Capela do Morumbi é a única posterior à consagrada década de 1930, mas sua valoração como bem cultural foi descartada pelo Condephaat graças à intervenção do arquiteto, e no Conpresp por pouco o fim não é o mesmo. 


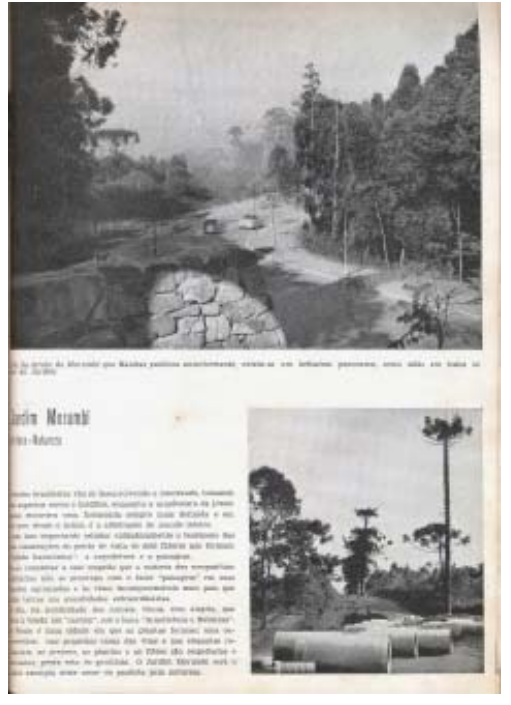

[551] Matéria na Habitat sobre o Morumbi. Na imagem superior da página exibida, a Avenida Morumbi vista do platô da capela.
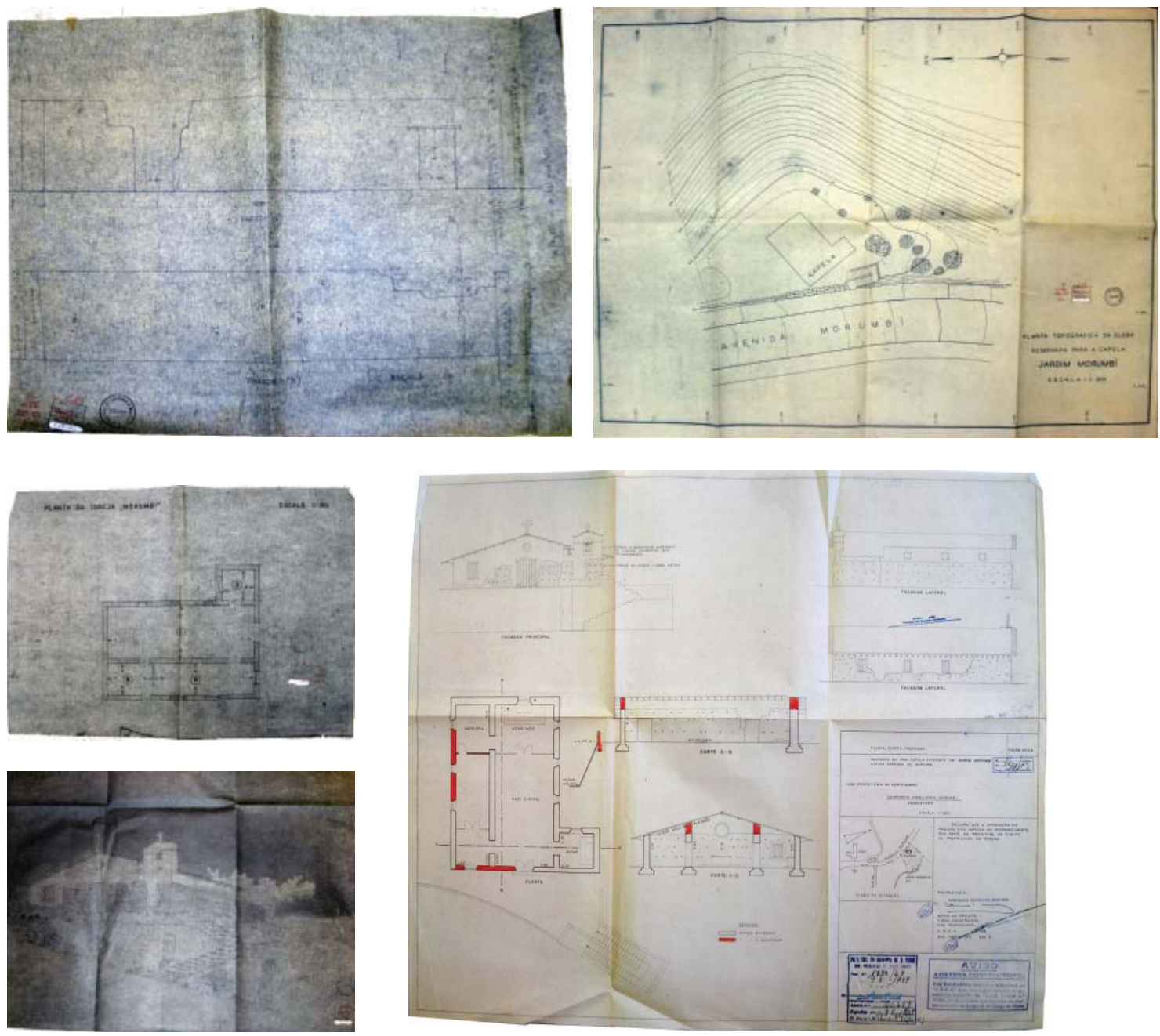

[552] Levantamento das paredes arruinadas em escala 1:10. [553] Levantamento planialtimétrico do local. [554] Planta da capela. [555] Perspectiva da capela. [556] Projeto aprovado pela municipalidade. 

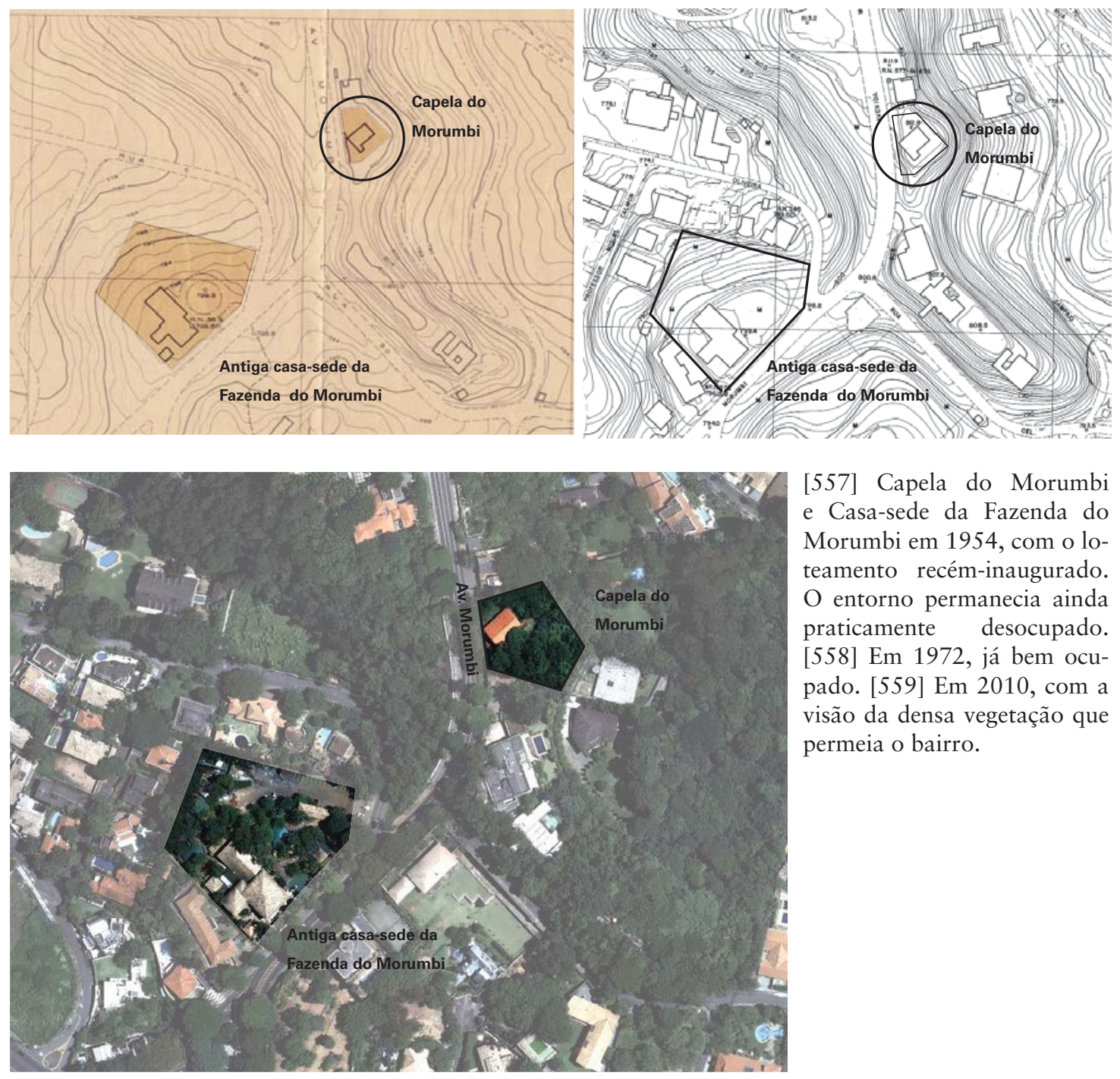

[557] Capela do Morumbi e Casa-sede da Fazenda do Morumbi em 1954, com o loteamento recém-inaugurado. $\mathrm{O}$ entorno permanecia ainda praticamente desocupado. [558] Em 1972, já bem ocupado. [559] Em 2010, com a visão da densa vegetação que permeia o bairro.
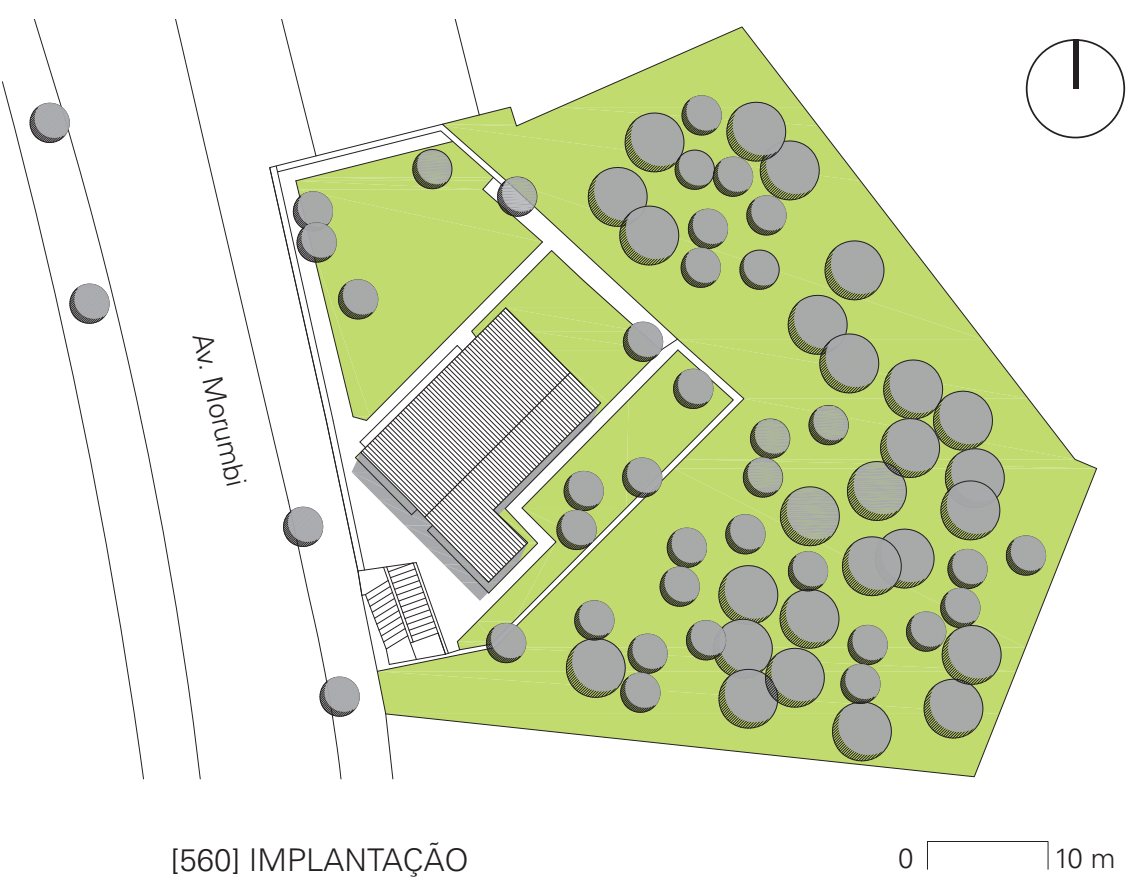


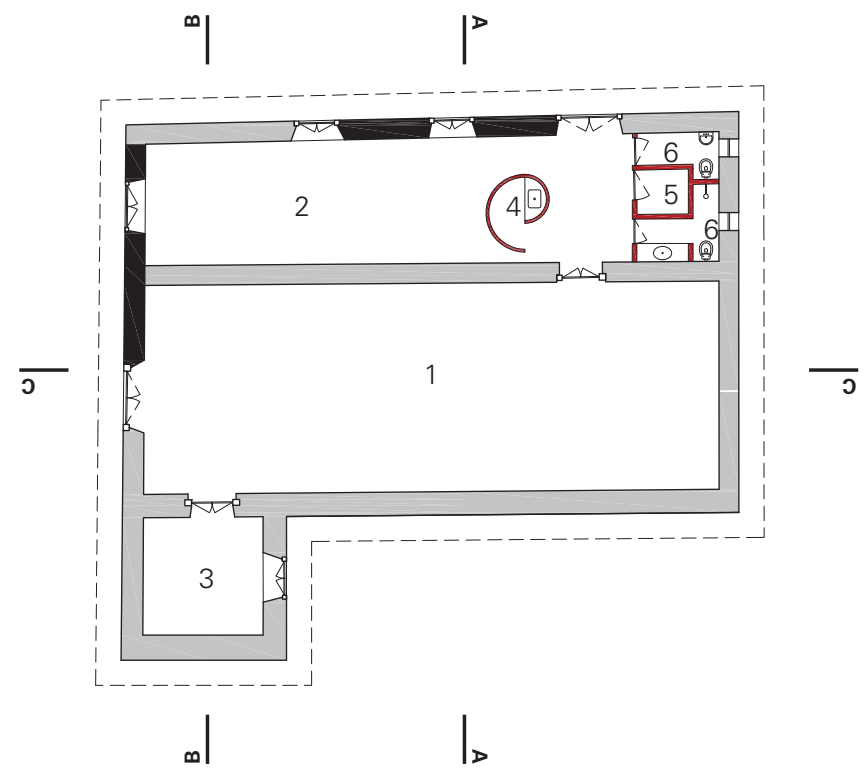

[561] PLANTA

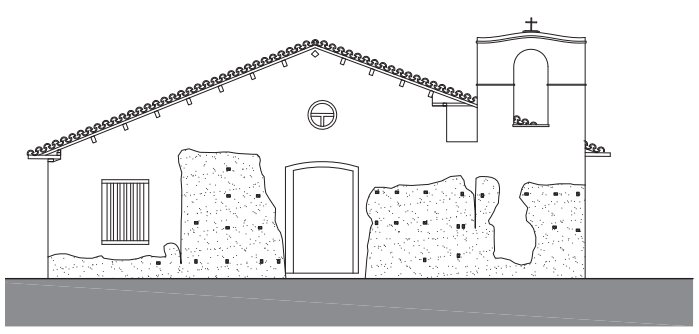

[562] ELEVAÇÃO SUDOESTE

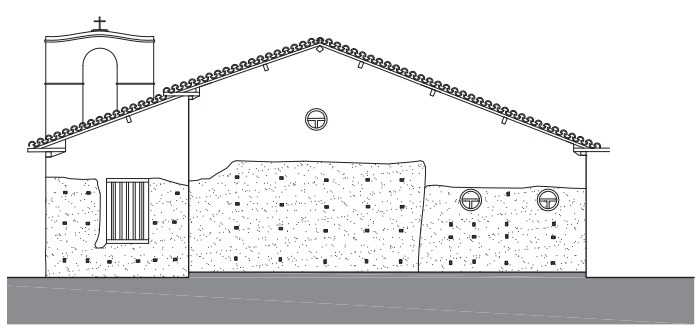

[564] ELEVAÇÃO NORDESTE

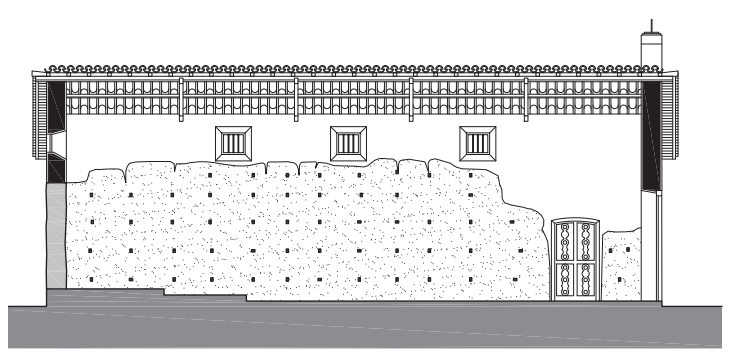

[567] CORTE CC
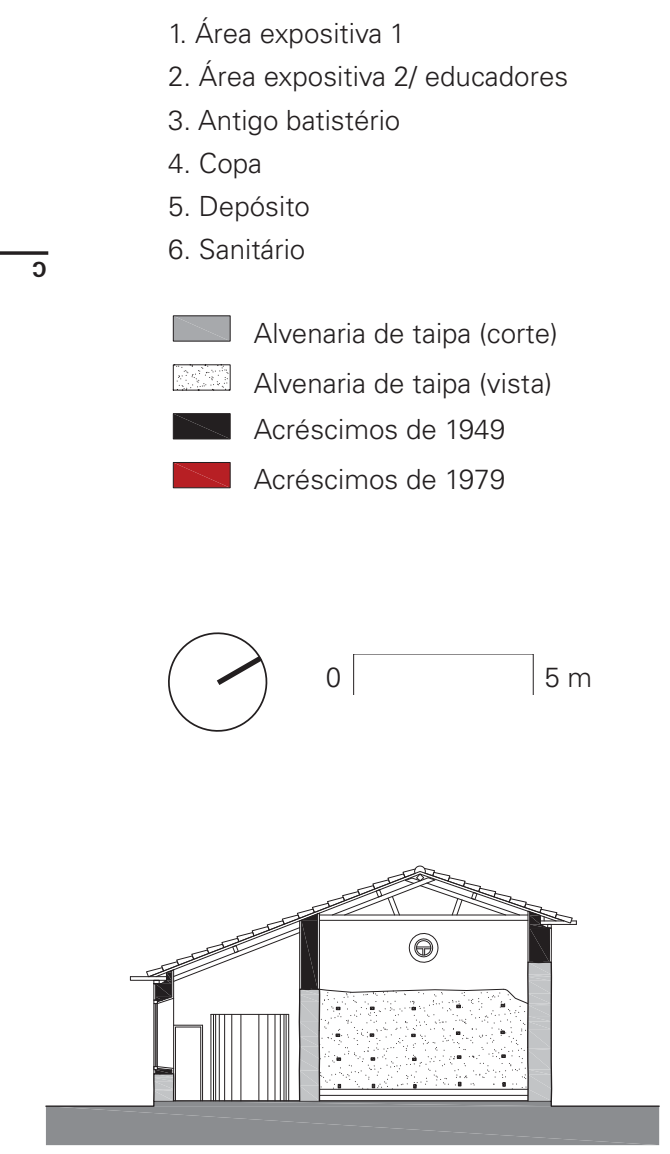

[563] CORTE AA

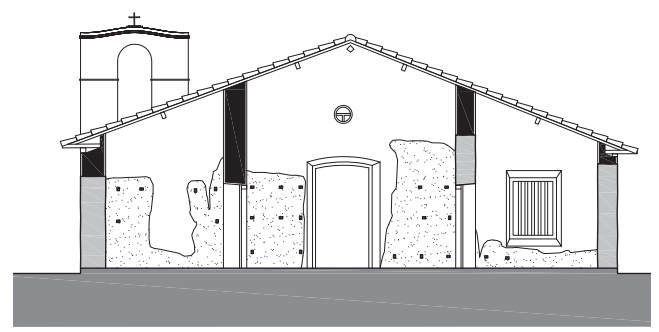

[565] CORTE BB 

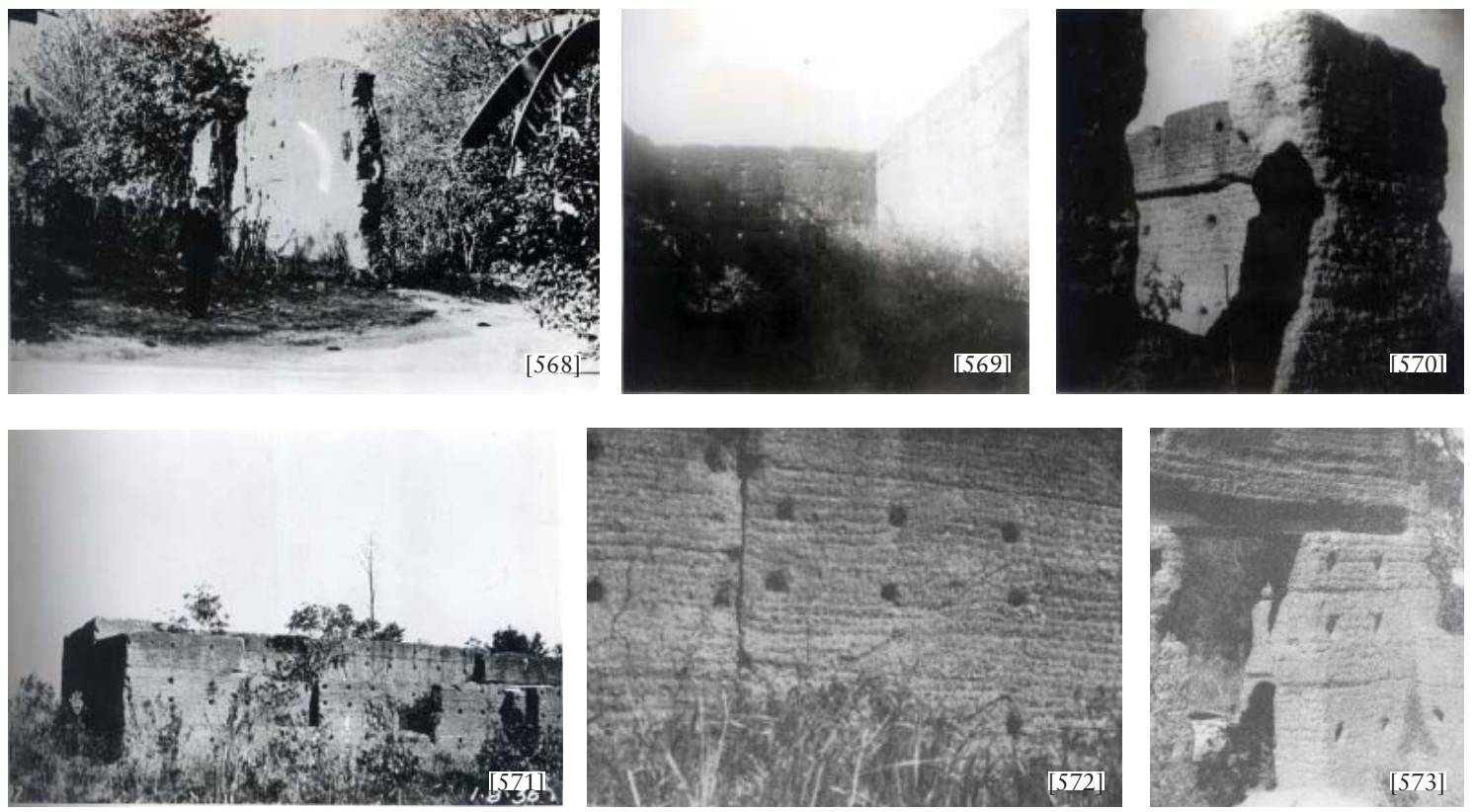

[568] a [571] Registros da ruína em 1936. Imagens da ruína em SCHMIDT, 1946: [572] Detalhe da junta da taipa sem amarração. [573] Vão da verga. Abaixo: [574] a [583] Imagens da Capela recém-inaugurada. [584] e [585] Pormenores do afresco.
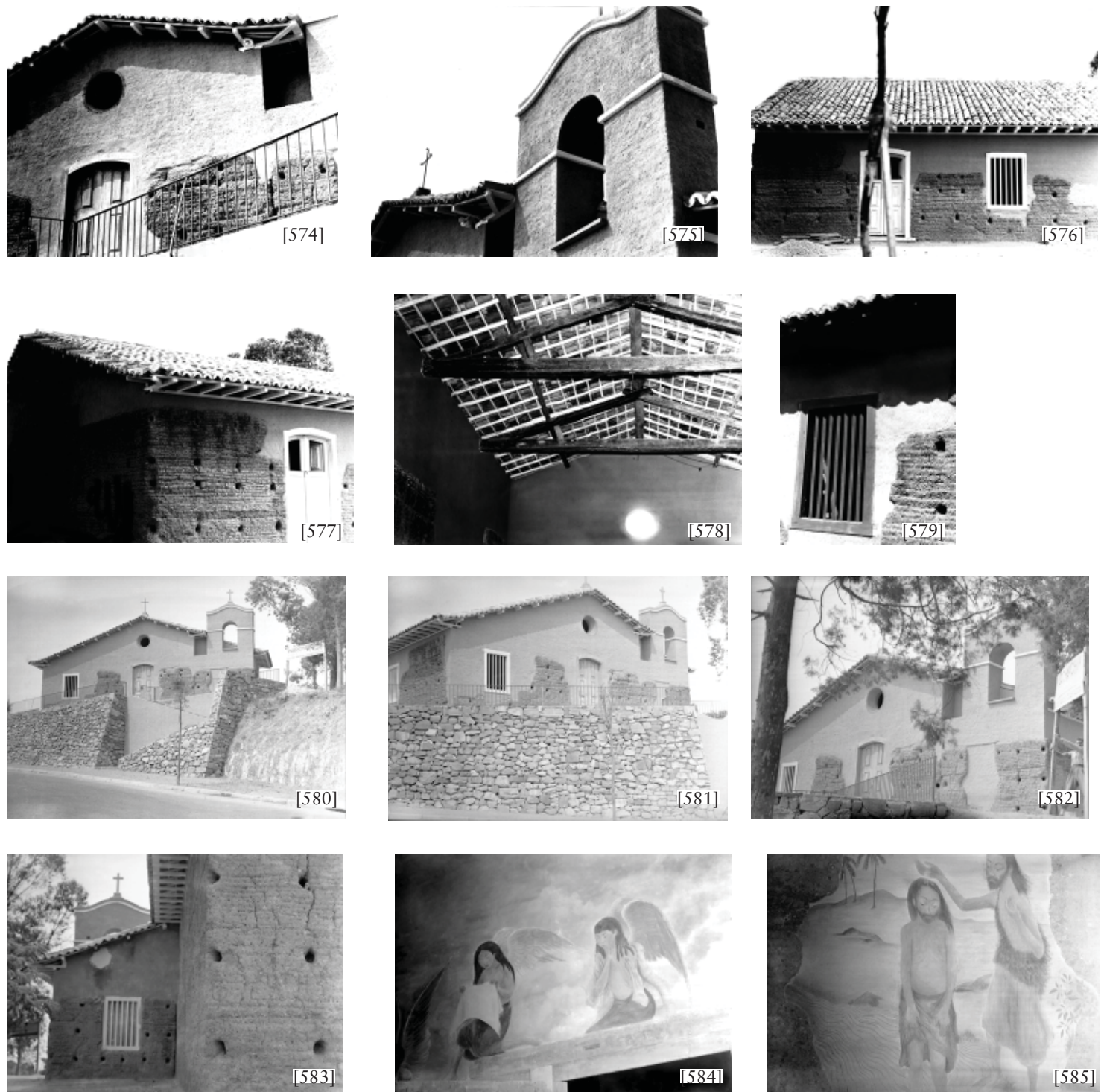

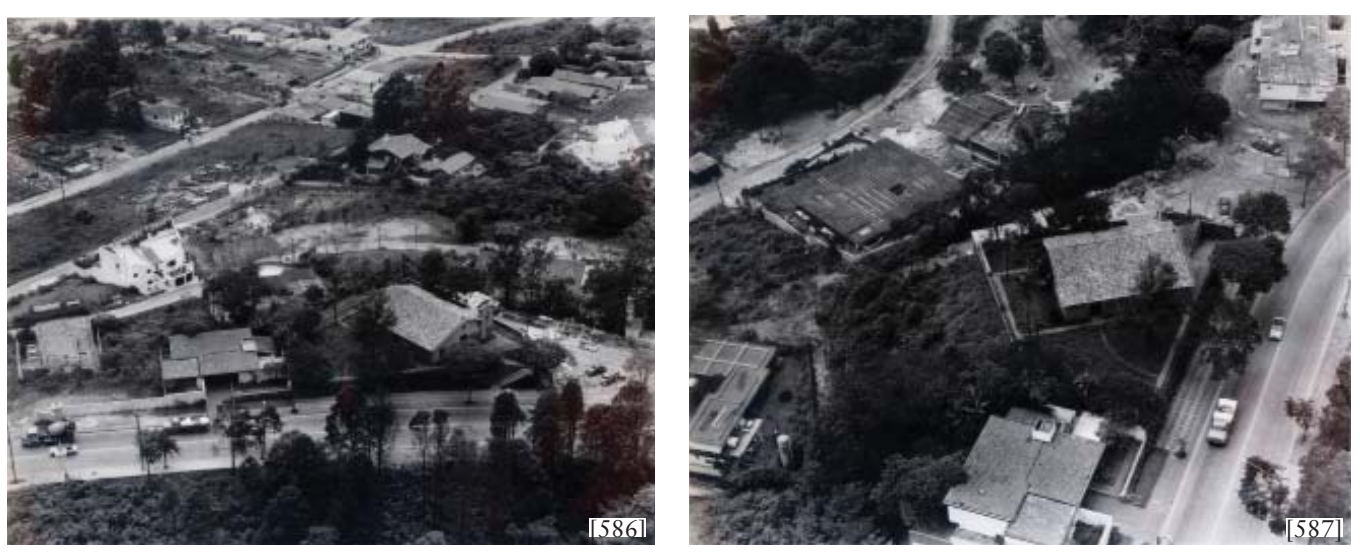

[586] e [587] Vista aérea do imóvel em 1975. Abaixo: [588] a [590] Obras de conservação de 1988.
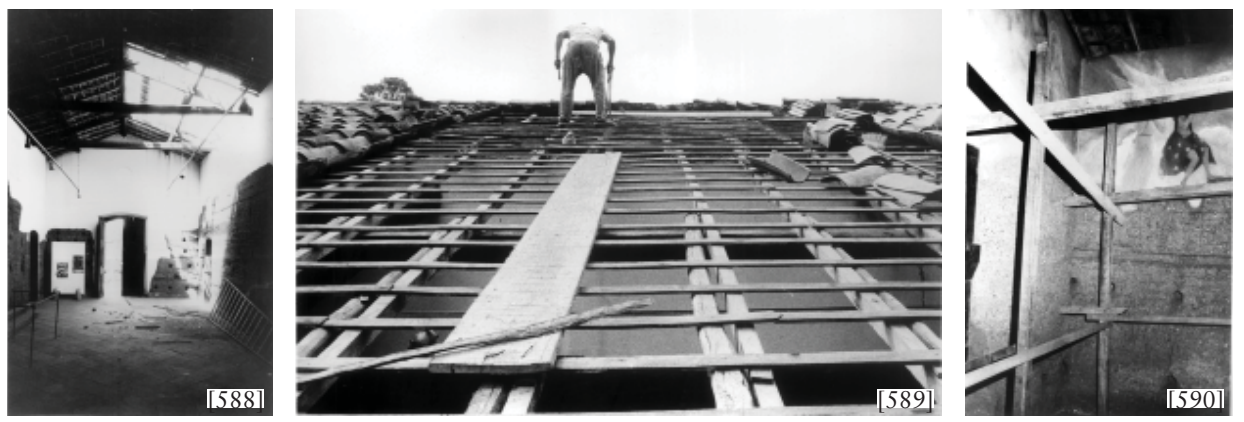

[591] e [592] Vistas frontais da capela hoje. [593] Detalhe da face noroeste. [594] Panorâmica do imóvel, com o muro arrimado de pedra. [595] Fachada noroeste, visto do jardim lateral. [596] A mesma fachada, mais próxima. [597] Fachada oposta, com o volume do batistério ao fundo.
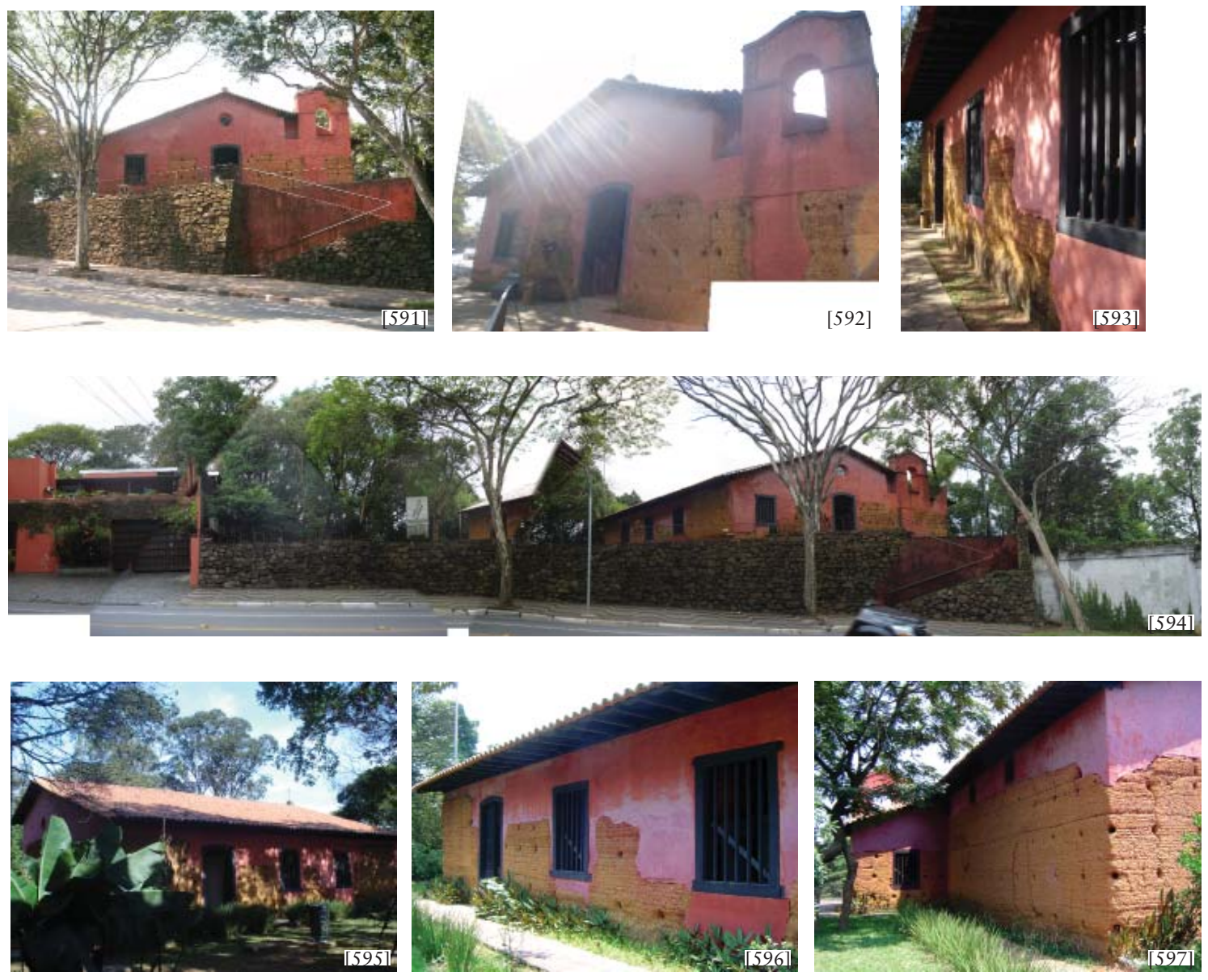

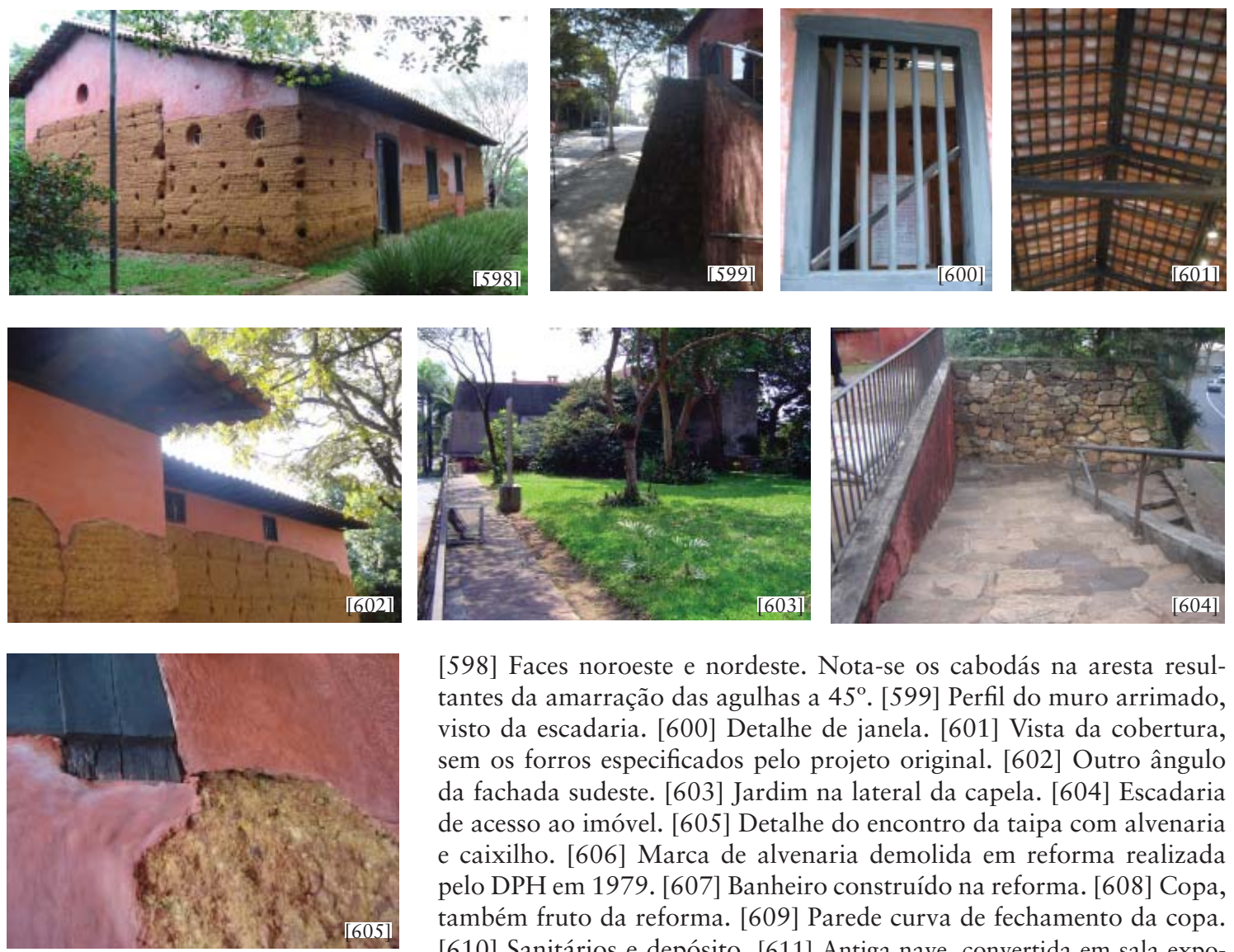

[598] Faces noroeste e nordeste. Nota-se os cabodás na aresta resultantes da amarração das agulhas a 45․ [599] Perfil do muro arrimado, visto da escadaria. [600] Detalhe de janela. [601] Vista da cobertura, sem os forros especificados pelo projeto original. [602] Outro ângulo da fachada sudeste. [603] Jardim na lateral da capela. [604] Escadaria de acesso ao imóvel. [605] Detalhe do encontro da taipa com alvenaria e caixilho. [606] Marca de alvenaria demolida em reforma realizada pelo DPH em 1979. [607] Banheiro construído na reforma. [608] Copa, também fruto da reforma. [609] Parede curva de fechamento da copa. [610] Sanitários e depósito. [611] Antiga nave, convertida em sala expositiva. [612] Sala pelo lado oposto. [613]. Sala lateral, de uso expositivo, administrativo e do serviço educativo. [614] a [615] Trechos do "Batismo de Cristo".
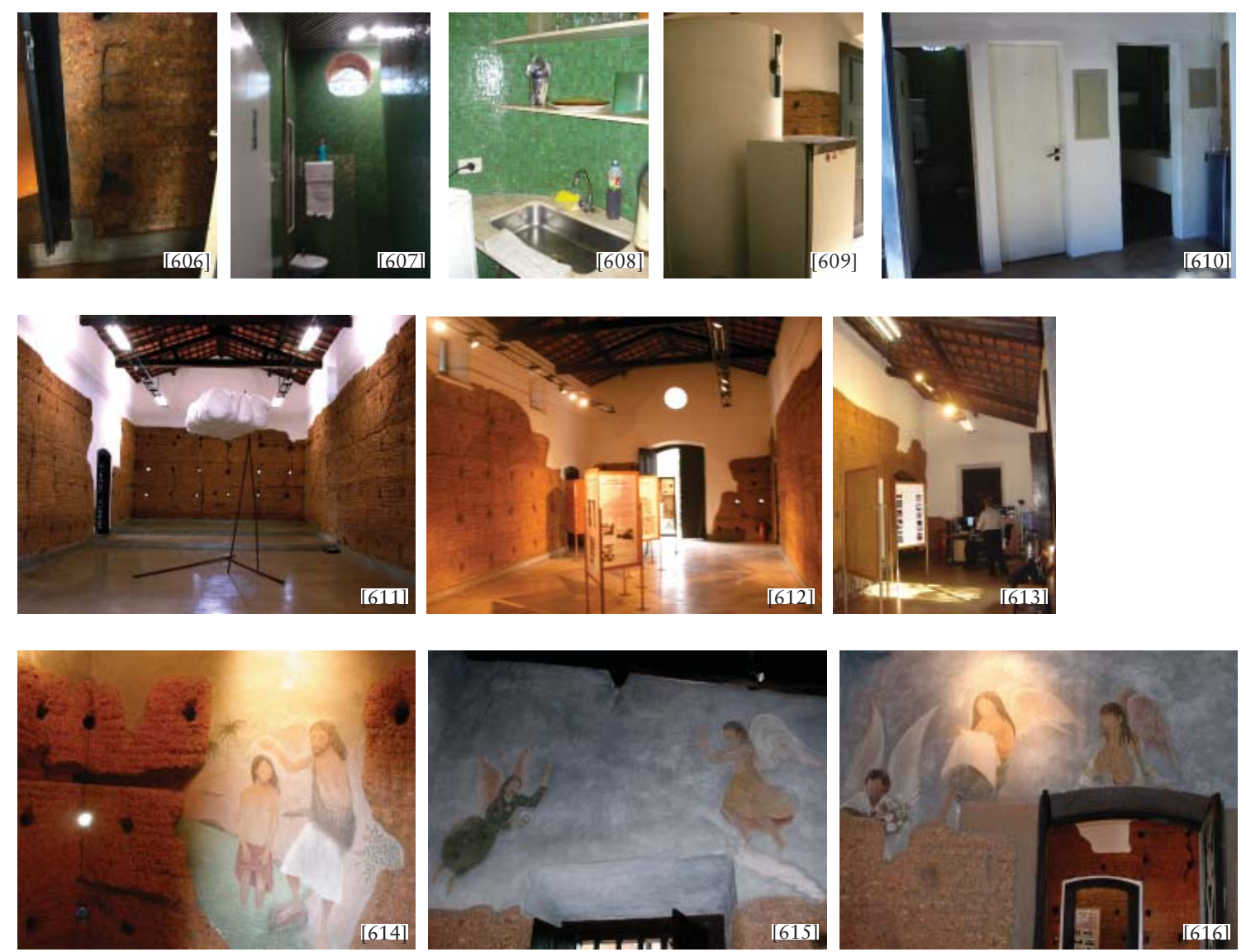


\section{CONSIDERAÇÕES \\ FINAIS}

A pesquisa permitiu um avanço para a compreensão do trabalho de Gregori Warchavchik e para o estudo da preservação do patrimônio brasileiro. Pudemos observar que das nove obras estudadas, seis foram tombadas por pertencerem ao período inicial, desbravador, pioneiro - para os órgãos de preservação, o período "realmente significativo" ${ }^{1}$ da produção do arquiteto: Casas das ruas Santa Cruz, Itápolis, Bahia, conjuntos das ruas Berta e Barão de Jaguara e edifício da Alameda Barão de Limeira, sendo apenas as três primeiras tombadas simultaneamente pelo Iphan, Condephaat e Conpresp.

Tal situação reflete os critérios de seleção das três esferas de preservação, que vêm priorizando a valoração de obras icônicas do movimento moderno em detrimento do reconhecimento de obras de arquitetos menos conhecidos, ou mesmo que não tenham como aspecto principal a autoria do projeto. Grosso modo, o Iphan privilegiando o cânone carioca, o Condephaat, ícones da produção paulista e o Conpresp, alargando o leque de exemplares em uma atuação mais permeável, contudo trabalhando sob demandas, sem uma política definida.

Isto nos parece espelhar a própria relação estabelecida com a historiografia da arquitetura moderna no Brasil, sendo o Iphan o mais próximo ao discurso hegemônico por sua ligação, ao menos historicamente, com os próprios protagonistas do movimento moderno, na dupla conquista do estabelecimento da arquitetura do presente e do passado.

E dos três casos restantes, dois ainda se ligam diretamente ao mesmo fenômeno. A Capela do Morumbi teve o processo de tombamento arquivado pelo Condephaat e por pouco teve preservado apenas o trecho da ruína em taipa pelo Conpresp. A intervenção de Warchavchik é rejeitada pelo órgão estadual, na figura do notório parecerista, Carlos Lemos, talvez o crítico mais contumaz com relação à modernidade da obra do arquiteto. A postura do Condephaat revela não apenas a incompreensão da intervenção como ato histórico, como também a permanência velada do paradigma estilístico por trás da crítica a não adoção das técnicas construtivas tradicionais dissimuladas. Paradigma este que reafirma uma concepção modernista de monumento e monumentalidade, como já desenvolvido por Cerávolo, Mayumi ou Gonçalves². A Vila Dona Bertha seguiu o mesmo caminho, tendo o tombamento cancelado na esfera estadual por ter sofrido intervenções do próprio autor, 
entendidas pelo órgão como descaracterizações.

A residência à Avenida Rebouças, como as seis primeiras, teve o pedido formulado pelo DPH fundamentado no valor da fase pioneira de Warchavchik, mas deixou de ser tombada tanto por supostamente estar descaracterizada quanto por estar degradada. Percebe-se com isso, a fragilidade da composição de um conselho, de caráter eminentemente político, quando surgem questões de natureza crítica e técnica. Para aferir a descaracterização ou degradação do imóvel, é evidente a necessidade de formação na área, entretanto incompatível com a execução do parecer por um relator formado em direito. Mais que isso, a visão pouco proativa deste fez com que o Conpresp se eximisse de sua responsabilidade na tutela dos bens que se quer protegidos.

Nestes arquivamentos, é possível identificar a ideia de que o que deve ser preservado é a obra em seu estado original, descartando-se as intervenções posteriores e contribuições que não se relacionem com a concepção original do projeto. Esta noção, procuramos expor no capítulo 2, terá consequências no tratamento contemporâneo dado ao patrimônio moderno, preferencialmente pautado pela repristinação, pela reconstituição do suposto estado original, nem que à custa da reinvenção desse estado nos moldes violletianos. A incompreensão das intervenções posteriores se dá em um primeiro nível por um tipo de formação dada aos arquitetos, calcada em uma historiografia que tem nas suas origens uma base idealista pouco afeita aos aspectos reais das obras no tempo, mas especialmente pelo fato de os órgãos de preservação privilegiarem os próprios arquitetos como os profissionais a se responsabilizarem pelos processos de seleção e atribuição de valores para a salvaguarda dos bens culturais - de modo geral, portanto, reduzidos aos bens arquitetônicos. Sobre este aspecto, talvez o Iphan venha se atentando mais a outras formas de manifestação cultural, com sua atuação cada vez mais estruturada sobre o patrimônio imaterial e toda a experiência do Instituto desde a sua fase moderna a partir de Aloísio Magalhães, implicando na diminuição do número de tombamentos e concomitante ampliação da prática de registros.

Já a casa da Rua Tomé de Souza obteve sua proteção apenas como forma de driblar a legislação urbanística para a implantação do Centro Cultural que se pretendia instalar no local, sem que de fato ocorresse qualquer reflexão sobre o significado cultural da obra, em um momento anterior à criação do Conpresp. O caso expõe, como tantos, a banalização dos instrumentos preservacionistas e seus conflitos com o planejamento da cidade, comumente ditado pelo desenvolvimento econômico e pela noção conservadora de progresso.

Neste sentido, outro aspecto negativamente exemplar dos casos estudados se refere ao recorrente trabalho de bombeiro dos órgãos de preservação. Os casos das Ruas Berta e Santa Cruz tiveram seus pedidos iniciais gerados pela ameaça de demolição pressionada pelo fantasma do mercado imobiliário. Em plano internacional, a possibilidade da perda tornouse também o mecanismo de sensibilização e reconhecimento de muitos dos exemplares do movimento moderno ao longo dos anos oitenta do século XX, quando então ganha corpo esta nova categoria de bens denominada patrimônio moderno.

$\mathrm{Na}$ atuação de Warchavchik propriamente, esta relação conflituosa com o mercado, 
entretanto, não ocorrerá. O arquiteto transitará livremente entre linguagens, terá sua produção em grande parte viabilizada pelo capital imobiliário familiar e atuará de modo decisivo nos estoques fundiários da família Klabin. A pesquisa se deparou com um vasto universo projetual, constatando que a atuação de Warchavchik como arquiteto e urbanista, ainda que marcando a própria fisionomia de área significativa da Vila Mariana, está por ser estudada. Apesar da maior parte de sua produção residencial voltar-se para um mercado destituído da aura vanguardista, mesmo que em projetos de boa qualidade, tal produção foi ignorada pelos órgãos de preservação. Nem mesmo as obras de maior repercussão publicadas em periódicos especializados nacionais e internacionais até os anos 1950, como os projetos para clubes em São Paulo ou casas de veraneio no Guarujá, mereceram qualquer estudo visando o tombamento. Sobre este aspecto, fica claro o poder que a historiografia hegemônica, focada no estudo genealógico do modernismo nacional, teve de apagar uma produção outrora tão divulgada, como procuramos demonstrar no capítulo 1. E este poder é aferível na permanência ainda hoje de trabalhos de mesma linhagem discursiva, que convivem com abordagens diversas.

Em geral observou-se uma diferenciação no tratamento dado a Warchavchik nas obras monográficas e gerais quanto à sujeição ao cânone, mas mesmo as leituras mais críticas não vêm abordando a obra arquitetônica como documento histórico material do presente. São contribuições de várias naturezas com diferentes pesos, heterogêneas nos enfoques e recortes, sendo alguns trabalhos fundamentais para o desenvolvimento desta pesquisa. Contudo, é necessário discutir as implicações que o distanciamento entre estes dois campos disciplinares - historiografia e preservação - têm trazido à conservação dos bens arquitetônicos.

O entendimento restritivo do papel da conformação original do monumento no que se refere à salvaguarda também trará implicações para o campo operativo do restauro, guiando o restauro da Vila Bertha e sua reconstrução das edículas e desencadeando um processo de restauração da casa da Santa Cruz cheio de problemas. Em ambos os casos, como o tombamento originado da ameaça de demolição, o restauro se coloca por imposição do Ministério Público contra os danos concretos ocasionados por demolição ou avançado estado de deterioração. No caso da Rua Berta, o restauro ocorre em seis das treze casas, recuperando a unidade deste segmento e contribuindo para a leitura harmoniosa do conjunto. O partido da reconstrução das edículas, pensado à luz da ideia de restabelecimento da unidade volumétrica visual no preenchimento das lacunas resultantes da demolição tornase compreensível, embora não se tenha atentado para o princípio da distinguibilidade. Por outro lado, a obra também assumiu a segunda fase figurativa da construção, com a manutenção da cobertura em duas águas em consonância com as cinco casas vizinhas, que mesmo tendo outras feições conseguem no todo preservar a ideia de bloco residencial. A história do processo de restauração do conjunto mostrou a importância da atuação das instituições de preservação, da apropriação e controle social do patrimônio - com o papel fundamental do Museu Lasar Segall - e do trabalho de conscientização e sensibilização para o patrimônio cultural, com a adesão - sem maniqueísmo - do advogado do antigo proprietário à "causa" da preservação. 
Já no restauro da casa da Rua Santa Cruz os desdobramentos foram outros. Vimos que a prática da repristinação prescinde da matéria autêntica à medida que tem como prioridade a forma original em detrimento do artefato como efetivamente se encontra constituído. O restauro a fórceps ocorrido nos anos 2000 denuncia o desprestígio da autenticidade material nas intervenções sobre obras modernas - em primeiro lugar, no real debate sobre a possibilidade de sua conversão à fisionomia de 1928; em segundo lugar, na restauração invasiva, que substituiu muito da matéria autêntica que poderia ter sido preservada. Somado a isso, a intervenção abriu mão de procedimentos caros ao campo do restauro, do levantamento das patologias à documentação do processo, descartando o momento como de investigação de dimensões desconhecidas da obra e tornando inacessível às futuras gerações o contato com a obra autêntica. Ainda no capítulo 2, vimos como a autenticidade fundamenta a noção ocidental de patrimônio, passando por ela o processo de reconhecimento de valor. Considerando que a valoração se origina da interpretação de significados depositados nos objetos por meio da crítica, e que portanto não são condições a eles imanentes, verifica-se o caráter mutável do processo de atribuição de valores. Por mais óbvia que possa parecer tal constatação, muito da prática da preservação não a vem levando em conta, acarretando em ações que negam a historicidade das próprias interpretações e consequentes intervenções por vezes irreversíveis.

Entretanto na casa da Rua Santa Cruz, os problemas observados no restauro do anos 2000 foram fruto não apenas desta visão de fundo, mas também do descaso do Governo estadual para com o imóvel refletido no abandono que fez com que chegasse ao estado de quase ruína, na execução de obras irregulares contratadas pelo menor preço por empresa não especializada, na ausência inicial de projeto de restauro, na falta de fiscalização, na indefinição de uso.

Mas com relação ao patrimônio moderno nem mesmo nos meios especializados ressoa o debate da preservação. Se o Brasil teve papel internacionalmente pioneiro no reconhecimento e proteção de exemplares modernos, pouco tem assistido a discussões teóricas sobre restauração e critérios de preservação e tampouco tem presenciado um número significativo de casos de restauro, refletindo no baixo número de publicações, mesmo em fóruns como o Docomomo. Índices deste fenômeno, até obras tidas como das mais significativas, como os edifícios do MASP e da FAUUSP, vêm sofrendo com o descaso e com intervenções pouco sensíveis à sua preservação.

Ainda nos casos das Ruas Berta e Santa Cruz, o valor econômico se sobrepôs inicialmente ao valor cultural e memorial, mas em ambos os casos a mobilização da comunidade no entorno foi fundamental para a interrupção das negociatas para construção de mais torres residenciais no bairro. No caso da Santa Cruz, há que se fazer a ressalva de que a população inicialmente estava interessada apenas na preservação da área verde, em um momento em que a pauta ambiental e a reivindicação por qualidade de vida passavam a se fazer presentes, e somente com a adesão do Museu Lasar Segall e instituições ligadas à arquitetura as construções de Warchavchik passariam a ser também defendidas. Em certa 
medida o mesmo ocorreu no conjunto da Rua Berta, mas o caso da edificação à Rua Tomé de Souza apresenta-se como o mais claro na utilização distorcida do tombamento, aqui como subterfúgio para driblar a legislação urbanística. Tal distorção acaba por enfraquecer o instrumento do tombamento como meio de reconhecimento de valor cultural e esvazia o sentido das leis de zoneamento e do planejamento urbano. Por outro lado, iniciado como forma de barrar o empreendimento imobiliário, o movimento pela preservação do "parque modernista" com o tempo assimilou a importância histórica do imóvel, exercendo fundamental papel na ocupação cultural do lugar e sua momentânea conservação no decurso do processo judicial.

Porém este tipo de situação é raro na rotina preservacionista, seja por uma prática dos órgãos de preservação pouco atenta à participação popular, seja por uma população que pouco se mobiliza em torno de temas ligados à memória. Com uma política de preservação fechada na repartição, executada por um corpo técnico prioritariamente formado por arquitetos, evidentemente a historiografia da arquitetura passa a exercer papel ativo, pois é através dela que se operarão os processos de seleção e intervenção em obras modernas. E assim, a abordagem sobre as obras destituídas de sua dimensão concreta, construída, real no tempo traz as consequências que procuramos demonstrar ao longo da dissertação. A discussão sobre os instrumentos (para além do tombamento), critérios de salvaguarda (o que preservar e o que não preservar) e critérios de restauro e conservação não vem sendo enfrentada pelos órgãos de preservação, sufocados por uma estrutura precária no atendimento de demandas e urgências.

A outra face desta história especializada, restrita a um seleto grupo de arquitetos é a ausência de consciência sobre a história da cidade por parte da população, a diminuta relação identitária dos grupos sociais com a cidade. Se pudéssemos pensar nas aproximações entre a negação da memória na cidade e na prática corrente do restauro da arquitetura moderna, diríamos que se trata de dois fenômenos devidos à modernidade. No primeiro caso, a urbanização avassaladora, os processos especulativos devastadores, o desterro, a aceleração do tempo-espaço e outros mecanismos se constituíram em formas de controle e espoliação urbana, contrárias às formas de apropriação da cidade. Como o flaneur de Baudellaire ${ }^{3}$, que perdeu seu lugar na metrópole regrada, ditada pelo ritmo do semáforo. Não é objetivo aqui debater sobre este amplo e complexo tema, mas considerando que a cidade não é reflexo, mas condição para realização do capital, tem-se como consequências a produção do espaço homogêneo, normatizado, funcional, acarretando na perda do espaço público, do encontro, do uso, do vivido, das práticas sociais, da memória ${ }^{4}$.

Enquanto o primeiro fenômeno decorre da cidade enquanto mercadoria na qual o valor econômico sobrepõe-se aos demais, o segundo caso, ainda que sofra interferências da questão econômica, apaga a experiência mais em virtude da permanência da ideologia 
moderna em um discurso no qual se quer recuperado um passado puro e ideal que remete às expectativas de quando o projeto moderno era ainda possível. Paradoxalmente, em nome deste passado não reconhecido enquanto tal, a negação do passado cara aos modernos permanece na cultura arquitetônica operativa nos restauros dos seus remanescentes, no descarte da passagem do tempo e como recuperação histórica de seus pressupostos. Entretanto ao restituir suas formas pretéritas, esta cultura arquitetônica contemporânea coloca-se em sentido contrário à preconizada a-historicidade, pois frente ao presente, retoma o passado.

O fenômeno não se restringe à arquitetura moderna nem ao caso brasileiro, mas a análise das obras tombadas de Warchavchik em São Paulo se mostrou adequada como ponto de partida para pensar o problema. Pensar as implicações de um tipo de interpretação historiográfica nas práticas preservacionistas mostrou a extensão e as consequências que a história como disciplina tem sobre os bens culturais. Por outro lado, a proposta de analisar as obras enquanto documentos históricos na chave material, relacionando-os com demais suportes documentais a partir de uma abordagem que trabalha com a noção de trajetória, nos pareceu demonstrar a riqueza de um material historiográfico que revela facetas das obras arquitetônicas ainda pouco exploradas pela bibliografia. A leitura dos processos de aprovação e dos processos de tombamento como instâncias de debate, por exemplo, trouxe elementos sobre as formas como as obras foram percebidas, revelou a possibilidade de uma atuação não documentada de Warchavchik, as datações, entre outros. A leitura das obras em sua consistência física, do olhar sobre as patologias aos canteiros de restauro, do mesmo modo se mostrou proveitosa.

Procuramos com esta pesquisa não apenas abordar outras etapas menos conhecidas de obras já consagradas ou refletir sobre os problemas relacionados aos tombamentos e restauros, mas também rever à luz desse olhar em perspectiva, o próprio momento inicial das obras, a forma de projetar e construir do arquiteto, o estabelecimento de um repertório recorrente calcado em variações de tipologias, esquemas de circulação, elementos arquitetônicos, detalhes construtivos, volumetrias, acabamentos, etc. Ao indagarmos os variados suportes documentais levantados, abriram-se pistas e perguntas sobre como Warchavchik se relacionou com clientes, família e poder público, como essas obras inserem-se na sociedade e na cidade, em que medida assimilam os saberes-fazeres tradicionais ou modernos, como são percebidas, etc.

Não tivemos como objetivo encerrar uma discussão, mas apenas buscar um olhar próprio sobre a obra de Warchavchik, verificando que há muitas possibilidades abertas de investigação sobre um legado que está longe de ter se esgotado, para além das pautas que vêm sendo priorizadas.

Torna-se evidente a necessidade do fortalecimento de uma abordagem menos idealista e mais afeita aos aspectos materiais e reais imersos nas múltiplas temporalidades contidas no objeto histórico, tanto na historiografia quanto na preservação da arquitetura moderna. Do contrário estaremos fadados a apreciar projeções contemporâneas sobre protótipos imperfeitos. 


\section{REFERÊNCIAS BIBLIOGRÁFICAS}

A PRIMEIRA REALIZAÇÃO da Arquitetura Moderna em São Paulo - Gregori Warchavchik, a quem cabe as honras da iniciativa, fala ao Correio Paulistano. Correio Paulistano, São Paulo, 08 jul. 1928

AB'SABER, Aziz. Falam as taipas da Capela. In: Taipa, tijolo e fantasia. São Paulo: SMC/ DPH/STAM/DIM, Capela do Morumbi, 1990

ALLAN, John. MOMO's second chance: The revaluation of inner urban housing in Britain. In: CUNNINGHAM, Allen (ed.). Modern Moviment Heritage. London: E \& FN Spon, 1998.

AMPLIADO o Acervo do Museu de Lasar Segall. A Gazeta, São Paulo, 22 nov. 1966.

ANDRADE, Antônio Luiz Dias de. Um estado completo que pode jamais ter existido. São Paulo: FAU USP, 1993 (Tese de Doutorado)

ANDRADE, Mario de. Cartas de Trabalho: correspondência com Rodrigo Mello Franco de Andrade (1936-1945). Rio de Janeiro: MINC/SPHAN/ Pró-Memória, 1981.

. Exposição duma casa modernista (considerações). Diário Nacional, São Paulo, 05 abr. 1930 a

ANDRADE, Oswald de. A Casa Modernista, o pior crítico do mundo e outras considerações. Diário da Noite, São Paulo, 15 abr. 1930b

ANDRADE, Paulo Raposo; CÂMARA, Andréa Nascimento Dornelas; MEDINA, Luciano L. Edifício do Pavilhão de Óbitos do Recife: Uma experiência de Restauro de Arquitetura Moderna. In: Seminário Docomomo Brasil, 5., 2003, São Carlos. Anais eletrônicos... São Carlos: DOCOMOMO, 2003. Disponível em: <http://www.docomomo.org.br/seminarios $\% 205 \% 20$ S\%20Carlos \%20apresentacao.htm>. Acesso em 20/02/2011

ANGIOLILLO, Francesca. Modernismo versão 2002 - Começa o restauro da Casa Modernista, projeto de Warchavchik que inaugurou o movimento arquitetônico no Brasil. Folha de São Paulo, São Paulo, 28 ago. 2001

ANZIVINO, Gino O. MO.MO. Primo Seminario Restauro del Moderno. Domus, $\mathrm{n}^{\circ}$ 721, 
nov. 1990

AQUINO, Paulo Mauro Mayer de (org.). Gregori Warchavchik-Acervo fotográfico. Vol. I. São Paulo: Família Warchavchik, 2005

(org.). Gregori Warchavchik - Acervo fotográfico. Vol. II. São Paulo: Família Warchavchik, 2007

ARANTES, Antonio Augusto (org); colaboração de Waldisa Russio. Produzindo o passado: estratégias de construção do patrimônio cultural. São Paulo: Brasiliense, 1984.

Documentos Históricos, Documentos de Cultura. Revista do Patrimônio Histórico e Artístico Nacional, Brasília, nº 22. p. 48-55, 1987

ARANTES, Otília. Uma Estratégia Fatal - A Cultura nas Novas Gestões Urbanas. In: ; MARICATO, Ermínia; VAINER, Carlos. A Cidade do Pensamento Único Desmanchando Consensos. Rio de Janeiro: Editora Vozes, 2000 Urbanismo em fim de linha. São Paulo: Edusp, 2001

ARANTES, Paulo. Providências de um Crítico Literário na Periferia do Capitalismo. In: ARANTES, Otília; Sentido da Formação - Três Estudos sobre Antônio Cândido, Gilda de Mello e Souza e Lúcio Costa. São Paulo: Paz e Terra, 1997

ARGAN, Giulio Carlo. História da Arte como História da Cidade. $4^{a}$ edição. São Paulo: Martins Fontes, 1998

ARQUITETURA: Warchavchik depõe sobre Le Corbusier, Gropius e F. L. Wright. Mirante das Artes, nº. 3. São Paulo, p. 18, mai-jun, 1967

ARQUITETURA e arquitetura de jardins. HABITAT - Revista de Artes no Brasil, São Paulo, no 13, ano IV, p. 52, dez. 1953

ASSOCIAÇÃO MUSEU LASAR SEGALL. Jenny K. Segall: alguns textos inéditos e ilustrações, críticas e ensaios sobre suas traduções. São Paulo: Museu Lasar Segall, 1982

ASSOCIAÇÃO PRÓ-PARQUE MODERNISTA. Abertura Parque Modernista. São Paulo: APPM, 1989 (folheto)

. Anita e Oswald de volta ao parque. São Paulo: APPM, 1990a (catálogo de exposição)

. Mobiliário Modernista $1^{\circ}$ tempo/ John Graz e o Design. São Paulo: APPM, $1990 \mathrm{~b}$ . Colibris. São Paulo: APPM, 1991 (catálogo de exposição) - Moya: O Arquiteto da Semana de Arte Moderna. São Paulo: APPM, 1992 
(catálogo de exposição)

São Paulo: A cidade e os trilhos. São Paulo: APPM, 1993 (catálogo de exposição)

BAFFI, Mirthes. Convênio Escolar: A Arquitetura Moderna a Serviço do Ensino Público. In: Seminário Docomomo Brasil, 3., 1999, São Paulo. Anais eletrônicos... São Paulo: DOCOMOMO, 1999. Disponível em: <http://www.docomomo.org.br/seminario\%203\%20pdfs/ subtema_A2F/Mirthes_baffi.pdf>. Acesso em 20/02/2011

BARACUHY, Joana L. Defensor Incansável. Arquitetura e Construção, São Paulo, n.1 v.20, p.74-77, jan. 2004

BARBIERI, Umberto. Il Restauro del Moderno. Abitare, Milano, $\mathrm{n}^{\circ}$ 417, p. 232-235, may 2002

BASILE, Giuseppe (ed.). Il Pensiero di Cesare Brandi dalla teoria alla pratica. Atti dei Seminari. Roma: Il Prato Editore, 2008

BAXANDALL, Michael. Padrões de Intenção - a Explicação Histórica dos Quadros. São Paulo: Companhia das Letras, 2006

BECCARI, Vera d'Horta. Lasar Segall: esboço de um retrato. São Paulo: FFLCH-USP, 1979 (dissertação de mestrado)

BENCLOWICS, Carla Milano. Prelúdio Modernista: Construindo a Habitação Operária em São Paulo. São Paulo: FAUUSP, 1989 (Dissertação de Mestrado)

BENEVOLO, Leonardo. História da Arquitetura Moderna. São Paulo: Perspectiva, 1998

BENJAMIN, Walter. Obras Escolhidas vol. 1 - Magia e Técnica, Arte e Politica. São Paulo: Brasiliense, 1996

BOITO, Camillo. Os restauradores. Tradução: Beatriz Mugayar Kühl, Paulo Mugayar Kühl. São Paulo: Ateliê Editorial, 2002.

BOLETIM do Instituto dos Arquitetos do Brasil. Modern Architecture in Brazil. Acrópole, n.219, jan. 1957

BONDUKI, Nabil. Origens da Habitação Social no Brasil. São Paulo: Estação Liberdade, 2004

BORIANI, Ma è difficile restaurarlo. Abitare, Milano, nº295, p.255, 1990

BOSI, Alfredo. A escrita do testemunho em Memórias do cárcere. Estudos Avançados, São Paulo, n. 9 v. 23, p. 309-322, 1995

BOURDIEU, Pierre. A ilusão biográfica. In: FERREIRA, Marieta de Moraes; AMADO, 
Janaína (org.). Usos \& abusos da história oral. Rio de Janeiro: Fundação Getúlio Vargas, 2000 . O Poder Simbólico. Lisboa: Difel, 1989.

BRANDI, Cesare. Teoria da Restauração. Tradução: Beatriz Mugayar Kühl. São Paulo: Ateliê Editorial, 2004

BRAUDEL, Fernand. Escritos sobre a História. $2^{\mathrm{a}}$ edição. São Paulo: Perspectiva, 2009

BRUAND, Yves. Arquitetura Contemporânea no Brasil. $4^{a}$ ed. São Paulo: Perspectiva, 2002 BURKE, Peter. Abertura: A Nova História, seu passado e seu futuro. In: (Org.). A Escrita da História: Novas Perspectivas. São Paulo: UNESP, 1992.

C. M. B. O Livro de Henrique Mindlin. Brasil-Arquitetura Contemporânea n.8, p.54, 1956 CAMARGO, Mônica Junqueira de. A arquitetura Paulista através das revistas de Engenharia, 1904-1947. Revista d'Art, São Paulo,n.2, p.33-35, 1998

Princípios de arquitetura moderna na obra de Oswaldo Arthur Bratke. São Paulo: FAUUSP, 2000 (Tese de doutorado)

Poéticas da Razão e Construção: Conversa de Paulista. São Paulo: FAUUSP, 2009 (Tese de Livre Docência)

CAMPOFIORITO, Quirino. A Arquitetura Moderna no Brasil. O jornal, Rio de Janeiro, 29 out. 1966

CAMPOS, Eudes. O arquiteto Warchavchik e a Capela do Morumbi-um ensaio intermpretativo. In: Taipa, tijolo e fantasia. São Paulo: SMC/DPH/STAM/DIM, Capela do Morumbi, 1990

CÂNDIDO, Antônio. A Formação da Literatura Brasileira (Momentos Decisivos). $4^{a}$ ed. São Paulo: Martins, 1962.

CÂNDIDO, Antônio. Uma Palavra Instável. In: Vários Escritos. São Paulo: Duas Cidades, 1995 , p. 293 a 305.

CAPPELLO, Maria Beatriz Camargo. Arquitetura em Revista: Arquitetura Moderna no Brasil e sua Recepção nas Revistas Francesas, Inglesas e Italianas (1945-1960). São Paulo: FAUUSP, 2005 (Tese de Doutorado)

CARBONARA, Giovanni. Il restauro del nuovo: problemi generali e il caso del Weissenhof . Avvicinamento al Restauro. Nápoli: Liguori, 1997, p. 581-594

. Il Restauro del Moderno. In: (org). Restauro Architettonico. Vol.

I. Torino: UTET, 2004, p. 75-99 
Il Restauro dell'Architettura Contemporanea. In: (org.). Restauro Architettonico. Vol. IX. Torino: UTET, 2007, p. 6-16

CARRILHO, Marcos. Restauração de Obras Modernas e a Casa da Rua Santa Cruz de Gregori Warchavchik. Revista Eletrônica Vitruvius, Nov. 2000. Disponível em: <http://www. vitruvius.com.br/arquitextos/arq000/esp030.asp>. Acesso em: 12/04/2008

A Restauração da Casa da Rua Santa Cruz. Revista Eletrônica Vitruvius, dez. 2000. Disponível em: <http://www.vitruvius.com.br/minhacidade/mc009/mc009.asp.>. Acesso em: 12/04/2008

O lastimável estado da Casa Modernista transcorridos mais de vinte anos de seu tombamento. Revista Eletrônica Vitruvius, jul. 2003. Disponível em: <http://www. vitruvius.com.br/arquitextos/arq062/arq062_02.asp>. Acesso em: 21/04/2008

CARVALHO, Cláudia S. R. de. Preservação da Arquitetura Moderna: Edifícios de Escritórios no Rio de Janeiro Construídos entre 1930-1960. São Paulo: FAUUSP, 2005 (Tese de Doutorado)

CARVALHO, Lilian Escorel de. A Revista Francesa L'Esprit Nouveau na formação das idéias estéticas e da poética de Mário de Andrade. São Paulo: FFLCH-USP, 2008 (Tese de Doutorado)

CASA DE 1925 na Lapa será tombada e doada. Diário de São Paulo, 23 jul. 1978

CASCIATO, Marstela; DELL'ERBA, Cristina. Saint'Elia Infant School, Como (Giuseppe Terragni). In: CUNNINGHAM, Allen (ed.). Modern Moviment Heritage. London: E \& FN Spon, 1998, p.103-108

CASTELLO BRANCO, Ilda H. Arquitetura no centro da cidade: edifícios de uso coletivo, São Paulo 1930-1950. São Paulo, FAUUSP, 1989 (dissertação de mestrado)

CASTEllo BRANCO, Ilda H. Diniz. No Pacaembu, um Marco da Arquitetura Paulista Moderna. Projeto. São Paulo, nº 60, p. 24-29, fev. 1984

CASTRO, Mariângela; FINGUERUT, Silvia (org.). Igreja da Pampulha: Restauro e Reflexões. Rio de Janeiro, Fundação Roberto Marinho, 2006

CAVALCANTI, Lauro. As Preocupações do Belo. Rio de Janeiro: Taurus, 1995

Quando o Brasil era Moderno: Guia de Arquitetura 1928-1960. Rio de Janeiro: Aeroplano, 2001

CERÁVOLO, Ana Lúcia. Interpretações do Patrimônio: Arquitetura e Urbanismo Moderno na Constituição de uma Cultura de Intervenção no Brasil, anos 1930-60. São Carlos: EESCUSP, 2010 (Tese de Doutorado) 
CHOAY, Françoise. A Alegoria do Patrimônio. Tradução Luciano Vieira Machado. São Paulo: Estação Liberdade/ Unesp, 2001.

Sete proposições sobre o conceito de autenticidade e seu uso nas práticas do patrimônio histórico. Tradução: Beatriz Mugayar Kühl. São Paulo, mimeo, sd (do original: Sept propositions sur le concept d'authenticité et son usage das les pratiques du patrimoine historique. In: Conference sur l'Authenticité. Paris: Unesco, 1995, p. 101-120)

COLLINS, Peter. Influencia de la literatura y la crítica. In: Los ideales de la arquitectura moderna; su evolucion (1750-1950). Barcelona, Gustavo Gili, 1970

COMAS, Carlos Eduardo. Moderna (1930 a 1960). In: MONTEZUMA, Roberto (org). Arquitetura Brasil 500 Anos - uma Invenção Recíproca. Recife: Universidade Federal de Pernambuco, 2002. (vol.1)

COMPANHIA CONSTRUTORA DE SANTOS - legítimo orgulho dos santistas! A Tribuna, 26 jan. 1939. Disponível em: <http://www.novomilenio.inf.br/santos/h0306.htm>. Acesso em: 26 maio 2009

CONGRESSO DE HABITAÇÃO (SÃO PAULO). Annaes do Primeiro Congresso de Habitação de São Paulo. São Paulo: Publicação official - Impresso nas Escolas Profissionaes do Lyceu Coração de Jesus, 1931

CORONA, Eduardo. Modern Architecture in Brazil, Acrópole, São Paulo, n 219, p.115, jan. 1957

COSTA, Eduardo. 'Brazil Builds' e a construção de um moderno, na arquitetura brasileira. Campinas: IFCH-UNICAMP, 2009 (dissertação de mestrado)

COSTA, Helouise; SILVA, Renato Rodrigues. A fotografia moderna no Brasil. São Paulo: Cosac Naify, 2004

COSTA, Lúcio. Arquitetura Brasileira. Rio de Janeiro: Ministério da Educação e Saúde, 1952

Lúcio Costa: Sôbre Arquitetura. XAVIER, Alberto (org.). Porto Alegre :

UFRGS, 1962

Lúcio Costa: Registro de uma Vivência. São Paulo: Empresa das Artes, 1995

COUTINHO, Nogueira. As lições que o mestre deixou. Folha de São Paulo, São Paulo, 29 jul.1972

COUTINHO, Sylvia de S. e S. R. Memória e Esquecimento - Casa Nordschild e a Formação da Arquitetura Moderna no Brasil. Rio de Janeiro: PUC-RJ, 2003 (Dissertação de Mestrado) CUNNINGHAM, Allen. Introduction. In: (ed). Modern Movement Heritage. 
(Preface Robert Maxwell). London: E \& FN Spon, 1998.

CURY, Isabelle (org.). Cartas Patrimoniais. Brasília: IPHAN/ DEPROM, 2000.

DEDECCA, Edgar S. 1930 - O Silêncio dos Vencidos - Memória, história e revolução. São Paulo: Editora Brasiliense, 1997.

DÊGELO, Marilena. Casas modernistas - O Começo de uma nova era. Casa \& Jardim, São Paulo, n. 587, v.50, p. 74-83, dez. 2003

DOCOMOMO. The challenge of change: dealing with the legacy of the modern movement. HEUVEL, Dirk van den (Ed.) [et al]. Amsterdam: IOS Press, 2008

DOMINGUES, José Antônio. Propostas de mudança de diretrizes no processo de restauro da Vila Modernista da rua Berta e proposta de reciclagem arquitetônica. São Paulo: FIAAMFAAM, 2004 (Trabalho Final de Graduação)

DUAS DATAS da arquitetura brasileira. Habitat - Arquitetura e Artes no Brasil, São Paulo, n'25, p. 16, dez. 1955

EMPLASA. Bens Culturais Arquitetônicos no Município e na Região Metropolitana de São Paulo. São Paulo: SMC/EMPLASA, 1984

FALBEL, Anat. As vicissitudes de dois arquitetos modernos. Arcoweb. São Paulo, dez. 2008. Disponível em: < http://www.arcoweb.com.br/index2.php?option=com_content\&task=view \&id=2484\&p...>. Acesso em: 17 jun. 2009

Cartas da América: Arquitetura e Modernidade. In: Seminário Docomomo Brasil, 8., 1 a 5 set. 2009, Rio de Janeiro. Anais eletrônicos... Rio de Janeiro: DOCOMOMO, 2009, 15 p. Disponível em: <http://www.klam.com.br/8docomomo_brasil/> acesso em: out. 2010

FARIAS, Agnaldo A. A Arquitetura Eclipsada: Notas sobre História e Arquitetura a Propósito da Obra de Gregori Warchavchik, Introdutor da Arquitetura Moderna no Brasil. Campinas: UNICAMP - IFCH, 1990 (Dissertação de Mestrado)

Gregori Warchavchik: introdutor da arquitetura moderna no Brasil. Óculum, PUCCAMP - Campinas, n.2, p.8-22, 1992

FAUSTO, Boris. A Revolução de 30: historiografia e história. São Paulo: Cia. das Letras, 1997 . História do Brasil. São Paulo: EDUSP, 2003

FAUUSP. Índice de Arquitetura Brasileira 1950/70. São Paulo: FAUUSP, 1974 . Índice de Arquitetura Brasileira 1971/80. São Paulo: FAUUSP, 1982 
Índice de Arquitetura Brasileira 1981/83. São Paulo: FAUUSP, 1992

Índice de Arquitetura Brasileira 1984/89. São Paulo: FAUUSP, 1995

. Índice de Arquitetura Brasileira 1990/91. São Paulo: FAUUSP, 1996

Índice de Arquitetura Brasileira 1992/93. São Paulo: FAUUSP, 1998

Índice de Arquitetura Brasileira 1994/95. São Paulo: FAUUSP, 2000

FERRAZ, Geraldo. Falta o Depoimento de Lúcio Costa. O Diário de São Paulo, São Paulo, 01 fev 1948. Publicado em Vitruvius - http://www.vitruvius.com.br/documento/arquitetos/ ferraz01.asp, acessado em 20/08/2008.

. Meditação de fim de ano - Uma palavra a arquitetos, engenheiros, urbanistas, sociólogos. Habitat - Arquitetura e Artes no Brasil, São Paulo, n²5, p.12-13 dez. 1955 . Individualidades na História da Arquitetura Brasileira - I. Gregori Warchavchik., no 28, São Paulo, p. 40-48, mar. 1956

Individualidades na História da Atual Arquitetura no Brasil -II -Affonso Eduardo Reidy. HABITAT - Arquitetura e Artes no Brasil, nº 29, p. 38-55, abr. 1956 . Individualidades na História da Atual Arquitetura no Brasil -III -Rino Levi. HABITAT - Arquitetura e Artes no Brasil, São Paulo, nº 30, p. 34-49, maio 1956 . Individualidades na História da Atual Arquitetura no Brasil -IV - M. M. M. Roberto. HABITAT - Arquitetura e Artes no Brasil, São Paulo, nº 31, p. 49-66, jun. 1956 . Individualidades na História da Atual Arquitetura no Brasil -V -Lúcio Costa. HABITAT - Arquitetura e Artes no Brasil, São Paulo, no 35, out. 1956, p. 28-43.

Individualidades na História da Atual Arquitetura no Brasil - VI - Roberto Burle Marx. HABITAT - Arquitetura e Artes no Brasil, São Paulo, n³6, p. 12-24, nov. 1956 . Arquitetura Moderna no Brasil. Habitat - Arquitetura e Artes no Brasil. $\mathrm{n}^{\circ}$ 43, p.30-34, Jul-ago 1957.

- Novos Valores na Arquitetura Brasileira - I - Abelardo Reidy de Souza. Habitat, São Paulo, no 39, p.02-21, fev 1957

Warchavchik e a Introdução da Nova Arquitetura no Brasil: 1925- 1940. São Paulo: Museu de Arte de São Paulo, 1965

. Depois de Tudo. São Paulo: Secretaria Municipal de Cultura/ Rio de Janeiro: Paz e Terra, 1983

FINCH, Paul. The listing of th US embassy was the wrong decision, but still an understand- 
able one. Architects' Journal, London, nº16, v.230, p.17, 5 nov. 2009

FIORE, Renato Hokmer. Warchavchik e o Manifesto de 1925. Arqtexto, Porto Alegre, $\mathrm{n}^{\circ} 2$ v.1, p. 76-87, jan-jun. 2002

FISCHER, S.; ACAYABA, M. M. Arquitetura Moderna Brasileira. São Paulo: Projeto, 1982 FISCHER, Sylvia. Os arquitetos da Poli - Ensino e profissão em São Paulo. São Paulo: Edusp, 2005.

FONSECA, Maisa de Almeida. Revista Acrópole Publica Residências Modernas - Análise da Revista Acrópole e sua Publicação de Residências Unifamiliares Modernas entre os Anos de 1952 a 1971. São Carlos: EESC-USP, 2008 (Dissertação de Mestrado)

FONSECA, Maria Cecília Londres. O Patrimônio em Processo: trajetória da política federal de preservação no Brasil. Rio de Janeiro: UFRJ/MinC - IPHAN, 2005.

FORTY, Adrian; ANDREOLI, Elisabetta (org.). Arquitetura Moderna Brasileira. Londres: Phaidon, 2004

FOUCAULT, Michel. A Arqueologia do Saber. $6^{a}$ ed. Rio de Janeiro: Forense Universitária, 2000

FRANCO, Luis Fernando. Warchavchik e a Arquitetura. Gávea, Rio de Janeiro (PUC-RJ), n. 3, p. 02-13, jun. 1986

FREEMAN, Revista K, n. 1, São Paulo, p.33-35, [200-]

FREITAS, Maria Luisa de. O "Lar Conveniente". Os engenheiros e arquitetos e as inovações espaciais e tecnológicas nas habitações populares de São Paulo (1916-1931). São Carlos: EESC-USP, 2005 (Dissertação de mestrado)

GALLO, Haroldo. O Restauro da Primeira Obra Modernista Brasileira. In: Desafios del Patrimônio Moderno. $2^{\circ}$ Seminário Docomomo Chile. Antofagasta: Emelnor, 2007

GALVÃO, Ana Beatriz. Proposta de restauração - Casa da rua Santa Cruz/Warchavchik. Trabalho de conclusão de curso - V Curso de Conservação e Restauração de Monumentos e Sítios Históricos da FAU-UFBA. Salvador: mimeo, 1984. 4 volumes

GEISER, Reto; STIERLI, Martino. Archtecture Officielle Maudite: The Zurich Kongressnaus Between Preservation and City Marketing. Future Anterior, New York, n ${ }^{\circ}$ 1, v.4, p. 1-12, summ. 2007

GENNARI, Luciana Além. As casas em série do Brás e da Mooca: um aspecto da constituição da cidade de São Paulo. São Paulo: FAUUSP, 2005 (Dissertação de Mestrado).

GIANNECCHINI, Ana Clara. Técnica e estética no concreto armado: Um estudo sobre os 
edifícios do MASP e da FAUUSP. São Paulo: FAUUSP, 2009 (Dissertação de mestrado)

GIEDION, Sigfried. O Brasil e a Arquitetura Contemporânea. In: MINDLIN, Henrique E. Arquitetura Moderna no Brasil. Rio de Janeiro: Aeroplano Editora/ IPHAN, 2004, p. 17-18

GONÇALVES, Cristiane Souza. A experiência do SPHAN em São Paulo, 1937-1975. São Paulo: Annablumme/ Fapesp, 2007

GONSALES, Célia Helena. A preservação do patrimônio moderno: Critérios e valores. In: Seminário Docomomo N-NE. Salvador, 2., 2008, Salvador. Anais eletrônicos... DOCOMOMO, 2008. Disponível em: <http://www.docomomobahia.org/nortenordeste2008.php>. Acesso em: 20/02/2011

GOODWIN, Philip L. Brazil Builds. Architecture New and Old, 1652-1942. Nova York, MoMA, 1943

GORDON, Alastair. Speak Out: "Utopia isn't what it used to be" - the challenge of preserving early modernist houses. Architectural Record, New York, n 185, p. 26, apr. 1997

GOUVEIA, Sonia Maria Milani. A fotografia de arquitetura de Peter Scheier em três publicações. In: Seminário Docomomo Brasil, 8., 1 a 5 set. 2009, Rio de Janeiro. Anais eletrônicos... Rio de Janeiro: DOCOMOMO, 2009, 19 p. Disponível em: <http://www.klam.com. br/8docomomo_brasil/> acesso em: 23 fev. 2011

GUERRA, Abílio. Lúcio Costa, Gregori Warchavchik e Roberto Burle Marx: síntese entre arquitetura e natureza tropical. Revista USP, São Paulo, nº53, p. 18-31, mar-maio 2002

HABITAT - Arquitetura e Artes no Brasil. São Paulo: [s.n.], 1950-1965

HARVEY, David. Condição Pós-Moderna. São Paulo: Loyola, 2006

HENKET, Hubert-Jan. The Icon and the Ordinary. In: CUNNINGHAM, Allen (ed). Modern Movement Heritage. London: E \& FN Spon, 1998. Preface Robert Maxwell

HEYNEN, Hilde. Transiotoriness of Modern Architecture. In: CUNNINGHAM, Allen (ed.). Modern Moviment Heritage. London: E \& FN Spon, 1998 . Architecture and Modernity - A critique. Cambridge: MIT Press, 1999

HITCHCOCK, Henry-Russell. Modern Architecture in Brazil. Journal of Architectural Historians, v.17, n.2, p.30-31, summer, 1958

HOFFMANN, Ana Maria Pimenta. Critica de Artes e as Bienais: As contribuições de Geraldo Ferraz. São Paulo: ECA-USP, 2007 (Tese de Doutorado)

INQUÉRITO NACIONAL DE ARQUITETURA - Gregori Warchavchik e Henrique E. Mindlin. Arquitetura - Revista do Instituto dos Arquitetos do Brasil, Departamento da Gua- 
nabara, $n^{\circ} 4$, p. 12-14, jan/fev 1962

JOKILEHTO, Jukka. A History of Architectural conservation. Oxford: Elsevier, 2006.

JOSÉ, Beatriz Kara. Políticas Culturais e Negócios Urbanos - A instrumentalização da Cultura na Revitalização do Centro de São Paulo 1975-2000. São Paulo: Annablume/ Fapesp, 2007

KOSSOY, Boris. Realidades e ficções na trama fotográfica. São Paulo: Ateliê Editorial, 2009

KÜHL, Beatriz M. Arquitetura do Ferro e a Arquitetura Ferroviária em São Paulo: Reflexões sobre a sua Preservação. São Paulo: Atelier Editorial, 1998

. Os Restauradores e o Pensamento de Camillo Boito. In: BOITO, Camillo. Os restauradores.São Paulo: Ateliê Editorial, 2002.

O problema da reprodução de obras arquitetônicas. Revista CPC, São Paulo, n. 7, pp. 127-136, nov. 2008/abr. 2009

- Preservação do patrimônio arquitetônico da industrialização: Problemas teóricos do restauro. Cotia: Ateliê Editorial, 2009

- Notas sobre a Carta de Veneza. Anais do Museu Paulista, São Paulo, n.2 v.18, p. 287-320, jul.- dez. 2010

L. C. Modern Architecture in Brazil. Brasil - Arquitetura Contemporânea n.8, p.55, 1956

LE GOFF, Jacques. História e Memória. 5ª ed. Campinas: Ed. da UNICAMP, 2003

LEFAIVRE, Liane. Docomomo goes to Paris - When is Modern really modern? Architecture, Washington, ${ }^{\circ} 11$ v.91, p.39-41, nov. 2002

LEFÈBVRE, Henri. O direito à cidade. São Paulo : Centauro, 2006

LEITE, Rogério Proença. Contra-usos da cidade: lugares e espaço publico na experiência urbana contemporânea. Aracaju: Editora UFS, 2004

LEMAIRE, Raymond. Autenticidade e Patrimônio Industrial. Tradução: Beatriz Mugayar Kühl. São Paulo, mimeo, sd (do original: Authenticité et Patrimoine Monumental, Restauro, Napoli, 1994, n.129, p.07-24)

LEMOS, Carlos A. C. Arquitetura Brasileira. São Paulo: EDUSP/ Melhoramentos, 1979 Arquitetura Contemporânea. In: ZANINI, Walter (org). História Geral da Arte no Brasil. Vol.II. São Paulo: Instituto Moreira Salles, 1983a, p.823 - 865.

Os três pretensos abridores de uma porta difícil. In: MUSEU LASAR SEGALL. Warchavchik, Pilon, Rino Levi - três momentos da arquitetura paulista. São Paulo: 
Museu Lasar Segall, 1983. Catálogo de exposição - 6 out a 11 dez 1983b, p.03-06

LEROY, Aline ; BIOLLE, Cécile; REPIQUET, Jacques. Villa Noailles, Hières: Villa Cavrois, Lile (Robert Mallet-Stevens). In: CUNNINGHAM, Allen (ed). Modern Movement Heritage. London: E \& FN Spon, 1998

LIRA, José Tavares Correia de. Ruptura e Construção: Gregori Warchavchik, 1917-1927. Novos Estudos CEBRAP, São Paulo, n. 78, p. 145-167, jul. 2007

Fraturas da Vanguarda em Gregori Warchavchik. São Paulo: FAU-USP, 2008

(Tese de Livre Docência)

LIVROS DE ARQUITETURA. Módulo, n.7, p.46, fev. 1957

LOPOMO, Mário. O Descampado Morumbi. In: São Paulo Minha Cidade.com: Mais de Mil Memórias. São Paulo: SPTURIS/PMSP, 2008, p. 125 e 126. Disponível em: <http://www. saopaulominhacidade.com.br/livro-sao-paulo-minha-cidade.pdf>. Acesso em: 25 abr. 2010

MACINNES, Katherine. The Politics of Preservation. Architectural Design, London, v.64, p.XVI-XIX, may/jun. 1994

MACUL, Márcia. A dor da perda: Casa da Rua Santa Cruz. Arquitetura e Urbanismo, São Paulo, n. 89, v.16, p. 44-46, abr-maio 2000

MARCO, Anita di. DPH Procura Evitar Destruição da Casa da Rua Santa Cruz. Projeto. São Paulo, nº 60, p. 22-23, fev. 1984

MARGALHO, Maurício Gonçalves. Klabin: os empresários, a empresa e as estratégias de construção da hegemonia (1930-1951). Niterói: UFF, 2008

MARINS, Paulo César Garcez. Habitação e Vizinhança: Limites da privacidade no surgimento das metrópoles brasileiras. In: SEVCENKO, Nicolau (org.). História da Vida Privada no Brasil. Vol. 3, Cia. das Letras, São Paulo, 1998

MARTÍNEZ, Ascención Hernández. La Clonación Arquitectónica. Madrid: Siruela, 2007

MARTINS, Carlos A. F. Arquitetura e Estado no Brasil. Elementos para uma Investigação sobre a Constituição do Discurso Moderno no Brasil: A Obra de Lúcio Costa 1924/1952. São Paulo: FFLCH-USP, 1987 (Dissertação de Mestrado)

Gregori Warchavchik: Combates pelo Futuro. In: WARCHAVCHIK, Gregori. Arquitetura do Século XX e outros escritos. São Paulo: Cosac Naify, 2006

"Há algo de irracional"... Notas sobre a historiografia da arquitetura brasileira. In: GUERRA, Abílio (org.). Textos Fundamentais sobre História da Arquitetura Moderna Brasileira - parte 2. São Paulo: Romano Guerra, 2010 
MATOS, Olgária C. F. A Cidade e o tempo: Algumas Reflexões Sobre a Função Social das Lembranças. Espaço e Debates, São Paulo, n 7, p. 45-52, Outubro/Dezembro de 1982

MAYUMI, Lia. Monumento e autenticidade: A preservação do patrimônio arquitetônico no Brasil e no Japão. São Paulo: FAUUSP, 1999 (dissertação de mestrado)

MAYUMI, Lia. Taipa, Canela Preta e Concreto: estudo sobre o restauro de casas bandeiristas. São Paulo: Romano Guerra, 2008

MAZA, Fábio. O Idealismo prático de Roberto Simonsen - Ciência, tecnologia e indústria na construção da Nação. São Paulo: FFLCH-USP, 2002 (Tese de doutorado)

MELHORANDO o aspecto da cidade. Os mais belos edifícios construídos em São Paulo nos anos 1939 e 1940 são os situados à alameda Barão de Limeira 1003 e rua Catanduva 4. A comissão julgadora do concurso instituído pela Prefeitura da Capital. O Estado de São Paulo, São Paulo, 09 jan. 1943

MELLO, Eduardo Kneese de. Sua divisa e pregação. O Estado de São Paulo, 28 jul. 1972

MENDELEZ, Adilson. O que o escotismo tem a ver com a Arquitetura Moderna no Brasil? ARCOweb. Disponível em: < http://www.arcoweb.com.br/memoria/memoria14.asp>. Acesso em: 12 abr. 2008

MENESES, Ulpiano Bezerra de. A História, Cativa da Memória? Para um Mapeamento da Memória no Campo das Ciências Sociais. Revista do IEB, n.34, p. 9-23, 1992

. Memória e Cultura Material: Documentos Pessoais no Espaço Público. Estudos Históricos. Rio de Janeiro, vol. 11, n²1, p. 89-103, 1998

Os Paradoxos da Memória. In: MIRANDA, Danilo (org.). Memória e Cultura - A Importância na Formação Cultural Humana. São Paulo, SESC, 2007

MEUCCI, Simone. Os quartéis, o Estado e a empresa: notas sobre Roberto Simonsen e os dilemas da racionalização institucional no Brasil. In: XIV Congresso Brasileiro de Sociologia, 2009, Rio de Janeiro. Anais eletrônicos... [s.1.]: SBS, 2009. Disponível em: < http://www.sbsociologia.com.br/portal/index.php?option=com_docman $\&$ task=cat_ view\&gid=50\&Itemid=171>. Acesso em: 26 jul. 2009

MICELI, Sérgio. Sphan: Refrigério da cultura oficial. Revista do Patrimônio Histórico e Artístico Nacional, no 22. Brasília, p. 44-47, 1987

Intelectuais à Brasileira. São Paulo: Companhia das Letras, 2001

. Nacional Estrangeiro - História social e cultural do modernismo artístico em

São Paulo. São Paulo: Companhia das Letras, 2003

MINDLIN, Henrique E. Arquitetura Moderna no Brasil. Rio de Janeiro: Aeroplano Editora/ 
IPHAN, 2004.

MIRANDA, Clara Luiza. A Crítica nas Revistas de arquitetura nos anos 50: a expressão plástica e a sintese das artes. São Carlos: EESC-USP, 1998 (Dissertação de Mestrado).

MIRANDA, Rosana Helena. Mooca: lugar de fazer casa. São Paulo: FAUUSP, 2002. (Tese de doutorado)

MODERN Architecture in Brazil. Arquitetura e Engenharia, n.42, ano VII, p.36-37, novdez. 1956.

MODERNIZAÇÃO da Escola de Belas Artes. Impressões de um arquiteto modernista. Jornal do Brasil, Rio de Janeiro, 22 out. 1931

MODERNIZA-SE a nossa arquitetura. Diário Nacional, São Paulo, 17 jun. 1928

MONNIER, Gerard. O Edifício-evento, a história contemporânea e a questão do patrimônio. Tradução: Beatriz M. Kühl. Desígnio - revista de história da arquitetura e do urbanismo, São Paulo, nº6, p.11-18, set.2006

MONTANER, Josep Maria. Intervenciones em la arquitectura moderna. Paradojas tecnológicas, funcionales y simbólicas: fragilidad, precisión funcional e innovación. In: COMAS, Carlos Eduardo; PEIXOTO, Marta; MARQUES, Sérgio M. (org). O Moderno já passado, O passado no moderno - reciclagem, requalificação, rearquitetura. Porto Alegre: Editora Uniritter, 2009, p. 39-53

MOORE, Rowan. Il Mondo Moderno Invecchia* ( ${ }^{*}$ Da Blueprint n.72, novembre 1990). Abitare, Milano, n²95, p.252-256, 1990

MORAES, Dácio A. de. Premios para os mais belos edificios - no concurso instituído pela Prefeitura Municipal de São Paulo. Acrópole, São Paulo, n.58, p. 370-371, fev. 1943.

MOREIRA, Pedro. Alexandre Altberg e a Arquitetura Nova no Rio de Janeiro. Arquitextos, São Paulo, 05.058, Vitruvius, mar 2005. Disponível em: <http://www.vitruvius.com.br/ revistas/read/arquitextos/05.058/484>. Acesso em: 10/03/2011

MURPHY, Kevin D. The Villa Savoye and the Modernist Historic Monument. Journal of the Society of Architectural Historians, Chicago, ${ }^{\circ}{ }^{1}$ v.61, p. 68-89, mar. 2002

MUSCHAMP, Herbert. Se è Già Storia, Non Va Conservato Anche il Modernismo? L'Architetura, Milano, nº47, p. 146-147, feb-mar. 2001

MUSEU DE ARTE DE SÃO PAULO. Warchavchik e as origens da arquitetura moderna no Brasil. São Paulo: MASP, 1971

MUSEU Lasar Segall vai ser inaugurado amanhã. Diário da Noite, São Paulo, 31 ago. 1966 
MUSEU Lasar Segall. Diário de São Paulo, São Paulo, 15 dez. 1966

MUSEU Lasar Segall. O dia, São Paulo, 31 ago. 1966

MUSEU LASAR SEGALL. Warchavchik, Pilon, Rino Levi - três momentos da arquitetura paulista. São Paulo: Museu Lasar Segall, 1983. Catálogo de exposição - 6 out a $11 \mathrm{dez}$ Parque Modernista: Luta Comunitária. Catálogo de exposição. São Paulo: Museu Lasar Segall, 1984

MUSTONEN, Tapani. The House of Culture, Helsinki (Alvar Aalto). In: CUNNINGHAM, Allen (ed.). Modern Moviment Heritage. London: E \& FN Spon, 1998, p. 96-102

NA FACULDADE de Arquitetura e Urbanismo . Habitat - Arquitetura e Artes no Brasil, São Paulo, nº25, p. 16 dez. 1955

NASCIMENTO, Flávia Brito do. Conjuntos Residenciais Modernos: valor e preservação. In: Seminário Docomomo Brasil, $7^{\circ}$, 2007, Porto Alegre. Anais eletrônicos... DOCOMOMO, 2007. Disponível em: < http://www.docomomo.org.br/seminarios \%207\%20Porto\%20 Alegre\%20apresentacao.htm>. Acesso em 20/02/2011, 13 p.

NEUTRA, Richard J. Observations on Latin America. Progressive Architecture, New York, n. 5, p.67-72, maio 1946

NEVES, Christiano das. A máquina de Habitar do Pacaembú. Diário de São Paulo, São Paulo, 16 abr. 1930

O'CONNOR, Helen. To Preserve it in Aspic is to Deny it a Life. Architects' Journal, London, $\mathrm{n}^{\circ} 2$ v.226, p. $25-35,12$ jul. 2007

OLIVEIRA, Cláudia T. de Andrade et al. O restauro do moderno: o caso do edifício Vilanova Artigas da FAUUSP. In: Seminário Docomomo Brasil, 7º 2007, Porto Alegre. Anais eletrônicos... DOCOMOMO, 2007. Disponível em: < http://www.docomomo.org.br/seminarios \%207\%20Porto\%20Alegre\%20apresentacao.htm>. Acesso em 20/02/2011

PAGANO, Carmela A. D. Aúthos Pagano - O Intelectual, a Obra, o Homem. São Paulo: Instituto de Estudos Superiores Aúthos Pagano, 2010. $2^{\mathrm{a}}$ edição

PAI DA ARQUITETURA É RUSSO E TEM 70 ANOS. Ultima Hora, São Paulo, 22 out. 1966

PAOLI, Maria Célia. São Paulo Operária e suas Imagens (1900-1940). Revista Espaço e Debates no 33, São Paulo, 1991

PEARSON, Clifford A. Renovation - Modern History. As the 20th Century becomes history, its buildings attract the attention of preservationists and raise questions of conservation, change, and authenticity. Architectural Record, New York, p. 141-160, nov. 2001 
PERECIN, Tatiana. Azaléias e Mandacarus: Mina Klabin, paisagismo e modernismo no Brasil. São Carlos: EESC-USP, 2003 (Dissertação de Mestrado)

PERELCHIN, Valeri. Gregori Warchavchik. (tradução: Gustavo Godoy). 1972 [Jornal russo-norte-americano não identificado]

PESSÔA, José (org.). Lúcio Costa: Documentos de trabalho. Rio de Janeiro: IPHAN, 2004

PINHEIRO FILHO, Fernando Antônio. Lasar Segall: Arte em Sociedade. São Paulo: Cosac Naify, 2008.

PINHEIRO, Maria Lúcia Bressan. Modernizada ou Moderna? A arquitetura em São Paulo, 1938-45. São Paulo: FAU-USP, 1997 (tese de doutorado), p. 286-288

Rumo ao moderno: uma historiografia da arquitetura moderna em São Paulo até 1945. In: Seminário Docomomo Brasil, 3., 1999, São Paulo. Anais eletrônicos... [s.1.]: DOCOMOMO, 1999. Disponível em: < http://www.docomomo.org.br/seminario\%20 3\%20pdfs/subtema_A1F/Maria_bressan.pdf>. Acesso em 20/07/2008

Dilemas na Preservação da Arquitetura Moderna: O edifício da Faculdade de Arquitetura da USP. In: Seminário Docomomo Brasil, 5., 2003, São Carlos. Anais eletrônicos... São Carlos: DOCOMOMO, 2003. Disponível em: <http://www.docomomo.org. br/seminarios\%205\%20S\%20Carlos\%20apresentacao.htm>. Acesso em 20/02/2011

. Arquitetura residencial verticalizada em São Paulo nas décadas de 1930 e 1940. Anais do Museu Paulista. São Paulo.N. Sér. v.16. n.1.p. 109-149. jan.- jun. 2008 . John Ruskin e as Sete Lâmpadas da Arquitetura - Algumas Repercussões no Brasil. In: RUSKIN, John. A lâmpada da memória. São Paulo: Ateliê Editorial, 2008 PIRES, Walter. Configuração territorial, urbanização e patrimônio: Colônia da Gloria (1876-1904). São Paulo: FAU USP, 2003 (Dissertação de Mestrado)

POLÍCIA interrompe demolição de casas. Folha de São Paulo, São Paulo, 19 fev. 2000

PRADO JR., Caio. A Cidade de São Paulo - Geografia e História. São Paulo: Ed. Brasiliense, 1998.

PROZOROVICH, Fernando Alvarez; ROIG, Jordi . La restauración de La Ricarda. Work in progress. Arquitextos, São Paulo, 05.055, Vitruvius, dez 2004 . Disponível em: <http:// www.vitruvius.com.br/revistas/read/arquitextos/05.055/516>. Acesso em: 15/08/2011

PRUDON, Theodore H. M. Preservation of Modern Architecture. New Jersey: John Wiley \& Sons, 2008

RIEGL, Aloïs. El culto moderno a los monumentos: Caracteres y origen. Madrid: Visor, $2^{\mathrm{a}}$. ed., 1999. 
RODRIGUES, Marly. Imagens do passado: a instituição do patrimônio em São Paulo 19691987. São Paulo: Imprensa Oficial do Estado, 2000.

RUBINO, Silvana. As Fachadas da História: os antecedentes, a criação e os trabalhos do Serviço do Patrimônio Histórico e Artístico Nacional, 1937-1968. Campinas: IFCH-UNICAMP, 1992

RUSKIN, John. A lâmpada da memória. Tradução: Maria Lúcia Bressan Pinheiro. São Paulo: Ateliê Editorial, 2008

SALMONI, Anita; DEBENEDETTI, Emma. Gregori Warchavchik. In: Architettura Italiana a San Paolo. São Paulo: Instituto Cultural Ítalo - Brasileiro, 1953. Coleção "Pasquale Petraccone" de Estudos Italo-Brasileiros ${ }^{\circ} 1$.

SALMONI, Anita; DEBENEDETTI, Emma. Gregori Warchavchik. In: Arquitetura Italiana em São Paulo. São Paulo: Perspectiva, 1981

SALVO, Simona. Arranha-céu Pirelli: Crônica de uma restauração. Revista Desígnio, São Paulo, nº 6, p.69-86, set. 2006

Il Restauro dell'Architettura Contemporanea come Tema Emergente. In: CARBONARA, Giovanni (org.). Restauro Architettonico. Vol. IX. Torino: UTET, 2007a, p. 265-335

. Restauro e "restauros" das obras arquitetônicas do século XX: intervenções em arranha-céus em confronto. Revista CPC, São Paulo, n 4, p. 139-157, maio/out. 2007b SANTOS, Cinthia Regina de Araújo Evangelista. Santos das Avenidas - a moradia burguesa do início do século XX. São Paulo: FAU-USP, 2007 (Dissertação de mestrado)

SANTOS, Paulo Ferreira. Raízes da Arquitetura Contemporânea. Arquitetura e Engenharia, Belo Horizonte, n.30, p.57-65, mar/abr. 1954

- Quatro Séculos de Arquitetura. Barra do Piraí: Fundação Educacional Rosemar Pimentel, 1977

No depoimento de Paulo Santos, um pouco da história da arquitetura brasileira. Projeto, São Paulo, n.33, p.22-24, set. 1981

SÃO PAULO (CIDADE). DEPARTAMENTO DO PATRIMÔNIO HISTÓRICO. Direito à Memória: Patrimônio Histórico e Cidadania. São Paulo: Departamento do Patrimônio Histórico, 1992

SÃO PAULO (ESTADO) Secretaria dos Negócios Metropolitanos. Empresa Metropolitana de Planejamento da Grande São Paulo S/A. Secretaria Municipal de Planejamento. Bens culturais arquitetônicos no município e na Região Metropolitana de São Paulo. São Paulo: SNM, EMPLASA, SEMPLA, 1984 
SARTORIS, Alberto. Gli Elementi dell'Architettura Funzionale - Sintesi Panoramica dell'Architettura Moderna. Milano: Editore Ulrico Hoepli, 1932

SCHMIDT, Carlos Borges. Construções de Taipa: Alguns aspectos do seu emprego e da sua técnica. Boletim de Agricultura. São Paulo: Secretaria de Agricultura, 1946, série $47^{a}$

SCHORSKE, Carl. Viena fin-de-siecle . São Paulo: Cia. das Letras, 1990 . Pensando com a História. São Paulo, Cia das Letras, 2000

SCHWARZ, Roberto. Cultura e Política. São Paulo: Paz e Terra, 2005, $2^{\circ}$ ed.

SE ESSA RUA fosse minha - moradores pedem o tombamento de casas na Vila Mariana. Veja SP, São Paulo, p.114, 24 maio 1989

SEGAWA, Hugo. Warchavchik, Silva Telles, Flávio de Carvalho e Rino Levi: Trajetórias do Modernismo. Projeto, n. 60, São Paulo, p.20, fev. 1984

Arquiteturas do Brasil - 1900 - 1990. São Paulo: Edusp, 2002, $2^{a}$ edição.

Rumo à industrialização: arquitetura da primeira metade do século XX. In:

BICCA, Briane E. P., BICCA, Paulo R. S. (Org). Arquitetura na Formação do Brasil. Brasília: UNESCO, 2006.

SEPULTADO ontem Warchavchik. Diário da Noite, São Paulo, 29 jul. 1972

SEVCENKO, Nicolau. Orfeu estático na metrópole. São Paulo: Cia. das Letras, 1992.

SILVA, Maristela Siolari. Os periódicos de Arquitetura e seus Discursos (décadas de 1920 e 1930 no Brasil). In: Os Periódicos de Arquitetura e a Formação da Arquitetura Moderna Brasileira: Tecnologia e Habitação Econômica (anos 1920 e 1930). São Carlos: EESC - USP, 2008 (Tese de Doutorado)

SILVEIRA, Helena. A morada de Geraldo e Warchavchik. Folha de São Paulo, São Paulo, 07 out. 1966

Paisagem e Memória. Rio de Janeiro: Paz e Terra; São Paulo: SMC, 1983 (coleção depoimentos)

SOUZA, Abelardo de. Gregori Warchavchik. Arquitetura no Brasil - Depoimentos. São Paulo: Livraria Diadorim/ Universidade de São Paulo, 1978, p.49-55

SOUZA, Ricardo F. C. de. Trajetórias da arquitetura modernista. São Paulo: Departamento de Informação e Documentação Artísticas, 1982

. Documento - Gregori Warchavchik: Do Modernismo Oficial à Realidade Brasileira. AU - Arquitetura e Urbanismo. São Paulo, n 44, ano 8, p. 78-90, out/nov. 1992 
. A Revista Especializada de Arquitetura. Revista d'Art, São Paulo, nº1, p.2325,1997

. O Debate Arquitetônico Brasileiro - 1925 - 36. São Paulo: FFLCH-USP, 2004 (Tese de Doutorado)

; MALACO, Jonas Silva. Arquitetura Brasileira: a Palavra de Geraldo Ferraz (entrevista). Revista d'Art, São Paulo, n²2, p.21-26, 1998

STEVENS, Gary. O Círculo Privilegiado: Fundamentos Sociais da Distinção Arquitetônica. Brasília: UnB, 2003

STINCO, Claudia Virginia. Quatro interpretações da Casa Moderna na América Latina. São Paulo: FAU-MACK, 2009 (Tese de Doutorado)

STUCHI, Fabiana T. Revista Habitat: Um Olhar Moderno sobre os Anos 50 em São Paulo. São Paulo: FAUUSP, 2007 (Dissertação de Mestrado).

TAFURI, Manfredo. Teorias e História da Arquitectura. Lisboa: Presença, 1972

TELLES, Augusto Carlos da Silva. Resenhas e notas: Arquitetura Brasileira. Barroco, UFMG, p.149-150, 1980/81.

TELLES, Sofia. A Arquitetura Modernista. Um Espaço sem Lugar. In: GUERRA, Abílio (org.). Textos Fundamentais sobre História da Arquitetura Moderna Brasileira - parte 1. São Paulo: Romano Guerra, 2010, p. 23-34

TINEM, Nelci. O Alvo do Olhar Estrangeiro - O Brasil na Historiografia da Arquitetura Moderna. $6^{a}$ ed. João Pessoa: Editora Universitária, 2006.

TIRELLO, Regina. A Casa Modernista - Relatório do trabalho de sondagens e prospecções de superfícies parietais, forros e caixilhos da CASA MODERNISTA, de Gregory Warchavchik na Rua Santa Cruz, SP. São Paulo, setembro de 2001 (mimeo). 2 volumes

TOURNIKIOTIS, Panayotis. The Historiography of Modern Architecture. Massachusetts: MIT Press, 1999

. Le Corbusier, Giedion and the Villa Savoye - From Consecration to Preservation of Architecture. Future Anterior, New York, nº 1 v.4, p. winter 2007. Disponível em: <http://www.arch.columbia.edu/files/gsapp/imceshared/gjb2011/V4N2_Tournikiotiss.pdf>. Acesso em: 19/02/2011

TRONCA, Ítalo. Revolução de 1930 - A dominação oculta. São Paulo: Editora Brasiliense, 1982

UMA DATA IMPORTANTE DA NOSSA ARQUITETURA. O Estado de São Paulo, São Paulo, 21 abr. 1960 
VÁRIOS AUTORES. Dossiê "Restauro do Patrimônio Construído: Teoria e Prática". Revista Desígnio, no 6 São Paulo: Annablumme e FAUUSP. Setembro de 2006.

VEYNE, Paul. Como se escreve a história. Brasília: UnB, 1982

VILLAÇA, Flávio. Espaço Intra-Urbano no Brasil. São Paulo: Studio Nobel, 1998.

VILLAÇA, Flávio. Sistematização Critica da Obra Escrita sobre Espaço Urbano. Tese de Livre Docência. São Paulo: FAU USP, 1989.

VIOLLET-LE-DUC, Eugène Emmanuel. Restauração. Tradução: Beatriz Mugayar Kühl. São Paulo: Ateliê Editorial, 2000

WARCHAVCHIC. Acrópole, no 334, ano XXVIII, p. 20, nov. 1966

WARCHAVCHIK arquiteto. Acrópole, São Paulo, n. 184, p.163-167, jan. 1954

WARCHAVCHIK Tem Homenagem: Museu. Correio da Manhã, Rio de Janeiro, 27 out. 1966

WARCHAVCHIK: A arquitetura perde um pioneiro. O Estado de Sâo Paulo, São Paulo, 28 jul. 1972

WARCHAVCHIK, Gregori. Arquitetura do século XX e outros escritos. São Paulo: Cosac Naify, 2006

WARCHAVCHIK, Mina Klabin. Moissi Elkana de Posselva. São Paulo, 1966 (mimeo)

WERNING, Remei Capdevila. Construing reconstruction : the Barcelona Pavilion and Nelson Goodman's aesthetic philosophy. Massachusetts: MIT, 2007 (Master of science in architecture studies)

XAVIER, Alberto F. M. (org.). Depoimento de uma geração. São Paulo: Abea, 1987

XAVIER, Alberto; LEMOS, Carlos; CORONA, Eduardo. Roteiro da Arquitetura Contemporânea em São Paulo. Construção São Paulo, São Paulo, n.1605, p.21-24, nov. 1978 . São Paulo - Arquitetura Moderna Paulistana. São Paulo: PINI, 1983.

ZANINI, Ivo. Museu Lasar Segall Fecha para Ampliação. Folha de São Paulo, São Paulo, 16 nov. 1966.

ZEIN, Ruth Verde; MARCO, Anita Regina di. Paradoxos do valor artístico e a definição de critérios de preservação na arquitetura, inclusive moderna. In: Seminário Docomomo N-NE. Salvador, 2., 2008, Salvador. Anais eletrônicos... DOCOMOMO, 2008. Disponível em: <http://www.docomomobahia.org/nortenordeste2008.php>. Acesso em: 20/02/2011 
PROJETOS DE GREGORI WARCHAVCHIK PUBLICADOS EM PERIÓDICOS

A NOVA SEDE do clube atlético paulistano. Habitat, São Paulo, n. 47, p.10-15, mar-abr. 1958

A PRIMEIRA REALIZAÇÃO da Arquitetura Moderna em São Paulo, Correio Paulistano, São Paulo, 08 jul. 1928

ANTE-PROJETO de um conjunto social-religioso - Sede Social e sinagoga da Congregação Israelita Paulista. Habitat, São Paulo, n. 21, p.10-14, mar-abr. 1955

ANTE-PROJETO de um prédio de apartamentos. Acrópole, São Paulo, n. 114, p. 52-53, out. 1947

APARTMENT HOUSE in Sao Paulo, Brazil. Architectural Record, New York, n. 4 v.96, p.88-89 out. 1944

APARTAMENTOS ECONÔMICOS GAMBOA. Architectos: Warchavchik - Lúcio Costa. Revista da Diretoria de Engenharia da Prefeitura do Distrito Federal, Rio de Janeiro, n. 1, p.6, jul. 1932

ARCHITECTURE of Brazil. Architectural Record, New York, n. 1 v.93, p. 34-56, jan. 1943

BRAZIL. Architectural Forum, New York, n. 5 v.87, p. 65-112, nov. 1947

CASA DE CAMPO (Estudo). Acrópole, São Paulo, n. 72, p.389, abr.1944

CLUBE ATLÉTICO PAULISTANO - Nova Sede Social. Acrópole, São Paulo, n. 130 p.299-302, fev. 1949

EDIFÍCIO DE APARTAMENTOS. Acrópole, São Paulo, n. 240, p.543, out

EDIFÍCIO 'LEÔNCIO PEREZ' - Proprietários: Snrs José Perez Moral e Theofilo Perez à Praça Rui Barbosa, 22-24 - Santos - Est. de São Paulo. Acrópole, São Paulo, n. 68, p.226-229, dez. 1943

ESPORTE CLUBE PINHEIROS. Acrópole, São Paulo, n. 218, p.58-61, dez. 1956

ESTÁDIO MUNICIPAL DE SANTOS, Acrópole, São Paulo, n. 60, p.405-412, abr. 1943

FÁBRICA DE EMBALAGENS DE PAPELÃO. Acrópole, São Paulo, n. 280, p.126-127, mar. 1962

GINÁSIO DA ASSOCIAÇÃO “A HEBRAICA”. Acrópole, São Paulo, n. 242, p.58-61, dez. 1958

HABITATIONS INDIVIDUELLES AU BRESIL. L'Architecture d'Aujourd'Hui, Paris, n. 18-19,p. 72-82, jul. 1948

IL 'PADIGLIONE DI MARJORIE’ alla spiaggia di Pernambuco. Domus, Milano, n.2-3, p. $276-$ 277, dez. 1952

LA CASA COL GIARDINO DE SABBIA. Domus, Milano, n.2-3, p. 276-277, dez. 1952

MORUMBI. Habitat, São Paulo, n. 5, p. 66, 1951.

NEUTRA, Richard. Sun Control Devices - A presentation based primarily on examples collected in South America. Progressive Architecture, New York, n. 10, p.88-91, out. 1946 
NOVA SEDE do Club Atlético Paulistano. Acrópole, São Paulo, n. 231, p.95-100, jan. 1958

NUMA IGREJA, Habitat, São Paulo, n.5, p. 67, out-dez.1951

O JARDIM MORUMBÍ - Arquitetura Natureza. Habitat, n.10, p. 26-30, 1953.

PRÉDIO DE APARTAMENTOS á Alameda Barão de Limeira no 1003 - São Paulo. Acrópole, São Paulo, n.35, p.387-389, mar.1941

PREDIO DE APARTAMENTOS TEREJEBA - Praia da Enseada - Guarujá - Est. de São Paulo. Acrópole, São Paulo, n. 111, p.79-81, jul. 1947

RESIDÊNCIA à Avenida Europa - São Paulo - Propriedade do Exmo. Snr. Jacob Klabin Lafer. Acrópole, São Paulo, n.66, p.159-160, out. 1943

RESIDÊNCIA à Avenida Rebouças. Acrópole, São Paulo, n.8, p. 19-21, dez. 1938

RESIDÊNCIA à rua Canadá esq. rua Honduras - Jardim América - São Paulo. Acrópole, São Paulo, n.50, p.76-77, jun. 1942

RESIDÊNCIA á Rua Venezuela, Jardim América - São Paulo. Acrópole, São Paulo, n.35, p.390394, mar. 1941

RESIDÊNCIA do Exmo. Snr. Clinton Edward Croke - Vila Mascote - Jabaquara - São Paulo. Acrópole, São Paulo, n.43, p.265-269, nov. 1941

RESIDÊNCIA do Exmo. Snr. José Perez Moral á Rua Chile, 43 - São Paulo. Acrópole, São Paulo, n.22, p. 5-40, fev. 1940

RESIDÊNCIA do Exmo. Snr. Salomão Klabin à Avenida Europa - Jardim Europa - São Paulo. Acrópole, São Paulo, n. 50, p.74-75, jun. 1942

RESIDÊNCIA EM GUARUJÁ. Arquitetura e Engenharia, Minas Gerais (IAB-MG), n. 16, p. 34 35, mar-abr. 1951

RESIDÊNCIAS modernas na Av. Europa - Jardim Europa - São Paulo. Acrópole, São Paulo, n. 50, p.78-79, jun. 1942

SALÃO DE FESTAS do Clube Pinheiros. Acrópole, São Paulo, n. 237, p.427-431, jul. 1958 SEDE DA FAZENDA Sta. Maria da Calunga. Acrópole, São Paulo, n. 159, p.102-103, jul. 1951 TRÊS TIPOS de Estruturas de Alumínio. Acrópole, São Paulo, n. 267, p.102-103, fev. 1961 UMA CASA NO GUARUJÁ de Gregori Warchavchik. Habitat, São Paulo, n.2,p.17-18, jan-mar. 1951. 


\section{TEXTOS DE GREGORI WARCHAVCHIK PUBLICADOS EM PERIÓDICOS}

O ARRANHA-CÉU tem de romper com o passado também na parte relativa à ornamentação. "Não se deve traduzir cimento armado em grego de Péricles", declara o prof. Gregori I. Warchavchik. Diário da Noite, São Paulo, 22 dez. 1928

WARCHAVCHIK, Gregori. Il Futurismo? Il Piccolo, São Paulo, 14 jun. 1925

Acerca da Arquitetura Moderna. Correio da Manhã, Rio de Janeiro, 01 nov. 1925 Arquitetura Brasileira. Terra Roxa e Outras Terras, São Paulo, 17 set. 1926 Decadência e Renascimento da Arquitetura. Correio Paulistano, São Paulo, 05 ago.

1928 . Arquitetura do Século XX - I. Correio Paulistano, São Paulo, 29 ago. 1928 Arquitetura do Século XX - II. Correio Paulistano, São Paulo, 05 set. 1928 Arquitetura do Século XX - III - Ainda as teorias de Le Corbusier. Correio Paulistano, São Paulo, 14 set. 1928

Arquitetura do Século XX - IV - Passadistas e Futuristas. Correio Paulistano, São Paulo, 23 set. 1928

. Arquitetura do Século XX - V - Um Congresso que Marcou Época na História da Arte. Correio Paulistano, São Paulo, 09 out. 1928

. Arquitetura do Século XX - VI - As Relações entre a Arte e a Cultura. Correio Paulistano, São Paulo, 21 out.1928

. Arquitetura do Século XX - VII - O que Foi a Exposição de Stuttgart. Correio Paulistano, São Paulo, 04 nov. 1928

Arquitetura do Século XX - VIII - Características da Construção Moderna. Correio Paulistano, São Paulo, 21 nov. 1928 Arquitetura do Século XX - IX - Arranha-céus. Correio Paulistano, São Paulo, 02 dez. 1928 Arquitetura do Século XX - X - Arranha-céus. Correio Paulistano, São Paulo, 16 dez. 1928 Arquitetura Nova. Diário da Noite, São Paulo, 20 dez. 1928 Arquitetura Nova. Correio Paulistano, São Paulo, 20 jan. 1929 . São Paulo e a Arquitetura Nova. Ilustração Brasileira, Rio de Janeiro, n.109, set. 1929 . A Exposição da Casa Modernista. Correio Paulistano, São Paulo, 23 mar.1930 Em Torno da Casa Modernista do Pacaembu - Breve Resposta para o Professor 
Christiano das Neves. Diário de São Paulo, São Paulo, 20 abr. 1930

O IV Congresso Panamericano de Arquitetura e Urbanismo que se realiza no Rio. Diário da Noite, São Paulo, jun. 1930

Como julgar a Tendência da Moderna Arquitetura - Decadência ou Ressurgimento? Correio Paulistano, São Paulo, 29 jun. 1930

Resguardando a Estética Arquitetônica da Paulicéia. Diário da Noite, São Paulo, 12 jan. 1931

. O Próximo Congresso de Habitação e o Problema das Casas Econômicas. Folha da Manhã, São Paulo, 06 fev. 1931

A Nomeação para Professores da Escola Nacional de Belas Artes. Diário da Noite, São Paulo, 22 abr. 1931

A Reforma da Escola de Belas Artes e o Salão Oficial deste ano. Diário da Noite, São Paulo, 26 ago. 1931

. A arquitetura viva. O Jornal, Rio de Janeiro, 01 nov. 1931

A arquitetura viva. CTC Cultura, Técnica, Ciência, Rio de Janeiro, 1931

105-109, 1931

L'architecture d'aujourd'hui dans l'Amerique du Sud. Cahiers d'Art, Paris, n.2, p.

Importância e diretivas da arquitetura brasileira. Acrópole, São Paulo, n.232, p. 149 150, fev. 1958 
PROJETOS CONSULTADOS NO ACERVO DA BIBLIOTECA DA FAUUSP

P W196/711.63 A ARRUAMENTO E LOTEAMENTO DE TERRENOS DE PROPRIEDADE DOS HERDEIROS DE MAURÍCIO F. KLABIN - VILA MARIANA - VILA AFONSO CELSO.

P W196/711.63 JM LOTEAMENTO JARDIM MORUMBI. SÃO PAULO, SP

P W196/711.63 LOTEAMENTO NA VILA MARIANA E IPIRANGA LOT

P W196/725.85 CLUBE MORUMBI: PROJETO PARA REFORMA DA SEDE, ANFM V.1-3 TIGA FAZENDA MORUMBY, DE PROPRIEDADE DE CIA IMOBILIÁRIA MORUMBY, SITUADO NO DISTRITO DE STO. AMARO.

P W196/728.1 BL EDIFÍCIO RESIDENCIAL PARA A Sra MINA KLABIN WARCHAVCHIK E GREGORI WARCHAVCHIK À ALAMEDA BARÃO DE LIMEIRA.

P W196/728.1 BLA APARTAMENTOS: ANTE-PROJETO PARA4 PRÉDIOS SITUADOS À ALAMEDA BARÃO DE LIMEIRA.

P W196/728.3 AB RESIDÊNCIA TULIO MINASI: PROJETO DE REFORMA À RUA BAHIA No 1126.

P W196/728.3 AC RESIDÊNCIA MINA KLABIN WARCHAVCHIK À RUA 9, LOTES 14 A 18, TRAV. RUA STA. CRUZ, VILA AFFONSO CELSO, VILA MARIANA: 5 CASAS.

P W196/728.3 AH RESIDÊNCIAS ECONÔMICAS DE PROPRIEDADE DE MINA KLABIN WARCHAVCHIK: ANTE- PROJETO.

P W196/728.3 AI RESIDÊNCIA BERTHA KLABIN.

P W196/728.3 AT RESIDÊNCIA LASAR SEGALL E JENNY KLABIN SEGALL.

P W196/728.3 BE RESIDÊNCIA À RUA DNA. BERTA N'S 14-16-18-20-22, VILA MARIANA: REFORMA.

P W196/728.3 D RESIDÊNCIA À RUIA DOMINGOS DE MORAES: 2 CASA.

P W196/728.3 EP RESIDÊNCIA LUÍS PRADO À RUA BAHIA, 1126.

P W196/728.3 GW RESIDÊNCIA GREGORI WARCHAVCHK À RUA SANTA CRUZ, 325, VILA MARIANA. CASA MODERNISTA (ver obs.)

P W196/728.3 HM RESIDÊNCIA À RUA SANTA CRUZ, PROPRIEDADE DA HERANÇA MAURÍCIO F. KLABIN.

P W196/728.3 RESIDÊNCIA CONJUGADAS ENTRE AS RUAS BARÃO DE JAGHMK UARA, XINGU E ODORICO MENDES, DE PROPRIEDADE DOS HERDEIROS DE MAURÍCIO F. KLABIN.

P W196/728.3 IT RESIDÊNCIA LILLY ALVARES PENTEADO À RUA ITÁPOLIS.

P W196/728.3 KS RESIDÊNCIA JENNY KLABIN SEGAL, 5 CASAS LOCALIZADAS NA VILA MARIANA, SÃO PAULO. 
P W196/728.3 LL RESIDÊNCIAS LUIZ LORCH E LUIZA KLABIN LORCH: PROJETO DE 5 CASAS. VILA AFFONSO CELSO, RUA 9 TRAVESSA DA RUA STA. CRUZ, QUADRA M, LOPES 9 A 13. SÃO PAULO, S.P.

P W196/728.3 MK RESIDÊNCIAS MINA KLABIN WARCHAVCHIK E GREGORI WARCHAVCHIK: PROJETO DE 8 CASS NA VILA MARIANA. SÃO PAULO, SP, 1946.

P W196/728.3 MW RESIDÊNCIA MINA KLABIN WARCHAVCHIK, 2 CASAS À RUA 1 TRAV. RUA 9, QUADRA N, LOTES 1 E 2 NA VILA AFONSO CELSO, VILA MARIANA, SÃO PAULO - SP;

P W196/728.3 PC RESIDÊNCIA MINA KLABIN WARCHAVCHIK: PROJETO DE OITO CASAS À RUA 7. SÃO PAULO

P W196/728.3 PE RESIDÊNCIA MINA KLABIN WARCHAVCHIK, PROJETO PARA CONSTRUÇÃO DE UMA CASA. SÃO PAULO, SP;

P W196/728.3 PS PLANTA DE SITUAÇÃO DE CONJUNTO DE CASAS SITUADAS À AV. DO ESTADO E RUA ODORICO MENDES, DESENHO DE ARTHUR SERRA. SÃO PAULO, SP;

PW196/728.3 RDA RESIDÊNCIA MINA KLABIN WARCHAVCHIK: 14 CASAS À RUA DESEMBARGADOR ARAGÃO, VILA MARIANA. SÃO PAULO, SP, 1957

P W196/728.3 RES RESIDÊNCIA GREGORI WARCHAVCHIK. SÃO PAULO, SP, 1937.

P W196/728.3 RL RESIDÊNCIA RUY LEMOS DE VASCONCELOS, RUA 3, LOTE 18, QUADRA 1, VILA MARIANA

P W196/728.3 RT RESIDÊNCIAS MINA KLABIN WARCHAVCHIK: PROJETO DE SOBRADOS GEMINADOS À RUA 3 ESQUINA RUA SANTA CRUZ, SÃO PAULO, SP.

P W196/728.3 ST RESIDÊNCIA MINA KLABIN WARCHAVCHIK NA RUA SANTA CRUZ, 31, VILA MARIANA: REFORMA.

P W196/728.3 VIL PROJETO DE UMA VILA A SER CONSTRUÍDA SOBRE O TERRENO SITO ENTRE AS RUAS AFONSO CELSO E DOMINGOS DE MORAES DE PROPRIEDADE DA VIÚVA MAURÍCIO F. KLABIN.

P W196/728.3 AX RESIDÊNCIA LUIZA KLABIN LORCH. 


\section{AROUIVOS E ACERVOS CONSULTADOS}

Acervo família Warchavchik

Acervo José Antônio Domingues

Arquivo Histórico Municipal de São Paulo

Arquivo Histórico Municipal de Santos

Arquivo Geral de Processos - PMSP

Biblioteca Nacional

Biblioteca da FAUUSP

Centro Cultural Aúthos Pagano

Centro Cultural São Paulo

CONDEPHAAT

CONPRESP

DPH

IPHAN

Museu de Arte de São Paulo

Museu Lasar Segall

PROCESSOS DE TOMBAMENTO/RESTAURO CONSULTADOS

Iphan

1121-T-84 - Tombamento da Casa da Rua Santa Cruz

1153-T-85 - Tombamento da Casa da Rua Bahia

1154-T-85 - Tombamento da Casa à Rua Itápolis

\section{Condephaat}

00497/74 - Tombamento da Casa-sede e Capela do Morumbi

22263/82 - Tombamento da Casa-sede e Capela do Morumbi

22831/83 - Tombamento da Casa da Rua Santa Cruz 
27030/89 - Tombamento das casas da Rua Berta

39292/99 - Restauro da Casa da Rua Santa Cruz, 325

39486/00 - Uso da Casa da Rua Santa Cruz, 325

39548/00 - Revitalização da Casa da Rua Santa Cruz, 325 (acompanhamento da obra)

\section{Dph/ Conpresp}

1989-0.002.598-8 - Tombamento do conjunto da Rua Berta

1990-0.004.774-9 - APT - Rua Barão de Jaguara, Alameda Barão de Limeira, Av. Rebouças.

1992-0.007.730-7 - Tombamento da Casa-sede e Capela do Morumbi

2000-0.036.456-4, 2000-0.036.457-2, 2000-0.036.459-9, 2000-0.036.461-0 - Processos de multa

- casas da Rua Berta

2000-0.119.140-0 - Demolições Rua Berta (diretrizes para o restauro)

2000-0.263.107-1 - Serviços emergenciais para manutenção da segurança, estabilidade e preservação da casa Modernista

2001-0.143.169-1 - Projeto de restauração da Casa Modernista

2003-0.008.245-9 - Restauro 5 casas - Rua Berta

2004-0.274.918-5 - Projeto de Restauro - Rua Berta nº 48, 58, 60, 70 e 72

2004-0.274.919-3 - Projeto de Restauro - Rua Berta nº2

\section{PROCESSOS MUNICIPAIS CONSULTADOS*}

* A listagem segue o padrão: $\mathrm{n}^{\circ}$ atual do processo; $\mathrm{n}^{\circ}$ original do processo; assunto; localização

\section{Casa da Rua Bahia}

$\begin{array}{llll}\text { 1984-0.017.419-4 } & 25.948 / 30 & \text { Alvará de construção } & \text { AGP } \\ 1994-0.172 .703 & 81.341 / 43 & \text { Habite-se } & \text { AHM } \\ 2010-0.066 .002-4 & 32.860 / 30 & \text { Abrir valla } & \text { AHM } \\ 2010-0.066 .104-7 & 05.833 / 31 & \text { Cancellamento } & \text { AHM } \\ 2010-0.066 .340-6 & 00.493 / 31 & \text { Abertura de valla } & \text { AHM }\end{array}$


Conjunto da Rua Barão de Jaguara

$\begin{array}{llll}\text { 1988-0.024.531-5 } & 52.338 / 27 & \text { Approvação de plantas } & \text { AHM } \\ 2010-0.065-994-8 & 59.400 / 28 & \text { Abrir vallas } & \text { AHM }\end{array}$

Edifício da Alameda Barão de Limeira

2010-0.066.119-5 65.271/39 Visto de alinhamento AHM

Vila Dona Berta - Rua Berta

1988-0.016.307-6 0.043.171/ 29 Alvará de construção AGP

1988-0.019.657-7 37.240/50 Alvará de construção AGP

1994-0.171.181-0 0.152.061/51 Auto de vistoria AGP

1988-0.024.898-5 0.169.422/61 Autenticação/ visto em planta AGP

Casa da Rua Itápolis

$\begin{array}{llll}1981-0.014 .533-4 & 66515 / 28 & \text { Alvará de Construção } & \text { AFW } \\ 1981-0.016 .381-2 & 20013 / 30 & \text { Fiscalização de obra } & \text { AFW } \\ 1981-0.014 .534-2 & 28266 / 30 & \text { Projeto modificativo } & \text { AFW }\end{array}$

Capela da Avenida do Morumbi

$\begin{array}{llll}\text { 1990-0.032.266-9 } & 001.730 / 49 & \text { Alvará de construção - capela } & \text { AGP } \\ \text { 2010-0.074.640-9 } & 002.053 / 49 & \text { Início de obras - capela } & \text { AHM } \\ \text { 1999-0.176.085-2 } & 004.662 / 51 & \text { Alvará de construção - Casa-sede } & \text { AGP }\end{array}$

\section{Casa da Avenida Rebouças}

$\begin{array}{llll}\text { 1991-0-038.711-8 } & 0.058 .674 / 37 & \text { Alvará de construção } & \text { AGP } \\ \text { 1991-0.041.354-2 } & 078.044 / 37 & \text { Desentranhamento de documentos } & \text { AHM } \\ 1991-0.041 .353-4 & 013.746 / 40 & \text { Auto de conclusão } & \text { AHM }\end{array}$

2010-0.219.675-9; 1981-0.014.343-9; 1999-0.073.843-8; 2004-0.272.329-1; 2004-0.272.341-0; 2004-0.272.365-8; 2004-0.272.392-5; 2004-0.272.400-0; 2004-0.272.444-1; 2004-0.272.454-9; 2004-0.272.458-1; 2004-0.272.466-2; 2004-0.272.476-0; 2004-0.272.600-2; 2004-0.272.603-7; 2010-0.219.677-5; 2010-0.219.666-0; 2004-0.272.605-3 - Processos de Alvará de Construção de outros imóveis da Cia. Gopouva à Avenida Rebouças 


\section{Casa da Rua Santa Cruz}

$\begin{array}{llll}1984-0.012 .548-7 & 007.759 / 27 & \text { Alvará de construção } & \text { AGP } \\ \text { 1984-0.014.010-9 } & 0.058 .806 / 34 & \text { Alvará de reforma } & \text { AGP }\end{array}$

\section{Casa da Rua Tomé de Souza}

$\begin{array}{cclc}2007-0.351 .089-0 & 0.052 .163 / 29 & \text { Alvará de construção } & \text { AGP } \\ 1986-0.014 .868-5 & 0.027 .498 / 30 & \text { Projeto modificativo } & \text { AGP } \\ 2007-0.351 .075-0 & 0.052 .959 / 31 & \text { Construção em desacordo } & \text { AHM } \\ 1988-0.025 .082-3 & 05-007.008-88-59 \text { Alvará de reforma } & \text { AGP } \\ - & 171.189 / 62 & \text { Alvará de reforma } & \text { CCAP }\end{array}$




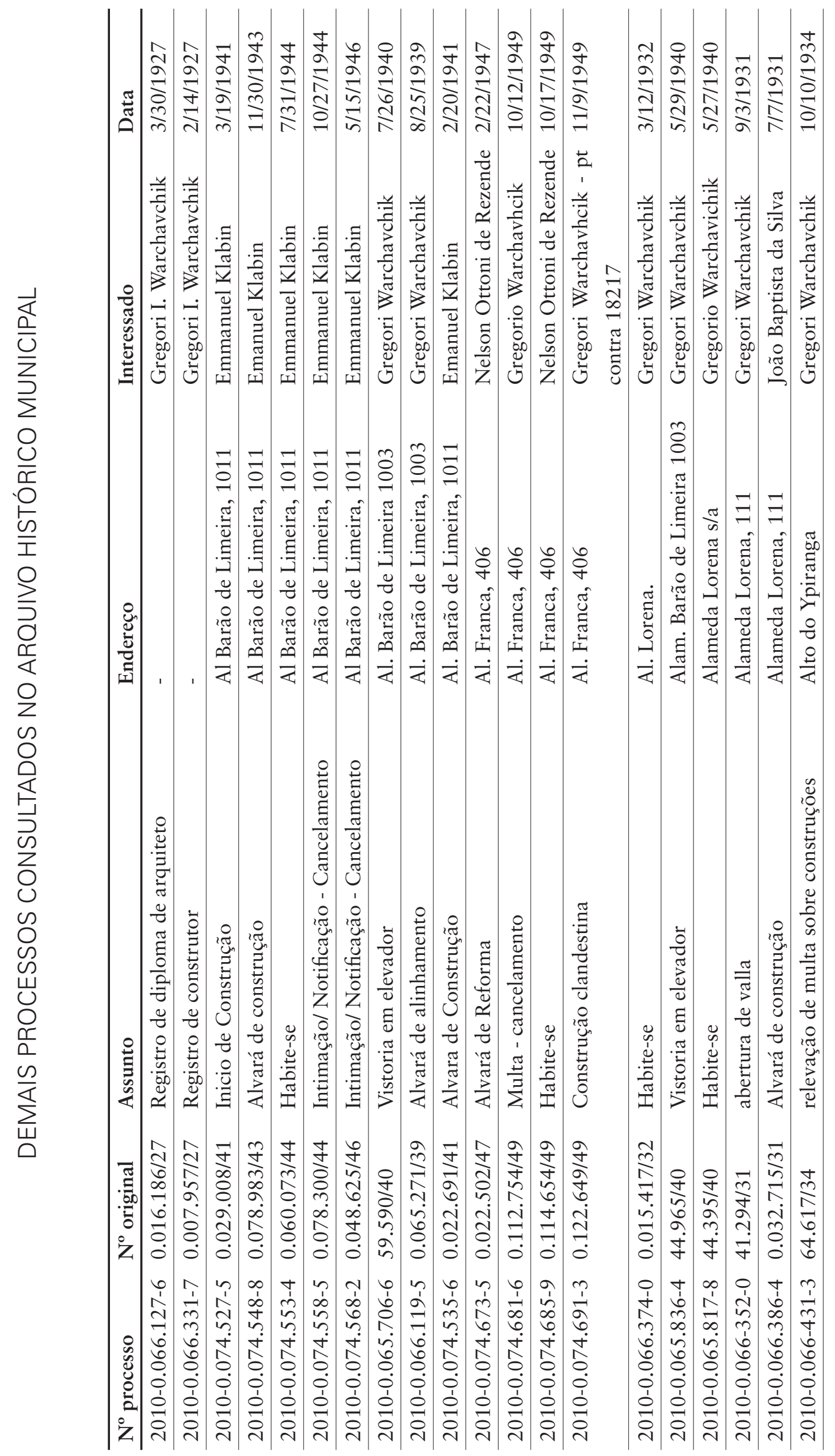



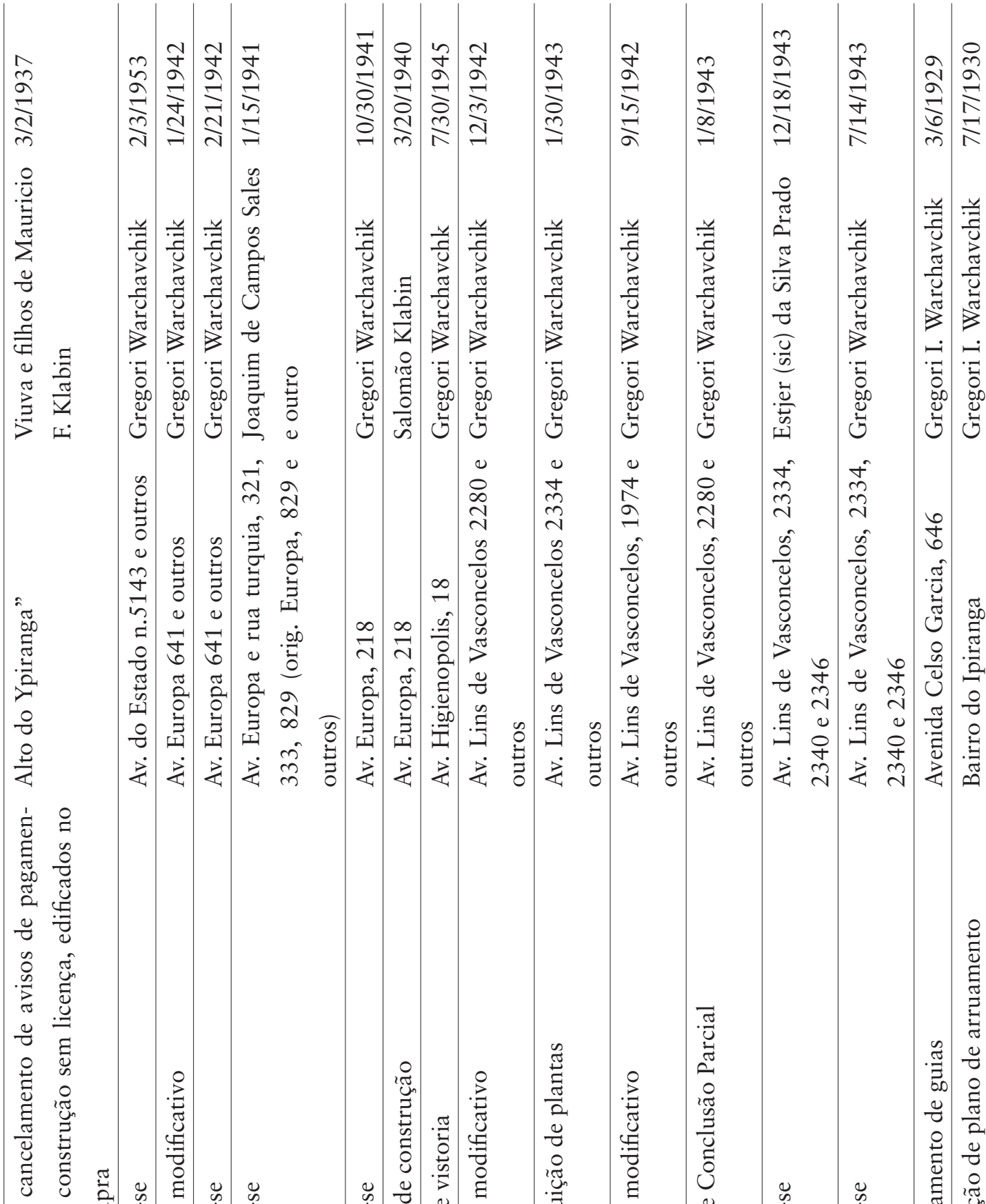

范

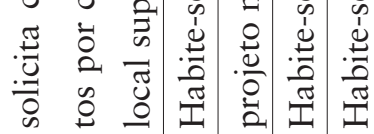
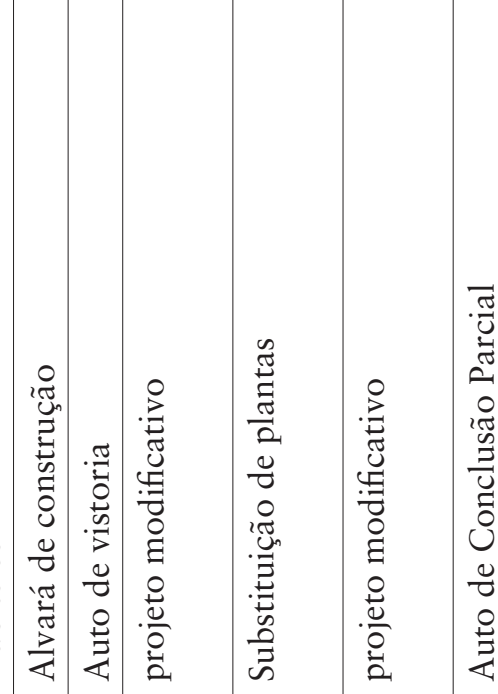

-

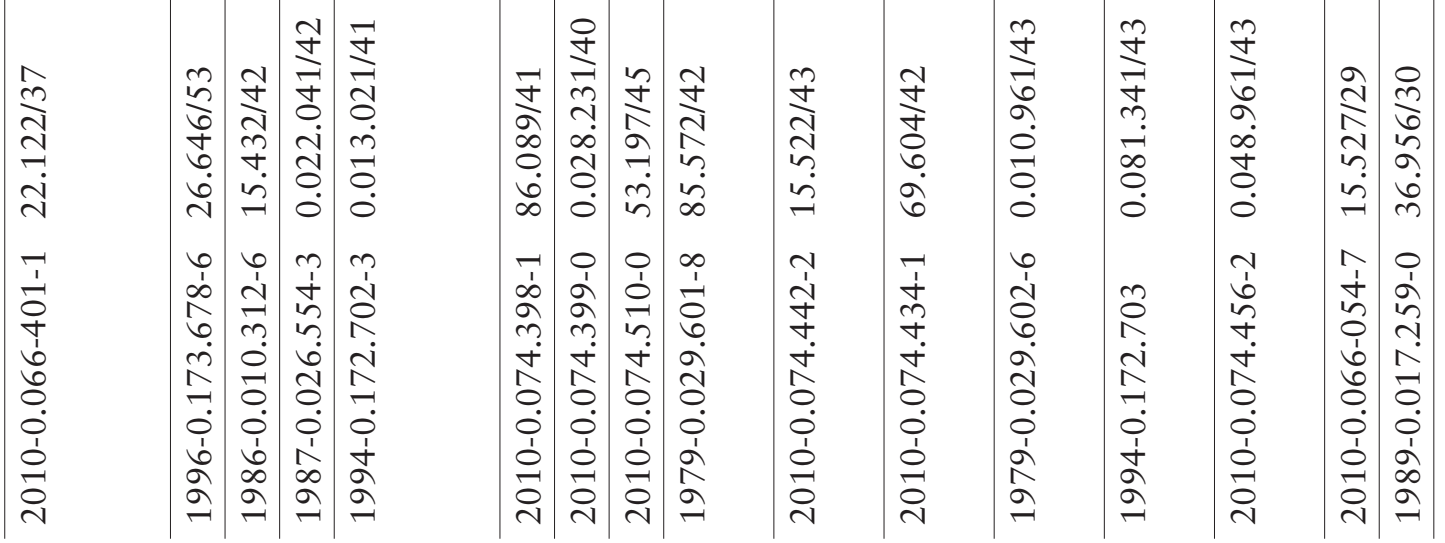




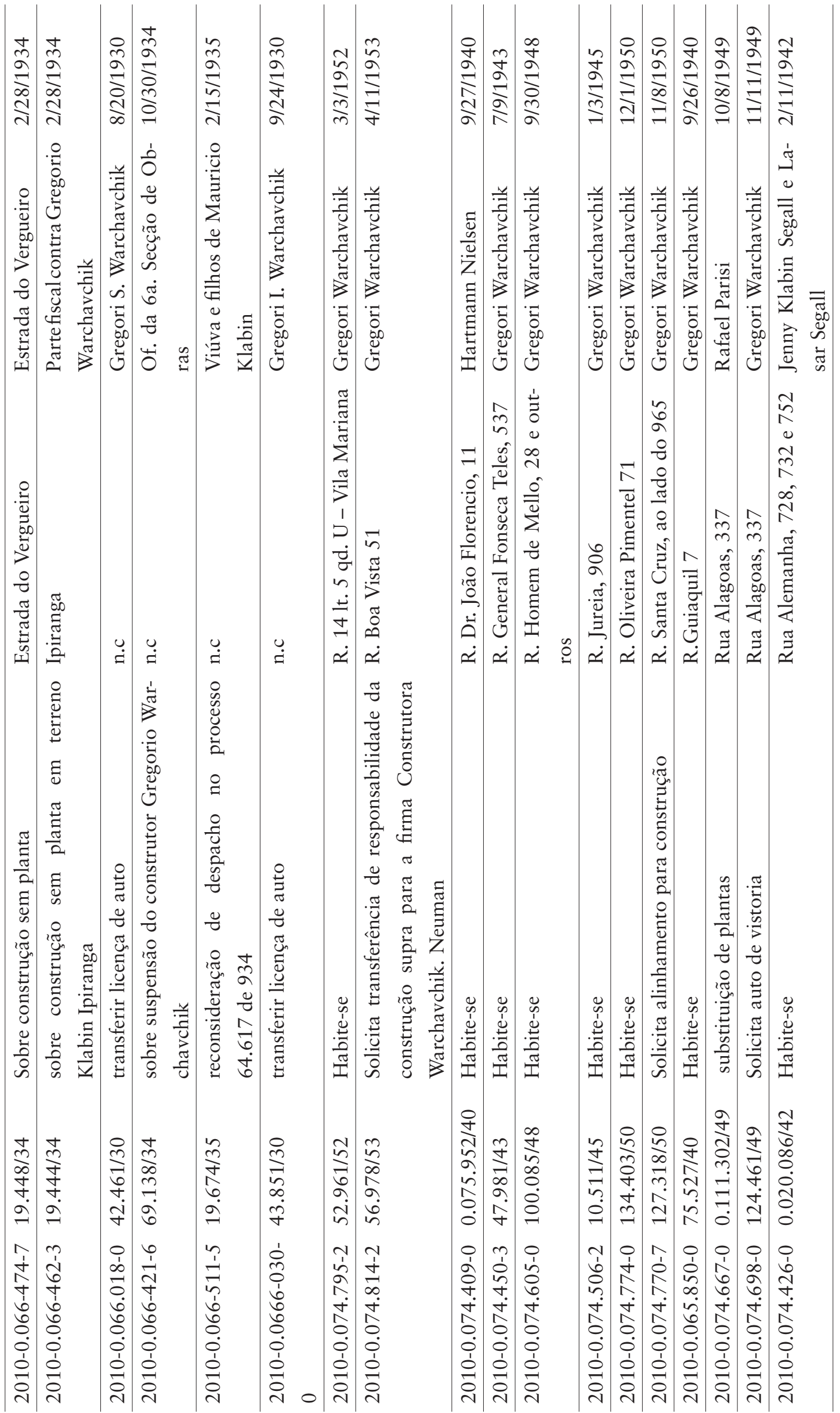




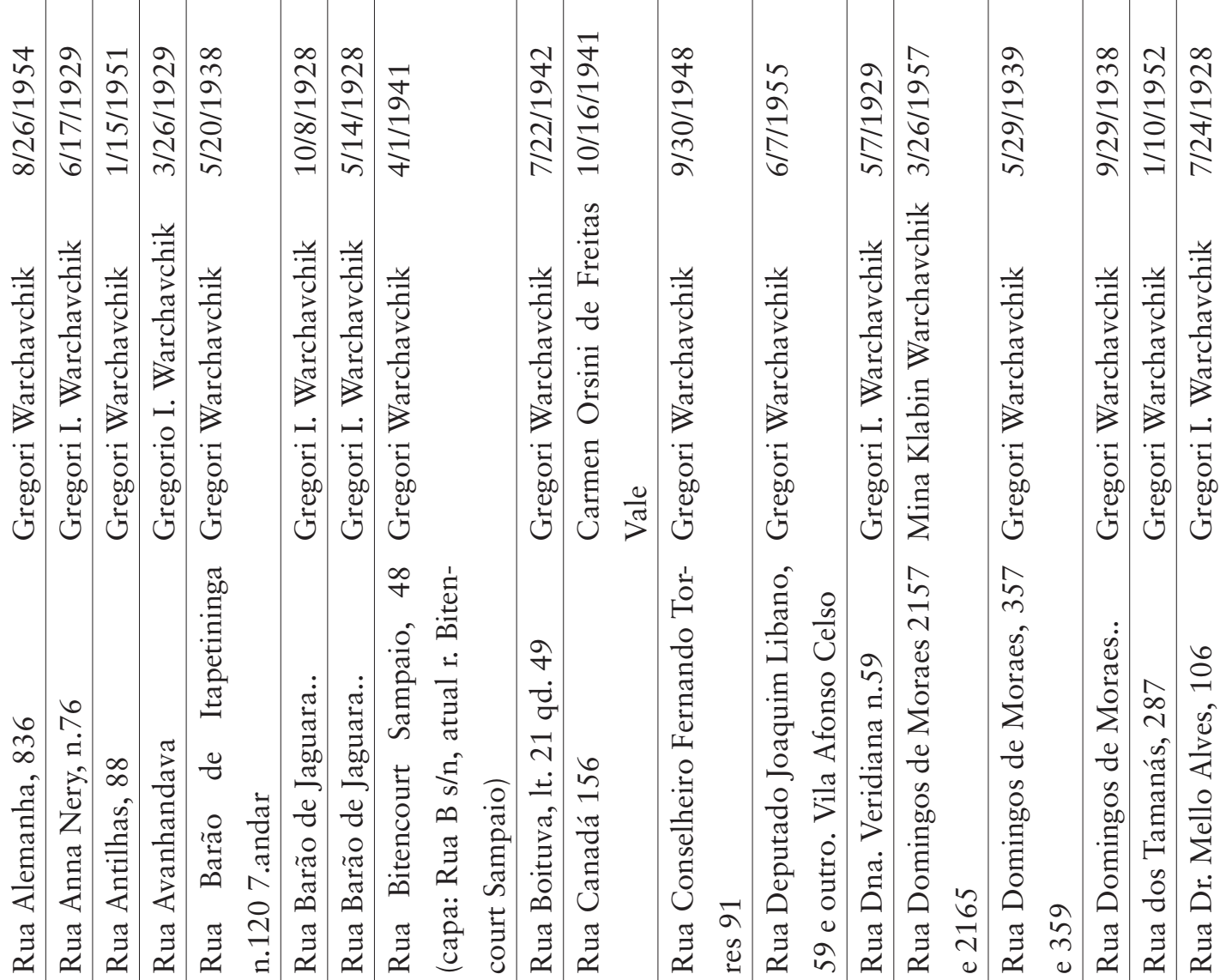

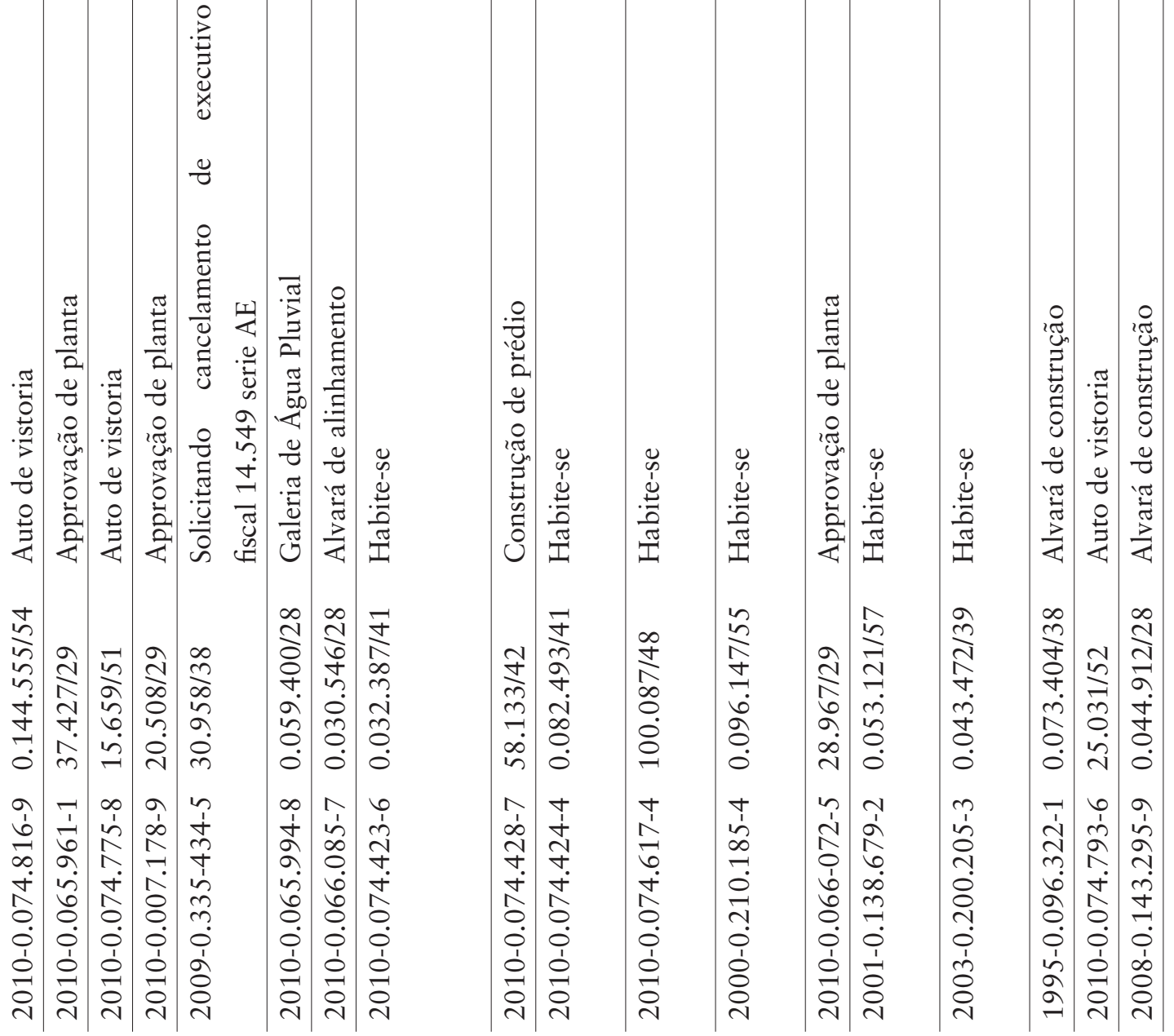




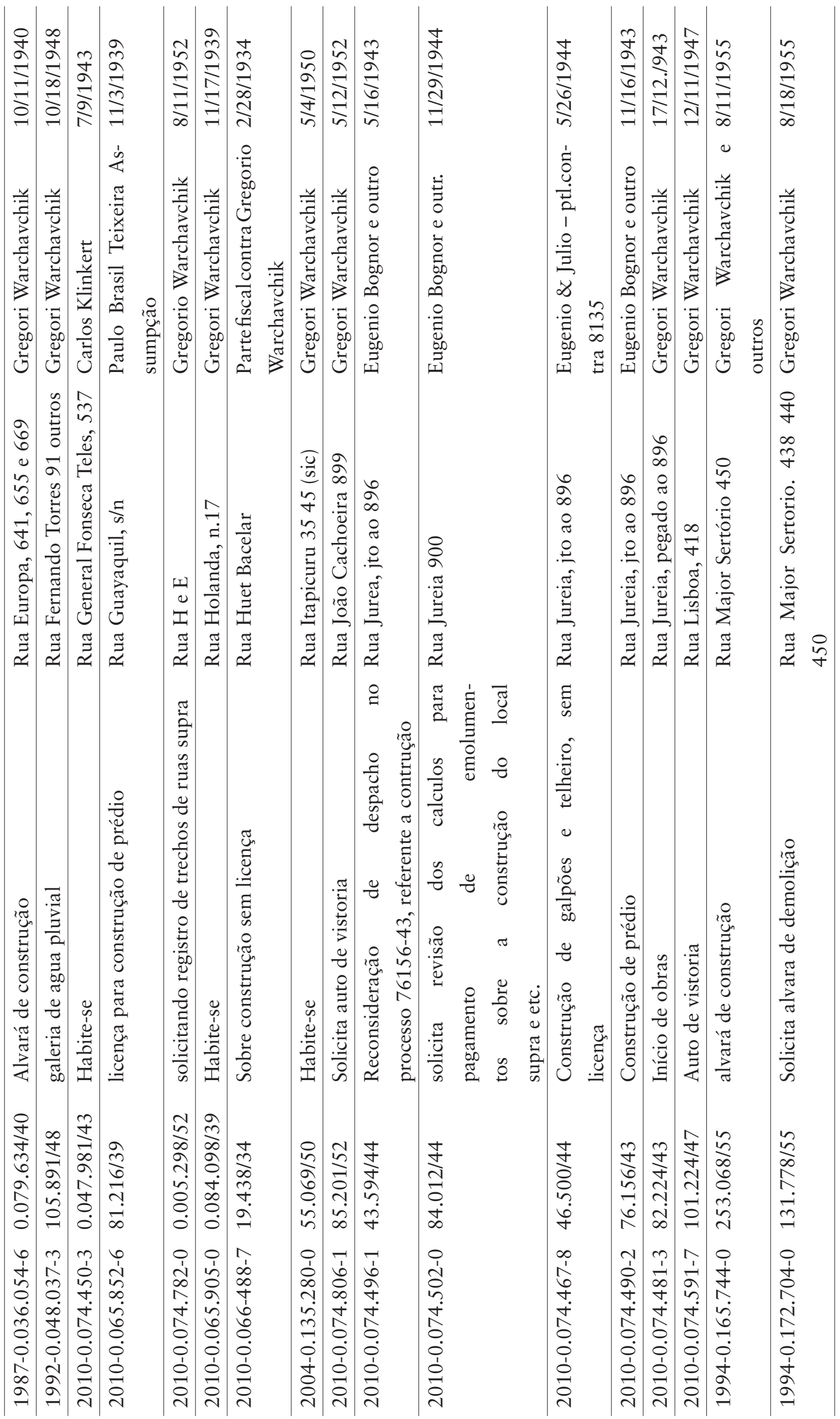




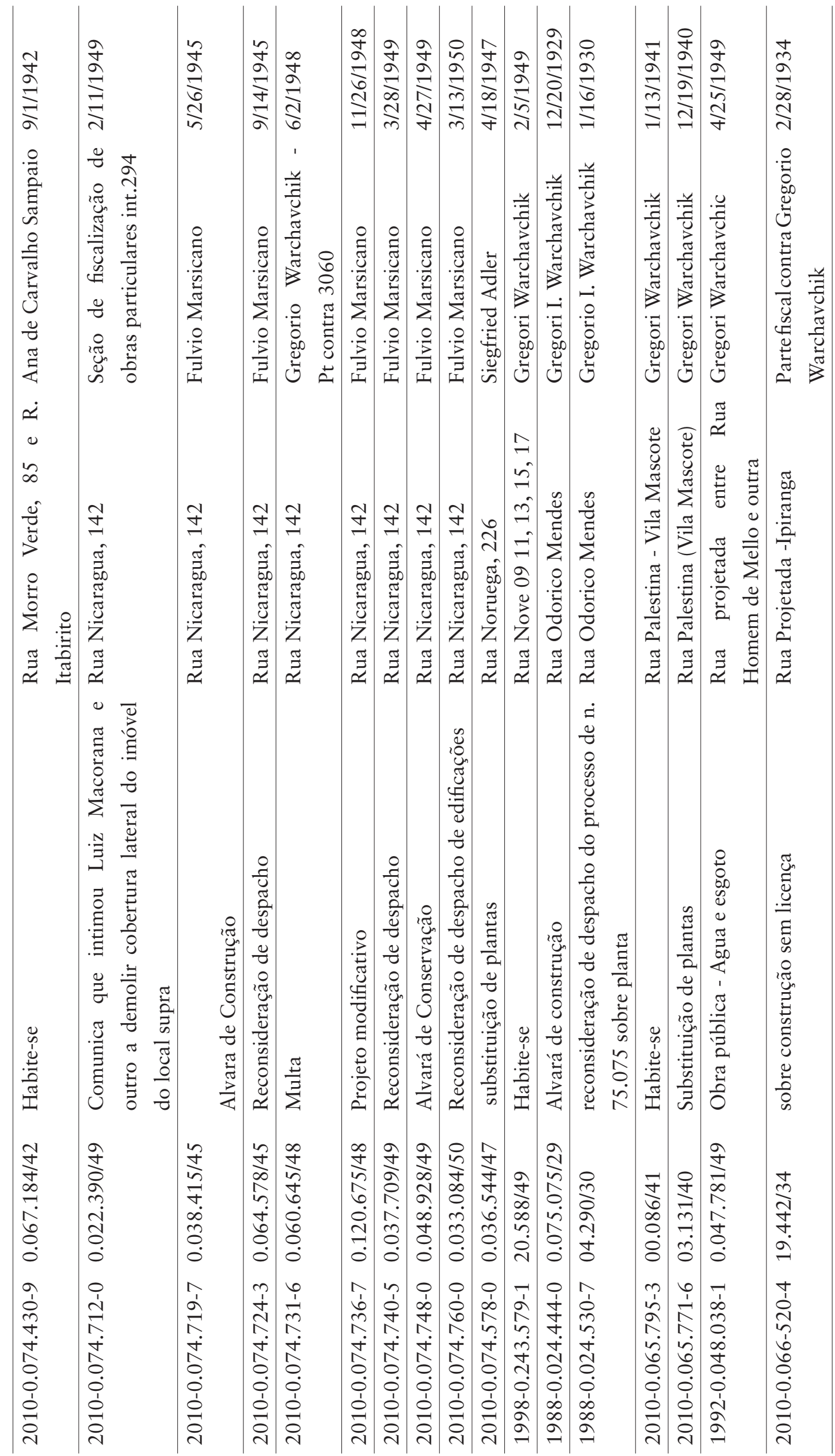




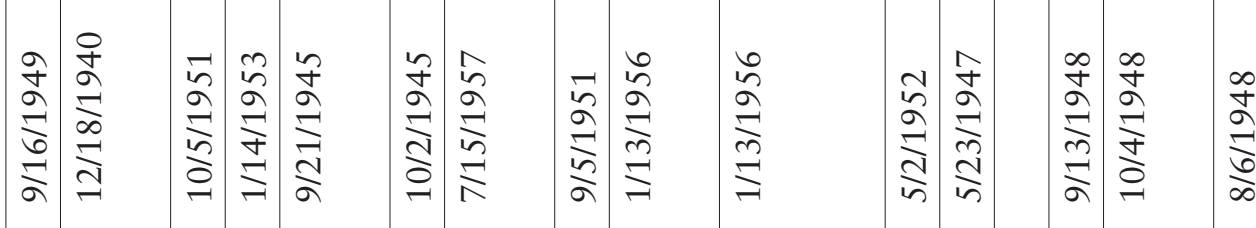

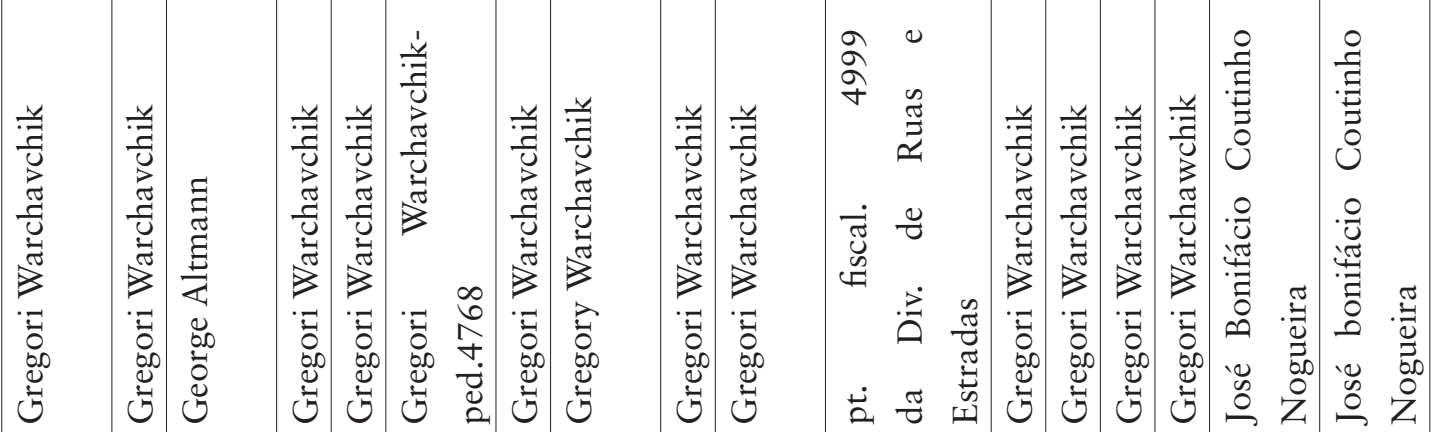

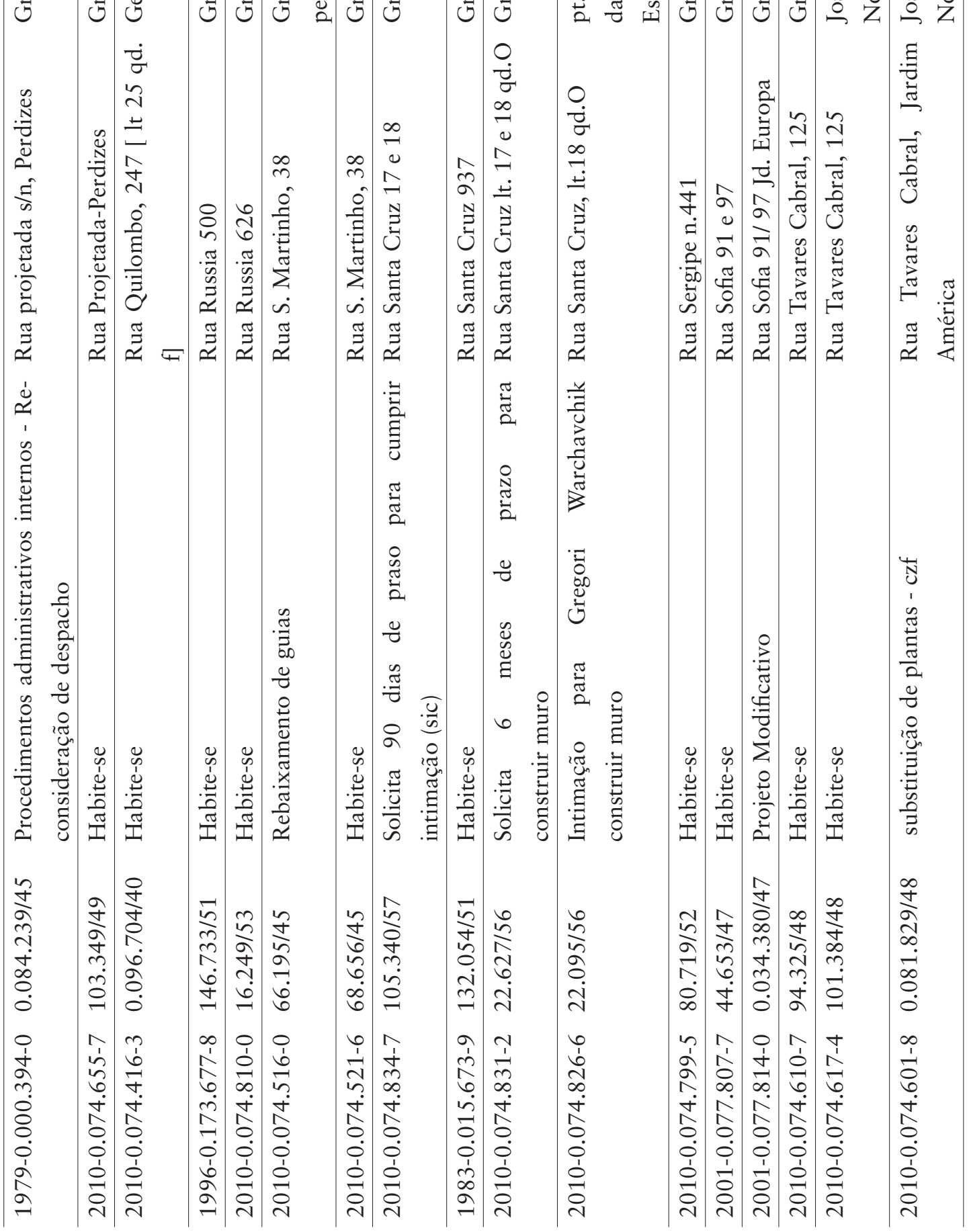




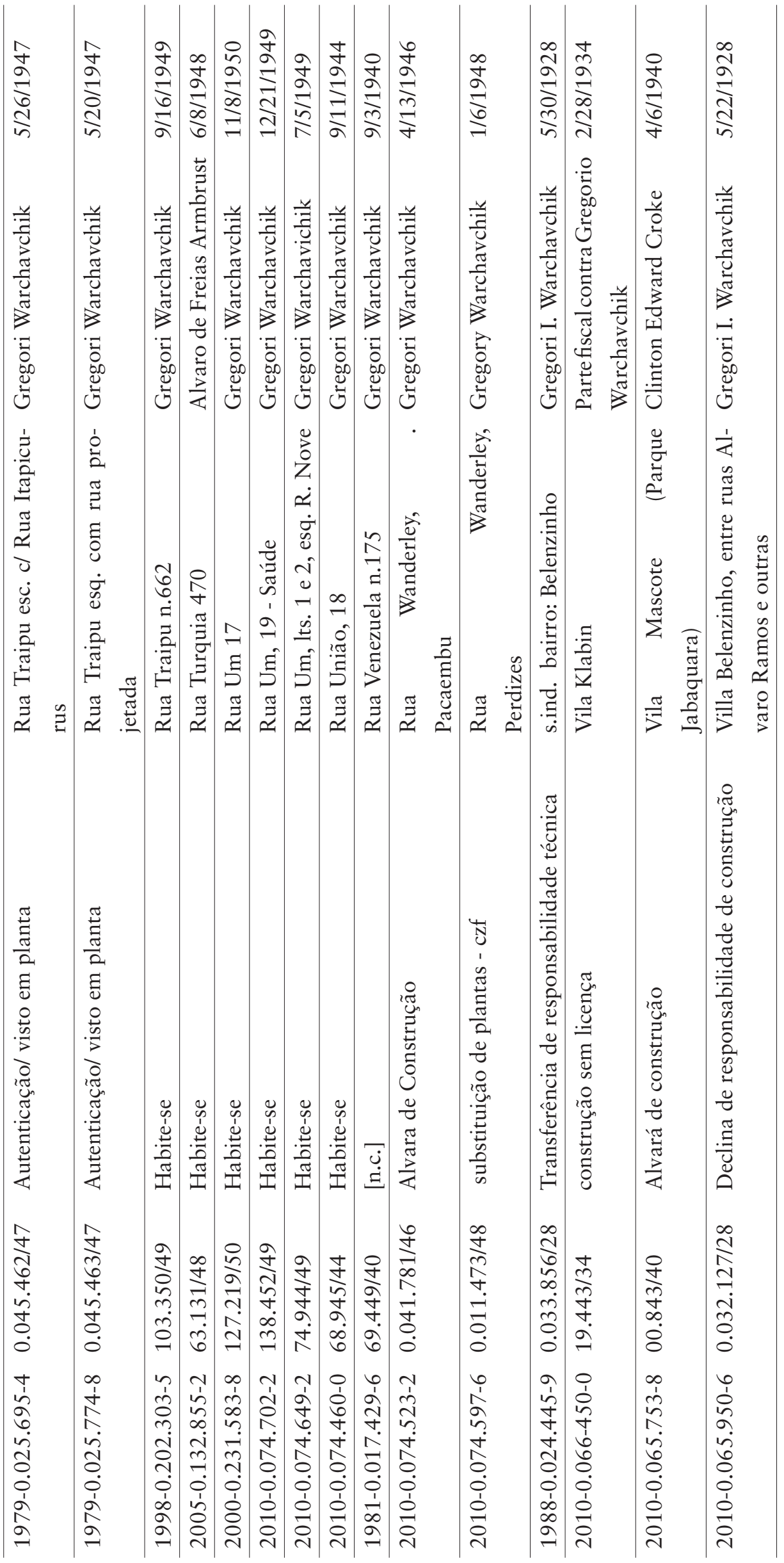

